<smiles>C1CCCC1</smiles> 


$$
E-5
$$

Dividion of Birds

7v. I. Lleignare Chiengmai, Siam qanceary. 1930 

A MANUAL OF THE BIRDS OF AUSTRALIA 


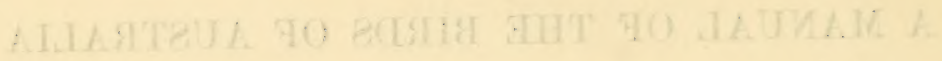
, 
A MANUAL OF THE BIRDS OF AUSTRALIA BY

GREGORY M. MATHEWS, F.R.S.E., M.R.A.O.U., AND

\title{
TOM IREDALE,
}

Members of the British Ornithologists' Union and Corresponding Fellows of the American Ornithologists' Union.

\author{
ILLUSTRATED WITH COLOURED AND MONOCHROME PLATES: \\ BY \\ LILIAN MEDLAND.
}

\section{VOLUME I.}

Orders Casuaru to Columbat

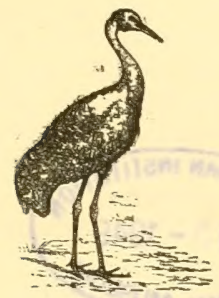

H. F. \& G. WITHERBY

326 HIGH HOLBORN, LONDON 
This Volume was first published on March 9th, 1921.

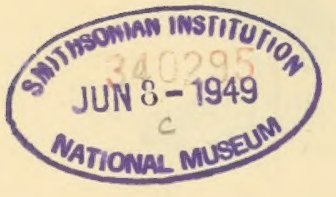




\section{INTRODUCTION.}

$\mathrm{W}^{\mathrm{E}}$

E have attempted to provide a handy book of reference to the known facts concerning Australian birds for the use of students, and to this end have given a complete primary synonymy, with reference to the coloured plates furnished in Gould's and Mathews's Birds of Australia, the standard works on the subject. The present work is entirely based upon Mathews's work, in which will be found complete accounts, as far as recorded, of the lifehistories and economics, with full discussion of all nomenclatural problems, dissertations on the phylogeny of the groups and detailed synonymy. Any item not fully understood in the present essay will be found elaborately explained in that place. We have extracted the detailed descriptions of the plumages from the same work, but have supplemented them whenever opportunity has been afforded by the receipt of new material, and have made reference to literature recently published for additional matter. With regard to the description of nests and eggs we have purposely restricted these to the smallest items possible, as Australians have already two magnificent works on this subject, viz., those of Campbell and North.

In his List of the Birds of Australia Mathews gave a résumé of the workers on the subject, and, consequently, we have not referred to that item here.

We have treated the Ornis under binomial headings, recording the subspecies differentiated in one item. This is somewhat different from general usage, but we believe it to be the most useful method of displaying subspecies, whether these be considered by the professional ornithologist or by the amateur field worker, and it is to this latter class we hope this book will appeal. We add a few notes under the headings Nomenclature, Classification and Zoogeographical Distribution, which should be of assistance to students.

\section{I.-NOMENCLATURE,}

This subject has long been a controversial one through the absolute carelessness of "authoritative" writers, whose action has misled those ignorant of the facts into belief of accuracy, whereas superficiality was most obvious to the critic. Moreover, such workers, when easy opportunity was afforded, made much stir about the changing of a single name, conceiving ostrich-like to hide their omissions by the pillorying of such an instance. It is the pride of the present writers that the reduction of this subject to its present status of comparative insignificance is due to their exertions, and that succeeding workers will be able to deal with the scientific side of ornithology without much trouble from this factor. The International Laws are now accepted by all workers, so that easy determination of the correct name to be used is 
possible. The older writers desired notoriety with the least labour, and their ambition was quantity, not quality. Consequently, accuracy in detail was not possible, as such would have curtailed production. The aim of the writers has ever been to allow of good work to those who, through lack of opportunity of access to complete literature, are dependent upon few books. Hence the nomenclature in this work is more complete than has ever been offered to any students in any previous book. The International Laws and Opinions have been followed in detail, save in the one exception of similarly formed words of the same origin. At the present time the recommendation regarding the acceptance of such names is a dead-letter, and so we have treated it as such, especially in view of the preparation of authoritative lists by Committees of World Ornithologists who have, so far, agreed to our methods of usage. There is nothing more to be said on this "contentious" subject, as there need be no further discussions, save where a few of the older men stubbornly argue non-debatable items.

Genus splitting has long been confused in the arguments of careless commentators with nomenclature, but it has no connection and should be dealt with in the consideration of classification; we do not agree with the famous ornithologist who considered the nomination of a bird-skin in a cabinet the highest work achievable, and consequently demurred at name changes.

\section{II.-CLASSIFICATION.}

In the Austral Avian Record, Vol. IV., pp. 29-48, we have given a sketch of the scheme we propose to follow in this book, and we will not detail it here, but cite the allied groups as we deal with the Austral orders, etc. It is necessary, however, to indicate the present state of bird systematics by synopsising the characters hitherto utilised.

Superficial features were first employed in a superficial manner but more recently attention has been given to the growth stages whereby convergence has been noted and its significance recognised. Thus the tarsal covering may show certain features in the adult, and examination of the nestling prove the adult formation to be secondary. It was long ago evident that assistance could be gained from study of internal features, and a few anatomists wrote essays on particular items, such as Nitzsch's on the Carotid Arteries. Nitzsch also showed that taxonomic evidence might be gained from study of the pterylosis of birds, and his well-known work on Pterylography is a standard, but little work has since been done on the subject. Then came the epoch-making study by Huxley of the skulls of birds and his revolutionary re-classification thereof. Had the superficial characters been thoroughly understood his essay would have caused little dismay but simply advanced our science a little more rapidly. As it was, the anatomists continued their researches and working upon new ground were apt to overrate the differences observed. The eulmination appeared in a series of articles which laid stress on the shape of the nasal openings, the presence or absence of cæca, the presence 
of the ambiens musele and other leg muscles, and other inconstant minor internal features. The author of these articles unfortunately died before he was able to revise his early guesses as to the ralue of these items, and for the last thirty years these have been accepted at an abnormal valuation. It is now time to attempt a reasonable classification. but as previous scheme. have quoted the above it is important that they should be cited.

In connection with the sluull the palate was used by Huxley as a distinguishing character capable of differentiating groups of birds accurately. He indicated four styles of formation to which he applied the namesdromrognathous, desmognathous, schizognathous and agithognathous. Parlier studied the matter more fully and added a fifth, saurognathous, at the same time putting on record many facts indicating the spurious nature of these divisions. As a matter of fact, all the forms are produced by convergence and divergence and cannot absolutely be used for the separation of groups. It has already been stated that none of the divisions are really satisfactory from the classificatory point of riew by a professional anatomist, but we consider they are valuable, after the external structure of the bird has been well studied, in connection with other items.

Garrod's great iden was the usago of the formation of the nasal bones, the differences being termed holorkinal or schizorhinal. Here, again, there was soon seen to be pseudo-holorhiny present, and consequently the terms as originally proposed were proved to be futile. Once more, it will bo found that as a subsidiary item the distinctions may be accepted as confirmatory evidence in many cases.

Again, the presence or absence of basipterygoid processes was supposed to be of importance, but the variability of their presence seems to relegate these to a subordinate position. Regarded as indicating reptilian ancestry they recur in the most specialised a vian forms and are absent from admittedly older groups, while in some groups they are present in the juvenile and absent. in the adult, and in very closely allied species do not occur at all. The absence or presence of supraorbital grooves is sometimes quoted, but in a closely allied series of species great variation may be seen. The form of the pterygoids varies, but not much importance has been given to this character though it appears just as worthy of usage as some of the other items cited by osteologists. The quadrate is sometimes quoted, and it is a little variable so that it may be used later in connection with other skeletal features. The lower jaw seems so far to have been ignored but, we think, incorrectly.

Owing to the exaggerated importance given to the palatal fearures the rest of the skeleton has been comparatively neglected. When extraordinary features were noted, through lack of knowledge these were unduly emphasised or unfairly minimised. The variability of the sternum may prove just as valuable as any feature of the skull when carefully studied. We hare recognised phylogenetic affinity in its rariation in a few cases we have recently studied; the features sometimes quoted, the presence of spina externa and intema, do not appear to have much significance. The forms of the vertebrie 
are four in number, but only two of these are generally utilised, the heterocolous and opisthocolous, and they vary rather erratically, so that they have little primary importance. The shape of the coracoids, clavicles and scapula varies considerably and has been extensively quoted and appears to have ralue in connection with the sternum. When the clavicles join, the combination is linown as the furcula, and the presence or absence of such an item is often important. The wing bones have not been much considered in connection with taxonomy, but detailed study should allow good characters from the development of these; but here, as in the leg bones, adaptive features must not be misunderstood. Thus, in the latter, the tarso-metatarsus has been commonly cited when the development was purely adaptive and not of the phylogenetic importance credited to it - the study of the birds would have explained this.

The first and most commonly utilised item of the soft parts, generally so called (not the soft parts external of the taxomomist), has been the formation of the syrinx. The Passeriform birds have been divided into primary sections by means of this organ, and it is certain that degradation has been mistaken for lack of derelopment. This is a matter which will be seftled when the new school of anatomists attack bird development from a scientific standpoint. We will deal more particularly with this feature later on, as the modes of syrinx derelopment in the groups now being dealt with are of little importance, the rariation being inconstant. As above noted the development of the carotid arteries was investigated by Nitzsch and elaborated by Garrod, who practically proved that the feature was so inconstant as to be useless when its confirmation would have been of value. The presence or absence of the caca was also studied with similar results, no satisfactory conclusions as to its ralue being possible. Like conclusions attended similar research in connection with the length of the intestines, the presence of the gall blader, the size and position of the liver, etc., etc. Gadow considered the position of the intestines as they are stowed away in the body, and Chalmers Mitehell followed with a criticism of the methods of coiling of the intestinal canal. From their results it appears that these follow definite lines and that, as confimatory evidence, they are probably quite as valuable a feature as any other internal character. Garrod also investigated the muscles of the leg, and, finding them variable as to their presence, endeavoured to influence classification by their means. The mystic formula ABNY + was invented by him, and its variations are always cited in connection with bird grouping, though its value is of little moment. The meaning of the letters had better be explained here. A stands for the femoro-catudal muscle, $B$ for the acessory femoro-caudal, $\mathbb{X}$ for the semitendinosus, and $\mathrm{Y}$ for the accessory semitendinosus, and the + sign for the presence of the ambiens muscle. The - minus is used if the latter be absent. The wing muscles have never been given ats much prominence. though they have just as much right and also slow variation, but their vartation has not been tabulated as fully as that of the leg muscles. Taken indiridually, as these characters have been, the 
general results are more or less of little value, but the consideration of them taken as a whole is of great value when the superficial characters are well understood.

Pterylosis is not well known at present, so that definite conclusions cannot be recorded, the only point to emphasise being the continual examination of specimens and that criticism of results will later follow. All we now lnow is that variation is seen when not anticipated and consequently commonly misunderstood, and the present facts are not of great significance through ignorance of basic data. It is a subject that will repay continued study, but not occasional excursions.

Another item contimually quoted is the presence or absence of the oil gland, and whether it be nude, tufted or feathered. The absurdity of the usage of such a character should be obvious. However, it has been seriously put forward as of value, but its true insignificance is now generally accepted. The presence or absence of the aftershaft and its size are also mentioned, but, of course, that character has also been minimised through better material and more study, as species which have been commonly cited as showing no aftershaft prove to possess one.

A peculiar feature of the wing feathering was noted, and immediately investigated as of import, but lere again its absolute ralue cannot yet be appreciated. We refer to the loss of the fifth secondary, though its covert is present. This state of the wing has two altemative terms, quincubital or eutaxic and aquincubital or diastataxic. The comparative value of this state is well seen among the Swifts, where both forms occur. More valuable as an absolute character is the coloration of the nestling from tho egg onward. The state of the nestling when it emerged from the egg was once utilised, but this seems of less value than the coloration of the first feathering. That this is extremely important is at once seen by study of downy nestlings of the Scolopacine group. It is always necessary to remember that secondary results are apt to obscure hasty examination in connection with many of the abore features, but the only conclusion possible from an unprejudiced viewpoint is that there are no internal features of outstanding importance, the exceptions being so numerous, and the main items so imperfectly investigated; while extermal characters show less variation and are better known and their development can be more perfectly studied through the much greater mass of material arailable. Consequently throughout this work we have giren full details of the extemal features, and also added the internal items as commonly giren in text books for the benefit of workers-the former all being drawn up from actual specimens, and therefore accurate; the latter compiled from various authoritative sources, and only in few instances, as yet, rerified by ourselves.

Before we leave this subject we may enter an apology as to the genus splitting complained of in connection with our work. We have given a description of the generic characters observed, and have endorsed these with a beautiful painting of the character noted. When we have studied all the 
groups with their plumigo changes and growth stages we may suggest genus lumping, and we prophesy now that our efforts in that direction will receive less encouragement than our present work. We have been accused of dogmatism, but never hats any work shown so little of that vice ; as a matter of fact, many complaints have been marle against our changeableness. Consequently we feel at liberty to allow our sucessors with better fateilities and more material to judge our conclusions.

An American reviewer has complained of our neglect of subgenera "so rommonly used now," but we would point out that in the American Ornithologists' Union Checklist, out of the first 180 genera (nearly), covering the sime ground as this volume, only " 13 " are subdivided into subgenera, while Ridgway's proportion is apparently the sume as ours, when dealing with the same groups.

\section{III. - ZOOGEOGRAPHICAL DISTRIBUTION.}

It is unfortunate for the study of zoology that political boundaries are adhered to in the nomination of localities and areas inhabited by animals. As a general rule such limits are never coincident with those imposed by nature, and nowhere is this fact seen so clearly as in Australia. Having studied the avifauma from the viewpoint of the zoogeographer, we here give a slight sketch of the peculiarities of the bird life as an ineentive to further study. When the limits of the zoological divisions are understood the arrangement of subspecies is a comparatively easy task and their non-admittance in certain cases is worthy of attention. The primary constituents appear to be complex, as there can be seen two early sources of endemie forms, with two later immigrations from the north. Confusion may arise through the earlier immigrants being mistaken for the later, and vice versa, while it is possible that the two early sources cannot be definitely differentiated. At the present time the study of palreontology in Australia cannot give us mueh help, though later it may be of service. It is probable, moreover, that when the study of ecological ornithology is well established, facts may be derived from that source, which, in conjunction with geological data, may assist us to valid conclusions. With the above limitations we may separate the facts into groups and use them conservatively in considering the existing avifauna with the following results. The Tasmanian faun shows a little peculiarity in the fact that the majority of the birds are separable from the mainland ones, but generally only with subspecific rank; a few are specifically distinet, while two have been commonly accepted as showing generic differences. It is remarkable that these two aro purely island degradation forms, whereas some of the restricted genera we utilise are more valuable phylogenetically as showing ancestral forms, the mainland representative being more specialised. A more peculiar feature is the absence from Tasmania of certain old forms which still persist on the almost adjacent mainland. These, moreover, inhabit the southem portion of Victoria which is so closely allied as to be ilmost, zoologrically, part of Tasmania. It must be hero confimed that the 
Tictorian fauma is divisible into three sections-a northern, southern, and western desert one.

Consequently Victoria is a confusing term when cited as the locality of any bird, and this refers to most other State names, though not so well marked in so circunscribed an area. The most famed endemic Australian birds, such as the Emu and Lyre Bird, are equalled in zoogeographic interest by less well-known forms which are too numerous even to mention here. Each provides an essay in itself as to its distribution, but it may here be asserted that all are confined to the southern part of Australia, both east and west. At the present time some show discontinuous range through the intervention of the great central desert. Some, apparently definitely rest ricted and evolved in this southern area, have again spread northwards and repopulated the areas from which their ancestors ranged southwards. At the same time the succeeding fauna has extended its limits and penetrated into Australia even to the southermmost limits, but scarcely ever reaching Tasmania. It is this complex which makes the study so interesting, as the facts are so obvious that these succeeding migrations can almost be defined with unfailing accuracy. However, we will suggest these movements, without dealing in great detail, thus: Palreontologically, we have not the data to assert a definite period, but we can fix an early migration from the north which overran Australia before the severance of the Bassian Isthmus and whose members quickly developed in a degenerate manner through lack of inimical opposition. The separation of Tasmania took place after degeneration had set in, so that the island forms were left as isolated unprogressives. On the mainland, changing conditions compelled a certain amount of competition, and we find the contemporaries of the island species a little more advanced on the mainland. Some of them eren, adapting themselves as the situations demanded, progressed so that they could not only defend themselves but take the offensive, and these, being barred from any advance southward, attempted a northward dispersal. These constitute the bulk of the Australian Omis and include the majority of the endemic genera and species. From the observed data we conclude that after the division of Bass Straits another immigration from the north took place and this also succeeded in overrumning Australia, but did not cross the Straits into Tasmania. It is probable that the competition between these two elements-the invaders and the settlers-resulted in the extermination of many of the weaker forms of the latter, a few resisting and being now recognised in such a survival as Atrichornis. The stronger settlers, of course, continued their progress accumulatirely under the stress of the stronger newcomers in order to retain their places. The new immigrants in their turn soon accustomed themselves to the environment and became adapted to the lack of great stress, and a few of these again evolved the rôle of pioneer and perforce had to retrace their ancestors' steps into the north. In these attempts probably many more failed than succeeded, and we have only record of the successes. This migration can be seen throughout Australia in the form of differentiated species of prevailing northern genera. 
The complex persists in the fact that it is sometimes difficult to judge whether a species, as it may show little distinction, should be referred to this or the carlier migration, and this can only be determined by the relative antiquity of the genus considered. This may be ganged to some extent by the distribution of the genus and its allies, and it is in connection with these studies that genus lumping proves so misleading. We conclude that when this second migration took place Australia was connected by land with New Guinea, and Torres Straits had not been evolved. Since the division a third irruption into Australia has taken place, and the procedure is still going on. This irruption has never overrun the continent, but has either run down the east coast or along the north coast into the north-west or both, and comprises species still living unchanged in New Guinea. It has been suggested that at one time a connection of Australia with the Northern Islands existed in the north-west, quite distinct and separate from the Torresian connection. There exist a few forms which seem to countenance this suggestion, as instance, Eremiornis, isolated in the north-west and living on the Montebello Islands, a form almost as peculiar as Atrichornis. To crystallise the above migrations we may cite a concrete example. The ancestral Moorhen arrived in Australia and penetrated into Tasmania ; retaining primitive features upon the separation of the latter country, the island form degenerated into a huge semi-flightless big-footed bird; the mainland one, through stress of environment, drought, ete., was compelled to retain its flying powers and also its smaller size, but still shows primitive appearance. In the north, alteration through necessity proceeded, and then the more highly developed bird with the second immigration proceeded to colonise Australia, and spread over the continent but not into Tasmania. At the third immigration a new development, the Rufous-tailed Moorhen, crossed Torres Straits and ranged along the north to the Northern Territory and into North Queensland. This sequence can be traced in connection with many other birds and is worthy of study. A few words must be given in connection with the desert forms; these are apparently referable to the first immigration and have been evolved through envirommental stresses, sometimes so much that their relationship has become obscure, and it is always possible that their ancestral relations have become extinct without leaving any obvious descendants. It is possible that complete anatomical and osteological examination would assist in tracing such to an acceptable ancestry, and as a good example for investigation we suggest Peltohyges, the Australian Dotterel.

Though the arrangement in this work is limited to species it must not be concluded that we minimise the ralue of the study of subspecies, but rather we have allotted to them their full value, and we appreciate their worth in the consideration of zoogeographical problems, especially such as are presented by the numerous "islands" indicated on the Australian mainland. These have been previously indicated by Mathews, so we will not deal with them here, but simply call attention to their presence once again. The study of subspecies is now being undertaken by Australian omithologists, and it is 
very pleasing to the senior author to see the new school attacking the live subject in so thorough a manner, and we hope that the present work will assist such in the most complete manner. In this volume we give an illustration of the subspecific characters of the Silver Gull, and we propose in the succeeding volumes to illustrate further such features when of sufficient import.

GREGORY M. MATHEWS.

TOM IREDALE.

12 th February, 1921. 


\section{SYSTEMATIC LIST OF CONTENTS AND ILLUSTRATIONS.}

\begin{tabular}{|c|c|c|c|c|c|c|c|c|}
\hline & & & & & & & PLATE & PAGE \\
\hline Class Aves & .. & $\cdots$ & .. & .. & $\cdots$ & .. & & 1 \\
\hline Subclass Dromæornithes & & . & $\cdots$ & $\cdots$ & $\cdots$ & $\cdots$ & & 1 \\
\hline Order Casuarii ... & & $\cdots$ & $\cdots$ & .. & $\cdots$ & $\cdots$ & & 1 \\
\hline Suborder Casuariiformes & & $\cdots$ & - & .. & $\cdots$ & $\cdots$ & & 2 \\
\hline Family Dromiceiidæ & . & .. & - & . & $\cdots$ & $\cdots$ & & 2 \\
\hline Genus Dromiceius & $\therefore$ & $\cdots$ & . & . & - & $\cdots$ & & 2 \\
\hline Dromiceius novahol & llandice. & & $\cdots$ & $\cdots$ & $\cdots$ & $\cdots$ & I. & 3 \\
\hline Genus Peronista & . & $\cdots$ & . & $\cdots$ & $\cdots$ & $\cdots$ & & 5 \\
\hline Peronista peroni & - & $\cdots$ & $\cdots$ & -. & .. & $\cdots$ & & 5 \\
\hline Family Casuariidæ & $\cdots$ & $\cdots$ & . & $\cdots$ & . & $\cdots$ & & 6 \\
\hline Genus Casuarius & $\cdots$ & $\cdots$ & *. & $\cdots$ & . & $\cdots$ & & 6 \\
\hline Casuarius casuarius & & $\cdots$ & . & $\cdots$ & $\cdots$ & $\cdots$ & II. & 6 \\
\hline Subclass Impennes & . & $\cdots$ & $\cdots$ & $\cdots$ & .. & . & & 7 \\
\hline Order Sphenisci .. & $\cdots$ & $\cdots$ & $\cdots$ & $\cdots$ & $\cdots$ & $\cdots$ & & 8 \\
\hline Suborder Sphenisciform & hes & . & -. & .. & . & $\cdots$ & & 8 \\
\hline Family Spheniscidæ & . & . & .. & . & . & $\cdots$ & & 8 \\
\hline Genus Eudyptula & $\cdots$ & .. & . & . & $\cdots$ & $\cdots$ & & 8 \\
\hline Eudyptula minor & $\cdots$ & $\cdots$ & $\cdots$ & $\cdots$ & $\cdots$ & $\cdots$ & IX. & 9 \\
\hline Genus Eudyptes & $\cdots$ & . & $\cdots$ & -. & $\cdots$ & $\cdots$ & & 10 \\
\hline Eudyptes pachyrhyr & nchus & $\cdots$ & $\cdots$ & $\cdots$ & $\cdots$ & $\cdots$ & III. & 10 \\
\hline - serresianus & . & . & $\cdots$ & $\cdots$ & $\cdots$ & $\cdots$ & & 11 \\
\hline - schlegeli & $\cdots$ & $\cdots$ & $\cdots$ & $\cdots$ & . & $\cdots$ & & 12 \\
\hline Family Aptenodytidæe & $\cdots$ & $\cdots$ & $\cdots$ & $\cdots$ & $\cdots$ & $\cdots$ & & 12 \\
\hline Genus Aptenodytes & $\because$ & $\cdots$ & . & $\cdots$ & . & $\cdots$ & & 12 \\
\hline Aptenodytes patagon & nica & $\cdots$ & $\cdots$ & $\cdots$ & $\cdots$ & $\cdots$ & & 13 \\
\hline Subclass Euomithes & & $\cdots$ & $\cdots$ & - & $\cdots$ & $\cdots$ & & 13 \\
\hline Order Procellarize or ' $\mathrm{T}$ & ubinare & & -. & $\cdots$ & $\cdots$ & $\cdots$ & & 14 \\
\hline Suborder Procellariiform & mes & . & $\cdots$ & . & $\cdots$ & . & & 15 \\
\hline Superfamily Procellario & gidea & $\cdots$ & $\cdots$ & $\cdots$ & $\cdots$ & $\cdots$ & & 15 \\
\hline Family Thalassidromid & & $\cdots$ & $\cdots$ & $\cdots$ & $\cdots$ & $\cdots$ & & 15 \\
\hline Genus Oceanites & $\cdots$ & - & $\cdots$ & $\cdots$ & $\cdots$ & $\cdots$ & & 16 \\
\hline Oceanites oceanicus & & $\cdots$ & $\cdots$ & $\cdots$ & $\cdots$ & $\cdots$ & IV., VII. & 16 \\
\hline Genus Garrodia . : & $\cdots$ & $\cdots$ & $\cdots$ & $\cdots$ & $\cdots$ & $\cdots$ & & 17 \\
\hline Garrodia nereis & $\cdots$ & $\cdots$ & $\cdots$ & $\cdots$ & $\cdots$ & $\cdots$ & IV. & 17 \\
\hline Genus Pelagodroma & $\because$ & $\cdots$ & $\cdots$ & $\cdots$ & $\cdots$ & $\cdots$ & & 18 \\
\hline Pelagodroma marin & & $\cdots$ & $\cdots$ & $\cdots$ & $\cdots$ & $\cdots$ & IV., VII. & 18 \\
\hline Genus Fregetta :- & $\cdots$ & $\cdots$ & $\cdots$ & $\cdots$ & $\cdots$ & $\cdots$ & & 19 \\
\hline Fregetta tropica & $\cdots$ & $\cdots$ & $\cdots$ & $\cdots$ & $\cdots$ & $\cdots$ & IV., VII. & 20 \\
\hline tubulata & $\cdots$ & $\cdots$ & $\cdots$ & $\cdots$ & $\cdots$ & $\cdots$ & & 20 \\
\hline Genus Fregettornis & $\therefore$ & $\cdots$ & $\cdots$ & $\cdots$ & $\cdots$ & $\cdots$ & & 21 \\
\hline Fregettornis grallari & ous & $\cdots$ & $\cdots$ & $\cdots$ & $\cdots$ & $\cdots$ & IV. & 21 \\
\hline Family Procellariidæ & $\cdots$ & $\cdots$ & *. & $\cdots$ & .. & $\cdots$ & & 21 \\
\hline Genus Puffinus & $\cdots$ & $\cdots$ & $\cdots$ & $\cdots$ & $\cdots$ & $\cdots$ & V. V. & $\begin{array}{l}22 \\
23\end{array}$ \\
\hline Puffinus assimilis & $\cdots$ & $\cdots$ & .. & .. & $\cdots$ & $\cdots$ & & 23 \\
\hline
\end{tabular}


Genus Calonectris Calonectris leucomelas

Genus Reinholdia Reinholdia reinholdi

Genus Thyellodroma .. Thyellodroma pacifica

Genus Neonectris

$$
\text { Neoneclris griseus ... }
$$
tenuirostris

Genus Hemipuffinus Hemipufinus carneipes

Genus Procellaria Procellaria aquinoctialis _ conspicillata

Genus Adamastor Adamastor cinereus.. Genus Priocella .
Priocella antarctica ${ }^{\circ}$

Genus Pterodroma Pterodroma macroptera - melanopus - inexpectata mollis .

Genus Estrelata.. Estrelata lessonii

Genus Cookilaria Cookilaria cookii

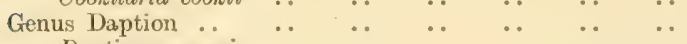

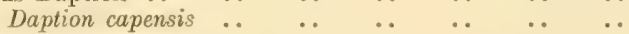

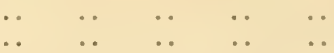

- $\quad \cdots \quad \cdots \quad \cdots \quad \cdots$

$\begin{array}{llll}\cdots & \cdots & \cdots & \cdots\end{array}$

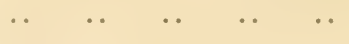

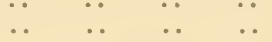

$\begin{array}{llll} & \cdots & \ldots & \ldots\end{array}$

\section{VI., VII.}

VI.

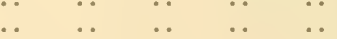

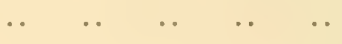

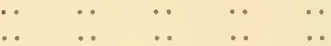

33

IV., VII. 33

VII. $\quad 36$

V. 37

V., VII. 37

$\begin{array}{lllllll}\text { Genus Halobæna } & \ldots & \ldots & \ldots & \ldots & \ldots & \ldots\end{array}$

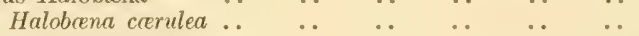

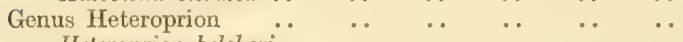

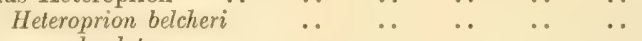

Genus Pseudoprion Pseudoprion turtur

Genus Pachyptila Pachyptila vittata $\ldots$

Genus Macronectes .. Macronectes giganteus

Family Pelecanoididæ ..

Genus Pelecanoides Pelecanoides urinatrix

Superfamily Diomedeoidea

Family Diomedeidx

Genus Phobetria

Phobetria fusca

․ $\quad$. $\quad$.

$\cdots$

.

$\begin{array}{lllll} & \cdots & \cdots & \cdots & \end{array}$

$\begin{array}{lllll}\text {. } & \ldots & \ldots & \ldots & \ldots\end{array}$

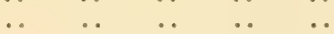

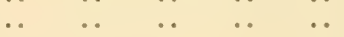

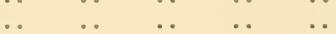

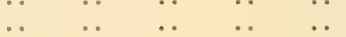

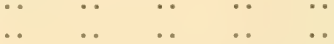

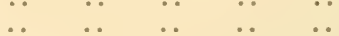

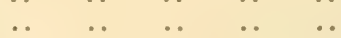

VI. 41

VI. 41

VI. 42

43

VI., VII. 43

IV. 45

VI., VII. 46

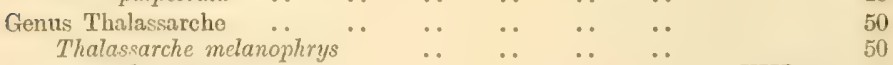

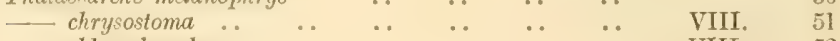

VIII. $\quad 52$ 
Genus Diomedella

PLATE PAGE

$\begin{array}{lllllll}\text { Diomedella caula } & \ldots & \ldots & \ldots & \ldots & \ldots & \ldots \\ \text { Di } & \ldots & \ldots & \ldots & \ldots & \ldots\end{array}$

VIII. 53

$\begin{array}{llllll}\text { Diomedea exulans } & \cdots & \ldots & \ldots & \ldots & \ldots\end{array}$

VII VIII 51

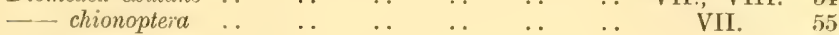

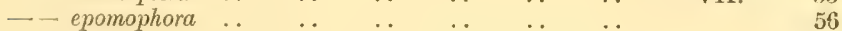

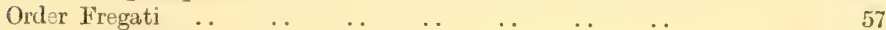

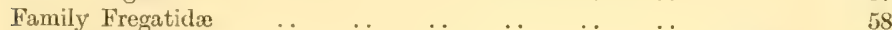

\begin{tabular}{lllllllll} 
Genus Fregata & $\ldots$ & $\ldots$ & $\ldots$ & $\ldots$ & $\ldots$ & $\ldots$ & $\ldots$ & \\
\hline
\end{tabular}

$\begin{array}{llllllll}\text { Fregata minor } & \ldots & \ldots & \ldots & \ldots & \ldots & \ldots & \text { IX. }\end{array}$

$\begin{array}{llllllllll}\text { Cariel } & \ldots & \ldots & \ldots & \ldots & \ldots & \ldots & \ldots & 60\end{array}$

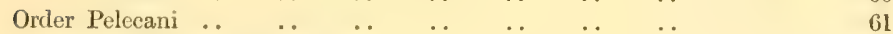

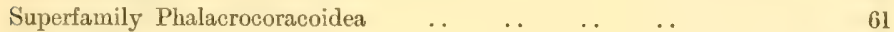

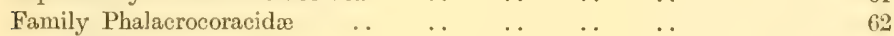

$\begin{array}{llllllll}\text { Genus Hypoleucus } & \ldots & \ldots & \ldots & \ldots & \ldots & \ldots & 62\end{array}$

$\begin{array}{llllllll}\text { Hypoleucus perlit .. } & \ldots & \ldots & \ldots & \ldots & \ldots & \text { XI. } & 63\end{array}$

— fuscescens $\quad \ldots \quad$ f

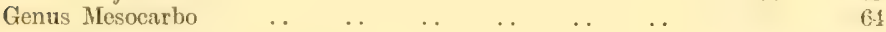

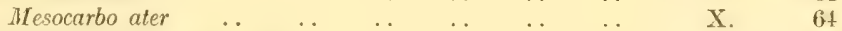

$\begin{array}{lllllll}\text { Genus Microcarbo } & \ldots & \ldots & \ldots & \ldots & \ldots & \ldots\end{array}$

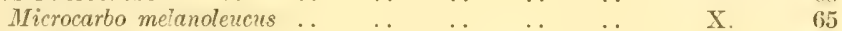

$\begin{array}{llllllll}\text { Genus Phalacrocorax } & \ldots & \ldots & \ldots & \ldots & \ldots & \ldots & \end{array}$

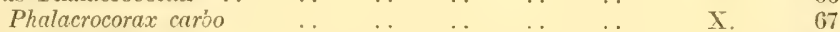

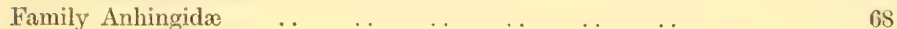

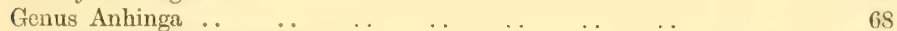

$\begin{array}{llllllll}\text { Anhinga novahollandia } & \ldots & \ldots & \ldots & \ldots & \ldots & \text { XI. } & 68\end{array}$

$\begin{array}{llllllll}\text { Superfamily Pelecanoidea } & \ldots & \ldots & \ldots & \ldots & \ldots & 69\end{array}$

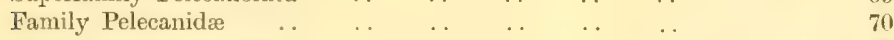

$\begin{array}{llllllll}\text { Genus Catoptropelicanus } & \ldots & \ldots & \ldots & \ldots & \ldots & 70\end{array}$

$\begin{array}{lllllll}\text { Catoptropelicanus conspicillatus } & \ldots & \ldots & \ldots & \ldots & \text { X. } & 70\end{array}$

$\begin{array}{llllllll}\text { Superfamily Suloidea } & \ldots & \ldots & \ldots & \ldots & \ldots & \ldots & 71\end{array}$

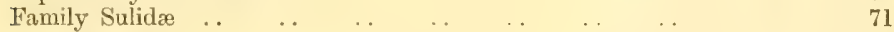

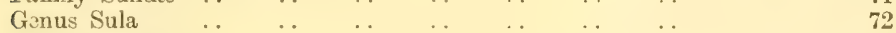

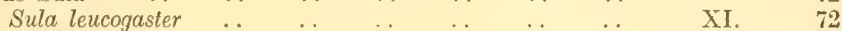

$\begin{array}{lllllllll}\text { Genus Piscatrix . . } & \ldots & \ldots & \ldots & \ldots & \ldots & \ldots & & 73\end{array}$

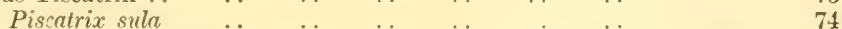

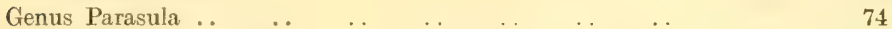

$\begin{array}{llllllll}\text { Parasula dactylatra.. } & \ldots & \ldots & \ldots & \ldots & \ldots & \text { XI. } & 75\end{array}$

$\begin{array}{lllllllll}\text { Genus Sulita } & \ldots & \ldots & \ldots & \ldots & \ldots & \ldots & \ldots & 76\end{array}$

$\begin{array}{lllllllll}\text { Sulita serrator } & \ldots & \ldots & \ldots & \ldots & \ldots & \ldots & \text { X. } & 76\end{array}$

$\begin{array}{lllllllll}\text { Order Lari } & \ldots & \ldots & \ldots & \ldots & \ldots & \ldots & \ldots & \\ \end{array}$

$\begin{array}{llllllll}\text { Suborder Phaëthontiformes } & \ldots & \ldots & \ldots & \ldots & \ldots & 77\end{array}$

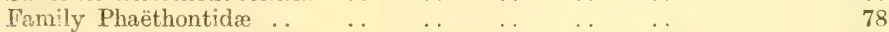

$\begin{array}{llllllll}\text { Genus Leptophaëthon } & \ldots & \ldots & \ldots & \ldots & \ldots & \ldots & 79\end{array}$

$\begin{array}{lllllll}\text { Leptophäthon lepturus } & \ldots & \ldots & \ldots & \ldots & \ldots & 79\end{array}$

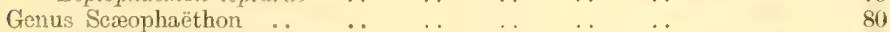

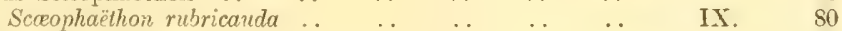

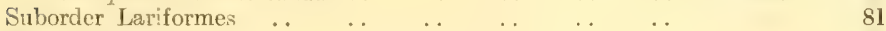

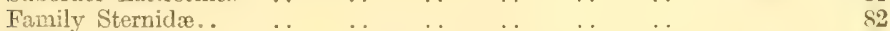

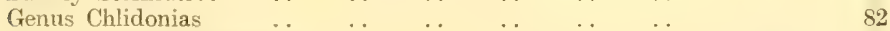

$\begin{array}{lllllll}\text { Chlidonias leucopareia } & \ldots & \ldots & \ldots & \ldots & \ldots & \\ \end{array}$

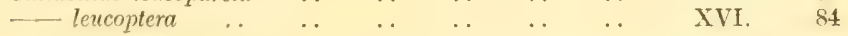




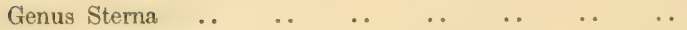

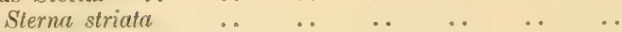

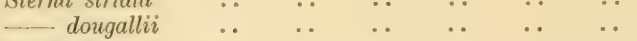

XII.

$\begin{array}{llllllll}\text { Genus Gygisterna } & \ldots & \ldots & \ldots & \ldots & \ldots & \ldots\end{array}$ Gygisterna sumatrana

XIV.

Genus

$\begin{array}{ccc}\text { Slernula albifrons } & \ldots & \ldots \\ \text { nereis .. } & \ldots & \ldots\end{array}$

Genus Pelecanopus Pelecanopus bergii .. P._. bengalensis

Genus Gelochelidon . Gelochelidon nilotica

Genus Hydroprogne Hydroprogne caspia

Genus Melanostema Melanosterna ancethetus

Genus Onychoprion Onychoprion fuscatus

Genus Megalopterus Megalopterus minutus

Genus Anous __. tenuirostris ..

Anous stolidus

Genus Procelsterna Procelsterna cerulea

Genus Leucanous

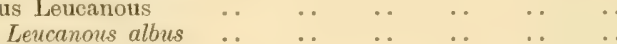

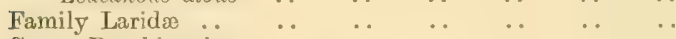

Genus Bruchigavia $\quad \ldots \quad$. Bruchigavia novahollandia

Genus Gabianus Gabianus pacificus ..

Family Stercorariidæe .

Genus Catharacta Catharacta lonnbergi

Genus Coprotheres Coprotheres pomarinus

Genus Stercorarius Stercorarius parasiticus

Suborder Charadriiformes

Superfamily Burhinoidea

Family Burhinidx

Genus Burhinus Burhinus magnirostris

Genus Orthorhamphus .. Orthorhamphus magnirostris

Superfamily Scolopacoidea

Family Rostratulid

Genus Rostratula Rostratula australis..

Family Scolopacidæ

$$
\begin{array}{lll}
\cdots & \cdots & \cdots \\
\cdots & \cdots &
\end{array}
$$

$$
\text { . }
$$$$
\text { .. }
$$$$
\text { . }
$$$$
\cdots
$$$$
\cdots
$$$$
\cdots
$$

XIII. 105

XII. $\quad 110$

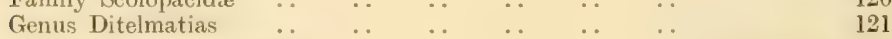

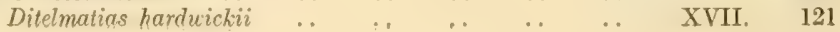


Genus Subspilura

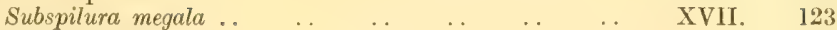

$\begin{array}{lllllllll}\text { Genus Calidris } & \ldots & \ldots & \ldots & \ldots & \ldots & \ldots & \ldots & \\ \end{array}$

$\begin{array}{lllllllll}\text { Calidris canutus } & \ldots & \ldots & \ldots & \ldots & \ldots & \ldots & \text { XIX. } & 124\end{array}$

$\begin{array}{llllllll}\text { Genus Anteliotringa } & \ldots & \ldots & \ldots & \ldots & \ldots & \ldots & \\ \end{array}$

$\begin{array}{lllllll}\text { Anteliotringa tenuirostris .. } & \ldots & \ldots & \ldots & \ldots & \text { XXII. } & 125\end{array}$

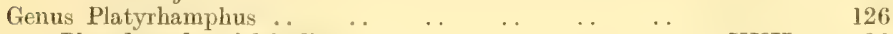

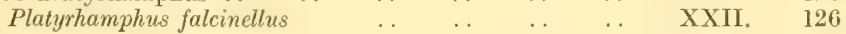

$\begin{array}{lllllllll}\text { Genus Erolia } & \ldots & \ldots & \ldots & \ldots & \ldots & \ldots & \ldots & 128\end{array}$

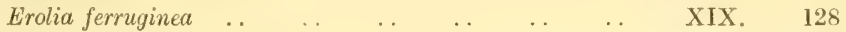

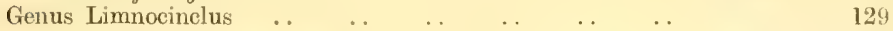

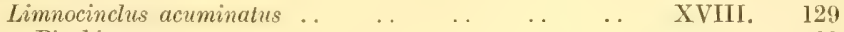

$\begin{array}{lllllllll}\text { Genus Pisobia } & \ldots & \ldots & \ldots & \ldots & \ldots & \ldots & \ldots & \end{array}$

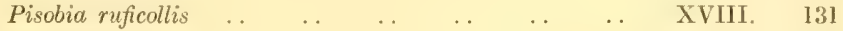

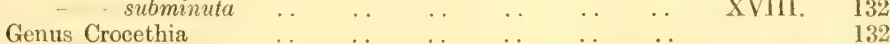

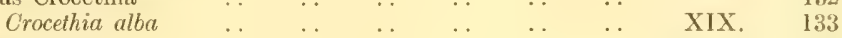

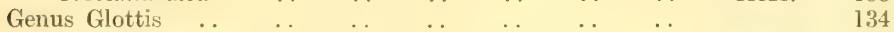

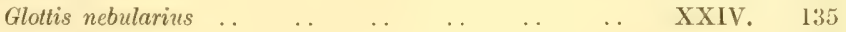

$\begin{array}{lllllllll}\text { Genus Iliornis } & \ldots & \ldots & \ldots & \ldots & \ldots & \ldots & \ldots & 136\end{array}$

$\begin{array}{lllllll}\text { Iliornis stagnatilis . } & \ldots & \ldots & \ldots & \ldots & \ldots & 136\end{array}$

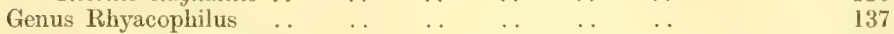

$\begin{array}{lllllll}\text { Rhyacophilus glareola } & \ldots & \ldots & \ldots & \ldots & \ldots & 138\end{array}$

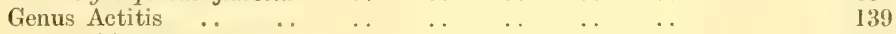

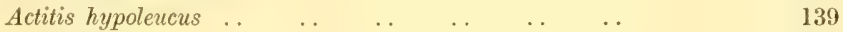

$\begin{array}{lllllllll}\text { Genus Terekia } & . & \ldots & \ldots & \ldots & \ldots & \ldots & \ldots & \\ 140\end{array}$

$\begin{array}{llllllll}\text { Terekia cinerea } & \ldots & \ldots & \ldots & \ldots & \ldots & \ldots & \text { XXIV. } 141\end{array}$

$\begin{array}{llllllll}\text { Genus Heteractitis } & \ldots & \ldots & \ldots & \ldots & \ldots & \ldots & 142\end{array}$

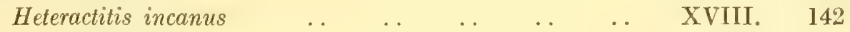

$\begin{array}{rllllllll}\text { Genus Bartramia } & \ldots & \ldots & \ldots & \ldots & \ldots & \ldots & \text { XVIII. } 143 \\ \end{array}$

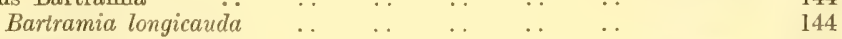

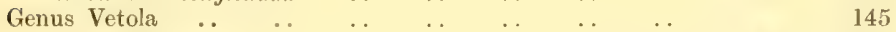

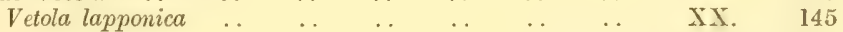

$\begin{array}{lllllllll}\text { Genus Limosa } & \ldots & \ldots & \ldots & \ldots & \ldots & \ldots & \ldots & \end{array}$

$\begin{array}{lllllllll}\text { Limosa limosa } & \ldots & \ldots & \ldots & \ldots & \ldots & \ldots & \text { XX. } & 147\end{array}$

$\begin{array}{llllllll}\text { Genus Mesoscolopax } & \ldots & \ldots & \ldots & \ldots & \ldots & \ldots & 149\end{array}$

$\begin{array}{llllllll}\text { Mesoscolopax minutus } & \ldots & \ldots & \ldots & \ldots & \ldots & \text { XIX. } & 149\end{array}$

$\begin{array}{llllllll}\text { Genus Phæopus .. } & \ldots & \ldots & \ldots & \ldots & \ldots & \ldots & 150\end{array}$

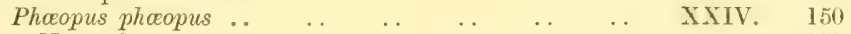

$\begin{array}{llllllll}\text { Genus Numenius } & \ldots & \ldots & \ldots & \ldots & \ldots & \ldots & 151\end{array}$

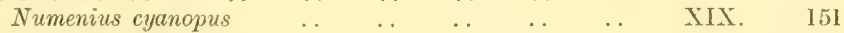

$\begin{array}{llllllll}\text { Family Recurvirostridæ } & \ldots & \ldots & \ldots & \ldots & \ldots & 152\end{array}$

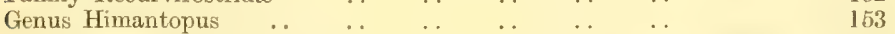

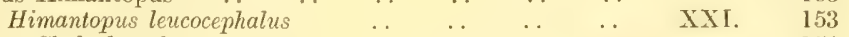

$\begin{array}{lllllll}\text { Genus Cladorhynchus . } & \ldots & \ldots & \ldots & \ldots & \ldots & 154\end{array}$

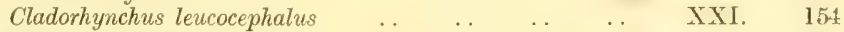

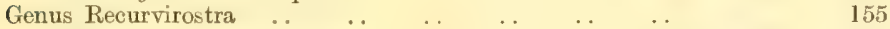

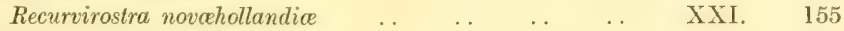

$\begin{array}{llllllll}\text { Superfamily Charadrioidea } & \ldots & \ldots & \ldots & \ldots & \ldots & 156\end{array}$

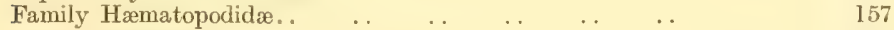

$\begin{array}{llllllll}\text { Genus Hæmatopus } & \ldots & \ldots & \ldots & \ldots & \ldots & \ldots & 157\end{array}$

$\begin{array}{lllllllll}\text { Homatopus ostralegus } & \ldots & \ldots & \ldots & \ldots & \ldots & \text { XVI. } & 157\end{array}$

$\begin{array}{llllllll}\text { unicolor } & \ldots & \ldots & \ldots & \ldots & \ldots & \ldots & \\ \end{array}$ 
Family Arenariidxe

PLATE

Genus Arenaria. Arenaria interpres.

Family Charadrida

Genus Squatarola Squatarola squatarola

Genus Pluvialis . Pluvialis dominicus

Genus Cirrepidesmus Cirrepidesmus mongolus

Genus Nesoceryx Nesoceryx bicinctus

Genus Pagoa Pagoa leschenaultii

Genus Leucopolius Leucopolius ruficapillus

Genus Charadrius Charadrines cucullatus

Genus Eupodella Eupodella vereda

Genus Elseyormis Elseyornis melanops

Family Vanellidx

Genus Lobibyx .. Lobibyx miles noverhollandice

Genus Zonifer Zonifer tricolor

Genus Erythrogonys . Erythrogonys cinctus

Superfamily Jacanoidea

Family Jacanidæ

Genus Irediparra Irediparra gallinacea

Superfamily Glareoloidea

Family Glareolidx

Genus Glareola .. . Glareola maldivarum

Genus Stiltia Stiltia isabella

Genus Peltohyas.. Peltohyas australis

Suborder Otidiformes

Family Otididæ ..

Genus Austrotis .. Austrotis australis

Order Psophii or Grues

Suborder Psophiiformes

Family Balearicidx

Genus Mathewsena Mathewsena rubicunda

Order Ralli

Suborder Ralliformes .

Family Rallidæ.. 
Genus Rallus $\quad \ldots \quad$.

PLATE PAGE

$\begin{array}{lllllll}\text { Rallus pectoralis } & \ldots & \ldots & \ldots & \ldots & \ldots & \end{array}$

XXVI. 191

Genus Tomirdus

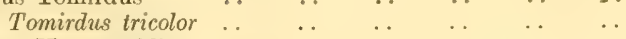

XXVI. $\quad 192$

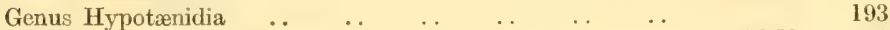

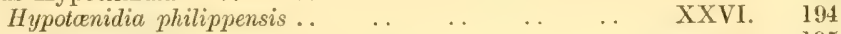

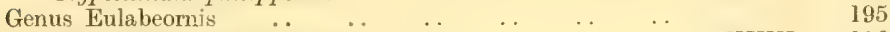

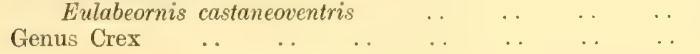

XXVI. $\quad 196$

196

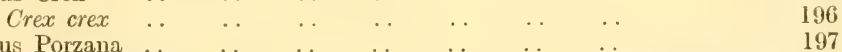

$\begin{array}{rllllllll}\text { Genus Porzana . } & \ldots & \ldots & \ldots & \ldots & \ldots & \ldots & 197 \\ \text { Porzana fluminea } & \ldots & \ldots & \ldots & \ldots & \ldots & \ldots & \text { XXVII. } & 198\end{array}$

$\begin{array}{llllllll}\text { Genus Zapornia . . } & \ldots & \ldots & \ldots & \ldots & \ldots & \ldots & 199\end{array}$

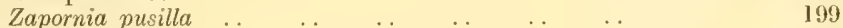

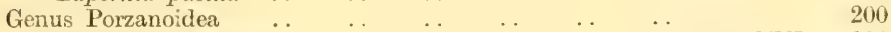

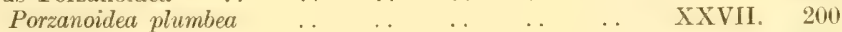

$\begin{array}{llllllll}\text { Genus Poliolimnas } & \ldots & \ldots & \ldots & \ldots & \ldots & \ldots & \\ \end{array}$

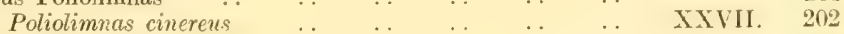

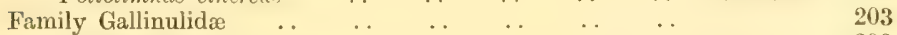

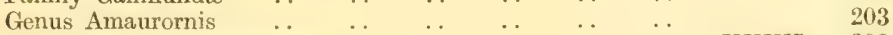

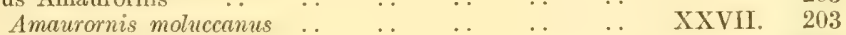

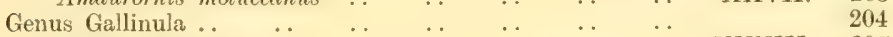

$\begin{array}{lllllll}\text { Gallinula tenebrosa } & \ldots & \ldots & \ldots & \ldots & \ldots & \text { XXVIII. } 205\end{array}$

$\begin{array}{llllllll}\text { Genus Mierotribonyx } & \ldots & \ldots & \ldots & \ldots & \ldots & \ldots & 205\end{array}$

$\begin{array}{lllllll}\text { Microtribonyx ventralis } & \ldots & \ldots & \ldots & \ldots & \ldots & \text { XXVII. } 206\end{array}$

$\begin{array}{llllllll}\text { Genus Tribonyx } & \ldots & \ldots & \ldots & \ldots & \ldots & \ldots & 207\end{array}$

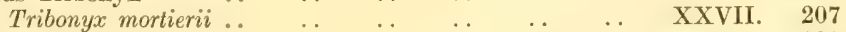

\begin{tabular}{lllllllll} 
Genus Porphyrio & $\ldots$ & $\ldots$ & $\ldots$ & $\ldots$ & $\ldots$ & $\ldots$ & & \\
\hline
\end{tabular}

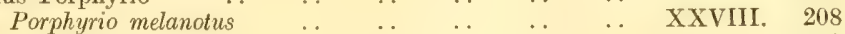

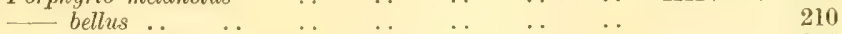

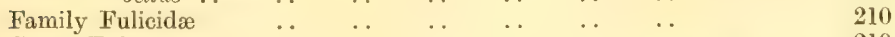

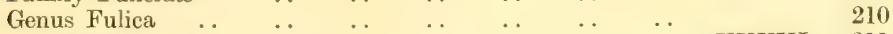

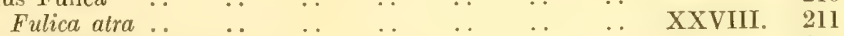

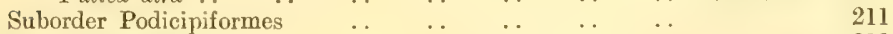

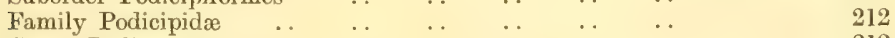

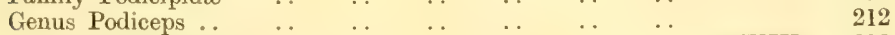

$\begin{array}{llllllll}\text { Podiceps cristatus } & \ldots & \ldots & \ldots & \ldots & \ldots & \ldots & \text { XXIX. } 213\end{array}$

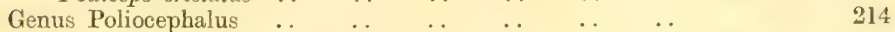

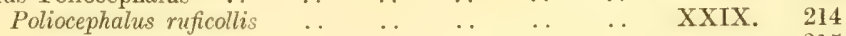

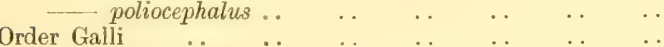

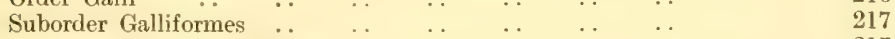

$\begin{array}{lllllll}\text { Superfamily Megapodioidea } & \ldots & \ldots & \ldots & \ldots & \ldots & 217\end{array}$

$\begin{array}{llllllll}\text { Family Megapodidæ } & \ldots & \ldots & \ldots & \ldots & \ldots & \ldots & 218\end{array}$

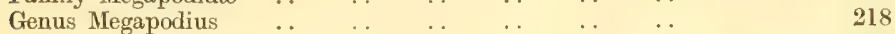

$\begin{array}{lllllll}\text { Megapodius reinwardt } & \ldots & \ldots & \ldots & \ldots & \ldots & \text { XXX. } \\ 218\end{array}$

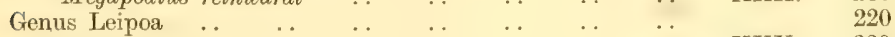

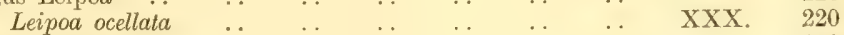

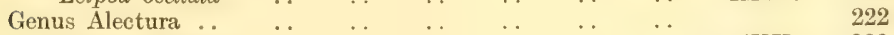

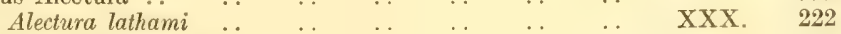

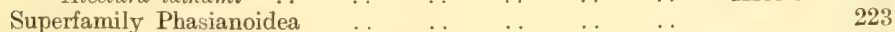

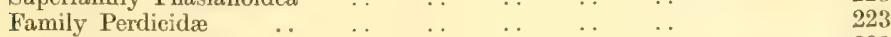

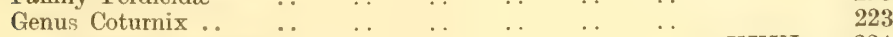

$\begin{array}{lllllll}\text { Coturnix pectoralis.. } & \ldots & \ldots & \ldots & \ldots & \ldots & \text { XXXI. } 224\end{array}$ 


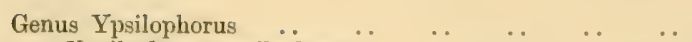

PLATE PAGE

Ypsilophorus ypsilophorus $\quad \ldots \quad \ldots \ldots$

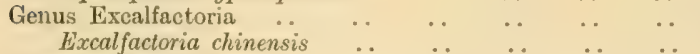

XXXI. 226

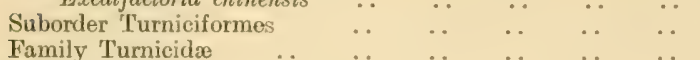

XXXI

$\begin{array}{llllllll}\text { Genus Turnix } & \ldots & \ldots & \ldots & \ldots & \ldots & \ldots & \ldots\end{array}$ $\begin{array}{lllllll}\text { Turnix maculosa } & \text {.. } & \text {. } & \text {. } & \text {. } & \text {.. } & \text {.. }\end{array}$

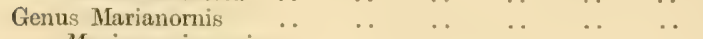
$\begin{array}{llllll}\text { Marianornis zarius } & \ldots & \ldots & \ldots & \ldots & \ldots\end{array}$

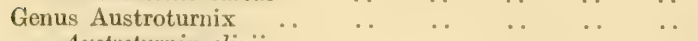
$\begin{array}{llllll}\text { Austrolurnix olivii .. } & \text {. } & \ldots & \ldots & \ldots & \ldots\end{array}$

$\begin{array}{lllllll}\text { castanota } & \ldots & \ldots & \ldots & \ldots & \ldots & \ldots \\ \text { Genus Alphaturnia } & \ldots & \ldots & \ldots & \ldots & \ldots & \ldots\end{array}$

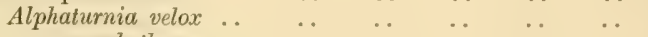

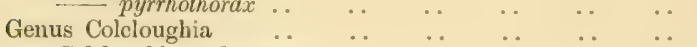

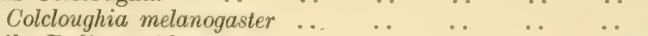

Family Pedionomid $x \quad$.

$\begin{array}{lllllll}\text { Genus Pedionomus } & \ldots & \ldots & \text {. } & \text {. } & \text {. } & \text {.. }\end{array}$ $\begin{array}{llllll}\text { Pedionomus torquatus } & \ldots & \ldots & \ldots & \ldots & \text {.. }\end{array}$

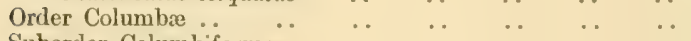

$\begin{array}{llllll}\text { Suborder Columbiformes } & \ldots & \ldots & \ldots & \ldots & \ldots\end{array}$

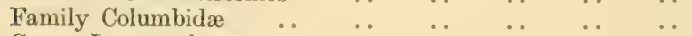

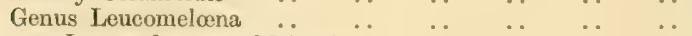

Genus Lacomeloena norfolciensis

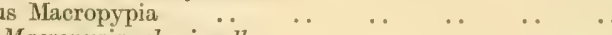

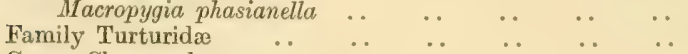

$\begin{array}{lllllll}\text { Genus Chrysauchœna } & \ldots & \ldots & \ldots & \ldots & \ldots & \ldots\end{array}$

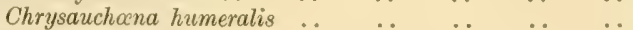

Genus Geopelia .. $\begin{array}{lllllll}\text { Geopelia placida } & \ldots & \ldots & \ldots & \ldots & \ldots & \ldots\end{array}$

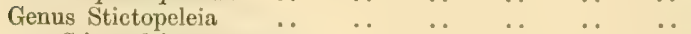

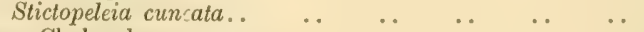

$\begin{array}{lllllll}\text { Genus Chalcophaps } & \ldots & \ldots & \ldots & \ldots & \ldots & \text {.. }\end{array}$

Genus Phaps Chalcophaps chrysochlora

\section{Gent} . $\quad$. $\quad$. $\begin{array}{ccccccc}\text { Phaps chalcoptera } & \ldots & \ldots & \ldots & \ldots & \ldots & \\ \text { Genus Cosmopelia } & \ldots & \ldots & \ldots & \ldots & \ldots & \end{array}$ $\begin{array}{llllll}\text { Cosmopelia elegans } & \ldots & \ldots & \ldots & \ldots & \end{array}$

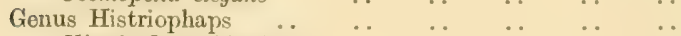
Histriophaps histrionica

Genus Petrophassa Petrophassa albipennis

Genus Geophaps Geophaps scripta

$\begin{array}{llllll}\text { Genus Lophophaps } & \ldots & \ldots & \ldots & \ldots & \ldots\end{array}$ 230
231

XXXII. 231

XXXII 233

XXXII 234

235

XXXII. 235

XXXII. $\quad 236$

237

XXXII. 238

239

239

XXXI. 239

240

241

242

242

XXXIII. 242

243

XXXIV。 243

244

245

XXXIII. 245

246

XXXIII. 247

247

XXXIV。 248

249

XXXir. 251

XXXIII. 251

252

252

253

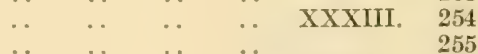

XXXIV. 255

․ 256

.. 256

. XXXV. 257

.. XXXV. 258

․ 259

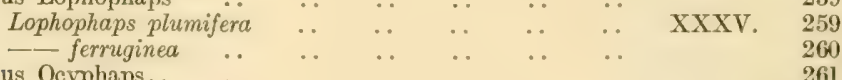

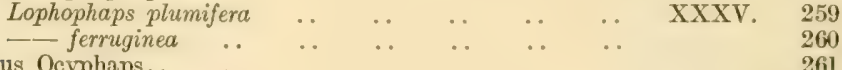

$\begin{array}{ccccccccc}\text { Genus Ocyphaps.. } & \cdots & \ldots & \ldots & \ldots & \ldots & \ldots & & 261 \\ \text { Ocyphaps lophotes } & \cdots & & \ldots & \ldots & \ldots & \ldots & \ldots & \text { XXXIV. }\end{array}$ 


\begin{tabular}{|c|c|c|c|c|c|c|c|}
\hline & & & & & & PLATE & PAGE \\
\hline Genus Loucosarcia $\quad$. & . & $\cdots$ & $\cdots$ & . & . & & 262 \\
\hline Leucosarcia melanoleuca & .. & .. & . & . & .. & XXXIV. & 262 \\
\hline Family Treronidæ .. & .. & .. & .. & . & $\ldots$ & & 263 \\
\hline Genus Ptilinopus & . & . & . & . & . & & 263 \\
\hline Plilinopus regina .. & . & $\ldots$ & . & . & . & XXXVI. & 264 \\
\hline __ superous & .. & . & $\ldots$ & . & . & & 265 \\
\hline Genus Megaloprepia & .. & . & .. & . & $\cdots$ & & 266 \\
\hline Megaloprepia magnifica & .. & . & . & . & .. & XXXV. & 267 \\
\hline Genus Leucotreron & .. & . & .. & . & . & & 267 \\
\hline Leucotreron alligator & .. & .. & $\cdots$ & . & .. & XXXVI. & 268 \\
\hline Genus Myristicivora . . & .. & . & . & . & . & & 268 \\
\hline Myristicivora bicolor & . & . & . & . & . & XXXV. & 269 \\
\hline Genus Globicera & . & . & . & . & . & & 269 \\
\hline Globicera pacifica . & . & $\cdots$ & . & . & - & XXXV. & 270 \\
\hline … rubricera & . & . & . & $\cdots$ & .. & & 270 \\
\hline Genus Lopholaimus & . & .. & . & .. & . & & 271 \\
\hline Lopholaimus antarcticus & . & .. & . & . & $\cdots$ & XXXVI. & 271 \\
\hline
\end{tabular}

\section{LIST OF COLOURED PLATES.}

Plato 1. Eudyptes pachyrhynchus (Big-crested Penguin). Eudyptes serresianus (Yellow-crested Penguin). Aptenodytes patagonica (King Penguin).

, 2. Bill features of Mollymawks and Albatrosses :-

1, Thalassarche melanophris (Black-browed Mollymawk). 2, Thalassarche chrysostoma (Grey-headed Mollymawk). 3, Thalassarche chlororhynchus (Yellow-nosed Mollymawk). 4, Diomedella cauta (White-capped Albatross). 5, Phobetria fusca (Sooty Albatross). 6, Phobetria palpcbrata (Lightmantled Sooty Albatross).

„, 3. 1, Caspian Tern. 2, 3, White Tern. 4, White-capped Noddy. 5, Lesser Crested Tern. 6, Roseate Tern. 7, Grey Noddy. 8, Gull-billed Tern. 9, Noddy. 10, White-faced Ternlet. 11, 12, Sooty Tern. 13, Bridled Tern.

„, 4. 1, Winter plumage of Lesser Crested Tern (Pelecanopus bengalensis). 2, Immature of White-faced Ternlet (Sternula nereis). 3, Immature of Whiskered Tern (Chlidonias leucopareia). 4, Immature of Gull-billed Tern (Gelochelidon nilotica). 5, Immature of White-fronted Tern (Sterna striata).

5. 1, Nestling of Whiskered Tern (Chlidonias leucopareia). 2, Nestling of White-faced Ternlet (Sternula nereis). 3, Nestling of Roseate Tern (Sterna dougallii). 4, Nestling of Pacific Gull (Gabianus pacificus).

., 6. 1, Nestling of Black-fronted Dotterel (Elseyornis melanops). 2, Nestling of Red-capped Dotterel (Leucopolius ruficapillus). 3, Nestling of Black-breasted Plover (Zonifer tricolor). 4, Nestling of Spur-winged Plover (Lobibyx novøhollandice). 
Plate 7. 1, Nestling of Stone Plover (Burhinus magnirostris). 2, Nestling of Avocet (Recurvirostra avosetta). 3, Nestling of Pied Oystercatcher (Homatopus ostralegus). 4, Immature of Lotus Bird (Irediparra gallinacca).

8. 1, Nestling of Noddy (Anous stolidus). 2, Nestling of White-capped Noddy (Megalopterus minutus). 3, Nestling of Tippet Grebe (Podiceps cristatus). 4, Nestling of Black-throated Grebe (Poliocephalus ruficollis).

„9. 1, Nestling of Bald Coot (Porphyrio melanolus). 2, Nestling of Black Moorhen (Gallinula tenebrosa). 3, Nestling of Black-tailed Water Hen (Microtribonyx ventralis). 4, Nestling of Coot (Fulica atra).

„10. 1, 2, Nestling of King Quail (Excalfactoria chinensis). Australian and extra-limital forms. 3, Nestling of Stubble Quail (Coturnix pectoralis). 4, Nestling of Painted Quail (Marianornis varius).

In this Volume the following subspecies have been named as new :Eudyptes serrecianus moseleyi: Tristan d'Acunha Group .. .. 11 - interjectus: Kerguelen Island .. Heteroprion desolatus alexanderi: West Australia $\quad \ldots \quad \ldots \quad \ldots \quad \ldots \quad 42$ Phoebetria palpebrata murphyi : South Georgia . $\quad \ldots \quad \ldots \quad \ldots \quad \ldots \quad 50$

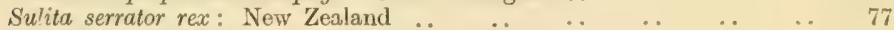

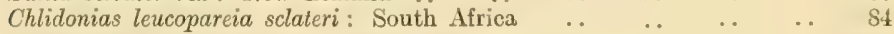

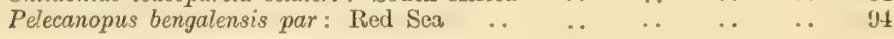




\title{
A MANUAL \\ OF THE BIRDS OF AUSTRALIA.
}

\author{
Cluass AVES.
}

Three subclasses are admitted in this class, all of which are represented in the Australian Ornis ; these are the Dromæornithes, the huge flightless forms previously known as Ratita or Palæognatha; the Impennes or Penguins; and the Euornithes, or normal flying birds.

All existing birds are clothed with feathers, have two wings, a tail, two legs and a horny-covered beak. In a few cases the wings have degenerated and become flightless, only remnants being recognisable, in a few others the wings have become specialised into swimming paddles-in the majority they are very noticeable and capable of flight. In a few instances the tail has become almost obsolete, and in these instances the flying power of the birds is generally lessened ; in others, the tail has become extremely lengthened and generally this is associated with greater powers of flight. Though two legs are absolutely constant, the number of toes varies, four heing the general number, three not uncommon, two in one case only, and no reduction to one is yet known, nor are five met with in nature. The legs may be so short as to be almost useless for walking purposes, or they may be so extremely long as to seem disproportionate. The beak shows many modifications in different ways, according to the feeding methods of the birds. Birds have been generally classified by the variations in these characters, and by means of judicial consideration of all these a fair appreciation of the relationships may be attained. When the results are checked by means of osteological and anatomical research we may prepare a definite system of arrangement with due deference to phylogenetic considerations. As all the subclasses are represented, we refer to the detailed figures and descriptions given throughout the work for amplification of the items above mentioned.

\section{SUBCLASS DROMAEORNTHES.}

This subclass is composed, as to recent birds, of three orders: Struthiones, Rher and Casuarii. The former is confined to Africa and the Syrian Desert, the second to South America, and the last named to the Papuasia-Australian Region. The differences between the orders are so marked that a very close relationship might be justifiably denied. As a matter of fact many more differential features can be cited than characters proving alliance, and it is now being aecepted that these may represent specialised forms. Superficially they are all very large birds with stout bodies, long necks and long stout legs, but no wings capable of flight, or distinet tail. The order Casuarii only interests us, as to discuss its non-affinity with the others would occupy too much space in a work like this.

\section{ORDER CASUARII,}

This is coequal with the suborder Casuariformes which covers two families, Dromiceiidx and Casuariidæ. These are superficially easily distinguished by the 
latter bearing a more or less strongly developed helmet, peculiar hollow spines as the wing feathers and a peculiarly developed immer elaw, and also having the head bare and fleshy wattles on the neck. The superficial features are described under the generic names, so we may just cite the known internal characters. Osteologically tho skull is dromeognathous, a term introrluced by Huxley, for the stylo of palatal formation found in connection with these birds, but which has proved to be of less value than was anticipated, as a similar state occurs in the Tinamous and Kiwi which have no near relationship. It may be noted that Huxley separated the Ratite fron the Carinate birds, and then divided the latter by means of the palate, providing dromreognathous for the Tinamous on aecount of their perfectly Struthious palate, and since then the term has been used in connection with the Struthious birds. The nasals are holorhinal and the basipterygoid processes are rery large and peculiar, articulating with the pterygoids at their extreme end, instead of half-way along, as commonly in the higher groups. The lachrymals show a foramen in the descending process. There is no fureula, only rudimentary clavicles being present, the coracoids fused with the seapula and the sternum has no keel; there are twenty cervical vertebre in Dromiceius, and eighteen or nineteen in Casuarius. The pelvis is peculiar, there being $n o$ osseous connection between the pubes and ischia and ilium. There are two carotid arteries and the digestive system is considered to represent the lowest avian type of coiling. The syrinx is indistinct, showing no pessulus or intrinsic musculature, a peculiar modification being seen in comnection with Dromiceius. The leg muscle formula is complete, being $\mathrm{ABXY}+$, while the biceps slip is absent. The oil gland is missing and the aftershaft is remarkably long, nearly the same length as tho main feather. The pterylosis is not well known, while the nestlings are striped, the down being of a peculiar hair-like texture. Fossil remains in Australia may be accredited to ancestral forms of this group, such as Genyornis newtoni suggested as a gigantic Emu-like form.

\section{SUborder CASUARIIFORMES.}

\section{FAMTLX DROMICEIID无.}

Characters as of the genus Dromiceius below, save that in size and proportions the extinct genus Peronista differed. We have no record of any other details in connection with the latter. We should note that there is a singular opening in the front of the windpipe, communicating with a tracheal pouch, which has a literature of its own and varied conjectures as to its usage, but this item has been entirely neglected by recent field observers.

\section{Genus DROMICEIUS.}

Dromiceius Vieillot, Analyse nouv. Ornith., p. 54, April 14th, 1816. Typo (by monotypy): Casuarius novchollandice Latham. Also spelt Dromaius on p. 70.

Tachea Fleming, Philos. of Zool., Vol. II., p. 257, June 1822. Typo (by monotypy): Casuarius notchollandice Latham.

Emou Griffith and Pidgeon's ed. Cuvier's Anim. Kingd., Vol. VIII, p. 443, "1829 " [? 1830],

New name for Dromaius Vieillot.

Large Dromæonithes with small heads, long necks, strong bodies, minute flightless wings, no tail, very stout legs and feet, three toes but no hind-toe. The bill is as long as head, the culmen ridge pronounced and narrow, the shape is elongately triangular, the sides sloping behind the nostrils, which are placed a little in front of the middle, flattened anteriorly. The nostrils are oblique slits. The under mandible is very shallow, the rami sloping slightly, the interramal space large and sparsely feathered; there is a narrow strip between the two rami at the tip. The 
head is small and completely feathered. The wing is very small with a long sharp claw but few short feathers similar to those on the body with no differentiated quills. There are no differentiated tail-feathers. The legs are very long and stout, feathered to the tarsal joint; the tarsus covered with scales of various sizes, those in front small hexagonal ones save at lower portion where a few large horizontal scutes occur which are separated from the pronounced scutes of the toes by minute hexagonal scales, those at the back develop into pointed protuberances. The middle toe is much longer than the inner and outer which are subequal, all bearing stout short claws. There is no hind-toe or claw. The feathers have the shaft and aftershaft of equal length. Adult coloration uniform. The downy young has a peculiar striped coloration and in structure shows the general adult features except that the claw of the inner toe is disproportionately lengthened, which character does not persist in the adult. Confined to Australia and Tasmania.

\section{Dromiceius novæhollandiæ.-EMU.}

Gould, Vol. VI., pl. 1. (pt. xxxmI.), Dec. Ist, 1848. Mathews, Vol. I., pt. 1, pls. 1 and 2, Oct. 31st, 1910.

Casuarius novahollandia Latham, Index Ornith., Vol. II., p. 665, (before Dec. 9th) 1790 : Sydney, New South Wales.

Casuarius a ustralis Shaw and Nodder, Nat. Miscell., Vol. III., pl. 99, April 1st, 1792 : Sydney, New South Wales.

Dromaius ater Vieillot, Nouv. Dict. d'Hist. Nat., Vol. X., p. 212, June 21st, 1817: New name for $C$, novcehollandice Latham.

Dromiceus emu Stephens, in Shaw's Gen. Zool., Vol. XIV., p. 307, pl. 39, 1826 (late) : Sydney, New South Wales.

Dromaus irroratus Bartlett, Proc. Zool. Soc. (Lond.), 1859, p. 205, Oct. 1st: interior of New South Wales.

Dromaus diemenensis Le Souëf, Bull. Brit. Ornith. Club, Vol. XXI, p. 13, Oct. 29th, 1907 : Tasmania.

Dromiceius novchollandice woodwardi Mathews, Nov, Zool., Vol. XVIII., p. 175, Jan. 31st, 1912 : Strelley River, mid-West Australia.

Dromiceius novahollandia rothschildi Mathews, ib. : Gracefield, South-west Australia.

Distribution.-Australia : Except the scrub country from Cardwell to Lloyds Bay, North Queensland. [Tasmania. Extinct.]

Adult.-General colour above blackish, the feathers being brown or ashy-brown, the shafts and the ends of the feathers black, giving the general tone to the uppersurface; sides of the body lighter than the back; the feathers of the lower back and rump very long and spine-like, black in the centre and rufescent on the margins ; sides of body grey, with black shaft-lines and ends to the feathers, imparting a spotted appearance; crown of head with long hairy crest-plumes, black, like the upper hind-neck; lower hind-neck light ashy-brown, with black shaft-lines and tips to the feathers; lores, eyelid, sides of face and sides of neck bare and of a bluish-white colour, with a few hair-like bristles; ear-corerts hidden with black bristly plumes, which also conceal the cheeks, but in a less degree; throat smoky-grey, the chin bare. The feathers of the neck for about half-way down from the head are short and hair-like, joining the other feathers abruptly. This gives the bird the appearance of having a ruff. This ruff is whitish in very old birds. Iris hazel; legs brownish-black; bill blackish (life). Total length about $183 \mathrm{~cm}$.; bill from gape $115 \mathrm{~mm}$., tarsus 355, middle toe and claw 200.

Adult female.-The general colour above is ashy-grey ; the feathers of the back are linear in shape and tipped with black or reddish-brown, which gives a streaked appearance to the upper side; the sides of the body and feathers of the wings are grey ; the feathers of the lower back, rump, and tail are more elongated and disintegrated, being of a pale brown intermixed with a dark shade of the same colour; 
the head and neck are covered with short, down-like plumes, which are black on the crown and hind-neck, somewhat paler on the sides of face, and ashy-grey or whitish with minute black, hair-like points on the throat and fore-neck; the undersurface of the body is grey, paler than that of the upper-surface, the feathers being shorter on the breast and abdomen, but becoming longer on the under tail-coverts, which are darker in colour, stiffer in texture and more disintegrated, like those of tho tail. Total length about $167 \mathrm{~cm}$.; culmen $95 \mathrm{~mm}$, tarsus 355 , middle too and claw 145. (Description of type of $D$. diemenensis Le Soü̈.)

A second example of this species in the British Museum is similar in colour of plumage, but not quite so dark on the sides of face and ear-coverts. It also shows some slight variations in the measurements. Culmen $97 \mathrm{~mm}$., tarsus 325 , middlo toe and claw 153. (Paratype with above.)

Immature (above half grown).-General colour above greyish-brown, all the feathers having whitish hair-like ends ; the feathers on the lower hind-neck and down the middle of the back are blackish, and impart a more or less streaked appearance; on the lower back, rump and tail the feathers are much more disinterrated, and are brown and white in colour ; the head and neck all round (including the lower foreneck) are covered with short black feathers, more thickly on the crown of the head and more sparsely on the neck; a longitudinal line of white feathers on the middle of the chin and throat and a few intermingled on the fore-head and sides of head; the remainder of the under-surface silvery-grey, all the feathers more or less intermixed with brown. Total length about $92 \mathrm{~cm}$; culmen $53 \mathrm{~mm}$., tarsus 228 , middle toe and claw 95. Nathews examined tho supposed "Black Emu "in the Liverpool Museum, and finds it is undoubtedly an immature of the eastern form ; it has the head and half the neck black, rest of plumage the ordinary grey-brown of the immature, the bases of the feathers moro silvery-grey ; it is darker towards the tail ; there are new black feathers appearing on the mantle; it is mounted and a little dirty. There are eleven large scutes on the front lower tarsus; fourteen on the middle toe, eight on the outer toe and eight on the inner toe. Space round the eye and lores bare. Total length $1,120 \mathrm{~mm}$; bill from tip to gape $\$ 5$, culmen 40 , tarsus 220 , middlle toe without claw 80, height (as mountell) to back $680 \mathrm{~mm}$., to top of head $980 \mathrm{~mm}$. Presented by Captain Mathews, S.S. Great Britain, March 24 th, 1854 .

Chick.-Covered with down of a sooty-black colour, and with longitudinal lines of white running from hinder part of the crown to the end of the body and down the thighs, giving a broadly striped appearance, with whitish hair-like tips; head similar in colour, but the dark portion blacker, with intensely black hair-like tips, the white interspaces tending rather to cross-bars ; sides of face, throat and fore-neck similar, but the white increasing in proportion to the black in longitudinal lines towards the abdomen, which is entirely white or whitish. Total length about $30.5 \mathrm{~cm}$. ; culmen $23 \mathrm{~mm}$., tarsus 58 , middle toe and claw 35 .

Nest.-A flat bed, composed of grass, bark, pieces of sticks, leaves, etc., trampled together by the bird, sometimes merely an unlined depression in the ground.

Eggs.-Clutch, avorage nine, from seven to eighteen; elliptical to swollen orals, finely granulated, the granulations dark metallic-green, the hollows paler; axis $125-140 \mathrm{~mm}$., diameter $82-90 \mathrm{~mm}$.

Breeding-season.-April to November.

Incubation-period.-About fifty-six days.

Distribution and forms.-Australia (and Tasmania, now extinct). Three mainland forms can be distinguished: $D . n$. novchollandice (Latham), from New South IVales; D.n. woodwardi ILathews, from North-west Australia, in its lighter coloration and more slender legs; and $D$. n. rothschildi Mathers, from Sonth-west Australia, in its darker coloration throughout and in having dark bases to the feathers. The rxtinct Tasmanian race, $D . n$. diemenensis Lo Souif, had apparently white throats. 


\section{Genus PERONISTA.}

Peronista Mathews, Austral Av. Rec., Vol. I., pt. 5, p. 107, Dec. 24th, 1912. Type (by original designation): Dromaius peroni Rothschild.

Dwarf Emus with small bills, stout legs, and long toes. This extinct form, apparently confined to Kangaroo Island, had a shorter bill, and shorter legs, though apparently the toes were almost the same length, therefore comparatively much longer. The tarsus is just three times as long as bill and less than twice as long as middle toe and claw, whereas in Dromiceius the tarsus is nearly four times as long as the culmen and much more than twice as long as the middle toe and claw. In addition, the feathering is said to differ in nature, so that the above name should be used in order to lieep in view the peculiarities present, that they may be investigated.

Coloration uniform.

\section{Peronista peroni.-DWARF EMU.}

Mathews, Vol, I., pt. 1, pls. 3 and 4 ? Oct. 31 st, 1910.

Dromaius peroni Rothschild, Extinct Birds, p. 235, pl. 40, 1907 : Kangaroo Island.

Dromaius parvulus Mathews, Birds Austr., Vol. I., pt. 1, p. 19, Oct. 31st, 1910 ; ex Gould, Penny Cyclop., Vol. XXIII., p. 145, 1842. Nom. nud.: Kangaroo Island.

? Dromiceius spenceri Mathews, Nov. Zool., Vol. XVIII., p. 176, Jan. 31st, 1912 [King Island $=$ ] Kangaroo Island.

Distributiox.-Kangaroo Island, off South Australia. (Extinct. Only one skin known.)

Adult,-The top of the head is covered with a crest of recurved feathers, which is continued on to the occiput and nape, in a band of similar but slightly longer feathers. These feathers differ in their woolly nature and their black colour from the brownish hair-like feathers, and the rather short curly feathers which cover the abdomen and nape of the Australian Emu. The cheeks are not entirely bare, and from the base of the neck springs a kind of moustache, which turns backwards and meets the hair-like feathers covering the ears, while in the Australian Emu a naked band extends across the lores and cheeks to the temples, where it begins to blend with another naked zone surrounding the ear and extending along the sides and the front of the neck. On the contrary, in the Emu brought home by the Baudin Expedition, the front of the neek is almost entirely covered with hair-like, blackish feathers, and the naked zones are narrower and turn towards the side of the nape. All the lower part of the neck is covered with a rery thick "ruff " of blackish, woolly feathers, very different from those which cover the same part of the Australian Emu. The feathers of the body, instead of being as in the latter, fulvous and marked with black at the tip and along the shaft, are mostly, in the Emu from Kangaroo Island, of a fulrous-brown at the base, and of a very dark brown from the middle to the tip ; finally, the feathers of the thighs, instead of being of a yellowish-grey colour spotted with brown, are a misture of fulrous and blackish-brown. The beak and feet are very dark brown, and the naked parts scem to have been blue as in the Common Emu. Total length 142 $\mathrm{cm}$, height to back $65 \mathrm{~cm}$.; bill from gape $75 \mathrm{~mm}$, tarsus 230 , middle too and claw 130 .

Nest and Eggs.-Unknown.

Distribution and forms.-Apparently confined to Kangaroo Island. Many bones have been discorered of a small Emu on King Island, which have been named Dromaius minor Spencer, but it is undetermined at present as to the relationship of these bones. 


\section{FAMUY CASUARIIDE.}

Only one genus is at present recognised, so that the characters given thereunder are those of the family, but later certainly more genera will be utilised, as the differences in the species known are very great from a systematic point of riew.

\section{Genus CASUARIUS.}

Casuarius Brisson, Omith., Vol. V., p. 10, 1760. Type (by tautonymy): Casuarius = Struthio castarius Linné.

Rhea Lacepède, Tabl. Ois., p. 20, Dec. 1799. Species added by Daudin, in Hist. Nat. Buffon, ed. Didot, Quadr., Vol, XIV., p. 345, [1799=] Oct, 1802. Typo (by monotypy) : Rhea casuarius $=$ Struthio casuarius Linné.

Cassowara Perry, Arcana, pt. 21 (pl. 82), Sept. 1st, 1811. Type (by monotypy): Cassowara eximia Perry = Struthio casuarius Linné.

Cela Oken, Lehrb. der Naturg., Vol. III., Zool, 2 Abth., p. 646, 1816. Type (by monotypy) : Struthio casuarius Linné.

Oxyporus "Brookes, Catal. Mus. Joshua Brookes, pt. Ir., p. 95, July 1828. New name for Casuarius Lin." Cf. Richmond (2), p. 628, Dec. 16th, 1908,

Hippalectryo Gloger, Hand- u. Hilfsb., pt. vi., p. 452, 1841, p. xxxxiii., 1842 (early). Type (by monotypy): Hippalectryo indicus Gloger = Struthio casuarius Linné.

Large Dromæornithes with small heads bearing a more or less developed bony helmet, long stout necks, stout bodies, small flightless wings bearing a few strong spines, no tail, very stout legs and feet with no hind-toe, but the inner toe much lengthened. The bill is as long as the head, with a large gape; from the base arises an elongate triangular bony helmet; the culmen is narrow with the side slopes steep, the tip decurved; the nostrils are placed forward as elongate ovals in a long shallow groove. The under mandible has the rami narrow and grooved and a long interramicorn with a narrow interramal space which has a few hair-like feathers on it; the edges of the tip of the under mandible are serrate. The head and neck are naked save for a few hair-like feathers and there are pendant wattles on front of neck, and wattle-like strips on sides. The wing is very short and shows about half a dozen hollow spines with no signs of barbs, succeeding a few degenerate feathers after the claw. There are no recognisable tail-feathers. The legs are rery stout and fairly long, feathered to the tarsal joint and bearing a few very large scutes towards the toes which are regularly scuted; sides of toes as rest of leg corered with hexagonal scutes. The middle toe is much longer than the outer and inner, which bears an elongated straight strong claw, the claws on the other toes being short and stout. There is no hind-toe and claw. All feathers with aftershaft equal to rhachis. Adult coloration black with coloured naked parts of neck. The downy young striped like that of preceding genus. Confined to Papuasia and North Queensland.

\section{Casuarius casuarius.-CASSOWARY.}

[Struthio casuarius Linné, Syst. Nat., 10th ed., p. 155, Jan. 1st, 1758: [Asia, Sumatra, Molucca, Banda $=1$ Ceram. Extra-limital.]

Gould, Suppl., pls. 70-71 (pt. v.), Aug. 1st, 1869. Mathews, Vol. I., pt. 1, pl. 5, Oct. 31 st, 1910. Casuarius australis Gould, Proc. Zool. Soc. (Lond.), 1857, p. 270, Jan. 2Sth, 1858: North Queensland.

Not Shaw, Nat. Miscell., Vol. III.; pl. 99, April 1st, 1792.

Casuarius johnsonii Mueller, Proc. Zool. Soc. (Lond.), 1867, p. 242, June 1st: Gowrie Creek, Rockingham Bay, Queensland.

Casuarius casuarius hamiltoni Mathews, Austral Av. Rec., Vol. II., No. 7, p. 124, Jan. 28th, 1915 : Cairns, North Queensland.

Distribution,-The thick scrubs north of Cardwell, North Queensland. 
Adult.-This species, which is distinguished by its very high easque (thinner above), long nail of inner toe, and the very large wattles on the fore-neck, is black both above and below with dark brown bases to the feathers-the feathers being much elongated, narrow, and disintegrated with black shining shafts which are destitute of webs towards the ends. The wings are rudimentary and furnished with porcupine-like black quills without any webs whatever; head and neck all round, including the two wattles on the lower fore-neck, bare. For colour of soft parts see below. Total length about 60 inches from top of casque to tips of feathers at the end of the body; bill from gape $139 \mathrm{~mm}$., culmen from base of casque 65 , tarsus 317 , middle toe and claw 159.

Young (quarter grown).--Head and hind-neck chestnut rufous. Chin, throat and fore-neck densely covered with short downy feathers of a brownish-buff colour. Rest of body clayey brownish-yellow mixed with dark rufous.

Young (two-thirds grown).--Plumage brown. Head and oeciput, dull pale

blue; lower hind-neck, orange; fore-neck leaden-blue; lower naked sides of neck blue, mixed with livid purple.

Chick.-Head and hind-neck pale rufous; fore-neck yellowish-buff ; rest of body yellowish-buff. From base of neck to end of tail along the back run three broad longitudinal black bands, variegated with rufous, and each about seven-eighths of an inch wide. On the sides are three irregular wavy black bands extending from the shoulder-girdle down the sides to the beginning of the metatarsus.

Nest.-A bed of sticks, leaves, and such-like vegetable debris, usually placed near the base of a large tree in dense scrub.

Eggs.-Clutch, four to six; some authorities state three to five; of a graceful elliptical form, and superficially like shagreen or rough American cloth, but not so rough or granulated as the Emu's (Dromiceius) egg. General appearance in colour, beautiful light pea-green, but if examined vertically the raised rough particles only of the shell will be found to be green, while the minute interstices are greenish-white. Dimensions 138-141 mm. by 92-97.

Breeding-season.-July to September.

Incubation-period.-About eight weeks.

Distribution and forms.-From Ceram through New Guinea into northern Queensland. Many forms have been separated, chiefly by means of coloration of head and neck, and as there are no definite conclusions yet possible we will simply note those of the two suggested forms living in Australia. In the form named $C . c$. hamiltoni Mathews the front and sides of the neck as well as the whole of the sides of the head and nape, pale blue ; the whole of the back of the neck pale orangeyellow; the lobe extending down the lower neck deep purple; appendages bright lake; between gape and ear a triangular spot of lake connected with the appendages by a raised rib of skin of the same colour. In descriptions of $C$. c. johnsonii Mueller we read coloration of fore-neck bright purplish-blue, and of nape pale greenish-blue, and of the lobe half deep orange and half purple, and a preoral patch is unmentioned.

\section{SUBCLASS IMPENNES.}

The limits of the subclass are coincident with those of the order and suborder, and the extraordinary superficial characters are common to all members. The erect stature, the degraded miniature wings, short flat feet are all distinctive. The wings have no specialised flight feathers but are covered with small scale-liko feathers, and are used for swimming only. They are all seabirds living in the Antarctic and Sub-antaretic Regions, the largest breeding among perpetual ice, and always gregariously.

We have separated two families, the Spheniscide or Thick-billed Penguins and the Aptenodytidee or Thin-billed Penguins, but recent investigation has suggested 
a further separation of the Austral-Neozelanic forms, Eudyptula, Eudyptes and Megadyptes from the Afro-Magellanic Spheniscus. The two families here recognised are easily distinguished by the bill formation, the thick-billed forms also having a more northerr distribution than the thin-billed ones, the largest of which are confined to the Antarctic Continent. As evidence of the value of the so-called superficial features we associated Pygoscelis with Aptenodyles from a study of these alone, and upon consideration of the known anatomical and osteological characters we find absolute confirmation of our association.

Osteologically the skull has the palate schizognathous, the nostrils holorhinal and basipterygoid processes are absent; the pterygoids are unique in size and shape, being proportionately very large and flattened, and perforated near their junction with the pala tines; the lachrymals have their descending process with a large foramen ; large supraorbital groores are usually present. The sternum. has a well-developed keel, the cervical vertebrse are fifteen in number and the dorsals are opisthococlous in character, the furcula prominent and the scapula unique in shape, being very large and posteriorly broadened, anteriorly narrowed. The wing bones are flattened in accordance with the usage of that $\operatorname{limb}$, while the tarsal bones are very short and not perfectly fused together, as in most other birds, and again the pelvis shows unique fertures. The carotid arteries are two in number and the syrinx is tracheobronchial, tending to the complete bronchial form. The digestive system is very specialised, of the orthocœlous style, but quite unlike that of any other group, though suggesting those of the Pelecani and Procellarii. The cæea are small. The muscle formula of the leg is $A B X+$, while the biceps muscle is absent, a feature restricted entirely to this group. The oil gland is present and tufted, while the aftershaft is present, though the feathers are so peculiarly adapted. The pterylosis is considered to be continuous though little research has yet been performed in this direction; the nestlings are down covered. The antiquity of the members of this subclass is proven by the recovery from the Tertiary deposits of New Zealand of fossil remains which show the distinctive features of the recent birds to hare been possessed at that epoch. The wings were longer but similarly adapted and the tarsal bones were imperfectly comected even as now. More recently extensive remains have been found in Patagonia and the Antarctic adjacent, many generic forms having been named but all obviously Penguins.

\section{ORDER SPHENISCI.}

\section{SUBORDER SPHENISCIFORMES.}

FAMILY SPHENISCIDE.

As Australian members of the family we have only Eudyptula and Eudyptes, the typical Sphcniscus being confined to South Africa and South America. The two former range to New Zealand where also Megadyptes is found. All are gifted with short stout bills, the first named without any head ornaments, Mcgadyptes having the crown full and semi-crested, while Eudyptes has long tufts of flowing feathers on the sides of the head, the crown also full. Anatomically the evolution is considered to have paralleled the erest growth, and Spheniscus, which has also no crest, is ranked on about the same level as Eudyptula, though they represent divergent types. It may be noted, through the confusion of generic types, Eudyptula was referred to Spheniscus with which it has little direct connection, and is the living representative of the immature state of Eudyptes.

\section{Genus EUDYPTULA.}

Eudyptula Bonaparte, Comptes Rendus Acad. Sci. (Paris), Vol. XLII., p. 775, May 1856. Typo (by monotypy): Aptenodytes minor Forster. 
Smallest Penguins with short stout bills, small flippers, rery short tail and short legs and stout feet. The bill is stout and laterally compressed, the tip descending and hooked, overlapping the under mandible; the culmen ridge is semi-keeled, the sides almost vertical. The nostrils are recognisable as narrow oval slits situated in a distinet irregular groove which runs from the fore-head diagonally across the mandible to a point about two-thirds the length of the bill; the lateral behind this groove a little expanded basally. The under mandible deep and consisting of two rami only enclosing a very short feathered interramal space. The flipper is small and delicate. The tail is composed of sixteen very narrow feathers, forming a rounded wedge and very short, being hidden by the upper tail-coverts. The tarsus is very short and broad, covered with minute reticulate scaling. There is a small hind-toe and claw present. The anterior toes are comparatively long and broad, covered with reticulate scales, the middle toe longest, the outer a little longer than the inner. The webbing is full and the claws are long, narrow and stout.

Coloration blue above, white below.

\section{Eudyptula minor.-FAIRY PENGUIN.}

[Aptenodytes minor Forster, Comm. Gotting., Vol. III,, p. 147, (after May 15th) 1781 : Dusky Sound, New Zealand. Extra-limital.]

Gould, Vol. VII., pl. 84 (pt. xvI.), Sept. 1st, 1844: pl. 85 (pt. xxxII.), Dec. 1st, 1848. Mathews, Vol. I., pt. 5, pls. 66 and 67, Oct. 31st, 1911.

Spheniscus novchollandia Stephens, in Shaw's Gen. Zool., Vol. XIII., pt. I., p. 68, Feb. 18th, 1826, based on Watling painting No. 291: Port Jackson, New South Wales.

Aptenodytes australis "Gray," Grifith and Pidgeon, Anim. Kingd, Cuvier, Vol. VIII., p. 563, "1829" (1830), for same as preceding.

Aptenodytes undina Gould, Proc. Zool. Soc. (Lond.), 1844, p. 57, Sept. : Circular Head, Tasmania.

Eudyptula minor woodwardi Mathews, Nov, Zool., Vol. XVIII,, p. 199, Jan. 31st, 1912 :

Sandy Hook Island, South-west Australia.

Distributron.-Coasts of extra-tropical Australia and Tasmania.

Adult male.-Upper-surface glossy bluish-grey, the feathers with black shafts and grey margins; flippers darker than the upper-surface, and the lower edge margined with white for about two rows of feathers; tail-feathers white with black shafts towards the base; sides of face and sides of breast ashy; chin and entire under-surface, including the flippers, white; the feathers of the fore-neck have dusky bases with blackish shaft-streaks; a line of feathers with dusky bases crosses the vent from the thighs on either side; bill brownish-black, lower mandible pinkishwhite; iris silvery-white with brown edge; feet pinkish-white. Total length 398 mm. ; culmen (exp.) 38, depth of bill 12, flippers 111, tail 28, tarsus 24, middle toe and claw 48. Average measurements, culmen 38.5, deptl of bill 14.4, flipper 118.8, tarsus 26.7 , middle toe and claw $49.7 \mathrm{~mm}$.

Adult female.-Similar to the adult male, but a shadesmaller. A verage measurements, culmen 36.9 , depth of bill 12.3, flipper 114.4, tarsus 25.5 , middle toe and claw $47.2 \mathrm{~mm}$.

Immature (about three-quarters grown).-Head, entire back, sides of the body and a band across the fore-neck sooty-brown, somewhat darker on the head and flippers, and paler on the fore-neck; the throat ashy-grey, and the remainder of the under-surface dull white; soft parts similar to those of adult.

Nestling. - Sooty-brown on the back and throat, becoming paler on the abdomen; top of the head and sides of the face black; soft parts as in aclult; feet bluish-white.

Nest.-A little dry grass or weeds, placed in cavities between rocks, a hollow scraped out underneath tussock grass or other regetation, or sometimes a deserted Petrel's burrow, usually on isolated islands. 
Eggs.-C'lutch, two; dull white, surface smooth; axis 55-57.5, diameter 42.51-3.

Breeding-season.-September to January.

Distribution and forms.- Throughout New Zealand and the Chatham Islands, and as far north as the Solitary Islands, New South Wales, in Australia, and westwards along the south coast to Cape Leeuwin, West Australia. Five subspecies have been distinguished: $E$. $m$, minor (Forster) from New Zealand; $E$. m. iredalei Mathews from the Chatham Islands, by its shorter, thicker bill and darker coloration ; E. $m$. novehollandice (Stephens) by its larger size, longer bill and greyer coloration; E. m. undina (Gould) by its small size and weaker bill and purer blue-grey coloration ; and $E . m$. wooduardi Mathews by its grey-blue coloration and grey flipper. Recently Alexander and Nicholls (Emu, X́VIII., p. 50, 1918), following Nicholls (Emu, XVII., p. 118, 1918) have concluded that all the Australian birds should be referred to one subspecies. From their figures, however, it is indicated that $E . m$. novcehollandice (Stephens) will again prove acceptable on account of its larger bill (probably also larger size and paler coloration), and also E. m. wooduardi Mathews on its greyer coloration and also slightly larger size, as to bill, etc., when longer series of these are studied.

\section{Genus EUDYPTES.}

Eudyptes Vieillot, Analyse nouv. Ornith., p. 67, April 14th, 1816. Endyptes, p. $67=$ Eudyptes, p. 70. Type (by subsequent designation, Gray, p. 77, 1810): Catarrhactes chrysocome Auct. = Gorfou sauteur Buffon (?=Eudyptes nigrivestis Gray).

Catarrhactes Cuvier, Le Règne Anim., Vol. I., p. 613, [1817=] Dec. 7th, 1816. Type (by monotypy): Apt, chrysocome Gm.= Gorfou souteur Buffon.

Chrysocoma Stephens, in Shaw's Gen. Zool., Vol. XIII., pt. I., p. 57, Feb. 18th, 1826. Type (by subsequent designation): C. saltator Stephens = Gorfou sauteur Buffon.

Geopega Billberg, Synops. Faune Scand., Vol. I., pt. Ir., tab. A, 1828. New namo for (Gorfou Cuv, =) Catarrhactes Cuvier (cf. Austral Áv. Rec., Vol. II., pts, 2 and 3, p. 42, Oct. 23rd, 1913). Microdyptes Milno-Edwards, Ann. Sci. Nat, (Paris), Ser. VI, Vol. LX., Art. 9, p. 58, (prob. after June) 1880. Type (by monotypy): Eudyptula serresiana Oustalet.

Penguinus Mathews, Nov. Zool., Vol. XVII., p. 495. Dec. 15th, 1910 (ex Brünich, Zool. Fund., p. 78, 1771). Type (by original designation): $P h$. demersus Linné, i.e., Auct. $=$ Eudyptes pachyrhynchus Gray.

Catarractes Auct., not Catarractes Brisson, which is indeterminable.

Large crested Penguins with short stout bills, medium flippers, long tail, and stout feet. The bill is short and rery stout, the latericorn laterally expanded. The culmen has the ridge flattened and the tip is hooked, while the nostrils are obsolete, but the nasal groove prominent. The lower mandible is very strong and the gape is comparatively short; the interramal space very small and feathered. A long crest is formed on each side of the head above the eyes, in some cases the feathers of the top of the head also elongated. The flipper is fairly long and narrow. The tail is composed of sixteen very narrow feathers in a very pointed wedge, the feathers flattened with the lower surface of the shaft excavate. The feet are typical.

Coloration blue abore and white below with a dark throat and yellow crest.

\section{Eudyptes pachyrhynchus.-BIG-CRESTED PENGUIN.}

Gould, Vol. VII., pl. 83 (pt. xxriI.), Sept. 1st, 1848. Mathews, Vol. I., pt. 5, pl. 65, Oct. 31 st, 1911 .

Eudyptes pachyrhynchus Gray, Voy. Erebus and Terror, Birds, pt. 2, p. 17, Oct. 1815 : Waikowaiti, South Island, New Zealand.

Distrinution,-Straggler to Tasmania, Victoria (?) and West Australia (?)

Adult male-General colour of the upper-surface dark bluish-grey ; a line of yellow feather from the lores over the eye, where it is elongated into a crest on the 
sides of the crown, mixed with black; throat and sides of face dusky-black; remainder of under-surface white; flippers white below, more or less blackish on the outer margin and tip ; bill red ; iris hazel ; toes and tarsus white. Total length $497 \mathrm{~mm}$. ; culmen (exp.) 43, flipper 147, tarsus 30 , middle toe and claw 63 .

Adult female. - Similar to the adult male.

Nestling.-Head, throat, hind-neck, and upper-parts-that is to say the surface that is coloured in the adult-covered with short sooty-black down, and the under parts with short white down; bill whitish-horn colour; feet pale brown.

Young.-Differs from the adult in being appreciably smaller in size, and in having a whitish-grey throat; the long crests are absent, being represented by a tuft of feathers little more than half an inch in length, commencing immediately above the eyes and extending back one and half inches towards the occiput, and being pale lemon-yellow, with blue tips. Bill black, with reddish-brown tips.

Immature.-Birds have the throat ashy-white and the superciliary line yellowishwhite, but no pronounced crest.

Nest.-No nest is built.

Eggs.-Clutch, one or two; ground-colour pale green, covered with a coating of lime; axis $62 \mathrm{~mm}$., diameter 45 .

Breeding-season.-November and December.

Incubation-period.-About six weeks.

Distribution and forms.-Sub-antaretic Islands and mainland of New Zealand. No subspecies known.

\section{Eudyptes serresianus. - YELLOW-CRESTED PENGUIN.}

[Eudyptula serresiana Oustalet, Ann. Sci. Nat,, Paris, Ser. VI., Zool., Vol. VIII., Art. 4, after August 1878: Tierra del Fuego. Extra-limital.]

Hitherto unfigured in Australian works.

Eudyptes filholi Hutton, Proc. Linn. Soc., N.S.W., Vol. III., pt. IV., p. 334, May, 1879 : Campbell Island, Now Zealand.

Distribution.-Straggler to Tasmania and South Australia? See Emu, Vol. XVI., pt. 3, p. 184, Jan, 1917.

Adult male.-As of general Penguin coloration, but differing from the preceding in being a smaller bird, with generally paler coloration above, while the throat and cheeks are dark slaty or grey-black, showing a great contrast with the black of the top of the head. The erest is different being composed of long flowing black and yellow feathers mixed, beginning as a thin yellow line on the lores, and apparently capable of lateral erection. The bill is shorter and more slender. Bill red ; iris rich brown; toes and tarsus pinkish-white. Total length unknown (according to stuffing in skins) ; culmen (exp.) $37 \mathrm{~mm}$., flipper 130, tarsus 25, middle toe and claw 60 .

Adult female.-Similar.

Immature and Nestling.-Undescribed from Neozelanic localities.

Nest.-None made.

Eggs.-Clutch, two; bluish-white; 75-80 mm. by 45.

Breeding-season.-October.

Distribution and forms,-Round the Sub-antarctic Circle. We are accepting the Falkland Islands birds as typical, as the name $E$. serresiana was given to an immature specimen, and we now name the following subspecies which have been distinguished in literature for many years: E. s. moseleyi subsp. nov., from Inaccessible Island, Tristan d'Acunha Group, with a longer bill, and a very long crest, very pale ashy throat and generally light upper coloration; E. s. interjectus subsp. nov., from Kerguelen Island, with a shorter bill and darker throat and less developed erest and apparently smaller size; and E. s. filholi Hutton, from Campbell Island, New 
Zealand, with a larger bill and darker throat, less crest still and darker upper coloration.

\section{Eudyptes schlegeli.-MACARONI PENGUIN.}

Not figured in Australian works.

Eudyples schlegeli Finsch, Trans. New Zeal. Inst., Vol. VIII., 1875, p. 204, July 1876 : Macquarie Island.

Eudyptes albigularis Milne-Edwards, Ann. Sci. Nat. (Paris), Ser. VI., Vol. IX., Art 9, p. 55, (prob. after June) 1880: Macquarie Island.

Distribution.-Straggler to Tesmania (one occurrence near Devonport, Tasmania, Sept. 1913).

Adult (?).- " Upper-surface fine dark metallic-blue, upper-surface of wing the same, tail somewhat lighter blue; under-surface silvery-white, except the throat and chin, which are ashy-uhite, with a small dark patch a little below the base of beak. Sides of the head below the crest, a clarkish grey; fore-head, bluish-grey. The wings above are of the same tint as the back; beneath, white, with broad pateh of dark blue at the tips, the same at the base, extending somewhat on to body in front of wing ; there is also a border of dark blue on the upper edge, but not extending to the tip. Beak dark red; feet reddish, webbed, with strong nails. The tail is long for a Penguin, and formed of stiff, narrow feathers. The crest is black, formed of fine pointed feathers, the pale yellow appearing only underneath, and beginning behind the eye. Total length 24 inches; wing 6 , tail 3 , foot (on flat, with tarsus) 4.5, beak 2, crest 3." (H. Stuart Dove, Ibis, 1915, p. 86 ; Hull, Rec. Austr. II us., Vol. XII., plate XI., fig. 2, 1918.)

We have reproduced this account under the above name as the items emphasised by Dore, and the photo reproduced by Hull, seem to refer the specimen to this species.

Adult of schlegeli.-General colour of preceding, but darker and larger, and with lores, chin, throat, sides of head and neck ashy-white ; crest of yellow feathers short and the frontal feathers also yellow, but with dark tips.

Immature-Paler, crest insignificant, frontal feathers all black.

Nest.-None.

Egg.-Clutch, one; chalky-white; $79 \mathrm{~mm}$. by 45.

Breeding-season.--September onwards.

Distribution.-Breeds at Macquarie Island, south of New Zealand.

\section{FAMUI APTENODYTIDE.}

The family of thin-billed Penguins is composed of large and small species with a more southward distribution than the preceding. Pygoscelis (papua) ranges alongside Aptenodytes (patagonica) with the southernmost species of Eudyptes (schlegeli) in Macquarie Island, but the other large species of Aptenodyles lives with a small species referred to Pygoscelis (but properly Dasyramphus) entirely in the ice-clad Antarctic and these have a large literature which does not concern us. Osteologically there are many differences between the groups, but these have never been systematically studied.

\section{Genus APTENODYTES.}

Aptenodytes Miller, "Var. Subj. Nat. Hist., pt. rv., pl. 23, 1778." Typo (by monotypy): A pienodytes patagonica Miller.

A pterodita Scopoli, Del. Flor. Faun. Insub., Vol. II., pt. II., p. 91, 1786. New name for "A ptcnodytes Mliller."

Pinguinaria Shaw, Mus. Lever., Vol. I., pt. III., p. 144 (pl, dated July 2nd), Nov, 22nd, 1792. New name for "A ptenodytes Miller."

Iargest Penguins with long thin bills, long flippers, short tail and stout legs and fect. The bill is long and thin, the upper mandible apparently much shorter 
Plate 1

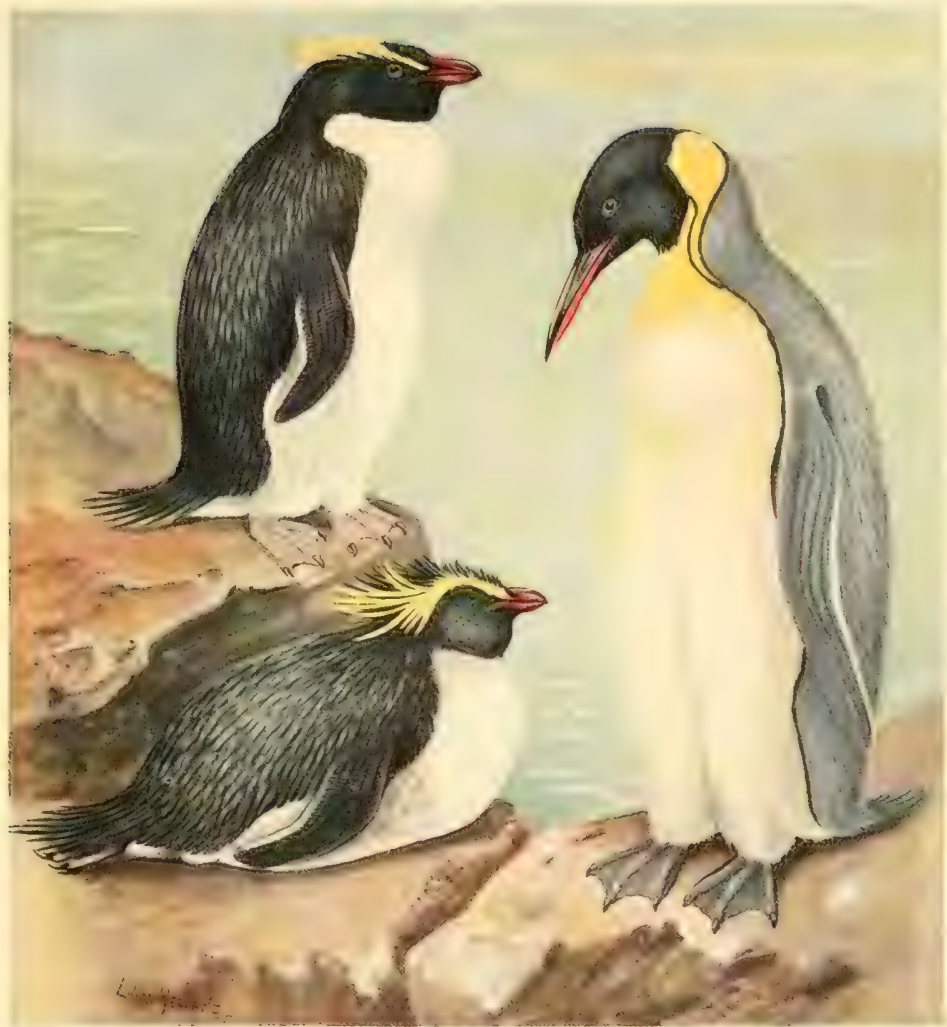

Eudyptes pachyrhynehus.

Big-crested Penguin.

Eudyptes serresianus.

Yellow-erested Penguin.
Aptendulyes jatasonica. King Penguin. 

than the lower owing to the encroaching frontal feathers into the nasal groove; the culmen ridge flattened, the latericorns not laterally expanded; the nostrils obsolete; the tip decurved but not strongly hooked. The under mandibular rami long and divergent, the interramal space feathered. There is no crest. The flipper is very long and narrow. The tail consists of twenty narrow feathers, forming a rounded wedge, not much exceeding the upper tail-coverts. The feet are stout and typical.

Coloration blue above and white below with a dark throat and yellow neck markings.

\section{Aptenodytes patagonica.-KING PENGUIN.}

[A ptenodytes patagonica Miller, "Var. Subj. Nat. Hist., pt. IV., pl. 23, 1778": Falkland Islands. Extra-limital.]

Not previously figured in Australian works.

Aptenodytes patagonica halli Mathews, Birds Austr,, Vol. I., pt. 5, p. 272, Oct. 31st, 1911 : Maequarie Island.

Distribution.-Tasmania (visitor). One occurrence recorded by Hall, Emu, Vol. IX., p. 250, 1910, at Maria Island (but specimen not preserved), and is listed on this authority.

Adult male.-General colour of the upper-surface bluish-grey, the feathers dusky at the base with black shaft-streaks and greyish-white spots more or less surrounded with black; the shaft-streaks more pronounced on the upper tail-coverts; the sides of the neck greyish-white; head, sides of the face, throat, and a line on each side of the breast black, with a greenish gloss on the throat, a patch of orange on the hinder part of the head, which is continued in a narrow line and joined to the somewhat deeper-coloured orange of the fore-neck; remainder of the under-surface creamy-white, becoming pure white on the lower-abdomen; flippers dark grey above, under-surface white, margined and tipped with bluish-grey; maxilla and tip of mandible black; base of mandible sealing-wax red, shading off into lead-grey towards the tips ; iris brown ; feet black. Total length 35 inches ; culmen $122 \mathrm{~mm}$., flipper 280, middle toe and claw 112.

Adult female.-Similar to the adult male, but the colour on the bill not so pronounced.

Immature.-As the adult but less brilliant in coloration and with a weaker, wholly blackish bill.

Nestling.-Covered with dusky-brown down, shortest about the face.

Nest.-No nest is made, the egg being placed on the bare ground.

Egg.-Clutch, one; ground-colour pale greenish-white, covered wholly or in part with a thin calcareous matter; tapering suddenly from the cliameter to the tip; axis 104 to 108 , diameter 75 to 76 .

Breeding-season.-March.

Distribution and forms.-Sub-antaretic regions of the southern hemisphere. Three subspecies hare been indicated: A. p. patagonica Miller, from South Georgia, Fallkland Islands, etc.; A. p. longirostris Scopoli, from Kerguelen Island, and Crozets, by its darker blue coloration and the larger amount of blue on the under side of the flipper; and A. p. halli Mathews, from Macquarie Island, by its paler coloration above and less blue on the under side of the flipper, and the feathers on the inside of the tarsus being white, not blue as in the typical form, as in the former.

\section{SUBCLASS EUORNITHES.}

Having eliminated the two preceding subclasses, comprising a few birds, all the rest of existing avian forms are referred to the present subclass. Twenty-fire orders are recognised, of which six do not occur in Australia, viz., Apteryges, Tinami, 
Syrrhaptes, Phoenicopteri, Pici and Trogoni. Most of these are of restricted range and of few species, as the Apteryges are confined to New Zealand, and the Tinami to South and Central America. These we place in juxtaposition between the orders Ralli and Galli, and they are so generalised in structure that both have been placed with the birds we class as Dromreornithes. The Syrrhaptes constitute another generalised group, living in the Southem Palxarctic area, and showing general features approximating in one direction to the Galli, in other details closely recalling the Columbre, and having peculiar feet. The Phœnicopteri or Amphimorphe similarly show general characters, recalling the Anates and Herodiones, but with specialised bills, neck and legs, so that they constitute quite a distinct group, their range being tropical Africa and America. All the preceding hare few species, but the order Pici is world wide, save the Austral-Maorian Regions, and comprises numerous species referable to four superfamilies, all notable and well-known birds. The last extra-limital order is another small one, consisting of the Trogons, a peculiar series of Coraciine-like birds inhabiting the tropies of Asia, Africa and America, and admittedly of generalised structure though specially modified in superficial appearance. Of the nineteen orders that will be dealt with in this work one only, the Menuræ, is restricted to Australia, all the others have a wider range.

\section{ORDER PROCELLARIE OR TUBINARES.}

This order comprises seabirds with webbed feet and hooked bills, the nostrils being tubular. Superficially the order is separable into two groups, one of which has the nostrils placed on top of the culmen, the other with the nasal openings distinet and on the sides. These two groups we propose to rank as superfamilies as no gradation is now known. The majority of the species nest in the southern hemisphere, breeding generally in holes and always gregariously. They live half the year at sea, but apparently do not range far from their breeding haunts. They are very slow in development, the time from egg-laying to young-flight varying from four to twelve months.

In size they vary from very small birds to tho largest flying birds, the wing varying in formation accordingly, but all have hooked bills and comparatively short feet, first toe very small, consisting of one phalanx only or even missing, anterior three large and fully webbed.

The diagnostic feature of the order is the superficial one of the tubular nostrils, and there is uo peculiar internal character whereby the group can be distinguished.

The osteological characters of the skull vary somewhat; the palate is schizognathous, but this is somewhat obscure in the Diomedeoidea; the nasals holorhinal, and basipterygoid processes are sometimes absent as in the Diomedeoidea, present and well developed or much reduced in the remainder; the supraorbital grooves may be wide and shallow or broad and deep or obscure. In some forms the lachrymal is free, in others anchylosed with nasals. The cervical vertebra are always fifteen in number, and heterocolous in form ; the stemum is keeled and sometimes the posterior border is entire, but generally notehed, and no collation of this variation has been attempted. Both carotids are present and the syrinx is variable from the tracheo-bronchial type to almost complete bronchial form. The digestive system belongs to the pericalous form, but is a very specialised product, becoming typically mesogyrous in the smallest forms, a result of great significance in connection with their phylogeny. The leg museles are variable, the ambiens, the accessory femoro-caudal, and the accessory semitendinosus being sometimes present and sometimes absent in different species. Much stress has been laid upon this fact, but in an imperfect manner. The biceps is present but degenerate, while the biceps slip is absent. The oil gland is present and tufted, while an aftershaft 
is present and the wing is aquincubital. The pterylosis is discontinuous, as is usual, and not specialised, the downy nestlings having very close down.

On account of their great powers of tlight not many fossil remains of Petrels have yet been recorded. Such a record as Diomedea anglica Lydekker from the London Clay can only be regarded with suspicion, as that author did not discriminate between the various forms of Diomedeoidea, and the fragment is rather indefinite.

\section{SUBORDER PROCELLARIIFORMES.}

The suborder is coequal with the order, being divided into two superfamilies, the Procellarioidea and the Diomedeoidea, externally so different that no confusion is possible, while internally there is almost as much distinction. Alexander has recently given some notes on the Australian species advocating the admission of sight records by good observers and the limits of Australian Seas as reaching half-way to the next land. He has also lumped some generic forms in his essay. We have since had the opportunity of discussing some of the points with him personally, and he admitted that the matter was not so easy as he had previously concluded, and that sight records of all but the most easily recognisable forms might still be doubted. As to the lumping of genera, Garrodia proves to be more closely related to Fregetta than to Oceanites, while Fregettornis is the most distinct of the series. Again Halobcena was included in Prion because he was not familiar with that form, and consequently he might correct that item.

\section{SUPERFAMLY PROCELLARIOIDEA.}

We divide this superfamily into three families: the first, of small birds with nostrils opening into a single tube, and legs with tarsal covering either reticulated, scutellate or booted; the second, from medium to very large birds with the nostrils separated by a septum, and tarsal covering always reticulate; the third, small birds with nostrils separated by a septum but the openings horizontal, and legs with reticulate covering and no hind-toe; in the two previous a hind-toe is present and the nasal openings are never horizontal. The technical name of the first family is in dispute, but their vernacular equivalent of Storm-Petrels is beyond all controversy. It is remarkable that such a compact little group superficially should have been disintegrated by the researches of anatomists, though had any ornithologist dared to suggest such a division there would have been more reason. At the present time some ornithologists, who have never studied the group carefully, disallow any separation in the order, which is mere nonsense. If the anatomists were correct in the valuation of the characters they deal with even more subdivision than we allow would be made by them. As a matter of fact there seems to be reason in still further subdividing the group. The Storm-Petrels are found more or less in all seas from the Arctic to Antaretic but are more rare in the tropics. Recently an Antarctic breeding form has been credited with a northward migration almost to the Arctic, though otherwise the species are not given to much wandering. In connection with the second subfamily, the Procellaridix, which includes the Fulmars and Shearwaters, erratic movements, which can scarcely be termed migrations as that term is commonly used, are common but certainly not at all known. The third family, the Pelecanoidida, lives only round the Sub-antaretic Circle and the south-west coast of South America, and may not be phylogenetically related at all closely to the preceding families, as both superficially and internally it is very different.

\section{FAMILY THALASSTDROMIDE.}

Storm-Petrels are the smallest forms of Procellariæ, and all have the tubes opening on the top of the bill with superficially a single orifice, the tails square or 
forked, the legs short or comparatively long, the wings always long and pointed. On account of internal differences two families have been separated, the long-legged species having the expansor secundariorum, a wing muscle present, and also the accessory semitendinosus, a leg muscle present, these muscles being absent in all other Petrels, small or large. In addition, the former are said to possess no creca, while the latter generally have. Superficially the so-called long-legged forms have the tarsal covering anteriorly scutellated or booted, all the remainder having a completely reticulate tarsus. Osteologically there is very little distinction between these as far as criticisin has yet extended but it is quite possible that there may be two families separable later, but at the same time many more will certainly be demanded for other groups. Geographically the long-legged forms are southern, the short-legged ones northem, the former penetrating into the Antarctic Circle to breed, also ranging to north of the Equator rarely, the latter never breeding south of the Equator but sometimes in the Arctic Circle. Consequently all the Australian species are long legged, but even these present quite appreciable differences, most of the species being regarded as generically separable. The ambiens muscle is absent from Fregetta (sensu lato) while in Garrodia it is present but the tendon does not cross the knee. These two genera are not distantly related. Basipterygoid processes are said to be entirely absent in Pelagodroma and Oceanites of the longlegged group while they appear as minute prickles in the short-legged series. Again, in the former group there are ten secondaries only.

\section{Genus OCEANITES.}

Occanites Keyserling und Blasius, Wirbelth. Europa's, p. xciii., (before April) 1810. (Type by monotypy) : Thalassidroma wilsoni Bonaparte $=$ Procellaria oceanica Kuhl.

Small Storm-Petrels with small hooked bills, long wings, medium emarginate tail and long legs and feet. The bill has the tubular nostrils semi-erect, about half the length of the bill, the tip strongly hooked but weak, the latericorns a little bowed and basally widening. The under mandible has the rami a little bowed and dirergent similar, the tip also weak. The wing is very long, the first four primaries forming the tip, the second being longest, the third longer than the first which is longer than the fourth; the secondaries are very short. The tail is slightly emarginate, a little less than half the length of the wing, the feathers broad. The legs are long, the tibia esposed for about one-third the length of the metatarsus, which is about half the length of the tail with the tarsal covering complete in front, but obscurely scutes may be seen indicated, while the back is reticulated. The toes are long, the inner shorter than the middie and outer which with their claws are subequal, the claws elongate, that of the middle toe longest. The anterior toes are fully webbed between, the hind-toe reduced to a minute, almost negligible, speck.

Coloration uniform, save white upper and under tail-coverts.

\section{Oceanites oceanicus. - YELLOW-WEBBED STORM-PETREL.}

[Procellaria occanica Kuhl, Beitr. Vergl. Anat., p. 136, 1820 (pref. April 9th) : South Atlantic Ocean. Extra-limital.]

Gould, Vol. VII., pl, 65 (pt. xxIr.), March 1st, 1816. Mathors, Vol. II., pt. 1, pl. 68, May 30 th, 1912.

Occanites oceanicus exasperatus Mathews, Birds Austr., Vol. II., pt. 1, p. 11, pl. 68, May 30th, 1912: New Zealand Seas.

Distribution.--Southern Australian Seas as far north as South Queensland. ? Breeding at Cape Adare, Antarctic Circle.

Adult male.--Sooty-black above and below, paler on the greater wing-coverts, which are fringed with whitish; upper tail-coverts pure white like the feathers on 
the sides of the rump; under tail-coverts whitish at the base, sooty-black at the tips; bill black; iris dark brown; feet black; middle of webs yellow. Total length $176 \mathrm{~mm}$. ; culmen (exp.) 13, wing 156, tail 72, tarsus 35.

Adult female.-Similar to the adult male.

Immature.-According to Murphy, recognisable by conspicuous white edgings on the feathers of the belly, and by a whitish spot on the lores. In addition they have weaker bills, with a less pronounced unguis, shorter wings and tails and smaller claws on the toes.

Nestling.-Covered with greyish-black down.

Nest.-A chamber at the end of a tunnel, lined with feathers.

Egg. - Clutch, one; dull white, sometimes sparingly dotted with reddish spots; sometimes these spots form a ring round the larger end; axis $33 \mathrm{~mm}$., diameter 23.

Breeding-season,-January. (Cape Adare.)

Distribution and forms.-Breeding round the Antarctic Circle, but wandering northwards, as above, in Australian waters; as far north as the Persian Gulf in the Indian Ocean, and in the North Atlantic Ocean common in Nova Scotia and northern coasts of the United States. Two forms have been differentiated: $O$. o. oceanicus Kuhl, South Atlantic Ocean, breeding at South Georgia and common in the North Atlantic Ocean in winter; and $O$. o. exasperatus Mathews, on account of larger size in all measurements.

\section{Genus GARRODIA.}

Garrodia Forbes, Coll. Sci. Papers Garrod, p. 521 (footnote), (pref. June 24th) 1881. Type (by original designation): Thalassidroma nercis Gould.

Small Storm-Petrels with small hooked bills, long wings, long rounded tail and long legs and feet. The bill is similar to that of the preceling genus, but the unguis is stronger and more powerfully hooked. The wing has the same formula, but the feathers are broader. The tail is slightly rounded, the feathers broad, the under tail-coverts reaching to the tips; the tail is more than half the length of the wing. The legs are long, with the tibia exposed for about half the length of the metatarsus, which is less than half the length of the tail. The tarsus is markedly scutellate in front and reticulate on the sides and behind. The toes are long and fully webbed, the webs however more deeply incised than in the preceding. The hind-toe is searcely recognisable while the outer is longer than the middle which exceeds the inner toe; the claws are elongate, that of the middle toe the longest and that of the outer toe the least.

Coloration : head dark, back grey, throat and upper-breast dark, rest of under parts white.

\section{Garrodia nereis. - GREY-BACKED STORM-PETREL.}

Gould, Vol. VII., pl. 64 (pt. xx.), Sept. 1st, 1845. Mathews, Vol. II., pt. 1, pl. 69, May 30th, 1912.

Thalassidroma nereis Gould, Proc. Zool. Soc. (Lond.), 1840, p. 178, July 1841 : Bass Straits, Australia.

Procellaria saltatrix Mathews, Birds Austr., Vol. II., pt. 1, p. 16, May 30th, 1912 (ex Solander MS.): off Kaikoura, Now Zealand.

Procellaria longipes, Mathews, ib., p. 17 (ex Solander MS.) : off Kaikoura, New Zealand.

Distrinotrons.-Bass Straits, Australia (breeding ?).

Adult male.-Head and neck all round, upper back, lesser wing-coverts, bastardwing, and primary-coverts sooty-brown with a grey tinge; greater wing-coverts and ecapulars dark grey, more or less edged with white; primary and secondary 
quills blackish, white on the inner webs towards the base; rump and upper tailcoverts grey; tail grey with a sooty-black band at the tip ; breast, sides of body, axillaries, greater under wing-coverts and abdomen white; sides of breast and outer alge of wing below greyish sooty-brown; under tail-coverts white, the lateral and longer ones barred and spotted with ashy-grey; bill, iris, and feet black. Total length $175 \mathrm{~mm}$. ; culmen (exp.) 13, wing 128, tail 65, tarsus 31 .

Adul female. - Similar to the adult male, but not quite so dark on the head.

Nestling.-Unknown.

Nest.-Situated in burrows about 18 inches deep, and resembling rat holes. (Tomahawk Island.)

Egg.-Clutch, one ; ground-colour white, the larger end covered with fine dots of deep reddish-brown and lavender, and a few reddish ones sparingly distributed over the rest of the surface. Dimensions $33 \mathrm{~mm}$. by 23-5.

Breeding-season.-November. (Guano Island.) January. (Tomahawk Island.)

Distribution and forms.-Apparently round the Sub-antarctic Circle. Threo forms have been distinguished: G. n. nereis (Gould) from Bass Straits, Australia, breeding in New Zealand and the Chatham Islands; $G$. n. couesi Iathews, from Kerguelen Island, on account of their smaller size, av. wing $124 \mathrm{~mm}$; and $G$. $n$. chubbi (Hathews) from the Falkland Islands, by its larger size, wing average $135 \mathrm{~mm}$., and darker head and breast and more grey on the back.

\section{Genus PELAGODROMA.}

Pelagodroma Reichenbach, Nat. Syst. Vögel, p. IV., 1852 (? 1853). Type (by original designation): Procellaria marina Latham.

Large Storm-Petrels with long hooked bills, long wings, long emarginate tail and long legs and feet. The bill is long with the tubes less than half its length; the tubes are similar in formation to those of the preceding genera, but the unguis is much longer and less sharply hooked. The latericorns are less sloping and the bill is narrower basally ; the under mandible has the unguis long and nearly straight, the rami little divergent and the interramal space feathered. The wing shows the same formula. The tail is appreciably forked, but only to a slight extent; the feathers are very broad, and its length is not quite half that of the wing. The legs are long, the exposed tibia long; the tarsal covering consists of well-marked seuten in front and weaker reticulate sealing behind. The lind-toe is still searcely discernible, but the anterior toes are very long, the outer toe the longest, and the inner noticeably shorter; the claws are long and narrow, that of the middle toe the longest, and on the outer shorter and broader. The toes are fully webbed.

Coloration brown and grey above, white below and upper tail-coverts white.

\section{I1. Pelagodroma marina. -WHITE-FACED STORM-PETREL.}

¡Procellaria marina Latham, Index Ornith., Vol. II., p. 826, (before Dec. 9th) 1790: South Atlantic Ocean. Extra-limital.]

Gould, Vol. VII., pl. 61 (pt. XviI.), March 1st, 1845. Mathews, Vol. II., pt. 1, pl. 70, May 30 th, 1912.

Pelagodroma marina dulcice Mathews, Birds Austr., Vol. II., pt. 1, p. 21, May 30th, 1912 : Breaksea Island, off Albany, South-west Australia.

Pelagodroma marina howei Mathews, ib., p. 26 : Mud Island, off Victoria.

Distribution,-Seas of New South Wales, Vietoria, Tasmania, South Australia, Southand mid-West Australia.

Adult male.-Crown of head and a line below the eye on to the car-coverts dark slate colour; hind-neck, sides of neck, and mantle and upjer back dark ash-grey with a brownish shade; lesser wing-coverts, primary-coverts, and quills brownish- 
black, the latter more or less white on the inner webs towards the base; greater coverts brown with pale margins; lower back and scapulars dark brown; upper tail-coverts grey barred with white at the base; tail brownish-black; fore-head, lores, an irregular line over the eye, and under-surface pure white like the axillaries and under wing-coverts; thighs and lateral under tail-coverts grey, the latter with white bases; bill black, iris hazel, feet black, webs yellow. Total length $209 \mathrm{~mm}$. ; culmen (exp.) 17, wing 156, tail 69, tarsus 41 .

Adult female.-Similar to the male, but larger in bill measurements.

Immature.-A very small, downy young show's the adult coloration to be taken on with the first feathers, the only noticeable difference being white edgings to the primary and secondary quills, and wavy grey and white undulating marks on the upper tail-coverts and rump.

Fully-feathered young are quite like the adult but cleaner looking, with conspicuous white elgings to the secondaries. The wing measurement is noticeably less.

Nestling.-Covered with ashy-grey down above, white below.

Nest.-In a burrow.

Egg.-Clutch, one; variable in size and shape as well as colour markings; sometimes pure white with scarcely any spots, sometimes with the larger end thickly speckled with minute pale rusty spots, and at others speckled sparsely all over with such spots, massed at larger end and intermingled with a few larger blackish streaks ; elongately oval to subrotundately oval ; axis $35-11 \mathrm{~mm}$., diameter $25-28 \mathrm{~mm}$.

Breeding-season.-November to January.

Distribution and forms. - Breeding in New Zealand, southern Australia, South and North Atlantic Ocean. Five forms have been separated : P. m. marina (Latham) breeling on Tristan d'Acunha, Nightingale Island, etc., South Atlantic Ocean; $P$. m. hypoleuca (Webb and Berthelot) with a longer bill and lighter coloration above, especially the ashy-grey mantle, breeding on the Great Salvage Islands, Canary Islands, Cape Verde Group, etc. ; P. m. dulcice Mathews, the West Australian form, with longer bill than the typical race, also lighter mantle and back, but darker than preceding; $P$. m. howei, the East Australian race, has the mantle and back distinctly darker grey with scarcely any fuscous shade; and $P . m$. maoriana Mathews, with a shorter bill and the mantle, sides of neck, and upper back light brown, not grey.

\section{Genus FREGETTA.}

Fregetta Bonaparte, Comptes Rendus Acad. Sci. Paris, Vol. XLI., p. 1113, (Dec. 31 st) 1855. Type (by original designation) : Thalassidroma leucogaster Gould.

Cymodroma Ridgway, Mem. Mus. Comp. Zool. Harvard (Water Birds N. Amer, Vol. II.). Vol. XIII., pp. 363, 418, (introduction dated March 31st) 1884. Type (by original designation): T. tropica Gould.

Small Storm-Petrels with short hooked bills, long wings, long emarginate tail and long legs and short toes. The bill is short, sharply hooked, the tubes as in the preceding almost half the length of the culmen; the unguis short and sharply hooked, the side slope fairly steep. The unguis of the lower mandible is correspondingly short, the interramal space narrow and feathered. The wing has the same formation as in the preceding genera. The tail is scarcely forked and is practically half the length of the wing, the feathers broad. The legs are long, the exposed tibia long; the tarsal covering booted in front, and covered with reticulate scaling behind ; the basal phalanges of the toes have also a smooth surface; the outer toe longest, the imner and middle being very little less; the claws are short and comparatively broad, that of the middle toe being slightly the longest. There is still only a minute hind-toe, and the anterior toes are fully webbed.

Coloration: head and all upper surface sooty; chest and abdomen white. 


\section{I2. Fregetta tropica.-BLACK-BELLIED STORM-PETREL.}

[Thalessidroma tropica Gould, Ann. Mag. Nat. Hist., Vol. XIII., p. 366, May 1st, 1844: Atlantic Ocean. Extra-limital.]

Gould, Vol. VII., pl. 62 (pt. xxvi.), March 1st, 1847. Mathews, Vol. II., pt. 1, pl. 71, May 30 th, 1912.

Fregetta tropica australis Mathews, Austral Av. Rec., Vol. II., pt. 5, p. 86, Sept. 24th, 1914 : New Zealand.

Distribution,-Australia (visitor). One specimen preserved in Macleay Museum, Sydney. Cf. Austral Av. Rec., Vol. III., pt. 4, p. 95, July 21st, 1917.

Adult male.-General colour above sooty-black, including the head and neck all round, breast, back, wings, and tail; the feathers of the back narrowly fringed with white like the scapulars and median wing-coverts; the feathers on the mickle of the abdomen and under tail-coverts sooty-black with white bases; upper tailcoverts and feathers on the sides of the rump pure white; outer tail-feathers white at the base; sides of the body and the inner under wing-coverts white, as also the axillaries; small coverts round the margin of the under wing sooty-black; bill and fect black, iris brown. Total length $201 \mathrm{~mm}$; culmen (exp.) 14, wing 164, tail 76 , tarsus 43 .

Adult female.-Deseription of Australian specimen: "The skin shows slight whitish tips to back feathers; whitish bases to throat feathers show as an obscure whitish patch; the belly mark distinct but ill defined; lower tail-coverts hare long black tips with white bases and extend to tip of tail; there is a whitish pateh on the inner wing-coverts and a brownish outer wing-covert patch. Wing 146, tail 69 , tarsus 41 , middle-toe 27 , culmen $15 \mathrm{~mm}$. Nostrils tending upward."

Nest-In the crevice of a rock.

Egg.-Clutch, one; dull white, minutely and sparingly dotted all over with small pink dots; axis $37 \mathrm{~mm}$., diameter 27. (Kerguelen Island.)

Distribution and forms.-Not well known. Apparently Mid and South Atlant:c Ocean, Indian Ocean and New Zealand Seas. $F$. $t$. tropica (Gould) inhabits the Atlantic Ocean; F. t. melanogaster (Gould) from the South Indian Ocean has a white spot on the throat and a mesial dark abdominal line; $F$. $t$. uustralis Mathew, from New Zealand seas, like the preceding as to coloration, but larger size and longer legs.

\section{I3. Fregetta tubulata.-ALLIED STORM-PETREL.}

Not figured anywhere.

Fregetta tubulata Mathews, Birds Austr., Vol. II., pt. 1, p. 42, May 30th, 1912, ex Gould MS. : "Near the coast of Australia" = Locality unknown.

Distributron.-Not known. One specimen preserved in the British Musenm.

"I have a small Petrel, presented to me by Mr. Denison, who killed it near the coast of Australia on his passage to Sydney, in which the nostril tube is much more lengthened than in any other speeies, and its apical portion turned upwards or recurved, instead of being attached to the bill throughout its entire length as in the other members of the genus. In the distribution of its colouring it is very nearly allied to $T$. tropica and $T$. leucogaster, and it may be a mere variety of one or other of those species; but the bill, in addition to the feature pointed out above, is of a more slender and attenuated form than is observable in any other." (Gouldi.)

The bird itself is in the British Mureum, where we have examined it. It has the tube erect as there noted, the feathers of the throat liave light bases, tie upjer tail-coverts are white without black tips, the tail square, the under tail-coverts dark; there are stray clark markings on the belly. It disagrees with the preceding, howerer, in having longer toes, not so much flattened, with the claws longer and more spatulate. 
It recalls Pealea lineata Peale, but as the basal phalanx of the middle toe is longer than the remaining joints and claw, it must be classed in the genus Fregetta. Its measurements are: culmen (exp.) 14, wing (worn) 155, tarsus 37, and middle toe without claw $21 \mathrm{~mm}$.

\section{Genus FREGETTORNIS.}

Fregettornis Mathews, Birds Austr., Vol. II., pt. 1, p. 31, May 30th, 1912. Type (by original designation): Procellaria grallaria Vieillot.

Small Storm-Petrels with short bills, long wings, long square tail, long legs and small feet. The bill has the tubular nostrils semi-erect, the unguis weak but strongly hooked, the laterals not much diverging; the unguis of the lower mandible is weak, the interramal space narrow and feathered. The wing is very long and the wing formula as before. The tail is square and about half the length of the wing, the feathers broad. The legs are long with tibia exposed, but rather short for this series; the toes are comparatively short with very short broad claws, and although the usual proportions obtain, the toes all appear almost subequal. The hind-toe is a mere speck, and the anterior toes fully webbed.

Coloration as in preceding genus, but also unicolour phases occur.

\section{Fregettornis grallarius.-WHITE-BELLIED STORM-PETREL.}

[Procellaria grallaria Vieillot, Nouv. Dict. d'Hist. Nat., Vol. XXV., p. 418, Dec. 26th, 1818 : Australian Seas $=$ South America. Extra-limital.]

Gould, Vol, VII., pl. 63 (pt. xxvr.), March 1st, 1847. Mathews, Vol. II., pt. 1, pl. 72, May 30 th, 1912.

Fregettornis innominatus Mathews, Austral Av. Rec., Vol. II., pt. 7, p. 124, Jan. 28th, 1915: Lord Howe Island.

Drstributron,-Lord Howe Island.

Adult female (type of $F$. innominatus Mathews).-Dark blackish-brown on the head and neck; mantle, back and scapulars blackich-brown, the feathers narrowly margined with white; median wing-coverts greyish-brown; lesser wing-coverts, bastard-wing, primary-coverts and quills black; rump and upper tail-coverts white, some of the feathers with black near the tip; tail-feathers black, the four outer feathers white on inner webs at bases; breast, abdomen, axillaries, and inner under wing-coverts jure white; smaller coverts round the margin of the under wing black ; under tail-coverts black with white bases; bill and feet black; iris brown. Total length $215 \mathrm{~mm}$.; culmen 14, wing 164, tail 80, tarsus 37.

Male and Young.-Very similar to the female.

Nest.-A tumel excavated about eighteen inches in a bank; the end enlarged to a hole about five inches in diameter and lined with a little dead grass on the bottom to form a nest.

Egg.-Clutch, one; dull white, slightly spotted at the larger end with reddishbrown. Dimensions 33.5 by $25 \mathrm{~mm}$.

Breeding-season.-January. (Lord Howe Island.)

Note-Examination of Vieillot's type proves that it is not the Lord Howe Island subspecies but the South American.

\section{Family PROCELLARIIDE.}

This may be a composite family, including as at present constituted the shearwaters, Fuimars, Prions and the Giant Petrel. The Shearwaters and Fulmars 
are superficia!ly similar but appear more distantly related when their nestlings are examined. The Prions are a peculiar little series, which may be nearly related to the Fulmars but which certainly are clearly differentiated now; while the Giant Petrel is a giant relation of the Fulmars showing, in the adult state, the immature bill formation of the Fulmar, but of course much exaggerated on account of its huge size, and it has added feathers to its tail, these numbering sixteen, Fulmars generally having twelve to fourteen, Shearwaters only twelve. The bill of the Shearwaters is generally long and narrow, the nasal apertures tending to open upwards, the body long and slender, the feet placed far backward; the bill of the Fulmars is shorter and stouter, the nasal apertures facing forward, the body stouter; the intenal exlges of the upper mandible sometimes producing lamella. The Prions are smaller forms with the bill varying from narrow to very broad, slender to very stout, lamellx produced on the internal edges of the upper mandible to the greatest extent or insignificant, with a distensible interramal pouch or no trace of such, these alterations taking place while the size, coloration and other structural features remain constant. All these are sub-antarctic in distribution, the Fulmars and Shearwaters generally southern, but a few species ranging and breeding in the nor thern temperate regions. Nearly every species of Fulmarine form has been generically separated, while those of Puffinine alliance have been lumped. We have shown that a constant supergeneric feature is seen in the parti-coloration of the feet of these two groups, the structure of the feet being comparatively similar. The feet of the Prions are structurally a little different, while those of the Giant Petrel again differ in shape, approaching those of the Albatrosses in size but differing in the presence of a large hind claw, the toe being obsolete; this species is also restricted to the Subantarctic and Antarctic regions.

\section{Genus PUFFINUS.}

Pufinus Brisson, Ornith., Vol. VI., p. 130, 1760. Typo (by tautonymy) : Puffinus = Procellaria pufinus Brünnich.

Nectris Kuhl, Beitr. Vergl. Anat., p. 146, 1820 (pref. April 9th). Type (by subsequent designation, Matherws, Birds Austr., Vol. II., p. 46, 1912): Procellaria puffinus Brünnich.

Thyellas Gloger, in Froriep's Notizen, Vol. XVI., p. 279, 1827 (May). New namo for Puffinus Brisson.

Rhipornis Billberg, Synops. Faunæ Scand., Vol. I., Tab. A, 1828. New name for Pufinus Brisson (cf. Austral Av. Rec., Vol. II., pts. 2 and 3, p. 42, Oct. 23rd, 1913).

Cymotomus Macgillivray, Man. Brit. Ornith., Vol. II., p. 13, May 28th, 1842. Type (by monotypy): Procellaria puffinus Brünnich.

Alphapuffinus Mathews, Austral Av. Rec, Vol. II., pt. 5, p. 110, Sept. 24th, 1914. Type (by original designation): Pufinus assimilis Gould.

Small Puffinine birds with long slender bills, long wings, short tail and small legs and feet. The bill is long and narrow with the unguis hooked; the nasal tubes about one-third the length of the culmen rery depressed; the apertures wide apart. separated by a thick septum, and oval in shape, opening nearly horizontally ; the latericorns very slightly basally expanded; the rami of the under mandible comparatively weak and little divergent, the unguis weak and decurved; the rery narrow interramal space feathered. The wing is long with the first primary longest. The tail is short and rounded, a little more than one-third the length of the wing. The tarsus is short, not much more than half the length of the tail and less than one and a half times the length of the culmen; it is very laterally compressed, and covered with reticulate scaling. The toes are long, the outer longest and the inner shortest ; the middle toe, without its claw, exceeds the tarsus in length. The claws are long and narrow, that of the middle toe the longest. The hind-toe is present only as a small projection.

Coloration dark above, white below. 


\section{Puffinus assimilis. ALLIED SHEARWATER.}

[Pufinus assimilis Gould, Synops. Birds Austr., pt. IV., App., p. 7, April 1st, 1838: "New South Wales " = Norfolk Island. Extra-limital.]

Gould, Vol. VII., pl. 59 (pt. xxxv.), Dec. 1st, 1848. Mathews, Vol. II., pt. 1, pl. 73, May 30 th, 1912.

Puffinus assimilis tunneyi Mathews, Birds Austr., Vol. II., pt. 1, p. 71, pl. 73, May 30th, 1912: Boxer Island, South-west Australia.

Distribution.-South-west Australian Sers.

Adult male.-General colour above bluish-black, including the head, back, wings and tail, the feathers having white or dusky bases; ; entire under-surface white, including the under wing-coverts and under tail-coverts; axillaries white, with ashbrown subterminal spots to some of the feathers; maxilla black, mandible blue; iris dark brown, feet blue, webs yellow. Total length $304 \mathrm{~mm}$.; culmen (exp.) 26 , wing 180 , tail 68 , tarsus 37.

Adult female.-Similar to the adult male. Total length $294 \mathrm{~mm}$; culmen (exp.) 25, wing 175 , tail 66 , tarsus 36 .

Immature-As in adult but with white edges to longer wing-coverts and secondaries.

Nestling.-Covered with down, ashy-grey above, paler below.

Nest.-Usually at the end of a burrow, the length of which varies from one to three feet; sometimes under a ledge.

Egg.-Clutch, one; surface smooth, pure white ; axis 48-51 mm., diameter 34-37, Breeding-season.-July.

Distribution and forms.-Atlantic, Indian and Pacific Oceans. Exact range unknown owing to interrelationship with $P$. lherminieri Lesson being in dispute. Mathews in 1912 indicated eight subspecies, and no emendation of consequence has since been made; thus, $P$. a. assimilis Gould from Norfolk Island and Kermadec Group (Mathews has since named $P$. a. howensis from Lord Howe Island, as being darker abore and with a shorter bill) ; $P$. a. gavia (Forster) from New Zealand, as being larger and with the upper part of the lores blue, wing av. $190 \mathrm{~mm}$.; P. a. kempi Mathews, from the Chatham Islands, in their heavier bills, shorter wings, lighter coloration especially on mantle and head, grey splashed axillaries and longer tarsi ; $P$. a tunneyi Mathews, from West Australia, in being slightly smaller and paler than the typical race, and with more white on the fore-head, and much paler young; $P$. a. munda Salvin (ex Solander MS.) for a South Pacific Ocean form with a heavy bill, breeding place unknown; $P$. $a$. subsp. indet. for Reunion specimens; $P$. a. elegans Giglioli and Salvadori from the South Atlantic Ocean, as being very pale birds like $P$. a. kcmpi, but with longer wings and tarsi, and $P$. $a$, baroli Bonaparte from Madeira, Canaries and Azores?; these are darker than the preceding with white lores, thinner bills, longer lateral under tail-coverts slate and small size.

\section{[Genus CALONECTRIS.}

Calonctris Mathews and Iredale, Ibis, 1915, pp. 590-2, July 2nd. Type (by original designation): Pufinus leucomelas Temminck and Laugier.

Large Puffinine birds with long stout bills, long wings, medium rounded tail and strong legs and feet. The bill has the unguis strongly hookerl of both mandibles, the nostrils short and elevated, the apertures facing forwards and only diagonally seen from above. Compared with Hemipuffinus, the bill is much longer. Tho wing is long and the first primary is longest, the secondaries fairly long for the family. The tail is roundly wedge shaped, not quite half the length of the wing. The legs and feet are diagnostic, the tarsus showing much less lateral compression 
and being shorter than the culmen; the hind-toe insignificant, and the tarsal covering reticulate scaling.

Coloration bicolour, grey-brown above, white below with a white head strealied with slate-brown.

\section{Calonectris leucomelas.-WHITE-FRONTED SHEARWATER.}

Procellaria lencomelas Temminck, Plan. Color. d'Ois., Vol. V., liv. 99, pl. 587, 1835: seas of Japan.

Godman, Mono. Petrols, pl. 21, pt. 2, March 1908.

Distrizution.-Cape York (?) and sees northward to Japan.

Adult male.-Mantle, back and scapulars brown, with pale edges and white bases to the feathers; wing-coverts blackish-brown, greater coverts and secondaryquills margined with white on the outer webs towards the tips; bastard-wing. prinury-coverts, and quills blackish, the latter white on the inner webs at the base; upper tail-coverts ash-brown edged with white; tail-feathers dark brown; crown of head slate-brown with numerous white feathers intermixed; hind-neck darker and inclining to sooty-brown; fore-head, sides of face, and sides of throat bromn, with white margins to the feathers, imparting a streaked appearance; throat and under-surface of body, including the axillaries and under tail-coverts, white; under wing-coverts white, with dark shaft-streaks, some of the outer greater coverts ashgrey fringed with white; bill horn colour; feet flesh colour, the outer toe a little darker (in dried skin). Total length $465 \mathrm{~mm}$.; culmen (exp.) 53, wing 307 , tail 146 , tarsus 50 .

Adult female.-Similar to the adult male.

Nest and Eggs.-Undescribed. Guinea.]

Distribution and forms.-Japanese Seas only, straggling as far south as New

\section{Genus REINHOLDIA.}

Reinholtia Mathews, Austral Av. Rec., Vol. I., pt. 5, p. 107, Dec. 21th, 1912. Typo (by original designation): Pufinus reinholdi Mathews.

Cinathisara Hull, Emu, Vol. XV., p. 205, Jan. 1916 (ex Bull. No. 5 R.A.O.U. 21/12/15. Unpublished). Type (by original designation): $C$. cycreolevca $\mathrm{Hull}=R$, reinholdi $b$ yroni Mathervs.

Small Puffinine Petrels with long bills, long wings, short tail and long legs and feet. The bill is very long and slender, typically Puffinoid, the wings are long with first primary longest, but the tail is rery short with a rounded appearance, and less than one-third the length of the wing. The bill characters are seen in the nextling which has a long bill with a weak nail. Other characters as in Puffinus.

Coloration bicolour.

\section{Reinholdia reinholdi. - FLUTTERING SHEARWATER.}

[Pufinus reinholdi reinholdi Mathews, Birds Alstr., Vol. II., pt. 1, p. 74, May 30th, 1912: New Zealand, Extra-limital.]

Mathews, Vol. II., pt. 1, pl. 7t, May 30th, 1912. Extra-limital specimen. Vol. VII., pt. 5, pl. 367, July 10th, 1919. Australian specimen.

Reinholdi reinholdi byroni Mathows, Austral Av. Rec., Vol. I., pt. 8, p. 187, March 20th, 1913: (Byron Bay, Now South Wales error $=$ ) Fivo Islands, south of Woollongong, New South Wales.

Cinathisma cyancoleuca Hull, Emu, Vol. XV., p. 205, Jan. 1916 (ex Bull No. 5 R.A.O.U., Dec. 21st, 1915. Unpublished): Murramurang or Brush Island, off Clladulla, New South Wiales.

Distributrox:-Seas of New South Wales and Yictoria. 
Adult.--General colour of the upper-surface including the crown of the head, back, wings, and tail, snoty-black with whitish philo tips to the feathers on the hinder crown, sides of face and nape; the margins of the greater upper wing-coverts rather paler; inner webs of flight-quills much paler, especially on the basal portion ; sides of face and sides of neck paler than the upper-surface and inclining to smoke-brown ; the feathers in front of the eye greyish-white with black hair-like tips; throat, breast, abdomen, under tail-coverts, and under wing-coverts white; sides of breast, lower flanks and thighs dark dusky-brown; axillaries and inner under wing-coverts pale dusky-brown with dark shaft-lines to the feathers and whitish margins at the tips ; under-surface of flight-quills greyish-brown; lower aspect of tail similar but the long white under tail-coverts reaching nearly to the tip of the tail. Bill horn; eves black; feet cream; inner toe and inner side of tarsus brown. Total length $338 \mathrm{~mm}$. ; culmen 35 , wing 206 , tail 69 , tarsus 40 . (The sexes are alike.) nature.

Vestling.-Wholly brownish-black with a long thin weak bill of the true Puffinoid

Nest.-At the end of a burrow, which is about two feet long, and about 4.5 inches in diameter. The chamber is 1 foot 6 inches long, and about 1 foot 8 inche. high ; in this there is a deepening with a few leaves.

Egg.-Clutch, one ; pure white; axis $53 \mathrm{~mm}$., diameter 39.

Distribution and forms.-East coast of Australia and New Zealand with the outlying islands. Four forms have been named: $R$. r. reinholdi (Mathews) from. New Zealand (exact locality unknown); R. r. hutoni (Mathews) with a longer bill and wing, culmen 38 , wing 226 , against culmen $35 \mathrm{~mm}$., wing $213 \mathrm{~mm}$.; and more brown on sides of chest, the sides of the body smoky-brown and inner wing white feathers with darker shaft-lines, from Snares Islands, south of New Zealand ; $R . r$. byroni Mathews from New South Wales on account of its darker upper coloration and smaller size; wing $191 \mathrm{~mm}$; and $R$. r. melanotis Mathews from the Kaipara Beach, North Island, New Zealand, in its blackish upper coloration and smaller size; wing $189 \mathrm{~mm}$., tail 60 , tarsus 39 , culmen 31 ; this last named may prove symonymous with the first named.

MEMo.-We have concluded the following refers to this species, though the locality has not yet been recorded.

\section{Puffinus lherminieri.-BROWN AND WHITE PETREL.}

[Pufinus lherminieri Lesson, Revue Zool,, 1839, p. 102: West Indies. Extra-limital.]

Not figured anywhere.

Pufinus lherminieri nugax Mathews, Birds Austr, Vol. II., pt. 1, p. 72, May 30th, 1912, ex Solander MIS. : off Townsville, Queensland.

Not Procellaria nugax Bonaparte.

Distribution.- " Off Townsville, Queensland." No specimen preserved.

Adult.-Above sooty, under-surface snow-white, the bill wholly lead-black, the nares a fourth of its length. Very like Nectris munda, but that the body is much less, the bill longer and narrower, ete, ; eyes black, iris grey. Length 1 foot; expanse of wings 2 feet; bill $1 \frac{3}{1}$ inches.

\section{Genus THYELLODROMA.}

Thyellodroma Stejneger, Proc. U.S. Nat. Mus., Vol. XI., p. 93, Nov. 8th, 18s8. Type (by original designation): Puffnus sphemurus Gould $=$ Puffinus chlororhynchus Lesson. Zalias Heine und Reichenow, Nomencl. Mus. Hein., p. 362, (pref. Sept.) 1890. Type (by subsequent designation, Mathews, List Birds Austr., p. 33, Dec. 1913): P. chlororhynchus Lesson.

? Microzalias Mathews and Iredale, Ibis, 1915, p. 597, July 2nd. Type (by original designation): Pufinus nativitatis Streets. 
Large Puffinine birds with long bills, long wings, long wedge-shaped tail and long legs and feet. The bill is typieally Puffinoid, with the nasal tubes depressed and the nostrils opening almost horizontally upwards. The long wedge-shaped tail is characteristic, being almost half the length of the wing, and about three times the length of the tarsus. The tarsus is typically Puffinoid and is a little longer than the culmen, and the long toes exceed the tarsus in length, the inner with the claw, the others without their claws. The webbing between the toes is full but narrow, and the hind-toe is minute.

Coloration uniformly sooty, or dark above and white below.

\section{I6. Thyellodroma pacifica.-WEDGE-TAILED SHEARWATER.}

[Procellaria pacifica Gmelin, Syst. Nat., Vol. I., pt. In., p. 560, (April 20th) 1789 : Pacific Ocean $=$ Kormadec Islands. Extra-limital.]

Gould, Vol. VII., pl. 58 (pt. xxxiv.), Dec. 1st, 1848. Mathews, Vol. II., pt. 1, pl. 75, May 30 th, 1912 .

Pufinus chlororhynchus Lesson, Traité d'Orn., 8e livr., p. 613, June 11th, 1831: No loc. = Slope Island, Shark Bay, West Australia.

Puffinus sphenurus Gould, Ann. Mag. Nat. Hist., Vol. XIII., p. 365, May 1st, 1844: Houtman'6 Abrolhos, West Australia.

Puffinus pacificus royanus Mathews, Birds Austr., Vol. II., pt. 1, p. 85, May 30th, 1912 : Sydney, New South Wales.

Distribution,-East and Southem Australian Seas.

Adult male,-General colour abore sooty-brown, with pale margins of lighter brown to the feathers of the mantle, back, scapulars and wings; under-surface dusky-brown, with hoary-grey on the chin, throat, and fore-neck; under wingcoverts and axillaries similar to the under-surface of body; bill dark horn or bone-brown, tarsus and feet (living specimens) fleshy-white or yellowish-flesh colour, with black mottlings down the whole of the outer side of the tarsus and outer toe to the base of the last phalanx ; toes whitish. Total length $420 \mathrm{~mm}$.; culmen (exp.) 37 , wing 285 , tail 135 , tarsus 46.

Adult female.-Similar to the adult male.

Nestling.-About two weeks old : covered with down, the upper- and most of the under-surface ashy-grey, throat and upper-breast greyish-white; bill black, with horn-coloured tip; feet yellowish-white. Total length 6 inches. Broughton Island, 30th January, 1911.

About ten weeks old.-True feathers on back and wings sooty-black, ashy-grey on the breast, throat darker; bill black, feet and toes yellowish-white. Total length 10 inches. Broughton Island, 13th March, 1911.

Nest.-At the end of a burrow.

Egg.-Clutch, one; white; axis 63 to $64 \mathrm{~mm}$., diameter $41-42$.

Breeding-season.-November. (Lord Howe Island.) September to December. (Solitary Islands.)

Distribution and forms.-Throughout the Indian and Pacific Oceans. Exact distribution and status undetermined. Nathews discussed the relationship of the present species and $P$. cuncatus, Salvin and later the present writers reviewed it again. The most recent investigator, Oberholser, acknowledges the same puzzling features, but suggests acquiescence in the separation of the two as we concluded, not without doubt. Four named subspecies were admitted as follows: T. p. pacifica (Gmelin) from the Kermadec Islands, of large size with a very long powerful bill $(=P . c$. irclali Mathews); T'. p. royana Mathews, from East Australia, with horn-coloured bill of smaller size, and sloorter wings, tail, etc.; T. p. chlororhyncha (Lesson) from West Australia, of a paler coloration and paler bill, and $T$. $\%$. hamiltoni Mathews, from the Scychelles, which are darker above and below, with bill " rose." 


\section{Genus NEONECTRIS.}

Neonectris Mathers, Austral Av. Rec., Vol. II., pt. 1, p. 12, Aug. 2nd, 1913. Type (by original designation): Puffinus brevicaudus Gould.

Large Puffinine birds with long bills, long wings, short tails and long legs aud feet. Agreeing with the preceling save in the wealier bill, shorter tail and consparatively longer legs. The bill is not so strong, while the tail is less than one-third the length of the wing and only one and a half times the length of the tarsus. The tarsus is about one and a half times the length of the culmen.

Coloration unicolour dusky.

Two species, with difficulty separable by means of the shorter bill and shorter legs of the latter which lacks the white irmer wing coloration of the former.

\section{Neonectris griseus.-SOMBRE SHEARWATER.}

Mathews, Vol, II., pt. 1, pl. 77, May 30th, 1912.

Procellaria grisea Gmelin, Syst. Nat., Vol. I., pt. Ir., p. 564, April 20th, 1789 : New Zealand Seas. Extra-limital.

Neonectris griseus nutcheri Mathews, Austral Av. Rec., Vol. III., pt. 3, p. 54, April 7th, 1916 : Sydney, New South Wales.

Distrimotion,-East Australian Seas.

Adult malc.-General colour above sooty-black, with darker shaft-lines; some of the feathers of the wings show a tendency to hoary-grey, sides of face and throat also hoary-grey, which colour pervades the entire under-surface; under wingcoverts mottled with white and brown, the shaft-streaks strongly pronouneed. Bill wholly black, but with a narrow thread-like white line at the base of the upper bill. Iris rery dark brown. Legs and toes black on the outer surface, but lilac or purple on the inner surface. Webs blackish. Claws black. Total length $345 \mathrm{~mm}$.; culmen (exp.) 39 , wing 299 , tail 85 , tarsus 60 .

Adult female.-Similar to the adult male.

Nestling.-Covered with thick slaty-grey down.

Nest.-At the end of a burrow.

Egg.-Clutch, one ; colour white; axis $80 \mathrm{~mm}$., diameter 49.

Breeding-season.-Norember. (Snares Island.) December to January. (Molsohinou Islands.) As late as March. (Island of Kapiti.)

Distribution and forms.-In the Pacific and Atlantic Oceans. Exact range and forms not settled. Mathews in 1912 admitted three subspecies: N. g. griseus (Gmelin) from New Zealand; N.g. chilensis Bonaparte, from West American coasts; and N.g. stricklandi Ridgway from Atlantic seas. Since then two forms from the North Pacific Ocean have been added by Mathews and Iredale, N. g. pescadoresi, from the Pescadores Islands, with longer, stouter bills and shorter legs and $N, g$. missus, from the Kurile Islands, with still longer bills and a purer ashy-brown coloration throughout.

\section{Neonectris tenuirostris.--SHORT-TAILED SHEARWATER.}

[Procellaria tenuirostris Temminck et Laugier, Plan. Color. d'Ois,, 99' livr. (Vol, V., pl, 587), 1835 : Japan. Extra-limital.]

Gould, Vol. VII., pl. 56 (pt. xxviI.), Sept. 1st, 1847. Mathews, Vol. II., pt. 1, pl. 78, May 30 th, 1912.

Puffinus brevicaudus Gould, Birds Austr., pt. xxvII. (Vol. VII., pl. 56), Sept. 1st, 1847: Green Island, Bass Straits.

Puffinus intermedius Hull, Emu, Vol. XI., pt. II., p. 98, Oct. 2n d :911 : Cabbage Tree Island, Port Stephens, New South Wales.

Neonectris tenuirostris grantianus Hull, Emu, Vol. XV., p. 206, Jan. 1st, 1916 (ex Bull. No. 5, R.A.O.U., 21/12/15. Unpublished): Ulladulla, New South Wales. 
Neonectris tenuirostris hulli Mathews, Bull. Brit. Orn. Club, Vol. XXXVI., p. 82, May 25th, 1916 : Barrier Reef, Queensland.

Distributron,-Eastern and Southern Australian Soas.

Adult male-Upper-surface sooty-black, including the head, entire back, wings, and tail, with pale margins to some of the feathers; primary-quills pale brown on the inner webs; secondaries inclining to hoary-grey, the whole of the under-surface sooty-brown, somewhat paler on the throat, and darker on the under tail-coverts; under wing-coverts sooty-brown, becoming ash-brown on the greater series; bill dark slate, tarsus slate, eyes brown. Total length 390 ; culmen (exp.) 32 , wing 280 , tail 82 , tarsus $52 \mathrm{~mm}$.

Adult female.-Similar to the adult male.

Immature.-Coloration similar; bill dark horn colour, tip light horn; iris dark brown; legs and feet slate and flesh in usual pattern.

Nestling.-Covered with brown down, paler on the under-surface.

Nest.-At the end of a burrow, which is sometimes 4 feet long. 45-46.

Egg.-Cluteh, one; pure white, minutely pitted; axis $67-71 \mathrm{~mm}$, diameter

Breeding-season.-The end of November and December.

Incubation-period.-Eight weeks.

Distribution and forms.-Australian and Japanese seas as far as yet known, but one specimen examined from Persian Gulf. Fire subspecies named, but probably only two valid, as $N$. t. tenuirostris (Temm, and Laug.) from Japanese seas, and $N, t$. brevicaudus (Gould) from East Australian seas with a differently coloured bill, dark slate, the former having a horn bill ; and the inner wing coloration, sooty instead of ashy. The other named forms, given in the synonymy abore, require confirmation by study of large series.

\section{Genus HEMIPUFFINUS.}

Hemipuffinus Irodale, Austral Av. Rec, Vol. II., pt. 1, p. 20, Aug. 2nd, 1913. Type (by monotypy): Puffinus carneipes Gould.

Large Puffinine Petrels with long, stout bill, long wings, medium tail and large legs and feet.

The bill is long, strongly hooked, with somewhat prominent $\mathrm{r}$ asal tubes, the laterals basally expanded. The nostrils are separated by a thick septum, and have their openings semi-vertical. The under mandible has the rami strong and little divergent, the unguis powerful. The wings are long with the first primary longest, and the secondaries comparatively long. The tail is weakly wedge shaped, about one-third the length of the wing and twice the length of the tarsus; the under tailcoverts reach to its end. The legs are long, the tarsus laterally compressed and covered with reticulate scales. The toes are very long, the outer longest, but little exceeding the middle toe which is longer than the imner which is a little shorter than the tarsus. The anterior toes are fully webled with long narrow acute claws. The hind-toe is minute.

Coloration wholly dark.

\section{Hemipuffinus carneipes.-FLESHY-FOOTED SHEARWATER.}

Gould, Vol. VII., pl. 57 (pt. xxxv.), Dec. 1st, 1848. Mathews, Vol. II., pt. 1, pl. 76, May 30th, 1912.

Puffinus carneipes Gould, Ann. Mag. Nat. Hist., Vol. XIII., p. 365, May 1st, 1844: near Cape Leeuwin, West Australia.

Distribution.-West and South Australian Seas.

Adult male.-General colour above sooty-black, somewhat darker on the head ; the feathers of the back, scapulars, and wings with pale bromn margins; quills 
black, inner webs pale brown, the shafts paler at the base; under-surface brown; sides of the face and throat tinged with hoary-grey; bill flesh colour; culmen and tips of both mandibles brown; iris brown; feet flesh colour. Total length $455 \mathrm{~mm}$.; culmen (exp.) 40, wing 310 , tail 104, tarsus 54.

Adult female. - Similar to the adult male but with shorter bill and shorter tarsus.

Immature--Similar to the adult.

Nestling.-Covered with brownish-grey down, much paler below; bill shor and stout; feet small.

Nest.-At the end of a long burrow.

Egg.-Clutch, one; pure white; axis 66-72 mm., diameter 47-48.

Breeding-season.-November to January.

Distribution and forms.-West Australia, New Zealand, Lord Howe Island and Japanese seas. Four forms have beon indicated from these diverse localities, as follows: H. c. carneipes (Gould) from West Australia ; H. c. hullianus (Mathews) from Lord Howe Island (the specimens were labelled Norfolk Island, where it does not occur, but collected on Lord Howe Island) on account of its larger size, and especially its stouter bill; $I$. c. hakodate (Mathews) from Japanese seas by its still larger size, paler coloration, weaker bill, and inner wing coloration; and $H, c$. carbonarius (Mathews) from New Zealand with its wealer bill than $H$. c. hullianus, and shorter wing, agreeing better with typical form, but with stouter bill than that.

This species has been procured off the coast of California, and Loomis's measurements suggest that this is a larger race still.

\section{Genus PROCELLARIA.}

Procellaria Linné, Syst. Nat., 10th ed., p. 131, Jan. 1st, 1758. Type (by subsequent designation Gray, p. 78, 1840): P. aquinoctialis Linné.

Priofinus Hombron et Jacquinot, Comptes Rendus Sci. (Paris), Vol. XVIII., p. 355, March

1844. Type: Procellaria cequinoctialis "Edw." = Linné. (P. cinerea Gmelin is not included.)

Majaqueus Reichenbach, Nat. Syst. Vögel, p. IV., 1852(?1853). Type (by original designa.

tion): $P$. eqquinoctialis Linné.

Cymatobolus Hoine und Reichenow, Mus. Hein., p. 363, (pref. Sept.) 1890. New name for "Majaqueus Reich."

Largest Puffinine birls with long stout bills, long wings, long rounded tails and strong legs and feet.

The bill is strong with a well-cleveloped unguis, about half the length of the bill, powerfully hooked ; the nasal tubes are short and are separated by a distinct septum, and open forwards with apparently a vertical ajerture. The laterals are strongly developed somewhat laterally. The under mandible has the rami strong and moderately close together, the unguis stout, the interramal space feathered. The wings are long with the first primary longest. The tail is long and rounded, a little less than one-third the length of the wing. The legs are long and stout, not so compressed as in the previous genera and covered with reticulate scales similarly. The toes are longer than the tarsus, the outer longer than the middle which exeeds the inner, all the claws long and sharp. The hind-toe minute, and the anterior toes fully webbed.

Coloration wholly sooty, sometimes with white markings about the head.

\section{Procellaria æquinoctialis.-WHITE-CHINNED PETREL.}

[Procellaria aquinoctialis Linné, Syst. Nat., 10th ed., p. 131, Jan. 1st, 1758: Capo Seas. Extramimital.]

Mathews, Vol. II., pt. 1, p. 112, May 30th, 1912.

Procellaria acquinoctialis steadi Mathews, Birds Austr., Vol. II, pt. 1, pp. 110-112, May 30th, 1912 : Antipodes Islands, New Zealand.

Distrindtion.-? East and South Australian Seas. 
Adult male.-General colour above sooty-black with brown edges ; interramal space only more or less white; bill with sides of the upper mandible and the tubes blue, the culmen and unguis black, the lower edge of the lower mandible flesh colour; legs and feet black. Total length $510 \mathrm{~mm}$. ; culmen 56 , wing 388 , tail 122 , tarsus 67.

Adult female.-Agrees in coloration and size.

Nestling.—Unknown.

Young.-According to Hutton, identical in coloration.

Vest.-Breels in hole.s made in the side of a slope, these holes being hollower out into a circular chamber at the end.

Egg.-White.

Breeding-season,-December.

Distribution and forms.-Round the Sub-antarctic Circle. Four subspecies have been discriminated by means of the white chin spot and size: $P$. a. aquinoctialis Linné from the Cape Seas, probably breeding at the Falkland Islands or South Georgia, with a very small chin spot; $P . \alpha$. mixtu Mathews from eastern Cape Seas, probably breeding at Kerguelen Island with a larger amount of white on chin and sides of face; wing average $374 \mathrm{~mm}$. $P$. a. sleadi Dathews, from New Zealand seas, breeding on Antipodes and Auckland Islands with a minute white interramal spot, average wing $385 \mathrm{~mm}$; and $P$. a. brabournei Mathews, from west coast of South America, breeding place unknown, a larger bird with a small white chin spot; average wing $399 \mathrm{~mm}$.

\section{Procellaria conspicillata.-SPECTACLED PEIREL.}

Gould, Vol. VII., pl. 46 (pt. $x \times x v$ ). Dec. 1st, 1848. Mathews, Vol. II., pt. 1, pl. 79, May 30th, 1912.

Procellaria conspicillata Gould, Ann. Mag. Nat. Hist., Vol. XIII., p. 363, May 1st, 1844 : Australian Seas ? = Capo Seas.

Procellaria larvata Lesson, Echo du Monde Savant, 12th year, No. 31, col. 971, June 1st, 1845: Capo Seas.

Distributron,-Australian Seas? ? No authentic specimens known, though commonly so recorded.

Adult male.-General colour above and below sooty, the feathers margined with brown; a band of white commences on the chin and extends backward along the cheeks to the sides of the head, but is not joined on the oceiput; another band extends from the chin, in front of the eyes, across the crown of the head. Nostrils and sides of the mandibles yellowish-horn colour; culmen, tips of both mandibles, and a groove rumning along the lower mandible black; feet black. Total length 476 mm. ; culmen (exp.) 53, wing 368, tail 105, tarsus 66.

Adult female and Young.-Unknown.

Nest, Egg, and Breeding-season.-Unknown.

Distribution and forms.-Unknown. "Very abundant in the Atlantic and Pacific Oceans." (Gould.) Nearly all skins available labelled "Australian seas," and nearly all records referring to Atlantic Ocean only: In the Austral Avian Record, Vol. II., p. 21, August 2, 1913, Iredale has recorded details of authentic Atlantic specimen in Vienna Museum, but no further information on the subject has since been received.

\section{Procellaria parkinsoni.-BLACK PETREL.}

Mathows, Vol. II., pt. 1, pl. 80, May 30th, 1912.

Procellaria parkinsoni Gray, Ibis, July 1862, p. 215 : New Zealand.

Distribution.-Australia (visitor). One specimen preserved in Macleay MIuseum, Sydney. 
Adult male--Entire plumage, both above and below, sooty-black, with no white on the head; bill yellow, culmen and tip black, iris hazel, feet black. Total length $545 \mathrm{~mm}$.; culmen 42 , wing 348 , tail 110 , tarsus 54.

Adult female. - Similar to the adult male. Total length $530 \mathrm{~mm}$. ; culmen 40 , wing 337 , tail 101, tarsus 52 .

Nestling.-Covered with dark grey down.

Nest.-A few leaves placed at the end of a burrow.

Egg.-Clutch, one; pure white; axis $72 \mathrm{~mm}$., diameter 51.

Breeding-season.-November and December.

Distribution and forms.-New Zealand Seas, breeding on the mainland and islands. No subspecies differentiated, but Loomis has recently (Proc. Calif. Acad. Sci., Vol. II., pt. II., p. 108, April 22nd, 1916) recorded the species killed at sea near the Galapagos Islands.

\section{Genus ADAMASTOR.}

Adamastor Bonaparte, Comptes Rendus Acad. Sci. Paris, Vol. XLIII., p. 595, Sept. 1856. Type (by original designation): Pr. hresitata Forster $=$ Procellaria cinerea Gmelin.

Priofinus Auct., not of Hombron and Jacquinot, 1814.

Large Puffinine birds agreeing with Procellaria with bill features, but with shorter wings, comparatively longer tail and shorter legs. The different coloration of the feet suggest a more close alliance with Puffinus (sensulatissimo) and Ardenna (s. str.). The culmen is less than the tarsus which is half the length of the rounded tail, which is one-third the length of the wing; in the preceding genus (Procellaria) the tarsus is more than half the length of the tail, which is less than one-third the wing-length.

Coloration brown-grey above, white below.

\section{Adamastor cinereus.-BROWN PETREL.}

Gould, Vol. VII, pl. 47 (pt. xxxv.), Dec. 1st, 1848. Mathews, Vol. II., pt. 1, pl. 81, May 30 th, 1912.

Procellaria cinerea Gmelin, Syst. Nat., Vol. I., pt. Ir., p. 563, April 20th, 1789: Antaretic Circle $=$ Seas south of New Zealand.

Procellaria gelida Gmelin, ib., p. 564: " inter $35^{\circ}$ and $50^{\circ}$ South."

Procellaria melanura Bonnaterre, Tabl. Encyel. Méth. Ornith., Vol. I., p. 79, 1791

Procellaria hoesitata Forster, Dese. Anim., ed. Licht., p. 208, (Jan. 1st) 1844

Not of Kuhl, Beitr. Vergl. Zool. Anat., p. 142, (pref. April 9th) 1820

Adamastor typus Bonaparte, Consp. Gen. Av., Vol. II., p. 187, Oct. Ist, 1857

Procellaria adamastor Schlegel, Mus. Pays-Bas, Vol. VI., Procell., p. 23, July

1863

Procellaria pallipes Mathews, Birds Austr., Vol. II., pt. 2, p. 123, July 31st, 1912 : New

Zealand. Ex Solander MS.

Priofinus cinereus dydimus Mathews, Austral Av. Rec., Vol. III., pt. 3, p. 54, April 7th, 1916 : New Zealand.

Drstributrow.-Australia. Gould says that ho got specimens between Hobart and Sydney.

But none preserved now.

Adult male.-General colour above ash-grey, including the feathers of the back, scapulars, and upper tail-coverts; the long scapulars and wing-coverts a little darker than the back, and show the shaft-streaks; bastard-wing and primary-coverts ash-brown; primary-quills, hoary-grey, paler on the inner webs, outer web of the first primary blackish; shafts white towards the base; secondaries hoary-grey, more or less white on the basal portion ; tail for the most part brown with hoarygrey on the outer webs of the feathers and becoming whitish towards the base; head and sides of the face darker than the back, and inclining to black or slate- 
grey; throat and under-surface of the body white; the long under tail-coverts ash-brown with pale edges ; axillaries and under wing-coverts also ash-brown, somo of the latter have pale edges; bill perfectly black on the ridge, ehanging to horn colour on the hook and having a black line down the middle of the lower mandible. widening out on meeting the unguis, which is dull horn colour, remainder of bill yellow; legs and feet greyish-flesh colour, shaded with dark on the heel and on the outer sides of the tarsus and toes; interdigital webs yellowish with grey edges, iris dark brown. Total length $425 \mathrm{~mm}$.; culmen (exp.) 45, wing 335 , tail 112 , tarsus 55 .

Adult female.-Similar to adult male.

Nest.-Cup-shaped structure, in a large chamber at the end of a burrow.

Egg.-Clutch, one ; pure white ; axis $70 \mathrm{~mm}$., diameter 50 .

Breeding-season.-October to December. (Macquario Island.)

Distribution and forms.-Round the Antarctic Circle, and at present no welldefined subspecies can be determined.

\section{Genus PRIOCELLA.}

Priocella Hombron et Jacquinot, Comptes Rendus Acad. Sci. Paris, Vol. XVIII., p. 357, March 4th, 1844. Typo (by monotypy): P. garnotii Hombron et Jacquinot $=F u l m a r u s$ antarcticus Stephens.

Accurately this genus would rank as a subgenus of Fulmarus, with which genus it agrees in detail save in the bill formation. The bill has long nasal tubes, lying on top of the culmen and developed in that position, thus differing from the preceding in a character probably of family value. The wing is long and the first primary longest. The tail consists of fourteen feathers, and is rounded and more than onethird the length of the wing and nearly three times the length of the tarsus. The tarsus is weak and not strongly laterally compressed, and much longer than the culmen.

Coloration blue-grey above, white below.

\section{Friocella antarctica.-SILVER-GREY PETREL.}

Gould, Vol. VII., pl. 48 (pt. $\operatorname{xxvv}$ ), Dec. 1st, 1848. Mathews, Vol. II., pt. 2, pl. 82, July 31 st, 1912.

Fulmarus antarcticus Stephens, in Shaw's Gen. Zool., Vol. XIII., pt. I., p. 236, Feb. 1Sth, 1826 : Cape Seas.

Procellaria glacialoides Smith, Illus. Zool. S. Africa, pl. 51, July, 1840 : Capo Seas.

Priocella garnotii Hombron et Jacquinot, Comptes Rendus Acad. Sci. (Paris), Vol. XVIII., p. 357, March 4th, 1844: Nomen nudum.

Thalassoica polaris Bonaparte, Consp. Gen. Av., Vol. II., p. 192, 1857 (after Oct. 1st) : Nom. nud.

Procellaria smithi Schlegel, Mus. Pays-Bas, Vol, V1., Procell., p. 22, July 1863. New name for $P$. glacialoides Smith.

Priocella antarctica addenda Mathews, Austral Av. Rec., Vol. II., pt. 7, p. 125, Jan. 23th, 1915 : New Zealand Seas.

Distribumion,-East Australian Seas. Two specimens in Melbourne Museum, collected at Queenscliff in December 1882.

Adult male.-Upper-surface, including the mantle, back, wings, and tail bluegrey, becoming paler and inclining to white on the hind-neck; bastard-wing dark grey, some of the feathers white on the inner webs; primary-coverts dark grey with pale tips; primary-quills clark srey with whitish tips, the greater portion of the inner wbs white, inner primaries paler grey towards the base; sccondaries grey on the outer wehs and white on the inner ones, the innermost secondaries like the back; mickile tail-feathers like the back; the outer ones white on the inner webs, 
the outermost entirely white; fore-part of head, sides of face, throat, and undersurface of body pure white; maxilla and mandible tipped with black, the middle portion of the bill flesh-coloured, and the base and nares cobalt-blue. The feet are pale flesh colour, the webs washed with yellow, and the claws black. The iris dark brown, and the pupil black. Total length $482 \mathrm{~mm}$.; culmen 45 , wing 340 , tail 132 , tarsus 49.

Adult female.---Similar to the adult male.

Nest.-At the end of a burrow in the sand. (Kerguelen Island.)

Egg.--Unknown.

Distribution and forms.-Pound the Antaretic Circle. No definite subspecies at present recognisable.

\section{Genus PTERODROMA.}

Pterodroma Bonaparte, Comptes Rendus Acad. Sci. Paris, Vol. XLII., p. 768, May, 1856. Type (by subsequent designation, Coues, Proc. Acad. Nat, Sci. Philad,, p. 137, May 1866) : Procellaria macroptera Smith.

Large Petrels for this series with short stout black bills, long wings, long tail and stout legs of peeuliar coloration. The bill has a short nasal tube, which is less than half the length of the culmen, and almost reaches the base of the unguis, which is very round and sharply hooked; viewed from in front the nasal aperture appears circular with a thin septum visible inside, separating the nostrils. The derelopment of this tube is quite unlike that of Puffinus, though the result is similar and is a good example of convergence. The latericorns are little expanded and the inside shows no lamellx. The rami of the lower mandible are strong, but little divergent, the interramal space feathered, the powerful unguis not deflected downward as in Puffinus. The wings are long with the first primary longest. The tail is long, somewhat wedge shaped of twelve broad feathers and about two-fifths the length of the wing. The legs are stout, much less compressed than in Puffinus, and the toes are comparatively shorter, the hind-toe being only present as a straight claw. The anterior toes are fully webbed.

All the birds of the genus are stoutly built and coloration dark above and sometimes also dark below.

\section{Pterodroma macroptera.-GREY-FACED PETREL.}

[Procellaria macroptera Smith, Illus, Zool. S. Africa, pt, xI., pl. 52, July 1840: Capo Seas. Extra-limital.]

Mathews, Vol. II., pt. 2, pl. 83, July 31st, 1912.

Pterodroma macroptera albani Mathews, Austral Av. Rec., Vol. I., pt. 2, p. 30, April 2nd, 1912 : Rabbit Island, Albany, West Australis.

Distribution,-West and South Australian Seas.

Adult male.-Sooty-black above and below ; fore-head, lores, chin, and throat greyish ; bill and feet black; iris hazel. Total length $392 \mathrm{~mm}$.; culmen 36 , wing 320 , tail 135 , tarsus 41 .

Adult female.-Similar to the adult male.

Immature.-Similar to adult.

Nestling.-Covered with greyish-black down.

Nest.- In large chamber at end of a burrow, lined with a few leaves and grass.

Egg.-Clutch, one; pure white; axis $68 \mathrm{~mm}$., diameter 50.

Breeding-season,-June, September.

Distribution and forms. - South Atlantic Ocean, Indian Ocean and Sonth-went Pacific Ocean. Three forms have been indicated: $P$. m. macroptere (Smith) from 
the Cape Seas; P.m. gouldi (Hutton) from New Zealand (which may occur in Fant Australian seas) with longer wings and a greyer face; and $P . m$. albani Mathews, from West Australia, smaller than preceding but with similar grey faces.

\section{Pterodroma melanopus.-BROWN-HEADED PETREL.}

Mathews, Vol. Il., pt. 2, pl. 84, July 31st, 1912.

Procellaria melanopus Gmelin, Syst. Nat., Vol. I., pt. I., p. 562, April 20th, 1789: North America $=$ Norfolk Island.

Procellaria solandri Gould, Ann. Mag. Nat. Hist., Vol. XIII., p. 363, May 1st, 1844: Bass Straits.

Procellaria phillipii Gray, Ibis, July 1862, p. 246 : Norfolk Island.

Estrelata montana Hull, Proc. Linn. Soc. N.S.W., 1910, Vol, XXXV., p. 785, March 1st, 1911 : Lord Howe Island.

Distribution.-Australia (visitor). Breeding on Lord Howe Island, formeriy on Norfolk Island. One occurrence in Bass Straits. Specimen preserved in British Museum.

Adult (type of $P$. solandri Gould).-Back, scapulars, and upper tail-coverts slate-serey with dark edgings to the feathers; lesser wing-coverts, bastard-wing, and primary-coverts dark brown; primary-quills also dark brown on the out $n$ webs and at the tips, paler on the inner webs, and becoming white at the base; median and greater coverts slate-grey, the secondaries similar but pale brown on the inner webs and whitish at the base; tail dark brown with hoary-grey on some of the outer webs of the feathers, pale on the inner webs and also at the base; heari and reck all round sooty-brown, the feathers having white bases give a scallojed appearance on the fore-head and sides of face; breast pale sooty-brown, becoming dull slate-grey on the abdomen, under tail-coverts, and sides of the body; the feathers on the sides of the body slightly edged with white at the tips like the axillaries: under wing-coverts dark brown, the greater under wing-coverts dull white like the base of the primaries; bill black; eyes dark brown; feet black, web greyish-black. Total length $450 \mathrm{~mm}$; culmen, from base of feathers on forehead, 40 , wing 296 , tail 128, tarsus 41 .

Adult male and female-Alike.

Immature.-We have examined many birds which still retained the grey clown on the abdomen. These show the characteristic mottling of the face, and agree entirely in coloration with the adult, save that the shades appear lighter or darker than they do in the adult, owing to the wearing; thus the secondary wing-coverts are lighter, while the median coverts show darker, the lesser again appearing lightcr, etc. The dark tips to the feathers of the under-surface are somewhat paler.

Nestling.-Covered with dark ashy-grey down, concolour.

Nest.-A large accumulation of grass in burrows, some as much as six feet in length, in which the egg is almost concealed.

Egg.-Clutch, one; dull white; $63 \mathrm{~mm}$. by 44.

"They lay but one egg, and that is full as large as a duck's egg." (Hunter, Norfolk Island.)

Breeding-season.-June, July and August.

"Most of the females taken in Mar were with egg." (Hunter, Norfolk Island.)

Distribution and forms.-Breeding at Lord Howe Island only ; only other record as above and consequently no subspecies.

\section{Pterodroma inexpectata.-MOTTLED PETREL.}

[Procellaria inexpectata Forster, Descr. Anim., ed. Licht., p. 204, (pref. Jan. 1st) 1844: Seas south of Now Zealand. Extra-limital.]

Mathews, Vol. VII, pt. 5, pl. 368, July 10th, 1919. 
Pterodroma inexpectata thompsoni Mathews, Austral Av. Rec., Vol. II., pt, 7, p. 125, Jan. 28th, 1915 : East Australia $=$ Tasmania.

Distributron.-Tasmania (visitor). One specimen preserved in Mathews's collection.

Adult male.-General colour of the upper-surface hoary-grey, with white bases to the feathers, which show through the grey in many places; the tips of the feathers on the head, back, scapulars, and short upper tail-coverts dark brown or blackish ; lesser and marginal upper wing-coverts, bastard-wing, primary-coverts, and outer webs of flight-quills blackish-brown ; the inner webs of the last for the greater part white; median and greater upper wing-coverts and secondary-quills hoary-grey with narrow white edgings on the outer webs, the inner webs for the most part white, except the innermost where both webs are grey; long upper tail-coverts and tailfeathers pale slate-grey, except the two outer ones on each of the latter which are mottled with white; fore-head and sides of face, including the feathers surrounding the eyes, white with minute dark tips to the feathers; chin and throat pure white ; breast, abdomen, and sides of body dusky-brown with white bases to the feathers which show through and impart a mixture of brown and white, some of the feathers on the sides of the body and lower flanks are barred with white and dusky-brown ; under tail-coverts cream-white and reach the tip of the tail ; axillaries white, mottled and barred with dusky-brown; under wing-coverts blackish-brown, more or less mottled and blotched with white; under-surface of flight-quills for the greater part white with pale brown along the shafts and at the tips of the primaries and grey tips to the secondaries; lower aspect of tail grey, the two outer feathers on each sides mottled with white, almost the whole of the tail below is obscured by the under tail-coverts, which are cream-white; bill black, tarsus fleshy, feet black with base of inner web whitish. Total length $283 \mathrm{~mm}$; culmen 25, wing 251 , tail 93 , tarsus 35 .

Adult female and Immature.-Similar to adult.

Nestling.-Sooty-grey down above and below.

Nest, Egg and Breeding-season.-Unknown.

Distribution and forms.-Breeding in south New Zealand and the islands south of New Zealand. A specimen was deseribed as a new species as Eistrelata fischeri by Ridgway from St. Paul, Kodiak Island, Alaska; another of the same form from the North Atlantic as Estrelata scalaris by Brewster, but breeding places unknown.

\section{Pterodroma mollis.-SOFT-PLUMAGED PETREL.}

Gould, Vol. VII., pl. 50 (pt. xxxv.), Dec. 1st, 1818. Mathews, Vol. II., pt. 2, pl. 86, July 3 lst, 1912.

Procellaria mollis Gould, Ann. Mag. Nat. Hist., Vol, XIII., p. 363, May 1st, 1814; South Atlantic Ocean.

Distributron,-West Australian Seas. (One occurrence, West Australia.)

Adult male.-Head, hind-neck, sides of neck, back, and short scapulars ashgrey, becoming much paler on the upper tail-coverts and tail; some of the outer tail-feathers whitish; the long scapulars and entire wing black with pale brown on the inner webs of the primaries; under-surface white, sides of body dusted and barred with grey; under wing-coverts sooty-brown; the feathers on the fore-head and sides of the face have more or less white fringes; bill black, tarsus and basal third part of the feet flesh colour, the remainder black; iris brown. Total length $395 \mathrm{~mm}$. ; culmen 29 , wing 259 , tail 112 , tarsus 35.

Adult female.-Similar to the adult male.

Nest, Egg and Breeding-season.-Unknown.

Distribution and forms. - Atlantic Ocean only, and the North Atlantic form has been named $E$. fece by Salvadori, yet the specimen recorded from Australia shows no appreciable difference from typical birds. 


\section{Genus ESTRELATA.}

Estrclata Bonaparte, Comptes Rendus Acad. Sci. Paris, Vol. XLII., p. 768, May 1856. . Typo (by subsequent designation, Coues, Proc. Acad. Nat. Sci. Philad,, p. 137, May 1866) : Pro. cellaria hasitata Kuhl.

There is a series of these Pterodromoid Petrels which do not show any very appreciable difference in structure, but which have probably followed a different route of development. We are keeping the present name in view in order to incite investigation into this matter.

Large Pterociromine birds with short stout black bills, long wings, long tail and stout legs and feet.

The bill is comparatively short and stout, only about three-fourths the length of the tarsus. The details are typically Pterodromine.

The wing is long with the first primary longest. The tail is long and redge shaped, nearly half the length of the wing, but less than three times the length of the tarsus. The legs are stout, not so much lateral compression, and covered as usual, with reticulate scaling; the hind-toe exists only as a projecting point and the long toes are fully webbed.

Coloration mainly white, wings and back dark coloured.

\section{Estrelata lessonii.-WHITE-HEADED PETREL.}

[Procellaria lessonii Garnot, Ann. Sci. Nat., Paris, Vol. VII., p. 54, 1826: Falkland Islands Seas, Extra-limital.]

Gould, Vol. VII., pl. 49 (pt. xxxv.), Dec. 1st, 1848. Mathers, Vol. II., pt. 2, pl. 85, July 31st, 1912.

Procellaria leucocephala Forster, Descr. Anim., ed. Licht., p. 206, (pref. Jan. 1st) 1814: Australian Seas.

Not of Kuhl, Beitr, Vergl. Anat., p. 142, 1820, nor Griftith "1829."

Procellaria vagabunda Mathews, Birds Austr., Vol. II., pt. 2, p. 155, July 31st, 1912 (ex Solander MS.): Bass Straits, Australia.

Not of Gray, Genera Birds, Vol. III., p. 648, 1S44, as synonym of lessonit.

Estrelata lessonii australis Mathews, Austral Av. Rec., Vol. III., pt. 3, p. 54, April 7th, 1916 : Sydney, New South Wales.

Distribution.-Southern Australian Seas.

Adult male-General colour abore pale grey, including the hind-neck, sides of seck, back, scapulars, and tail, darker on the wings and long scapulars; lesser and median wing-coverts blackish like those round the margin of the wing-and primarycoverts; primary-quills blackish, paler on the inner webs; secondaries slate-grey, white at the base; feathers of the back and short scapulars grey with paler grey margins ; upper tail-corerts paler grey than the back, margined with white ; micldle tail-feathers grey, the outer ones white-mottled or dusted with grey ; feathers round the eye blackish ; fore-head, lores, and chin white, mottled with grey ; throat and remainder of under-surface white; axillaries ash-grey, white at base and fringed with white at the tips; under wing-coverts pale brown with whitish margins; bill black, iris black; tarsi and base of feet fleshy-white, toes and outer portion of webs black. Total length $413 \mathrm{~mm}$.; culmen 36, wing 314, tail 130, tas us 48 .

Adull female.-Similar to the adult male; wing 308 .

Immature.-Similar.

Nestling.-Undescribed.

Nest.-A large chamber at the end of a burrow.

Egg.-Clutch, one; pure white; axis $72 \mathrm{~mm}$., diameter 51 .

Distribution and form.-Round the Sub-antaretic Circle. Two forms hare been suggested: A. l. lessonii (Garnot), from the Falliand I-lands stas; A. l. australis 
Mathews, from East Australian seas (probably breeding on the New Zealand Subantaretic Islands) in their slighter bill, and more uniform grey tail and shafts of tail-feathers yellowish, not white.

\section{Genus COOKILARIA.}

Coolilaria Bonaparte, Comptes Rendus Acad. Sci. Paris, Vol. XLIII, p. 994, Nov. 1856. Substitute name for " Rhantistes Reichenbach." Type (by original designation): Pro. cellaria cookii Gray.

Rhantistes Reichenbach, Nat. Syst, Vögel, pt. IV., 1852 (? 1853). Type (by original designation): $P$. cookii Gray.

Not Kaup, Skizz. Entwick.-Gesch. Nat. Syst, p. 105, 1829.

M[edium delicately-built Petrels with short bills, long wings, medium tail and medium legs and feet.

The bill is comparatively short and generally stout, as in Pterodroma, usually a little less than the length of the tarsus; the variation in bill formation in this genus is noteworthy, one form having quite an elongate bill almost equalling the tarsus, and with the unguis less strong and hooked than in the other forms.

The wing is long with the first primary longest, and the tail is wedge shaped, much more than one-third the length of the wing and in some cases nearly half the length. The legs are slender, not laterally compressed and covered with reticulate scaling, the toes fully webbed anteriorly, the hind-toe a simple straight claw. The tarsus is about one-third the length of the tail and the legs are typically coloured.

Coloration bluish-black above, white below.

This genus is an example of the fatuity of depending upon "structural" characters alone, as these, calculated from the skin, do not take into review the trunk features, which are significant. These birds are very difierent in form, habits, cry and colour pattern of downy young from the large Pterodromine species, but in structure they differ but little as to proportions of wing, bill, etc.

\section{Cookilaria cookii.-WHITE-WINGED PETREL.}

[Procellaria cookii Gray, in Dieffenbach's Travels in New Zeal., Vol, II., p. 199, 1843, middlo Jan. : New Zealand. Extra-limital.]

Gould, Vol. VII., pl. 51 (pt. xxv,), Dec. 1st, 1846. Mathews, Vol. II., pt. 2, pls. (S7) and 88, July 31 st, 1912.

Procellaria leucoptera Gould, Ann. Mag. Nat. Hist., Vol. XIII., p. 364, May 1st, 1844 : Cabbage Tree Island, Port Stephens, Now South Wales.

Rhantistes velox Bonaparte, Comptes Rendus Acad. Sci. Paris, Vol. XLII., p. 768, May 1856:

New name for $P$. leucoptera Gould.

Cookilaria cookii byroni Mathews, Bull. Brit. Orn. Club, Vol, XXXVI., p. 48, Fob. 3rd, 1916 :

" Byron Bay, N.S.W." errore = Cabbage Tree Island, New South Wales.

Distribution.-New South Wales.

Adult male-Head, hind-neck, sides of neck and mantle black, like the lesser wing-coverts, bastard-wing, primary-eoverts, outer webs and tips of primaries and the long scapulars; inner webs of primaries brown near the shafts, white on the remaining portion of the inner webs; median and greater wing-coverts ash-grey as also the back and short scapulars; innermont primaries and secondaries ashygrey, basal portion of inner webs white; axillaries white; upper tail-coverts and tail pale ash-grey, some of the outer feathers minutely mottled with white and grey on the imer webs; feathers of the fore-head black, fringed with white; lores, chin, throat, and entire under-surface white, including the long under tail-coverts, sides of borly and under wing-coverts; the small coverts round the margin of the wing slate-grey narrowly edged with white; sides of breast dark slate-grey. Total length $307 \mathrm{~mm}$; ; culmen 25, wing 215, tail 95, tar us 30. (Taken from the co-type of 
serenty years ago.) Freshly moulted specimens have head, hind-neck, sides of neck and mantle dark bluish-grey; median and greater wing-coverts and back ashy-grey with noticeable white fringes to the feathers; lower back lighter; rump dark, like head; upper tail-eoverts and tail like lower back, but tips of tail-feathers darker. All the feathers of the upper-surface with lighter bases; from the back to the tail pure white bases.

Arlult female.- Not so dark above as the male and slightly smaller in all the measurements.

Nestling.-Abont four weels old. Head and the whole upper-surface covered with bluish-grey down, extending on to the flanks; chin, throat, and upper-breast, white; centre of breast, abdomen, and under-tail, white. Bill, black, interdigital membrane fleshy-white and basal half, black. Total length 8 inches. surface.

Younger birds, about 5 inches in length, show more of the white on the under-

Nest.-A depression in the ground, or a crevice among loose stones, lined with a small quantity of broken pieces of dead fronds of the cahbage palm.

Egg.-One; soft chalky-white, rounded oval; dimensions $50 \mathrm{~mm}$. by 37 .

Breeding-season.-November and December.

Distribution and forms.-Pacific Ocean only. Seren forms are known, but whether these should be considered subspecies or specifically distinct is problematical. These forms are C.c. cookii (Gray) from New Zealand mainland; C. c. leucoptera (Gould) from Eastern Australia, in its darker coloration above and smaller size; C. c. nigripennis (Rothschild) from the Kermadec Group, in its dark inner webs to the primaries; C. c. axillaris (Salvin) from the Chatham Islands, on account of its black axillaries (all the other forms have white axillaries); C.c.defilizquana (Giglieli and Salvadori) from western South America, paler than the typical form with shorter legs and tail; C. c. longirostris (Stejneger) from the Japanese Isles with a longer, thinmer bill and dark upper coloration with white inner webs to primaries; and C.c. hypoleuca (Salvin) from the Marshall and Bonin Group with a dark upper coloration and dark imer webs to primaries and also a decidedly longer tail than any of the others. And Dr. Einar Lönnberg has described C. c. masafuerce from Juan Fernandez.

\section{Genus DAPTION.}

Daption Stephens, in Shaw's Gen. Zool., Vol. XIII., pt. I., p. 239, Feb. 18th, 1826. Type (by original designation): Procellaria capensis Linné.

Calopctes Sundevall, Meth. Nat. Av. Disp. Tent., p. 142, (before June 12th) 1873. New name for Daption.

Petrella Mathers, Auk, Vol. XXXI., p. 91, Jan. 1st, 1914, ex Zimmermann. Type (by monotypy): $P$. capensis Linné. (Discarded as of a binary, but not binomial writer.)

Medium Fulmarine Petrels with long broad bills, long wings, long tail, and strong legs and feet. The bill is long with long nasal tubes lying along the culmen about half its length and the unguis comparatively weak; the laterals are expanded and inside have obsolete pectinations. The lower mandible has a curved unguis, while the mandibular rami are curved and wide apart enclosing an unfeathered skin, which can be puffed out like a pouch. The wing has the first primary longest. The tail is rounded, with fourteen feathers, more than one-third the length of the wing. The legs are comparatively stout and of less lateral conpression than on the Puftinine forms, and the tarsus is a little longer than the culmen; the niddle toe is exceeded by the outer, and the hind-toe is a mere spur. below.

Coloration unique, brown spots above, brown head, back and wings and white 


\section{Daption capensis.-SPOTTED PETREL.}

[Procellaria capensis Linné, Syst. Nat., 10th ed., p. 132, Jan. 1st, 1758: Cape of Good Hope. Extra-limital.]

Gould, Vol. VII., pl. 53 (pt. xxIx.), Dec. 1st, 1847. Mathews, Vol. II., pt. 2, pl. 90, July 31 st, 1912.

Daption capense australis Mathews, Austral Av. Rec., Vol. I., pt. 8, p. 187, March 20th, 1913 : Now Zealand.

Distribotion,-Southern Australian Seas.

Adult male.-General colour above dark lead-grey, chequered with white on the back, wings, and tail; lesser wing-coverts dark lead-grey with white bases; median coverts grey with white on the inner webs like the outer greater coverts; inner greater coverts white with a wedge-shaped spot of grey at the tips ; marginal coverts and bastard-wing dark hoary-grey with pale bases; primary-coverts dark grey, white at the base of the inner webs; primary-quills blackish along the outer webs and at the tips, inner webs white, which colour extends on to both webs at the basal portion of the inner primaries; secondaries white, tiplped with slate-grey; feathers of the back and scapulars, as well as those of the upper tail-coverts, white tipped with grey; tail white with the apical portion blackish; head and neck all round dark plumbeous-grey inclining to blackish on the occiput and becoming white on the lower throat; a short white line immediately under the lower eyelid; undersurface of boly white with a few seattereil spots of grey, particularly on the under tail-coverts and sides of body ; axillaries and under wing-coverts white, the marginal coverts plumbeous-rgrey; bill and feet black; iris dark brown, eyelids black; the bare skin beneath the mandible, dusky-red. Total length $375 \mathrm{~mm}$.; culmen 41 , wing 177, tail 128, tarsus 44.

Adult female.-Similar to the adult male.

Of three birds obtained at the same time the one described has the throat the same colour as the head, while the other two have the white of the under-surface encroaching up to the chin. Another adult example in Nathews's collection has the terminal band on the tail-feathers, and many of the feathers of the wing brown instead of slate-black, due to wearing.

Young in down.-Generally greyish above, greyish-white below.

Nestling.-Slate-grey above, and paler and sooty on the under-surface.

Nest.-Composed of a few small angular fragments of rock and a little earth, placed on open exposed ledges of cliffs. (Laurie Island.)

Egg.-Clutch, one; pure white; axis $65 \mathrm{~mm}$., diameter 42.

Breeding-season.-December and January. (South Orkneys.)

Incubation-period.-About forty-two days.

Distribution and forms.-Pound the Sub-antarctic and Antarctic Circles. Two forms have been named : D. c. capensis (Limné) from Cape Seas, and $D$. c. australis Mathews, from New Zealand Seas in its darker coloration above.

\section{Genus HALOBFNA.}

Halabana Bonaparte, Comptes Rendus Acad. Sci. Paris, Vol. XLII., p. 768, May 1856. Type (by monotypy): Procellaria carulea Gimelin.

Zaprium Coues, Bull. U.S. Nat. Mus. No. 2, p. 34, Nov. 1875. Type (by monotypy): $P$, carrulea Gmelin.

Small Prionitic (?) birds with long narrow bills, long wings, long tail and short legs and feet. The bill has a long hooked unguis about half the length of the culmen, the nasal tubes short; these are placed on top of the culmen and open outwards as a single tube with a thin septum internally; the latericoms are a little basally expanded. The under mandible has the rami divergent, the interramal space narrow 
and fully feathered, the unguis fairly strong and decurved. The wing is long with the first primary longest. The tail is faintly wedge shaped, the two middle feathers absolutely the longest, and the two outside shortest; the upper-tail coverts extend to about two-thirds its length, the under fully as long. The legs are short, fairly compressed laterally, the toes fully webbed, the webs narrow, the outer and middle subequal, the inner shorter; claws long and narrow, that of the middle toe the longest.

Coloration bluish-grey above, white below with the fore-head mottled and side of face white; the tips of the tail white.

\section{Halobæna cærulea.-BLUE PETREL.}

Gould, Vol. VII., pl. 52 (pt. xxIx.), Dec. 1st, 1847. Mathews, Vol. II, pt. 2, pl. 91, July 31 st, 1912.

Procellaria carulea Gmelin, Syst. Nat., Vol. I., pt. II., p. 560, April 20th, 1789 : Southern Ocean $47^{\circ}$ to $58^{\circ}$.

Procellaria forsteri Smith, Ill. Zool. South Africa, pl. LIrI, July 1840 : Cape Seas.

Not Latham, Index Ornith., Vol. II., p. 827, 1790.

Procellaria similis Forster, Descr. Anim., ed. Licht., p. 59, (pref. Jan. 1st) 1844: Antarctic Ocean.

Halobcena carulea victorice Mathews, Austral Av. Rec., Vol. III., pt. 3, p. 54, April 7th, 1916: Victoria.

Halobcena murphyi Brooks, Bull. Mus. Comp. Zool. Harv., Vol. 61, p. 146, June 1917 : South Georgia.

Distribution.-Southern Australian Seas.

Adult male.-General colour above pale blue-grey; lesser and median wingcoverts darker than the back, like the bastard-wing and primary-coverts; greater wing-coverts like the back; the four outer primaries dark brown on the outer webs, white on the inner ones, with black shafts ; inner primaries blue-grey like tlee back; secondaries mostly white with grey on the outer webs, innermost secondarien like the back; the long scapulars tipped with white; tail blue-grey broadly tipped with white, more narrowly on the outer feathers, the outermost pair are white, dusted with grey at the tips; crown of head and feathers surrounding the eyes blackish, more or less mixed with white on the latter; fore-head rariegated with brown and white, imparting a scalloped appearance; lores, chin, sides and upper neck as also the under-surface of body white, including the axillaries and under wing-coverts; sides of lower neck blue-grey like the back; bill bluish-black, the latericorn of the maxilla distinctly bluish. Legs and toes pale cobalt-blue; webs pink in the centre, grey borders at the free edges. Total length $275 \mathrm{~mm}$; culmen 25, wing 209 , tail 85 , tarsus 29.

Adult female.-Very similar to the adult male but the upper-surface not so dark

Nestling.-Covered with slate-coloured down. The newly-hatehed young have bill and toes slaty-blue, with apparently pale-yellowish webs and brownish-black elaws. The horny speck upon the bill is whitish, and situated high above the tip of the bill. The region about the base of the bill is largely cienucled. They begin to hatch out about November 12 th.

Nest.-A burrow (excavated beneath the mounds of the umbelliferous plant Azorella selago) running straight inwards for a foot or more, then turning sharply to the right or left, parallel with the hill-side, thence downwards, often doubling once or twice upon themselves, and communicating with other entrances. At the bottom is an enlarged cavity, lined with fine root-fibres, twigs, ferns, or leaves of the "Kerguelen tea," and quite dry.

Egg.-Clutch, one; white and glossless; axis $44 \mathrm{~mm}$., diameter 32.

Breeding-season.-October and November.

Distribution and forms,--Round the Sub-antarctic Circle, but a rare bird in 
collections. Forms ill defined; three have been named : H.c. carulea (Gmelin) probably Kerguelen Land breeding bird; H. c. victorice Mathews from Victoria as being smaller; Brooks has named as a species Halobcena murphyi from South Georgia as having the bill much smaller, less slender and wider at the base; wing 212, tarsus 31 , bill $25 \mathrm{~mm}$.

\section{Genus HETEROPRION.}

Heteroprion Mathews, Birds Austr., Vol. II., pt. 2, p. 222, July 31st, 1912. Type (by original designation): Heteroprion belcheri Mathews.

Small Petrels agreeing in general characters with species of the genus Pachyptila, but differing in the shape of the bill; whereas in that genus the lateral plates are widely horizontally developed, and the under mandible rami enclose a broad distensible sac, in this the lateral plates are not abnormally laterally extended, and the rami of the under mandible are normal and no sac is present, the interramal space being narrow and feathered. The general nature of the bill is, however, similar, the nasal tubes being short, the nail weak and small, and the space between the nasal tubes and the nail longer than the former.

\section{Heteroprion belcheri.-THIN-BILLED PRION.}

Mathews, Birds Austr., Vol. II., pt. 2, figs. in text, p. 215, July 31st, 1912.

Heteroprion belcheri Mathews, Birds Austr., Vol. II., pt. 2, p. 224, figs. in text, p. 215, July 31st, 1912: Geelong, Victoria.

Distribution.- Southern Australian Seas.

Adult.-Like the $H$. desolatus group in general coloration, but easily separated by its very thin bill, whose width is less than a third of its length; bill blue with yellow tip, nasal tube black. Feet blue with yellow webs. Wing $183 \mathrm{~mm}$; culmen (exp.) $25 \mathrm{~mm}$. long, 8 wide at base, tarsus 33 .

Immature, Nestling, Nest and Eggs.-Unknown.

Distribution and forms. - Since this species was differentiated as above, we havo seen single specimens from New Zealand, West Australia and the Falkland Islands, indicating a Sub-antaretic Circle range. The Neozelanic form has a longer, slightly wider bill, and a series from the Cottesloe Beach, West Australia, show young birds with a bill $24 \mathrm{~mm}$. long by 8.5 broad, and adult male and female with bills $25 \mathrm{~mm}$. long by $10 \mathrm{~mm}$. wide; an immature and adult from the Falkland Islands hare bills 23 by $8 \mathrm{~mm}$. and 25 by $10 \mathrm{~mm}$. respectively.

\section{Heteroprion desolatus.-DOVE PRION.}

[Procellaria desolata Gmelin, Syst. Nat., Vol. I., pt. II., p. 562, April 20th, 1789 : Kerguelen Island, Extra-limital.

Mathews, Birds Austr., Vol. II., pt. 2, figs. in text, p. 231, July 31st, 1912.

Heteroprion desolatus mattingleyi Mathews, Birds Austr., Vol. II., pt. 2, p. 226, July 31 st, 1912: Geelong, Victoria.

Distribetion.- Southern Australian Seas.

Adult male,-Blue-grey above, including the head, hind-neck, back, wings, and tail; the head and rump darker than the back; lesser wing-coverts and long seapular blackish, as also the tips of the middle tail-feathers; bastard-wing and primary-coverts black, the latter narrowly margined with white at the ends; the four outer primaries black, inclining to white on the imner webs ; inner primaries and secondaries grey, with more or less white on the inner webs; lores, cheeks, a line over the eye and under-surface pure white (no blue wash on flanks) including 
the axillaries and unter wing-coverts. Bill blue; iris black; feet all blue. Total length $275 \mathrm{~mm}$; ; culmen (exp.) 26 , wiclth of bill 12, wing 189 , tail 95 , tarsus 32 . Adult female.-Similar to the adult male.

Immuture.-As arlult in coloration but with a much weaker, narrower bill, which is paler, and the wings and feet are smaller.

Nestling.-Covered with slaty-grey down.

Nest.--In a burrow, about two feet long.

Egg.-Clutch, one; white; 43-45 mm. by 33.

Breeding-season.-October to December.

Distribution and forms.-Round the Sub-antarctic Circle. Many subspecies will be later differentiated, six at present being defined on bill characters alone, thus : H. d. desolatus (Gmelin) from Kerguelen Island; H. d. banksi (Smith) from Cape Seas, with a broader bill, breeding place unknown, probably in the Antaretic as $P$. rossi Bonaparte, from Antaretic seas, is at present inseparable; $H$. d. peringueyi Mathews, from the Pondoland coast, South Africa, with a narrower bill, like the typical race, but longer, breeding place unknown; $H$. $d$. mattingleyi Mathews, from East Australian seas, with the narrowest bill in the species; H. d. macquariensis Mathews, from Macquarie Island. New Zealand, broader bill than former and near tice typical race; and $H$. $d$. alter Mathews from the Auckland Islands, with a broader bill again, very near that of $H . d$. banksi. While these differences are apparent to the eye it is very difficult to give measurements showing the details clearly.

A series from Cottesloe Beach, West Australia, show two skins with bills 27 by $12 \mathrm{~mm}$., thus agreeing with $H . d$. mattingleyi, the Fastern form, and many others with broader bills, an immature bill measuring 29 by 13.5 and many adults, male and female, averaging the bill 29 by $15 \mathrm{~mm}$. which seem to indicate a distinct western form which may be called $H$. $d$. alexanderi subsp. nov.

\section{Genus PSEUDOPRION.}

Pseudoprion Coues, Proc. Acad. Nat. Sci. Philad., 1866, p. 164, May. Type (by original designation): Procellaria turtur Kuhl.

Fulmariprion Mathews, Birds Austr., Vol. II., pt. 2, p. 215, July 31st, 1912. Typo (by original designation): Pseudoprion turtur crassirostris Mathews.

A very distinct Prionitic genus, agreeing with the other Prionitic genera in general, but with a noticeably different style of bill.

The nail is strong and almost half the length of the chord of the culmen, while there is very little space between it and the nasal tube. The under mandible is strong, and the strong rami direrge at an acute angle enclosing a triangular fullyfeathered interramal space. The whole bill recalls that of Fulmanus.

\section{Pseudoprion turtur.-FAIRY PRION.}

Gould, Vol. VII., pl. 54 (pt. xvI.), Sept. 1st, 1844. Mathews, Vol. II., pt. 2, pl. 93, July 31st, 1912.

Procellaria turtur Kuhl, Beitr. Vergl. Zool. Anat, p. 143, (pref. April 9th) 1820: Bass Straits. Procellaria velox "Banks," Kuhl, ib. In synonymy.

Halobana typica Bonaparte, Consp. Gen. Av., Vol, II., p. 194, (Oct.) 1857: Bass Straits (WVaigiou Island is an error).

Prion ariel Gould, Ann. Mag. Nat. Hist., Vol. XIII., p. 366, May 1st, 1844: Nom. nud.

Prion ariel Schlegel, Mus. Pays-Bas, Vol. VI., Procell., p. 18, July 1863: Bass Straits.

Pseudoprion turtur nova Mathews, Austral Av. Rec., Vol. III., pt. 3, p. 55, April 7th, 1916 :

Sydney, New South Wales.

Distribution.-Eastern and Southern Australian Seas.

Adult.-Simaller in general measurements than members of the genera Prion and Heteroprion, paler in colour with the head unicolonr with the back and rump, 
with a large amount of black tipping to the tail, and a strong blue wash on sides of body and with a distinetly smaller and more compressed bill. Culmen (exp.) $22 \mathrm{~mm}$., width of bill 10 , wing 180 , tail 82 , tarsus 30 .

Immature.-Similar, but smaller, especially with a much weaker bill.

Nestling.-Unknown.

Nest.--In crevices of rock or under the densely matted stems and roots of pigface weed.

Egg.-Clutch, one ; pure white, surface dull ; axis $41-43$, diameter $30-33$.

Breeding-season.-October, November, and December.

Distribution and forms.-Apparently round the Sub-antarctic Circle. Six subspecies have been named, thus : P. t. turtur (Kuhl) from East Australian Seas ; $P . t$. brevirostris (Gould) from "Madeira" (?) probably breeding in the South Atlantic, smaller than precerling with $a$ shorter, more robust bill; $P$. $t$. caloni Mathews from Kerguelen Island, with a longer, heavier bill; $P$. $t$. solanderi Mathews, from west coast of South America, with the same wing measurement but with a longer bill than in the typical form; $P$. $t$. huttoni Mathews from the Chatham Islands and (?) the mainland of New Zealand, with a stronger bill and longer wing than the East Australian form; and $P$. $t$. crassirostris Mathews, from the Bounty Islands, larger still and with an extremely powerful bill as compared with other races.

\section{Genus PACHYPTILA.}

Pachyptila 1lliger, Prodr. Mamm, et Av,, p. 274, (pref. April) 1811. Type (by subsequent designation, Salvadori, Ornit. Pap. e Mol, Vol. III, p. 467, Dec. 1882): Procellaria vittata Gmelin.

Prion Lacepède, Tabl. Oiseaux, p. 15, 1799 (Dec.). Indeterminable.

?Priamphus Rafinesque, Analyse Nat., p. 72, 1815. New name for " Prion Lac." cf. Auk,

Vol. XXVI., p. 50, Jan. 1909.

Prion Lesson, Manuel d'Orn., Vol. II., p. 399, June 28th, 1828. Type (by monotypy):

$P$. vittata Gmelin.

Small Petrels with a very broad bill, with short nasal tube; the rami of the under mandible divergent and enclosing a distensible pouch which is unfeathered; the nail of the upper mandible is small and weak, and separated from the short nasal tube by a long flattened space; the lateral plates are extended and flattened so that they present a horizontal surface rather than a vertical one; its breadth at the widest part more than half the length of the chord of the culmen; as a matter of fact, very nearly two-thirds ; inside the upper mandible on each side is a row of comb-like lamellæ which extend the whole length of the lateral plates.

The wing has the first primary the longest and the tail, consisting of twelre feathers, is long and wedge shaped. The feet are of medium length, and slender.

\section{Pachyptila vittata-BROAD-BILIED PRION.}

Gould, Vol. VII., pl. 55 (pt. xvI.), Sept. 1st, 1844. Mathews, Vol. II., pt. 2, pl. 92, July 31st, 1912.

Procellaria vittata Gmelin, Syst. Nat., Vol. I., pt. II., p. 560, April 20th, 1789 : New Zealand. Procellaria forsteri Latham, Index Ornith., Vol. II., p. 827, before Dec. 9th, 1790. New name for Procellaria vittata Gmelin.

Procellaria latirostris Bonnaterre, Tabl, Encycl. Néth. Ornith., Vol. I., p. 81, 1791: New Zealand.

Prion magnirostris Gould, Proc. Zool. Soc. (Lond.), 1862, p. 125, August 1st: New Zealand. Prion australis Potts, Ibis, 1873, Jan., p. 85 : New Zealand.

Prion vittatus gouldi Mathews, Birds Austr., Vol. II., pt. 2, p. 211, July 31st, 1912 : Bass Straits, Vietoria.

Prion vittatus missus Mathews, ib., p. 212 : near Perth, South-Test Australia.

Distributron.-Southern Australian Seas. (The New Zealand subspecies has occurred off New South Wales.) 
Adult male.-General colour above dark blue-grey, including the head, hindneck, sicles of breast, back, scapulars, and tail, the head and rump darker than the back; lesser wing-coverts dusky-brown becoming darker and inclining to black on the bastarl-wing and primary-coverts, the latter edged with white at the tips; the four outer primary-quills black on the outer webs, white on the inner ones, with black shafts; inner primaries and secondaries pale blue-grey with a certain amount of white on the inner webs and dark shaft-streaks; the long scapulars blackish tipped with white; middle tail-feathers blue-grey like the back, with broad black tips which become obsolete on the outer feathers, the colour of which is paler; the feathers of the crown are black subterminally; base of fore-head and lores whitish like the superciliary streak; throat, breast, abdomen and sides of body white like the axillaries and under wing-coverts; under tail-coverts white at hase, the long ones blackish at the tips, the short coverts blue-grey like the lower flanks; upper bill, pale bluish-grey, shading into black at the base and on the nostrils, the central part of the culmen also black and the terminal part or point of the upper bill yellow. MIandible pale blue, with a black line along the centre of each side, and the tip black ; iris dark brown, legs and toes pale blue; webs, flesh pink, with the free borders grey. Total length $300 \mathrm{~mm}$. ; culmen (exp.) 33, wing 209, tail 104, tarsus 33, width of bill 20 .

Adult female.-Similar to the adult male.

Immature.-Coloration as in adult, but wings shorter and bill much weaker, shorter and narrower and paler coloured.

Nestling.-The young taken out of the nest on the 20 th November are clothed entirely with a dense covering of dark smokr-grey, lightest on the neek and undersurface; pectinations of the upper mandible undeveloped; the bill measures from gape to point 1 inch, greatest width only 4 lines.

Nest.-At the end of a straight burrow, which dips slightly for eighteen to twenty-four inches. Or in the cavities of the eliffs on the sea-shore.

Egg.-Clutch, one; pure white, glossless and minutely pitted; axis 48.5, diameter 35. (Chatham Islands.)

Breeding-season.-September. (Chatham Islands.)

Distribution and forms.- Round the Sub-antaretic Circle. Six forms are recognised: $P . v$. vittata (Gmelin) from New Zealand, with the broadest bill ; $P$. $v$. gouldi Mathews, from Bass Straits, with a much smaller bill, culmen 31.5 long by $17 \mathrm{~mm}$. wide; the former, 33 by $20 \mathrm{~mm}$. ; P. v. missa Mathews from West Australian waters, with a longer, narrower bill, length $36 \mathrm{~mm}$. by 17.5 wide; $P$. v. macgillivrayi Mathews, from St. Paul's Island, with a bill like that of $P . v$. gouldi, but slightly shorter and wider; $P$. v. salvini Mathews from the Crozets (type) and Marion Island with the bill like that of $P$. v missa, but slightly shorter and narrower; and $P$. v. keyteli Mathews, from Tristan d'Acunha, with a bill like that of $P$. v. vitlata, but paler coloration above. It may be noted that the three first-named subspecies occur in Australian seas.

\section{Genus MACRONECTES.}

Macronectes Richmond, Proc. Biol. Soc. Wash., Vol. XVIII., p. 76, 1905, Feb. 21st. Typo (by original designation): Procellaria gigantea Gmelin.

Ossifraga Hombron et Jacquinot, Comptes Rendus Acad. Sci. Paris, Vol. XVIII., p. 356,

March 1844. Typo (by monotypy): P. gigantea Gmelin.

Not Wood, Analyst, Vol. II., p. 305, June 1835.

An unmistakable generic type of Procellarian bird, being of large size, surpassing some of the smaller Albatrosses. The bill is rery stout, longer than the head, and also longer than the tarsus. The nasal tube is more than half the length of the chord of the culmen, and reaches to the unguis; it is flattened and broad 
at the base, and showing a median keel, and narrowing to a small circular aperture, apparently single, the septum being far within. A specimen measured gave breadth at base $28.5 \mathrm{~mm}$., at aperture $14 \mathrm{~mm}$., diameter of aperture $9 \mathrm{~mm}$. The interramal space is feathered.

In the wing the first primary is longest, and the general shape is rounded. The tail is also rounded, and the rectrices number sixteen, a feature shared with no other member of this family, and is about one-third the length of the wing. The legs are very strong and the tarsus is nearly as long as the culmen; the toes very long and fully-webbed and a distinct hind-toe present, of only one phalanx.

Coloration uniform brown to uniform white.

\section{Macronectes giganteus.-GIANT PETREI.}

[Procellaria gigantea Gmelin, Syst. Nat., Vol. I., pt. II., p. 563, April 20th, 1789 : Staten Island, off Tierra del Fuego. Extra-limital.]

Gould, Vol. VII., pl. 45 (pt. Xxxvi, ), Dee, 1st, 1848. Mathews, Vol. II., pt. 2, pl. 89, July 31 st, 1912 .

Macronectes giganteus dovei Mathews, Austral Av. Rec., Vol. III., pt. 3, p. 54, April 7th, 1916 : Sydney, Now South Wales.

Drstribution.-East Australian Seas. Occurrence in West Australian Seas recorded, but no specimens seen.

Adult: dark phase.-Sooty-black above and below; wing $513 \mathrm{~mm}$., culmen 101, tail 177, tarsus 88 ; bill, pale yellowish horn ; feet and legs grey.

Adult: white phase.-Entire upper-and under-surface white, with a few darktipped feathers sparsely scattered over the whole plumage. The dark feathers vary in pattern; some are entirely dark grey, while others are only tipped, or the grey restricted to the outer web; there are also some with black shafts, the black increasing in width at the tips. Total length $865 \mathrm{~mm}$; culmen 104, wing 483 , tail 165, tarsus 94.

Immature-Darker, and almost pure black in the Sub-antarctic forms, but brownish in the Antarctic races, and, of course, showing smaller measurements, and generally paler bills and feet.

Nestling.-Covered with grey down.

Nest.-A depression in the ground.

Eggs:-Clutch, one; white; $100 \mathrm{~mm}$. by 63.

Breeding-season.-November.

Distribution and forms.-Round the Antarctic and Sub-antarctic Circles. Six subspecies have been proposed: M. g. giganteus (Gmelin) may breed on Graham's Land and the South Orkneys; $\boldsymbol{M}$. $g$. solanderi Mathews, for the Falliland Islands bird, of uniform dark coloration, small size and pale sellow bill; $M$. g. halli Mathers, from Kerguelen Island, uniform dark brown with a white face, long and massive bill, but less than the Antarctic forms ; $M$.g. albus Potts, an albino, the New Zealand race is uniformly dark coloured, darker than the preceding, with a much smaller bill and shorter tarsus $(M . g$. dovei Nathews was named from Sydney, as being smaller); M. g. wilsoni Mathers, from the Ross Sea, Antaretica, of very large size and notably paler coloration, a majority being almost white, and to which has been attached the Maequarie Island birds; and II. g. forstcri Mathews, from the west coast of South America the smallest and darkest subspecies with small bill, wings, and feet. It may be observed that the Antaretic breeding birds are larger and paler than the Sub-antarctic breeding series.

\section{FAMILY PELECANOIDIDE.}

At present only two genera are recognised in this family and, as the difierential characters are only seen in the bill formation, the features of the family may be 
given as follow: : Very small Petrels, with small bills having tulbular nostrils opening horizontally and a more or less distensible sac between the rami of the lower mandible. The bolly is short and compact, the neck short and thick; the wings are short and the tail square and rery small; the legs have a short compressed tarsus and the anterior toes are long with long claws, but there is no hind-toe. The plumage is thick and glossy.

Superficially these birds are so like members of the genus Alle, referable to a different orcler, that close examination of the head is necensary to distinguish them. The coincidence is regarded as a good instance of convergence through similar habits of life, viz., swimming and diving.

The distribution is circumpolar, Antarctic and Sub-antaretic, the later erolved genus living up the west coast of South America almost into the tropies, this range agreeing with the cold current which is supposed to wash the Galapagos Archipelago and allow of the presence of Penguins in that locality.

Osteologically, the skull is peculiar in the great width of the basi-temporal region, the derelopment of the sternum with its entire posterior edge being quite difierent from that of any other of the order, while the pelvis is also peculiar, agreeing in many features with that of the Auks, and there is reason to believe that later research will reconsider the classification of this group. In almost every osteological feature this group differs from other Procellarians, but all the differences have been minimised on account of the tubular nostrils, which howerer are quite unlike those of any other form of Petrel or Albatross.

\section{Genus PELECANOIDES.}

Pelecanoides Lacepède, Tabl. Ois., p. 13, 1799 (Dec.). Type (by monotypy): Procellaria urinatrix Gmelin.

Haladroma Illiger, Prodr. Mamm. et Av., p. 274, (pref. April) 1811. Type (by monotypy): $P$. urinatrix Gmelin.

Onocralus Rafinesque, Analyse Nature, p. 72, 1815. New name for "Pelecanoides Lac." (c\%. Auk, Vol. XXYI., p. 50, Jan. 1909).

Smaller Pelecanoidine Petrels with short bills, short wings, very short tail and short legs and long toes, but no hind-toe.

The bill is short, the unguis long and hooked, the sides basally widening, but rather flattened above, supporting the almost horizontally open tubular nostrils. These are characteristic and are almost kidney shaped, elongate and adjacent, separated by a noticeable septum. Internally from the inner edge of each a minute projection can be scen. The unguis is compressed and almost keeled. The lower mandible has the rami curved, meeting the separated unguis, but not each other, and enclosing a distensible sac, whence the genus name. The wings are short and rounded, though the first primary is longest, the secondaries short but the tertials longer. The tail is very short and square, the feathers not very broad. The legs are short, the tarsus compressed and covered with reticulate scaling; the anterior toes very long, the outer and middle subequal, the inner much less; the claws are very long and narrow, that of the middle toe the longest. There is no hind-toe. The webbing is full.

Plumage thick, coloration black above, white below.

\section{Pelecanoides urinatrix.-DIVING PETREL.}

[Procellaria urinatrix Gmelin, Syst. Nat., Vol, I., pt. Ir., p. 560, April 20th, 1789: Queen Charlotte's Sound, South Island, Now Zealand. Extra-limital.]

Gould, Vol. VII., pl. 60 (pt. xv.), June 1st, 1844. Mathows, Vol. II., pt. 2, pl. 94, July 31st, 1912.

Pelecanoides urinatrix belcheri Mathews, Austral Av. Rec., Vol. I., pt. 4, p. 81, Sept. 1Sth, 1912: Victoria.

Distribution,- South-eastern Australian Seas. 
Adult male.-Upper surface glossy blue-black, including the head, back, wings. and middle tail-feathers; some of the scapulars grey with white tips, the small coverts round the bend of the wing edged with giey; primary-quills pale brown on the inner webs; some of the innermost secondaries fringed with white at the tips; outer tail-feathers pale brown, narrowly edged with white at the tipss; fore-head sooty-black without any gloss; sides of face dark slate-grey; sides of neek and fore-neck paler slate-grey with white tips to the feathers, which a give minutely barred appearance, this is also shown on the sides of the body ; throat, breast, abdomen, and under tail-coverts white; axillaries ash-brown, slightly fringed with white; under wing-coverts ashy-grey, margined with white and having black shaft-lines; bill black, the base of the eutting edge of the upper mandible, and line along the lower edge of the lower, blue-grey; iris very dark greyish-brown; tarsi and toes beautifully light blue. Total length $230 \mathrm{~mm}$.; culmen 15 , wing 113 , tail 40 , tarsus 22.

Adult female.-Similar to the adult male.

Immature-As adult, but weaker bill and feet and shorter wing, and with whitish tips to back feathers, wing-coverts and secondaries.

Nestling.-Covered with dark ashy-grey down, paler on the under-surface;

bill black; feet and legs blue.

Nest.-At the end of a crooked burrow.

Egg.-Clutch, one; white, surface dull; axis 38-42 mm., diameter 32-33.

Breeding-season.-July and August. (Mokohinou Islands.) November. (Northeast Island, Bass Strait.) October and November. (Macquarie Island.)

Distribution and forms.-Round the Sub-antarctic Circle. Forms at present under review by Murphy and Harper, but results not yet published. Seven subspecies up to now named: P. u. urinatrix (Gmelin) from Queen Charlotte's Sound, South Island of New Zealand; $P$. u. chathamensis Murphy and Harper from the Chatham Islancls as being larger and throat more splashed; $P$. $\iota$. bctcheri Mathews in being smaller, the under-surface of the wings white, the grey of the chest separate and the nostrils larger; $P . u$. exsul Salvin from Kerguelen Island, larger, with grey feathering on side of chest extensive, and flanks mottled with grey as under wingcoverts ; P. u. dacunhe Nicoll, from Tristan d'Acunha and (?) Gough Island, smaller and with much less grey on flanks and sides of throat; $P$. u. berard Quoy and Gaimard, from the Falkland Islands, with lesis grey on throat than preceding, but larger, though less than $P$. u. exsul; and $P$. u. coppingeri Mathews from Straits of Magellan, smaller still and with very little splashing on throat.

\section{SUPERFAMILY DIOMEDEOIDEA.}

Only one family is at present recognised, consisting of very large birds with the nasal openings separated into two distinct tubular orifices opening on each side of the bill, very long wings with very numerous secondaries and strong webbed feet with no hind-toe. Their distribution is a little curious and worthy of consideration, as, mainly Antarctic and Sub-antarctic, a series live in the North Pacifie. The groups aro easily separated by the bill formation, but more detailed research will probably allow of still better segregation as we find the following facts; all the North Pacific forms are referable to the genus Phobastria, characterised by the descent of the culminicorn basally behind the nasal apertures to overlap the latericorns. The species of similar size allotted to Thalassarche are sub-antarctic circumpolar and have the culminicorn basally more or less separated from the latericorns by a naked strip of skin which also sometimes separates the culminicorn from the frontal feathering. The largest forms have the same distribution, Diomedca (sensu stricto), and have no naked skin between the culminicorn, and latericom while the base of the lower mandible shows no basal bar. An intermediate form, Diomedella, has a 
large amount of bare slin between the frontal feathering and the culminicom as well as between the eulminicorn and the latericoms, while the basal bar shows the method of disappearance of the lower mandible stripe seen in the next group. This is Phobetria, the dark plumaged Antaretic forms with long wedge-shaped tails and with tho bill showing the culminicorn entering the frontal feathering at an acute angle, and with a naked strip of skin along the sides of the lower mandible. We considered this showed the most primitive features, and that independently the other genera have evolved from the same source, the Thalassarche group howing the loss of the lower mandibular ramal streak, a basal bar remaining to indicate its presence, while Diomedella has the basal bar still retaining marks of its reduction while in size it is less than Diomedea which has no trace of the bar but shows the feathering of the face entering at an angle the base of the lower mandible. We would therefore conclude that this largest series was the furthest developed, and wo find that a professional anatomist ignorant of these items also concluded: "Phoebetria is probably the most primitive."

Osteologically, the lack of basipterygoid processes, the tendency to fusion by the conjunction of the vomer and maxillo-palatines and the peculiarity of the former, the characteristic pterygoids all characterise the skull in this group. The wing muscles are complicated as would be anticipated by the extreme development of the wing. The thoracic vertebra also differ in the absence of hypapophyses and the pelvis is more specialised than in the preceding superfamily.

Between the anterior ends of the mandibular rami there is a narrow strip of horn, known as the interramicorn, which is not found in other Petrels outside this superfamily.

\section{FAMILY DIOMEDEIDA.}

\section{Genus PHCEBTRIA.}

Phaletria Reichenbach, Nat. Syst, Vögel, p. vo, 1852 (?1853). Typo (by original designation): Diomedea fuliginosa Gmelin.

Medium Albatrosses of dark coloration, with long bills, long wings, long wedgeshaped tail and medium legs and feet.

The bill is characterised by the presence of a deep groove along the sides of the lower mandible filled with a loose, coloured skin. The culminicorn slopes backward, meeting the frontal feathers at a sharp angle but descending behind the nasal openings to meet the latericom ; the nostrils are placed near to the base of the culmen, opening as semicircular tubes, sometimes termed "naricorns" ; the unguis is comparatively weak, the latericorns not much expanded laterally, eonsequently the bill is somewhat compressed laterally. The lower mandible has a deep groove absent. in other Albatrosses, feathering of the face approaching far forward. The wing is long, the feathers somewhat pointed and secondaries fewer than in Diomedea. The tail is composed of long narrow feathers forming a strong wedge and is almost half the length of the wing and about twice the length of the culmen. The legs arestout, the tarsus only about three-fourths the length of the culmen and about four-fifths the length of the middle toe. There is no hind-toe, and the anterior toes are fully webbed.

Coloration entirely dusky.

\section{Phœbetria fusca.-SOOTY ALBATROSS.}

[Diomedea fusca Hilsenberg, in Froriep's Notizen, Vol. III., No. 5 (49), p. 74, Sept. 18:2: INozambique Channel. Extra-limital.]

Gould, Vol. VII., pl. 44 (pt. xxxvr.), Dec. 1st, 1848. 
Plate 2.
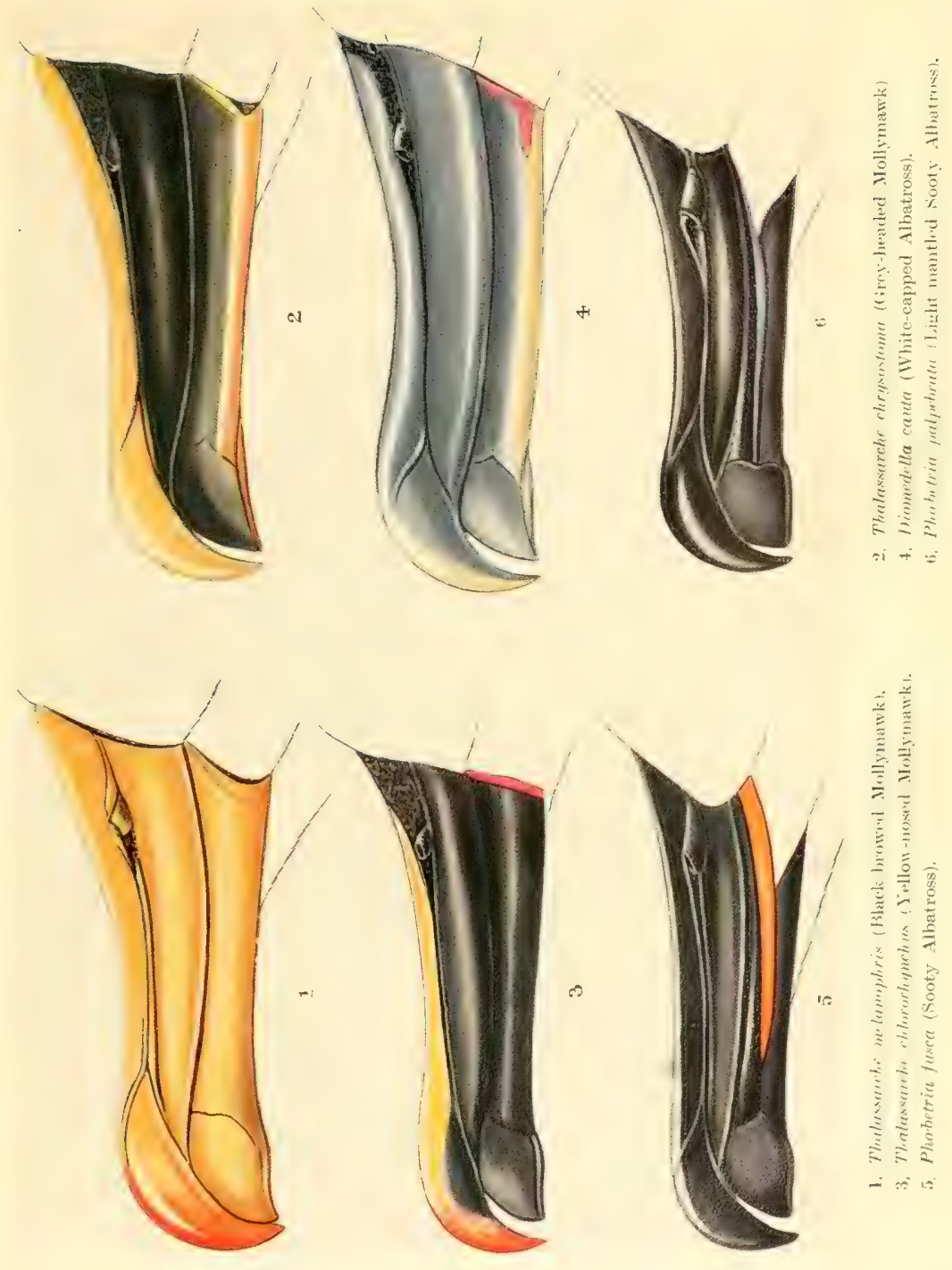

Phobetria fusca campbelli Mathews, Birds Austr., Vol. II., pt. 1II., p. 304, Sept. 20th, 1912: Australian Seas.

Distribution.-Southern Australian Seas. One specimen from Hobson's Bay preserved in Melbourne Museum.

Adult.-General colour above and below sooty-brown, slightly darker on the top of the head; blackish on the lores and above and behind the eyes; wings and tail blackish-brown; shafts of the tail-feathers and primaries straw coloured. Short feathers round the eye, interrupted in front, white; bill black, the groove on the lower mandible long and deep, and filled with a yellow skin. Total length $790 \mathrm{~mm}$. ; culmen (exp.) 115, wing 482 , tail 250 , tarsus 73 .

Immature, Nest, Egg, and Breeding-season.-Unknown.

Distribution and forms. - Not at all well known, found at sea in the southem Atlantic and Indian Oceans, and about southern Australian seas. Twu forms named : $P$.f. fusca (Hilsenberg) from the former and P.f. campbelli Mathews from the latter, differing notably in its smaller size throughout. Nichols and Murphy contrasted Mathews's measurements with their own; but we would point out that their method of measuring is unknown to us and we cannot reconcile any of their figures with our own data.

\title{
Phœbetria palpebrata. - LIGHT-MANTLED SOOTY ALBATROSS.
}

\author{
Diomedea palpebrata Forster, Mém. Math. Phys. (Paris), Vol. X., p. 571, 1785: "47 South \\ Lat." $=64^{\circ} \mathrm{S} .38^{\circ} \mathrm{E}$., i.e., duo south of Prince Edward and Marion Islands. \\ Mathews, Vol. II., pt. 3, pl. 101, Sept. 20th, 1912. \\ Phochetria palpebrata huttoni Mathews, Birds Austr., Vol. II..pt. 3, p 297, Sept. 20th, 1912 : \\ New Zealand Seas.
}

Distribution.—? South Australian Seas. Records by sight, but no skins.

Adult male.-Mantle pale ash-grey, with lighter edges to some of the feathers ; wings, scapulars, and upper tail-coverts dark greyish-brown; primary-quills blackish-brown on the outer webs and at the tips, with white shaft for the greater part of their length, becoming black at the tips, the inner webs somewhat paler; tail blackish-bromn, the shafts white; head, sides of face and throat sooty-black; under-surface ashy-brown, somewhat darker on the lower throat and under tailcoverts; axillaries slightly darker than the under-surface of the body; under wing-coverts jale brown with dark shaft-lines; the short feathers encircling the eye have the frontal portion black, and the hinder part white; bill black, groove on mandible blue; iris hazel ; tarsi and feet pink. Total length $820 \mathrm{~mm}$. ; culnen 114, wing 525, tail 228, tarsus 78 .

Adult female.-Similar to the adult male.

Nestling.-Covered entirely with pale ashy-grey down.

Nest.-Placed in crevices in the rock.

Egg.-Clutch, one; whitish, round the larger end covered with very tiny spots of reddish which merge together at the apex; axis $103 \mathrm{~mm}$, diameter 66 . (Collected November 4th, 1894.)

Breeding-season.-Norember to February. (Macquarie and Campbell Islands.) Distribution and forms.- Round the Sub-antarctic Circle. Nichols and Murphy (Auk, Vol. XXXI., p. 526, Oct. 1914) have recently reviewed these birds, admitting four forms: $P . p$. palpebrata (Forster) from Kerguelen Island, and probably also Crozets, Prince Edward Island, ete. ; $P . p$. luttoni Mathews, from Australian seas and New Zealand, breeding on the New Zealand Sub-antarctic Islands, paler than preceding, and smaller in all measurements than next; $P . p$. antarctica Mathews from South Georgia, with larger heavier bill, and paler than last named; and $P . p$ auduboni Nichols and IIurphy from west coast of America, on account of 
more slender and more strongly hooked bill, and much darker coloration. We find that Solander's name of $D$. antaretica had been eited as a synonym of the typical form and is therefore untenable for a subspecies, so we rename the South Georgian form $P . p$. murphyi name new.

\section{Genus THALASSARCHE.}

Thalassarche Reichenbach, Nat. Syst. Vögel, p. v., 1852 (?1853). TJpe (by original designa. tion): Diomedea melanophris Temminck.

Thalassogeron Ridgway (in Baird, Brewer and Ridgway's Water Birds of North America, Vol. II.), Mem. Mus. Comp. Zool. Harvard, Vol. XIII.,pp. 345, 357, (Introd. March 31st) 188 1. Type (by original designation): Diomedea culminata Gould.

Nealbatrus Mathews, Birds Austr., Vol. II., pt. 3, p. 274, Sept. 20th, 1912. Type (by original designation): Diomedea chlororhynchus Gmelin.

Medium Albatrosses of white coloration with dark wings, long bills, long wings, long tails and very strong legs and feet with no hind-toe.

The bill differs from the preceding in the formation of the base of the culminicorn and the absence of groove in lower mandible, at the base of which there is a short bar suggesting reduction of groove. The forms above named differ in minor details and as the connecting links are existent are here amalgamated again. They are all of the same size and coloration, but the last named has a mueh more delicate bill than the two preceding it, in it a sulcus filled with loose skin separates the base of the culminicorn from the frontal feathers, and also from the latericoms posterior to the nostrils. In Thalassogeron the basal sulcus is reduced though the lateral sulei are still very pronounced; as the width varies in the subspecies we find the distinctions deereasing; and in "D. bulleri" it is diffeult to decide whether it should be considered a degracled relation of Thalassogeron or a true Thalassarche, which has no sulci, either at the base or sides. longest.

The wing is long as usual with numerous secondaries, the first primary

The tail is long and rounded, about two-fifths of the wing's length.

The legs are very stout, covered with reticulate scaling; the tarsus less than three-fourths the length of the middle toe, which is equal to the culmen. The anterior toes are rery long, the outer longest, and fully webbed. There is no hinkitoe, but under tho skin a rudiment has been found.

Coloration white with black wings and back.

\section{Thalassarche melanophrys.-BLACK-BROWED IAOLLYMAWK.}

[Diomedea melanophris Temminck et Laugier, Planch. Color. d'Ois. (? 77c) 76 livr. (Vol. IV.), pl, 456, 1828, April 23rd (? March) : Cape of Good Hope. Extra-limital.]

Gould, Vol. VII., pl. 43 (pt. xiv.), March 1st, 1841. Mathews, Vol. II., pt. 3, pl, 96, Sept. 20th, 1912 .

Thalassarche melanophris imparida Mathews, Eirds Austr., Vol. II., pt. 3, p. 267, Sept. 20th, 1912, ex Solander M1S. : Tasmania.

Distribution.--Southern Australian Sens.

Adult male.-General appearance of the upper-parts dark brown and white ; scapulars, wings and tail clark brown; rump and upper tail-coverts white, back slaty-black; quills black, with white shafts towards the base, inner webs whitish at the base; secondaries blackish, inner webs white at the basal portion ; feathers of the olecranal patch blackish, becoming white at the base; humeral feathers white, shaded with giey; tail-feathers blackish, with conspicuous white shafts; loren, and a streak through and behind the eye black, more intenve in front of the eye ; head and neck all round, throat and entire under-surface white; axillaries and under 
wing-coverts white, more or less shaded with grey, the smaller coverts round the margin black, like the upper wing-coverts; quills below brown with white shafts, which are blackish towards the tips; bill uniform, gamboge-yellow, shaded with orange on the hook and with a very fine line of black round the base of the mandibles ; iris light brown; feet delicate blue-grey, darker on the joints and interdigital webs; claws white-horn colour. Culmen (exp.) $115 \mathrm{~mm}$., depth at base 45 , wing 510 , tail 200 , tarsus 78.5 , middle toe 115 .

Adult female.-Similar to the adult male.

Young.-Differs from the adult in having the head and neck ash-grey, and the upper-surface of wings and interscapular region brownish-black, the smaller wing-coverts with paler margins, the bill blue-black, and the legs and feet bluish-grey.

Nestling.-Covered with long, thick woolly down, of a pale grey colour; bill brownish-black with yellowish-horr coloured tip; legr and feet yellowish-white.

Nest.-A conical mound from $8 \mathrm{in}$. to $18 \mathrm{in}$, in height constructed of mud mixed with regetable substances, the cup-shaped depression is lined with finer materials.

Eggs_-Clutch, one; surface dull, and having a ring round the larger end of reddish-brown specks and blotches; axis 97 to $114 \mathrm{~mm}$., diameter 54 to 69 .

Incubation-period.-Sixty days.

Breeding-season.-November to January.

Distribution and forms.-Round the Sub-antarctic Circle. Four forms have been separated: T. m. melanophrys (Temm. and Laugier) from the Cape Seas, probably breeding at Gough Island, Tristan d'Acunha and the Falkland Islands; $T$. $m$. belcheri Mathews, with longer bills of paler coloration, from Kergnelen Island; T. m. imparida Mathews, with shorter bills, grey lores, and more black in front and above the eyes; and $T$. m. richmondi Mathews from the west coast of South America with long bills, deeper than that those of the Kerguelen form, no grey on the lores and the black about the eye reduced to a very faint marking.

\section{Thalassarche chrysostoma.-GREY-HEADED MOLLYMAW}

[Diomedea chrysostoma Forster, Mém. Math. Phys. (Paris), Vol. X., p. 571, 1785 : Capo Soas. Extra-limital.]

Gould, Vol. VII., pl. 41 (pt. xxxiI.), Sept. 1st, 1818. Mathews, Vol, II., pt, 3, pl. 97, Sept. 20 th, 1912 .

Diomedea culminala Gould, Proc. Zool. Soc. (Lond.), 1843, p. 107, Dec. : "Southern, Indian and South Pacinic Oceans " = Cape Seas.

Thalassogeron chrysostoma alexanderi Mathews, Austral Av. Rec., Vol. III., pt, 3, p. 55, April 7th, 1916: West Australia.

Distribution, - Southern Australian Seas. One specimen preserved in Mathews's collection and another in Perth Museum. Cf. Alexander, Emu, Vol. XIX., pt. I., p. 59, July 1st, 1919.

Adult male.-Head, hind-neck and mantle grey with white base to the feather's, becoming dark brown or black on the middle of the back, scapulars and wing-coverts; lesser, median, and greater wing-coverts dark brown, with whitish bases like the bastard-wing, primary-coverts and quills, the latter with white shafts and pale brown inner webs; secondaries dark brown with white on the basal portion ; olecranal feathers dark brown with pale inner webs which become white at the base ; rump and upper tail-coverts pure white; tail dark hoary-grey with white shafts ; feathers above and in front of the eye black; sides of throat, face, and fore-neck white, more or less washed with grey; remainder of the under-surface white; axillaries pale grey with whitish tips; feathers round the margin of the under-wing blackish ; bill black, the culmen yellow, divided from the tip, which is horn colour, by a black patch, base and lower edges of mandible yellow; fect and legi grey, webs fleshy-pink. Total length $910 \mathrm{~mm}$; ; culmen 111, wing 518, tail 213, tarsus 86.

Adult female.-Similar to the adult male. 
Immature.-When the young flies it has a dark grey head which extends on to the throat; the ocular patch distinctly blackish; the grey is a dirty-brown grey, while the bill is practically all black, but the lower edges of the under mandible show pale brownish. The grey head and neck lose their brownish tinge while the culmen takes on a light yellowish-brown shade, the strip on the lower edges of the Jower mandible becoming paler. The fully-adult has a beautiful pearl-grey head, neck and throat, while the eulmen is pale clear yellow and the lower edge of the lower mandible is also clear light horn or yellowish. Some birds, howerer, in the change, as shown by the coloration of the bill, have the head white and the back of the neck inclining to white.

Nest, Egg, and Breeding-season-Unknown.

Distribution and forms. - Sub-antarctic as far as is known. Four forms can bo recorded, but more material is necessary before finality can be suggested. Theso are: T. c. chrysostoma Forster, from Cape Seas (of which D. culminata Gould may be a synonym); T. c. matheusi (Rothschild) from (amplocll Island, New Zealand, as having the cheeks and throat pure white, and top of head white, not grey : back browner; T. c. harterti Mathews, from South Indian Ocean (Kerguelen I-land breeding) in its deeper, heavier bill, coloration as in preceding; T. c. alexanderi Mathews, from West Australian seas, with smaller and paler bill.

\section{Thalassarche chlororhynchus. - YELLOW-NOSED MOLLYMAWK.}

[Diomedea chlororhynchos Gmelin, Syst. Nat., Vol. I., pt. II., p. 568, April 20th, 1789: Cape Seas. Extra-limital.]

Gould, Vol. VII., pl. 42 (pt. xv.), June 1st, 1844. Mathews, Vol. II., pt. 3, pls. 98 and 99 , Sept. 20th, 1912.

Thalaseogeron carteri Rothschild, Bull. Brit. Ornith. Club, Vol. X1V., p. 6, Oct. 30th, 1903: Point Cloates, mid-West Australia.

Diomeaca bassi Mathews, Nov. Zool., Vol. XVIII., p. 206, Jan. 31st, 1912: "New South Wales."

Distribution.- Southern Australian Seas.

Adult male.-Back, scapulars and wings slaty-brown, tail-feathers hoary-grey, Iesser, median, and greater wing-coverts dark brown with white bases, like tho bastard-wing and primary-coverts; primary-quills black on the outer webs, hoarygrey on the inuer ones, with white shafts at the basal portion ; secondaries clark brown, white on the inmer webs; some of the feathers of the olceranal region dark brown while others are white with brown tips ; humeral feathers also dark brown; rump and upper tail-coverts white; a patch on each sicle of the breast grey, like the back; a pale grey line in front and over the eye ; head and neck all round, mantle and entire under-surface white, as also the axillaries; under wing-coverts white, those around the margin dark brown ; bill black, culmen yellow, passing into orange at the tip; a line at the base of the mandible yellow; legs flesh colour. Tutal length $710 \mathrm{~mm}$, ; culmen 118, wing 464, tail 190, tarsus 75 .

Adult female.-Similar to the adult male.

Immature.-Agrees in general coloration with the adult, but differs from that in the colour of the bill, which is in this wholly black (due to immaturity) ; irides black; feet and legs yellowish-white. Culmen (exp.) $114 \mathrm{~mm}$. long, depth at base 36 , wing 462, tail 165, tarsus 75. ( $T$. carteri Rothsch.)

Nestling, Eggs, and Nesting-place.-Unknown.

Distribution and form. - Apparently sub-antarctic but not well known. Races not yet determined. Thus the West Australian bird was named from an immaturo specimen and the Tristan d'Acunha bird dencribed as 1 ). cximia Verrill, owing to a misunderstanding of the species. When breeding places are discorered forms may be accurately circumscribed. 


\section{Genus DIOMEDELLA.}

Diomedella Mathews, Birds Austr., Vol. II., pt. 3, p. 275. Sept. 20th, 1912. Typo (by original designation): Diomedea cauta Gould.

Larger Mollymawks with long bills, long wings, medium tails and stout legs: and feet.

The bill shows a space between the culminicorn and the latericorns posterior to the nostrils, and also between the culminicorn and the frontal feathers; these spaces are diminished in extent in some of the forms but the culminicom nerer broadens out, or conversely, narrows as in forms of Thalassarche. In the lower mandible the bar at the base shows an entry into the edge, not bounding it as in that genus. The wing is longer, but the tail is practically the same length. The feet are larger but of same nature.

Coloration similar to that of Thalassarche.

This genus approximates in some items to Diomedea.

\section{Diomedella cauta.-WHITE-CAPPED ALBATROSS.}

Gould, Vol. VII., pl. 40 (pt. xv.), June Ist, 1844. Mathews, Vol, II., pt. 3, pl. 100, Sept. 20 th, 1912.

Diomedea cauta Gould, Proc. Zool. Soc. (Lond.), 1840, p. 177, July 1841 : Bass Straits. Diomedella cauta rohui Mathews, Austral Av. Rec., Vol. III., pt. 3, p. 55, April 7th, 1916: Sydney, New South Wales.

Diomedella cauta wallaca Mathews, ib., pt. 6, p. 160, June 25th, 1918. Now name for preceding.

Distribution.-Eastern and Southern Australian Seas.

Adlult male-Upper back slate-grey, with white bases and pale margins to the feathers; scapulars ash-brown, white only at the extreme base; wing-coverts dark brown with white bases; the smaller coverts showing pale edges; primarycoverts and primary-quills dark brown, the latter with white shafts and white on the inner webs; secondaries also clark brown, with the basal portion of the inner webs white; tail-feathers hoary-grey with white shafts; a narrow eyebrow and a spot in front of the eye black, becoming pale towards the base of the bill, a pratch behind the eye including the ear-coverts washed with plumbeous-grey; head and neck all round white, as also the under-surface of body, including the axillaries, under wingcorerts white, the marginal ones blackish ; bill bluish horn, lower mandible darker, upper mandible with a narrow belt of black and on each side of the nostrils ; base of lower mandible with a belt of orange reaching to the corner of the gape; iris brown ; feet bluish-white. Total length $987 \mathrm{~mm}$.; culmen 137, wing 590, tail 204 , tarsus 86 .

Adult female.--Similar to the adult male (? smaller) but with the grey on the sides of the neck paler, and the yellow markings on the bill duller.

Immature.-Undescribed.

Nestling.-Covered with white down; bill black.

Nest.-Composed of chocolate-coloured soil, largely mixed, when in a wet state, with rootlets and other vegetation, which gives it the appearance of peaty substance. It is smoothed over and holds together fairly well, varying in height exterually from 3 to 7 inches. The measurements of an average nest are as follows : internal diameter 111 inches, external diameter 14 , basal diameter $16_{2}^{1}$; external height $5 \frac{1}{2}$, internal depth $3 \frac{3}{4}$.

Egg.- Clutch, one; creamy-white, freckled more or less with reddish-brown surface-markings on the larger end. In some eases these markings were minute, numerous, and almost continuous, while in others they were much larger and darker, on a slightly reddish ground, but there were various gradations between the two 
types. The colour could be washed off, by a little friction. Dimensions 104$112 \mathrm{~mm}$, by $66-69$.

Breeding-season.-October to November.

Distribution and forms.-Round the Sub-antaretic Circle. Four good races have been separated : D. c. cauta (Gould), from East Australian seas, breeding in Bass Straits ; D. c. salvini (Rothschild) from New Zealand, breeding at Bounty Island, with a smaller bill, darker coloured and with shorter legs and feet; $D$. $c$. Inyardi (Salvin) from Cape Seas with still smaller and narrower bill, shorter tarsus and toes and whiter head and neck; and D.c. platei (Reichenow), from west eoast of South America, with the culminicorn almost touching the feathers of the head, and of this last named Salvadori's $T$. desolationis is a synonym, as the bill coloration with pale culminicorn and pale basal portion of lower mandible recalls that of " $T$. culminata" as noted by Salvadori.

\section{Genus DIOMEDEA.}

Diomedea Linné, Syst. Nat., 10th ed., p. 132, Jan, 1st, 1758. Type (by subsequent designa.tion, Gray, p. 78, 1840): Diomedea exulans Linné.

Albatrus Brisson, Ornith., Vol. I., p. 54, Vol. VI., p. 126, 1760. Type (by monotypy): D. exulans Linné.

Albatrossa Brünnich, Zool. Fund., p. 80, 1771. No species added. Type (by monotypy): D. exulans Linné.

Albatros Lesson, Manuel d'Orn., Vol. II., p. 389, June 28th, 1828. Substitute name for Diomedea $\mathbf{L}$.

Rhothonia Murphy, Bull. Amer. Mus, Nat. Hist., Vol. XXXVII., p. 861, Dec. 10th, 1917. Typo (by monotypy): D. sanjordi Murphy.

Largest Albatrosses with long bills, rery long wings, rery numerous secondaries, long tails and strong legs and feet.

The bill is very long and hooked of the usual Albatross character, with the nostrils of two forms as shown by Murphy (loc. cit.). At the base of the lower mandible the feathers run forward, quite unlike those in Thalassarche and recalling that of Phocbetria.

The wing is notable for its extreme length and extraordinary number of secondaries. The tail is rounded, and though long, is comparatively short, being one-third the length of the wing.

The legs are very stout, the tarsus about three-fourths the length of the culmen and much less than the toes, the outer of which is longest, the anterior toes being fully webbed and the hind-toe missing altogether.

Coloration white in the adult, but generally brown in the immature.

\section{Diomedea exulans.-WANDERING ALBATROSS.}

[Diomedea exulans Linné, Syst. Nat., 10th ed., p. 132, Jan. 1st, 1758: Cape of Good Hope. Extra-limital.]

Gould, Vol, VII., pl. 38 (pt. xIv.), March 1st, 1844, Mathews, Vol. II., pt. 3, pl. 95, Sept. 20th, 1912.

Diomedea exulans rothschildi Mathews, Birds Austr., Vol. II., pt. 3, p. 246, Sept. 20th, 1912 : off Now South Wales coast.

Diomedea exulans westralis Mathews, Bull, B.O.C., Vol. XXXIX,, p. 29, Nov, 30th, 1918 : Albany, West Australia.

Distribution.-Australian Seas.

Adult male.-General colour above white with wary cross-bars of ash-brown, more narrowly and faintly on the hind-neck, broaler and more pronounced on the back and upper tail-coverts; the scapulars white, vermiculated and broadly tipped with brum, more especially on the outer webs; short feathers of the humerals 
black on the outer webs, and rermiculated on the inner ones with ash-brown, the longer ones black with white on the basal portion; olecranal feathers white, some of the longer ones tipped with black; lesser, median, and greater wink-coverts black with white bases like the marginal coverts round the bend of the wing; primary-coverts and quils black, the latter with flattened straw-coloured shafts and pale brown on the inner webs towards the base, this portion of the web being white on the inner primaries; tail white at the base, dark biown at the tip, the white approaches much nearer the tip on the inner web than on tho outer one; inner web of outer tail-feathers white with the exception of a little mottling at the tip, middle feathers dark brown with white bases; crown of head mottlerl with the remains of brown feathers; fore-head, sides of face, throat and under-surface white, with the exception of the fore-neck and sides of body, which are crossed by wavy bars of ash-brown; under wing-eoverts and axillaries white, like the under-surface of the body ; some of the latter are dark brown on the outer welos, and vermiculated with ash-l,rown on the inner ones; irides rich dark 1 rown; bare eyelids pu rplish:green; bill white, with a pinky tinge, vellowish-brown coloured at the tip ; less and feet flesh-white, sometimes with a pinky tinge. 'Total length $1,368 \mathrm{~mm}$; culmen (exp.) 165, wing 633, tail 204, tarsus 121 .

Adult female.-Similar to the adult male.

Immature male.-Upper-parts brown, paler on the head, neck and mantle, darker on the back, scapulars, rump, upper tail-coverts and tail; the feather of the head and hind-neck are white tipped with brown, while thoce of the mantle, though similar in colour, are everywhere intermixed with white feathers finely vermieulated with brown; the wing-feathers are similar to the adult male described, but the whito olecranal patch is absent; tail very dark brown, white only at the extreme base ; fore-head, sides of face, and throat white; remainder of under-surface brown and white, many of the feathers are brown with white bases, more particularly on the sides of the body and lower-abdomen, while others are white vermiculated with brown at the tips, more especially on the fore-neck and breast; the under wingcoverts are white, and the axillaries are similar to those of the adult.

Nestling.-Covered with light or slate-grey down lighter on the head.

Nest.-A cone-shaped strueture composed of earth and grass cemented together. Usually about 2 feet in diameter, and about 18 inches high.

Egg.-Clutch, one ; surface rough and glossless ; white, but mostly ne:t-stained ; axis $122 \mathrm{~mm}$, diameter 78 .

Breeding-season.-January, February. (Auckland Island.) February. (Antipodes Island.)

Incubation-period.-Nine weeks.

Distribution and forms.--At present unlnown exactly through confusion with D. chionoptcra. Apparently breeding on the Sub-antaretic Islands of New Zealand, and in the South Atlantic probably in the Tristan d'Acunha Group and Gough Island, but Indian Ocean breeding place unknown. The Atlantic typical $D$.e. exulans Linné has the eyelids scarlet, while the West Australian D. e. wertralis Nathews has blue eyelicls, and the East Australian and Neozelanie D. c. rothschildi Mathews has purplish-green eyelids. The latter appears to be smaller than the preceding.

\section{Diomedea chionoptera.-SNOWY ALBATROSS.}

Diomedea chionoptera Salvin, Cat. Birds Brit. Mus., Vol. XXV., p. 443, (pref. Dec. 16th, 1895) 1896 ? : Kerguelen Island.

Mathews, Vol. VII., pt. 5, pl. 369, July 10th, 1919.

Diomedea exulans rohui Mathews, Austral Av. Rec., Vol. II., pt. 7, p. 125, Jan. ¿Sth, 1915: Sydney, New South Wales.

Distribution.-Australia (visitor). One specimen preserved in Mathews's collection. 
Adult female.-Entire head and neck all round, back, rump, and upper tailcoverts, breast, sides of body, abdomen, under tail-coverts, axillaries and under wing-coverts pure white ; scapulars white mottled with greyish-brown subterminally; chiefly on the outer webs; upper wing-coverts also white mottled and externally marked with greyish-brown; hastard-wing dark brown, the inner webs for the most part white; primary-eoverts and primary-quills white at the base, dark brown on the terminal half, the white encroaching farthest towards the tips on the inner webs, shafts of outer primary-quills straw colour and much flattened; secondary-quills similar, but the dark pattern almost restricted to the outer webs, the white reaching to the tips on the inner webs and sometimes encroaching along the margins of the outer webs ; under-surface of quills similar to that of above but many of the secondaries pure white; tail white both above and below with the outer feathers on each side marked and mottled with greyish-brown. Bill pinkih-cream; eyes black, feet cream. Total length $1,050 \mathrm{~mm}$.; culmen 16.), wing (6), tail 19.), tarsus 123 .

Adult male,-Differs from adult $D$. e. exulans in its larger size and whiter coloration, only the primaries, outer webs of the outer secondaries, and the lester wing-coverts and inner secondaries, with the tips of the scapulars, being black; the rest of the plumage is white. The soft parts do not appear to have been deseribed from life. Wing $660 \mathrm{~mm}$. Breeding birds always in white coloration.

Immature.-The young of the year are quite black, or very dark brown, excepting the under parts of wings, throat, and cheeks, which are white, more or less mottled with black.

Nestling.-Covered with pure white silky down.

Test.- Made up of peaty grass interwoven with fibrous earth. A typical nest measured 37 inches, diameter of bowl 18 inches, depth of bowl 5 inches. The floor of this bowl would be about 2 inches deep, as all was simply matted with the natural short grass, and appeared as if merely placed upon it. Many nests are raised $1 \frac{1}{2}$ feet. Some have well-trimmed sides of earth, and are conical, but they are in the minority. 81-84.

Egg.-Chalky-white; coarse to the touch. Dimensions 127-132 $\mathrm{mm}$. by

Breeding-season.-January (fresh eggs); February (half-incubated eggs).

Distribution and forms.-Apparently round the Sub-antarctic Circle, but owing to ignorance of breeding places no certainty can be expressed. Only definitely linown from Kerguelen Island, but conflicting accounts even from that locality. May breed on one of the Neozelanic Sub-antarctic Islands, or even in the South Atlantic.

\section{Diomedea epomophora.-ROYAL ALBATROSS.}

Diomedea epomophora Lesson, Ann. Sci. Nat., Paris, 1st ser., Vol. VI., p. 95, 1825: Campbell Island (breeding).

Distribution.-Australian Seas (Campbell Island, Now Zealand breeding).

Adrult.- Snow-white on the head, neck, back, tail and all under-surface, including the under wing-eoverts and axillaries; on the lower back and rump a few narrow cross-bars may be seen, but it is probable these disappear with age; a few clark speckles are sometimes seen towards tjps of outer tail-feathers; scapulars white at the berses, the ends being solid black; wing coloration generally black, an indintinct olecranal patch of white being noticeable on the oldest specimen, the feathers along the bend of the wing showing white tips; primaries black, the immer webs white towards their bases; secondaries mostly white on the inner web; eyes very dark brown, almost black; bare eyelids jet-black; bill white, with a roseate or pinky tinge in life, yellowish-hom coloured on the terminal hook; legs and feet flesh-white. Culmen (exp.) $170 \mathrm{~mm}$., wing 660, tarsus 117, tail 206. 
Immature, with down still adhering.-Agrees in detail with the preceding; it has fewer white markings on the wing, and the cross-bars on rump and lower back are more pronounced, with longer, black ends to the scapulars; these seem the only noticeable differences; the tail is just as white, and the bill is more dully coloured.

Nestling, just commencing to lose down.-Coloration exactly the same; bill dark coloured, but tail pure white.

Nestling.-Covered with pure white down, thick and woolly in appearance.

Nest.-Apparently like that of $D$. e. rothschildi.

Egg.-White. Dimensions 126 by $79.5 \mathrm{~mm}$.

Breeding-season.-Commence to lay at the end of December.

Distribution and forms.-East Australian and New Zealand seas ; single specimens also known from east and west coasts of South America. From the former localities two subspecies have been separated : D. e. epomophora Lesson, breeding at Campbell Island; and D. e. mecormicli Nathew's, from Enderby Island, Auckland Group, with the scapulars cross-barred, only the longer ones having black tips; the olecranal patch larger, and wing coloration lighter. Murphy (Bull. Amer. Mus. Nat. Hist., Vol. XIXVII., p. 861, Dec. 10th, 1917) has founded a new sulggenu. Rhothonia, on a new species Diomedea sanfordi, killed at sea, forty miles off Corral, Chile. This is obviously a form of the present species, agreeing in all details of structure. We do not understand Murphy'i measurements, otherwise we should conclude his bird was less than the typical form, but he does state that "sanfordi shows no trace of the white olecranal patch."

\section{Order FrEGATI.}

The order covers only one family with a few species of large seabirds with long hooked bills, nostrils not obvious, very long wings, very long forked tails and small webbed feet. They have comparatively very slight borlies and the male has a gular pouch which is capable of large distension in the breeding-seanon. The peculiar fect are diagnostic, the tarsus being unique in character. The distribution is purely tropical throughout all oceans, the birds breeding gregariously on isolated islands.

This peeuliarly well-defined order has been merged by anatomists with the Steganopodes on account of the absurdly trivial superficial feature of the interwebbing of all four toes.

Osteologically, the palate is termed denmonathous but it is a pseudo-desmognathis $m$ which has puzzled osteologists, really only a simple development from the schizognathous form, and the romer is fused posteriorly with the palatines only in the adult. The nasals are holorhinal and there are no hasipterygoid processes: the lachrymal is large with a large descending process which reaches the jugal bar ank an uncinate bone which reaches the palatine. The quadrate is also peculiar. The cervical vertebræ are twelve or thirteen and opisthocelous; the stermum differs from that of the succeeding in its greater depth posteriorly and the furcula is anchylosed with the acrocoracoid and the carina sterni while the pelvis differ and is similar to that of some Procellariz, as is also the skull. The tarsal bones are more or less separated, in this respect recalling those of the Inmennes alone. Both carotids are present and the syrinx is tracheo-bronehial but flattened from befure backwards. The digestive system is pericolous and orthocolous and shows little peculiarity, the cæca being small. The leg muscles are restricted to the femoro-caudal and the ambiens, the others missing; the biceps slip is also abcent from the wing muscles and, as would be anticipated, the biceps it-elf is preculiarly formed. The oil gland is present and tufted, a minute aftershaft is present and the wing is aquineubital. The pterylosis is very uniform and the down is rery thick. 


\section{FAMILY FREGATIDAE.}

\section{Genus FREGATA.}

Fregata Lacepède, Tabl. Ois., p. 15, Dec. 1799. Species added by Daudin, in Hist. Nat (Buffon), ed. Didot, Quadr., Vol. XIV., p. 317 [1799 =] Oct. 1802. Type (by monotypy): Pelecanus aquilus = P. minor Gmelin.

Tachypetcs Vieillot, Analyse nouv. Ornith., p. 63, April 14th, 1816. Typo (by monotypy): "Frégate Buff." = Pelecanus minor Gmelin.

Aquilus Bronn, Zur angewandten Naturg. u. Phys., p. 159, 1824. Nomen nudum, based on "Fregatt-vögel."

Atagen Gray, List Genera Birds, 2nd ed., p. 101, Sept. 1841. Type (by original designation) : "A. aquilla (L.) G. R. Gray" =P. minor Gmelin.

Not Attagen Kaup, Skizz. Entwick.-Gesch. Nat. Syst., p. 170, (pref. April) 1829.

Parvifregata Mathews, Birds Austr., Suppl. No. 1, Check List, p. 64, Feb. 16th, 1920. Type (by original designation): Atagen ariel Gray.

Large birds with long hooked bills, very long wings, very Iong forked tails, slender bodies, and very small legs and feet, the toes semipalmate, but the hind-toe connected with a web. The bill is very long, much longer than the head; it is very strongly hooked, both mandible tips being downward bent; the upper mandible is composed of separate pieces recalling that of a Procellarian bird ; the culminicorn is broad and flattened, a groove extending its length separating it from the laterals, which are also broad and flattened ; the edges of the mandible are complete, no serration being present. The rami of the lower mandible are straight and deep and enclose an unferthered tract which develops in the male into a huge gular pouch. The length of the chord of the culmen is about twice the length of the midde toe. The nostrils are linear slits placed near the base of the culmen. The wings are very long and pointed, the first primary much the longest. The tail is rery long and very deeply forked; it is more than half the length of the wing. The metatarsus is very short and feathered. The toes are comparatively long and thin, and are totipalmate, but the webs are so deeply ineised that semipalmate would better describe them; the toes are obscurely scutellate, the middle toe about twice the length of the metatarsus and half the length of the chord of the eulmen; the hind-toe is long, not much shorter than the inner, the middle toe being longest, the outer longer than the inner; the claw of the middle toe is very long and serrated.

\section{Fregata minor-FRIGATE BIRD.}

[Pelecanus minor Gmelin, Syst. Nat., Vol. I., pt. II., p. 572, April 20th, 17S9: [West Indian Seas =] Jamaica. Extra-limital.]

Mathews, Vol. IV., pt. 3, pl. 229, June 23rd, 1915.

Fregata minor listeri Mathews, Austral Av. Rec., Vol. II., pt. 6, p. 119, Dec. 19th, 1914 : Christmas Island, Indian Ocean.

Distribution.-Australia (visitor). One specimen preserved in Perth Museum, West Australia. Cf. Alexander, Emu, Vol. XVII., pt. IV., p. 238, April 1st, 1918. Probably common in North Queensland.

Adult male.-General coloration throughout black; a brownish tinge observer on the under parts; the feathers of the head long and narrom and showing a dull blue-green sheen; the feathers of the back lanceolate and elongate, showing a shiny oil-green gloss; the primaries and rectrices are tinged with a bluish blocm : innermost secondaries brownish ; the median wing-eoverts dark brown; bill slaty-grey; feet pale flesh; eyclids bright pink. Culmen $96 \mathrm{~mm}$., wing $55 \mathrm{~s}$, tail 365 , miclde toe 50 .

Two birds in the British Muscum supposed to have been procured in Queensland agree fairly well and measure-

$$
\begin{aligned}
& \text { Culmen } 100 \text { Wing } 550 \\
& \text { " } 105 \text {," } 565 \\
& \text { Tail } 420 \\
& \text {, } 370
\end{aligned}
$$


Adult female.-Head and neck all round and all upper-parts dark ; throat ashy ; lower neck, breant, and sides of body pure white; micldle of lower-breast, abdomen, and flanks black; the feathers of the head are shorter than in the male and are comparatively dull; brown collar on back of neck; the feathers of the back are not conspicuously elongated and lack the brilliant sheen of the lanceolate plumes of the male; innermost secondaries brownish; the lesser and median coverts are brownish with paler margins, forming a somewhat conspicuous bar parallel to the shoulder. Culmen $107 \mathrm{~mm}$., wing 599, tail 410, middle toe 54 .

Immature male.-Head and neck all round white, pouch showing; breast with rusty patch; lower-breast black as are sides of body; centre of abdomen, lower flanks, and rent white; under tail-corerts black with small white tips; rest of upper-parts dusky-brown and black according to wear ; median wing-covert brownish forming a narrow bar. Coloration of iris, bill, and feet unrecorded. Culmen $92 \mathrm{~mm}$., wing 570 , tail 350, middle toe 49. (New Zealand.) (Another collected by J. Macgillivray at Oomaga I:land, Torres Straits, agrees but is slightly larger.)

Nestling.-Pure white down.

Next stage.-Scapulars and mantle of brown feathers with subterminal bars; round the eyes, over fore-head and chin naked.

$N$ ext.-Red down comes on the naked part of the head but not on the chin; secondaries commence as black feathers.

Next.-Larger, and tail-feathers begin black.

Next. - The red extends over the top of the head and on to the face; the scapulars are fully developed and the feathers of the back growing : these are clark brown with lighter tips. The tail has rapidly lengthened, being $150 \mathrm{~mm}$. long and showing slight but deeicled fork, their feathers being black with a blue sheen : the wing-coverts are more or less greyish-white throughout, the primaries and secondaries long and black with a metallic sheen; the breast feathers just beginning to show.

Next.-Larger and similar to preceding; the tail, more forked, measures $214 \mathrm{~mm}$; the head is darker and the dark breast-feathers show more prominently, but otherwise the under parts are still covered with down.

Flying young.-Head nearly all white, with a few red feathers remaining; upper-breast dark rusty-red; bromin on sides of body ; abdomen white ; rent black.

Immature.-The patch of dark rusty-red on the upper chest vanishes and the dark colour goes from sides, but immediately black feathers begin to be seen on the abdomen.

These notes are taken from a series in the Rothschild Huseun collected by Schauinsland at Laysan. From other localities intervening stages can be seen. The adult male is wholly black, with lanceolate breeding plumes on the back showing strong metallic gloss. The adult female has the breast white, the throat not fully black and no breeding plumes, though a metallic sheen is noticeable on some of the back feathers; she is larger and has no gular pouch. Immature males show this coloration, but are distinguishable by the possession of an orange gular pouch and the presence of lanceolate metallic breeding plumes. It is also certain that the immature of both sexes breed when in the white-headed stage noted above, but then the male has only a partially developed pouch and searcely differs from the female save in size.

Nest.-Placed in trees or on the ground; rather bulky, composed of sticks.

Eggs.-Clutch one, white; covered with creamy lime; axis 66 to $68 \mathrm{~mm}$., diameter 45 to 46 .

Distribution and forms.-Throughont the tropical oceans, and the criticism of Rothschild, Oberholser, ete., tends to accept the novel arrangement proposed by Hathews in 1915 whereby four species were discriminated from the previously accepted one only, and of the present species many subspecies, as follows : $\mathfrak{F}^{\prime} . m$. minor Gmelin from the Wert Indies; $F$. m. nicolli Mathews, from the South Atlantic Ocean 
with larger bills though smaller wing measurement with a very broad pale wing band; $F$. $m$, aldabrensis Mathews from the Seychelles, Aldabra, ete., in the West Indian Occan, with dark oil-green sheen, dark wing-coverts, Iarger size than typical, about equal to last named form; $F$. m. listeri Mathews, type from Christmas Island, East Indian Ocean, a very small form which has occurred in Western Australia; F. m. palmerstoni (Gmelin) from the Pacific Ocean, with which has been included F. m. strumosa Hartert from Laysan, and to which the Torres Straits birds are at present tentatively referred, with a narrow dark brown wing band and larger than the preceding; and $F . m$. ridguayi Mathews from the Culpepper and Wenman Islands, Galapagos Group, with brownish wing-bar and oily-green male breeding plume., short bill and same size as last.

The only point at issue is the type locality of Gmelin's $P$. minor, which must be Jamaica as selected by Mathews.

\section{Fregata ariel.-LESSER FRIGATE BIRD.}

Gould, Vol. VII., pl. 72 (pt. xxxv.), Dec. 1st, 1848. Mathews, Vol. IV., pt. 3, pl. 230, June 23rd, 1915.

Atagen ariel Gray, Genera Birds, Vol. III., p. 669, pl. 183 (often 185), Jan. 1845 : Raine Island, North Queensland.

Fregata ariel tunnyi Mathews, Austral Av. Rec., Vol. II., pt. 6, p. 121, Dec. 19th, 1914 :

Bedout Island, mid-West Australia.

Distribution.-Tropical Northern Australia.

Adult male.-General coloration black, the under parts with a brownish tinge : the head with long narrow feathers showing a deep blue sheen, as do also the lanceolate breeding plumes on the back; wing-coverts uniformly black; a white patch on each side of the body; legs and feet black; bill grey ; skin of throat red; eyes and eyelids black. Culnen s0 mm., wing 53.5, tail 270, middle toe 45. (Raine Island.)

Adult female.-Differs from the adult male in having the breast and sides of breast buffy-white; a chestnut collar on the lower hind-neck; lesser and median upper wing-coverts brown with whitish elges and blackish shaft-streaks, the long scapulars brown at the ends; bill bluihh-hom; iris brown; eye rim and gular sac red; feet fleshy-red. Total length $800 \mathrm{~mm}$, ; culmen 92, wing 565 , tail 335 , tarsu. 23. (Bedout Island.)

Immature with down adhering on under parts.-Head, neek and throat deep rustyred; back brown with lighter tips ; scapulars Iong. brownish-black; primaries ancl primary-coverts, bend of wing inside and out black; secondary-coverts brown with pale whitish tips; breast downy, showing black frathers in the form of a bancl across the lower-breast; abdomen white; under tail-coverts black; tail black, long and slightly forked; bill and feet of a white colour with a shade of blue; eyes black. (Raine Island.)

Nestling.-Pure white domn throughout save round eres and fore-head, where it is rusty-red ; gullet naked ; patch of brown feathers on back; iris black; leg. white. Born naked like young Gannets.

Older birds are covered with white down, with a saddle-shaped band of dark grey feathers across the back and scapular region.

Nest.-Of stalks of grass and I pomra, small twigs, ete. The a verage climensions of each nest were about one foot in height by a little more in diameter.

Eggs.-Clutch, one; pure white; very thin-shelled, with only a very slight limy coating. Measurements $59.7-70.6$ by $41-47.7 \mathrm{~mm}$.

Breeding-season.-April, May.

Distribution and forms.-Principally Northern Australian seas, but also East Indian Ocean and South Atlantic Ocean as a very rare brecler. F. ariel ariel Gray, from East Australia, breeding on Raine Island; F. a.tumyi Mathews, from West 
Australia, breeding on Bedout Island, a larger form; and F. a. ircdalei Nathews, from Aldabra, Western Indian Ocean, a smaller form with a very smal bill. The species has also been recorded from the South Atlantic Ocean, but series are not available to determine the subspecies.

\section{Order PELECANI.}

This order, consisting of large seabirds, nith long more or less hooked bills with obsolete nostrils, long wings, stiff wedge-shaped tails and webbed feet, all four toes being conmected with large webs, the first large and the fourth longest, is separable into three superfamilies. These are the Phalacrocoracoidea, including the Cormorants and Darters, the Pelecanoidea for the Pelicans, and the Suloidea for the Gannets. The feet formation in all these agree fairly closely, though the bill has raried somewhat considerably while the size of the birds has altered also. The first named contains the smallest species (but still largo birds), with long necks and slender elongate bodies, long wings and long wedge-shaped tail and short legs and feet. The Pelicans are the largest forms, with extraordinarily long bills with huge characteristic gular pouch, short necks, very heary stout bodies, long wings, short rounded tail and large stout legs and feet. The Gamnets are intermediate in size, with long thick necks, stout bodies, long wedge-shaped tail, strong legs and feet.

The diagnostic feature of the group is the superficial one of the webbing of the feet; there is no characteristic internal feature that will define the group succinctly. The superficial differences of the bill are so great that similar differences are easily observed in the skull. The palate is desmognathous, and the nasals holorhinal, while there are no basipterygoid processes (rudiments are recorded in Pelecanus only as yet). The lachrymals vary in size and form. The sternum is somewhat peculiar in the formation of the carina which is produced forward, decreasing rapidly backward and disappearing about the middle of the corpus sterni. The furcula is connected by ligaments with the keel of the stemum, being even anchylosed in Pelecanus. The cervical rertebre vary in number in the three groups, also showing little peeuliarities in each. Both carotids are present, the syinx tracheo-bronchial but variable, intrinsic museles being present or absent in the lifferent groups. The digestive system does not seem to have been studied in detail, being pericolous and orthocolous in general, and ceeca small. The leg muscle formula is variable in the tifferent groups as is the prenence or absence of the biceps slip, and the arrangement of the biceps itself. The oil gland is present and tufted but the number of orifices is variable, the aftershaft superficially absent and the wing aquincubital. The pterylosis is very uniform and the down very close, the young born naked. Many fossils from Tertiary strata have been recorded as Steganopodes, using that term in the broad sense. Lydekker has referred Argillomis Owen from the London Clay to the neighbourhood of this group, but Furbringer would class it with the Ichthyomithes. Similarly Furbringer would include Remiornis (which Gadow considered Struthious) and (henomis which was supposed to be Anserine. Such divergence of opinion suggests the unsuitability of depending on osteological characters alone. Marsh recorded Graculavus from the Cretaceous, concluding it could be determined as not only Steganopodous but even referable to the Phalacrocoracine branch. Odontopteryx Owen has been regarded as a Steganopod, but Andrews showed that there were important Anserine-like features, though Steganopod-like items were still recognisable. Prophathon shrubsolei Andrews from the London Clay, considered as ancestral to Phä̈thon, secms to show more ancestral Suline features and would be better classed here.

\section{SUPERFAMTY PHALACROCORACOIDEA.}

Only two families are recognikerl, one with hooked bills, long wings, short stouti, h necks, wedge-shaped tail of very :tiff feathers and typically Steganopod feet; the 
other with sharp pointed bill and long thin neck with a "lkink" in it, but exactly similarly formed feet. The former, the Phalaerocoracide or Cormorants, is composed of scabirds with a work-wide distribution, some species now living on inland lakes and marshes; the latter, the Anhingida or Darters, has become restricted to the rivers of the tropics and subtropical portions of America, Asia, Africa and Australia.

The skull of these two raries in the latter lacking the nasal hinge and less modifieations purely adaztive. The desmognathism of the palate is similar as are the holorhinal nostrils, though reduced to mere chinks in the latter. There are no basipterygoid processes and the descending process of the lachrymal fuses with the ectethmoid, while there is a small bonelet resting upon the jugal bar in front of the lachrymal; a peculiar style-like bone is present, attached to the occipital, and also the quadrate is peculiar in form. The cervical vertebra are twenty in number, the dorsal vertebrie opisthocolous with very large hypapophyses, the sternum with the keel as deseribed for the order and the furculum articulating with the lieel but not anchylosed. The carotids are one or two and the syrinx with a single pair of intrinsic muscles and a complete bronchidesmus in the first family, incomplete in the second. The accessory semitendinosus is always missing in the leg muscles and gencrally the accessory femoro-caudal, but the latter sometimes met with in the first-naned family, while the biceps slip may be missing also in that group, though generally present. The oil gland is always present and tufted with two or four orifices, the aftershaft apparently absent, and the wing aquincubital. The pterylosis has not been eriticised carefully, being cited as uniform with narrow spaces. The young are hatched naked, but are covered with thick down later.

\section{FAMILY PHALACROCORACIDE.}

This family comprises the Cormorants and shags, and the generie distinctions tenable in this group are unsettled. In connection with Australian species we admit four genera, Hypoleucus, HLesocarbo, Microcarbo and Phalacrocorax. These are well differentiated forms and their geographical range confirms their distinction. Some workers are so peculiar in their generie values that they deny generic distinction to Nannopterum, a flightless form of large size. As it is still a Steganopod, whatever its evolution may have been, it must belong to the genus Phalacrocorax which includes, to them, every Cormorant-like bird, large or small. Good osteological differences exist but these are minimised as being due to disuse, etc., as if every alteration in structure were not due to disuse or the opposite. In the genera above mentioned similar structural differences exist, much more striking ones than are accepted as ralid in the Procellarie. Osteological features of distinction have been recorded as also anatomical items, thus the biceps slip is present or absent, while the syrinx varies, etc., etc.

\section{Genus HYPOLEUCUS.}

Hypoleucus Reichenbach, Nat. Syst. Vögel, p. vII, 1852 (?1853). Type (by original designa. tion): Pelecanus varius Gmelin.

Leucocarbo Bonaparte, Consp. Gen. Av., Vol. II., p. 176, 1856. Type (by subsequent designation, Ogilvie-Grant, Cat. Birds Brit. Míus., Vol. XXVI., p. 331, 1898) : Carbo bougainvillii Lesson.

Medium to large Phalacrocoracine birds with long slcnder bills, long rings, short tails composed of twelve feathers.

These birds approach species of Phalacrocorax close'y, from which they differ in the number of the tail-feathers. 
The tail is less than half the wing length and more than twice the length of the metatarsus, which is generally exceeded by the culmen chord.

This genus is Antarctic in distribution and is composed of birds of bright coloration, usually white underneath and often with facial ornaments of fleshy caruncles.

\section{Hypoleucus perthi.-PIED CORMORANT.}

Gould, Vol. VII., pl. 68 (pt. XI.), June 1st, 1813. Mathews, Vol. IV., pt. 2, pl. 222, Feb. 17th, 1915.

Carbo varius perthi Mathews, Austral Av, Rec., Vol. I., pt. 4, p. 88, Sept. 18th, 1912 : Perth, West Australia.

Hypoleucus varius whitei Mathews, Birds Austr., Vol. IV., pt. 2, p. 187, Fob. 17th, 1915: Lake Albert, South Australia.

Distributron.-Extra-tropical Australia and Tasmania.

Adult male.--Sides of the upper back, scapulars, upper- and under-surface of the wings dark oil-green with very narrow elgings to the feathers; head, hind-neck, a narrow line on the middle of the upper back and entire lower back, rump, and upper tail-coverts blue-black like the flanks and outer aspect of the thighs; quills and tail-feathers uniform black; sides of the face, sides of neck, throat, fore-neck, and entire surface pure white. Bill dark horn ; bare space in front of the eye bright orange, eyelid and rim round the eye rich indigo-blue; throat and cheeks light bluish-ash; iris pale green; feet black. Total length $800 \mathrm{~mm}$.; culmen 70, wing 324 , tail 150 , tarsus 66 .

Adult female.-Similar to the adult male.

Immature.-This individual, which has nearly attained its full plumage, is conspicuous by having some brown feathers scattered among the white on the foreneck and sides of the neck.

Nestling.-Naked.

Nest-- Similar to that of $H$. fuscescens, sometimes placed on the ground, at others in trees.

Eggs.-Clutch, two; similar to those of other members of the family; axis 55 to 58 , diameter 35 to 37 .

Breeding-season.-September to November; March to May.

Distribution and forms.-Apparently confined to Southern Australia outside the tropies and not ranging to New Zealand, where a different species has been confused with this. We are not recognising any subspecies at present, as the characters hitherto used for differentiating " species " in comnection with this group) in Now Zealand have proved unstable.

\section{Hypoleucus fuscescens. -WHITE-BREASTED CORMORANT.}

Gould, Vol. VII., pl. 69 (pt. xI.), June Ist, 1843. Mathews, Vol, IV., pt. 2, pl. 221, Feb. 17 th, 1915.

Hydrocorax fuscescens Vieillot, Nouv. Dict. d'Hist. Nat., Vol. VIII., p. 86, March 15th, 1817 :

"Australasie" = Tasmania.

Carbo hypoleucos Brandt, Bull. Sci. Acad. Imp. Sci. St. Petersb., Vol. III., p. 55, Nov, 16th, 1837 : South Australia.

Phalacrocorax leucogaster Gould, Synops. Birds Austr., pt. 1V., App., p. 7, April 1st, 1838 :

"Now South Wales" = Tasmania.

Not Hydrocorax leucogaster Vieillot as above, p. 90, 1817.

Hypoleucus gouldi Salvadori, Ann. Mus. Civ, Gen., Vol. XVIII., p. 404, 1882. Now name for $P$. levcogaster Gould.

Carbo gouldi tunneyi Mathews, Austral Av. Rec., Vol. I., pt. 4, p. 88, Sept. 18th, 1912 : Peak Islands, South-west Australia.

Distributios.-Extra-tropical Australia and Tasmania 
Adult male-Head, hind-neck, entire back, outer sides of the thighs and under wing-coverts glossy blue-black with white plumes intermixed on the sides of the nape, upjer hind-neck, and sides of the rump; scapulars and wings oil-green with very narrow black margins to the feathers ; quills uniform dark brown; tail greenishblack; sides of the face, throat, fore-neck and entire under-surface of the body pure white. Bill dark hom, base and bare space purple; iris green; feet black. Total length $700 \mathrm{~mm}$; ; culmen 54, wing 273, tail 107, tarsus 60.

Adult female.-Similar to the adult male but slightly smaller. Culmen $50 \mathrm{~mm}$., wing 270 , tail 107 , tarsus 54 .

Immature.-Distinguished chiefly by the brown on the upper-surface, sides of the body, and the outer thighs; gular pouch grey.

Young.-Similar to the above but darker brown, and the head and hind-neck narrowly streaked with white.

Nest-Placed on a reef or on rocks and composed of seaveed, saltbush, etc. ; outside dimensions 18 by 4 inches, egg eavity about 9 inches by 2 .

Eggs.-Clutch, two or three; similar to those of other members of the family; axis 57 to $60 \mathrm{~mm}$., diameter 36 to 38 .

Breeding-season.-November, December and January.

Distribution and forms.-Apparently confined to Southern Australia, outside the tropics. No subspecies are admitted at present as only unstable characters have been used for separating forms in this genus, and long series are not at hand; while Carter states it may not occur west of Albany, so that it has a very limited range.

\section{Genus MESOCARBO.}

Mesocarbo Nathews and Iredale, Ibis, 1913, p. 415, July 1st. Type (by original designation) : Carbo sulcirostris Brandt $=$ C. nter Lesson.

Small Phalacrocoracine birds with comparatively short, slender bills, ratler short necks, long wings, and medium tail composed of twelve feathers.

The bill is more delicately formed than in the preceding genus, but on exactly the same pattern; the eulmen engraved with parallel shallow grooves and ridges.

The tail is about three times the length of the culmen or metatarsus, which are subequal, and more than half the wing length.

When we separated this form (loc. cit.) we wrote: "The species of Mlesocarbo ilifier from those of Hypoleucus in their shorter and more slender bills, their longer tails and more slender build; from those of Microcarbo in their longer and proportionately more slender bills as well as their proportionately shorter taik," and apparently there is no crest in the breeding-season.

\section{Mesocarbo ater.-LITTLE BLACK CORMORANT.}

Gould, Vol. VII., pl. 67 (pt. Xxxv.), Dec. 1st, 1848. Mathews, Vol. IV., pt. 2, pl. 220, Feb. 17 th, 1915.

Carbo ater Lesson, Traité d'Orn., $8^{\complement}$ Jivr., p. 604, June 11th, 1831 : Shark Bay, West Australia. Carbo sulcirostris Brandt, Bull. Sci. Acad. Imp. Sci. St. Petersb., Vol. III., p. 56, 1837 : New South Wales.

Microcarbo stictoccphalus Bonaparte, Consp. Gen. Av., Vol. II., p. 178, 1856: New South Wales.

Carbo squamatus Pelzeln, Ibis, 1873, p. 124, Jan. 1st. Nomen nudum.

Mesocarbo ater lerritori Mathews, Birds Austr., Vol. IV., pt. 2, p. 176, Feb. 17th, 1915 : Northern Territory.

Distribetion,-Australia generally and Tasmania.

Adult male.-Upper-back, sides of breast, scapulars and wings hoary-grey, with black margin: and black - laft-line: to the featlers, all of which are rery gloser ; 
lower back, rump, and upper tail-coverts uniform blue-black glossed with green ; bastard-wing, primary-coverts and quills uniform dark brown, the quills paler on the inner webs and hoary-grey on the outer webs of some of the secondaries; tail dark brown; head and neck all round, dark brown with an oily-green reflection, darker on the crown of the head and hind-neck, paler and inclining to brown on the throat and sides of the face; sides of the face, ear-coverts, and sides of crown covered with white-tipped plumes; remainder and entire under-surface blue-black glossed with green. Bill : culmen black, remainder of bill and bare skin leadengrey; iris green; tarsi and feet black. Total length $610 \mathrm{~mm}$; ; culmen 48 , wing 253 , tail 131, tarsus 52.

Adult female.-Very similar to the adult male but smaller and with a fer whiteplumed feathers seattered down the hind-neck. Culmen $42 \mathrm{~mm}$., wing 238, tail 120 , tarsus 44 .

Immature.-Differs from the adult in being more or less brown on the head, sides of the face, fore-neck and chest, and the white-tipped plumes on the head much less numerous.

Nestling:-Born naked.

Nest.-Constructed of sticks, leaves, etc., and placed in a tree ; in rookeries.

Eggs.-Clutch, three to four; ground-colour pale green covered with white lime ; axis 50 to $56 \mathrm{~mm}$., diameter $33-37$. (Victoria.) Clutch, four; axis 49 to $50 \mathrm{~mm}$., diameter 31. (Port Darwin.)

Breeding-season.-August to December; May and June.

Distribution and forms.-Australia and the islands to the north and New Zealand. The Neozelanic form $M$. a purpuragula Peale appears to differ in its larger wing, shorter bill and tarsus, but no big series is available The soft parts also scem to differ in coloration.

\section{Genus MICROCARBO.}

Microcarbo Bonaparte, Comptes Rendus Acad. Sci. Paris, Vol. XLIII., p. 577, Sept 1856. Type (by original designation): Pelecanus pygmeus Pallas.

Halietor Heine, Journ. für Orn., May 1860, p. 202. New name for Microcarbo Bp.

Melanocarbo Bernstein, Bijdr. Taal- Land-en Volkenk. Ned.-Indie, Ser. IV., Vol. VII., p. 119,

1883. Type (by monotypy): Hydrocorax melanoleucos Vieillot.

Smallest Phalacrocoracine birds with very short bills, long necks, long wings, rery long tails and short legs and feet. The bill is very short, being less than onesixth the length of the wing and shorter than the metatarsus. The wing has the primary formula difierent from any of the preceding genera, having the second and third primaries subequal, the third sometimes the longest, while the first is exceeded by the fourth. The tail, composed of twelve feathers, is very long, about two-thirds the length of the wing, and four times the length of the culmen or metatarsus.

The feet are delicately formed when contrasted with those of the preceding genera, though comparatively they agree in their proportions.

There appears to be no crest in the breeding-season, at least, in the Australian species.

\section{Microcarbo melanoleucus.-LITTLE CORMORANT.}

Gould, Vol. VII., pl. 70 (pt. xII.), Sept. 1st, 1843. Mathews, Vol. IV., pt. 2, pl. 223, Feb. 17 th, 1915 .

Hydrocorax melanoleucos Vieillot, Nouv. Dict. d'Hist. Nat, Vol. VIII., p. 88, March 15th, 1817: "Australasie" = New South Wales.

Carbo dimidiatus Lesson, Traité d'Orn., 8c livr., p. 604, June 11th, 1831 : New South Wales.

Phalacrocorax Aavirhynchus Gould, Synops. Birds Austr., pt. IV., App., p. 8, April 1st, 1838 : New South Wales.

Graucalus flavirostris Gray, in Dieffenbach's Travels in New Zeal., Vol. II., p. 201, (middle Jan.) 1843. Emendation of Gould's name. 
Halieus le ucomelas Gloger, Journ, für Ornith., Jan. 1857, p. 14. Emendation of Vieillot's name.

Carbo melanoleucus melvillensis Mathews, Austral Av. Rec., Vol. I., pt. 3, p. 74, June 28th, 1912 : Melville Island, Northern Territory.

Distribution.-Australia generally and Tasmania.

Adult male.-General colour of the upper-surface glossy black; wing-coverts hoary-grey with black marginal or submarginal edgings; quills and tail-feathers uniform glossy black; the feathers on the fore-head, narrow and stiffened, are black ; sides of the fore-head, sides of face, throat, fore-neck, and entire under-surface pure white except the axillaries, under wing-coverts, and under tail-coverts, which are black. Bill and gular pouch yellow, culmen black; bare skin on face brownishyellow ; iris greyish-white; feet black; second scale on middle toe plum colour. Total length $610 \mathrm{~mm}$; ; culmen 34, wing 238, tail 165, tarsus 38 .

Adult female.-Similar in every respect to the adult male but smaller. Wing $232 \mathrm{~mm}$.; culmen 32, tail 155.

Nestling.-With tail and wing-feathers partially developed; is dense black with white feathers interspersed over the entire abdomen, more thickly on the thighs and rent; the head is quite naked as far as the ear-coverts, which have white tufts. Bill black, basal portion and a patch near the tip of the lower mandible yellowishwhite; fore-head and crown of head dirty white; throat purplish-flesh colour ; interramal space pale greenish-white; iris, outer ring dirty white, inner one brown; feet black.

Immature.-In this species, as in the majority of others, is chiefly distinguished by its brown upper-surface.

Nest.-Composed of sticlss and lined with leares, and placed in low trees.

Eggs.-Clutch, three to five; similar to those of other members of the family; axis 43 to $46 \mathrm{~mm}$., diameter 30 to 32 .

Breeding-season.-September to January. (Queensland and New South Wales.) May. (Darwin, Northern Territory.)

Distribution and forms.-Australia generally and recorded from the islands to the north, but not New Zealand, as we now consider the Neozelanic species of Microcarbo distinct. Australian forms not well known owing to lack of specimens.

\section{Genus PHALACROCORAX.}

Phalacrocorax Brisson, Ornith., Vol. I., p. 60, Vol. VI., p. 511, 1760. Type (by tautonymy): Phalacrocorax $=$ Pelecanus carbo Linné.

Carbo Lacepede, Tabl. Ois, p. 15, Dec. 1799. Species added by Daudin in Hist. Nat. Buffion, ed. Didot, Quadr., Vol. XIV̌., p. 318 [1799] = Oct. 1802. Type (by tautonymy) : Carbo vulgaris $=P$. carbo Linné.

Halieus Illiger, Prodr. Mamm, et Av,, p. 279, (pref. April) 1811. New name for preceding. Carbonarius Rafinesque, Analyse de la Nature, p. 72, 1815. New name for "Carbo Lac." = Lacepède, cf. Auk, Vol. XXVI., p. 50, Jan. 1909.

Hydrocorax Vieillot, Analyse nouv. Ornith., p. 63, April 14th, 1816. Type (by monotypy); Cormoran $=P$. carbo Linné.

Not Hydrocorax Brisson, Ornith., Vol. IV., p. 566, 1760.

Cormoranus Baillon, Mem. Soc. Roy. Abbeville, p. 76, 1833 [1834]. Type (by subsequent designation, Mathews, List Birds Austr., p. 95, 1913) : P. carbo Linné.

Graucalus Gray, List Genera Birds, 2nd ed., p. 101, Sept. 1841. Type (by original designa. tion): P. carbo Linné.

Not Graucalus Cuvier, Le Règno Anim., Vol. I., p. 341, Dee. 7th, 1816.

Ecmeles Gistel, Naturg. Thierr. Schul., p. IX., (pref. Easter 1817) 1848. New name for Hydrocorax Vieillot.

Large Phalacrocoracine birds with long hooked bills, long neck, long wings, medium tail, short legs and long toes, all the toes, including the hind one, connected with a web.

The bill is long and slender, with culmen depressed, and a rery sharp, prominent hook. The culmen is separated from the lateral portions by a narrow groove in 
which the nostrils, obsolete and scarcely apparent in the adult, are placel at about a quarter the bill's length from the frontal feathering. The bill is longer than tho head and about equal to the metatarsus in length. The under mandible is narrow, the rami enclosing a very narrow unfeathered tract, which develops into a more or less distensible gular pouch. The head is erested and the lores are bare. The wings are long with the second primary longest, the third a little shorter, almost subequal, while the first is longer than the fourth though shorter than the third; all the primaries show scalloping. The tail is comparatively short, less than half the length of the wing and about twice the length of the culmen or metatarsus. It is wedge shaped, composed of fourteen very stiff feathers with short, insignificant upper tail-coverts. The legs are short, the toes long. The metatarsus is very stout, laterally compressed, reticulated throughout, the scales on the front and sides small but those on the hind portion very minute. The metatarsus is about half the length of the tail and two-thirds the length of the outer toe.

The toes are all fully connected with a web, the outer toe longest, the middle longer thar the inner, the inner exceeding the hind-toe. The claws are long, hooked, the middle one bearing pectinations.

\section{Phalacrocorax carbo.-BLACK CORMORANT.}

[Pelecanus carbo Linné, Syst. Nat., 10th ed., p. 133, Jan. 1st, 1758: Europe. Extra-limital.] Gould, Vol. VII., pl. 66 (pt. xxxiv.), Dec. 1st, 1848. Mathews, Vol. IV., pt. 2, pl. 219, Feb, 17 th, 1915 .

Phalacrocorax novcehollandia Stephens, in Shaw's Gen. Zool., Vol. XIII., pt. I., p. 93, Feb. 18th, 1826 : Tasmania.

Phalacrocorax carboides Gould, Synops. Birds Austr., pt. Iv., App., p. 7, April 1838: Tasmania. Carbo carbo westralis Mathews, Austral Av. Rec., Vol, I., pt. 2, p. 33, April 2nd, 1912 : Swan River, South-west Australia.

Phalacrocorax carbo gracemeri Mathews, Birds Austr., Vol. IV., pt. 2, p. 167, Feb. 17th, 1915 : Gracemere, Queensland.

Distribution.-Australia generally and Tasmania.

Adult male (in winter).-Upper back, scapulars, and wings greyish-brown with black margins to the feathers; lower back, rump, and upper tail-coverts uniform blue-black; quills and tail-feathers dull black with rery glossy shafts; head and neck all round and the entire under-surface glossy black with green reflections in certain lights; chin and sides of the face, including the eye, white; a few white feathers on the lower flanks Bill yellow, culmen purplish, naked skin gambogeyellow; iris emerald-green; feet black. Total length $780 \mathrm{~mm}$.; culmen 67 , wing 357 , tail 155, tarsus 60 .

Adult female.-Similar to the adult male but smaller. In summer the adults have a white patch on the flanks and white lanceolate feathers on the neck.

Inmature.-Distinguished by its browner appearance, especially on the head, neck, and under parts, the absence of the white flank plumes, and in being whitish in the middle of the belly.

Nest.-Composed of twigs, etc., saucer-shaped, about three inches deep and 16 to 18 inches wide, placed (often in colonies) in low bushes or rocky ground.

Eggs.-Four (sometimes three); ground-colour greenish and dull, covered with a white coating of lime ; axis $59-60 \mathrm{~mm}$., diameter $35-6$.

Breeding-season.-August to November.

Distribution and forms.-World-wide and forms not yet detailed. In 1915 Mathews suggested six subspecies: $P$. c. carbo Linné, Europe, with large size, deep purplish gloss and heavy nuptial ornamentation (since, following Mathews's suggestion, separated into two by Hartert, $P$. c. carbo Linné from Northern Europe, and $P$. c. subcormoranus Brehm, from Southern Europe); P. c. americanus Reichenbac! from North America; P.c. indicus Nathers, from India, by small size and purplish- 
green coloration; P. c. sinensis Shaw and Nodder, from China and Japan, in its small size and generally oily-green coloration; $P$. c. novahollandice Stephens from Australia in its deep oily-green coloration and sparse nuptial ornaments, rarely observed due to their evanescent nature; and $P$. c. steadi Mathews and Iredale, from New Zealand, like the preceding generally, but of smaller size.

\section{FAMILY ANHINGID E.}

Only one genus was admitted in this family, but it is possible that the four species may prove to represent different genera as the intemal characters differ somewhat appreciably according to good workers. The peculiar mechanism of the neck is common to all, but "Donitz's briclge," as it is called, is fibrous in the ty]e, ossified in the others. There is said to be no expantor secundariorum in the wing, while rudiments exist in the members of the preeeding family. Again, only one, the left, carotid is recorded in this group, while both are always found in the Phalacrocoracida. Here it may be noted that some of these records refer to only one species, while the absence of an independent tongue must be noted, and also the peculiarities of the syrinx.

\section{Genus ANHINGA.}

Anhinga Brisson, Ornith., Vol. 1., p. 60, Vol. VI., p. 476, 1760. Type (by tautonymy): Anhinga $=$ Plotus anhinga Linné.

Plotus Linné, Syst. Nat., 12th ed., p. 218, (pref. May 24th) 1766. Type (by monotypy): $P$. anhinga Linné.

Plottus Scopoli, Introd. Hist. Nat., p. 474, 1777. Type (by monotypy): A. anhinga.

Noloplotus, Mathews, Birds Austr., Suppl. No. 1, Check List, p. 62, Feb. 16th, 1920. Type (by original designation): Plotus novchollandice Gould.

Iarge slender birds with very small heads and very long necks, long thin pointed bills, long wings, long stiff tail, short legs and long toes, totipalmate.

The bill is very long and thin, straight and pointed, longer than the head and more than one and a half times the length of the metatarsus, compressed laterally and the edges of both mandibles are finely serrated. The loral space is naked and there is a small gular pouch; the nostrils obsolete in an ill-defined groore. The neck is very long and the body slender. The wings are long, the second and third primaries subequal and longest, the first shorter than the fourth. The tail is rery long, composed of twelve broad stiff feathers, fairly evenly rounded, the outside feather rather short. The legs are very stout and short; the metatarsus is less than one-fourth the length of the tail, coarsely reticulate on the front and sides but minutely reticulate on the back. The toes are long, the middle almost as long as the outer one, hind-toe comected with others by a web; all the toes therefore are fully webbed. The outer toe is little longer than the middle one, and is about one and a half times the length of the metatarsus; the middle claw is finely pectinate.

An extraordinary feature is the wrinkling of the two centre tail-feathers and the longest secondaries.

The Darters, though superficially unlike, have been shown to be specialised Cormorants, and show the closest relationship of any of the totipalmate group.

\section{I. Anhinga novæhollandiæ.-DARTER.}

Gould, Vol. VII., pl. 75 (pt. xxviri.), Sept. Ist, 1847. Mathers, Vol. IV., pt, 3, pl. 224, June 23rd, 1915.

Plotus novchollandice Gould, Proc. Zool. Soc. (Lond.), 1847, p. 34, April 27th: New South Wales.

Plotus novcchollandice derbyi Mathews, Austral Av. Rec., Vol. I., pt. 3, p. 74, June 28th, 1912 : Derby, North-west Australia.

Distribution.-Australia generally. Not Tasmania. 
Adult male.-General colour above and below glossy blue-black; a broad white band on each side of the hearl enclosing the eye and extending on to the sides of the upper neck; naked part of throat edged with white; a large patch of chestnut on the fore-neck; the feathers on the lower hind-neck and upper mantle more or less chestnut at the base; scapulars and wing-coverts centred with white; quills and tail-feathers uniform black, the two central tail-feathers being transversely waved; innermost secondaries and tail-feathers ribbed. Bill olive-green, base of upper mandible brown, base of lower mandible and bare skin yellow; iris pale yellow; feet whitikh-brown, toes darker. Total length $890 \mathrm{~mm}$.; culmen 79 , wing 347 , tail 217 , tarsus 48 .

Adult female.-Head and hind-neck dark brown, becoming paler on the latter and everywhere mixed with white, a white line from the cheeks extending down the sides of the neek; middle of back rust-brown; scapulars dark brown centred with white; wing-coverts brown, or black, also centred with white, major covests black and white; bastard-wing, primary-coverts and quills uniform slaty-black, the innermost secondaries white on the outer webs; tail, centre feathers silvery-grey, the outer ones darker and more slate-grey; chin, throat, and entire under-surface buffy-white, a black patch on each side of the breast; outer edge of wing buffywhite. Bill bluish-grey, yellowish-grey below; iris pale yellow; feet creamyyellow. Culmen 67 mm., wing 357 , tail 230 , tarsus 44 .

Immature male (bird of the first year). - Similar to the adult female, but differs in being darker on the back, the throat and fore-neck buff, the crown of head and hindneck much darker brown, and the white streak on the cheeks distinctly outlined, as also the white edges to the feathers of the throat.

Immature male (second year).-This bird shows an advance of plumage by being darker on the head, hind-neek, and entire back; the lower fore-neck is black, dark feathers are distributed over the under-surface, and the under tail-covertis are mixed with rufous.

Immature male (third year).-This individual is very nearly in the adult plumage, but still retains the brown of the immature on the top of the head and hind-neck; the rufoil: on the fore-neck is more extensive and is intermixed with the black of the throat, and the white on the chin and sides of the head is well developed.

Nestling.-Covered with white down below and rusty-red on the neck and wingcoverts The head and throat bare; on the sides of the neck the white streak is just noticeable. Wings and tail black, tipped with buff.

Nest.-A platform composed of twigs and lined with leaves, about 16 in. across ; usually placed in low trees.

Eggs.-Clutch, three or four; ground-colour greenish, covered with a coating of whitish lime; axis 54-58 $\mathrm{mm}$, diameter $33-36$.

Breeding-season.-October to January. (East Australia.) February and March. (North-west Australia.) May and June. (Northern Territory.)

Distribution and forms.--Australia and the islands north. Forms at present accurately indefinable owing to scarcity of material.

\section{Superfamity PELECANOIDEA.}

Only one family of very large birds is included in the superfamily, the distinction, obvious at sight, being the extraordinary development of the bill with the huge gular pouch; the birds have large stout bodies, being heavily built, with strong large feet to support them. The tail is evenly rounded of many stiff feathers. They are distributed through the tropieal and temperate regions of both Worlds.

The osteological features of the skull agree somewhat with the superficial characteristics; thus the palate is desmognathous, in fact, doubly so, for the palatines are anchylosed behind the posterior nares, while the nostrils are holorhinal, and there 
are generally no basipterygoid processes, but rudiments have been recorded; the nasal hinge is mesent but imperfect; the lachrymal is large and fused with frontal. The cervical vertebra are seventeen in number, the dorsal heterocolous; the sternum is similarly shaped, but the furcula is anchy losed to the keel. There is only one carotid artery, the syrinx is tracheo-bronchial and there are no intrinsic muscles, the bronchidesmus complete. The leg muscle formula is $\mathrm{AX}$-, and the biceps slip is absent. The oil gland is tufted with twelve orifices, the aftershaft apparently lacking and the wing aquincubital. The pterylosis is not known to offer any peculiarity, the young hatched naked and soon covered with thick down.

\section{FAMILY PELECANIDAE.}

Not many genera have been separated and practically only one has been commonly recognised, but the Australian species should be generically differentiated, as it alone out of all the species in the world has the lores feathered. Other features of importance are mentioned in the generic definition below.

\section{Genus CATOPTROPELICANUS.}

Catoptropelicanus Reichenbach, Nat. Syst. Vögel, p. vir., 1852 (?1853). Typo (by original designation): $C$. perspicillatus $=P$. conspicillatus Temminck et Laugier.

Large Pelecanine birds, characterised by their feathered lores. All other members of the family have the lores naked.

The family is diagnosed by the huge bill with broad flattened upper mandible and immense gular pouch; the birds are very large, heavily built, with long wings, medium neck, short tail, and short stout legs and feet. The bill is very long, broad and flattened; the culminicorn consists of a flattened portion, continuous with the small sharply-hooked nail; the laterals are cleanly divided by a narrow groove, at the base of the culmen almost concealing the linear nostrils; the laterals broaden and flatten past the middle; the rami of the lower mandible are vertical, thick and strong at the base, where they extend beyond the upper mandible edges, but becoming slender about the middle, where they are overlapped by the upper edges ; the nail is short and hooked; the interramal region develops a huge distensible naked pouch. The culmen is about two-thirds the length of the wing. The lores are feathered, but the eyes are surrounded by a bare patch : a breeding crest is assumed. The wings are long, the third primary longest, the fourth longer than the second, the first about equal to the fifth; the wing-coverts long and lanceolate. The tail is short, wedge shaped, composed of twenty-two feathers, and is less than half the length of the culmen. The legs are short and stout, reticulate throughout, but the scales smaller on the back; the metatarsus is more than half the length of the tail but less than one-third the length of the culmen. The toes are long, scutellate, the hind-toe long, the middle toe longest, all connected by webs.

\section{Catoptropelicanus conspicillatus.-PELICAN.}

Gould, Vol. VII., p. 74 (pt. $\operatorname{xxr}$.), Dec. 1st, 1847. Mathews, Vol. IV., pt. 3, pl. 233, June 23rd, 1915.

Pelecanus conspicillatus Temminck et Laugier, Planch. Color. d'Ois., 47e livr. (Vol. III., pl. 276), (Vol. V., pl. 118), June 26th, 1824: New South Wales.

Pelecanus a ustralis Stephens, in Shaw's Gen. Zool., Vol. XIII., pt. I., p. 113, Feb. 18th, 1826 : New South Wales.

Catoptropelicanus perspicillatus Reichenbach, Nat. Syst. Vögel, p. VI., 1852 (? 1853): Now South Wales.

Pelecanus conspicillatus westralis Mathews, Nov. Zool., Vol, XVIII., p. 244, Jan. 31 st, 1912 : Perth, West Australia.

Distributron.-Australia generally, Not Tasmania. 
Adult male (in brecding-plumage).-Head and neck all round, entire undersurface, middle of back, upper and under wing-coverts white; the small coverts along the inner margin of the wing black, median and greater upper wing-coverts also black with white on the outer webs of the greater series; bastard-wing, primarycoverts and quills black, some of the secondaries white at the base; scapulars black, extreme basal portion white; sides of the rump and some of the upper tailcoverts black; tail-feathers black, white only at the extreme base; nuchal crest more or less greyish-brown; a few of the under wing-coverts black, others partially black and white; ornamental feathers on the fore-neck well developed. Bill, culmen flesh colour, grooves and tip and sides of upper and lower mandible slate-blue, nail of upper mandible greenish-horn colour, pouch pale flesh colour; eyes dark brom, eyelids deep indigo-blue; feet light slate colour. Total length $1,620 \mathrm{~mm}$. ; culmen 464, wing 653, tail 180 , tarsus 126 .

Adult female.-Similar to the adult male.

Immature.--Differs from the adult in having the dark portions of the uppersurface brown instead of black.

Nestling.-Naked, skin fleshy-pink.

Nest.-A slight depression in the ground; placed in colonies.

Eggs.-Clutch, two; white and chalky; surface uneven and glossless; axis 87-94 mm., diameter 56-58.

Breeding-season.-July to November.

Distribution and forms.-Australia generally, but not extra-limital. Two subspecies have been named: $C$. c. conspicillatus Temminck and Laugier, from East Australia and C.c. westralis Mathews, from West Australia, on account of its smaller size throughout, but no long series are available.

\section{SUPERFAMILY SULOIDEA.}

The limits of this superfamily are coequal with those of the family, which consists of large seabirds with powerful conical bills in which in the adult no nasal openings are visible; a small gular pouch is present, the neck short and stout, the tail long and regularly wedge shaped, the legs short but the toes long. They are all stoutly built birds, generally breeding in colonies on isolated rocks and islands throughout the tropies, a few species ranging into the temperate zones, both north and south.

In the skull the palate is desmognathous, the nasals holorhinal and basipterygoid processes absent; the lachrymal differs from those of the preceding, the nasal hinge pronouneed. The cervical vertebre are eighteen in number, the dorsals opisthocolous, hypapophyses present according to one authority, absent according to another. The stemum and furcula are similar to those of the preceding. The carotids are one or two, and the syrinx is different from those of the foregoing; the leg muscle formula is $\mathrm{AX}+$ while the biceps slip is sometimes present and sometimes absent. The oil gland is tufted with two orifices, the aftershaft apparently absent, and the wing aquincubital. The pterylosis las not been critically studied, and the nestling is born naked and later covered with thick down.

\section{FAMILY SULIDAE.}

All the forms of Gannet were referred to one genus until recently, and the exact number of genera recognisable is at present in suspense. The four we here admit are definitely separable and easily defined as will be seen by the descriptions given. Their relationships and suggested phylogeny have been fully discussed by Mathews and are simply indicated below in connection with the genera. 


\section{Genus SULA.}

Sula Brisson, Ornith., Vol. I., p. 60, Vol. VI., p. 491, 1760. Typo (by tautonymy): Sula = Sula leucogaster Linné.

Dys parus Illiger, Prodr. Mamm. et Av., p. 279, (pref. April) 1811. New name for Sula Brisson. Sularius Rafinesque, Analyse de la Nature, p. 72, 1815. New name for "Sula Lac." = Sula Brisson, c\%. Auk, Vol. XXVI., p. 50, Jan. 1909.

Abeltera Heine und Reichenow, Nomencl. Mus. Hein., p. 351. (pref. Sept.) 1890. Newname for "Sula Reichb. 1853" = Sula Brisson.

Hemisula Mathews, Austral Av. Rec., Vol. II., pts. 2 and 3, p. 55, Oct. 23rd, 1913. Type (by original designation): Sula leucogaster rogersi Mathews.

Sinall Suline birds of dark coloration above, with general characterr as in Piscatrix, but with different proportions.

The bill is a little longer, but the tail is much shorter, while the metatarsus and toes are notably long. The bill is typically Suline, more than half the length of the tail, but less than twice the metatarsus. The wing is long, more than twice the length of the tail. The metatarsus is coarsely reticulate with small scales, the scales being smaller on the hinder aspect. The toes have the posterior joints clearly reticulate, the anterior ones covered with scutes more or less broken up. This genus is defined by the coloration of the adult, a character differentiating it at once from the rest of the Suline birds.

The immature plumage of this bird and Piscatrix show great similarity, while the adults show just as great a dissimilarity. The erolution of Piscatrix from it. immature whole brown plumage passes through the stage when the brown is lost on the belly first. The present genus seems to show a peculiar stoppage in this course, this bird showing a brown coloration throughout, save the breast and abdomen, which are pure white. Though practically the same wing length is dereloped, the tail in Piscatrix has grown much lor ger, the metatarsus lengthening in Sula.

\section{Sula leucogaster.-BROWN GANNET (BOOBY).}

[Pelecanus leucogaster Boddaert, Tabl. Planch. Enlum., p. 57, (pref. Dec. 1st) 1783: Cayenne. Extra-limital.]

Gould, Vol. VII., pl. 78 (pt. xxiII.), June 1st, 1846. Mathews, Vol. IV., pt. 3, pl, 228, June $23 \mathrm{rd}, 1915$.

Pelecanus plotus Forster, Deser. Anim., ed. Licht., p. 278, (pref. Jan. 1st) 1844: near Now Caledonia.

Sula leucogaster rogersi Mathews, Austral Av. Rec., Vol. I., p. 189, March 20th, 1913 : Bedout Island, mid-West Australia.

Distribution.-Tropical Northern Australia.

Adult male.-Entire upper-parts, throat, fore-neck, and sides of breast chocolatebrown, somewhat darker and more blackish on the primary-quills; secondaries white at the base of the inner webs; under wing-corerts chocolate-bromn, except the median series which are white; breast, abdomen, sides of body, axillaries, and under tail-coverts pure white. Bill and skin yellow, spot in front of the eye blue; iris silver-grey; feet pale yellow. Total leugth $710 \mathrm{~mm}$; culmen 84 , wing 374 , tail 200 , tarsus 43 .

Adult female.-Similar to the adult male but larger.

Immature and young.-Deseribed by Dr. Macgillisray: The young birds are hatched with eyes elosed, with only an indication of down on head, back, humeral, femoral, and each pectoral region. The eyes open very soon, and the birds become covered with whitish down at an early stage, the beak and legs being of a pale slatygrey, much the same colour as the naked skin; the gape also a pale slate colour. They grow almost to full size before aequiring any feathers, the first to appear being 
the primaries, then the seapulars and feathers of head, and secondaries, with the tail-featbers, this first feathering being a brownish-grey. This colour is general on head, back and wings, with dirty-greyish breast, abdomen, and under-surfaco of wings when they fly. The young birds hatched out often show great disparity in size, one being hatched some days later than the other. This usually results in only one surviving, as, in proportion to the number of nests containing a pair of eggs, very few seem to rear more than a single young one. The naked skin on the face of the adult Brown Gannet shows a good deal of variation in colour, some being of a greenish-yellow, others of quite a blue colour.

Nest.-A small hole scratched in sand, sometimes a few pieces of sponge, etc., strewn round.

Eggs.-Clutch, two; bluish-white, covered with lime; axis 53-63 mm., diameter 36-46.

Breeding-season.- July onwards to October (?).

Distribution and forms.-Throughout the tropies, breeding on isolated islands ; forms insufficiently studied and the only fact certain is that two subspecies can be admitted: S. $l$. leucogaster Boddwert, the Atlantic Ocean form, and S. l. plotus (Forster) from New Caledonia, for Australian birds which are larger than typical birds, and deeper brown coloration above.

\section{Genus PISCATRIX.}

Piscatrix Reichenbach, Nat. Syst, Vögel, p. VI., 1852 (? 1853). Type (by original designation): Piscatrix candida Reieh. = Pelecanus sula Linné.

Large Suline birds, comparatively small for this family, with long straight bilis not hooked but bent at the tip, long thick neck, long wings, short legs and long toes, all the toes, including the hind-toe, being connected with a web.

The bill is longer than the head, rather broad at the base, laterally compressed anteviorly; culmen ridge flattened and separated from laterals by a linear groove extending the whole length of the bill and showing no nostrils. The edges of the mandibles coarsely serrated, the serrations obsolete towards the base, the rami of lower mandible strong and deep enclosing a very narrow unfeathered pouch, the featherless tract extending round the base of the mandibles and round the eyes, the chin being naked. The eulmen is less than half the length of the tail and more than twice the length of the metatarsus. The wing is long, but not twice the length of the tail ; the first primary is longest. The tail is very long and wedge shaped; it is composed of fourteen or sixteen feathers: probably the latter is the full number, the former due to age or moult. It is more than twice the length of the culmen and more than half the length of the wing. The legs are short and stout; the metatarsus is coarsely reticulate throughout, the scales smaller on the back; in length the metatarsus is less than half the culmen. The toes are long, the outer one slightly exceeding the middle one, which has the claw pectinated; the outer toe is about one and a half times the length of the metatarsus; all the toes are fully webbed, tho hind-toe connected to the inner with a web. The toes are reticulate ; this is peculiar, as generally in birds even having different metatarsal covering the toes bear regular scutes, apyarently for ease in bending. This would seem to be the oldest toe-covering, but examination of the downy young of this genus shows the toe-covering to be more or lexs reticulate at that stage, the anterior joints showing irregular scutes broken up, the posterior joints regular reticulation. The downy young also shows no peetination on the middle claw ; in the bill in the same stage a rather distinct hooker tip is seen and the nostrils are distinctly shown as linear slits in a broad groove between the culmen and lateral edge, while serrations are not yet in evidence on the edges of the mandibles. 


\section{Piscatrix sula. -RED-LEGGED GANNET.}

[Pelecanus sula Linné, Syst. Nat., 12th ed., p. 218, (pref. May 2tth) 1760: Ascension Island. Extra-limital.]

Gould, Vol. VII., pl. 79 (pt. XxIV.), Sept. 1st, 1846. Mathews, Vol. IV., pt. 3, pl. 225, June 23rd, 1915.

Sula rubripes Gould, Synops. Birds Austr., pt. IV., App., p. 7, April 1st, 1838: [New South Wales =] Raine Island, North Queensland.

Distrtbution,-Queensland, New South Wales (?).

Adult female.-General colour above and below white tinged with buff; greater upper wing-coverts, bastard-wing, primary-coverts and quills hoary-grey, inner webs of quills paler and becoming white towards the base on the secondaries; under wing-coverts white with the exception of the median and greater series which are for the most part grey. Bill light horn colour shading to pink at base ; naked skin round the eye blue; gular pouch black, bordered with bright pink; line across the fore-head and running along the line of the upper mandible to the gaje pink; eyo grey and white; feet rose colour. Total length $710 \mathrm{~mm}$.; culmen 83, wing 392, tail 230, tarsus 40 .

Adult male.-Similar to the adult female.

Immature and Nestling.- "The young are hatched out blind, with pale leadencoloured skin, and with only an indication of down, distributed in the same way as in the other species, but with a very dark and shorter bill and dark mask, and this, instead of getting lighter as the bird grows older, gets darker, the bill and face of the fully-feathered young being almost black. The down on the nestling is also darker than in the other two kinds, and the fully-feathered young bird is of a dirty grey general colour, especially on the head, back, breast and abdomen, which is white in the adult. The bill and mask in the adult is ereamy-white, with red border abore the eyes and under the chin, and red legs. The legs of the mature young are leaden, with a tinge of pink. We find two adults, sitting on small young, with the bill and mask as in a mature adult, but with the general feathering of immaturity, leading us to believe that these birds do not attain to their mature plumage until two years at least have elapsed, and that they breed during the stage of immaturity." (Macgillivray,)

Nest.-A platform of sticks about 8 to 12 inches across, with the depression in the centre about one inch.

Eggs,-Clutch, one; ground-colour bluish-white, covered with lime, axis 56-58 mm., diameter 38-40.

Breeding-season.-May and July to September.

Distribution and forms.-Tropical oceans breeding on isolated islets. Two subspecies have been suggested: $P$. s. sula Limné, from the Atlantic Ocean, breeding on Ascension Island; and P.s.rubripes (Gould) from the Pacific Ocean, breeding on Raine Island, North-east Australia, larger in every dimension and probably differently coloured soft parts.

\section{Genus PARASULA.}

Parasule Mathews, Austral Av. Rec., Vol. II., pts. 2 and 3, p. 55, Oct. 23rd, 1913. Type (by original dosignation): Sula dactylatra bedouti Mathews.

Large Suline birds with long bill, medium thick neck, long wings, long tail, stout short legs and long toes, totipalmate; the base of the jaws and chin naked, but no naked strip down centre of throat.

In general structural characters this genus agrees with the succecling, differing 
in the naked bases of the jaws and chin, different proportions of wings, tail, culmen, etc., different number of tail-feathers and the metatarsal and toe-covering. The culmen is longer than the head, more than half the length of the wing, but less than twice the length of the metatarsus. The tail is wedge shaped, consisting of sixteen feathers, the central feathers broader, the outside ones not so short as in Sulita, and the length less than half that of the wing. The legs are short and stout and more than half the length of the culmen; the metatarsus coarsely reticulate on the front and sides, smaller scales behind but the scales not so fine as in the preceding genus : the toe-covering consists of reticulations which can be traced in the juveniles as scutes irregularly broken up, but even in the downy young no regular scutes are preserved. The toes are long, the middle claw strongly pectinated.

This genus has a tropícal distribution and would probably clajm nearer relationship to Sulita than either Piscatrix or Sula. This should demand the attention of future investigators.

\section{Parasula dactylatra.-MASKED GANNET.}

[Sula dactylatra Lesson, Traité d'Orn., 8e livr., p. 601, June 11th, 1831 (ex Voy Coqu., Vol. I., p. 494, April 1828) : Ascension Island, Atlantic Ocean. Extra.limital.]

Gould, Vol. VII., pl. 77 (pt. xxin.), June 1st, 1846. Mathews, Vol. IV., pt. 3, pl. 227, June $23 r d, 1915$.

Sula personata Gould, Proc. Zool. Soc. (Lond.), 1846, p. 21, May: Raine Island, North. Queensland.

Sula dactylatra bedouti Mathews, Austral Av. Rec., Vol. I., pt. 8, p. 189, Mnrch 20th, 1913: Bedout Island, mid-West Australia.

Distributron.-Tropical Northern Australia.

Adult male-General colour above and below pure white; bastard-wing, primary-coverts and quills chocolate-brown, somewhat paler on the secondaries; inner webs of primaries hoary or silvery-grey, becoming white on the inner webs of the secondaries towards the base; tail-feathers also chocolate-brown with white shafts. Bill light yellowish-horn; base and skin dull purplish-blue; iris yellow; feet blue. Total length $840 \mathrm{~mm}$.; culmen 99, wing 417, tail 177, tarsus 56 .

Adult female.-Similar to the adult male but larger. Total length $860 \mathrm{~mm}$. ; culmen 105 , wing 429 , tarsus 59.

Immature.-Head, neck and breast white, mottled with brown, and the wings brown.

Downy young.--Pure white in colour.

Nest.-None made.

Eggs.-Almost invariably two in number; bluish-white, covered with lime; axis 64-69 mm., diameter 44-46.

and locality.

Breeding-season.-July onwards to December and later according to season

Distribution and forms.-Atlantic, Indian and Pacific Oceans, throughout the tropics only. Rothschild in 1915 proposed fire subspecies, as follows : $P$. d. dactylatra (Lesson) from Ascension Island and South Atlantic Coasts with bill homy blue-grey, very slender, feet and legs yellow: $P$. d. melanops Hartlaub, from Westem Indian Ocean, with bill greenish-yellow, slender, feet and legs slaty-blue to dull black; $P$. d. personata (Gould) from Westem Pacific, with bill yellow, very stout and large, feet and legs greenish-blue; $P$. $d$. califormica Rothschild, from Coasts of Califomia and Central America, with bill bright yellow, very thick, feet and legs orange; and $P$. $d$. granti Rothschild, with bill red and fect bluish-green, from Galapagos Islands. To which should be added: $P$. $d$. bedouti Mathews from Bedout Island, mid-West Australia, with a much smaller bill than $P$. $d$. personata Gould. 


\section{Genus SULITA.}

Sulita Mathows, Austral Av. Rec., Vol. II., pt. 7, p. 123, Jan. 28th, 1915. Typo (by original designation): Pelecanus bassanus Linné.

Morus Vieillot, Analyse nouv. Ornith., p. 63, April 14th, 1816. Type (by monotypy):

"Fou de Bassan" = P. bassanus Linné.

Not Morum Bolten, Mus. Bolten, p. 53, 1798.

Moris Forster, Synopt. Cat, Brit. Birds, p. 59, Dec. 1817. Type (by monotypy) : P. bassanus

Linné. Mis-spelling only.

Plancus Reichenbach, Nat. Syst. Vögel, p. vI., 1852 (? 1853). Type(by original designation):

Plancus major = Pelecanus bassanus Linné.

Not Curtis, Entom. Mag., Ser. I., Vol. II., p. 188, Jan. 1833.

Largest Suline birds with long Suline bill, medium thick neck, long wings, stout body, long tail, short legs and long toes, totipalmate.

The bill is long, longer than the head, straight not hooked, but slightly bent at the tip which is sharp; bill rather broad at the base, but laterally compressed anteriorly, the culmen ridge flattened and separated from the laterals by a deep linear groove extending the whole length of the bill and showing no nostrils in the adult stage. The edges of the mandibles are finely serrated; the rami of the lower mandible strong and deep, enclosing a very narrow triangular unfeathered tract, which extends lincarly a short way down the throat. In front of the eyes and below, bordering the gape, bare skin is present, but the cheeks and chin, save for the narrow strip above mentioned, are feathered. The neck is of medium length and thick. The wing is long, with pointed feathers scalloped towards their tips, the first primary longest, the remainder rather rapidly shortening. The tail is long, about half the length of the wing and more than twice the length of the culmen; it is composed of twelve feathers, being wedge shaped, the two middle feathers rery pointed. The legs are short, but comparatively long and slender; the metatarsus is more than half the length of the culmen. The metatarsal covering is rery peculiar, as figured. It should be noted that the hind-toe is very short in comparison with the hind-too of Sula and the covering is exactly the opposite. Thus, whereas the three front toes are very regularly covered with scutes, the hind-toe shows a reticulate face. In the genus Sula the three front toes are reticulately covered, whereas the hind-toe shows fairly regular scutes. The nestling with egg-tooth still present on the culmen has the leg-covering as seen in the adult.

\section{Sulita serrator.-GANNET.}

Gould, Vol. VII., pl. 76 (pt. xxIv.), Sept. 1st, 1846. Mathers, Vol. IV., pt. 3, pl. 226, Jun $23 r d, 1915$.

Sula serrator Gray, Dieffenbach's Travels New Zeal., Vol. II., App., p. 20, (middle Jan.) 1843, as synonym of S. australis Gould: Tasmanian Seas.

Sula australis Gould, Proc. Zool. Soc. (Lond.), 1840, p. 177, July 1841 : Tasmanian Seas. Not of Stephens, in Shaw's Gen. Zool., Vol. XIII, pt. I., p. I04, Feb. 18th, 1826.

Sula serrator dyolti Mathews, Austral Av. Rec., Vol. II, pts. 2 and 3, p. 63, Oct. 23rd, 1913: Tasmania.

Distrindtion.-Extra-tropical Australia.

Adult male.-General colour above and below pure white ; crown of head, sides of face, and upper hind-neck golden-buff; bastard-wing, primary-coverts and quills dark greyish-brown, paler and more hoary-grey on the inner webs of the quills : the latter have white shafts towards the base; the four middle tail-feathers greyishbrown with white shafts, remainder of tail white. Bill slate, bare skin on the face slate-blue ; iris silver-grey, feet dull greenish-black with the toes light green. Total length $980 \mathrm{~mm}$. ; culmen 89 , wing 470 , tail 240 , tarsus 60 .

Adult female.-Similar to the adult male.

Immature.-General colour above greyish-brown, all the feathers tipped with 
white, wedge shaped on the back, scapulars, wing-coverts, head, and hind-neck, and edged with whito at the tips of the primary-quills; under-surface for the most part white, with some brown feathers on the throat, fore-neck, and thighs.

Nestling.-Covered with white down.

Nest.-Composed on the ground, shaped like a flat cone from 4 to 6 inches high. Egg cavity from 6 to 8 inches by one to two deep.

Eggs.-Clutch, one; lime covered ; axis 78 to $82 \mathrm{~mm}$., diameter 49-50.

Breeding-season.-October to January.

Distribution and forms.-Extra-tropical Australia and New Zealand. The Australian birds have the colouring of the head and neck of a much lighter shade than the Neozelanic birds and consequently we must admit two subspecies: S. s. serrator Gray, from Tasmanian seas, and S. s. rex subsp. nor. from New Zealand. This alteration is necessary through the fact that Gray quoted S. serrator as a synonym of $S$. australis Gould, and when the latter name proved to be preoceupied the former comes into service in the same connection and with the same type locality.

\section{ORDER LARI.}

This order is a complex of sea and wading birds of different aspects and not easily circumseribed owing to their development in different directions, some having become almost entirely seabirds, others partly seabirds, and others purely land birds.

We subdivide the order into seven suborders, of which three have no representatives in the Australian fauna These are the Alciformes, Colymbiformes and Chionidiformes, the former two being confined to the Arctic and North Temperate zones, the latter including two families-one. the Chionididæ, of sub-antarctic distribution; the other, the Dromadick, of tropical range, and probably with little real affinity. As to the Alciformes and Colymbiformes, both of which are restrieted to the Arctic and North Temperate Regions, we may quote Ridgway, who concluded : "Undoubtedly these are closely related; but the evidence seems to point to a closer relationship of the former to the Gulls than to the latter." We suggest that their development has been from a Larine ancestor on somewhat similar lines, the differences observed being such as would be satisfied by such an hypothesis. Probably the Skuas are almost as far away, but their line of descent has somewhat approximated to that of their Larine relations, with which they are associated. The literature of the anatomy and osteology of the Chionidiformes is rast and the results appear to be that both are somewhat generalised forms agreeing in items with the suggested ancestral Limicoline form. They are as peculiar in anatomical details as they are superficially, and the external items appear just as suggestive as any internal ones.

The whole group shows so much variation in the deeper-seated features that no diagnosis can be drawn up covering the series, every character showing exceptions. Thus the bavic position has been denied the Larine forms, as basipterygoid processes are absent in the adult, though present in the juvenile, while they persist in the adult in the Chararlriine group; such an argument seems futile in view of its variation in this order.

\section{SUBORdER PHAËTHONTIFORMES.}

This suborder consists of seabirls with straight heavy bills, long wings, wedgeshaped tails with two rery elongated and attenuated central feathers and short legs with the four toes webbed, the middle toe longest, and the hind-toe small. The suborder covers the only family of few species, formerly referred to a single genus, but now this is acknowledged as incorrect. These are all tropical in habitat, ranging 
through all the oceans, breeding on few rocky and desolate islands, and never in great numbers though somewhat gregariously.

Three distinct genera can be recognised : typical Phathon with barred plumage in the adult as in the jurenile and the tail with fourteen feathers; Scaophacthon, birds as large with similar jurenile plumage but in the adult a uniform silky-white to pink, with sixteen tail-feathers, the central ones being very elongated and attenuated; and Leptophathon, smaller birds, also barred as immature but uniform white or even orange in the adult with only twelve tail-feathers, the tail proper being longer proportionately than in the former genera, the long elongated central feathers broader.

Osteologically, the palate has commonly been recorded as desmognathous, but as the young shows it to be schizognathous, the desmognathism is spurious ; similarly the nasals are superficially holorhinal, but again it is pseudo-holorhiny, the juvenile showing its development from a schizorhinal form. They have no basipterygoid processes, but there is an imperfect nasal hinge present in the adult, which is absent in the nestling. The lachrymals are free and there are apparently rudiments of an uncinate. The cervical vertebræ are given as twelve or thirteen by some writers, fifteen by others, while the dorsals are heterocalous. The stemum has the carina produced forwards but it terminates at the posterior extremity as is usual in this group, and unlike that of the Steganopods; the posterior border of the sternum is doubly notched and the furculum does not articulate with the acrocoracoid and the clavicles are attached to the keel behind the extremity; the pelvis is also quite unlike that of a Steganopod while the humerus, ulna and manus are quite Limicoline and different from those of the Steganopods; the leg bones are also distinctive when compared with those of the Steganopods and show generalised structure comparable with that of Limicoline forms. The vomer is divided posteriorly, a fact of which the importance is unknown but which should be noted here. There are two carotids present, while the digestive system does not appear to have been specially studied, being orthocelous and pericœlous, cæea being present. The leg muscle formula is AXY - or + , as good observers have had different results, probably working with different species which are here referred to distinct genera; a peculiar item is the lack of the tendinous loop for the biceps to pass through. In the wing there is no expansor secundariorum. The oil gland is present and tufted with six orifices, while the aftershaft is apparently lacking, and the wing aquincubital. The pterylosis is fairly uniform and the nestling is covered with thick down soon after its birth.

As noted previously we would refer Prophälthon shrubsolei Andrems from the London Clay to the Steganopod series and would not consider it a direct ancestral form of the present forms.

\section{FAMTLY PHAËTHONTIDE.}

We have allowed three genera as differentiated above in this family whose limits are equivalent to those of the suborder. The diverse results recorded by anatomists and osteologists are very probably due to the fact that such workers simply use any species as "typical " of the group without investigation as to the accuracy of their actions. Thus Phä̈thon flacirostris has been commonly used and differences have been noted in $P$. rubricauda, and these two we refer to different genera. We have tabulated the general osteology and anatomy of the species and have been compelled to refer them to the basie position in the order Lari, and separate them from the Steganopodous birds, from which they differ in every detail, extemally and intemally, as has been admitted by every anatomist and osteologist who has studied the group. 


\section{Genus LEPTOPHAËTHON.}

Leptophaëthon Mathews, Austral Av. Ree., Vol. II., pts. 2 and 3, p. 56, Oct. 23rd, 1913. Type (by original designation): Phaëthon lepturus dorothece Mathews.

Lepturus Reichenbach, Nat. Syst. Vögel, p. VII., 1852 (? 1853). Type (by original designa. tion): L. edwardsii Reichenbach = Phaëthon lepturus Daudin.

Not Brisson, Ornith., Vol. VI., p. 479, 1760, nor Swainson 1838.

Small Phaëthons with strong bills, long wings, long tail, small legs and feet. In general features the species of this genus agree with Scaophaethon, but they differ appreciably in size. Proportionately the wing and tail are much longer, the tail being differently formed.

In Sccoophaethon the culmen is more than half the length of the tail without the central pair of tail-feathers, which is less than one-third the length of the wing. In Leptophaethon the culmen is less than half the length of the tail as above, which is more than one-third the length of the wing. The central tail-feathers in Leptophaethon are very long with the webs normal and fairly wide, and the pair next to the central pair are long and are twice the length of the oustide pair, the tail being thus strongly wedge shaped. In Sccophäthon the central pair are very long, but the webs are degenerate and are scarcely broader than the shaft, while the tail otherwise is wedge shaped but without much gradation. The metatarsus is less than a quarter of the length of the tail in Leptophaëthon, while in Sccophaëthon it is more than one-third. The middle toe is never pectinate in this family.

\section{Leptophä̈thon lepturus.-WHITE-TAILED TROPIC BIRD.}

[Phaëton lepturus Daudin, in Hist. Nat. Buffon, ed. Didot, Quadr., Vol. XIV., p. $319(1799=$ ] Oct. I802: Ile de France = Mauritius. Extra-limital.]

Mathews, Vol. IV., pt. 3, pl. 232, June 23rd, 1915.

Phaëthon lepturus dorothea Mathews, Austral Av. Rec., Vol. II., pt. 1, p. 7, Aug. 2nd, 1913: Queensland.

Distribution.--Queensland, breeding on Fiji Islands (?)

Adult male.-General colour above and below pearl-white ; a circular black line in front and over the eye which broadens out behind the latter ; the feathers of the hinder crown and nape have dark bases ; median upper wing-coverts black ; primaryquills black on the outer web and, including the shafts, white at the tips, the black decreasing on the inner ones which have only a black shaft; outer secondaries white, inner ones black and white; scapulars white, subterminally black with white edges; rump and upper tail-coverts white with black bases and black shafts; tail-feathers white with black shafts; feathers on the sides of the rump black with white margins. Bill red ; eyes white; feet black; tibia yellowish. Total length $400 \mathrm{~mm}$; culmen 44, wing 281, tail 115, middle feathers 380 , tarsus 24.

Adult female.-Similar to the adult male.

Immature and Nestling.-Not described.

Nest.-A hole or hollow of a rock or tree stump.

Eggs.-Clutch, one ; ground-colour buff ; freekled all over with purplish-brown ; axis $57 \mathrm{~mm}$, diameter 44 .

Distribution and forms.- Throughout the oceans within the tropics, breeding on isolated islets. Three forms were recognised by Mathews in 1913, and no amentment of consequence has since been provided, thus: L. l. lepturus (Daudin) from the Indian Ocean breeding at Mauritius and Rodriguez; $L . l$. dorothece (Mathews) from the East Australian Seas and the Pacific Ocean, in its smaller size throughout; average : culmen 45, wing $25 \mathrm{~s}$, tail $105 \mathrm{~mm}$, ; average of typical birds : culmen 50 , 
wing 275, tail $120 \mathrm{~mm}$, ; and L. l. ascensionis Mathews, from the Atlantic Ocean, breeding at Ascension Island and Fernando Noronha, also smaller than the typical; averago measurements : culmen 5l, wing $260-265$, tail $110 \mathrm{~mm}$.

\section{Genus SCÆOPHAËTHON.}

Scacophä̈thon Mathews, Austral Av. Rec., Vol. I1., pts. 2 and 3, p. 56, Oct. 23rd, 1913. Type (by original designation): Phaëthon rubricauda wesiralis Mathews.

Phonicurus Bonaparte, Comptes Rendus Acad. Sci. Paris, Vol. XLI., p. 1115, (end Dec.) 1855. Type (by monotypy): P. rubricauda Boddaert.

Not Forster, Synopt. Cat. Brit. Birds, p. 16, (Dec.) 1817.

Large Phaëthontid birds, with short deep, laterally compressed, not hooked, bills, long wings, short tails with extraordinary elongated central pair of tail-feathers, short legs and feet, the four toes connected with a web.

The bill is longer than the head, not hooked, but the culmen arched, deep, much laterally compressed, the edges of both mandibles coarsely serrated. The nostrils are open linear slits placed high up near the base of the culmen, the feathering running back from the nostrils to the gape at a very acute angle; the gape is wide; the rami of the lower mandible are thick, placed close together, enclosing a very narrow feathered tract, and fusing at two-thirds the length of the mandible; the culmen chord is twice the length of the metatarsus. The wing is Iong with the first primary longest. The tail is short, slightly wedge shaped, composed of sixteen feathers, the central pair very much elongated, the webs very nuch diminished: this pair are about six times the length of the culmen, while the second pair are less than twice its length. The legs are short and thick, the toes short and rough. The metatarsus is less than half the length of the culmen and is covered with hexagonal roughened scutes, the scutes much smaller at the back. The toes are all connected with webs, but are nothing like the feet of any Steganopod. That is, the middle toe is longest, the outer toe longer than the inner, while the hind-too is very small and placed posteriorly. The scaling of the toes consists of regular scutes.

\section{Scæophaëthon rubricauda.-RED-TAILED TROPIC BIRD.}

[Phä̈ton rubricauda Boddaert, Tabl. Planch. Enlum., p. 57, (pref. Dec. 1st) 1783: Mauritius. Extra-limital.]

Gould, Vol. VII., pl. 73 (pt. xxxv.), Dec. 1st, 1848. Mathews, Vol. IV., pt. 3, pl. 231, June 23rd, 1915.

Phaethon novahollandice Brandt, Mem. l'Acad. Imp. Sci. St. Petersb., Ser. VI., Vol. V., pt. II., p. 272, 1840: Lord Howe Island.

Phaëthon rubricauda erubescens Rothschild, Avifauna Laysan, pt. III., p. 296, Dec. 1900 : Kermadec Islands.

Phaëthon rubricauda westralis Mathews, Austral Av, Rec., Vol. I., pt. 4, p. 88, Sept. 18th, 1912: [Rottnest Island] = Houtman's Abrolhos, West Australia.

Distribution.-Queensland, South and West Australia.

Adult male.-General colour both above and below silky-white with a pinky hue; the feathers on the crown and nape have dark bases; a black patch in front and behind the eye; bastard-wing, primary-coverts, greater corerts and quills white tinged with pink, all the feathers having conspicuously black shafts; some of the innermost secondaries black broadly margined with white; the long flank feathers white, lead-grey on the inner portion of the outer webs, and those on the sides of the rump grey, broadly margined with white; tail-feathers pinky-white with black shafts becoming red on the elongated middle feathers. Bill orange-red, nostrils brown; feet and upper part of legs faint blue, rest black. Total length $520 \mathrm{~mm}$.; culmen 67 , wing 343 , tail 92 , micllle feathers 442 , tarsus 32. 
Adult female.-Similar to the adult male.

Immature.-The feathers of the head black with broad white tips, giving a scalloped appearance; the fore-head white, a square black spot in front and round the eye; the feathers of the back of the head, neck, sides of neck, mantle, rump and upper tail-coverts barred brownish-black and white, a white tip and three bars, shorter feathers with two bars only; axillaries similarly barred; and lesser wingcoverts with bars as also seapulars; primaries white with black shaft and black line alongside, developing into an elongate spot on second and third primaries and decreasing on fourth and fifth so that spot alone is seen; the primary-coverts are similarly marked; secondaries and secondary coverts pure pinkish-white as are the major coverts; the tertials almost all black with a white border, the outermost two showing semi-barring indicating method of evolution of white feathers; all the inside of the wing pure pinkish-white as all the under-surface ncluding the under-tail corerts, but a few flank feathers are obsoletely barred; the tail is wedge shaped with a slight attenuation of the ceutral feathers which show black tips; the other tailfeathers have three spots on outer webs, remmants of bars, otherwise all white with black shafts. Bill black; eyes brown; feet yellowish-white and black.

A bird a little older has the tail white and the axillaries white and the markings less pronounced, the bill showing pale brownish.

Nestling.-Covered with whitish or greyish down.

Nest.-A depression in the sand, placed under a shelving rock.

Eggs.-Cluteh, one; reddish-white covered more at the top end with purplishblack streaks and brownish-red spots and blotches; or covered similarly all over; axis 68-70 mm, diameter 48-49.

Breeding-season.-July. (Raine Island.) November, December and January. (Kermadec, Lord Howe and Norfolk Islands.)

Distribution and forms.-Confined to the Indian and Pacific Oceans, breeding on isolated islets. Six subspecies were recognised by Mathews in 1915, as follows: S. r. rubricauda (Boddaert) from Mauritius; S. r. westralis Mathews, from West Australia and Christmas Island, Indian Ocean, with a rosier coloration, smaller bill and longer wing, bill 65 against $76-80 \mathrm{~mm}$. and wing 347 versus $320-336 \mathrm{~mm}$.; S. $r$. novcehollandice Brandt from the Kermadees, Lord Howe and Norfolk Islands, and Raine Island with a deep rose coloration with a heavier bill and longer wing than typical form; S. r. melanorhynchus (Gmelin) from Turtle, Palmerston and Society Islands, differing in lacking the rose colouring ; S. r. rothschildi Mathews from Laysan and Niihau with a shorter, weaker bill, shorter wing and pure white coloration ; and S. $r$. brevirostris Mathews from the Bonin Islands, with a very short bill $56-59 \mathrm{~mm}$. only, and whiter coloration.

\section{SUBORDER LARIFORMES.}

Four families of web-footed seabirds constitute this suborder, of which the most peculiar, the Rynchopidæ, does not occur in Australia, being represented in Tropical America, Africa and India by distinct but very closely related species. The other three have somewhat peculiar distribution each in a different manner; thus, the Sternidis include two groups which will probably later claim family rank, viz., the Terns and the Noddies. Extemally they differ, but from the recorded anatomical items they show even more marked internal differences but as yet little research has been done in this direction. Together they have somewhat delicate pointed bills, delicate bodies, very long wings, generally very long forked tails and small legs and webbed feet, the webbing varying in degree. The Noddies are separable by their heavier bills, stouter build, shorter wings, though still long, broader double-forked tails and stouter legs with fully webbed toes. The Laridæ are distinguished by their differently formed heavier, somewhat hooked, bills, much hearier build, shorter wings, shorter square (a couple of species have semi-forked) 
tails and stouter legs and always fully webbed feet. They vary in size, from species as small as a Tern to rery large birds, the majority being larger than the majority of Terns and Noddies. The Stercorariidre is a family consisting of few species of different facies but absolutely close relationship. The bill is somewhat (full-like but easily distinguished by having a cere-like covering over the nontrils; the largest species are heavily built, but strong flyers, and have long wings and long square tail and jowerful legs and fully webbed toes, while the least species is delicately built with long wings and long tail with very elongated central feathers and comparatively delicate legs and feet similar in formation to the others, as is also the bill but more gracefully formed.

Osteologically, in the skull the palate is shizognathous and the nasals schizorhinal, but in the stcreortiede there is a distinct tendeney towards pseudo holorhiny, while there are no hawipterygoid proce ses or cecipital fortanelles (which are, howeter, present in juveniles) and well-marked supraorbital grooves. The lachrymals are firmly united with prefrontals while the furcula s how a hypocleidium. The cervical vertebre number fifteen, the dor-als opisthocalous, and the stermum is strorgly lieeled, the posterior border generally doubly notched. Both earotid arteries are present and the syrinx is typically tracheo-bronchial with one pair of intrinsic muscler, while the digentive system is pericolous and orthocolous, cacea present and rariable in size. The leg muscle formula is also variable, the biceps slip present but the expranis secundariorum present or absent. The oil gland is always present and tufted, an aftershaft present and the wing aquincubital. The pterylosis of a few species has been studied. The young are hatched covered with down, and we suggert there is more of value in the study of the downy nestlings than has been alloweci, and that they provicle good elues to the phylogeny of the groups. The Tems have downy young showing colour patterns of more than one distinct style, and this indicates the heterogeneous nature of the commonly admitted groupings. Thus the nestlings of some of the Terns recall those of the Gulls very clearly and we find that these species show internal items of resemblance.

Fossils hare been described as referable to the present suborder, but little of real value has yet been discorered, the characters used for identification beirg variable ones.

\section{FAMILY STERNIDE.}

We have included here, the Terns and Noddies, but are doubtful as to the association of these two groups. We have noted above the superficial distinctions and may here add a few of the internal characters. The leg mu:cle formula of the Tems is always ABXY + (an instance of the loss of the accessory femoro-caudal has been recorded in conmection with a temlet), while in the Noddies some specie: agree, while Leucanous has lost the aceessory femoro-caudal. The cryansor secundariorum is absent in the Tems, but it is present in some of the Notidies. The caca are ructimentary but in Leucanous the crea are long. The digestive system is pericalous in the Tens but not definitely stated in detail for the Noddies.

\section{Genus CHLIDONIAS.}

Chlidonias Rafinesque, Kentucky Gazette, Vol. 36 (new ser., Vol. 1.), No. 8, Feb. 21 st, 1822 [3]. Type (by monotypy): Stcrna melanops Rfsque. = Sterna surinamensis Gmelin (cf. Rhoads, Auk, Vol. XXIX., p. 197, April 1912).

Hydrochelidon Boie, Isis, heft 5, col. 563, May 1822. Type (by subsequent designation, Gray, p. 100, 1841): Sterna nigra Linné.

Viralva Stephens, in Shaw's Gen. Zool., Vol. XIII., pt. I., p. 166, Feb. 18th, 1826 (ex Leach IS.). Type (by subsequent designation, Coues, Proc. Acad. Nat. Sci. Philad., p. 554, 1862): Sierna nigra Linné.

Pclodes Kaup, Skizz. Entwick.-Gesch, Nat. Syst., p. 107, (pref. April) 1829. Typo (by monotypy): Sterna leucopareia Temminck. 
Small Terns with slender, short bills, long wings, small legs and feet, and short tails. The diagnostic features of this genus are the short tail and deeply-incised webs of the feet. The metataris is a little less than the middle toe alone, and $i$ : cmly about two-thirds the Jength of the culmen. The tail is less than half the length of the wing, and is slightly forlied, the lateral feathers not developed into streamer. but still the longest. The legs and feet are small, the tarsus shorter than the middle toe; the tarial covering eonsists of horizontal seutes in front, rest of leg reticulately scutellated; the webs deeply incised, the outer less than the inner; the inner toe shorter than outer, which is less than the middle one; hind-toe fairly long. The -pecies $C$. leucoparcin has a more powerful bill and the wels of the feet more deeply incised, and for it the genus Pelodes was provided.

Coloration black above and below.

\section{Chlidonias leucopareia.-WHISKERED TERN.}

[Sterna leucopareia Temminck, Manuel d'Orn., 2nd ed., Vol, II., p. 746, before Oct. 21st, 1820 : Hungary, Europe. Extra-limital.]

Gould, Vol. VII., pl. 31 (pt. xxxmr.), Dec. 1st, 1848. Mathews, Vol. II., pt. 3, „pl. 103, Sept. 20 th, 1912.

Hydrochelidon fluviatitis Gould, Proc. Zool. Soc. (Lond.), 1842, p. 140, Feb. 1843: Interior of New South Wales.

Hydrochelidon lencopareia rogersi Mathews, Nov. Zool., Vol. XVIII., p. 207, Jan. 31st, 1912 : Parry's Creek, North-west Australia.

Distribution.-Australia.

Adult male.-General colour pale grey including the back, wings and tail; outer web of first primary dark brown, and showing scarcely any grey, the remainder silvery-grey on the outer webs, darker at the tips, and on the immer webs near the shafts as also the inner margins; basal portion of inner webs white, which extends in a narrow line towards the tips of the feathers; inner primaries and secondaries pale grey with white on the inner webs; tail pale grey, the outer feathers margined and tipped with white; head and hind-neck black; sides of face, throat, under tail-coverts white, like the axillaries and under wing-coverts; fore-neck pale grey ; breast and abdomen dark slate colour, more intense on the latter ; bill clusky-red, base of upper mandible black, tinged with red; iris blackish-brown ; feet and legs red. Total length $274 \mathrm{~mm}$.; culmen 31, wing 231, tail 90, tarsus 23.

Adult female.-Similar to the adult male, but paler on the upper-parts and the dark slate-grey of the under part: restricted to the abdomen, the breast being similar to the fore-neck. Total length, " in the flesh, $250 \mathrm{~mm}$." ; culmen 28 , wing 213 , tail 70 , tarsus 22 .

Adult male in winter.-Differs from the adult male in breeding-plumage, in having the crown of the head white with minute pear-shaped black spots, which increase in size on the nape; the ear-coverts duslsy-black, and the entire undersurface pure white. A male example, which we do not consider to be quite adult, appears to be just assuming the breeding-plumage, and has the head black with the remains of white feathers intermixed, and the dark lead-grey of the breast approaching.

Young.-Differs from the adult in having the feathers of the back white, tipped with dark brown and edged with ochreous-buff ; scapulars and innermost secondaries slark brown edged and barred with ochreous-buff like the inner greater wing-coverts ; tips of tail-feathers brown, edged with white; head dark brown with ochreous-buff tipss to the feathers; fore-head white, tinged with buff; lores white, tipped with dark brown; an indicated band of buff on the middle of the abdomen, which appears to be the remains of a younger plumage.

Immature.-Almost pure white below with only a tinge of grey on the abdomen ; 
more or less strealied with dusky on the lesser wing-coverts; head black with a mixture of white on the fore-head; feathers of the nape black, with a brownish tinge.

Immature.-With remnants of down on head, back, throat, flanks, etc. All under-surface pure white, rusty down on throat and blackish down on sides of neck, and rusty down on flanks. Fore-head black down, top of head rufous-brown down with black blotches; upper back black with minute rufous tips, scapulars blackishbrown with broad rufous edges, back feathers coming grey with rufous dom still adhering; wing-coverts grey with seant rufous tips; primaries dark grey with faint brownish tipping; tail-feathers grey with buffish tips. Bill brownish-dusky, fleshy at base of lower mandible; iris brown; legs dusky-red.

Testling in down.-Rufous-buff above with black blotches on back of neek and on back, smaller black spots on top of head; blotehes appear to be ranged in series of three; one of which at hase of winglet tip is rufous; fore-head deeper rufous with black spot at base of bill, chin white, throat and sides of neck black, breast white, rest of under parts tawny, centre of abdomen paler.

Nest.--Built of aquatic regetation of large size and well shaped, floating in swamps.

Eggs.-Clutch, three; ground-colour greyish-olive to brownish-olive, sometimes dark stone, blotched and spotted with dark brown, often masing at the larger end, with underlying spots of grey ; axis $35-39$, diameter $26-28 \mathrm{~mm}$.

Breeding-season.-October to December.

Distribution and forms.-Throughout the Old World. Mathews has separated right subspecies, as follows: Chlidonias leucopareia lencopareia (Temmincls) from South and Central Europe and North Africa (this may be further sublivided when $\therefore$ fair amount of material is studied); C. $l$. indica (Stephens) from India, differing in the obviously darker under coloration, especially of the upper-breast, in breedingplumage and smaller size (here also there may be more than one subspecies later admitted); C. l. leggei (Mathews) from Ceylon, small as the preceding but notably. paler underneath ; C. l. delalandii (Mathews) ex Bonaparte MS., from South Africa, easily separable from the typical form in their darker coloration above, ill-refined black cap, dark throat, pronounced white "moustache" and dark grey axillaries, they are larger than the darkest Indian birds; accorling to the Rules as now rendered the name delalandii may be convidered invalid, so we propose for this race C. l. sclateri nom. nov.; C.l. suinhoëi (Mathews) from Foochow district, China, agreeing with $C . l$. indica in under coloration but with a lighter, almost white, throat and smaller in size; C. l. jazanica (Horsfield) from Java, for Siamese and Pegu birds, paler than Indian ones, but features not well differentiated yet; $C$. $l$. fluviatilis (Gould) from East Australia, in its very light upper coloration and notably paler under $\rightarrow$ urface with ill-defined moustache; and C. l. rogersi (Mathews) from Northwest and North Australia in its paler coloration, above and below, weaker bill and white axillaries. Nothing has since been written about this species.

\section{6o. Chlidonias leucoptera.-WHITE-WINGED MARSH-TERN.}

[Stcrna leucoptera Temminck, Manuel d'Orn., p. 483, 1815 (pref. 1814) : Moditerranean Sea. Extra-limital.]

Mathews, Vol. II., pt. 3, pl, 102, Sept. 20th, 1912.

Sterna grisea Horsfield, Trans. Linn. Soc. (Lond.), Vol. XIII., pt. I., p. 199, 1821 : Java. Hydrochelidon leucoptera belli Mathews, Austral. Av. Rec., Vol. III., pt. 3, p. 55, April 7th, 1916: Lord Howe Island.

Distribution,--Winter visitor to Australia. Extra-limital.

Adult male in breding-plumaje.-Head and neck all round glosis-black like the breast, abdomen, sides of body, axillaries, and under wing-eoverts ; spot below the eye white; back and scapulars dull slaty-black; lesser wing-coverts white; 
Plate :.

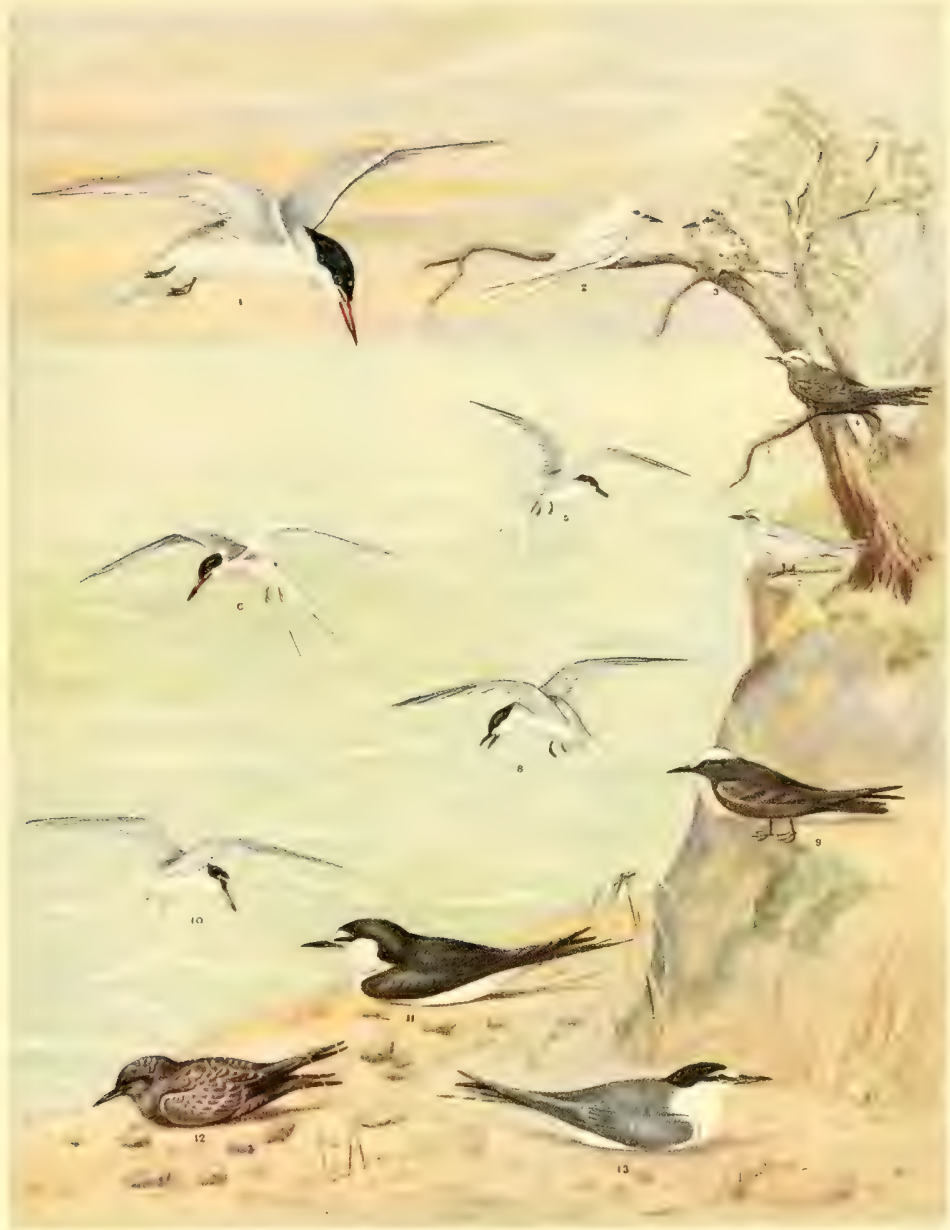

1. Caspian Tern, 2, 3, White Tern. 4, White-capped Noddy. 5, Lesser Crested Tern. 6. Roseate Tern. 7, Grey Noddy. 8, Gull-billed Tern. 9, Noddy. 10, White-faced Ternlet. 11, 12, Sooty Tern. 13, Bridled Tern. 

bastart-wing and primary-coverts pale silvery-grey, becoming clarker grey on the median and greater coverts, the innermost greater series dark slate-grey ; primaryquills silvery-grey along the outer webs, inner webs dark brown near the shafts with the remainder white; inner primaries almost entirely silvery-grey; secondaries slate-grey, becoming much darker on the innermont feathers; upper and under tail-coverts, as also the tail, white; bill red; iris brown; feet red. Total length $221 \mathrm{~mm}$.; culmen 24, wing 217 , tail 73 , tarsus 21.

Adult female in breeding-plumage. - Similar to the adult male, but duller black on the back, breast, abodmen, sides of body, and under wing-coverts, the latter inclining to white on the greater series; the tail show's a distinct grey wash, while the measurements are distinctly smaller.

Adult in winter plumage.-The fore-head, back of the neck, all the under-surface and under wing-eoverts white; back of the head and nape dark brown with whitish tips ; the feathers of the upper back are dark brownish-grey ; the tips lighter, and their bases white; the back lighter; the rump and upper tail-coverts light grey ; the tail-feathers are grey, the outer whitish on the immer webs ; there is a distinctly defined black spot in front of the eye, and the ear-coverts form a dark brown patch ; the primaries are all worn dull brown, while the scapulars and median wing-coverts retain their grey colour.

This description is drawn up from one of Gould's Cape York specimens, and agrees very closely with the type of Sterna grisea Horsfield from Jara. Another bird collected on the voyage of the Rattlesnake, "Female, Cape York, Nov. 9th, 1849 ," agrees, but it is not so worn ; there are fewer white tips to the back of the head feathers, and the two outer tail-feathers are pure white, the rest whitish on the inner web.

Another bird collected by Elsey, "Victoria River, March '56, Male," is in the same plumage, and has the additional information on the label, "Iris blue-black."

Adult in change.-The feathers on the lower back are coming blackish; the rump, upper tail-coverts, and the tail are all white, save the fifth pair from the outside which are still grey; the second outside pair and the centre pair are only half grown; about half the scapulars and secondaries are new black-grey feathers; all the primaries are new grey feathers while the outside half of the inner wingcoverts are new black feathers; the inside half and the whole of the under-surface are still pure white, while the head and necl coloration is still as in the winterplumage. This description is drawn up from another of Gould's Cape York specimens.

Another bird collected by Elsey, "Victoria River, March 1856, Female," is in much the same plumage, but the tail contains fewer white feathers; the head is missing, and on the label is noted, "Stomach contained grasshoppers."

The preceling descriptions taken from specimens procured in Australia may be supplemented by accounts of further plumage changes as these may occur.

A bird from the Andamans, April 16th, 1879, shows a further change than the preceding; the whole of the tail is white; the whole of the inner wing-coverts are black; the primaries, upper wing-covert, and secondaries are all completely new ones; the black feathers are beginning to come on the back and under-surface, commencing on the belly and lower-breast.

Immature.- "Pegu ㅇ 13/10/78, very young and small, E. W. Oates," is much like that which we have decribed as the winter-plumage, but the head feathers are deep brown, while the feathers of the upper back as well as the scapulars have clark brown tips; the upper tail-coverts are white; the tail-feathers browni-grey, the outer ones lighter.

Nestling.-Like that of preceding species, but generally duller brownish-red; the black markings on the head bolder and larger, the lores white which extends round the eye ; there is no black on the fore-head; throat dusky-bromn, white chin spot much smaller, no white breast patch, all under-surface dusky pale buff. 
Nest.-Made of reeds and rushes, floating on marshes.

Eggs.-Cluteh, three, rarely four; rarying from pale stone to buff-brown in ground-eolour, boldly blotched with dark brown, with paler brown spots and grey underlying markings; axis $32-34 \mathrm{~mm}$., diameter $24-25 \mathrm{~mm}$.

Breeding-season.-May and June in northern hemisphere.

Distribution and forms.- Southern Palxarctic Region, wandering in winter to Africa, India, Java, Celebes and Australia. Nathews in 1912 recorded that the birds which bred in China had more powerful bills and longer wings, and therefore admitted two subspecies: Chlidonias leucoptera leucopterc (Temminck) from Europe; and $($. . . grisea (Horsfield) for the Chinese race. Only three occurrences from North Australia were then on record, but in 1917 thousands appearer in Western Australia : as recorded by Alexander (Emu, Vol. XVII., p. 95, Oct. 1917), who has given further details of the plumages, stating that the females had white tails and a fully coloured bird had a black bill.

\section{Genus STERNA.}

Sterna Linnó, Syst. Nat., 10th ed., p. 137, Jan. 1st, 1758. Typo (by tautonymy): Sterna hirundo Linné.

Chelido Billberg, Synops, Faunx Scand., Vol. I., pt. Ir., p. 193, 1828. New name for Sterna Lin. (cf. Austral Av. Rec., Vol. II., pts. 2, 3, p. 42, Oct. 23rd, 1913).

Thalassœe Kaup, Skizz. Entwick.-Gesch. Nat. Syst., p. 97, (pref. April) 1829. Typo (by monotypy): Sterna dougallii Montagu.

Hydrocecropis Boie, Isis, 1844, heft 3, col. 178, March. New name for Sterna Auct.

Medium-sized Terns with slender bills, short legs, long wings and very long tails. The bill is longer than the head and twice the length of the tarsus, which is shorter than the middle toe and claw. The tail is long and forked, the length of the streamers more than half the length of the wing. Toes completely webbed, the tarsus very short and regularly scutellate in front, reticulate behind, the hincttoe small.

Coloration: black cap, grey back and wings, and whitish below.

\section{Sterna striata.-WHITE-FRONTED TERN.}

[Sterna 8triata Gmelin, Syst. Nat., Vol. I., pt. II, p. 609, April 20th, 1789: New Zealand, based on Ellis's drawing No. 57. Extra-limital.]

Gould, Vol. VII, pl, 26 (pt. xxxvi.), Dec. 1st, 184S. Mathews, Vol. II., pt. 4, pl. 109, Nov. 1st, 1912.

Sterna velox Gould, Proc. Zool. Soc. (Lond.), 1842, p. 139, Feb. 1813 : Bass Straits.

Not Rüppell, Atlas Reise nord. Africa, p. 21, pl. 13, Cretzschmar [1826=]1827.

Sterna melanorhyncha Gould, Birds Austr., pt. Xxxvi. (Vol. VII., pl. 26), Doc. 1st, 1818 : Tasmania.

Not Sternula melanorhyncha Lesson, Descr. Mamm, et Ois, rec. decouv., p. 256, 1847.

Sterna striata incerta Mathews, Nov. Zool., Vol, XVIII., p. 208, Jan. 31st, 1912 : Tasmania. Sterna striata yorki Mathews, Austral Av. Rec., Vol. II., pt. 5, p. 86, Sept. 24th, 1914 : Cape York, North Queensland.

Distribution.-Queensland south to Tasmania.

Adult male in breeding-plumage.-Head and nape deep black, wings, scapulars, back and tail rery pale grey; the outer web of the first primary blackish, praler torards the tip, inner webs chiefly white, with a shade of grey near the shafts: secondaries for the most part white, with grey on the outer webs: tail-featherwhite on the inner webs towards the base; fore-head, lores, sides of the face, sides of the neck, and the entire under-surface silky-white, including the under tail-coverts. axillaries, and under wing-covert. Bill black; iris brown ; fect and legs bromnishred. Total length $451 \mathrm{~mm}$; culmen 40 , wing 272 , tail 185, tarsus 21 .

Adult female.-Similar to the adult male. 
Adult in winter-plumage.-Differs from the adult in breeding-plumage, in having the fore-part, and entire crown of the head white, the feathers being slightly tipped with black.

Immature.-Head, lores, under eyes and nape, speckled through feathers having white bases, black bar and pale brownish-white tips, the latter shorter on the nape; on the back of the neck the tips almost disappear and the black bar decreases ; the back has similar feathering, but bolder, showing a somewhat scalloped appearance; the rump and upper tail-coverts pure grey with blackish tips, often absent ; bend of wing pure white, lesser and median coverts dark grey with obsolete tipping, greater coverts paler with more pronounced black and brownish-white tipping; scapulars and tertials boldly barred and broadly tipped with buffish ; secondaries and primarycoverts grey with white edges; primaries grey with white tips and inner wels, outer ones much darker grey, outermost black on outer web; tail-feathers pale grey, tips scalloped with black and buffish, less pronounced on outer ones; all undersurface including wing lining, pure white.

Nestling in down.-Mottled with grey to almost brown spots on a buffy-white ground-colour above, tinged with fulvous on the head, and pure white below.

Nest.-A depression in the sand or gravel.

Eggs.-Clutch, two; ground-colour stono, blotched with dark brown and light grey; axis 47-48 mm., diameter 33-34. (Tasmania.)

Breeding-season.-November and December.

Distribution and forms. - Throughout New Zealand and its sub-antarctic islands and East Australia. Four subspecies may be admitted at present: S. s. striata (Gmelin) from New Zealand; $S$. s, bethunei Buller, from the Auckland Islands and probably the Chatham. Islands, a larger form with longer bill and larger feet; S. s. melanorhyncha Gould, from Tasmania, a smaller and darker race; and $S . S$. yorki Mathews from North Queensland, still smaller and paler.

\section{Sterna dougallii.-ROSEATE TERN.}

[Sterna dougallii Montagu, Omith. Dict. Suppl., 1813, pref. June, no pag. : Scotland. Extra. limital.]

Gould, Vol. VII., pl. 27 (pt. xxxI.), June 1st, 1848. Mathews, Vol. II., pt. 4, pl. 108, Nov. 1st, 1912.

Sterna gracilis Gould, Proc. Zool. Soc. (Lond.), 1845, p. 76, Oct.: Houtman's Abrolhos, West Australia; and again in 1847, p. 222, March 29th, 1848. Same locality.

Sterna nigrifrons Masters, Proc. Linn. Soc. N.S.WV., Vol, I., p. 62, Feb. 1876 : Warrior Reef, North Queensland.

Sterna striata christopheri Mathows, Nov, Zool,, Vol. XVIII,, p. 209, Jan. 31 st, 1912 : Point Cloates, mid-West Australia.

Distribution.-Australia generally.

Adult male in breeding-plumage.-General colour of the upper-parts pale grey, including the back, wings, and tail ; outer primary black on the greater part of the outer web, the remainders silvery-grey with white on the inner webs and grey adjoining the shafts; inner primaries and secondaries pale grey with white on the inner webs; crown of head, nape and hind-neck black; checks, throat, and undersurface of body white, as also the axillaries and under wing-coverts; bill black. base red; iris grey; feet red, claws black. Total length $400 \mathrm{~mm}$.; culmen 40 , wing 212 , tail 152 , tarsus 21 .

Adult female.-Similar to the adult male.

Adult male in vinter-plumage.-Differs from the adult in breeding-plumage by its white fore-head and black and white head and nape; iris sometimes black; bill black with yellow base.

Immature.-Similar to the adult in winter-plumage, but having the primaries 
greyish-brown, the bill black, iris brown, feet dark reddish-black. The nape and head blackish-brown, and a grey band along the upper wing-coverts.

Nestling.-" Channel Rock, Torres Straits, June 1881: Iris black, bill black, Iegs and feet grey." The bill is black; the whole of the top of head, taking in the eyes, nape and back of neck black with white tips, the black in front of the eye and the ear-corerts more distinetly marked. Back of the neek pure whito; upper back black or dark bromn and white spottings, lower back, rump, and upper tail-coverts pale grey with indistinct white tipss ; tail-feathers grey, with bromn triangular spots near the apex, which is white-tipped; greater wing-corerts dark grey, median and lesser pale grey with lighter tips, primary-quills dark ashy"grey, the outer ones almost black, inner half of inner webs pure white, inner secondaries and long scapulars brownish spotted with white, and with grey base and white tips; all the under-surface pure white.

Young in down.--Brown and buffish-whito mixed above and throat; breast and belly whitish; feet and bill pink; eyes dark.

Nest.-A slight depression (about 5 inches across by 1 inch deep) in the sand or ridge of dead coral, sometimes partially lined with fine pieces of coral shells, ete. Nests in colonies.

Eggs.-Clutch, two ; ground-colour buff or stone, boldly marked with reddishbrown, to very light grey, blotches; axis 40-41 mm., diameter 29.

Breeding season.-April, June, November, December.

Distribution and forms.-Described from Great Britain, breeds in Eastern North America, through Europe, North Africa, Asia, Australia, New Caledonia, ete., etc. The Palæarctic and Nearctic forms are classed together as S. d. dougallii Montagu, but probably there is a confusion of distinct subspecies in this case; all the Eastern birds used to be also classed as one subspecies, but Mathews has separated four which are easily recognisable, thus: $S$. $d$. bangsi Mathews from Foochow, China, and the Liu Kiu Islands with a short stout bill, culmen $36-37 \mathrm{~mm}$.; S. d. korustes (Hume) from the Andamans, with a small weak bill, culmen not exceeding $36 \mathrm{~mm}$.; $S$. $d$. arideensis Mathews, from the Seychelles Group with short slender bills, shorter wings and darker upper coloration than preceding; and S. d. gracilis Gould from Australia and New Caledonia with longer slender bills reaching $42.5 \mathrm{~mm}$. and paler coloration.

\section{Genus GYGISTERNA.}

Gygisterna Mathews, Birds Austr., Vol. II., pt. 4, p. 365, Nov. 1st, 1912. Type (by original designation): Sterna sumatrana kempi Mathews.

Medium Terns with long bills, long wings, rery long tails and small legs and feet. The bill is long and slender, twice the length of the tarsus. There is no crest, but a black nape band which may be erectile. The wings are long and the tail has very lengthened streamers. The legs are stronger, the tarsus scutellate in front, and reticulate behind, the toes long, the webs strongly incised. Hind-toe short.

Coloration pale grey above with a black line through the eje and round the head; below white.

\section{Gygisterna sumatrana.-BLACK-NAPED TERN.}

[Sterna sumatrana Raffles, Trans. Linn. Soc. (Lond.), Vol, XIII., pt. II., p. 329, 1822: Sumatra. Extra-limital.]

Gould, Yol. VII., pl, 28 (pt. xxIrr.), June Ist, 1846. Mathews, Vol. II, pt. 4, pl, 110, Nov. 1st, 1912.

Sterna sumatrana kempi Mathews, Nov. Zool., Vol. XVIII., p. 210, Jan. 31st, 1912: Torres Straits, Queensland.

Distribution.-Northern Australia. 
Adult male in breeding-plumage.-Back, wings, and tail silvery-grey ; crown of head, hind-neck, and the entire under-surface of body silky-white, including the axillaries and under wing-coverts; a line from behind the eye which widens out on the nape and forms a broad black collar; an elongated black spot in front of the eye; outer web of first primary black. Total length $300 \mathrm{~mm}$.; culmen 38 , wing 197, tail 120, tarsus 19 .

Adult female.-Similar to the adult male. Iris dark brown; feet dark brown ; bill black; extreme tip white.

Adult in winter-plumage.--Differs from the adult in breeding-plumage, in having less extensive black on the nape and in front of the eye.

Immature.-The fully-fledged young of the year differs from the adult in having the black on the head dark brown mottled with white, and the whole of the uppersurface and wings variegated with dark brownish-grey.

Nestling.-Pale grey spotted all over above with black fairly thickly; uniform greyish-white below.

Nest.-A depression in the sand.

Eggs.-Cluteh, two; ground-colour buff, marked all over with irregular shaped markings of chestnut, light grey and lavender; axis 39-4l mm., diameter 29.

Breeding-season.-November.

Distribution and forms. - From the Andamans through the Moluccas as far north as Foochow, China, and east to Fiji, and south to Northern Australia. Only two subspecies at present recognised: G. s. sumatrana (Raffles) from Andamans to Celebes; and $G$. s. kempi (Mathews) from Northern Australia with a longer bill and shorter wing; Foochow birds may be separable and the Fiji birds may later bear the name G. s. decorata (Hartlaub) but series are not yet available.

\section{Genus STERNULA.}

Sternula Boie, Isis, 1822, heft 5, col. 563, May. Type (by monotypy): Sterna minuta Linné = S. albifrons Vroeg.

Least Terns, with comparatively long stout bills, short legs, long wings and tails. The bill is longer than the head, but less than twice the length of the tarsus, which is about equal to the middle toe and claw. The tail is long and forked, but the streamers are generally much less than half the length of the wing. The diagnostic features are the small size, stout bill proportionally, and the webbing of the feet. The toes are long, with the intervening webs notably incised in front, recalling the incision of the Marsh-Terns, and differing appreciably from the Common Tern.

Coloration grey above with black cap, white below.

\section{Sternula albifrons.-WHITE-SHAFTED TERNLET.}

[Sterna albifrons Vroeg, (ex Pallas MS.) Cat. Rais. d'Ois. Adumb., p. 6, ante Sept. 22nd, 1764 : Europe. Extra-limital.]

Gould, Birds New Guinea, Vol. V., pl. 72 (pt. III.), May 1st, 1876. Mathews, Vol. II., pt. 4, pl. 111, Nov. 1st, 1912.

Sternula placens Gould, Ann. Mag. Nat. Hist., Ser. IV., Vol. VIII., p. 192, Sept. 1st, 1871 : Torres Strait, Queensland.

Sternula inconspicua Masters, Proc. Linn. Soc. N.S.W., Vol. I., p. 63, Feb. 1876 : Cape York, Queensland.

Sterna sinensis tormenti Mathews, Nov. Zool., Vol. XVIII., p. 210, Jan. 31st, 1912: Point Torment, North-west Australia.

Distribution.-Victoria, New South Wales, Queensland, Northern Territory, North.west Australia.

Adult male in breeding-plumage-General colour of the upper-surface grey, including the mantle, back, scapulars, and wings; the four outer primary-quills 
have a dark brown patturn on the outer web and adjoining the shaft on the inner one, the inner portion of which is white; the innermost primaries and secondaries grey, the latter white on the inner webs and fringed with white at the tips; upper tail-coverts and tail ivory-white; a line of feathers from the base of the bill to the eye black, like the hinder part of the crown and nape; fore-part of head and entire under-surface of body silky-white, including the under wing-coverts and under tailcoverts; bill bellow, black at tip ; iris brown; feet orange-yellow. Total length $240 \mathrm{~mm}$. ; culmen 30 , wing 176 , tail 70 , tarsus 18 .

Adult female.-Similar to the adult male.

Adult in winter-plumagc.-Distinguished from the summer-or breeding-plumage by the eneroachment of the white of the fore-part of the head on to the hinder crown, leaving only the nape and sides of the crown black, and a shade of black in front of the eye.

Immature.-A gool series from Point Torment, North-west Australia, and Melville Island are worthy of detailed description, as they seem to indicate that these Ternlets take on the adult state as soon as they have obtained their full first-season's plumage. Thus, a bird killed on February 28th has the head mostly white, as are also the lores, while the tail is grey and short; the primaries are apparently fullgrown and perfect, but they are short. Close examination reveals the fact that though they are unworn, new primaries are commeneing from the inside to replace them. The bill is given as "black, the basal half of lower mandible olive-brown." Another has more black feathers coming on the head, but still, though the new adult primaries are more advanced, the perfect immature primaries are scarcely worn. The bill is changing colour, "basal half olive-brown, tip black." The next stage has the lores black and white, mostly black, the top of the head shows the new black feathers to be in the majority; the tail-feathers are new and white, the streamers half grown; the primaries are mostly adult, only the two outside immature ones left but they are very little worn; the bill is now "yellow and black," as in full breeding-plumage.

Nestling.- - Upper coloration sandy-grey obscurely spotted with grey-brown rather thickly, the spots darker on the head, and simulating a linear arrangement; there appears to be an obsolete loral line and also an indistinct frontal clarker line; the winglet is spotted at the base but unspotted for the major portion; the undersurface pure white; the bill is short and yellow, the tip darker.

Nest.-A depression in the sand.

Eggs.-Clutch, two; ground-colour stone, spotted all over, but more on the larger end, with purplish-red and sparingly with lavender-coloured spots; axis $33 \mathrm{~mm}$., diameter 26.

Breeding-season.-December. (Byron Bay.) October. (Tweed River.) November. (Victor Island.)

Distribution and forms.-Throughout southern Palrearctic Regions on coast linen but exact range and forms undetermined. Hartert has giren the range as: "Breeds in Europe from the shores of southern Sweden to the IIediterranean, along the coasts of Northern Africa, in the Canaries and on Madeira, and in north-west Asia as far as Turkestan. It winters in Africa and in Asia as far north (sic) as India, Burmah, Malacea and Java. Replaced by allied forms in Syria, Egypt, the Nalay Archipelago, the China Seas and Japan, Australia, America, and perhaps parts of Africa." Americans distinguish their Ternlets specifieally, and we camnot deal with the western forms here; the Indian $S . \alpha$, saundersi Hume may even comprise more than one distinct subspecies. The Australian race was called sinensis, which, of course, was given to the Chinese bird, so that in Australia there are two races, S. a. placens Gould, from East Australia, and S. a. tormenti Mathews from North-west Australia, the latter larger and with a heavier and longer bill than the former, and also paler upper coloration. 


\section{Sternula nereis. -WHITE-FACED TERNLET.}

Gould, Vol. VII., pl. 29 (pt. XIV*), March 1st, 1844. Mathews, Vol. II., pt. 4, pl. 112, Nov. Ist, 1912.

Sternula nereis Gould, Proc. Zool. Soc. (Lond.), 1842, p. 140, Feb. 1843 : Bass Straits.

Sterna nereis horni Mathews, Nov. Zool., Vol. XVIII, p. 209, Jan. 31st, 1912 ; Kalgan River, South-west Australia.

Distribution.-Victoria, Tasmania, South Australia, South-and mid-West Australia.

Adult male in breeding-plumage.-Wings, scapulars, mantle, and middle of back silvery-grey, becoming white on the upper tail-coverts and tail ; outermost primaryquills slightly edged with darker on the outer web, and a shade of the same colour on the inner web adjoining the shaft; a spot in front of the eye, hinder part of the crown, and nape black; fore-head to the middle of the crown, lores, and entire under-surface silvery-white including the axillaries, under wing-coverts, and under tail-coverts; bill and feet orange-yellow, claws brown; eyes black. Total length $262 \mathrm{~mm}$.; culmen 34, wing 185, tail 96, tarsus 18 .

Adult female.-Similar to the adult male.

Adult in vinter-plumage.-Similar to the adult in breeding-plumage, but the black in front above the eye less pronounced.

Immature.-Top of head white, nape dull black, tail greyish, otherwice as in adult; iris black, legs brown tinged with yellow, bill olive-brown tinged with yellow at gape.

Nestling (flying).-Fore-head and fore-part of head white, back of head and neck blackish-brown and white tipped with buff; primaries and primary-coverts deep grey, mont of the inner webs white ; greater series of wing-covert d dark grey, median and lesser lighter grcy, some of the median with brown spots ; feathers of back and scapulars with brown spot; and tipped with buff; tail white, faint brown tips to centre feathers.

Nestling.-Covered with white, black and buff down on the upper-surface, with irregular, zigzag short lines and spots, especially on the head and sides of the face, the dark pattern less defined on the body where the down is longer ; under-surface pure white.

Nest.-A depression in the sand.

Eggs.-Clutch, two; ground-colour pale stone, spotted with dark brown, chestnut, and lavender; axis 34-37 mm., diameter 25-26.

Breeding-season.-November. (Waller Island, Bass Straits.) December, February. (Mud Island.)

Distribution and forms.--Southem extra-tropical Australia, New Caledonia and New Zealand. Four forms have been scparated: S. $n$. nereis Gould, from Eastem Australia, Victoria, Tasmania, and South Australia; S. n. horni Hathews, from South-west Australia, by its paler upper coloration; S. n. exsul Mathews, from New Caledonia, by its smaller size, average male wing $171 \mathrm{~mm}$; ; and $S$. $n$, davisce Iathews and Iredale, from New Zealand, by its darker coloration and larger size; average male wing $200 \mathrm{~mm}$.

\section{Genus PELECANOPUS.}

Pelecanopus Wagler, Isis, 1832, heft 3, col. 277, March. Typo (by monotypy): Sterna pelecanoides King.

Large Terns with long stout bills, long tails, long wings and short legs, and decided occipital crest in their breeding-plumage. The diagnostic features of this genus are the long stout bills, long tails, and small feet. The metatarsus is about half the length of the eulmen, which is longer than the head, while the tail is just about half the length of the wing. The tarsus is seutellate in front, and reticulate 
behind, and althongh short, is longer than the middle toe; the webs between the anterior toes noticeably incised and the hind-toc short.

Coloration grey above with black top of head, full crest, and white below.

\section{Pelecanopus bergii.-CRESTED TERN.}

[Sterna bergii Lichtenstein, Verzeichn. doubl. Zool. Mus. Berlin, p. 80, (pref. Sept.) 1823: Cape of Good Hope. Extra-limital.]

Gould, Vol. VII., pls. 23, 24 (pt. XXXIV.), Dec. 1st, 1848. Mathers, Vol. II., pt. 3, pl. 106, Sept. 20th, 1912.

Sterna pelecanoides King, Survey Intertrop. Coasts Austr., Vol. II., p. 422, "1827" = April 26th, 1826 : Torres Strait.

Sterna poliocerca Gould, Synops. Birds Austr., pt. II., pl. (37), April 1st, 1837 : Tasmania.

Sterna novchollandice Pucheran, Revue Zool., Oct. 1850, p. 545, Nov. ex Cuvier MS.:

Nouvelle Hollande, coll. by Peron and Lesueur = Tasmania.

Not of Stephens, in Shaw's Gen. Zool., Vol. XIII., pt. I., p. 161, 1826.

Pelecanopus nigripennis Bonaparte, Comptes Rendus Acad. Sci. Paris, Vol. XLII., p. 772, May 1856: Now name for "S. novchollandia Cuv."

Thalasseus bergii gwendolence Mathews, Nov. Zool., Vol. XVIII., p. 208, Jan. 31st, 1912: Perth, South-west Australia.

Distribution.-Australia generally and Tasmania.

Adult male.-Back, scapulars, wings, and tail ash-grey; primary-quills silvery. grey on the outer webs, somewhat dark on the outer web near the base, inner webs grey next the shaft, inner portion white; inner primaries silvery-grey with white on the immer webs ; secondaries white with grey on the outer webs, the grey increasing in extent on the innermost feathers; middle tail-feathers like the back, the outer ones grey with white inner webs, the outermost pair almost entirely white; crown of head and long nape feathers black; fore-head, lores, neck all round, and undersurface of body white, like the axillaries and under wing-coverts; a small patch of grey feathers on the sides of the breast; bill yellow, base green; iris brown, feet black. Total length $480 \mathrm{~mm}$; ; culmen 55, wing 345, tail 176, tarsus 27.

Adult female.-Similar to the adult male; culmen 52, wing 326 , tail 164 .

Adult in vinter-plumage.-Differs from the adult bird in breeding-plumage by the absence of the black on the crown of the head; the feathers on the fore-part of the head, face, and sides of nape with white margins, becoming black on the occiput.

Immalure female.-Differs from the adult female in having some of the feathers of the upper back with dark shaft-streaks, the lesser wing-coverts rusty-brown, bastard-wing and primary-coverts brown; primary-quills bromn, inner webs white; secondaries white with brown on the outer webs, middle tail-feathers white tipped with grey, outer feathers bromn with white on the inner webs, the outermost pair white tipped with brown; the feathers on the fore-part of the head black margined with white, while those on the nape are brown.

Immature (before moulting into full breding-plumage).-Head more or less dark brown, feathers with white bases and whitish tips; fore-head and lores whitish with a few brown speckles; a spot just in front of the eye dark; a few brown tips to the feathers on the sides of the neck; feathers of the bend of the wing whitish, greater wing-covert: dark brownish-grey ; median wing-coverts ashy-grey; lesser wingcoverts darker ashy-grey.

Immalure (in change from juxcnile plumagc). - A few bromn-tipped feather: remain on the upper baek; the majority of the feathers slaty; the seapulars and median coverts, however, show the juvenile plumage to still predominate.

Jucrnile (young bird just renty to fly).-The feathers of the head have white bases and tips, the midclle being clark brown, the head having thus an even mottled apjearance ; the sides and hack of the neck are white, some of the feathers haring 
brown spots on the tips, giring a speckled appearance. These brown tips become larger and more frequent on the feathers of the upper back, with fewer but more strongly marked on the lower back, rump, and upper tail-coverts; the tail-feathers have white bases and white tips, the anterior portion brown in varying proportions; the middle feathers are mostly grey, with a brownish marking towards their apices, but all the tips white; the next pair have more brown, less grey, and less white tipping, and so on outwards ; the scapulars are marked like the midille tail-feathers; the bend of the wing is white; the greater wing-coverts are deep brown with white tips; the median white with brownish tips, the extreme tips, however, white again ; the lesser wing-coverts ashy-brown tipped with white; the secondaries ashy-grey with white tips; the primaries deep brown on the outer and half of the inner web; the inner half white, distinctly marlied off ; the remainder of the under-surface white.

Nestling in down.-Dirty white above and below, the upper-surface with a few black speckles, but pattem not diseemible. Iris pale brown; legs and feet bromishwhite; bill white.

Nest.-A depression in the sand.

Eggs.-Clutch, one, sometimes two; ground-colour dark to light stone, marked with blotehes and wary lines of very dark purple, other markings of lavender which appear as if beneath the shell; axis 56, diameter 39.

Breeding-season.-October to January.

Distribution and forms.- Round the coast of South and East Africa, through the Indian and Pacific Oceans, as far northwarl as the Japanese seas and eastward to the Low Archipelago. Oberholser has recently reviewed the species, almitting eleven subspecies, as follows: $P$. $b$. bergii (Lichtenstein) from South Africa; $P . b$. thalassinus (Stresemann) from the Seychelles Islands, as decicietly smaller and somewhat lighter in colour; $P$. b. velox (Cretzschmar) as decicledly darker than the typical from the Red Sea ; P. b. bakeri (Mathews), as clarker still and larger than preceding, from the Persian Gulf and south-western Baluchistan; $P$. $b$. eduardsi (Mathews) from Ceylon and southern India, much smaller and even a little darker; P. b. cristutus (Stephens) from southern China, the Liu Kiu Islands, the Philippine Archipelago (northern islands), etc., smaller than $P . b$. cduardsi, but about same coloration ; P. b.halodramus (Oberholser) from the southern islands of the Philippine Group, much paler above than last named; $P . b$. pelecanoides (King) decidedly larger than the preceling, from North Auntralia, the East Indies, and Melanesia, darker and smaller than the typical race; $P$. b. rectirostris (Peale) from Polynesia, paler than the former, both as to adult and young; P.b. poliocercus (Gould) is darker and smaller, from New South Wales, Victoria, Tasmania and South Australia; and $P . b$. gwendolence (Iathews) the South-western Australian race, larger and paler.

\section{Pelecanopus bengalensis.-LESSER CRESTED TERN.}

[Sterna bengalensis Lesson, Traité d'Orn., 8* livr., p. 621, Juno 11th, 1831 : India. Extra. limital.]

Gould, Vol. VII., pl. 25 (pt. xxxvI.), Dec. 1st, 1818. Mathews, Vol. II., pt. 3, pl. 107, Sept. 20 th, 1912 .

Sterna media Horsfield, Trans. Linn. Soc. (Lond.), Vol. XIII., pt. I., p. 199, 1821 : Java. Not Vieillot, Tabl. Ency. Méth. Ornith., Vol. I., p. 347, 1820.

Thalasseus torresii Gould, Proc. Zool. Soc. (Lond.), 1812, p. 140, Feb. 1813 : Port Essington, Northern Territory.

Thalasseus bengalensis robini Mathews, Austral Av. Rec., Vol. III., pt. 3, p. 55, April 7th, 1916: Cape York, Queensland.

Distribution.-North Queensland, Northern Territory, North-west Australia.

Adult male in breeding-plumage-Head and nape deep black; upper wingcoverts, seapular, back, and middle tail-feathers dove-grey ; beni of wing white; primary-quills silvery-grey, inner webs white at base, dark brum near the shaft:, 
this colour increasing in extent and becoming pale towards the tips; the inner primaries and secondaries grey on the outer webs, fringed and tipped with white on the inner ones, the white increasing in extent on the secondaries; tail for the most part grey like the back with a certain amount of white on the immer webs of the feathers; lores, hind-neck and upper mantle, throat and entire under-surface silky-white, including the axillaries, under wing-coverts, and under tail-coverts; bill reddish-orange ; iris dark brown; feet black. Total length $420 \mathrm{~mm}$. ; culmen 50 , wing 308 , tail 152, tarsus 26.

Adult female.-Similar to the adult male.

Adult in winter.--Differs from the breeding-plumage in having nearly the who!e of the head white, with the exception of a black spot in front of rach eye, a fow on the crown, and the naje feathers, which are black, more or less fringed with white; bill pale in colour.

Immature-Fore-head white, on top of head nape black former with white edges as in winter, but darker; wing-coverts grey with brown elges; seconklarie; brownish-grey and imner secondaries brown, but with long white edging; primarycoverts brown-grey; primaries brown with scant greyish bloom ; tail-feathers with long brown edges and tips, bases grey; legs brown mottled with yellow.

Nestling.-Does not appear to have been described.

Nest.-A slight depression in the sand or coral.

Eggs.-Clutch, one; ground-colour light stone, blotched or spotted with very dark purple, with lavender ones appearing as if beneath the surface ; axis $54.5 \mathrm{~mm}$., diameter $35-36$.

Breeding-season.-November. (South Barnard Island.)

Distribution and forms.-From the Red Sea, on the Indian coasts, through Malaysia to Northem Australia. Three subspecies may be recognised : P. b. bengalensis (Lesson) from India (exact range undetermined); $P$. b. arabicus (Mathews), from the Red Sea, is a paler and smaller race; and $P$. b. torresii Gould is also paler and smaller (with which P. b. robini (Mathews) is included). A fourth is indieated by. Sterna zimmcrmanni Reichenow (Orn. Monatsb., Vol. XI., p. 82, 1913), from Kiaoutschon, but diagnosis indeterminate and no specimens available. Under the late-t ruling of the Nomenclatural Laws, the subspecific arabicus Mathews is inadmissible, being a synonym of the typical race, so we rename the Red Sea race Pelecanopus bengalensis par nom. nov.

\section{Genus GELOCHELIDON.}

Gelochelidon Brehm, Vögel Deutschl,, p. 771, (pref. July) 1831. Typo (by monotypy): G. meridionalis Brehm = Sterna nilotica Gmelin.

Laropis Wagler, Isis, 1832, heft 11, col. 1225, Nov. Type (by monotypy): S. anglica Montagu $=$ S. nilotica Gmelin.

Larger Terns, with short stout bill, long wings, short tail, and long legs. The diagnostic features of this genus are the short stout bill and short tail with feet with webs incised. The metatarsus is longer than the middle toe and claw, but shorter than the culmen, which is also shorter than the head. The tail is deeply forked, but still less than half the length of the wing.

Coloration as in Sterna, etc.

\section{Gelochelidon nilotica.-GULL-BILLED TERN.}

[Sterna nilotica Gmelin, Syst. Nat., Vol. I., pt. Ir., p. 606, April 20th, 1789 : Egypt, North Africa. Extra-limital.]

Gould, Suppl., pl. 81 (pt. III.), Sept. 1st, 1859. Mathews, Vol. II., pt. 3, pl. 104, Sept. 20th. 1912. 
Sterna macrolarsa Gould, Synops. Birds Austr., pt. II., pl. (37), April 1st, 1837 : Tasmania. Gelochelidon nilotica normani Mathews, Austral Av. Rec., Vol. II., pt. 7, p. 125, Jan. 28th, 1915: Normanton, Queensland.

Distributron.-Australia generally and Tasmania.

Adult male in brealing-plumage.-General colour above rery pale grey on the back, wings, and scapulars; primary-quills silvery-grey, white on the inner webs, the outer quills edged with clark brown on the outer webs; upper tail-coverts and tail pure white; crown of head black; feathers of the naje white with black tips; chin, throat, and entire under-surface white, like the axillaries and under wingcoverts; bill black, mouth orange, iris dark hazel; feet and legs black, soles with an orange tinge. Total length $432 \mathrm{~mm}$.; culmen 45 , wing 342 , tail 141, tarsus 36 .

Adult female.-Similar to adult male but smaller in all measurements.

Adult male in winter.-Differs from the male in breeding-jlumage in the absence of the black on the head and nape, which is represented by white feathers more or less streaked with black; ear-coverts and feathers surrounding the eye black.

The female in winter has the same plumage as the male in the same season.

Immature.-Pale grey, the feathers edged with pinkish-buff above; the head and nape with short black shaft-lines, a small black spot in front of eyes ; ear-corert: ashy-black; feathers of upper back with darker centres and broad pinkish-buff edges; rump with pale tips; tail-feathers with darker tips edged with white; rcapulars and inner secondaries grey, bases with clark triangular patches and broarl pinkish-buff edges; coverts with pale tipping; under-surface pure white.

Immature with down adhering.- Similar to preceding but paler; head fainter, streaks less pronounced and pinkish-buff obscure; scapulars and upper backpinkish-buff with dark shaft-lines to latter feathers only; seant buff tiplping to coverts; down on rump and tail-feathers which are pale grey with obsolete tipping : under-surface pure white with dom still present; ear-coverts scarcely noticeably darker, but dark crescent in front of eye ; bill brownish, tip of lower mandible bromin, base paler; feet brown.

Nestling in down.-Above pale brownish-grey with a few scattered brownish blotches; a few small spots on back of head, forming two irregular stripes on sides of neck, and a merlium stripe down middle of back, and two spots om sides of rump; winglet with a dark spot at base; under-surface pure white; bill bromn ; legs and feet orange-brown.

Nest.-Placed close to one another, and composed of a few bits of dry grass or stems of cane grass, on a small piece of ground surrounded by water.

Eggs.-Clutch, two to four; buffy-white or whity-brown, sparingly marked with light umber, the remainder of the surface being boldly splashed and spotterl with purplish-red and purplish-grey, some with obsolete patches of a lighter tint appearing as if beneath the surface of the shell; axis $51-55 \mathrm{~mm}$, diameter $37-38$.

Breeding-season.-April, May, November.

Distribution and forms.-From Europe through Asia to Australia, wintering in Africa. Also breeding in North and South America. Six subspecies have been separated: G. n. nilotica (Gmelin) from Europe and North Africa (winter); av. measurements: culmen 39-41, wing 310-320 mm.; G. n. aranea (Wilson) from North America, with shorter bills and wings; av. culmen 34-37, wing below 305 $\mathrm{mm}$. ; G. n. affinis (Horsfield) from Java (winter) and India; with paler coloration above ; shorter bills and same wing length at typical form ; $G$, n. macrotarsa (Gould) from Australia in its more powerful and longer bill, longer legs, long wing and paler coloration $(G, n$. normani Mathers has been named on account of its smaller bill); $G$. $n$. addenda Mathews, from China, in its short and stout bill with paler coloration approaching preceling; ar. culmen $36-37 \mathrm{~mm}$.; wing $310 \mathrm{~mm}$.; and G. n. gronvoldi Mathews, from South America with long bills and long wings, nearly as big as $G . n$. macrotarsa, av. culmen 42-45 $\mathrm{mm}$., wing 325 . 


\section{Genus HYDROPROGNE.}

Hydroprogne Kaup. Skizz. Entwick.-Gesch, Nat. Syst., p. 91 (pref. April) 1829. Type (by subsequent designation, Gray, Gen. Birds, Vol. III., p. 658, Nov. 1846): Sterna cas pia Pallas. Sylochelidon Brehm, Vögel Deutschl., p. 767, (pref. July) 1831. Typo (by monotypy): S. balthica Brehm $=S$, caspia Pallas.

Helopus Wagler, Isis, 1832, heft 11, col. 1224, Nov. Type (by monotypy): S. caspia Pallas. Pontochelidon Hogg, Edinb. Now Philos. Journ., Vol. XLI., p. 69, 1846. Type (by subsequent designation, Mathews, Austral Av. Rec., Vol. II., p. 133, 1915): S. caspia Pallas.

Heroprogne Buller, Suppl. Birds New Zeal., Vol. I., p. 157, 1905. Error only.

Largest Tems, with long stout bills, long wings, short legs, and short tails. The diagnostic features of this genus are the large size and the long stout bills and short tail. The metatarsus is much shorter than the culmen, which is longer than the head. The tail is forked and only about a third of the wing.

Coloration as in Sterna.

\section{Hydroprogne caspia.-CASPIAN TERN.}

[Sterna caspia Pallas, Nov. Comm. Acad. Sci. Petrop., Vol. XIV., pt. I., p. 582, 1770 : Caspian Sea. Extra-limital.]

Gould, Vol. VII., pI. 22 (pt. xxIr.), March 1st, 1846. Mathews, Vol, II., pt. 3, pl. 105, Sept. 20 th, 1912.

Sylochelidon strenuus Gould, Birds Austr., pt. XxIr., Vol. VII., pl. 22, March 1st, 1846 : Port Stephens, Now South Wales, error $=$ Tasmania.

Hydroprogne tschegrava yorki Mathews, Austral Av. Rec., Vol. II., pt. 7, p. 125, Jan. 28th, 1915 : Cape York, Queensland.

Distribution.-Australia generally and Tasmania.

Adult male in breeding-season.-General colour above pale grey, including the back, scapulars, wings, and tail; primary-quills silvery-grey on the outer webs, dark brown on the inner edge of the inner webs; head and nape black, with a short white line immediately below the eye; cheeks, chin, throat and neck all round as well as the under-surface of body white, like the axillaries and under wing-coverts; bill red ; feet black. Total length $555 \mathrm{~mm}$.; culmen 77 , wing 422 , tail 164 , tarsus 47 . Adult female.-Similar to the adult male.

Adult in winter.-Distinguished from the adult in breeding-plumage by the absence of the entire black head, which is represented on the fore-head by black feathers with white margins, the black increasing in extent on the nape, ear-coverts. and feathers in front of the eye.

Immature.-Pure white below, except for a few minute grey spots on the foreneck; the feathers of the back with substantial dark brown spots and fringed with sandy-buff; lesser wing-corerts blackish, fringed with white like the bastard-wing and primary-coverts; merlian and greater coverts ash-grey fringed with white; primary-quills hoary"-grey fringed with white on the inner webs, the inner primaries tipped and margined with white on both webs; secondaries white with dark slate colour on the outer webs; scapulars white at base becoming sandy-buff towards the tips, with two longitudinal brom streaks on each side of the shaft which conrerge at the tip. These brown marks do not always follow the same course: sometime.: they form twin spots, whereas in others they are irregular bars; rump and upper tail-coverts fairtly marked with grey, but some of the feathers have darker pearshaped spots; middle tail-feathers are white, with dark grey running longitudinally towards the tips and margined with white, the outer feathers dark brown, tipled with white and fringed with tho same colour near the base; feathers of the hindneck white, with an apieal spot of black and fringed with sandy-buff; feathers of the head white at the base, centred with black and fringed with buff, the black being more pronounced on the nape and sides of crown; a black spot in front of each eye. 
PInte 1

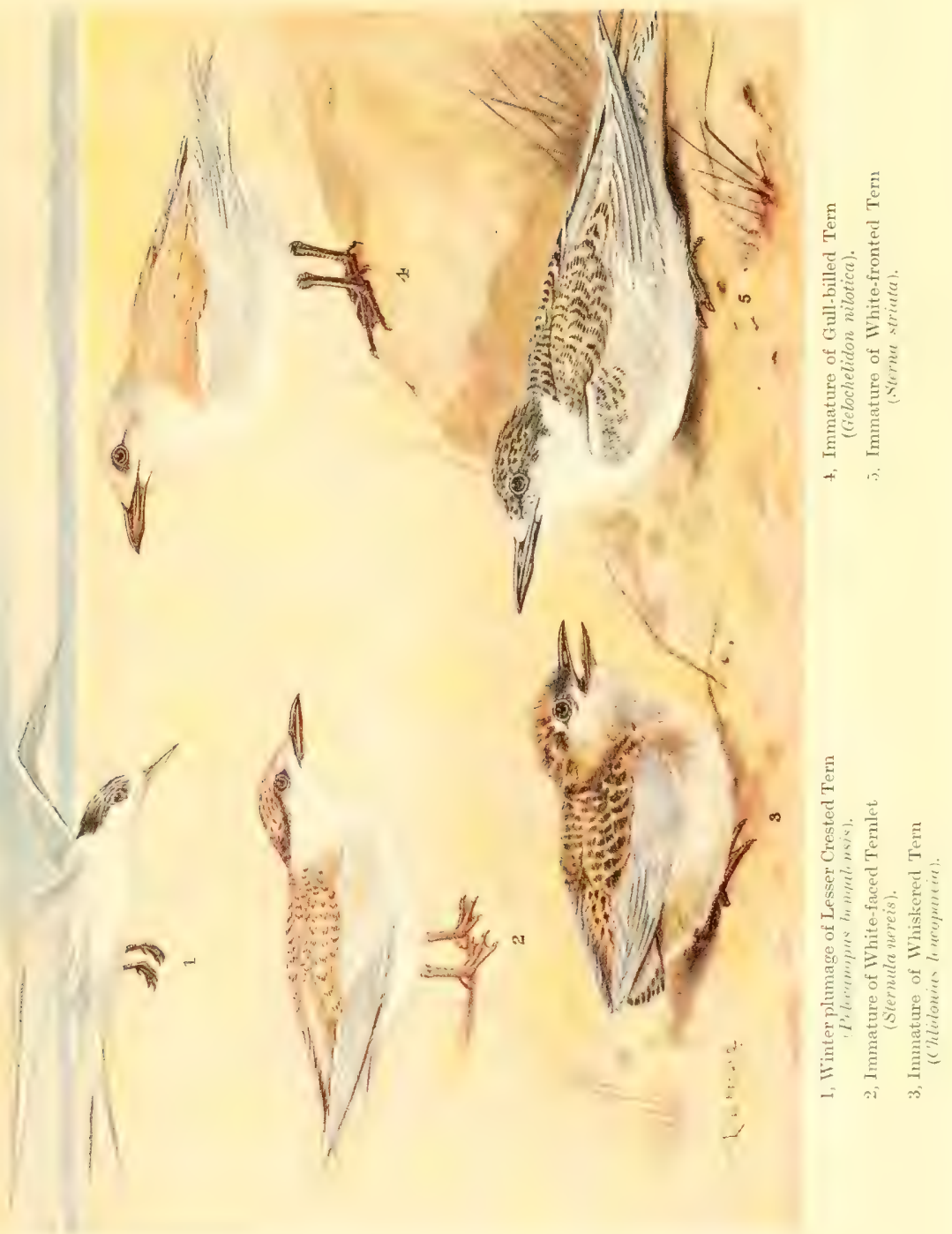



Nestling in down.-Buffy-white, darker on the throat and paler on the abdomen, with an admixture of black on all the upper-parts, except the head.

Nest.-A depression in the sand.

Eggs.-Clutch, two; ground-colour stone, marked all over, but more at the larger end, with dark purple and brown spots; axis $63 \mathrm{~mm}$., diameter 45 .

Nesting-season.-March, April, May, August, September, and November. (IVest Australia.) October and November. (Island in Franklin Sound.)

Distribution and forms.- World-wide distribution, but forms not yet accurately determinel, thus: H.c.caspia (Pallas) from the Caspian Sea is in use for all Palmaretic birds, while the North American H. c. imperator Coues, from North America, though obviously a larger form, is not yet acknowledged by American authorities; there may be other recognisable forms, but the Australian $H$. c. strenua (Gould) from Tasmania, is notably larger in all its measurements, the bill noticeably so, while H. c. yorki Mathew's from North Queensland is smaller throughout, but still large, and $H$. c. oliveri Mathews and Iredale from New Zealand is another smaller race, though still larger than the typical form; thus, culmen $71, H$. c. strenua $75, H . c$. caspia $66 \mathrm{~mm}$.; wing 400 against $420 \mathrm{~mm}$, for the Australian form.

\section{Genus MELANOSTERNA.}

Melanosterna Blyth, Journ. As. Soc. Bengal, Vol. XV., p. 373, $1846[=1847$ ?]. Type (by monotypy): Sterna ancethetus Scopoli.

Medium-sized Terns with long bills, long wings, very long tails and short legs and feet. The dark coloration, very long tails and incised webbing of the feet distinguish this genus. The bill is not twice as long as the tarsus, though long, while the tail is more than three-fourths the length of the wing, the outer feathers extremely attenuated. The tarsus shows a reticulate surface in front, whereas all the other genera of Sternidce retain the scutes unbroken. The inner toe is extremely short, while the toes are very much incised between the middle and inner toe and only moderately so between the outer and middle, which are nearly equal. The claw of the middle toe is extremely long.

Coloration dark above, white below.

\section{Melanosterna anæthetus.-BRIDLED TERN.}

[Sterna ancethetus Scopoli, Del. Flor. Faunæ Insub., pt. II., p. 92, 1786 : Philippine Islands. Extra-limital.]

Gould, Vol. VII., pl. 33 (pt. $\Sigma s x v$. ), Dec. Ist, 1848. Mathews, Vol. II., pt. 4, pl. 114, Nov. Ist, 1912.

Sterna novchollandice Stephens, in Shaw's Gen. Zool., Vol, XIII., pt. I., p. 161, Fob. 18th, 1826: New South Wales, based on Watling drawing No. 274.

Melanosterna ancethetus rogersi Mathews, Austral Av. Ree, Vol. II., pt. 7, p. 126, Jan. 28th, 1915 : Admiralty Gulf, North-west Australia.

Distribution.-Tropical Australian Seas.

Adult male in breeding-plumage.-Crown of head, nape, and lores black ; wings, scapulars, back and middle tail-feathers dark brown; small coverts round the bend of the wing white; inside webs of primary-quills paler and becoming white towards the base; this is more especially shown on the secondaries; outer tail-feathers for the most part white, the terminal portion blackish on the inner wels; fore-head and a narrow line over to behind the edge white like the throat, breast, and under wingcoverts; abdomen and under tail-coverts grey; bill and feet black; iris lead colour. Total length $430 \mathrm{~mm}$.; culmen 40, wing 260, tail 218, tarsus 23.

Adult female.-Similar to the adult male ; bill and feet black; iris dark brown. 
Adult in winter-plumage.- Similar to the adult in breeding-plumage, but lores and the crown of the head mottled with white.

Immature mule.-Wings dark brown; entire back ash-brown, the feathers edged with white; upper tail-coverts paler with no white edges; middle tail-feathers similar, slightly fringed with white on the inner welss, outermost pair of feathers white at the base and fringed with white at the tip on the outer webs; fore-head and lores white, the latter with a few dark dots which indicate the black of the adult; head black with white margins to the feathers, which imparts a streaked appearance; hind-neck very pale grey ; entire under-surface pure white.

Immature (first plumage).-- Uniform brown above, the scapulars, secondaries and upper wing-coverts buff tipped; sometimes the whole of the feathers of the upper back havo bright buff tips ; sometimes the tips are almost absent; the feathers of the top of the head have white tips, the eye-stripe being indicated by a lighter streak, the loral patch being darker; the back of the neck darker than the head or back, and the under-surface white with a dirty grey wash varying in intensity.

Nestling.-Brownish all over above, the down with a mixture of white, obsolete darker patches being indistinctly seen; throat and chest as back; abdomen dirty white. With age the down appears lighter and the first feathers show with rufous tips.

Nest.-A fissure of a rock close to the water's edge, without any nest, or well concealed under a tussock of grass.

Egg.-Clutch, one; ground-colour stone, spotterl all over with rich chestnut, and smaller spots of grey; axis $44 \mathrm{~mm}$., diameter $31-32$.

Breeding-season.-October to December.

Distribution and forms.-Throughout the tropical seas of the world, breeding on isolated islets. Mlathews separated five forms and two have since been added, thus: M. a. anathelus (Scopoli) from the Philippine Islands and the China Sea; AI. a. noxchollandia (Stephens) from East Australia, sejarable by its greyer neck, darker brown upper coloration, larger size and different tail coloration; the West Australian M.a.rogersi Jathews is similar but much darker; $M$. a. antarclica (Lesson) from the Seychelles, Mauritius and Laccadives is a smaller race than the preceding, which it resembles in coloration; $M$. a. fuligula (Lichtenstein) from the Red Sea is larger than above and has less white on inner web of the primaries and more white on: the tail-feathers; M. a. rccognita Mathews, from East America, breeding on the Bahamas, is generally lighter above, epecially on the tail, and obsolete grey wash on under-surface and lifferent tail coloration; and 11 . a. nelsoni (Ridgway) from Pacific Coast of Mexico and Central America, larger than preceding with relatively longer or more slender bill and under parts of body tinged with pale grey.

\section{Genus ONYCHOPRION.}

Onychoprion Wagler, Isis, 1832, heft 3, col. 277, March. Typo (by monotypy): Sterna serrata Wagler = S. fuscata Linné.

Planetis Wagler, Isis, 1832, heft 11, col. 1222, Nov. Type (by monotypy): S. guttala ex Forstor MS. = S. fuscata Linné.

Haliplana Wagler, Isis, 1832, heft 11, col. 1224, Nov. Typo (by monotypy): Sterna fuliginosa Gmelin = S. fuscaı L Linné.

Thalassipora Rüppell, Syst. Uebers. Vögel Nord-ost Afrika, p. 140, 1815. Typo (by monotypy): S. infuscata Lichtenstein $=$ S. juscata Linné.

Dipsaleon Gistel, Naturg. Thierr. Schul., p. 10, 1848 (pref. Easter 1817). New namo for Planetis Wagler.

Medium-sized Terns with comparatively short stout bills, short legs, long wings and very long tails. The culmen is a little longer than the head, and much longer than the tarsus. The nature of the nostrils shows an approach to that seen in the Noddies. The toes are comparatively short arrl fully webbed. The streamers are well developed, making the tail more than half the length of the wing. 
Most writers upon the Terns have intimated their disapproval of lumping this species in with Sterna, but have all been unable to find distinct structural differences in the skin to justify the separation. The nature of the young has influenced us in accepting Onychoprion, while most writers have commented upon its habit of laying one egg only.

\section{Onychoprion fuscatus.-SOOTY TERN.}

[Sterna fuscata Linné, Syst. Nat. 12th ed., p. 228, (pref. May 24th) 1766 : Santo Domingo, West Indies. Extra-limital.]

Gould, Vol. VII., pl. 32 (pt. xxvIII.), Sept. 1st, 1847. Mathews, Vol. II., pt. 4, pl. 113, Nov. lst, 1912.

Sterna serrata Wagler, Natur. Syst. Amphib., p. 89 (note), 1830 (ex Forster MS.): New Caledonia.

Sterna melanura Gould, Synops. Birds Austr., pt. IV., App., p. 7, April 1st, 1838 : New South Wales.

Sterna gouldii Reichenbach, Aves Natat. Longip., pl. XXII., f. 829, 1818 : West Australia. Onychoprion fuscatus kermadeci Mathews, Austral Av. Rec., Vol. III., pt. 3, p. 55, April 7th, 1916: Kermadec Islands = Long Reef, Sydney.

Distribution.-Tropical Australian Seas.

Adult male in breeding-plumage.-Crown of head and nape black, as also a line of feathers from the gape to the eye; hind-neck, back, scapulars, wings and tail sooty-black; the small coverts along the upper margin of the wing white; inner webs of secondaries whitish towards the base; outer tail-feathers greyish-brown, darker towards the tips on the inner webs; fore-head and a narrow line to above the middle of the eye white; sides of neck, throat, and under-surface of body also white, becoming shaded with grey on the lower-abdomen, under tail-coverts, axillaries, and under wing-coverts; bill and feet black; iris black and white. Total length $475 \mathrm{~mm}$. ; culmen 42 , wing 304 , tail 210 , tarsus 24.

Adult female.-Similar to the adult male, but smaller in every dimension.

Adult in winter-plumage. - Similar to the adult in breeding-plumage, but the lores and crown of head intermixed with white and black.

Nestling (a few hours old).--Covered with dirty white down, more inclining to white on the abdomen; bill yellowish, tip black; iris deep brown; feet and legs nearly black.

Nestling (three days old).-A mixture of brown, black, and white down on the upper-surface, somewhat darker on the lores and sides of face ; under-surface white, with indistinct dark pectoral band and ashy-black throat.

Progress of young.- South Island, Houtman's Abrolhos:-

January 17th, 1843.-In down. Mottled brownish and white above and on sides of the breast; under-surface white.

January 30th, 1843.-Fore-head and throat and flanks still down covered. Head dark brown with darker tips; all back, wing-and tail-feathers brown, with more or less extensive white tips; under-surface ashy-brown with white patch on the abdomen.

February 16th, 1843.-No down remaining. Wing- and tail-feathers half grown. Head and under-surface all brownish, lighter on tlanks; under tail-coverts paler with rufous tips; back and tail, scapulars and lesser wing-coverts faintly rufous and tipped with white; primaries untipped.

hermarlecs.-About the same age as second above. Has down remaining on head, which shows slightly rufous tips underneath; the general upper coloration is slightly darker, while the tips on the back, wing-coverts and tail-feathers are distinctly rufous, those on the seapulars being rufous-white; the under-surface is darker and more mottled with greyish-white.

Kermadces. - Slightly older than third above, about ready to fly. Has the head 
feathers tipped with rufous, the back having slightly smaller tips; tail tips worn off; underneath darker but more mottled with grey, expecially the throat; under wing-coverts pure grey with whitish tips; axillaries deep grey with darker tips; under tail-coverts dark grey with rufous tips.

Test.- Lays a single egg on the bare ground beneath the thick scrub, or in the open.

Egg.-Cluteh, one; ground-colour stone, spotted with rich chestnut (more noticeable on the larger end), and small markings of grey or larender ; axis 53-55, diameter 35-36. Pure white eggs have been talien on the Kermadec Islands, whero great variation is seen.

Breating-season.-November. (Lord Howe Island and Kermadec Islands.) December and January. (Houtman's Abrolhos.) May and June. (Torres Strait.) September to December. (Norfolk Island.)

Distribution and forms,-Throughout intertropical seas, Atlantic, Indian and Pacific Oceans. Mathews admitted four subspecies, but sucgesterl more, and Ridgway has arlmitted one of these, so that five definite forms are at present accepted, thus: O.f. fuscatus (Linné) from mid-Atlantic Ocean breeding on West Indies, ete. ; O. $f$. infuscatus (Lichtenstein) for the Eastern Indian Ocean bird which has the under parts faintly orrey and the tail with less white on longest feathers; $0 . f$. serratus (W'agler) from Wast Australian seas with very long streamers, larger size and deeper grey wash on under-surface $(O . f$. gouldi (Reichenbach) would be the name of the West Australian race which seems smaller but more specimens must be examined); $O$. $f$. oahuensis (Bloxham) from the Hawaiian Group, with long streamers and grey under-surface but streamers not as white as $O . f$. serratus; and $O$. $f$. crissalis (Lawrence) from Pacific Coast of Central America, with shorter tail and darker towards the ends.

\section{Genus MEGALOPTERUS.}

Megalopterus Boie, Isis, 1826, heft 10, col. 980, Oct. Typo (by monotypy) : Sterna tenui. rostris Temminck et Laugier.

Micranous Saunders, Bull. Brit. Ornith. Club, Vol, IV., p. 19, Jan. 29th, 1895. Typo (by monotypy): S. tenuirostris Temminck et Laugier.

Anousella Mathews, Birds Austr., Vol. II., pt. 4, p. 412, Nov. 1st, 1912 . Type (by original designation): Anous leucocapillus Gould $=$ A. minutus Boie.

Medium-sized Noddies with long slender bills, long wings and tails, short legs and long toes. The culmen is like that of Anous, but is longer and slenderer, being longer than the heal. The tail has the third or fourth rectrix from the outside longest, the first being the shortest. The legs are shorter and fully webbed, with a large hind-toe.

Coloration all dark with a paler head and shoulders, which is seen in the immature nestling.

\section{Megalopterus minutus.-WHITE-CAPPED NODDY.}

Anous minutus Boie, Isis, 1844, heft 3, col. 188, March : North-east Australia.

Anous leucocapillus Gould, Proc. Zool. Soc. (Lond.), 1845, p. 103, Feb. 1846 : Raine Island, Queensland.

Anous atrofuscus Stone, Proc. Acad. Nat. Sci. Philad., p. 117, June 5th, 1894: New Guinea.

Megalopterus minutus kermadeci Mathews, Austral Av. Rec., Vol. III., pt, 3, p. 55, April 7th,

1916: Kermadec Islands = Mackay, Queensland.

Distribution.-East Australian Tropical Seas, New Guinea.

Adult male.-General colour above and below sooty-black; entire wings darker and more inclining to black; tail dark plumbeous-grey ; crown of head whito shading off into grey on the nape and merging into the sooty-black of the mantle; lores and 
feathers in front of the eye jet-black like the upper throat ; short feathers encircling the eye black with a white spot above and a short white line below; bill and feet black; iris blackish Total length $330 \mathrm{~mm}$; culmen 45, wing 228, tail 118 , tarsus 23.

Adult female.-Similar to the adult male.

Immature.-Pure or yellowish-white distinct cap on top of head; lores black -otherwise dark brown throughout.

Neslling.- Sooty-brown, upper part of the head pale ash-grey forming a cap, becoming more whitish on the fore-head; under-surface a shade paler.

This may develop into a paler brown plumage with fainter tipping, which only" lasts for a very short time, becoming darker and losing the tipping.

Nest.-Slightly cupled, composed of fresh seaweed, which is firmly cemented to a bough of a tree.

Egg.-Clutch, one; ground-colour whitish, spotted round the larger end with reddish-brown; sometimes a few pale grey spots over the rest of the egre axis 45-47 mm., diameter 31.5-33.

Breeding-season.-November, December. (Norfolk Island.)

Distribution and forms.-Throughout the tropical oceans, breeding on isolated islets. Mathews admitted seven subspecies, but wo find that $M$. melanognys (Gray") (=A. hawaiiensis Roths.) must be reinstated as a distinct species, having the grey head and neck of MI. tenuirostris, but with the black lores of the present species and with a very distinet pale grey tail. This leaves six forms, as follows: 11 . m. minulus Boie ( $=A$. leucocapillus Gould) from North-castern Australian seas breeting on Norfolk Island and the Kermadees (more than one subspecies may be here included) ; MI. m. worcesteri (McGregor) from the Philippine Islands, in having a darker, greyer tail and longer toes; M. m. marcusi (Bryan) from Marcus Island (eompared only with $M$. hawaiiensis Roths.); $M I$. m. diamesus (Heller and snodgrass) from the Cocos and Clipperton Islands, intermediate between $M$. leucocapillus and M. hauaiiensis in both colour of plumage and size of bill; $M . m$. americanus Nathew's from the Caribbean Sea, British Honduras, separated by its stouter bill and browner tail, while it is less bluish-plumbeous on the upper back and throat; and $H$. m. allanticus Mathews from Ascension Island, St. Paul's Rocks and Frrnando Noronha with longer stouter bills, white more restricted to crown of head, long wings and blackish tail.

\section{Megalopterus tenuirostris.-LESSER NODDY.}

[Stcrna tenuirostris Temminck et Laugier, Planch. Color. d'Ois., 34 livr. (Vol, II., pl. 202), (Vol. IV., pl. 104 ? May), July 26th, 1823: "Senegal" errore = Seychelles. Extra-limital.) Gould, Vol. VII., pl. 35 (pt. xxm.), March 1st, 1816. Mathews, Vol. II., pt. 4, pl. 116, Nov. 1st, 1912.

Anous melanops Gould, Proc. Zool. Soc. (Lond.), 1815, p. 103, Feb. 1816: Houtman's Abrol. hos, West Australia.

Distribution.-South-west Australia.

Adult male.-Entire wings, back, tail, breast and abdomen sooty-black, like the under-tail coverts and under wing-coverts; head greyish-white becoming ashgrey on the hind-neck, darker on the sides of the neck, and inclining to black on the throat and fore-neck; short feathers encircling the eye velvety-black, bill and feet black; iris ashy. Total length $393 \mathrm{~mm}$.; culmen (exp.) 39, wing 209, tail 112, tarsus 24.

Adult female.-Similar to the adult male.

Young in down. - Sooty-black, upper part of the hearl moulcly-white, bill and feet black.

Immature.-Does not appear to have been deseribed; may be similar to adult. 
Nest.-Construeted of seaweel, thrown across the branch, without any regard to form, until it has accumulated to a mass rarying from two to four inches in height.

Egg.-Clutch, one; ground-colour dull white, a ring round the larger composed of dark brown blotehes, a few spots of this colour and others of light grey sparingly placed over the rest of the surface ; axis 43-46, diameter 29-31.

Breeding-season.-September to December.

Distribution and forms.-Apparently Indian Occan only. Two forms have been recognised: $M$. $t$. tenuirostris (Temminck and Laugier) from the Seychelles, and MI. $t$. melanops (Gould) from Wost Australia, differing in its smaller size.

\section{Genus ANOUS.}

Anous Stephens, in Shaw's Gen. Zool., Vol. XIII., pt. I., p. 139, Feb. 18th, 1826 (ex Leach MS.). Type (by subsequent designation, Gray, p. 79, 1840): A. niger Stephens $=$ S. slolida Linné.

Stolida Lesson, Traité d'Orn., 8e livr., p. 620, June 11th, 1831. Type (by monotypy): S. stolida Linné.

Gavia Swainson, Classif. Birds, Vol. I1., p. 373, July lst, 1837. Typo (by monotypy) : Gavia leucoceps Swainson $\Rightarrow$ Sterna stolida Linné.

Not Gavia Forster, Enchirid. Hist. Nat., p. 38, 1788.

Aganophron Gloger, Hand- u. Hilfsb. Naturg., livr. 8, p. 463, (early) 1842, Type (by mono. typy): S. stolida Linné.

Noddi "Cuvier" Gray, Genera Birds, Vol. III., p. 661, Jan, 1846. In synonymy of Anous.

"Nodinus Rafin.?" Gray, Cat. Gen. Subgen. Birds, p. 131, Oct. 1855. In synonymy of Anous.

This and the preceding genus of the Sternidee are characterised by the nature of the bills and especially the formation of the tail. In no case are the outer rectrices dereloped into streamers, but in some genera they are absolutely the shortest.

Largest Noddies with long stout bills, long wings and tails (though no streamers are present), short legs but long toes.

The culmen is as long as the head, stout, broad at the base, much longer than the tarsus. The nostrils are placed in a deep sulcus which extends almost half the length of the bill, and the anterior end of the nostril is about half way from the base of the bill to the tip. The tail is long, more than half the length of the wing, forked, but the fourth pair of feathers from the outside is the longest, while the outside pair is the shortest ; the middle pair is longer than the pair next the outside, but shorter than the third pair from the outside, which is subequal with the fifth pair. The toes are long and fully webbed, the inner and outer long and little less than the middle one.

Coloration uniformly blackish-brown, with a pale whitish cap.

\section{Anous stolidus.-NODDY.}

[Sterna stolida Linné, Syst. Nat., 10th ed., p. 137, Jan. 1st, 1758 : Atlantic Ocean. Extra. limital.]

Gould, Vol. VII., pl. 34 (pt. sxir.), March Ist, 1846. Mathews, Vol. II., pt. 4, pl. 115, Nov. 1st, 1912 .

Anous stolidus gilberti Mathews, Birds Austr., Vol. II., pt. 4, p. 405, Nov. 1st, 1912 : Bedout Island, West Australia.

Anous stolidus antelius Mfathews, Austral Av. Rec., Vol. III., pt. 6, p. 159, June 25th, 1918 : Cooktown, North Queensland.

Distributron.-Tropical Australian Seas.

Adult male.-General colour above and below sooty-brown, inclining to black on the bastard-wing, primary-coverts and quills; head and nape hoary-white; lores blackish, the short feathers encircling the eye white on the upper and under 
portions, remainder black; a blush of hoary-grey pervades the sides of the face and hind-neck; under wing-coverts plumbeous-black; bill and feet black. Total length $395 \mathrm{~mm}$. ; culmen 39, wing 262 , tail 150, tarsus 26. smaller.

Adult female. - Similar to the adult male but browner in colour and somewhat

Immature--Uniform brown, without a cap.

Nestling (two days old).-Covered with down, sooty-brown on the upper-surface as well as on the throat, fore-neck and chest, becoming paler and inclining to whito on the abdomen, with the fore-head dirty white, darker on the top of the head, only an indistinct cap being seen.

Nest.-Constructed of seaweed, about six inches in diameter, and varying in height from four to eight inches, but without anything like regularity of form; the top is nearly flat, there being but a very slight hollow to prevent their single egg from rolling off.

Egg.-Clutch, one; ground-colour light stone; spotted on the larger end with reddish-brown and sparsely spotted all over with dull grey ; axis 54-56 mm., ciameter 36-38.

Breeding-season.-October to January.

Distribution and forms.-Throughout the tropical oceans, breeding on isolated islets. Mathews differentiated eight forms and has since added a ninth; these are as follows: $A$. s. stolidus (Linné) from the Atlantic Ocean; A.s. rousseaui Hartlaub from Madagascar, Mauritius, ete, in its larger size and clarker coloration; A. s. plumbeigularis Sharpe, from the Red Sea, in its smaller size and slightly paler coloration; A. s. pileatus (Scopoli) from the Philippine Islands, Liu Kiu Islands, and China Seas in being darker and again larger; A. s. unicolor (Nordmann), from the South Pacific Islands (Society, Paumotu, etc.) in its still larger size; $A . s$. gilberti Mathews from West Australia, Iighter and larger than A. S. pileatus and smaller than A.s. unicolor; A. s. antelius Mathews from East Australia, browner with head lighter and with longer wings; A. s. galapagensis Sharpe from the Galapagos Islands with its dark blackish coloration and dark grey cap, a very distinct form; and A.s. ridgwayi Anthony from the Pacific Coast of Mexico, paler than preceding, but darker than A.s. stolidus, the top of the head darker grey, etc.

\section{Gerus PROCELSTERNA.}

Procelsterna Lafresnaye, Mag. de Zool., 1842, pl. 29. Type (by monotypy) : P. tereticollis = Sterina cerulea Bennett.

Small Noddies with short slender bills, long wings, long tails, and long toes fully webbed.

The tail has the outer rectrix shorter than the second, which is longest, but longer than the middle feathers. The middle toe without the claw is about the same length as the exposed portion of the culmen and longer than the metatarsus. The tail is slightly more than half the length of the wing.

Coloration all bluish-grey.

\section{Procelsterna cerulea.-GREY NODDY.}

[Sterna cerulea Benmett, Narr. Whaling Voy., Vol. II., p. 248, (pref. April 14th) 1840: Christmas Island, Pacific Ocean, Extra-limital.]

Gould, Vol. VII., pl. 37 (pt. xxxv.), Dec. 1st, 1819. Mathews, Vol. II., pt. 4, pl. 118, Nov. 1st, 1912.

Anous cinereus Gould, Proc. Zool. Soc. (Lond.), 1845, p. 104, Feb. 1846 : northern coasts of Australia (? error $=$ Lord Howe Island). 
Procelsterna albivitta Bonaparte, Comptes Rendus Acad. Ści. Paris, Vol. XLII., p. 773, May 1856. New name for $A$, cinereus Gould.

Procelsterna cerulea kermadeci Mathews, Austral Av. Rec., Vol. III., pt. 3, p. 55, April 7th, 1916: Kermadec Islands.

Distribution.-Probably as a straggler to east coast of Australia.

Adult male.-General colour above ash-grey, paler and inclining to white on the head, sides of face and entire under-surface of body, including the under wingcoverts; under tail-coverts ash-grey like the upper-surface; inner webs of outer primary-quills inclining to black near the shaft, the innermost portion becoming whitish; most of the secondaries grey margined with white at the tips; short feathers encircling the eye, black in front and white on the hinder portion; bill black; iris blackish-blue ; tarsi and toes black, webs lemon-yellow. Total length $279 \mathrm{~mm}$, ; culmen 29, wing 207, tail 120, tarsus 24.

Adult female.-Similar to the adult male but smaller.

Immature.-Difiers from the adult in being dark slate-grey both above and below, the wings being somewhat darker than the back and the primary-quills inclining to black.

Nestling.-Almost the same colour as the parent bird.

Nest.-None; the eggs are laid on the bare rock or sand.

Egg.-Clutch, one ; ground-colour stone, with underlying spots of grey sparingly distributed, and fewer spots of chestnut-brown; axis $42 \mathrm{~mm}$, diameter 30 .

Breeding-season.- September to January. (Norfolk Island.)

Distribution and forms.-Apparently Pacific Ocean only where, however, five forms have been distinguished, as follows: $P$. c c certea (Bennett) from Christmas Island and Hawaiian Group; P. c. teretirostris (Lafresnaye) from the Paumotus, Marquesas and Society Groups; P. c. nebouxi Mathew, from the Ellice and Phonix Groups darker and smaller than preceding which are all darker than the next two; $P$. c. cinerca (Gould) from Norfolk, Lord Howe, Kermadec Islands, probably Friendly Islands, much paler above and below and also larger; the form $P$. c. imitatri, Mathews, from St. Ambrose Group of the coast of South America, agreeing almost exactly in coloration but a little larger.

\section{Genus LEUCANOUS.}

Leucanous Mathews, Birds Austr., Vol. II., pt. 4, p. 432, Nov. 1st, 1912. Typo (by original designation): Gygis microrhyncha Saunders.

Gygis Wagler, Isis, 1832, heft 11, col. 1223, Nov. Type (by monotypy): Sterna candida Gmelin.

Not Gyges Bory de St. Vincent, Ency. Meth., p. 449, 1825.

Alphagygis Mathows, Austral Av. Rec., Vol. II., pt. 5, p. 110, Sept. 24th, 1914. New name for Gygis Wagler 1832, as above.

Small Noddies with long stout bills, long wings, medium tails and very short legs, and long toes with indented webs. The diagnostic characters of the genus are the shape of the bill and the very short legs, and long toes with deeply indented webs. The bill is longer than the head with the culmen straight or even slightly upturned, while.it is very deep at the base proportionately. The tail is less than half the length of the wing and the outer reetrix is shorter than the second which is longest. The middle toe is almost twice as long as the metatarsus though not much more than half the culmen.

The bird described as Gygis microrhyncha by Sianders differs from the above in having a long slender bill and a proportionately shorter tail of different formation, the third rectrix from the outside being the longest, while the first is absolutely shortest. In Sterna alba Sparrman the outside rectrix is longer than the two centre pairs, the centre feather being the shortest.

Coloration all white. 


\section{Leucanous albus.-WHITE TERN.}

[Sterna alba Sparrman, Mus. Carlson fasc. I., No. 11, 1786: "India orientali, at Promontorium Bonæ Spei, etc." = Ascension Island. Extra-limital.]

Gould, Vol. VII., p. 30 (pt. xxxv.), Dec. 1st, 1818. Mathews, Vol. II., pt. 4, pl. 119, Nov. 1st, 1912.

Gygis alba royana Mathews, Birds Austr., Vol. II., p. 433, Nov. 1st, 1912 : Kermadec Islands Distributron.-Probably as straggler to east coast of Australia.

Adult male.-Entire upper- and under-surface of body ivory-white; short feathers surrounding the eye black; shaft-lines of primary-quills dark brown, somewhat darker and inclining to black on the shafts of the tail-feathers; bill black at tip, base blue ; iris brown; tarsi, toes and webs yellow. Total length $330 \mathrm{~mm}$.; culmen 45 , wing 250 , tail 110 , tarsus 16 .

Adult female. - Similar to the adult male but somewhat smaller. Total length $260 \mathrm{~mm}$.; culmen 40, wing 243 , tail 108 , tarsus 14 .

Immature (half grown). - Petaining down adhering to back of head, sides of rump, throat, etc. ; nape with pale rusty-brown tipping to white feathers, back similarly barred with rusty tips, scapulars and inner secondaries prominently so marked with darker bars, wing-coverts with rusty edges; black spots in front of eye; rest of plumage snow-white. Iris dark brown, feet dark blue with cream webs, bill greyish-blue and black. (Norfolk Island.)

Testling (a few days old).-Shows down to have been mottled and not uniform as commonly accepted; a large black patch above and extending behind the eye, pale brown line above, and then black markings towards nape, greyish-brown on fore-head with lighter edge; back dark brownish-grey with indistinct pale blotches; wing. similarly blotched, method of disposal of blotehes indistinguishable; throat dark grey, abdomen lighter grey. Iris, very dark brownish-grey, feet light blue, web. flesh, bill bluish-black all over. (Idem.)

Nestling.-Covered with black down. From dark brownish-grey to rery light grey, or almost white.

Nest.- The egg is laid in a depression on the branch of a tree or on a point of rock.

Egg.-Cluteh, one; ground-colour stone, blotched all over with recklish-brown and lavender. Some examples have a resemblance to the eggs of Chlamydera ; axis $42-44 \mathrm{~mm}$., diameter 33 .

Breeding-season.-October to February.

Distribution and forms.-Throughout tropical seas breeding on isolated islands. Mathews in 1912 suggested half a dozen subspecies and since then no critical work appears to have been done on this speeies. Nathews proved that Stema alba Sparrman must be used for this species and fixed the type locality as Ascension Island. The North Pacific form differs in dark coloration of the shafts of the primaries, and different shape and parti-coloured bill, the Atlantic form having a wholly black bill, slenderer and narrower at base. For this North Pacific form Leurchous albus candidus (Gmelin) may be used, the type locality being Christmas Island, to which may be referred the Hawaiian Group birds ; series are not available to determine whether the Caroline and Marianne birds are separable, but, if so, their name would be Leucanous albus kittlitzi (Hartert); Kermadec breeding birds have longer wings and longer bills and bear the name Leucanous albus royanus (Mathews); to this race has been assigned Norfolk Island birds and these would occur on the east Australian Coast ; Leucanous albus pacificus (Lesson) can be used for the birds from the Society Group and Samoa, which have shorter wings but longer bills than the preceding. Probably other races occur in the Pacific Ocean. The Indian Ocean form, breeding at the Seychelles, can be called Leucanous albus monte Mathews, differing in their shorter wings from the Pacific forms but having bills as long as L. a. royanus. All Atlantic birds are classed as Leucanous albus albus 
(Sparmann), but probably more than one race will be admitted, the South Trinidad race having been named Leucanous albus crawfordi (Nicoll.)

\section{FAMILY LARIDÆ.}

Gulls are superficially easily separable from the other members of the suborder a. ahove diagnosed. The two genera recorded for Australia deserve investigation as to the internal features, as one of them, Gabianus, has received generic recognition by writers who commonly lumped the most diverse species together. It differs very appreciably from the other Australian species referred to Bruchigazia, and comparison would be valuable.

Internally, the Gulls differ from the Terns in the leg muscle formula being always $A X Y+$, the accessory femoro-caudal being always absent, while the expansor secundariorum is always present. The caca are rudimentary, the digestive system pericelous and mesogyrous. The pterylosis is a little different from that of the preceding family and the coloration of the downy young scems to be of one style only.

\section{Genus BRUCHIGAVIA.}

Brucligavia Bonaparte, Consp. Gen. Av., Vol. II., p. 22S, Oct. 1857. Typo (by monotypy): Larus wucchollandice Stephens.

Gulls are seabirds with mebbed feet and a hooked bill, but the nostrils are not tubular. As before noted they superficially resemble Petrels, but have had a different origin. At the present time no up-to-date classification exists.

The bill is short and stout, between two and three times as long as it is deep, with the maxilla longer, and the tip bent over the mandible; the tail is short and and generally square. The nostrils are placed in a suture at some distance from the base of the bill, and are oblong in shape. The tarsus is fairly moderate and the feet are large and fully webbed; the hind-toe fully developed, though small. First primary longest. 'The tail is shorter than the wing, and square.

Bruchigavia is characterised by having the tail less than half the length of the wing, and the bill is short and robust, though of a delicate shape ; the nostrils are proportionately very long and linear.

Coloration grey above, white below.

\section{Bruchigavia novæhollandiæ.-SILVER GULL.}

Gould, Vol. VII., pl. 20 (pt. xxxv.), Dec. 1st, 1848. Mathews, Vol. II., pt. 4, pl. 120, Nov. 1 st, 1912.

Larus novahollandice Stephens, in Shaw's Gen. Zool., Vol. XIII., pt. I., p. 196, Feb. 18th, 1826 : New South Wales, based on Watling drawing No. 277, the source of Latham's Crimson. billed Gull.

Larus jamesonii Wilson, Illustr. Zool., pt. vI., pl. xrrir., 1829: "shores of New Holland" = Tasmania.

Larus erythrorhynchus "Lath." Burton, Cat. Coll. Mamm. Birds Mus. Fort Pitt, Chatham, p. 46, (pref. April lst) 1838, based on Latham's Crimson-billed Gull : New South Wales. Gavia gouldii "Bp." Bruch, Journ. für Ornith., 1853, heft 2, p. 102, March. In synonymy of jamesonii Wilson, from Vandiemens Land.

Gavia andersonii Bruch, ib., p. 102: "Neu-Seeland" = ? New South Wales.

Gavia pomarre Bruch, ib., p. 103: "Gesellschaft's-Inseln" errore = ? New South Wales. Type in Mainz Mus.

Gilastes corallinus Bonaparte, Naumannia, 1854, p. 216: New South Wales.

Giclastes gouldi Bonaparte, ib.: Torres Straits, Queensland.

Not of Bruch 1853 as above.

Bruchigaria longirostris Masters, Proc. Linn. Soc., N.S.W., Vol. II., p. 113, July 1S77:

Fing George Sound, South-west Australia. 
Larus novahollandice gunni Mathews, Nov. Zool, Vol, XVIII., p. 212, Jan. 31st, 1912 : Tasmania.

Larus novchollandice ethelce Mathews, Austral Av. Rec., VoI. I., pt, 2, p. 30, April 2nd, 1912 : Kangaroo Island, South Australia.

Bruchigavia novachollandia yorki Mathews, Birds Austr., Suppl. No. 1, Check List, p. 30, Feb. 16 th, 1920: Torres Straits, Queensland. Nom. nov, for Gelastes gouldi Bonaparte, 1854. Distribution.-Australia generally and Tasmania.

Adult male.-Back and wings blue-grey; head and neck all round and entire whder-surface of the body pure white including the axillaries and under tail-coverts ; upper tail-coverts and tail also white as well as the small coverts round the bend of the wings, both above and below; inner under wing-coverts inclining to grey; bastard-wing and primary-coverts white; the first primary black with a white mirror towards the end which occupies both webs, slightly fringed with black on the inner one; the second primary has a line of white near the base which occupies the shaft and a small portion each side of it, a mirror near the tip similar in shape to the one on the first primary but more broadly margined with black on the inner web; the third primary has a similar line of white from the base to beyond the middle of the feather, and another elongated spot on the inner web which is joined by the continous white shaft, also tipped with white; the fourth quill is white on the outer web for the greater part of its length, towards the end it crosses on to the inner web : the basal portion of the inner web is greyish-brown near the shaft with a subapical black and white tip; the fifth primary is white on the outer web nearly the whole length, dark grey and fringed with black on the inner web, with a subapical black band and white tip; the sixth quill is blue-grey fringed with black on the inner web towards the end and a narrow subapical black band and white tip; the seventh primary blue-grey with a very slight fringe of black on the inner web near the tip ; secondaries entirely blue-grey; bill and feet red; iris white, eyelid red. Total length $440 \mathrm{~mm}$; culmen 36 , wing 309 , tail 120 , tarsus 50 .

Adult female.-Similar to the aduit male but smaller.

Immature.-Differs from the adult in having the tips of the feathers on the nape, hind-neck, and mantle brown; the lesser wing-corerts brown tipped with white and fringed on the sides more or less with ochreous-buff, the greater corerts grey with a subapical brown spot and white tip; bastard-wing dark brown on the inner web; the secondaries grey with subapical brown marks and tipped with white; the innermost secondaries brown with grey bases irregularly marked and fringed with white at the tips, also a slight mottling of buff; some of the scapulars similarly marked but paler; the feathers of the rump grey with subapical brown spots and fringed with buff at the tips; some of the upper tail-coverts blackish at the tip; tail-feathers white with a subapical dark band mottled with buff and tipped with white. As the bird advances in age the brown of the upper wing-coverts seems to be the last to change. Iris light grey, eyelid orange, bill dark horn, legs and feet greyish-black.

Immature with traces of down.-Channel Rock, Torres Straits, June 1st, 1881 : "Iris brown, bill hom, legs and feet light bromn"; top of the head uniform light brown, bases of all feathers white tipped with light brown with a penultimate bar of much darker brown; these colours increase in depth on the scapulars; rump white; tail-feathers with white tips, penultimate brown bar and white bases; general under coloration white; primaries black with white tips, the first two primaries showing incipient mirrors (which are not present in first complete immature plumage, but reappear at a later age); greater coverts white, the outermost with irregular black markings, the next two fringed on outer web with darker brown. (These are similar in immature birds, but are pure white in adult.) white.

Nestling.-Heavily mottled with brown on the upper-surface; under-surface

Nest.-Formed of a few rushes and grasses. 
Eggs.-Two usually; sometimes three; ground-colour buff-brown blotched with dark reddish-brown and grey; axis 54, diameter 37-39. Very variable in coloration.

Breeding-season.-October, November and December.

Distribution and forms.- Round the coasts of Australia, New Caledonia and New Zealand, the South African B. harllaubi (Bruch) being scarcely specifically separable. The Austral forms are separable by means of the white pattern on the primaries ir connection with other features, as follows: B. n. nockhollandia (Stephens) from New South Wales, with a light coral bill and first three primaries with elongate "mirrors"; B. n. jamesonii (Wilson) from Tasmania (=B. n. gunni Nathews) with very large white markings on the primaries, an unmistakable race, probably also occurring in Victoria; B. $n$. cthele (Mathews) from South Australia, similar to the typical race but larger ; $B$. n. longirostris Masters, from South-west Australia, is larger with longer bill which is black for a long time and very deep red when fully coloured, longer legs, and mirror usually missing on third primary ; $B . n$. yorki Mathews, from North Australia, larger than typical race, with a stouter bill and usually no mirror on third primary; $B . n$. forsteri Mathews, from New Caledonia, smaller than the preceding but larger than the next with no mirror on third primary and medium on first two; and B. n. scopulinus (Forster) from New Zealand, a smaller race with a paler red bill and bold white tips to the primaries which are persistent, and no mirror on third primary, but there may be more than one race throughout New Zealand and its Sub-antarctic Islands.

\section{Genus GABIANUS.}

Gabianus Bruch, Journ. für Ornith., 1853, heft 2, p. 100, March (ex Bonaparte MS.). Type (by monotypy): Larus pacificus Latham.

Gabianus Bonaparte, Journ. für Ornith., 1853, heft 1, p. 47, Jan. Nomen nudum.

Large Gulls with square tails ; the bill short, very deep and laterally compressed, the nostril placed well forward, small and pyriform in shape.

The bill is strongly hooked, the gonys very pronounced and the bill is scarcely twice as long as deep at the base and not twice as long as depth at the gonys; the lateral compression is also very remarkable, while the small pear-shaped nostril placed about half the length of the culmen almost suggests a Skua-like cere, the nasal groove being merely an impression.

The wings are very long, but the tail, while square and with broad feathers, is two-fifths its length, though at first sight it may appear short.

The legs and feet are large and powerful, the claws small and little hooked; the tarsus is scutellate in front and reticulate behind, the toes long and fully webbed, inner shorter than outer, which is a little less than middle one ; hind-toe small.

Coloration: white head and under-surface, back and wings black, and tail white with a black subterminal bar.

\section{Gabianus pacificus.-PACIFIC GULL.}

Gould, Vol. VII., pl. 19 (pt. xxrmr.), Sept. 1st, 1847. Mathews, Vol. II., pt. 5, pl. 121, Jan. 31st, 1913.

Larus pacificus Latham, Index Ornith. Suppl., p. 68, 1801, after May: New South Wales, based on Watling drawing No. 275.

Larus frontalis Vieillot, Nouv. Dict. d'Hist. Nat., Vol. XXI., p. 505, May 30th, 1818 : Tasmania.

Not of Reich., Mlag. Thierreichs, Vol. III., p. 129, 1795.

Larus leucomelas Vieillot, ib., p. 509: Tasmania.

Larus bathyrinchus Macgillivray, Mem. Wern. Soc., Vol. V., pt. I., p. 253, 1824 (after March

21st): Coasts of New Holland = New South Wales. 

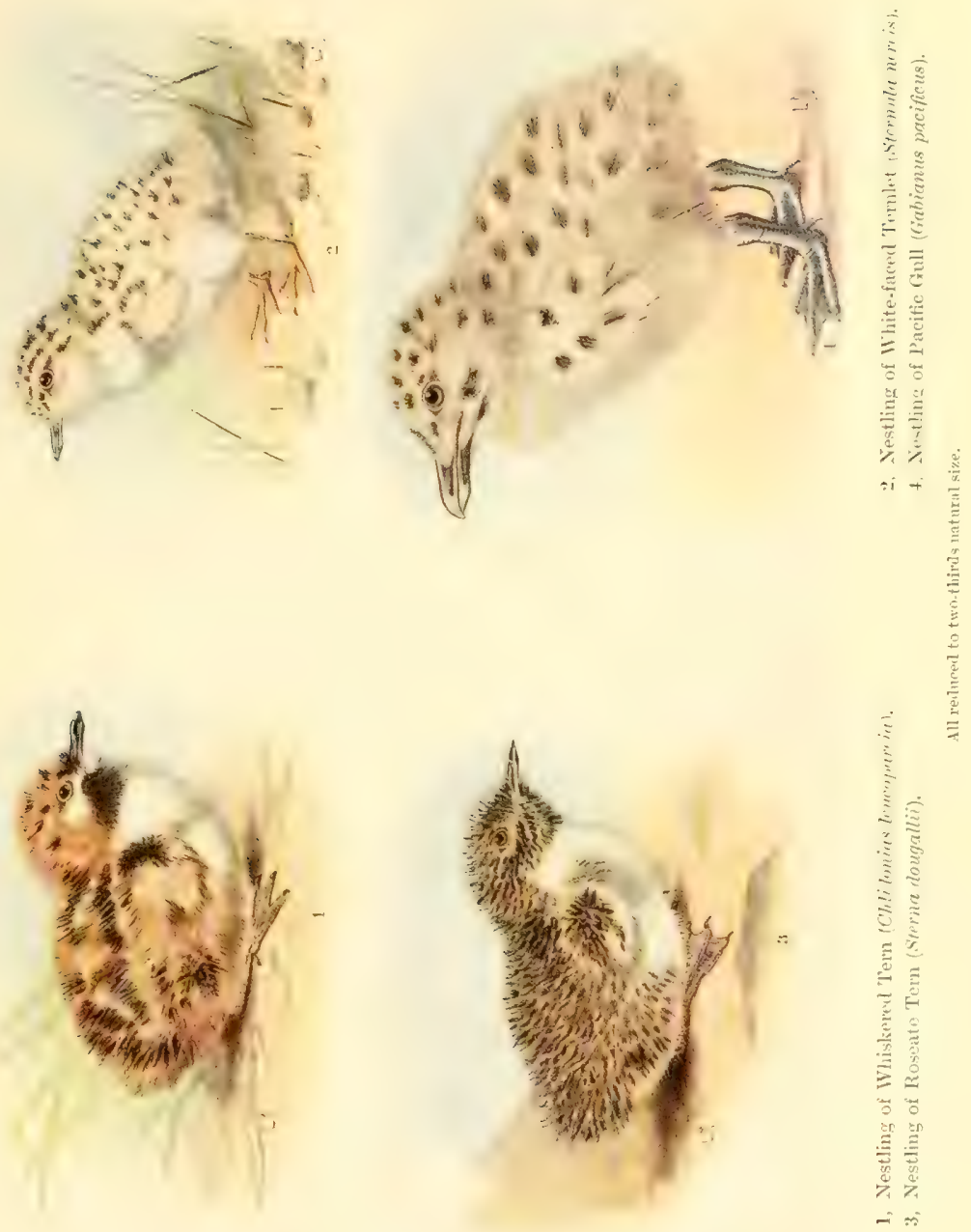

Larus georgii King, Survey Intertrop. Coasts Austr., Vol. II., p. 423, "1827" = April 26th, 1826 : King George Sound, West Australia.

Gabianus pacificus kingi, Mathews, Austral Av. Rec., Vol. III., pt. 3, p. 56, April 7th, 1916 : Queensland.

Distribution.-Australia generally (not in extreme north) and Tasmania.

Adult male.-Back and wings dark brown ; small coverts round the bend of the wing pure white ; lesser, median, and greater wing-coverts blackish like the bastardwing, primary-coverts and quills, some of the latter tipped with white, more broadly on the innermost primaries which are also margined with white on the inner webs towards the tip; sides of rump, upper tail-coverts, and tail white, the latter with a broad subterminal band of black on all the feathers except the outer pair, each of which have a very slight mottling of black and a black shaft-streak on the subterminal portion of the feather; head and neck all round white like the under-surface, which includes the axillaries, under wing-coverts, and under tail-coverts; bill green, tip red, cutting edges yellowish-green; iris silvery-white; eyelid yellow; feet yellow. Total length $645 \mathrm{~mm}$; ; culmen 62, wing 475, tail 192, tarsus 78 .

Adult female.-Similar to the adult male but the subterminal black band on the tail much more irregular in shape, the outer feathers pure white with the exception of the subterminal black shaft-streak, the second pair has a slight mark on the outer web with a black shaft-streak and a large blotch on the inner web, while on the corresponding feather there is only a black shaft-streak and a small black spot on the inner web; iris brown. Total length $645 \mathrm{~mm}$; culmen 60, wing 443 , tail 178 , tarsus 64 .

Immature.-Upper-surface brown, most of the feathers margined with white or ferruginous, and showing dark shaft-streaks on the scapulars and upper tailcoverts; bastard-wing, primary-coverts and quills dark brown fringed and tipjed with white, the shafts of the latter white on their basal portion; secondaries similar but paler at the base of the inner web; tail-feathers dark brown fringed with whitish at the tips, outer feather on one side margined with white, and white on the immer web at the base; head and neck all round brown with white bases to the feathers ; throat white with brown pear-shaped spots to the feathers; remainder of undersurface brown with white bases to the feathers; under wing-coverts dark brown; axillaries uniform pale brown; iris dusky slate-grey, eyelid brick-red; legs dull ochre tinged with olivaceous; toes and tarsi olivaceous-slate, claws black.

Nestling.-Buffy-white, with longitudinal spots of brown on the upper-surface, the brown pattern somewhat darker on the head, the under-surface paler and uniform save on throat, which is obscurely spotted; bill bluish-hom colour, tip light horn colour; feet and iris black.

Nest.-Very neat, the grass used being wound round and round, making a beautiful symmetrical hollow-three to four inches deep. Placed under the lee of a bunch of tussock grass, or some sheltering bush.

Eggs.-Clutch, one to three; ground-colour light olive-brown blotched all over with reddish-brown and lavender; axis 73-76 mm., diameter 50-53.

Breeding-season.-October to January.

Distribution and forms.-Confined to Australia and Tasmania. Three subspecies may be easily recognised : G. p. pacificus (Latham) from New South Wales, Victoria, Tasmania and (?) South Australia; G. p. kingi Mathews from Queensland similar in coloration, but smaller; and G. p. georgii (King) from South-west Australia, with the band across the tail much more irregular and narrower, the broadest part only $20 \mathrm{~mm}$. deep.

\section{FAMILY STERCORARIIDE.}

Skuas are recognisable at sight by their cere-bearing gull-like bill, and the long sharply hooked claws. Otherwise they vary in size and form from small 
delicate birds to stout heary forms. They have the leg muscle formula of the Gulls but differ in the presence of long caea and the absence of the expansor secundariorum. The coracoids are separated whereas in the preceding they are in contact. The most interesting feature, however, is the differentiation of the Antaretic forms as to the skull and also in connection with the syrinx. In skull characters the Antaretic Sliuas are more Pluvialine than Larine and the syrinx is also of the former nature. No detailed comparison between these and Stercorarius appears to have been instituted.

\section{Genus CATHARACTA.}

Catharacta Brünnich, Ornith. Boreal., p. 32, (pref. Feb. 20th) 1764. Type (by subsequent designation, Reichenbach, Nat. Syst. Vögel, p. V., 1852 (? 1853): Catharacta skua Brünnich. Pomarinus G. Fischer, Nat. Mus. Naturg. Paris, Vol. II., p. 185, (pref. March 6th) 1803. Type (by monotypy): Pomarinus fuscus $=C$. skua Brünnich.

Megalestris Bonaparte, Comptes Rendus Acad. Sci. Paris, Vol. XLIII, p. 643, Sept. 1856. Typo (by monotypy): Stercorarius catarrhactes $=C$. skua Brünnich.

Buphagus Coues, Proc. Acad. Nat. Sci. Philad, 1863, p. 124, May. Type (by original designa. tion): Catharacta skua Brünnich.

Not Gray, Cat. Gen. Subgen. Birds, p. 129, 1855.

Largest Skuas with stout powerful hooked bills, long wings, long wedge-shaped tail and strong legs and feet with stout hooked claws, the inner claw peculiarly dereloped. The bill has a horny eere, extending half way along the upper mandible, orerhanging the nostrils which appear as elongately oval apertures; the tip of the mandible is strongly hooked, and the gonys is not very pronounced. The wing is long and the square tail is about two-fifths the length, the central feathers being normal and not elongated in any way. The legs are very strong, and the feet with very broad webs, the claws very hooked, the inner claw powerfully and abnormally so, the hind-toe small.

Coloration uniform dusky above and below.

\section{Catharacta lonnbergi.-ANTARCTIC SKUA.}

Gould, Vol: VII., pl. 21 (pt. xxxv.), Dec. 1st, 1848. Mathews, Vol. II., pt. 5, pl, 122, Jan. 31 st, 1913.

Catharacta antarctica lonnbergi Mathews, Nov. Zool., Vol. XVIII., p. 212, Jan. 31st, 1912: New Zealand Seas.

Distributron.-Southern Australian Seas.

Adult male.-General colour above dark brown, inclining to blackish on the wings; some of the scapulars fringed and mottled with white, as also some of the upper tail-coverts; wing-coverts uniform dark bromn like the bastard-wing and primary-corerts; primary-quills white at the base, dark brown or blackish at the tips, the shafts for the greater part white ; secondaries and tail-feathers dark brown, white at the base; head and neck all round, rufous-brown like the under-surface of the body; the feathers on the hind-neck and sides of the neck lanceolate in form and show glossy shaft-streaks; under wing-coverts and axillaries darker than the abdomen and more glossy; a short, narrow streak of white below the eve; bill black; iris dark brown; feet black. Total length $690 \mathrm{~mm}$.; culmen (exp.) 57 , wing, 433 , tail 170 , tarsus 78 .

Arlult fema'c.-Similar to the adult male. Total length $610 \mathrm{~mm}$. ; culmen 56 , wing 410 , tail 155 , tarsus 77.

Captain Hutton says: "Sometimes the feathers of the back of the neck are finely strealied with pale yellow ; but usually they are of a uniform brown."

Immature.- Uniform brownish-black on the upper-surface ; the lower, uniform brownish-grey; the white bases of the primary-quills extensire. 
Nestling in down.-Smoky-grey, darker abore and paler below, with indistinct darker blotches on the upper-surface.

Nest.-None; a shallow depression.

Egg3.-Clutch, two; ground-colour dark stone, sparingly marked with blotches of brown, and a few dark grey ones round the middle; axis $76 \mathrm{~mm}$., diameter 52 .

Breeding-season.-November. (Chatham Island, Macquarie Island.)

Distribution and forms.- Round the Sub-antaretic Circle. Probably many forms will be later differentiated, but Mathens only separated three, as : C.l. lonnbergi from New Zealand and its sub-antaretic Islands; C.l. intercedens Mathews, from Kerguelen. Island, smaller than the preceding, with a large bill, wing average $410 \mathrm{~mm}$; typical form $430 \mathrm{~mm}$; ; and $C . l$. clarkei Mathews from South Orkneys is a smaller form. still, the wing generally under $400 \mathrm{~mm}$.

\section{Genus COPROTHERES.}

Coprotheres Reichenbach, Nat. Syst. Vögel, p. v., 1852 (1853 ?). Type (by original designation): Larus $=($ Lestris $)$ pomarinus Temminck.

Medium Skuas with stout bills, long wings, long tail with central pair of feathers elongated and twisted, but not attenuated, strong legs and feet. Differing from Catharacta in its smaller size, with a less stout bill and the elongation of the central tail-feathers, which are, however, broad, and from Stercorarius in its much larger size and stouter bill, stronger legs and feet and in lacking the attenuation of the longest central tail-feathers. As to proportions, it might be noted that the bill is just over one-tenth the length of the wing; in the latter it is less, and in the former, it is more than one-eighth, and other items are in agrement as the wing is less than twice the length of the tail as in the latter, but in the former it is more.

Coloration dark brown-black above with the under-surface more or less white.

\section{Coprotheres pomarinus.-POMARINE SIUUA.}

[Lestris pomarinus Temminck, Manuel d'Orn., p. 514, (pref. dated 1814) 1815: Arctic Europo. Extra-limital.]

Mathews, Vol. II., pt. 5, pl, 123, Jan. 31st, 1913.

Catarractes camtschaica Pallas, Zoogr. Rosso-Asiat, Vol. II., p. 312, 1827 : Kamtschatka. Coprotheres pomarinus nutcheri Mathews, Austral Av. Rec., Vol. III., pt. 4, p. 72, July 21 st, 1917 : Broken Bay, New South Wales.

Distributron.--Siberia (breeding) migrating southward to Australia (visitor). One specimen preserved in Mathews's collection.

Adult male.-General colour of the upper-surface sooty-black including the crown of head, cheeks, back, wings, and tail; primary-quills black on the outer webs and tips, brown on the inner webs and white at the base, the shafts white, dark brown at the tips ; secondaries dark brown, white at the base ; tail dark brown with white shafts at the basal portion, the two middle feathers jroduced beyond the rest of the tail and twisted; hind-neck and sides of neck straw colour; a band which encircles the fore-neck and lower hind-neck, is composed of white feathers barred with brown and fringed with white at the tijss. This colour extends on to the sides of the body ; throat, breast, and abdomen white; axillaries and under wing-coverts sooty-black like the vent and under tail-coverts; bill hom brown; tari and toes reddish-black. Total length $550 \mathrm{~mm}$.; culmen 3S, wing 366, tail 227, tarsus 53 .

Adult female.-Similar to the male. Nearly adult.-General colour of the upper-surface brown with pale edges and sometimes white bars to the feathers, crown of head rather paler than the back with buff edgings to the feathers; sides of the crown, nape, and hind-neck pale brown with buffy-white bars and dgings to the feathers; upper back and scapulars dark brown, the feathers 
margined with buff; lesser upper wing-coverts dark brown with earth-brown margins to the feathers; bastard-wing and primary-coverts uniform pale brown; primary and secondary flight-quills dark brown on the outer webs, paler on the inner ones which are white at the base, the shafts of the feathers conspicuously white on the outer primaries, most of the secondaries have pale narrow edges at the tips; lower back almost uniform ash-brown; rump and upper tailcorerts barred with white or smoky-white; tail dark brown, white on the basal portion of the inner webs, the two middle feathers only slightly exceeding the lateral ones in length; a pale eyebrow slightly indicated; hinder face isabelline with darls narrow shaft-lines to the feathers; throat white with pale brown pear-shaped marks on the middle of the feathers, lower throat similar, but tinged with buff; fore-neck, sides of neek, upper-breast and sides of breast pale brown barred with white or buffywhite like the sides of the body and under tail-coverts; breast, abdomen and rent white; under tail-corerts and axillaries pale brown barred with white; quills below, white at the base and brown on the apical portion like the lower aspect of the tail. Eyes and bill black. Tarsus pale blue-black on the back. Toes and webs black. Total length $475 \mathrm{~mm}$. ; culmen 39 , wing 375 , tail 155, tarsus 52.

Immature.-General colour above dark brown, the feathers everywhere margined and spotted with ochreous or rufous, more thickly on the rump and upper tailcoverts and more sparsely on the head and hind-neck; the small coverts round the bend of the wing white with dark centres; under parts more rufous and barred almost entircly over the whole surface, each feather being white at the base with two brown bars and fringed with rufous, more coarsely on the flanks; the long under tail-coverts have four brown bars; under wing-coverts brown barred with white; axillaries, some uniform grey with twin spots of rufous at the tips, others are greyishbrown barred and irregularly marked with white, fringed also with the same colour at the tips; a dark spot in front of the eye. below.

Nestling in doun.-Pale sooty-brown above with a tinge of rufous, paler sooty

Nest.-None made, the eggs are placed on the moss.

Eggs.-Clutch, two; the eggs have, on a yellowish-olive ground-colour, a few spots of greyish-brown, irregular and fairly pale, and other overlying spots of a rather deep olive-brown; others have a pale greenish ground-colour, varied by small pale ashy spots, and olive-brown ones smaller than the former and a little deeper in colour. The surface is fairly rough and a little glossy. Length 61-64 mm., by 42-46.

Breeding-season.-July.

Distribution and forms.-Along the Arctic Circle, wintering in the southern hemisphere. An castern and western form has been admitted, but the Australian specimens are not exactly in agreement, and consequently Mathews proposed the above name until more material is examined and the exact status determined.

\section{Genus STERCORARIUS.}

Stercorarius Brisson, Ornith., Vol. I., p. 56, Vol. VI., p. 149, 1760. Type (by tautonymy) : Stercorarius = Larus parasiticus Linné.

Lestris Illiger, Prodr. Mamm. et Av., p. 272, (pref. April) 1811. Type (by subsequent designation): $L$. parasiticus Linné.

Prodatrix Vieillot, Analyse nouv. Ornith., p. 65, April 14th, 1816. Typo (by monotypy): Labbe Buffon = Larus parasiticus Linné.

Oceanus Koch, Syst. baier. Zool., p. 380, (July) 1816. Type (by monotypy): L. parasiticus Linné.

Not of Montfort, Conch. Syst., Vol. I., p. 58, 1808.

Labbus "Rafinq. 1816" Gray, Cat. Gen. Subgen. Birds, p. 129, Oct. 1855. In synonymy. Atalolestris Mathews, Birds Austr., Vol. II., pt. 5, p. 500, Jan. 31st, 1913. Typo (by original designation): Stercorarius longicaudus Vieillot. 
The two species restricted to the genus Stercorarius are small Skuas with slender bills, weak legs and feet (comparatively), long wings, and very long central tailfeathers, acuminate, and attenuated into long streamers in the subgenus Atalolestris. In the subgenus Stercorarius the tail does not exceed the wing, but is about equal to it.

\section{Stercorarius parasiticus.-ARCTIC SKUA.}

[Larus parasiticus Linné, Syst. Nat, 10th ed., p. 136, Jan. 1st, 1758: coasts of Sweden. Extra-limital.]

Mathews, Vol. II., pt. 5, pl. 124, Jan. 31st, 1913.

Stercorarius parasiticus visitori Mathews, Austral Av. Rec., Vol. II., pt. 7, p. 126, Jan. 28th, 1915: Sydney, New South Wales.

Distribution,-Australia. Winter visitor.

Adult: darli phase.-General colour above and below sooty-black with white shafts to the primary-quills; the lanceolate feathers on the sides of the neck rufousbrown, nostril plumes dull white; bill brownish-horn colour, tip black; tarsi and toes black. Total length $525 \mathrm{~mm}$. ; culmen 32 , wing 333 , tail 212, tarsus 50 .

Adult: light phase.-Differs from the dark phase in having the breast and abdomen dull white like the sides of the head; cheeks, throat, and fore-neck pale brown; hind-neck pale brown with straw-coloured shaft-streaks.

Female.-General colour above smoke-brown with a hoary tinge; the feathers at the base of the fore-head whitish and those on the fore-part of the head with pale edges, hinder cromn and nape uniform brown somewhat darker than the back; the feathers on the hind-neck, grey at the base and fringed with isabelline at the tips ; the feathers on the mantle margined with pale umber as also are some of the short scapulars, but rather darker; marginal upper wing-coverts fringed with whitish or isabelline; inner webs of the primary-and secondary-quills white on the basal portion, the shafts of the primaries flattened in structure and conspicuously white in colour, but becoming dark at the extreme tips; upper tail-coverts white, more or less tinged with isabelline, banded and rery slightly tipped with brown; tail white at the base-the white decreasing in extent on the outer feathers-and brown at the tip, somewhat darker on the two central feathers which are extended beyond the lateral ones and pointed in shape; fore-part of the face inclucling the eye smoke-brown ; chin dull white ; the feathers of the throat and sides of the hinder face white at the base with a pear-shaped mark of brown at the tips; fore-neck and sides of the upper-breast almost uniform brown; remainder of the undersurface white barred and fringed at the tips of the feathers with brown, narrowly on the middle of the breast and sides of the abdomen, and broadly on the sides of the body, flanks and under-tail coverts; axillaries also broadly banded and more or less isabelline as well as white; under wing-coverts isabelline irregularly marked brown or ash-brown, some of the feathers on the margin of the wing are only fringed with white; quill-lining white at the base and ash-brown on the apical portion; lower aspect of tail brown, becoming white towards the base. Eyes and bill black; tarsus pale blue, toes and webs black. Total length $455 \mathrm{~mm}$. ; culmen 33 , wing 310 , tail 169 , tarsus 45 .

Immature male: dark phase--Dark brown above, the small coverts along the edge of the wing margined with fulvous, the head and neck all round very similar in colour, which colour is spread, more or less, over the breast; remainder of undersurface rufous or rust-brown, becoming almost black on the under tail-coverts, which have slightly pale edges.

Immature: light phase.-Upper-surface greyish-brown, the feathers having rufous edgings, the head and neck streaked with rusty-brown, sometimes rufous, the neck paler than the head; the under-surface irregularly barred, more or less distinctly with brownish bars. Individual variation very pronounced. 
Neslling in down,-Sooty-brown above, paler below.

Nest.-A depression in the moss.

Eggs.-Clutch, two; ground-colour dark stone to greenish-buff, spotted, but more at the larger end, with very dark brown to light grey; others have large irregular markings of light brown; axis 56 to $59 \mathrm{~mm}$., diameter 40 to 41 .

Breeding-season,--June, July? (Bering Island.)

Distribution and forms.-Throughout the Aretic and Subarctie zones of the Holarctic Region. The rariation seen in this species has so confused investigators among Palearctic forms that Austral-Neozelanic specimens have been incorrectly named. The eastern breeding form is different from the western, but there may be more than one subspecies also breeding in the east; therefore the only sure name is the one proposed by Mathews as given above, which should be u-eil for Australian and Neozelanic birds at present.

\section{SUBORDER CHARADRIIFORMES.}

A congregation of Stone-Plovers, Waders (commonly so called), Plovers, Jacanas, Coursers and Pratincoles constitute this suborder, which show development in many directions from an easily recognisable basis. We lave subdivited this suborder into five superfamilies, Burhinoidea, Seolopacoidea, Charadrioidea, Jacanoidea and Glareoloidea, and as we give more study to these higher groupings we recognise that this suborder is due to a misconception of the value of the internal features formally used in so dogmatic a manner, and that, later, revision will be undertaken upon reasonable lines. The anatomists refer continually to generalised features, and misunderstand specialised characters and their value, though they accept the law of recapitulation, which they do not thoroughly understand. By means of the application of this law to exterual characters and colour pattern we get a good view of the evolution of many forms whose status has entirely puzzled students of internal items only. The Burhinoidea, or Stone-Plovers, are probably the most isolated, though the Jacanas have given a lot of trouble to systematists, and the Pratincoles have met with poor treatment. From the superficial characters of these forms a fairly correct idea of their relationships should have been reached. The StonePlovers would appear to be related to the Plovers, while the Jacanas similarly show Vanelline relationship, the Coursers and Pratincoles seeming to have varied in the opposite direction from a similar Vanelline ancestral form. The large congregation of Waders and Plovers have been commonly lumped, though there are ralicl differential features characteristic of each group which merit superfamily distinction, which is here allotted. The Waders seem to have independently evolved from a pre-Larine ancestor while the Plovers have developed in a different direction; we can trace the facts in many ways, so that when more knowledge of osteological and anatomical items is attained we may be able to determine more accurately the phylogeny of the groups.

Osteological items have been littlestudied in detail : the sliull shows a schizognathous palate and schizorhinal nasals, though those of the Burhinoidea have been commonly recorded as holorhinal, through a misusage of that term; the nasals in the Burhinoidea are pseudo-holorhinal, being obviously schizorhinal in development. The presence or absence of ba ipterygoid processes varies according to the groups, being present in the superfamilies Seolopacoidea, Charadrioidea and Jacanoidea, absent in the Burhinoidea and Glareoloidea. The romer is rariable in shape and the lachrymal bone articulates with the ectetbmoid in varying clegrees. There are conspicuous supraorbital grooves and oceipital foramina in some of the groups. There are fifteen or sixteen cervical veitebra and the dor-als opisthocalous, or heterocalous: the coracoids are generally scparated and the posterior horder of the stemum two notehed; the fureula is reported as sometimes vith and without 
a hypocleidium. The carotids are two, the syrinx tracheo-bronchial, a single pair of intrinsic muscles present or absent ; the cligestive system is pericelous and orthocalous, tending to the typically mesogyrous, and caea usually large though sometimes rudimentary. The leg musele formula is variable, generally AXY + , but in many cases ABIY +. The biceps slip and expansor secundariorum generally present, but in a few cases altogether missing. The oil gland is present and feathered, an aftershaft present and the wing aquimeubital. The pterylosis of a few species is known but the variation has not been determined. The nestlings are hatched covered with down and the colour pattern of this down seems a valuable character for the recognition of groups, as it is very constant.

\section{SUPERFAMLY BURHINOIDEA.}

An ancient group with only a single family and few genera distributed generally through the Temperate and Tropical zones of the world. Superficially the whole series arree, only showing variation in size, shape and size of bill and proportions of wings, legs, etc. Thus EEdicnemus contains the smaller specios, Burhinus the larger ones with small bills, Orthorhamphus larger ones with very large straight stout bills, and Esacus larger ones with large stout recurved bills. The same style of coloration is retained by all with not much variation.

Osteologically great stress has been laid upon the holorhinal nostrils, as all other Charadriiform birds are credited with schizorhinal ones, but upon examination the holorhiny will be seen to be spurious and that the nasals are of schizorhinal origin. Another peculiar item is the variation of the leg museles within the limits of the "genus" Eidicnemus, some members having lost the femoro-caudal, while others possess the full complement. There are no basipterygoid processes nor occipital foramina but supraorbital grooves are present. The lachrymals are united to the prefrontals. The cervical vertebro are sixteen in number, while the coracoids overlap; the dorsal vertebræ are heterocelous and the sternum is four notehed at the posterior border. There are generally no intrinsic muscles to the syrinx.

\section{Family BURHINIDA.}

Four genera only are artmitted in this family, of which two are represented in Australia, one being endemic. It is noteworthy that the extra-limital "genus" Edicnemus shows more internal variation than appears externally, the variation in the leg muscles being extraordinary. The Australian endemic genus Burhinus has the formula BXY +, in this respect agreeing with the type of Eidicnemus, while other species of " $E$ dicnemus" have the formula ABXY + . Such a difference is e!sewhere regarded as of great importance, but in this group merely as of specific value.

\section{Genus BURHINUS.}

Burhinus Illiger, Prodr. Mamm. et Av., p 250, (pref. April) 1811. Type (by monotypy): Charadrius magnirostris Latham.

Planorhamphus Billberg, Synops. Faun Scand,, Vol, I., pt. II., Aves, tab. A, 1828. New name for "Burrhinus Iil.?" cf. Austral Av. Rec., Vol. II., pts 2 and 3, p. 40, Oct. 23rd, 1913.

Burhinine birds with short bills, short wings, long tails, and long legs and feet. The bill is shorter than the head, thick, and strong; nostrils pervious; the nasal depression is less than half the length of the bill with the linear nostrils placed in its anterior portion; the culmen is much lews than half the length of the metictarsus. The wing is short with the second primary longest, the first equal to the third; the wing is much less than three times the length of the metatarsus. The tail, consisting of twe!re rectrices, is long and welge shaped, and more than half 
the length of the wing. The legs are long; a long tibia is exposed ; the metatarsus is reticulate throughout, and is nearly half the length of the wing. There is no webling between the toes, and there is no hind-toe.

The genus Edicnemus differs in its smaller size and in the proportions of the wing, tail, and culmen. Thus the culmen is almost equal to half the metatarsal length; the tail is about half the wing length; and the wing, with the first primary longest, is about three times the length of the metatarsus.

Coloration grey, sandy or sandy-rufous, blotehed with black above, throat striped with black; abdomen, ete., white. Orthorhamphus is of similar coloration, but more uniform like Esacus with a huge straight, not upturned bill.

\section{Burhinus magnirostris.-STONE-PLOVER.}

Gould, Vol, VI., pl. 5 (pt. xxI.), Dec. 1st, 1845. Mathews, Vol. III., pt. 4, pl. 173, Dec. 31 st, 1913.

Charadrius magnirostris Latham, Index Ornith. Suppl., p. Lxvi, 1801 after May: Now South Wales, based on Watling drawing No, 251.

Charadrius grallarius Latham, ib. : New South Wales, based on 26. No. 246.

Charadrius frenatus Latham, ib., p. LxvII. : New South Wales, based on $i b$. No. 252.

GEdicnemus longipes Vieillot, Nouv. Dict. d'Hist. Nat., Vol. XXIII., p. 232, Sept. 5th, 1818, ex Geoffroy St. Hilaire MS. : Nouvelle Hollande ex Baudin Exp. $=$ New South Wales.

Burhinus novehollandioe Stephens, in Shaw's Gen. Zool., Vol. XIV., pt. I., p. 342, 1826 (end).

New name for $C$. magnirostris Latham.

Charadrius giganteus Wagler, Isis, 1829, heft 6, col. 648, June: New South Wales.

Edicnemus major Brehm, Isis, 1845, heft 5, col. 357, May : New South Wales.

Edicnemus australis Selater, Proc. Zool. Soc. Lond., 1859, p. 212. Error only. Nom. nud.

GEdicnemus longipes Ramsay, Tab. List. Austr. Birds, p. 35, 1888: Gulf of Carpentaria, Queensland.

Not of Vieillot as above 1818.

Burhinus magnirostris rufescens Mathews, Nov. Zool., Vol. XVIII., p. 225, Jan. 31st, 1912 :

Parry's Creek, North-west Australia.

Burhinus magnirostis ramsayi Mathews, ib. : Mackay, Queensland.

Burhinus magnirostris broomei Mathews, ib., p. 226 : Broome Hill, South-west Australia.

Distribution.-Australia generally and Tasmania.

Adult mole.-General colour of the upper-surface pale grey with black shaft-lines, more broadly on the scapulars, and brown bars and mottlings on the upper tailcoverts and tail; lesser upper wing-coverts brown margined with buff, the median coverts broadly margined on the basal portion with buffy-white, which give the appearance of an irregular wing-band; the marginal coverts round the bend of the wing greyish-brown with black shaft-lines ; bastard-wing, primary-coverts and quills black with a broad white band on the four outer primaries, secondaries dark brown with paler margins, the long innermost secondaries like the long scapulars; outer tail-feathers mottled with grey and barred with brown on the outer web and barrel with brown and white on the inner webs and tipped with black ; fore-head, lores, cheeks, a streak below the eye, and supereiliary line white like the chin and throat; ear-coverts, fore-neck and breast buff with dark shaft-streaks, which are much broader on the breast; abdomen and axillaries white; flanks and under tail-coverts buff; under wing-coverts grey with dark brown shaft-lines, the greater series with brown tijs; ; bill black; iris greyish-yellow; legs yellow, feet brown. Total length $550 \mathrm{~mm}$.; culmen 51, wing 297 , tail 170 , tarsus 138 .

Adult female. Similar to the adult male, but smaller; culmen 50, wing 275 . tarsus 132 .

Nestling in doun.-Whitish-grey above with four longitudinal black lines, two of which meet on the tail, each fringed with sandy-buff; head whitish-grey, more or less mixed with black; a black spot on the fore-head, which is continued over the eye on to the ear-coverts, also a black spot in front of the eye and a line of the same colour below the latter; throat and under-surface white with a more or less buffy tinge. 
Nestling in partial down.-Crown of head, hind-neck, back, scapulars, and tail blue-grey with dark centres to the feathers; outer scapulars tinged with rufous; the grey down still adhering to the feathers on the sides of the crown, sides of neck, rump, and tail ; fore-head, eyebrow, and throat white ; lores and ear-coverts blackish ; quills black with white downy tips ; lower throat and fore-neck dark buff with broad black shaft-lines which extend on to the sides of the body; abdomen, lower flanks, and thighs buffy-white; under tail-coverts sandy-buff.

Young.-Head and hind-neck grey, with dark central streaks to the feathers, the down still adhering to the feathers of the latter; the feathers of the back, scapulars, and lesser wing-coverts broadly margined with rufous, becoming brighter and inclining to chestnut on the wings; median coverts for the most part white with dark shaft-lines; tail grey barred and mottled with brown ; cheeks and ear-coverts buff with dark shaft-streaks; abdomen and thighs white, the latter tinged with buff ; under tail-coverts cinnamon-buff.

Nest.-A depression.

Eggs.-Cluteh, two; ground-colour stone, blotched with dark brown, more especially on the larger end ; axis $53 \mathrm{~mm}$., diameter 39.

Breeding-season.-September and October. August to January.

Distribution and forms.-Confined to Australia and Tasmania. Four subspecies are recognisable: $B$. m. magnirostris (Latham), from New South Wales, Victoria, South Australia and South Queensland; $B . m$. ramsayi Mathews, from North Queensland, Gulf of Carpentaria, etc., with longer legs $(146 \mathrm{~mm}$.) though similar length of wing ; $B . m$. rufescens Mathews, from North-west Australia and Northerm Territory, in their generally smaller size (tarsus $125 \mathrm{~mm}$.) and more rufescent upper coloration; and $B . m$. broomei Mathews, from South-west Australia, in their still smaller size, especially their shorter legs, tarsus $115 \mathrm{~mm}$., average leg measurement of typical form $135 \mathrm{~mm}$.

\section{Genus ORTHORHAMPHUS.}

Orthorhamphus Salvadori, Ann. Mus. Civ. Genova, Vol. V., p. 312, 1874. Type (by monotypy): QEdicnemus magnirostris Vieillot.

Burhinine birds with very long stout bills, short wings, short tail, and stout long legs. The bill is massive, longer than the head, with tip slightly decurved; the nasal depression is about half the length of the culmen with the long linear nostrils anteriorly placed ; the length of the culmen almost approaches that of the metatarsus.

The wing is short with the first three primaries longest and subequal. The tail is rounded and short, being less than half the length of the wing. The legs are long and stout; the metatarsus is reticulate throughout and is only about one-third the length of the wing. No hind-toe.

\section{Orthorhamphus magnirostris.-LONG-BILLED STONE-PLOVER.}

[Edicnemus magnirostris Vieillot, Nouv. Dict. d'Hist. Nat., Vol. XXIII., p. 231, Sept. 5th, 1818, ex Geofiroy St. Hilaire MS. No locality = Binongka, Celebes, in error $=$ Timor, collected by Peron. Extra-limital.]

Gould, Vol. VI., pl. 6 (pt. xxr.), Dec. 1st, 1845. Mathews, Vol. III., pt. 4, pl. 174, Dec. 31 st, 1913.

Esacus magnirostris neglectus Mathews, Nov, Zool., Vol. XVIII., p. 226, Jan. 31 st, 1912 : Lewes Island, mid-West Australia.

Esacus magnirostris melvillensis Mathews, Austral Av. Rec, Vol. I., pt. 4, p. 85, Sept. 18th, 1912: Melville Island, Northern Territary.

Esacus magnirostris queenslandicus Mathews, Austral Av. Rec., Vol. II., pt. 1, p. 6, Aug. 2nd, 1913 : Mackay, Queensland.

Distribution.-North-west Australia, Northern Territory, Queensland. 
Adult male.-Head, neck all round, back, and scapulars brown, with dark shaftlines to the feathers of the head and hind-neck; lesser upper wirg-corerts dark brown; median coverts banded with white, which shows a narrow wing-bar, the small corerts round the bend of the wing and greater coverts pale grey, outside edge of wing white; bastard-wing and primary-coverts dark brown; primary-quills also dark brown with white on the inner webs, the outer primary white on the outer web towards the tip, the second one mottled only with white, the third, fourth, and fifth have no white on the outer web, the sixth, seventh, eighth and ninth entirely white except a small patch of brown on the outer web of the sixth near the tip; secondaries white, obliquely banded with browz, the long imnermost secondaries like the back; tail-feathers brown banded with white, the white band preceded by a dark narrow cross line; lores, sides of erown, and a line under the eve black like the sides of the nape and lower cheeks; a white line above and below the eye which unites behind the latter and extends backward on to the sides of the nape; chin and throat white; breast grey, becoming paler and inclining to buffy-white on the abdomen; thighs and under tail-eoverts buff; axillaries and under wing-coverts white: bill black, operculum at base of bill, eyelid and naked skin yellow; feet yellowish grey. Total length $530 \mathrm{~mm}$.; culmen 76, wing 280, tail 120, tar.us 95 .

Adult female.-Similar to the adult male but smaller; culmen 72, tarsus 30 .

Nesiling.-Undescribed.

Nest-None made.

Eggs.-Clutch, one; ground-colour cream-white, streaked and marked all over with dark olive-brown, some of the markings being large and bold without assuming any regular form, and others mere blotches about an eighth of an inch in diameter, while many of the streaks were as fine as hair, and were of a crooked or zigzag form ; axis 61-66 mm., diameter 44-46.

Breeding-season.--October to February.

Distribution and forms.-Through the Moluccas, New Guinea and the coasts of tropical Australia. The extra-limital specimens are all lighter than Australiar ones and each may represent more than one race. Thus Mathews has separated $O$. $m$. melvillensis from Melville Island, as being darker above with the lesser wing-coverts almost black, and $O$. m. queenslandicus from Mackay, Queensland, also in being lighter above than the last named, though darker than the typical form. Oberholser has recently renamed the extra-limital form $O . m$. scommophorus, on the grounds that Vieillot's name was given to an Australian specimen, but the locality label was simply one of the many errors apparent in the relabelling of Peron's specimens.

\section{SUPEREAMILY SCOLOPACOIDEA.}

This superfamily is composed of four families, Painted Snipe, Waders (restricted), Phalaropes, and Avocets and Stilts. The relationship of the first ramed is still somewhat obseure, while the clistribution is peculiar, species being found in southern South America, South Africa, Southern Asia and Australia. The IV aders, as restricted, are all peculiar in that they breed in the Aretic and North Temperate zones and migrate southwards into the South Temperate and Antaretic zones as soon as their breeding-season, which is rery short, is over. They remain in the North Temperate zones, outside their breeding localities, cluring the winter as well as travel farthest south, while non-brecting birds will remain during the breeding-season in their southern quarters. The Phalaropes are a small group of specialised swimming waders, three in number, each of them laving lobed toes but otherwise rather distinct, and breeding in the extreme north, migrate southwards as the preceding, but sometimes erratic extensions of their migrations oceur. None have as yet occurred in Australia, but one species not uncommonly occurs as near as the Moluceas, while a specimen of another species has been recorded from New Zealand. In contradis- 
tinction to these, the Avocets and Stilts occur in tropical and subtropical regions of the world and in this family Australia has three species referable to three genera, the whole number admitted, and one of which is restricted to Australia.

The osteological items vary in this superfamily as detailed under the suborder and little attention has yet been paid to this matter. Lowe has recently begun a veries of articles but the material available is not sufficient to determine the debatable items accurately. At the present time the superficial details hereafter giren are of considerably more importance than the variable and inconstant anatomical items recorded.

\section{FAMUY ROSTRATULIDE.}

Mathews separated the Painted Snipe with family rank from a study of the superficial features and Ridgway has since suggested its separation also. The superficial features are those given for the genus which has the extraordinary rauge of South America, South Africa, South Asia and Australia, and the species are rery difficult to distinguish. The females are larger and more beautifully feathered than the males, who have to undertake the duties of incubation, while the female is said to be polyandric. The windpipe is convoluted in the adult female, but not in the male or immature female.

Recently Lowe has published some notes on the osteology of the genu:, especially as regards the skull and has concluded it "is neither Scolopacine nor Paline. It is, however, Limicoline, possibly a surviving relic of a primitive Limicoline stock." The palate is schizognathous and the nasals schizorhinal; there are well-dereloped basipterygoid processes, occipital foramina and indistinct supraorbital grooves. The premaxilla is quite peculiar when compared with that of other Scolopacoid forms.

\section{Genus ROSTRATULA.}

Rostratula Vieillot, Analyse nouv. Omith., p. 56, April 14th, 1816. Typo (by monotypy): Bécassine de Madagascar Buffon = Scolopax capensís Linné.

Rhynchaca Cuvier, Règne Anim., Vol. I., p. 487, Dec. 7th, 1816. Type (by monotypy): Scolopax capensis Linné.

Rostratuline birds with long deeurred bills, long wings, long legs and feet.

The bill is long, hard, narrow, and decurved at the tip; a deep narrow groore extends more than half-way along the sides of the upper mandible and ends abruptly ; the bill is narrow at the base and about the same width all the way, somewhat flattened immediately after the ending of the groove, but then the tip is obsoletely keeled with a slight grooving at the sides; the under mandible can scarcely be said to be grooved, but shallowly channelled on the side, and the tip of the same form as that of the upper mandible. The culmen is less than one-third the length of the wing and about equal to the metatarsus, which is longer than the middle toe.

The wing is somewhat concave though the first primary is longest, the second and third being little shorter.

The metatarsus is scutellate in front and behind with part of the tibia unfeathered; the toes are long with no interwebbing; the tail is short, composed of sixteen feathers. We can see no close relationship between the birds of this genus and Gallinagine birds.

\section{Rostratula australis.-PAINTED SNIPE.}

Gould, Vol. VI, pl. 41 (pt. Ix.), Dec. Ist, 1842. Mathews, Vol. III., pt. 4, pl. 168, Dec. 31st, 1913.

Rhynchaa australis Gould, Synops. Birds Austr, pt. Iv., App., p. 6, April 1st, 1838: New South Wales.

Rostratula australis fitzroyi Mathews, Austral Av. Rec., Vol. I., pt. 4, p. 85, Sept. 18th, 1912 :

Parry's Creek, North-west Australia.

Distribution.-Australia generally and Tasmania. 
Adult female.-Head olive-brown, minutely barred with black and divided in the middle by a white line from the base of the bill over the top of the head, a white eye-ring which widens out at the back of the eye into a large white spot; nape and hind-neck chestnut, the feathers minutely barred with black; upper back and scapulars greenish-grey, the feathers minutely speckled and barred with dark bromı; the inner webs of the inner scapulars buft which form a longitudinal line on each side of the back; the upper, lesser, median, and greater wing-coverts with narrow dark cross-bars; some of the primary-coverts, inner primaries, and secondaries silvery-grey, with narrow bars of black and buff and also white blotehes edged with black, the long innermost secondaries more inclining to dark green barred and finely vermiculated; outer primary-quills brown, darker towards the base, with goldenolive on the outer webs and oval spots of buff ; lower back, rump, upper tail-coverts, and tail silvery-grey, with wide bars of white or buff and very narrowly lined across with black; lores, sides of face, sides of neck, throat, and fore-neck dark brown, more or less mixed with white especially on the chin and throat; a pateh of dark brown on each side of the breast which terminates with olive-coloured feathers which are very narrowly barred; a broad band of white on each side of the fore-neck, which extends in a narrow line on each side of the mantle, where it joins the buff streak on the inner scapulars; middle of breast, abdomen, and under tail-coverts white like the axillaries and inner under wing-coverts; marginal under wing-coverts and the greater series grey, minutely barred with black and tinged with goldenolive; bill yellowish-brown; iris hazel; feet blue-grey. Total length $290 \mathrm{~mm}$.; culmen 45 , wing 150 , tail 52 , tarsus 43 .

Adult male.-Differs chiefly from the adult female in its smaller size and by the abseuce of the chestnut on the hind-neek, the more golden-olive on the upper wingcoverts, which have large twin spots of buff, and by the much paler and more white on the throat and fore-neck; bill, iris, feet, and legs brown. Total length $282 \mathrm{~mm}$. ; culmen 41, wing 139 , tail 49 , tarsus 38 .

Immature and Nestling.-Unknown.

Nest.-A depression lined with grass.

Eggs.-Clutch, four; around-colour cream-white, almost completely hidden by irregular broad lines of black wound round the thicker end and extending longitudinally towards the thin end, the lines are curverl and twisted forming loops and blotches; axis 30-31 mm., diameter 27-28.

Breeding-season.-November and December.

Distribution and forms.-Confined to Australia. Subspecies at present requiring confirmation, the north-western form having been separated by Mathews as $R$. $a$. fitzroyi on account of its larger size and paler wing markings.

\section{FAMILY SCOLOPACIDE.}

The inclusion of the Snipe, Sandpipers, ete., in one family has long been accepted, but it is probable that the association will prove faulty when the grouj is studied more fully. We have recently indicated the separation of three subfamilies, Calidritinæ (= Canutinæ or Eroliinæ olim), Tringinæ (= Numeninæ or Tringina olin, i.e., Totanine of older writers), and Scolopacina (Woodeocks only.) These may later be granted family rank as the differences seem ralid and important. No detailed comparison of the constituents has yet been carried out, but Lowe found many items peruliar to these groups in the osteology of the species he examined. Our separation was framed from a study of the colour pattern of the downy young of which at least three distinct types are seen. These types are somewhat permanent, as the adults ray appreciably, being referred from struetural characters to distinct genera by genus-lumpers. In the Calidritine a summer breeding-plumage of bright coloration is attained, often red, while in the Tringina little change is made for 
breeding purposes, while none at all appears in the Scolopacins (as here restricted). In the external features the first named are generally smaller birds with soft-tipped bills and short legs, the toes cleft to their bases and a small hind-toe, rarely missing; in the Tringine the species are generally larger with hard-tipped bills and longer legs, the toes with small webs between their bases and a long hind-toe, never missing ; in the Scolopracinæe the bill is hard-tipped, the birds stoutly built, the legs short and stout, the hind-toe short and thick and the toes without webs. Variations in some of these items occur which study of downy nestlings will at once explain.

Lowe's osteological features for the separation of the subfamilies are less important than the superficial ones, and some of the former are coincident with the latter, as the status of the distal end of the premaxilla, while others cited require confirmation from study of more material. Thus he apparently classed Gallinago with Scolopax, whereas it should go nearer, or with, the Calidritinæ; the bony orbital ring is complete in some cases, imperfect in others, and its value has vet to be demonstrated; the pterygoids are also said to differ but this is not entirely proven, and this remark applies to most of the insignificant characters cited.

\section{Genus DITELMATIAS.}

Ditelmatias Mathews, Birds Austr., Vol. III., pt. 4, p. 282, Dec. 31st, 1913. Type (by original designation): Gallinago hardwichii Gray.

Gallinagine birds with eighteen tail-feathers.

The bill is very long, narrow, not deep at the base, straight and not expanded at the tip, where it is wrinkled; the wrinkling is only seen at the terminal third, and the culmen shows scarcely any flattening at that point. The nostrils are short slits placed in a groove near the base of the culmen; this groove extends about two-thirds the length of the bill, but becomes indistinct after the middle. The lower mandible is similarly grooved and punetulate, and is shorter than the upper, which becomes thickened at the tip and orerlaps it. The wing is long and pointed, the first primary longest, and is more than twice the length of the culmen. The legs: and feet are strictly Totanine; the metatarsus is short, regularly covered with scutes both in front and behind, and is about half the length of the culmen. The toes are long and not webbed between; the middle toe is slightly shorter than the metatarsus, but with the claw slightly exceeds it. The hind-toe and claw are long and slender and regularly Totanine in appearance.

The tail is composed of eighteen feathers, which show little attenuation throughout, though the outermost is thin and but little shorter than the eentral ones. The tail is more nearly even than in the typical Gallinagine birds ; the outermost tail. feather in $G$. gallinago (Linné) is much shorter than the middle ones.

\section{Ditelmatias hardwickii.-SNIPE.}

Gould, Vol. VI., pl. 40 (pt. xxxII.), Sept, 1st, 1848. Mathews, Vol. III., pt. 3, pl, 166, Aug. $18 \mathrm{th}, 1913$.

Scolopax australis Latham, Index Ornith. Suppl., p. LxV., 1801, after May: New South Wales, based on Watling drawing No. 241.

Not of Scopoli., Annus 1., Hist. Nat., p. 94, 1769.

Scolopax hardwickii Gray, Zool. Miscell., pt. 1., p. 16, Nov. 5th, 1831 : Tasmania.

Distrubutron.-. Winter visitor to Australia and Tasmania, breeding in the northern hemi. sphere.

Adult male.-General colour above dark brown, the feathers everywhere barred and mottled or margined with ochreous-buff; head black, dirided in the middle and skirted on each side by sandy-buff, this latter colour more intense on the hindneck, where it almost obliterates the dark portion of the feathers; lesser upper 
wing-coverts dark brown, very narrowly fringed with white at the tips; median and greater coverts barred and tipped with ochreous-buff; bastard-wing and primary-coverts dark brown tipped with white; primary- and secondary-quills lark brown more or less edged with white at the tips, the outer web of the first primary nottled with buff, the long innermost secondaries black, barred and fringed with ochreous-buff like the scapulars; lower back, rump, and upper tail-coverts moro thickly spotted and barred with sandy-buff, some of the latter fringed with white; middle tail-feathers black with a broad subterminal bar of rufous narrowiy lined with black and tipped with white, the rufous and black fading away on the outer feathers, which are for the most part buffy-white; throat and sides of face buffywhite; a dark line from the base of the eye and passing below the latter on to the sides of the neck; fore-neck and sides of neck ochreous-buff with irregular bars of brown; middle of abdomen white; sides of body and flanks barred with brown and white as also the axillaries and under wing-coverts; under tail-coverts sandy-buff barred with brown; bill black; iris brown; feet brown. Total length $324 \mathrm{~mm}$. ; culmen 72 , wing 157 , tail 69 , tarsus 37 .

Adult female.-Similar to the adult male.

Immature.-The immature plumage of this species appears to be little clifferent from that of the adult, a more rufous shade being the only noticeable character, though the throat and breast appear more boldly streaked with black.

Nestling.-Unknown.

Nest.-A depression in the ground.

Eggs.-Clutch, three to four; ground-colour pale stone, blotched all over, but more on the larger end, with dark purplish-red spots and underlying ones of lavender ; axis $40-43 \mathrm{~mm}$., diameter $30-31$.

Breeding-season.-May. (Japan.)

Distribution and form.-Breeding in Japan, and wintering in eastern Australia and Tasmania, its northern limits being undetermined and no subspecies known.

\section{Genus SUBSPILURA.}

Subspilura Mathews, Birds Austr., Vol. III., pt. 4, pp. 295, 300, Dec. 31st, 1913. Type (by original designation): Gallinago megala Swinhoe.

Gallinagine birds with twenty tail-feathers, the outer ones attenuated.

The bill is very long, straight and thin, not much expanded at the tip, neither is it noticeably wide nor deep at the base; it is grooved along the upper mandible, but the groove becomes obsolete towards the tip where the bill is punctulate or wrinkled; the tip of the upper mandible extends beyond the lower manclible and is thickened at that point; an obsolete grooving can be seen along the side of the lower mandible, which is likewise punctulate and wrinkled towards the tip. The nostrils are short slits at the base of the bill. The wing is pointed with the first primary longest, and is a little more than twice the length of the culmen. The tibia is unfeathered for a short distance and the metatarsus, which is short, is regularly scutellated before and behind; the metatarsus is a little more than half the length of the bill. The toes are long and there is no webbing between them ; the middle toe is rery little shorter than the metatarsus, and with the claw much exceeds it. The hind-toe and claw are long. The tail is composed of twenty feathers, regularly rounded save that the two central ones are very broad and generally much longer. From the centre to the outside the tail-feathers become thin, so that the outside fire on each sicle are less than $3 \mathrm{~mm}$. in brearth, the outermost being the most attenuated.

In the genus Syilura the tail-feathers are twenty-six in number, and eight on cach side are very attenuated; these aro also much shorter than the middle ones; but in Subspilura no such distinction in size is seen. 


\section{Subspilura megala.-PIN-TAILED SNIPE.}

Mathews, Vol. III., pt. 4, pl. 167, Dec. 31 st, 1913.

Gallinago megala Swinhoe, Ibis, 1861, p. 343, Oct.: Pekin, China.

Gallinago heterocerca Cabanis, Journ, für Orn., 1870 (June No.), p. 235 : Luzon.

Gallinago australis oueni Mathews, Nov. Zool., Vol. XVIII., p. 223, Jan. 31st, 1912 : Parry's

Creek, North-west Australia.

Distribution.-Winter visitor to Northern Australia, breeding in the northern hemisphere.

Adult male.-Differs from Ditelmatias hardwiclii (Gray) in its smaller size, and in baving twenty tail-feathers, the outer six on each side being rery narrow, the outermost being the narrowest and the others increasing in wicith. The light streaks in the head are much lighter-that is, with only a tinge of buff; the colouring of tho upper-surface is much lighter. The two outer tailffeathers are tipped with white, with irregular bands of brown, more noticeable on the inner web: the next four becoming gradually more uniform blackish-brown; distal half of bill blackishbrown, basal half of upper mandible greyish-brown; base of lower mandible grey; iris brown; feet and tarsus lead-grey. Total length $257 \mathrm{~mm}$. (in the flesh); culmen 59 , wing 138 , tail 55 , tarsus 35.

Adult female.-Similar to the male.

Immature.-Duller above, with rufous edgings to the feathers above and behind the eyes, to the inner webs of the scapulars and upper tail-coverts; the wing-coverts more dusky; the markings on the seapulars and secondaries are more rufous; the outer tail-feathers lack the bold white tips of the adult, the markings being dusky ; the under tail-coverts are also dusky-rufous, not pale buffy-white, and the feathers of the throat and upper-breast have longitudinal black centre-streaks.

Nestling.-Does not appear to have been described.

Nest.-A hollow, lined with grass.

Eggs.-Clutch, four; ground-colour, creamy-white or a little more yellow or pale, dirty ochre. The spots of the lower end are of pale reddish, the upper reddish-brown or brown; the larger ones slanting, and coming together at the larger end, where there are also sometimes either zigzags or spots; on the rest of the surface there are only dots and little stripes; axis $40-43 \mathrm{~mm}$., diameter $30-32$.

Breeding-season.-June. (Siberia.)

Distribution and forms.-Breeding in Eastern Siberia from Lake Baikal to the Sea of Japan, ranging southward in winter to Northern Australia, where it has been recorded from Northern Territory and North-west Australia, but oceurs in Dutch New Guinea, so should be looked for in Queensland. No subspecies are linown.

\section{Genus CALIDRIS.}

Calidris (Anon.) Allg. Lit. Zeitung, Vol. 2, No. 168, June 8th, 1804, col. 542. Type (by tautonymy): Tringa calidris=Tringa canutus Linné. (cf. Richmond (3) p. 581, Aug. 25th, 1917.)

Canutus id., ib. Type (by monotypy): "Knot" = Tringa canutus Linné.

Calidris Cuvier, Règne Anim., Vol. I., p. 489, "1817" = Dec. 7th, 1816 . Type (by monotypy): Tringa canutus Linné.

Canutus Brehm, Handb. Naturg. Vögel Deutschl., p. 653, (pref. July) 1831. Type (by tautonymy) : Tringa canutus Linné.

Tringa Gray, List. Genera Birds, 1st ed., p. 69, April 1840. Typo (by original designation) : Tringa canutus, Linné.

Not of Linné, Syst. Nat., 10th ed., p. 148, 1758.

Stout medium Warters with short straight bills, long wings, short tail, short stout legs and feet. The culmen is short, stout and straight, the tip decidedly expanded but not punctulate; the groove in the upper mandible extends almost to the tip. The culmen is noticeably depressed, in the terminal half, to the tip; 
is longer than the motatarsus, and a little more than half the length of the tail. The wings are long and very pointed, the first primary longest. The tail is short and even less than half the length of the wing. The tarsus is short and stout, regularly scutellate in front and behind; it is about the same length or a little lens than the culmen, but longer than the middle toe. The toes are short, strong, and widely margined, though cleft to the base; the middle toe is about two-thircls the length of the tarsus. A strong hind-toe and claw are present.

\section{Calidris canutus. - KNOT.}

[Tringa canutus Linné, Syst. Nat, 10th ed,, p. 149, Jan. 1st, 1758: Europe. Extra-limital.] Mathews, Vol. III., pt. 3, pl. 163, Aug. 18th, 1913.

Canutus canutus rogersi Mathews, Birds Austr., Vol. III., pt. 3, p. 270, Aug. 18th, 1913 : Japan.

Distributxon,-Winter visitor to Australia, breeding in the northern hemisphere.

Adult male in summer-plumage.-Sides of face, sides of crown, throat, and under-surface rufous, abdomen white, and the under tail-coverts have narrow black streaks; axillaries white with brown bars; under wing-coverts white with small dark frecklings; the top of the head black with rufous margins to the feathers ; hind-neck grey with dark shaft-lines; back and scapulars black with chestnut or white edgings to the feathers of the former and twin spots on the latter; lesser upper wing-coverts, median, and the greater series pale brown, the latter tipped with white ; bastard-wing dark brown, as also the primary-coverts, which have white tips; primary-quills dark brown, black at the tips and white shafts; secondaries paler brown with white tips and whitish inner webs, the long innermost feathers like the back ; rump grey with whitish tips to the feathers; upper tail-coverts white, barred and longitudinally lined with black; tail-feathers grey; eyes brown; feet olivebrown ; bill black. Total length $258 \mathrm{~mm}$. ; culmen 31 , wing 156 , tail 64 , tarsus 31 .

Adult female in summer-plumage.-Very similar to the adult male.

Adult male in winter-plumage.-Ash-grey above, with narrow dark shaft-lines to the feathers; wings much the same as that of the summer-plumage; upper tailcoverts also similar but not so strongly pronounced; sides of face, throat, and entire under-surface white, with minute pale brown shaft-streaks on the sides of the face and frecklings of the same colour on the breast and sides of the body and, more sparsely, on the abdomen and under tail-coverts; axillaries longitudinally marked with brown and white.

Adult female in winter-plumage.-Similar to the adult male.

Immature.-Differs from the winter-plumage in having black submarginal lines fringed with white to the feathers of the back and wings, which are brown; under parts buffish-white, with an indistinct ehest band of darker shade.

Nestling in down.-Fore-head warm buff, with a central black line; over the eye a double black line ; crown, from centre backwards, black slightly raried with rufous and dotted with buff; nape creamy-buff, slightly varied with blackish; upper-parts black, slightly varied with reddish-brown, and profusely dotted with creamy-white; under parts very slightly washed with warm buff. Specimens in the British Museum, probably through exposure, are greyish-brown, mottled with black and spangled with white; under parts nearly white.

Nest.-In a hollow in the ground, lined with lichen.

Eggs.-Clutch, four; greenish-grey, finely spotted all over with pale inky shell markings and blackish surface spots, sometimes the latter larger and bolder at the larger end; somewhat variable in coloration. Average measurements: axis $43 \mathrm{~mm}$, diameter $30 \mathrm{~mm}$.

Breeding-season.-July. 
Distribution and forms.-Throughout the Arctie Regions of the northern hemisphere ranging southward in winter almost into the Antaretic Regions. Three subspecies have been differentiated, as follows: Calidris canutus canutus (Linné) from the European Region; Calidris canutus rufus (WVilson) from the American Region; and Calidris canutus rogersi (Mathews) from the Eastern Asiatic Region, the last named visiting Australia in winter. In summer-plumage the first named is darkest, the second palest, the last somewhat intermediate, but has a white abdomen; in winter-plumage the Ameriean birds are paler than the European and similar to the Eastern Asiatic birds. In series the races are very marked.

\section{Genus ANTELIOTRINGA.}

Anteliotringa Mathews, Birds Austr., Vol. III., pt. 3, p. 274, Aug. 18th, 1913. Type (by original designation): T'otanus tenuirostris Horsfield.

Medium, stoutly-built Waders with long straight bills, long wings, short tails and short stout legs, and strong feet.

The bill is long, straight, and fairly stout; it is however proportionately more slender than that of Calidris = Canutus, with which genus it has been confused ; the nostrils are very long, and the tip is less expanded than in Calidris = Canutus ; the culmen is longer than the metatarsus.

The wings are long and narrow with the first primary longest. The tail is short and square, somewhat emarginate, about one-third the length of the wing. The metatarsus is stout and short, noticeably shorter than the culmen, and about half as long again as the toes. The middle and hind-toe are short and strong.

\section{Anteliotringa tenuirostris.-GREAT KNOT.}

Gould, Vol. VI., pl. 33 (pt, xxxiv.), Dec. 1st, 1848. Mathews, Vol. III., pt. 3, pl. 164, Aug. 18 th, 1913.

Totanus tenuirostris Horsfield, Trans, Linn. Soc. (Lond.), Vol. XIII., pt. I., p. 192, 1821 : Java. Schoniclus magnus Gould, Proc. Zool. Soc. (Lond.), 1818, p. 39, Nov. 14th: Australia.

Tringa crassirostris Temminck et Schlegel, Fauna Japonica (Siebold), pl. 64, 1849: Japan.

Distribution.-Winter visitor to Australia, breeding in the northern hemisphere.

Adult male in summer-plumage.-Upper-surface black, white, and chestnut; head and hind-neck black, streaked with white or grey; back and seapulars black, fringed with white and twin spots of chestnut on the latter; wings dark grey or pale brown with lighter edges to most of the coverts, the major coverts more distinctly margined with white; bastard-ming and primary-coverts blackish, more or less tipped with white; primary-quills also blackish on the outer webs and at the tips, pale brown on the inner webs and the shafts white; secondaries ash-brown, fringed with white, the long innermost feathers dark brown with hoary edges; lower back pale brown with white fringes to the feathers; upper tail-coverts white with dark lanceolate shaft-lines or irregular dark spots; tail ash-grey, somewhat darker on the middle feathers; sides of face, throat, and under-surface white with streaks of brown on the fore-head and sides of face, and oval spots of dark brown on the fore-neck, breast, and sides of body-much more sparsely on the latter; a few dark streaks on the under tail-coverts and some elongated brown marks on the flanks; axillaries white, irregularly marked with pale brown longitudinally; under wingcoverts white; iris brown; feet olive-brown; bill black, base of lower mandiblo brown. Total length $292 \mathrm{~mm}$.; culmen 40, wing 186, tail 70, tarsus 34 . back.

Adult female in summer-plumage.-Differs only in having less rufous on the

Adult in winter-plumage.-Differs chiefly in being greyer above with no black 
or chestnut, and the streaks and spots on the breast and sides of body are paler in colour and smaller in size.

Immature.-Somewhat like summer-plumage; heal with broader brown tips, feathers on back dark brown but with faint white tips; coverts with white tips, primaries and tail-feathers with white tipping; very pale brownish spotting on breast and flanks, a few elongated streaks on latter; no chestnut on back, and much darker than winter-plumage; bill weak.

Nestling, Nest and Eggs.-Appear to be undescribed.

Distribution and forms.-Eastern Siberia to Japan, ranging in winter to Australia, hitherto chicfly from the northem parts, but recently recorded by Alexander from the southern coast of South-mest Australia. No subspecies are linown.

\section{Genus PLATYRHAMPHUS.}

Platyrhamphus Billberg, Synops. Faunx Scand., Vol. I., pt. II, Aves, tab. A and p. 172, 1828. Type (by monotypy): Numenius pusillus Bechstein = Scolopax falcinellus Brünich, $c f$. Austral Av. Rec., Vol. II., pts. 2 and 3, p. 4l, Oct. 23 rd, 1913.

Limicala Koch, Syst. baier. Zool., p. 316, July 1816. Type (by monotypy): Limicola pygmara = Scolopax falcinellus Brünnich.

Not Limicula Vieillot, Analyse nouv. Ornith., p. 56, April 1816.

Falcinellus Kaup, Skizz. Entwick.-Gesch. Nat. Syst., p. 37, pref. April 1829. Type (by monotypy): Tringa platyrhyncha Temminck $=$ S. falcinellus Brünnich.

Not of Vieillot, Analyse nouv. Ornith, p. 47, 1816.

Smallest Waders with very long broad bills, long wings, medium tail, short legs and feet.

The culmen is very long, broad, from the middle flattened and with the tip decurved; the groove in the upper mandible becomes obsolete in the terminal half, due to this flattening; the culmen is much longer than the tarsus which is again longer than the middle toe.

The wings are long and narrow with the first primary longest. The tail is more than one-third the length of the wing, and is doubly emarginate like that of Pisobia. The metatarsus is short, regularly scutellate both in front and behind; it is not much more than two-thirds the length of the culmen, and nearly half as long again as the middle toe. The feet are small, the midclle toe being much shorter than the metatarsus; short hind-toe present.

\section{Platyrhamphus falcinellus.-BROAD-BILLED SANDPIPER.}

[Scolopax falcinellus Brünnich, Ornith. Boreal., p. 49, (pref. Feb. 20th) 1764, ex Pontoppidan, Der Danske Atlas, Vol. I., p. 623, pl, xxv1., 1763: "Siælandia," Europe. Extra-limital.]

Mathews, Vol. III., pt. 3, pl. 165, Aug. 18th, 1913.

Limicola sibirica Dresser, Proc. Zool. Soc. (Lond.), 1876, p. 674, Oct. 1st: China.

Limicola falcinellus rogersi Mathows, Austral Av. Rec., Vol. III, pt. 4, p. 70, July 21 st, 1917 : Melvillo Island, Northern Territory.

Distribution.-Winter visitor to Northorn Australia, breeding in the northern hemisphere.

Adult male (winter).-General colour above ash-grey with dark shaft-lines and white fringes to the feathers, some of the feathers on the upper back black, margined on the sides with ferruginous, like some of the long seapulars; bastard-wing and lesser marginal wing-coverts sooty-brown; median coverts brown with darker shaft-lines and fringed with white, greater coverts similar but paler and inclining to ash-grey; primary-covert.s blackish; primary-quills dark brown with white shafts, paler on the inner webs and inclining to white towards the base; secondaries pale brown, margined with white and with nore or less white at the base ; some of 
the long innermost secondaries sooty-black, with ferruginous margins anrl tipped with ash-grey; middle of the lower back, rump, and upper tail-coverts sootyhlack, fringed with white, grey, or ferruginous; tail-feathers ash-brown with white shaft-lines and white margins, crom of head, hind-neck, and sides of neek blackishbrown, with grey and sometimes white margins to the feathers; sides of the fore-head and an indistinct line over the eye white, the feathers above and behind the latter more or less streaked with dusky-brown; loral streak and ear-coverts dusky-brown, the feathers on the fore-neck inclining to grey with broader clark centres, which form a band; remainder of the under-surface white, including the breast, abdomen, under tail-coverts, sides of rump, sides of body and axillaries; thighs dusliy-grey; under wing-coverts white, finely mottled with brown round the margin, the primarycoverts and quill-lining greyish-brown. Total length $175 \mathrm{~mm}$; culmen 31, wing 106, tail 37, tarsus 23. The sexes are alike.

Adult male (summer).-General colour of the upper-surface sooty-black with ferruginous and white margins to the feathers; bastard-wing and marginal wingcoverts dark brown, lesser and median coverts grey with dark centres; greater coverts pale brown, margined with white; primary-coverts and primary-quills dark brown, the latter having white shafts and pale inner webs becoming white at the base; secondary quills pale dusky-brown with white margins and white bases, the long innermost secondaries black, broadly margined with ferruginous; upper tail-coverts black, narrowly fringed with ferruginous; tail-feathers pale brown, margined with white, becoming much paler on the outer feathers; crown of head black with slight ferruginous margins to the feathers and divided by a whitish streak on each side of the crown; sides of fore-head white, superciliary line also white, more or less intermixed with minute lines of pale brown like the cheeks and sides of neck; loral spot blackish, sides of breast grey, narrowly centred with dark brown; under-surface white with a buffy tinge; axillaries and sides of rump pure white; under wing-coverts white, mottled with pale brown on the margin ; primary-coverts and quill-lining pearl-grey.

Immalure. - Fore-head grey with white tipping, top of head dark brown, neck grey, back dark brown with pale buff and white tips, coverts grey with black centres and tips grey, primaries with white tips, tail-feathers with white tips; under-surface white with indistinct ashy-grey breast-band; bill small and weak, otherwise very like summer-plumage but lacking ferruginous edging to the feathers.

Nestling in down.-Upper-surface mottled with black and rich red-brown, definite pattern indeterminable, the black being predominant, very thickly spangled with minute white specks; frontal streak distinct, and as well as a loral streak there is a pronounced malar stripe; under-surface very pale buffish tinge on chest, otherwise pure white; the bill is long and shows the beginning of the flattening of the tip.

Nest.-A depression in the moss, on a marsh, lined with withered leaves and grass.

Eggs.-Clutch, four; ground-colour stone-buff with a few pale purplish underlying shell spot; and closely marked, so as sometimes to almost appear uniform, with rich dark umber-brown or rufous-umber spots. Arerage measurements: axis $32 \mathrm{~mm}$., diameter $23 \mathrm{~mm}$.

Breeding-season.-June.

Distribution and forms.--Northern Europe and Asia, migrating southward for the winter, and two well-marked subspecies are distinguirhable: $P$. f. falcinellus (Brimnich ex Pontoppidan) from Europe; and P. f. sibiricus Dresser from Chin and East Siberia, a much paler race, in summer-plumage having the feathers on the upper side with bright rufous margins, while the western race has black back with narrow white or ochreous-white margins. 


\section{Genus EROLIA.}

Erolia Vioillot, Analyse nouv. Ornith., p. 55, April 14th, 1816. Type (by monotypy) : Erolia variegata Vieillot $=$ Tringa jerruginea Brünich.

Falcinellus Cuvier, Regne Anim., Vol. I., p. 486 [1817 =] Dec. 7th, 1816. Type (by mono. typy): Scol. pygmea Lin. $[=$ Gmelin $]=T$. ferruginea Brünnich.

Not of Vieillot, Analyse nouv. Ornith., p. 47, April 1816.

Ancylocheilus Kaup, Skizz. Entwick.-Gesch. Nat. Syst., p. 50, (pref. April) 1829. Type (by monotypy): Tringa subarquata Gueldenstadt $=T$. ferruginea Brünich.

Acrolia Temminck et Laugier, Planch. Col. d'Ois., Vol. V., pl. 510, note, 1830 . Error only.

Small Waders with long decurved bills, long wings, short tails, short legs, and short toes.

The long slender culmen is decurved, with the groove in the upper mandible extending almost to the tip, which is not expanded. The culmen is longer than the metatarsus, and almost exactly twice the length of the middle toe. The wings are long and pointed, the first primary longest. The tail is short, doubly emarginato as in Pisobia, much less than half the length of the wing and not much longer than the culmen. The metatarsus is short, about three-fourths the length of the culmen ; it is regularly scutellate, both in front and behind. The toes are all cleft to the base, the middle toe about two-thirds the length of the metatarsus; a long hindtoe present.

\section{Erolia ferruginea.-CURLEW-SANDPIPER.}

[Tringa /crraginea Brünnich, Ornith. Boreal., p. 53, (pref. Feb. 20th) 1764: Iceland. Extra. limital.]

Gould, Vol, VI., pl. 32 (pt. xxxII.), Dec. 1st, 1848. Mathews, Vol, III., pt. 3, pl. 162, Aug. 18 th, 1913 .

Tringa (Pelidna) chinensis Gray, Zool. Miscell., pt. I., p. 2, Nov. 5th, 1831: China.

Erolia ferruginea wilsoni Mathews, Austral Av. Rec., Vol. III., pt. 4, p. 70, July 21st, 1917 : Wilson's Inlet, South-west Australia.

Distribution.-Winter visitor to Australia, breeding in the northern hemisphere.

Adult male in summer-plumage.-Head and hind-neck dark brown with rufous margins to the feathers, which is shown more intensely on the latter; the feathers of the mantle, upper back, and scapulars tipped with white, and spotted with chestnut on the margins; lower back blackish with pale edges to the feathers; upper tailcoverts white, barred with black; tail ash-grey with white shafts to the feathers; lesser wing-coverts dark brown like the bastard-wing and primary-coverts, some of the latter tipped with white; median coverts pale, as also the greater coverts which are tipped with white; primary-quills dark brown with white shafts and pale brown inner webs, some of the inner primaries edged with white on the outer wobs; secondaries for the most part white with brown on the outer webs, the long innermost secondaries blackish, edged with rufous and fringed with white at the tips; sides of face, throat, and under-surface of body chestnut, more or less tinged with white, becoming paler on the vent and uncler tail-coverts, the latter having dark sagittate markings and cross-bars; axillaries and under wing-coverts white, the small marginal coverts dotted with pale brown; bill and feet black; eyes brown. Total length $210 \mathrm{~mm}$, ; culmen 39, wing 127, tail 48, tarsus 30 .

Adult female in summer-plumage.-Similar to the adult male.

Adult male in winter-plumage.-Differs from the summer-dress by the grey of the upper-surface and the almost uniform white on the under parts.

An alult female collected in March is just beginning to put on the summerdress, which may be seen by the rufous feathers on the fore-neck, breast, and the sides of the body.

Immature.-[Tper-surface brown, feathers with white tips forming a scalloped 
appearance; head speckled, the feathers of the back of the neck dull grey tips, the upper back darker; scapulars and inner secondaries bright brown with buffish tips, coverts with broad whitish tips, secondaries with broad white edges; rump feathers with dull grey tips; upper-tail coverts pure white; tail tipped with white ; undersurface white with a greyish breast-band, feathers with dark shaft-stripes.

Vestling in down.-Golden-buff and rich red-brown mottling above, with white spangling; under-surface buffy-white, darker on chest, paler on abdomen.

Nest.-A depression in the ground.

Eggs.-Clutch, four; ground-colour pale greenish-grey, marked with a few purplish-grey underlying spots, and rich deep rufous-brown surface spots and large blotches, the latter collected at the larger end; axis $36.75 \mathrm{~mm}$., diameter 25.65 .

Breeding-season.-June. (Taimyr River, Siberia.)

Distribution and forms.-Breeding in the Aretic Regions of Europe and Asia, migrating southward to Australia in the winter. Eastern and western subspecies are admitted, the eastern form being paler in both summer- and winter-plumage.

\section{Genus LIMNOCINCLUS.}

Limnocinclus Gould, Handb. Birds Austr., Vol, IY, p. 254, Dec. 1865. Type (by subsequent designation, Salvadori, Ornit. Pap. e Mol., Vol. III., p. 312, Dec. 1882): Totanus acuminatus Horsfield.

Small Waders with short straight bills, long wings, short tails, short legs, but stout and long toes.

The culmen is short, straight, and slightly expanded at the tip, the groove in the upper mandible extending almost to the tip; it is shorter than the metatarsus and about equal to the middle toe alone.

The wings are long and pointed, with the first primary longest. The tail is less than half the length of the wing, and is just twice the length of the metatarsus. It is strongly wedge shaped. The metatarsus is short but stout, regularly scutellate in front and behind; quite appreciably longer than the culmen, also than the middle toe and claw. The hind-toe is comparatively short; all the toes are cleft to the base.

\section{Limnocinclus acuminatus.-SHARP-TAILED STINT.}

Gould, Vol. VI., pl. 30 (pt. xxvII.), Sept. 1st, 1847. Mathews, Vol. III., pt. 3, pl. 161, Aug. 18 th, 1913.

Totanus acuminatus Horsfield, Trans. Linn, Soc. (Lond.), Vol. XIII., pt. I., p. 192, 1821 : Java.

Tringa australis Jardine and Selby, Hlustr. Ornith., Vol. II., pl. 91, Aug. 1830 : New Holland. Not of Gmelin, Syst. Nat., Vol. I., p. 679, 1789.

Limnocinclus acuminatus rufescens Mathews, Bull. Brit. Orn. Club., Vol. XXXVI., p. 82, May 25th, 1916 : North-west Australia.

Distribution.-Winter visitor to Australia and Tasmania, breeding in the northern hemisphere.

Adult male.-Upper-parts dark brown with paler brown bases and ferruginous or grey margins to the feathers of the head, hind-neck, back, scapulars, rump, and central upper tail-coverts; sides of rump and lateral upper tail-coverts white with dark shaft-streaks, some of the long coverts have a dark submarginal line; lesser and marginal upper wing-coverts dark brown narrowly edged with ash-grey, the median coverts greyish-brown with darker shaft-lines, the greater coverts moro uniform brown with pale elges and broadly fringed with white at the tips; bastardwing and primary-coverts dark brown, the latter edged with white at the tips, more conspicuously on the inner ones; marginal coverts on onter edge of wing dark brown fringed with white; primary-quills clark brown, paler on the inner webs and at the tips, the shafts partially white, the secondary-quills similar but the inner 
ones paler and more broadly edged with white; central tail-feathers dark brown fringed with ferruginous, the outer feathers pale brown and edged with white; a circle of short white feathers surrounds the eye ; fore-head, lores, a line over the eye, sides of face, and throat white, with dark pear-shaped spots on the middle of the feathers, which become larger and coarser on the ear-coverts, sides of neck, lower throat, and chest which are tinged with ferruginous, some of the feathers on the sides of the chest and breast are more or less grey; breast and sides of body paler with dark V-shaped markings to the feathers; middle of abdomen white ; under tail-coverts white with dark lanceolate markings to the feathers; under wing-coverts dark brown broadly fringed with white, the greater series greyishbrown with white borders; under side of quills also greyish-brown, paler on the inner webs at the basal portion, and with conspicuous white shafts; bill brown, base of lower mandible pale brown; iris brown; feet and legs olive. Total length $230 \mathrm{~mm}$. ; culmen 25, wing 125-130, tail 55, tarsus 30 .

Adult female.-Similar to the adult male.

Immature.-Head, upper back, and scapulars black, with rufous or white elgings to the feathers; hind-neek dark brown, the feathers margined with buffy-grey; lesser, median, marginal, and greater wing-coverts dark brown, edged with white at the tips, inclining to grey on the inner coverts; bastard-wing and primarycoverts dark brown, some of the latter narrowly tipped with white; primaryand secondary-quills also dark brown, the latter fringed with white at the tips; lower back, rump, and upper tail-coverts dull black, the feathers of the latter margined with rufous at the tips; the lateral upper tail-coverts white, with black shaft-lines; middle tail-feathers dark browr, edged with rufous, the outer feathers pale brown with white margins; throat, lores, and eyebrow whitish; sides of face, sides of neck, fore-neck, and sides of breast buff with dark narrow shaft-lines; middle of breast and sides of body uniform sandy-buff; abdomen and under tailcoverts dull white, with dark shaft-streaks to the latter; axillaries and under wingcoverts white; the marginal coverts dark brown, edged with white, the greater under wing-coverts grey, tipped with white; bill brown, base of lower mandible olive-brown; iris brown; tarsi and feet olive-yellow. Total length $215 \mathrm{~mm}$.; culmen 25, wing 128 , tail 56, tarsus 30 .

Nestling, Nest and Eggs.-Unknown.

Distribution and forms.-Breeds in Siberia, migrating southward to Australia, etc., in winter.

\section{Genus PISOBIA.}

Pisobia Billberg, Synops. Faura Scand., Vol. I., pt. Ir., p. 136, 1828. Type (by subsequent designation, Amer. O.U. Comm., Auk, July 1908, p. 366): Tringa minuta Leisler (cf. Austral Av. Rec., Vol. II., pts, 2 and 3, p. 40, Oct. 23rd, 1913.)

Leimonites Kaup, Skizz. Entwick.-Gesch. Nat. Syst., p. 37, (pref. April) 1829. Type (by monotypy): Tringa temminckii Leisler.

Actodromas Kaup, ib., p. 55. Type (by monotypy): T. minuta Leisler.

Heteropygia Coues, Proc. Acad. Nat. Sci. Philad., 1861, p. 190, July. Typo (by original designation): Tringa bonapartei $=$ Tringa fuscicollis Vieillot.

Delopygia Coues, ib. (note). Alternative namo for Heteropygia.

Neopisobia Mathews, Birds Austr., Vol. III., pt. 3, p. 245, Aug. 18th, 1913. Type (by monotypy): Totanus damacensis Auct. not Horsfield = Tringa subminuta Middend.

Smallest Waders with short straight slender bills, long wings, comparatively long tails, short legs, and short feet. The culmen is short, straight, and slender, with the groove in the upper mandible extending almost to the tip ; the tip is somewhat expanded and fairtly punctulate. The culmen is shorter than the metatarsus, and less than half the length of the tail.

The wings are long and pointed with the furst primary longest. The tail, which is strongly doubly emarginate, is less than half the length of the wing but more than 
one-third, and is twice the length of the culmen. The metatarsus is short, regularly scutellate both in front and behind, longer than the culmen and also the middle toe. The toes are all cleft to the base and a hind-toe is present.

The bird described by Middendorff as Tringa subminuta differs from the preceding in its longer legs and especially longer toes and claws. The hind-toe and claw is also very long. The metatarsus is more than a fourth the length of the wing, and the middle toe is longer than the culmen; in typical members of the genus Pisobia the metatarsus is less than one-fourth the wing and the middle toe is shorter than the culmen.

\section{Pisobia ruficollis.-RED-NECKED STINT.}

Gould, Vol. VI., pl. 31 (pt. xxxII.), Sept. 1st, 1848. Mathews, Vol. III., pt. 3, pls. 159-160, Aug. 18th, 1913.

Trynga ruficollis Pallas, Reise Russ. Reichs., Vol. III., p. 700, 1776 (pref. Feb. 10th, O.S.): Siberia.

Totanus damacensis Horsfield, Trans. Linn. Soc. (Lond.), Vol. XIII., pt. I., p. 192, 1821 : Java. Tringa albescens Temminck et Laugier, Planch. Color. d'Ois., 7e livr. (Vol. I., pl. 41), Feb. 1821 : Australia.

Trynga salina Pallns, Zoogr. Rosso-Asiat., Vol. II., p. 199, 1827 : Mongolia.

Calidris australis Lesson, Traité d'Orn., 7e livr., p. 558, April 9th, 1831 (ex Cuvier MS.). New name for Tringa albescens Temm.

Distribution,-Winter visitor to Australia and Tasmania, breeding in the northern hemisphere.

Adult male in summer-plumage.-Head and neck all round rufous, like the back and scapulars, with dark centres to the feathers; the long innermost secondaries dark brown with chestnut margins ; bastard-wing, lesser, median, and greater wingcoverts dark brown, the latter tipped with white, which forms a wing-bar ; primarycoverts dark brown, the inner ones tipped with white, primary-and secondaryquills also dark brown with white shafts ; rump and upper tail-coverts dark brown, the feathers edged with white, the long central upper tail-coverts black; middle tail-feathers dark brown, the outer feathers pale grey; base of fore-head and chin whitish; sides of breast grey with blackish centres to the feathers; remainder of the under-surface white, with a tinge of buff on the abdomen, sides of body, and under tail-coverts; bill and feet black; eyes brown. Total length $152 \mathrm{~mm}$.; culmen 17 , wing 102 , tail 43 , tarsus 21 .

Adult female in summer-plumage.-Similar to the male, but rather more grey on the feathers of the upper-surface, throat, and sides of face; it is also paler.

Adult male in winter-plumage.-Upper-parts grey, with dark shaft-lines to the feathers of the head, back, scapulars, and wings; the small marginal upper wingcoverts dark brown like the bastard-wing and primary-coverts, major coverts tipped with white which forms a wing-bar; primary-quills dark brown with white shafts ; secondaries brown, with white on the inner webs ; rump, upper tail-coverts, and tail much the same as in the summer-plumage; fore-head, sides of face, and a faintly indicated superciliary streak white, like the chin, throat, and the entire under-surface.

Another bird, collected in May and still in winter-plumage, differs in being somewhat paler grey, and in having the dark central spot to the feathers on the side of the breast larger.

An adult female, collected in March, is just beginning to assume the breedingdress, which is by the appearance of rufous on the throat and top of the head, and the chestnut on the margins of the scapulars.

Adult female in winter-plumage.-Similar to the adult male.

Immature.-Top of head brownish-black with buffish edges to the feathers; bromish loral stripe; back black with buffish and white edges; lower back and 
rump with grey tipping; coverts with paler tips, scapulars with broad whitish tips. inner secondaries with buffish tips, outer seconlaries with white elgings; undersurface white with an indistinct ashy band across chest.

Nestling, Nest and Eggs.-Appear to be undescribed.

Distribution and forms.-Breeding in the Arctic Regions of eastem Palnarctica, migrating southwards to Australia and Tasmania in winter. No sub-pecies are known and it is a distinct species from $P$. minuta, though apparently geographically replacing that species.

\section{Pisobia subminuta.-LONG-TOED STINT.}

Mathews, Vol. III., pt. 3, pls. 159-160, Aug. Sth, 1913.

Tringa subminuta Middendorf, Sibirische Reise, Vol. II., pt. 2, p. 222, 1851 : Siberia.

Pisobia subminuta boucri Mathers, Emu, Yol. XVI., pt. 1, p. 35, July 1st, 1916: Fitzroy River, North-west Australis.

Drstrmbtrox. - Siberia to Australia (visitor). One specimen preserved in Mathews's collection.

Adult male in summer-plumage.-General colour abore black, rufous, and grey ; cromn of head, back, and scapulars black, the feathers margined with rufous; ujijer lind-neck inclining to brown, with gres margins ; lesser, median, and greater mingcorerts brown, with pale or whitish margins at the tips ; bastard-wing and primarycoverts dark brown, the latter tipped with white; primary-quills also dark brown, the outer, or first, primary with a white shaft ; secondaries pale brom, fringed with white at the tips, the long immermost secondaries dark brown with rufous margins; rump and upper tail-coverts black, the lateral feathers white: middle tail-feathers blackish with pale margins, the outer feathers grey with white edges ; superciliary line whitish; sides of face and sides of neck butt. with pale brown streaks becoming broader on the sides of the neck and narrower again on the lower throat; chin and upper throat white like the breast, abdomen, and under tail-coverts : sides of breast like the sides of the neck; axillaries white as also the median under wing-corerts, the marginal coterts and the greater series pale brown; bill black, base of lower mandible olive-brom, iris dark brom ; feet greenish-yellow. Totallength $163 \mathrm{~mm}$; culmen 18 , wing 93 , tail 40 , tarsus 22 .

Adult female.-Similar to the adult male.

Adult in winter-plumage - Differs from the male in summer-dress by the absence of rufous on the feathers of the upjer-surface, which is replaced by olive margins; the grey on the hind-neck as well as the darli grey on the fore-neck and chest, and the marginal corerts on the under-wing being almost black.

Immature.-Top of head dark brown with pale eigings to the feathers ; indistinct loral brown streal; ; back of neck grerish-brown with paler grey elges: upper back black with buff elgings: lower back black as rump, latter with white tips: tail-feathers with white tips, centre pair with luthsh tips: seapulars and inner secondaries with broad buff elges. corerts with white tips: throat white, chest mith dusky-grey streaks, rest of under-surface pure white.

Nestling, Nest and Eggs.-Appear to be undescribed.

Distribution and forms.-Breeds in Eastern and Central Siberia. not farther north than $66^{\circ} \mathrm{X}$. in ea-temmet parts of its range. ranging to Australia in winter. Yo subspecies are linwm, and the long toes sutficiently distirguish this as a species from its allies, like $P$. minuta and $P$. minutilla.

\section{Genus CROCETHIA.}

Crocethia Bulberg, Synops, Faunx Scand., Vol. I., pt. I., tab. A and p. 132, 1S28. Nem name for Calidris Illiger 1811 not of (Anon.) 1804. TSpo (by monotypy): Charadrius calidris Linné $=$ Trynga alba Vroeg. 
Arenaria Bechstein, Ornith. Taschenb. Deutschl., p. 462A, 1803. Type (by monotypy): Arenaria vulgaris Bechstein = Trynga alba Vroeg.

Not of Brisson, Ornith., Vol. V., p. 132, 1760 .

Calidris Illiger, Prodr. Mamm. et Av., p. 249, pref. April 1811. Typo (by monotypy): Charadrius calidris Linné $=T$. alba Vroeg,

Not of (Anon.) Allg. Lit, Zeitung, Vol. 2, No. 168, col, 542, June 8th, 1804.

Morinellus Gray, List Genera Birds, 2nd ed., p. 90, Sept. 1841. In synonymy.

Not Morinella Meyer und Wolf, Taschenb. d. Vogel, p. 383, note, 1810.

Small Waders with short straight bills, long wings, short tails, rery short legs and toes, and no hind-toe. The culmen is short and straight with the tip somewhat expanded and slightly decurved; the groove in the upper mandible is long, extending almost to the tip ; the culmen is about equal to the very short metatarsus and about half the length of the tail.

The wings are long and pointed with the first primary longest. The tail is short, doubly emarginate as in preceding, and less than half the length of the wing. The metatarsus is very short and only about one-fifth the length of the wing ; it is regulariy scutellate in front and behind. The toes are very short, the middle toe being about half the length of the metatarsus ; there is no webbing between the toes.

\section{Crocethia alba.-SANDERLING.}

[Trynga alba Vroeg (ex Pallas MS.), Catal. d'Ois, Adumb., p. 7, ante Sept. 22nd, 1764. Holland, Europe. Extra-limital.]

Mathews, Vol, III., pt. 3, pl. 158, Aug. 18th, 1913.

Tringa tridactyla Pallas, Zoogr. Rosso-Asiat., Vol. II., p. 198, 1827 : Lake Baikal, Asia. Arenaria leucophaca carteri Mrathews, Enu, Vol. XVI., p. 35, July 1st, 1916 : Point Cloates, mid-West Australia.

Distribution.-Winter visitor to Australia, breeding in the northern hemisphere.

Adult male in summer-plumage.-Head and neck all round rufous with narrow brown shaft-streaks; a narrow crescentic white line immediately below the eye; back and scapulars blackish the feathers fringed with rufous or white, some of the rufous margins mottled with black; lesser wing-coverts brown, median and greater coverts tipped with white ; bastard-wing and primary-coverts dark brown ; primaryquills also dark brown on the outer webs and at the tips, inner webs paler brown, shafts white except at the extreme tips, some of the inner primaries white on the outer webs; secondaries brown, some of the inner ones almost white, the innermost like the back; upper tail-coverts blackish with white tips, the long central ones entirely blackish; middle tail-feathers dark brown, blackish towards the tips, the outer feathers much paler and mottled or dusted with brown and white; breast, abdomen, and under tail-coverts white as also the axillaries and under wing-coverts, the small marginal coverts show minute blackish dots. Total length $207 \mathrm{~mm}$.; culmen 25 , wing 125 , tail 51 , tarsus 25 .

Adult female in summer-plumage.-Similar to the adult male, but larger and not quite so bright rufous.

Adult male in winter-plumage-Upper-parts pale grey with dark shaft-lines, including the head, hind-neck, sicles of neck, median wing-coverts, and scapulars; lesser upper wing-coverts dark brown; greater wing-coverts dark brown broadly tipped with white; bastard-wing and primary-coverts dark brown or blackish, some of the latter tipped with white; primary-quills also dark brown on the outer webs and at the tips, much paler and inclining to white on the inner webs, some of the inner primaries white on the outer webs towards the base ; secondaries for the most part white with brown at the tips, the long innermost secondaries like the back; upper tail-coverts rather darker than the back, the lateral ones broadly fringed and tipped with white; micllle tail-feathers dark brown with white on the outer webs near the base and narrowly fringed with white, the outer feathers similar but paler; 
fore-head, sides of face, and entire under-surface white including the under tailcoverts, axillaries, and under wing-coverts.

The bird in autum differs from the summer-and winter-plumages in having the dark brown feathers on the crown of the head, back, and scapulars fringed with grey ; feathers on the side of the neck and breast brown with grey edgings; throat and abdomen white.

Immature.-Fore-head white, loral brown stripe; top of head blackish-brown with buffish tips; back black with white spots to tips of feathers, lower back grey with black bars; upper tail-coverts black with white tips; wing-coverts with white tips, secondary coverts, scapulars and inner secondaries with white edges, all undersurface pure white.

Nestling.--Upper-surface mottled with pale reddish-buff and black, the pattern not determinable; the frontal and loral streaks distinct, but no malar stripe ; spangled thickly with small white spots; the under-surface buffish-white, the breast darker buffish. There is no hind-toe.

Nest.-A depression in the ground.

Eggs.-Clutch, four; the eggs oro-conical, somewhat oblong; have the background green, more or less bright or a little darker, with the under spots reddish-grey, the middle ones brown and the surface ones dark or blackish-brown; on the eggs with light background the spots are deeper and vice versâ; the spots in general small, more or less round, mixed with streaks, numerous and almost equally distributed over all the surface; axis $38-45 \mathrm{~mm}$., diameter 26 to 26.5 .

Breeding-season.- June.

Distribution and forms.-Breeding throughout the Arctic Circle, ranging southward in winter almost into the Antarctic Regions. Three subspecies are distinguishable; Crocethia alba alba (Vroeg) from Europe; Crocethia alba tridactyla (Pallas) from Eastern Asia (occurring in Australia) a paler and slightly less form ; and Crocethia alba rubida (Gmelin) from America, a still paler and slightly larger form with a noticeably longer bill.

\section{Genus GLOTTIS.}

Glottis Koch, Syst. baier. Zool., pp. xur., 304, July 1816. Type (by monotypy): Glotis natans $\mathrm{Koch}=S$, nebularia Gunnerus.

Limicula Forster, Synopt. Cat. Brit. Birds, p. 23, Dec, 1817 : Typo (by monotypy): Limicula glottis Forster = Scolopax nebularia Gunnerus.

Not Limicula Vieillot, Analyse nouv. Ornith., p. 56, April 14th, 1816.

Limosa Stephens, in Shaw's Gen. Zool., Vol. XII., pt. I., p. 85, 1824. Type (by monotypy):

Scolopax glotis Latham = Scolopax nebularia Gunnerus.

Not of Brisson, Ornith., Vol. V., p. 261, 1760.

Nea Billberg, Synops. Faunæ Ścand., Vol. I., pt. II., tab. A and p. 155, 1828. Type: S. nebularia Gunnerus (cf. Austral Av. Rec., Vol. II., pts. 2 and 3, p. 41, Oct. 23rd, 1913).

Large Totanine Waders with long upturned bills, long wings, short tail, long legs, and small feet. The culmen is stout with a distinct upward tendency; the groove in the upper mandible is very short, being less than half the length of the culmen; though long the culmen is less than either the metatarsus or the tail.

The wings are long and pointed with the first primary longest, and are more than three times the length of the eulmen and more than twice the length of the tail. The tail is comparatively short, being less than half the wing but longer than the metatarsus or culmen. The metatarsus is regulariy scutellate in front and behind, and is longer than the culmen though shorter than the tail; the exposed tibia is equal in length to the middle toe and claw. The toes are short, and the middle toe is less than half the length of the metatarsus. A long hind-toe is present; between the outer toe and middle one is a distinct basal web, between the inner and middle toe is an indistinct and scarcely appreciable web. 


\section{Glottis nebularius.-GREENSHANK.}

Gould, Vol. VI., pl. 36 (pt. xvI.), Sept. 1st, 1844. Mathews, Vol. III., pt. 3, pl. 155, Aug. 18th, 1913.

Scolopax nebularia Gunnerus, in Knud Leem, Beskrivelse over Finmarken's Lapper, p. 251 (note), (pref. Jan. 29th) 1767: Norway, Europe.

Scolopax cineracea Latham, Gen. Synops., Suppl. I., p. 292, (pref. May 1st) 1787 : Spalding, Lincolnshire, England.

Scolopax canescens Gmelin, Syst. Nat., Vol. I., pt. II., p. 668, April 20th, 1789. Based on same as preceding, viz., Pennant, Brit. Zool., Vol. II., no. 180 , pl. XLVr.

Limasa varia Dumont, Dict. Sci. Nat. (ed. Levrault), Vol. IV., p. 64, 1805 : Europe.

Totanus griseus Bechstein, Gemein. Naturg. Deutschl, Vol. IV., p. 231, 1809 : Europe = Germany.

Totanus fistulans Bechstein, ib., p. 211.

Totanus chloropus Meyer und Wolf, Taschen. deutsch Vögel, p. 371, 1810 (pref. Aug. 20th, 1809): Germany.

Glottis natans Koch, Syst. baier. Zool., pp. XuI., 305, July 1816. New name for preceding. Limicula glottis Forster, Synopt. Cat. Brit. Birds, p. 23, Dec. 1817 : England.

Totanus longipes Brehm, Beitr. z. Vogelk., Vol. III., p. 517, 1822, pref. May : shores of Baltic. Totanus glottoides Vigors, Proc. Comm. Zool. Soc. (Lond.), 1831, p. 173, March 2nd, 1832 : Himalayan Mountains, India.

Glottis floridanus Bonaparte, Geogr. Comp. List Birds Europe and North America, p. 51, April 14th, 1838 : Florida, North America.

Glottis vigorsi Gray, List Sp. Birds Brit. Mus., pt. III, sect. I., p. 99, 1844. Now name for T. glottoides Vigors.

Glottis albicollis Brehm, Isis, 1845, heft 5, col. 352, May. New name for T. glottoides Vigors. Glottis nivigula Gray, Cat. Mamm. and Birds Nepal, pres. Hodgson Brit. Mus., pp. 138, 156, pref. Dec. 10th, 1846 : Nepal, India.

Glottis linnei Malm, Götebergs and Bohuslans Fauna, p. 278, 1877. New name for "S. glottis Linn." = Lath.

Glottis nebularius georgi Mathews, Austral Av. Rec., Vol. II., pt. 7, p. 126, Jan. 28th, 1915 : Now South Wales.

Distribution.-Winter visitor to Australia, breeding in the northern hemisphere.

Adult male in summer-plumage.-Head and hind-neck dark brown with whito margins to the feathers ; mantle and upper back black with grey edgings, the dark markings becoming more elongated on some of the long scapulars where the margins are grey barred with black; lesser, median, and greater wing-coverts dark brown, some of the major coverts edged with white at the tips, the small marginal coverts round the bend of the wing also edged with white; bastard-wing, primary-coverts and quills dark brown, the latter paler brown on the inner webs, some of the short inner primaries narrowly tipped with white, the shaft of the first, or outer primary, is white; secondaries greyish-brown, mottled with white on the inner webs, and edged with white at the tips, the long innermost secondaries like the long scapulars; lower back and the rump white; upper tail-coverts and tail white, barred with brown, the bars much more sparsely shown on the outer feathers of the latter; a ring of short white feathers encircles the eye ; fore-head, sides of face, and throat white, with dark central streaks to the feathers; the central lines become larger and more pear-shaped on the sides of the neck, fore-neck, and breast; these markings are more or less broken up into bars on the sides of the body and lateral under tailcoverts; axillaries and under wing-coverts white, barred with brown; greater under wing-coverts uniform grey with white edges; bill bromn, basal third leadengrey; iris blackish-brown; tarsi and feet light grey. Total length $335 \mathrm{~mm}$.; culmen, 52, wing 183 , tail 80 , tarsus 58 .

Adult female in summer-plumage.-Similar to the adult male but larger.

Adult male in winter-plumage. - Differs from the summer-plumage in being greyer and less black on the upper-surface, and by the uniform white under-surface. The bird in autumn has the dark upper-surface similar to the summer-plumage, and the all-white under-surface like that of the winter-plumage.

Young bird of the year.- Similar to the adult in winter-plumage but differs on 
the upper-parts where the feathers are more mottled and the margins regularly edged with white.

Nestling.-Upper-surface brownish-grey with blackish-brown marking somewhat linearly arranged showing an obscure striped appearance; a marked frontal streak and prominent loral stripe running through the eye; under-surface pure white; legs and bill long.

Nest.-A depression in the grass.

Eggs.-Clutch, four; ground-colour pale stone, covered with very dark red blotehes and underlying ones of lavender; axis $48-50 \mathrm{~mm}$., diameter 34 .

Breeding-season-May, June. (Siberia.)

Distribution and forms.-Throughout northern Europe and Asia, migrating southward in winter. Though many authorities have recognised the eastern form as differing in its paler plumage at the present time this appears to be ignored on account of lack of good series.

\section{Genus ILIORNIS.}

Iliornis Kaup, Skizz. Entwick,-Gesch. Nat. Syst., p. 156, (pref. April) 1829. Type (by monotypy): Totanus stagnatilis Bechstein.

Medium Totanine Waders with long straight slender bills, very long wings, very long legs with long exposed tibia, and tails of medium length.

The culmen is long and slender, with the tip of the upper mandible hard and not expanded but turned down over the lower mandible; the grooves in both mandibles are short and less than half the length of the culmen. The wings are long and pointed, the first primary longest.

The metatarsus is very long and regularly scutellate both in front and behind and equal to, or more than twice the length of, the middle toe ; it is also more than one-third the length of the wing. The exposed tibia is very long, equalling the middle toe in length. The tail is a little longer than the metatarsus. The toes are long and slender with a distinct web between the outer and the middle one, and a scarcely noticeable web between the middle and inner toe. Hind-toe present.

\section{Iliornis stagnatilis.-LITTLE GREENSHANK.}

Gould, Vol. VI., pl. 37 (pt. $x x x 1$ I. $_{\text {) }}$, Dec. 1st, 1848. Mathews, Vol. III., pt. 2, pl. 149, May 2nd, 1913.

Totanus stagnatilis Bechstein, Ornith. Taschenb. Deutschl., pt. Ir., p. 292, 1803 : Germany. Trynga guinetta Pallas, Zoogr. Rosso-Asiat., Vol. II., p. 195, 1827 : Russia.

Limosa horefieldii Sykes, Proc. Comm. Zool. Soc. (Lond.), 1832, p. 163, Nov, 22nd: Dukhun, India.

Totanus lathamii Gray and Hardwicke, Illus. Ind. Zool., Vol. II., pl. 51, fig. 3 (? May 3rd), 1834: Cawnpore, India.

Totanus gracilis Brehm, Vollständ. Vogelfang, p. 313, 1855 (pref. Nov. 8th, 1854) : north East Africa.

Iliornis stagnatilis addenda Mathews, Austral Av. Rec., Vol. 1I., pt. 7, p. 126, Jan. 2Sth, 1915: Northern Territory.

Distribution,-Winter visitor to Australia, breeding in the northern hemisphere.

Adult male in brecding-plumage.-Mantle and back ash-grey with dark shaft. lines and arrowhead black blotehes; some of the long scapulars irregularly marked and barred with black, the long innermost secondaries similarly marked; lesser and greater wing coverts dark brown, the latter tipped with white; some of the median coverts blotehed with black like the back; bastard-wing, primary-coverts and quills dark brown, the shaft of the outer primary white, the inmer primaries paler and margined with white like the secondaries; lower back and rump pure white; upper tail-coverts and middle tail-feathers white, barred with brown, the 
outer feathers with irregular dark lines on the outer margins; head and hind-neck grey, minutely streaked with black ; sides of face, throat, and breast white, sparsely spotted and streaked with black more coarsely on the sides of the breast and sides of body, sometimes taking the form of bars on the latter ; remainder of under-surface white with a few dark narrow streaks on the under tail-coverts; axillaries and under wing-coverts also white; lower primary-coverts grey, fringed with white.

Adult female.-Similar to the adult male but larger.

Adult in winter-plumage.-Differs from the adult in summer-plumage in the absence of the dark arrowheaded black blotches on the feathers of the back, the long secondaries not so conspicuously barred, in having fewer dark striations on the sides of the neck and body, and in having the fore-head quite white; bill black, lower base grey; iris brown; feet and legs olive-yellow. Total length 210 ; culmen 38 , wing 146 , tail 62 , tarsus 53 .

Bird of the year.--Hinder crown, hind-neck, mantle, scapulars, and long innermost secondaries ash-grey with dark shaft-streaks and pale margins to the feathers, some of the long innermost secondaries have longitudinal dark lines; wings darker than in the breeding-plumage, as also the lower back and rump; tail white, mottled with grey on the outer webs and more or less barred on the inner webs of the middle feathers; inner webs of outer feathers pure white; under-surface white.

Nestling.-Like those of the preceding in general style of plumage, but with shorter legs and of paler shade.

Nest.-A depression in the grass.

Eggs.-Cluteh, four; surface glossy; ground-colour very pale yellow, sometimes shading to a greenish tint. The spots larger on the larger end, where they often form a kind of irregular zone; in some there are large spots on the smaller end, but never so large as those on the upper end. Dimensions : axis 38 to $39.6 \mathrm{~mm}$., diameter 26 to 28 .

Breeding-season.-June. (Siberia.)

Distribution and forms.--Throughout northern Europe and Asia, migrating southward as far as Australia in winter. Though Mathews recorded: "Eastern specimens in summer-plumage are certainly brighter on the upper-surface, the black markings being less noticeable, while the spotting on the breast and flanks is not so bold and probably larger," these differences have not been accepted yet, mainly on account of lack of series.

\section{Genus RHYACOPHILUS.}

Rhyacophilus Kaup, Skizz. Entwick.-Gesch. Nat. Syst., p. 140, (pref. April) 1829. Type (by monotypy): Tringa glareola Linné.

Small Totanine Waders with short straight slender bills, long wings, short tail, long legs, and long feet. The culmen is short, straight and slender, with the groove in the upper mandible scarcely extending beyond half its length; it is less than one-fourth the length of the wing and shorter than the metatarsus, and only about equal to the middle toe and claw.

The wings are long and pointed with the first primary longest, and more than twice the length of the tail and more than three times the length of the metatarsus. The tail is comparatively short and rounded, less than half the wing and longer than the metatarsus, but shorter than the metatarsus and exposed tibia.

The metatarsus is of medium length, being less than the tail but longer than the culmen or middle toe : the exposed tibia is however proportionately long, being more than half the length of the metatarsus. The toes are long, the midclle toe being two-thirds the length of the metatarsus, longer than the exposed tibia, and little less than the culmen, with the claw exceeding the last named. The webbing of the feet is as in the preceding genus and a long hind-toe is present. 


\section{Rhyacophilus glareola.-WOOD SANDPIPER.}

Mathews, Vol. III., pt. 3, pl. 156, Aug. 18th, 1913.

Tringa glareola Linné, Syst. Nat, 10th ed., p. 149, Jan. 18t, 1758 : Sweden, Europe.

Tringa grallatoris Montagu, Suppl. Ornith. Dict., App. S., "Sandpiper, Long-legged," 1813 :

England. New name for $T$. glareola Linné.

Totanus afinis Horsfield, Trans. Linn Soc. (Lond.), Vol. XIII., pt. I., p. 191, 1821 : Java.

Totanus sylvestris Brehm, Handb. Naturg. Vög. Deutschl., p. 638, 1831 (pref. July): Germany. Totanus palustris Brehm, ib., p. 639 : Germany.

Totanus kuhlii Brehm, ib., p. 641 ; Java.

Totanus glareoides Gray, Zool. Miscell., pt. VI., p. 86, June 29th, 1844 : Nepal. Nom. nud.

Totanus glareola vulgaris A. E. Brehm, Verz. Samml., p. 12, 1866. Nom. nud.

Rhyacophilus glareola picturata Mathews, Bull. Brit. Orn. Club, Vol. XXXVI., p. 82, May

25th, 1916 : North-west Australia.

Drstributron.-Winter visitor to Australia, breeding in the northern hemisphere.

Adult male in breeding-plumage.-Dusky-brown above, with blotches of darker brown distributed over the upper-surface ; head and hind-neck streaked with white, and white spots distributed over the back and wings; upper wing-coverts for the most part browr, more or less fringed and barred with white ; bastard-wing, primarycorerts and quills dark brown, shaft of outer primary white; secondary-quills somewhat paler brown, and edged with white at the tips; the innermost secondaries like the back; upper tail-coverts white, barred with brown; middle tail-feathers brown, barred with white or buffy-white, the outer feathers for the most part white with irregular markings of pale brown; eye-ring white; eyebrow and sides of face minutely spotted with brown; ear-coverts brown, intermixed with white; chin white, the feathers of the lower throat brown with white margins; fore-neck and breast ash-grey, more or less barred with white; the feathers on the sides of the body white, barred with brown like the under tail-coverts, but more sparsely on: the latter; middle of abdomen dull white; axillaries white, regularly barred with brown; under wing-coverts brown, fringed with white, the greater series grey with white tips; bill blackish-brown, base of lower mandible brown; iris dark brown; tarsi and feet light olive-brown. Total length $225 \mathrm{~mm}$.; culmen 31 , wing 128 , tail 50 , tarsus 37.

Adult female.-Similar to the adult male but larger.

Adult in winter-plumage.--Differs from the summer-dress in being more uniform on the head and hind-neck, and in having a well-pronounced white superciliary streak; also in having the breast uniform grey.

Immature.-The upper spotting is rufous and the spots are closer together; the throat and chest ashy with distinct shaft-stripes of brown which also occur on flanks; axillaries not regularly barred.

Nestling in down.-Upper-surface for the most part black, with longitudinal smoky-grey lines on the head, hind-neck, and back; a narrow black loral streak which cuts through the eye on to the sides of the hinder crown; entire undersurface white.

Nest.-A depression in the earth.

Eggs.-Clutch, four; ground-colour bluish, covered more thickly at the larger end with large spots and blotches of dark purplish-red, and underlying ones of lavender; axis 39 , diameter 27.

Breeding-season.-May, June. (Siberia.)

Distribution and forms.-The northern regions of Europe and Asia, ranging southward to Australia in winter. No subspecies are at present recognised, though Mathews observed "the eastern form is smaller and paler," and probably fuller series will later confirm that statement. 


\section{Genus ACTITIS.}

Actitis Illiger, Prodr. Mamm. et Av., p. 263, (pref. April) 1811. Type (by subsequent desigaation, Reichenbach, Nat. Syst. Vögel, p. xav., 1852, 1853 ?): Tringa hypoleucos Linné. Tringoides Bonaparte, Ann. Lyceum Nat. Hist. New York, Vol. II., p. 326, "1828" [November 1827.] Type (by subsequent designation, Richmond (3), p. 627, Aug. 16th = 25th, 1917) : Tringa macularia "Wils."

Guinetta Gray, List Genera Birds, 1st ed., p. 68, April 1840 : Type (by original designation) : Tringa hypoleucos Linné.

Smallest Totanine Waders with short straight bills, long wings, long tail, short legs, and long toes. The culmen is short, straight, and slender with the groove in the upper mandible extending three parts its length ; the culmen is scarcely longer than the metatarsus, which is about equal to the middle toe and claw; the interramal space is feathered.

The long wings have the first primary longest. The tail is long, rounded and about half the length of the wing or twice the length of the culmen. The metatarsus is regularly scutellate in front and behind and about equal to the middle toe and claw in length; the exposed portion of the tibia is less than half the length of the metatarsus.

The toes are long and a basal web connects the outer and middle, an indistinet web joining the middle and inner toe. Long hind-toe present.

\section{Actitis hypoleucus.-COMMON SANDPIPER.}

Gould, Vol. VI., pl. 35 (pt. $x \times x$ II.), Sept. Ist, 1848. Mathews, Vol. III., pt. 3, pl. 153, Aug 18 th, 1913.

Tringa hypoleucos Linné, Syst. Nat., 10th ed., p. 149, Jan. 1st, 1758 : Sweden.

Trynga ralloides Vroeg (ex Pallas MiS.), Catal. d'Ois., Adumb., p. 7, ante Sept. 22nd, 1761: Holland.

Tringa aurita Latham, Index Ornith. Suppl., p. Lxvi., 1801, after May: New South Wales, based on Watling drawing No, 244.

Totanus guinetta Forster, Synopt. Cat. Brit. Birds, p. 24, Dec. 1817. New name for Tringa hypoleucos Linné.

Trynga leucoptera Pallas, Zoogr. Rosso-Asiat., Vol. II., p. 196, 1827 : Siberia.

Actitis cinclus Brehm, Naturg. Vögel Deutschl,, p. 648 (pref. July) 1831 : Germany.

Actitis stagnatilis Brehm, ib., p. 649 : Germany.

Actitis empusa Gould, Proc. Zool. Soc. (Lond.), 1847, p. 222, March 29th, 1848: Port Essington, Northern Territory.

Actitis megarhynchos Brehm, Vollständ. Vogelfang, p. 314, 1855, pref. Nov, 8th, 1854 : "Im Morgenlande, selten im Sudeuropa."

Acitis cinclus major and minor A. E. Brehm, Verz. Samml., p. 13, 1866. Nom. nud.

Distribution,-Winter visitor to Australia, breeding in the northern hemisphere.

Adult male in summer-plumage.-General colour above olive-brown, including the head, back, wings, and tail ; the feathers of the head, hind-neck, and mantle having narrow dark shaft-lines, while those of the back and wings have dark crossbars, some of the lateral upper tail-coverts are edged with white; the small marginal coverts round the bend of the wing as also the outer edge of the bastard-wing and outer primary-coverts white; bastard-wing, primary-corerts, and primary-quills pale brown, the latter white on the middle inner webs, except the outer one, the inner ones edged with white at the tips; secondaries white at the base and brown at the tips, the middle ones edged with white at the tips, some of the inner quills almost entirely white, the innermost olive-brom barred with darker brown; middle tailfeathers like the back, the outer feathers paler, notched and tipped with white also mottled with buffy-white; a white spot in front of the eye and a dark line through the latter; sides of face and ear-coverts pale brown, intermixed with white, giving a streaked appearance; throat, abdomen, under tail-coverts white, like the axillaries and under wing-coverts; fore-neck and breast white with narrow brown shaft-lines 
becoming brown on the sides of the breast where it forms a patch. Total length $215 \mathrm{~mm}$.; culmen 26, wing 112, tail 58, tarsus 24.

Adult female in summer-plumage.-Similar to the male but larger, and the streaks on the midcle of and the pateh on the sides of breast not so strongly pronounced.

Adull male in winter-plumage.-Differs from the summer-plumage in being more bronzy-olive on the back and scapulars, the crossing and shaft-lines not so strongly pronounced, the bars on the wings minute and composed of black and buff ; bill brown, base of lower mandible grey; iris brown; feet leaden-grey tinged with brown.

Adult female in winter-plumage.-Similar to the male.

Immature.- Upper-surface brown, each feather fringed with a buffish tip and darker succeeding mark; wing-coverts baried with whitish and with buffish tips; inner seeondaries barred with white on outer webs; tail barred, tips buff, otherwise as in summer-plumage.

Nestling.-Upper-surface pale ash-grey and with a black striped pattern of marking and no spangling; a black loral line and a black frontal line ; under-surface creamish-grey.

Nest.-A depression in the grass.

Eggs.-Clutch, four ; ground-colour either greyish or yellowish-white, corered all over with underlying spots of grey, and others, few and irregular, of deep or coffeebrown. On some there are a few lines and zigzags; generally the markings are thicker on the large end, which is sometimes even smudged with brown; axis 33 to $37.2 \mathrm{~mm}$., diameter 24.8 to 26.2 .

Breeding-season.-June and July. (Sakhalin Island.)

Distribution and forms.-Breeding in Europe and Asia, migrating southward in winter. The eastern form is at present indefinable, but later study with good series may reinstate it.

\section{Genus TEREKIA.}

Terekia Bonaparte, Comp. List Birds, Europe and N. Amer, p. 52, April 14th, 1838. Type (by monotypy): Totanus jaranicus Horsfield $=$ Scolopax cinerea Gueldenstadt.

Xenus Kaup, Skizz. Entwick.-Gesch. Nat. Syst., p. 115, pref. April 1829. Typo (by monotypy): Scolopax cinerea Gueldenstadt.

Not Xenos Rossi, Mantissa Insect., Vol. II., p. 114, 1794.

Simorhynchus Keyserling und Blasius, Wirbelth. Europa's, p. LXXIV., (before April) 1840 :

Type (by monotypy): S. cinerea Gueldenstadt.

Not of Merrem, Ersch und Gruber, Allg. Ency., Vol. II., p. 405, 1819.

Rhynchosimus Heine und Reichenow, Nomencl. Mus. Hein., p. 326, (pref. Sept.) 1890. New name for Simorhynch us Keys. und Blasius.

Smallest Totanine Waders with very long upcurved bills, long wings, medium tail, short legs, and long toes. The culmen is very long and distinetly upturned, with the tip not expanded but deeurved; the base of the culmen is considerably wider than the tip, and the lower mandible has the base proportionately more swollen, the interramal space being unfeathered; the groove in the upper mandible extends more than half the length of the culmen. The culmen is less than half the length of the wing, but more than one-third. The wings are long and pointed with first primary longest, and are more than twice the length of the tail. The tail is rounded and of medium length being longer than the culmen, but less than half the length of the wing. The metatarsus is short, but is more than half the length of the culmen, and is regularly scutellate in front and behind. The toes are long and the outer connected with the middle by a distinct basal web which almost extencls to tho second joint, the inner showing a distinct web with the middle one which extends to the first joint; the middle toe is shorter than the metatarsus, and a long hind-too is present. 


\section{Terekia cinerea.-TEREK SANDPIPER.}

Gould, Vol. VI., pl. 34 (pt. xxxiv.), Dec. 1st, 1848. Mathews, Vol. III., pt. 3, pl. 154, Aug. $18 \mathrm{th}, 1913$.

Scolopax cinerea Gueldenstadt, Nov. Comm. Acad. Sci. Imp. Petrop., Vol. XIX., p. 473, pl. 19, 1774: shore of Caspian Sea.

Scolopax terek Latham, Index Ornith., Vol. II., p. 724, before Dee. 9th, 1790. New name for preceding.

Totanus javanicus Horsfield, Trans. Linn. Soc. (Lond.), Vol. XIII., pt. I, p. 193, 1821: Java. Scolopax sumatrana Raffles, ib., pt. II., p. 327, 1822 : Sumatra.

Fedoa terekensis Stephens, in Shaw's Gen. Zool., Vol, XII., pt. 1., p. 83, 1824. New name for S. cinerea Gueldenstadt.

Limosa recurvirostra Pallas, Zoogr. Rosso-Asiat., Vol. II., p. 181, 1827. New name for $S$. cinerea Gueldenstadt.

Limicola indiana Lesson, Traité d'Orn., livr. 7, p. 554, April 9th, 1831 : India.

Totanus terekius Seobohm, Geogr. Distr. Charadr, p. 369, 1888. New name for T. cinerea. Terekia cinerea australis Mathows, Austral Av. Rec., Vol. III., pt, 4, p. 69, July 21 st, 1917 : Melville Island, Northern Territory.

Distribution.-Winter visitor to Australia, breeding in the northern hemisphere.

Adult male in summer-plumage.-General colour above, brown with a bronzy sheen, the feathers lined with brown shaft-streaks on the head, back, and scapulars, some of the short seapulars almost entirely black, which looks like two brown parallel lines; lesser, median, and greater wing-coverts for the most part dark brown, like the bastard-wing, primary-coverts and quills, the latter paler and inclining to whitish on the inner webs, shaft of outer primary white; secondary-quills greyishbrown broadly tipped with white, becoming less white on the inner ones, the long innermost secondaries like the back; rump and upper tail-coverts ash-grey; the long upler tail-eoverts barred with buff, and dark brown on the margins of the feathers; tail-feathers ashy-grey becoming lighter on the outermost ones; the eye is encircled by a ring of short white feathers; sides of face, sides of neck, throat and breast dull white streaked with dusky-brown; abdomen and under tail-coverts white like the axillaries and under wing-coverts, the small marginal coverts on the under-wing brown, tipped with white; bill black, base olive-brown; iris brown; feet, tarsus, and lower tibia dull yellow. Total length $290 \mathrm{~mm}$.; culmen 50 , wing 136, tail 57, tarsus 30 .

Adult female in summer-plumage.-Similar to the adult male but larger.

Adult in vinter-plumage.-Differs from the adult in summer-plumage in being greyer and less bronzy above.

Immature-Differs from the adult in having the base of the bill yellowish instead of brown, the head and hind-neck grey with scarcely any perceptible dark shaft-streaks; the dark markings on the back less pronounced, the rump paler grey, and the sides of face, throat and fore-neck more faintly streaked.

Nestling in down.-Upper-surface greyish-buff; a broad black longitudinal line along the middle of the back; a narrow black streak from the fore-head over the middle of the crown on to the hind-neek; loral streak and a narrow line beyond the eye also black; entire under parts creamy-white.

Young partly fledged. - The feathers on the sides of the breast, back, scapulars, and tail grey tinged with sandy-buff, and black shaft-lines; the crown of the head similar but more minutely marked; fore-head whitish; loral streak black; lesser, median, and greater upper wing-coverts blackish like the primary-eoverts and quills ; the greater coverts broadly tipped with white; hind-neck, throat, and foreneek covered with grey down; abdomen white, down still adhering to the feather: of the abdomen, under tail-coverts, and tail.

Nest.-A depression in the grass.

Eggs.-Clutch, four; surface glossy; ground-colour pale stone, sparingly covered all over, but more at the larger end, with medium-sized blotches of dark 
purplish-red and underlying ones of lavender; axis $35-36.5 \mathrm{~mm}$., diameter 26-27.

Breeding-season.-June and JuIy. (Siberia.)

Distribution and forms. - Breeding throughout northern Europe and Asia, migrating southward in winter. Mathews recognised an eastern form as smaller and paler which recently has not been accepted, but we anticipate that on later reconsideration this will be allowed.

\section{Genus HETERACTITIS.}

Heteractitis Stejneger, Auk, Vol. I., p. 236, July 1884. New name for Heteroscelus Baird 1858. Type (by monotypy) : Totanus brevipes Vieillot $=$ Scolopax incanus Gmelin.

Heteroscelus Baird, Rep. Expl. Surv. Pac. Ocean, Vol. IX., p. 734, Oct. ? 1858. Type (by monotypy): $T$. brevipes Vieillot.

Not Heteroscelis Boisduval, Voy. Astrol., Entom., Vol. II., p. 25, 1835.

Medium Totanine Waders with short, somewhat stout bills, long wings, medium tails, short stout legs, and strong feet.

This genus is easily recognisable by the stout bill in conjunction with the nature of the metatarsal covering from which it gains its name.

The culmen is stout and short, being less than one-fourth the length of the wing and almost exactly half the length of the tail. The nasal groove varies from one-half to two-thirds the length of the culmen. Wings long and pointed, the first primary longest. Tail doubly emarginate like that of Pisobia, rather less than haif the length of the wing. Metatarsus short, less than the eulmen, but longer than the middle toe and claw, the exposed tibia being about half the length of the metatarsus. There is a distinct web between the outer and middle toes towards the base, but only an indistinct webbing between the middle and inner toes. The hind-toe and claw are proportionately long. The metatarsus is corered with transverse scutellæ in front and the sides are coarsely reticulate; the back is clothed with little larger reticulation in some, in hexagonal scales approaching transverse scutes in others, and in apparently regular scutelle in others.

\section{Heteractitis incanus.-WANDERING TATTLER.}

Mathews, Vol. III, pt. 3, pl. 152, Aug. 18th, 1913.

Scolopax incana Gmelin, Syst. Nat., Vol. I., pt. Ix., p. 658, April 20th, 1789: Eimeo and Palmerston Islands, Pacific Ocean.

Scolopax solitaris Bloxham, Voy. "Blonde," Sandwich Is., p. 252, "1826" = Fob. 20th, 1827 : Sandwich Islands.

Totanus fuliginosus Gould, Voy. "Beagle," Birds, p. 130, March 1841 : Galapagos Islands. Scolopax undulata Forster, Descr. Anim., ed. Licht,, p. 173, (pref. Jan. 1st) 1844: Tahiti.

Not of Boddaert, Tabl. Planch. Enlum., p. 54, (after Dec.) 1783.

Scolopax pacifica Forster, ib., p. 174: Tahiti.

Totanus oceanicus Lesson, Descr. Marnm. et Ois., p. 244, April 1847: Pacific Ocean.

Totanus polynesice Peale, Zool. U.S. Expl. Exped., Vol. VIII., p. 237, 1848 (cf. 2nd ed., p. 318, 1858): Fiji.

Heteroseclus incanus perteri Mathews, Bull. Brit. Orn. Club, Vol. XXXYI., p. 82, May 2jtl., 1916 : Cape York, Queensland.

Distribution.-Cape York in winter, as far as yet recorded.

Adult male in summer-plumage.-Upper-parts olive-giey including the crown of the head, entire back, wings and tail ; the small marginal upper wing-coverts dark brown fringed with white like some of the major and primary-coverts ; primaryand secondary-quills dark brown, paler on the inner webs, the shaft of the outer primary inclining to white; an ill-defined white line running from the base of the bill over the eye and along the sides of the crown; sides of face, ear-corerts, sides of neck, and fore-neek streaked with brown and white; chin and upper throat with small ovate spots of slate-brown; remainder of the under-surface slate-grey 
barred with white; axillaries slate-brown; under wing-coverts similar in colour, faintly edged on the inner, and more broadly on the outer, coverts with white. Total length 260 ; culmen 38 , wing 164 , tail 70 , tarsus 34 .

Adult female.-Similar to the adult male.

Adult in winter-plumage -Differs from the adult in summer-plumage in lacking the barring on the under-surface. There is a greyish band on the breast, and the sides of the body are also of the same colour. Throat, abdomen, vent, and under tail-corerts white; bill greyish-green ; iris brown; feet and legs dull green.

Immature.-Similar to the winter-plumage, but upper back, scapulars and inner secondaries indistinctly edged with whitish and the feathers of the flanks also faintly edged with white.

Nestling, Nest and Eggs.-Undescribed.

Distribution and forms.-Breeding in Alaska, and wandering southward through the Pacific to Cape York in winter. No subspecies, and the representative species, $H$. brevipes, seems almost generically separable, instead of subspecifically as recently suggested.

Forbes and Robinson (Bull. Lixerp. Mus., II., (2), p. 70, 1899 (Sept.) record:

"Torres Straits, collected by Macgilliviay in 1844, a male is referable to this species not brevipes," so that probably it occurs more commonly than recorded.

\section{Heteractitis brevipes.-GREY-RUMPED TATTLER.}

Gould, Vol. VI., pl. 38 (pt. $\times x \times I r$.), Dec. 1st, 1848. Mathews, Vol. III., pt. 3, pl. 151, Aug. 18th, 1913.

Totanus brevipes Vieillot, Nouv. Dict, d'Hist. Nat,, Vol, VI,, p. 410, Dee. 14th, 1816 : No loc. = Timor, coll. by Mauge fide Pucheran, Rev. Mag. Zool., 1851, p. 570.

Totanus pulverulentus Muller, Verh. Nat. Gesch. Land- en Volkenk., p. 153, 1842: Timor.

Totanus griseopygius Gould, Proc. Zool. Soc. (Lond.), 1848, p. 39, Nov. 14th; Port Essington,

Northern Territory.

Distributron.-Winter visitor to Australia, breeding in the northern hemisphere.

Adult male in breeding-plumage.-General colour above slate-grey, the feathers everywhere narrowly margined with white, more broadly on the greater wing-coverts and upper tail-coverts; bastard-wing dark brown; primary-coverts dark brown, the inner ones tipped with white; primary-quills dark brown, the outer one with a white shaft; secondaries pale slate-grey fringed with white, the long innermost secondaries like the back; fore-head, a line over the eye, ear-coverts, and throat white, minutely spotted and streaked with grey; fore-neck, breast, and sides of body barred with slate-grey; abdomen and under tail-coverts white, the latter barred with grey at the tips; axillaries and under wing-coverts slate-grey fringed with white at the tips; bill black, base of lower mandible brown; iris dark brown ; feet dull yellow. Total length $280 \mathrm{~mm}$. ; culmen 39 , wing 161 , tail 67 , tarsus 35 .

Aduit female in breeding-plumage.-Similar to the adult male.

Adult male in vinter-plumage.-Differs from the adult in nuptial-dress in being uniform slate-grey above, also in the uniform pale grey of the fore-neck, breast, and sides of body.

Adult female.-Similar to the adult male.

Immature male (bird of the year).-Dark slate-grey above, and the margins of the feathers dappled with white, some of the wing-coverts margined with white; crown of head, hind-neck, and mantle uniform slate-grey; lores dusky; fore-neck, chest, and sides of body uniform grey, darker on the latter like the axillaries; lower flanks more or less barred with white.

Nest and Eggs.--Undescribed.

Distribution and forms.-Breeds in Eastern Siberia from Lake Baikal to the Sea of Japan, and wandering southward to Australia in winter. No subspecies, and quite distinct specifically from preceding. 


\section{Genus BARTRAMIA.}

Bartramia Lesson, Traité d'Orn., livr. 7, p. 553, April 9th, 1831. Type (by monotypy): B. laticauda $=$ Tringa longicauda Bechstein.

Actidurus Bonaparte, Giornale Arcadico (Roma), Vol. LII., p. 208, 1831, 1832. Typo

(by monotypy) : Tringa longicauda Bechstein. New name for Bartramia Less.

Euliga Nuttall, Man. of Ornith., Vol. II., p. 167, 1834. Type (by original designation):

Tringa bartramia Wilson = Tringa longicauda Bechstein.

Medium Totanine Waders with short bills, long wings, long tails, long legs, and long toes.

The culmen is short and straight, the tip slightly swollen and decurved; the groove in the upper mandible extends for more than half the length of the culmen, which is scarcely longer than the middle toe and claw and less than two-thirds the length of the metatarsus.

The wings are very long, with the first primary longest. The tail is very long and wedge shaped, more than half the length of the wing, and three times the length of the culmen. The metatarsus is more than half the length of the tail but less than twice the middle toe; the exposed portion of the tibia is more than half the length of the metatarsus and equal to the middle toe. Tarsus regularly scutellated before and behind.

The toes are long, and the middle toe is more than half the length of the metatarsus and little less than the culmen; the webbing between the toes is as in the preceding Totanoid genera. A long hind-toe is present.

\section{Bartramia longicauda.-LONG-TAILED SANDPIPER.}

Gould, Suppl., pl. 77 (pt. Iv.), Dec. 1st, 1867. Mathews, Vol. III., pt. 3, pl. 157, Aug. 18th, 1913.

Tringa longicauda Bechstein, Kurze Uebers. Vögel, p. 453, (pref. ApriJ 12th, 1810), 1811 : North America.

Tringa bartramia Wilson, Amer. Omith, Vol. VII., p. 63, pl. 59, fig. 2, 1813 (pref. March 1st) : Pennsylvania, North America.

Totanus variegatus Vieillot, Nouv, Dict. d'Hist. Nat,, Vol. VI, p. 397, Dec. 14th, 1816 : South America.

Totanus campestris Vieillot, $i b$, p. 400 : Paraguay, South America.

Totanus melanopygius Vieillot, $i b .$, p. 401 : North America.

Bartramia laticauda Lesson, Traité d'Orn., livr. 7, p. 553, April 9th, 1831. New name for Tringa bartramia Wilson.

Distribution.-No Australian-shot specimens preserved, and record very doubtful.

Adult male.-General colour above black, the feathers everywhere margined with sandy-rufous and white; head black with sandy-rufous edges to the feathers; hind-neck rufous with dark brown centres to the feathers, giving a streaked appearance; mantle and back black, the feathers edged with rufous; lower back, middle upper tail-coverts and rump uniform black, the lateral upper tail-coverts barred with buff and black; lesser wing-coverts dark brown fringed with sandy-rufous ; greater coverts olive-brown barred with darker brown, fringed on the sides with sandyrufous and tipped with white; bastard-wing blackish, tipped with white; primarycoverts black with pale elges to some of the inner ones; primary-quills dark brown on the outer webs, the inner webs barred with white; first primary mottled and barred with brown and white, shaft also white; inner primaries barred with pale and dark brown, fringed and tipped with white, the secondaries similarly" coloured ; the long innermost secondaries like the back; middle tail-feathers greyish-brown tinged with rufous and barred with black, becoming rufous on the outer feather: which are also barred with black and broally tipped with white; throat white; sirles of face, lower throat, and upper-breast sandy-buff, with narrow brown streaks; ablomen and under tail-coverts buffy-white; sides of body sandy-rufous barred 
with brown; axillaries and under wing-coverts white barred with dark brown; bill gremish-yellow, culmen and th dark brown; iris hazel : tarsi and fect yellowishgreen. Total length $285 \mathrm{~mm}$; ; culmen 29, wing 165, tail 82, tarsus 47.

Adult female. - Similar to the adult male.

Young. - Similar to the adult, but the buff of the head, jugulum, wings, etc., much deeper, the streaks on the fore-neck and jugulum much less distinct, and the back plain black, the feathers bordered with buff.

Nesting in down.-Upper-surface black, rufous, and white; lores, sides of the face, collar on the hind-neck, and the entire under parts white, with a tinge of pale buff on the abdomen; lower flanks, thighs, and under tail-coverts marked with rufous and black.

Nest.-A rather deep depression in the ground, sparingly lined with fine weed stems, grasses and a few bits of manure, and one or two small feathers.

Eggs.-Clutch, four; ground-colour light stone, sparingly marked all over, but more at the larger end, with spots of dark chestnut to yellowish-brown, and underlying ones of lavender; axis 41.5 to $43 \mathrm{~mm}$., diameter 32 to 32.5 .

Breeding-season.-June.

Distribution and forms.-Breeding in North America, migrating southward to South America in winter, and accidental in Europe, and has been recorded from Australia but no specimens are preserved. No subspecies.

\section{Genus VETOLA.}

Vetoln Mathews, Birds Austr., Vol. III., pt. 2, p. 191, May 2nd, 1913. Type (by original designation): Scolopax lapponica Linné.

This genus, which has been continually confused with Limosa, is as well characterised as the majority of the Scolopacine genera. It is easily distinguished by its short legs, differing much in the same way as Psendototanus differs from Glottis. Compared with Limose the bill is promotionately shorter and more slender and distinctly moro uptumed; the groove on the upper mandible becomes obsolete at about three-quarters the length of the culmen orving to the strong vertical compression of the upper mandible, the groove on the lower mandible, however, persists as in Limosa. The legs are short, the exposed tibia being less than the length of the middle toe, the metatarsus is less than twice the middle toe and also less than onethird the length of the wing, the scutellation of the front of the metatarsus becomes irregular and broken up into hexagonal scales torwards the tibio-tarsal joint, whereas in Limosa the scutellation is quite regular. The middle claw is normal, untoothed and short, being one-fourth, or less, the length of the middle toe.

\section{IOI. Vetola lapponica.-BARRED-RUMPED GODWIT.}

[Scopolax lapponica Linné, Syst. Nat., 10th ed., p. 147, Jan. Ist, 1758: Sweden, Europe. Extra-limital.]

Gould, Vol. VI., pl. 29 (pt. xxrur.), Dec. Ist, 1848. Mathews, Vol. III., pt. 2, pl. 148, May 2nd, 1913.

Limosa baueri Naumenn, Vögel. Deutschl., Vol. VIII., p. 429, (pref. Oct.) I836: New Holland = Victoria.

Limosa australis " Briss." Bennett, Cat. Spec. Nat. Hist. Austr. Mus., (after July 26th) 1837, p. 48. Nom. nud.

Limosa brevipes Gray, List Sp. Birds Brit. Mus., pt. III., p. 95, 1814 : New Zealand. Nomen surdum.

Limosa australasiana Gray, ib., p. 96 : Port Essington, Northern Territory. Nomen nudum. Limosa lapponica var. novcealandice Gray, Voy. "Erebus and Terror," Birds, p. 13, Oct. 1845: New Zealand.

Limosa foxii Peale, Zool. U.S. Expl. Exped., Vol. VIII, p. 23, 1848 (cf. 2nd ed., p. 314, 1858): Samoa.

Limosa uropygialis Gould, Proc. Zool. Soc. (Lond.), 1818, p. 38, Nov. 14th: Australia $=$ Victoria.

Distrubution.-Winter visitor to Australia, breeding in the northern hemisphere. 
Adult male in summer-plumage-Head and hind-neck cinnamon-rufous with dark brown shift-streakis to the feathers; ulper back and seapulars dark with white and bufí marginal spots to the feathers; the feathers of the lower back pale brown fringel with white- these edgings becoming rufous on the short upper tail-coterts, the long ones barrel with rufous and brows and tipened with white ; tail pale brovar, harred and tipped with white; leser, median, and greater wing-coverts brown, fringed with white; bastard-wing and primary-coverts uniform dark brown; primary-quills also dark brown, paler on the imner webs and mottled with white towarls the base, the shafts conspicuously white; the imer primaries and cocondarices pale brown and elged with white; tail brown, tipped and barred with white; a short white line immediately below the ere; evebrow, throat, breast, abdomen, and uncler tail-coverts cimanion-rufous, some of the under tail-coverts have dark bromn bars; under wing-corerts white with a subteminal brown bar ; axillaries white barred with brown; bill blackish, pale at base of lower mandible ; iris brown; feet blackish. Total length $373 \mathrm{~mm}$, ; culmen 83, wing 224, tail 78, tarsus 51 .

Adult female. - Similar to the male but larger. According to Jiddendorff, coloration appreciably different.

Arlult male in winter-plumage.-Top of head and hind-neek a-h-srey with narrow pale brown struks to the feathers beceming clarker' on the back and scapulars, some of the feathers of which are dark brown fringed with white; upper tail-coverts brown larred and fringed with white, the long ones bared with brown and white; tail dark brown mottled with white towards the base, some of the middle feathersubterminally barres with white, the shafts of the feathers white at the hase ancl brown near the tips; lesse1, median, and greater wing-eoverts pale brown with whitish margins like the secoudary-quills; bastard-wing and primary-coverts uniform dark brown; primary-(quills clark brown on the outer webs and at the tips. paler bown on the inner webs and mottled with white towards the base, the shafts conspicuously white; an ill-defined whito eyebrow; sides of face dusky-whito with minute dlark shaft-lines, an indistinet line in front of the eye and the ear-corerts a shade darker than the rest of the face; a narrow white line immediately below the eye ; throat dull white; lower throat and breat anh-grey with narrow blackish shaft-lines on the lower throat and fore-neck; the feathers of the breast, sides of body, ank under tail-coverts more or less barred with pale brown; abolomen and vent whitish; axillaries brown, barred and margined with white; under wingcoverts pale brown barred and margined with white.

Immature.-Top of the heal brown with pale tips, the lack of the neck greyishbrown with paler tips; the upper back tipped with broaler edges, griving a sealloped appearanee; the rump and tail barred, the feathers with whitish tips; the wingcoverts with long whitish edges; there is an ill-elefued superciliary line of whitish; throat whitish, the lower throat and chest fawnish-white, abdomen dirty white; inclefinite brownish flank stripes; under wing-coverts brown with white bases and broad white edges; axillaries white barred irregularly with pale brown.

Neslling in doun.-- Rufous-brown above with black blotehes, rather irregularly. placed so that linear arrangement is not easily scen; a black frontal line spreading out into an irregular black blotched cap; a pronounced white superciliary succeded by a black loral line jasing through the eye; checks and all under-surface palo buffy-red, the thighs tinged with yellow; the winglet brown edged with paler buffy centre.

Nest.-A depression in the grass.

Eggs.-Clutch, four; ground-colour deep greenish-drab to pale drab; the markings are scattered in the form of irregular blotehes of a dilute umber. In some the marlings are more pronounced and more aggregated towards the larger end and of a much deeper shade of umber; axis $57 \mathrm{~mm}$., diameter $36-37$.

Breeding-season.-In Siberia, June and July. 
Breeds in Eastern Siberia as far north as Taimyr Peninsula and tundras at the mouth of Kolyma. Breeds in colonies, and is very noisy.

Distribution and forms.-.Throughout northern Europe and Asia, migrating southward in winter to Australia. Tro subspecies are commonly recognised: V. l. lapponica (Iimné) from Europe, and V. l. baueri (Naumann) from Eat siberia, separable by its darker rump and more heavily barred flanks and generally paler.

\section{Genus LIMOSA.}

Limosa Brisson, Ornith., Vol. I., p. 48, Vol. V., p. 261, 1760. Type (by tautonymy): Limosa = Scolopax limosa Linné.

Limicula Vieillot, Anal. nouv. Orn., p. 56, April 14th, 1816. Typo (by monotypy): "Barge Buffon" = Scolopax limosa Linné.

Gambetta Koch, Syst. baier. Zool., pp. xII., 307, July 1816. Type (by monotypy): S. limosa Linné.

Fedoa Stephens, in Shaw's Gen. Zool., Vol. XII., pt. I., p. 70, 1824. Type (by tautonymy): Scolopax fedoa Linné.

Not of Forster, Synopt. Cat. Brit. Birds, pp. 20, 56, 1817.

Actites Billberg, Synops. Faune Scand., Vol. I., pl. 2, Tab. A and p. 153, 1828. Type:

Scolopax limosa Linné. Cf. Austral Av. Rec., Vol. II., pts. 2 and 3, p. 41, Oct. 23rd, 1913.

Not of Illiger, Prodr. Mamm, et Av., p. 263, 1811.

Large Scolopacine Warling birds with rery long straight bills, long wings, rery long legs, and long toes.

The culmen is very long and straight but with a faint upward tendency towards the tip; the tip is slightly expanded and projects beyond the lower mandible hut it is not curved down over the latter. A slight vertical compression is noticeable towards the tip of the upper mandible. Nostrils are linear and placed near the bave of the culmen, in a groove which extench the length of the bill until stoplext by the expanded tip. In the lower mandible a similar groove is observed, quite as distinet as that in the upper, while the tip is similarly expranded. The culmen is longer than the tail or tarsus. Wings long with first primary longest. Tail rounded or almost square, longer than the tarsus but less than half the length of the wing. The legs are very long; the exposed portion of the tibia being longer than the middle toe; the metatarsus is rery long, being more than one-third the length of the wing and more than twice that of the middle toe; it is regularly scutellated both before and behind. The outer and middle toes are connected by a web at the base, but only the indication of a web exists between the middle and inner one. Hind-toe long. The claw of the middle toe is peculiar, being very long, linear, fragile, and strongly pectinate; it is more than one-fourth and almost one-third the length of the middle toe.

\section{Limosa limosa.-BLACK-TAILED GODWIT.}

[Scolopax limosa Linné, Syst. Nat., 10th ed., p. 147, Jan. 1st, 1758 : Europe. Extra-limital.] Gould, Vol. VI., pl. 28 (pt. xxxrv.), Sept. 1st, 1846. Mathews, Vol. III., pt. 2, pl. 147, May 2nd, 1913.

Limosa melanuroides Gould, Birds Austr., pt. xxxiv. (Vol. VI., pl. 28), Sept. 1st, 1846 : Port Essington, Northern Territory.

Distribution.-Winter visitor to Australia, breeding in the northern hemisphere.

Adult male in summer-plumage.-Head and hind-neck cinnamon-rufous, the feathers centred with brown, more strongly pronounced on the crown of the head; upper back and scapulars blackish-brown, barred and margined with rufous; marginal upper wing-coverts dark brown, as also the bastard-wing; some of the median coverts blackish with pale margins, greater coverts brown, broadly tipjed with white; primary-coverts blackish edged with white at the tipk, more broadly on the inner ones; primary-quills dark brown on the outer webs and at the tips, 
inmer webs much paler and becoming white towards the base, some of the inner primaries entirely white at the base; secondaries white tipped with brown, the latter colour beesming rery gale and almont white towares the inner ones, the long innerment secondaries grey ish-brown and blackish, with rufous s puts on the mare ns: lower back uniform dusky-brown; upper tail-coverts white, the long ones tipped with black; tail white at the base, the white increasing in extent on the outer feathers which are black at the tips, the black much more extended on the middle feathers, which are : lightly edged with wh te at the tign: : throat and a line frem the base of the bill to the eye white; a small crescent-shaped white line immediately below the eye; lores, sides of face, and ear-coverts cinnamon-rufous minutely streaked with blackish like the fore-neck and sides of neck, somewhat darker in colour on the latter; breast similar in colour to the fore-neck but barred with brown, more broadly on the sides of the breast and sides of body; midale of abdomen, rent and under tail-coverts white barred with brown, some of the latter barred and margined with black; axillaries and under wing-coverts pure white, the lesser coverts round the margin of the wing dark brown or blackish; billdistal half of mandible brown, shading to pale brown at the base of upper mandibie and greyish-white at base of lower mandible; iris brown ; tari and feet olive-browal. Total length $360 \mathrm{~mm}$.; culmen 73, wing 190, tail 71, tarsus 65 .

Adult female.--Similar to the adult male but larger.

Adult male in vinter-plumage.-Head, hind-neck, and sides of neck ash-grey, with a wash of rufous on the fore-part of the head; back, scapulars, and lesser marginal wing-corerts dark greyish-brom; Iower back dark brown with pale narrow margins to the feathers; upper tail-corerts white, the long ones tipjes? with black; tail white at base and black at the tip, the latter colour more pronounced on the middle feathers, and the former more extended on the outer ones; median and greater wing-eoverts fringed with white at the tips more broally on the latter; bastard-wing, marginal covert, and primary-coverts blackish; quills black :h cal the outer wely and at the tips, with white sliafts for the greater part of their length, inner webs paler brown and becoming entirely white at the base of the inner ones; secondaries white with bromn tips, on some of the feathers the brown is restricted to the inner web; the long innermost secondaries greyish-brown like the back; a pale line from the base of the bill orer the eye ; a small crescent white line immedately below the eyo; chin whitish; throat, fore-neck, chest, and sides of body ash-grey; abdomen and under tail-coverts white, the latter margined with black; axillaries and under wing-coverts pure white, the small marginal coverts round the bend of the wing dark brown edged with white.

Immature male.-Top of head dark brown, the feathers margined with buff; sides of face and neck all round grey, the latter washed with rufous; upper back anci : eapulars dark brown, the feather everywhere margined with bufi ; the margisal upleer wing-coverts, bastard-wing, and primary-covert: blarkikh, some of the latter tipued with whitilh; median ming-corerts dark brown with grey celges, the major coverts broadly tipped with white; primary-quills are much the same in colour as the summer and winter birds dencribed above: the long innernost accondaries differ from the winter-plumage in being clark with rufous or sandy-buff margins: lower back blackish with slightly jaler margins to the feathers: upuer tail-eoverts and tail also similar, but differ in laving dusy tips to the latter, throat whitish; lower-breast, abdomen and under tail-coverts white washed with grey.

Nestling.-Rusty-yellow marked with black, especially on crown and rump; a narrow streak through the eye; wing joints, cheeks, and belly light yellowith.

Nest.-A depression in tho grass.

Eggs.-Clutch, four; surface not glossy; ground-colour pale olive-green to pale yellowish; covered all over with small ppots of a more or less olive-brown; some on the larger end being olive-gres ; axis 5l-55 mm., diameter 35-37. 
Breeding-season.--July. (Siberia.)

Breeds in Eastem Siberia as far south as Kamtschatka (perhans Commander Islands) shores of Okhotsk Sea, Baikal, and as far west as Upper Yenisei Valley (rare).

Distribution and forms.-Throughout the Arctic Regions of Europe and Asia, migrating southward in winter to Australia, India, ete. Two well-marked subspecies are recognisable: $L$. $l$. limosa (Linné) the westem race, and $L . l$. melanuroides (Gould) the eastern form visiting Australia, easily separable by its smaller size; culmen average, $86 \mathrm{~mm}$. against 115 ; wing av. 195 against 220 ; tarsus av. 66 against 86 ; middle toe 32 against $35 \mathrm{~mm}$.

\section{Genus MESOSCOLOPAX.}

Mesoscolopax Sharpe, Cat. Birds Brit. Mus., Vol. XXIV., pp. 338, 371, (pref. dated July 10th) 1896. Type (by monotypy): Numenius minutus Gould.

Small Scolopacine Waders with a short arched bill, long wings, legs and feet, and long tail. The bill is only slightly curred and is less than a fourth of the wing, and also shorter than the metatarsus. The metatarsus is regularly scutellated both before and behind ; a feature which separates it at once from the Numenioid Waders, and shows its relationship with the Totanoid forms. The middle toe is slightly shorter than half the length of the metatarsus. The tail is long and rounded.

\section{I03. Mesoscolopax minutus.-LITTLE WHIMBREL.}

Gould, Vol. VI., pl. 44 (pt. $x \times x$. ), June 1st, 1848. Mathews, Vol. III., pt. 2, pl. 146, May 2nd, 1913.

Numenius minutus Gould, Proc. Zool. Soc. (Lond.), 1840, p. 176, July 1841: New South Wales.

Numenius minor Muller, Verh. Nat. Gesch. Land-en Volkenk., p. 110, 1841 : Amboina.

Not of Forster, Synopt. Cat. Brit. Birds, p. 58, 1817.

Distribution.- Winter visitor to Australia, breeding in the northern hemisphere.

Adult male.-Cpper-parts dark brown with white or rufous spots on the margins of the feathers; some of the long upper tail-eoverts regularly barred with grey ; the small marginal coverts round the bend of the wing very dark brown like the bastard-wing and primary-coverts; median and greater coverts similar to the back; primary-quills dark brown, shaft of tir-t primary white, some of the inner quills fringed with white at the tips; seconlaries pale brown slightly tipped with white, the long innermost secontaries like the back; crom of head brown spotted with white or buff with a searcely defined meial streak; lores, eycbrow, ear-corerts, and sides of face buff minutely streaked with brown; hind-neck brown with pale margins to the feathers; throat whitish; lower throat and fore-neck buff with dark shaft-streaks, becoming coarser on the breast and sides of the body whero the feathers are barred with brown; mickle of ablomen inclining to white: the long under tail-coverts buffy-white barred with brown like the axillaries and under wing-coverts; bill blackish-brown, base of fower mandible flesh colour ; iris blackishbrown, tarsi and feet lead-grey. Total length $333 \mathrm{~mm}$; culmen 43, wing I82, tail 68 , tarsus 50 .

Adult female.-Similar to the male but slightly larger; culmen 48, wing 184, tail 75, tarsus 53 .

Immature.-Similar with pale rufous tips to upper feathers.

Nestling in down.-Apparently not described.

Nest and Eggs.-Undescribed.

Breeds evidently on Cpler Yana (near Verkhojansk, about 67! ${ }^{\prime}{ }^{*}$.) and Middle Lena. Not farther south than about $59^{\circ} \mathrm{N}$. 
Distribution and forms.--Breeding in East Siberia, migrating southward to Australia in winter. No subspecies have been named.

\section{Genus PHAEOPUS.}

Phaopus Cuvier, Règne Anim., Vol. I., p. 485, Dec. 7th, 1816. Type (by monotypy and tautonymy): Scolopax phæopus Linné.

Medium scolopacine Waders with long arched bills, long wings, long tails, moderately long legs, and strong feet.

Though the structural features are gencrally as in the succeeding, the proportions differ; the bill is more slender, more strongly arched, and shorter than the tail and less than laalf the wing. The tail is proportionately longer, with the legs shorter and the feet stronger; the middle toe is more than half the length of the metatarsus and the two together exceed the bill in length.

\section{Phæopus phæopus.-WHIMBREL.}

[Scolopax phreopus Linné, Syst. Nat,, 10th ed., p. 146, Jan. 1st, 1758; Europe. Extralimital.]

Gould, Vol. VI., pl. 43 (pt. xxxI.), June 1st, 1848. Mathews, Vol. III., pt. 2, pl. 145, May 2nd, 1913.

Tantalus variegatus Scopoli, Del. Flor. Faun. Insub., fasc. II., p. 92, 1786, based on Sonnerat, p. 85, pl. 48 : Luzon, Philippines.

Scolopax luzoniensis Gmelin, Syst, Nat., Vol. I., pt. I., p. 656, April 20th, 1789. Same basis as preceding.

Numenius atricapillus Vieillot, Nouv. Dict. d'Hist. Nat., Vol. VIII., p. 303, March 15th, 1817. New name for preceding.

Numenius uropygialis Gould, Proc. Zool. Soc. (Lond.), 1840, p. 175, July 1841 : south coast of Australia.

Distrimution.--Winter visitor to Australia, breeding in the northern hemisphere.

Fully-plumaged male of first season.-General colour above dark brown, with buff or white spots on the margins of the feathers; upper tail-corerts barred with white and brown, tail darker than the back and barred with white; wing-coverts paler than the back but similarly marked; bastard-wing, small marginal coverts, and primary-coverts dark brown tipped with white; primary-quills dark brown notehed with white on the inner webs, the four outer primaries uniform on the outer web, the remainder tipped and notehed with white on both webs; secondaries similarly marked but rather paler in colour, imnermost long secondaries likie the scapulars; head dark brown with an irregular white line down the middle; lores, eyebrows, and sirles of face minutely streaked with brown and white, neck all round brown with buff margins to the feathers, beconing paler and coarser on the breast and sides of the body"; middle of abdomen almost white; under tail-covert, buffywhite barred with brown; axillaries and under wing-eoverts regularly barred with brown and white; bill black, white at base of lower mandible ; iris blackish-brom ; feet olivaceous-grey. Total length $405 \mathrm{~mm}$. ; culmen 62 , wing 223 , tail $\mathrm{s} 6$, tarsus 56 .

Fully-plumaged fcmale of first scason.--Similar to the adult male but larger; culmen 72, wing 228 , tail 99 , tarsus 58.

Broding male and female.-Bill black; head dark brown with imperfect but distinct mesial stripe of pale whitish: superciliary line white, brownish tizk to feathers; lores brown; sides of face with brown streaks; chin pure white ; breast white with broad shaft-stripes; flanks white more or less barred with brown; axillaries and wing-lining barred with brown and white; under tail-coverts faintly and irregularly barred; back white with clark shaft-stripes almost obsolete, on rump more pronounced, becoming bars on upper tail-coverts; tail barred with 
brown and grey ; back brown with indistinct paler edges, as are inner secondaries, seapulars and upper wing-coverts; secondaries toothed on outer edge with white; primaries toothed on inner edge with white.

Winter-plumage.-As above but more worn.

First autumn bird.-As described.

Nestling out of down.-With broader edges, otherwise as preceding.

Nestling in down.-Upper coloration pale greyish-brown with black blotches linearly arranged on back, down centre and more irregularly on sides; frontal brown stripe and loral stripe; pale mesial stripe on centre of crown; stripes on head darker than other blotches; under-surface pale fuscous-grey.

Nest.-A depression.

Eggs.-Clutch, four; olive-green, blotched with dark brown, more boldly at the larger end; axis 58 , diameter $40 \mathrm{~mm}$.

Breeds in Eastern Siberia as far west as Lena and Baikal. In the north it breeds in large numbers on Kolyma as far as $69^{\circ} \mathrm{N}$, on the borders of the tundras.

Distribution and forms.-Northern Europe and Asia, migrating southward to Africa, India and Australia in winter. Two subspecies are commonly accepted: $P . p$. pheopus (Limné), the Europeau race, and P.p. varicgatus (S'copoli) the Eastern Asiatic race, visiting Australia, slightly smaller with the rump more barred, and the axillaries with narrower and eloser bars; in summer breeding-plumage paler, and with under-surface more heavily streaked with paler brown.

As above described, breeding birds have black bills and have lost the bold spotting of the immature form, which has been generally described as breeding.

\section{Genus NUMENIUS.}

Numenius Brisson, Vol. I., p. 48, Vol. V., p. 311, 1760. Type (by tautonymy) : Numenius = Scolopax arquata Linné.

Cracticornis Gray, List Genera Birds, 2nd ed., p. 88, Sept. 18t1. Type (by original designation): Scolopax arquata Linné.

Largest Seolopacine Warlers with very long arched bills, long wings, moderately long legs, strong feet, and medium tails.

The very long bill is strongly arehed, with the tip of the upper mandible curved down and projecting beyond the lower, obtuse and little thickened. The nostrils are linear, near the base of the bill, placed in a groove which extends more than half the length of the bill. The culmen is longer than the tail and more than half the length of the wing. Wings long with the first primary longest. Tail rounded and moderately long but less than half the length of the wing.

Tarsus long and partly scutellated in front, but regularly covered with the hexagonal seales on the hind rer part. In the newtling the frontal sentellation is quite regular, but in many adults the scutellie appear broken up towards the heel. The toes are strong, about half the length of the metatarsus; the anterior ones are connected by a web near the base only, the skin of the soles laterally dilated; claws flattened and blunt; hind-toe rather long, provided with a claw.

\section{Numenius cyanopus.-CURLEW.}

Gould, Vol. VI., pl. 42 (pt. xxxIv.), Dec. 1st, 1818. Mathews, Vol. III., pt. 2, pl. 144, May 2nd, 1913.

Numenius cyanopus Vieillot, Nouv, Dict. d'Hist. Nat., Vol. VIII., p. 306, March 15th, 1817 : Nouvelle Hollande $=$ New South Wales, based on Latham's $N$. arquatus var., described from Watling drawing No. 239.

Numenius australasianus Gould, Synops. Birds Austr., pt. Iv., App., p. 6, April 1st, 1838 : New South Wales.

Numenius australis Gould, Proc Zool. Soc. (Lond.), 1837, p. 155, Dec. 5th, 1839 : New South Wales. 
Numenzius rostralus Gray, Ann. Mag. Nat. Hist., Vol. XI., p. 121, March 1st, 1813, ex Latham MS. for Watling plate, basis of Latham's Numenius arquatus var. = N. cyanopus Vieillot. 2Numenius rufescens Gould, Proc. Zool. Soc. (Lond.), 1862, p. 286, April 1st, 1863 : Formosa.

Distributron.-Winter visitor to Australia, breeding in the northern hemisphero.

Adult female.-General colour of the upper-parts dark grey and brown, some of the feathers, particularly on the wings, marcion with white; the feathers of the? back and seapular: dark brown margined with praler brown; rump, up joer taileoverts and tail regularly barred with dark hrown and grey, the latter tipeped with white: leser wing-coverts almost black with white or pale margins, medium and greater enverts somewhat paler; bastard-wing and prinary-coverts black ; primaryquills cark brown notehed with white on the inner weh, the fint three uniform on the outer web, the remainder mottled with light-coloured spots on the outer web and tipred with white, the shafts straw coloured : recondaries brown noteled on both webs with white; head and hind-neck brown, the feathers nargined with grey ; fore-head, lores, and sides of face minutely strealed with hown and white ; throat almost pure white; fore-neck and chest more coarsely streaked; abdomen and under tail-eoverts paler and more inelining to white and the shaft-streaks narrower; some of the under tail-coverts narrowly barrel with bromn; axillaries and under wing-coverts barred with brown and white: b:1l ciark brown, tip black, base of lower mandible flesh-white; iri: brown; tami and fuet leaden-b!ue. Total les gth $650 \mathrm{~mm}$.; culmen 187, wing 317 , tail 122, tarsus 93.

Adult male.-Similar to the adult female but smaller.

Adult in summer-plumage.-Has distinctly rufecent edges to the feathers.

Immature.-Like the adult but with pale rufous edges to the feathers of the upper-surface, somewhat reealling the summer-plumage, but paler and easily reengnisable by the smaller measmements, especially of the bill. The uncler-surface with the streaks more pronounced.

Nestling in down.-Does not appear to have been described.

Nest and Eggs.-Apparently undeseribed.

Breeds in southern parts of Eastern Siberia, as far west as Southern Baikal and $\mathrm{U}^{\mathrm{p}}$ pper Olekina (tributary of the Lena) and as far north as about $56-57^{\circ} \mathrm{N}$. on (Lena) Olekina.

Distribution and forms.- Eastem Siberia, migrat ner southwarts to Australia in winter. No subspecies are lnomn.

\section{FaMLY RICURVIROSTRIDA.}

This family connints of a group of lialing hirls with lor:g sencler bills, long recks, and very long legs. Scebohm inchuded all the snecies in hi genus Himantupus, as he pointed out that the species were connected by various features. Thus the the members of that genus, as commonly and here res tricted, have straight bills, 110 hind-toe, and small webs to their toes. Cladorhynchus has also a straight bill, but the toes are fully webbed and no hind-tne. Recurvirostra has the bill upturned, the toes fully webbed, and a hind-toe is present. In coloration, upon which Seebohm based his affinities, a similar range is noticeable.

The straight-billed birds are called Stilts, and tho; e with upturned bill: Arnect ; they are very elosely related, as some of the speeies of Avoct have straight:-h bills when immature.

There appear: to be little recolded as regarls the anatomical characters of this family ; the peculiar slenclerness of the Jachrymals has been notel, as well an the vomer with the extremity excarate instead of pointed. The muscle formula of the leg is ABXY+ and there are no intrinsic muscles to the syrinx which is of the tracheo-bronchial pattem. A cemparison of the aratomy and osteology if the three Australian genera from nestling to adult would be very valuable. 


\section{Genus HIVANTOPUS.}

Himantopus Brisson, Ornith., Vol. I., p. 46, Vol. V., p. 33, 1760. Type (by tautonymy): Himantopus = Charadrius himantopus Linné.

Macrotarsus Lacepède, Tabl. Ois., p. 18, Dec. 1799. Species added by Daudin, in Hist. Nat. Buffon, ed. Didot, Quadr., Vol, XIV., p. $336[1799=]$ Oct. 1802. Type (by monotypy): C. himantopus Linné.

Not of Link, Beytr. Nat., I (2), pp. 51, 65, 1795.

Hypsibates Nitzsch, in Ersch und Grüber's Ency., sect. I., Vol. XVI., p, 150, 1827. New name for Himantopus Bonnaterre = Brisson.

Calobatus Lesson, Manuel d'Orn., Vol. II., p. 339, June 28th, 1828. New name for Himantopus Brisson. Typo (by monotypy): Charadrius himantopus Linné.

Himantellus" Rafinq. 1815" Gray, Cat. Gen. Subgen. Birds, p. 117, Oet. 1855. In synonymy of Himantopus Brisson.

The members of the genus Himantopus have the bill long, thin, and flattened; it is straight, with the tip of the upper mandible decurved over the lower one. The culmen is about half the length of the metatarsus; shorter than the exposed tibia, but longer than the middle toe with claw. The nostrils are linear, placed near the base of the culmen and situated in a groove which extends half the length of the bill. The wings are long and pointed, about twice the length of the metatarsus. The tail is short and square, about one-third the length of the wing. The legs are very long-about twice as long as the culmen and half the length of the wing; the bare tibia is longer than the culmen; the metatarsus is covered with reticulated scales, which tend to fusion in the adult. The outer toe is connected to the middle one by a small basal web; the inner toe is not connected. No hind-toe.

\section{I06. Himantopus leucocephalus.-WHITE-HEADED STILT.}

Gould, Vol. VI., pl. 24 (pt. Iv.), Sept. 1st, 1841. Mathews, Vol. III., pt. 2, pl. I41, May 2nd, 1913.

Himantopus leucoceplalus Gould, Synops. Birds Austr., pt. II., pl. 34, April 1837 : New South Wales.

Himantopus novchollandice Bonaparte, Comptes Rendus Acad. Sci. Paris, Vol. XLIII., p. 421, Sept. 1st, 1856. New name for Himantopus leucocephalus Gould.

Himantopus seebohmi Hartert, Katal. Vögels Mus. Senckenb., p. 220, 1891, mid-January. New name for $H$. leucocephalus Gould.

Hypisbates leucocephalus assimitis Mathews, Nov. Zool., Vol. XVIII., p. 219, Jan. 31st, 1912 : Parry's Creek, North-west Australia.

Distributiox:-Australia generally. Not Tasmania.

Adult male.-Hind-neck, mantle, scapulars, and wings, both above and below, glossy black with obsolete wavy cross-bars on the long innermost scapulars; head, lower hind-neck and back below the mantle pure white ; tail also white, the middle feathers tinged with grey; throat and entire under-surface white including the axillaries; primary- and secondary-quills below fringed with white at the tips; bill black; iris dark red; tarsi and feet pink. Total length $388 \mathrm{~nm}$. ; culmen 59 , wing 223-230, tail 75, tarsus 109-119.

Adult female.-Similar to the adult male but smaller, and the feathers of the mantle and scapulars inclining to brown.

Immature male.-Distinguished from the adult by the dark grey on the head and nape, the brown on the back and scapulars and the darker tips to the tailfeathers. Some of the feathers of the back have white edgings and the under wingcoverts are margined with white. As the bird advances in age the grey on the head and nape disappears.

Nestling.-Yellowish down, the upper side with black markings.

Nest.-A bare shallow hollow in the earth. A slight structure consisting merely of a few short piece: of rushes and grans placed in and around a depression 
at the foot of a clump of ru-hes growing near the water's edge. Compo-ed principally of a clried algr, with other acpuatic plants, placed on clumps of the dwarf salt marsh plant, being built up about 9 inches above the water. They measured approximately 8 inches across.

Eggs,-Clutch, four; ground-colour greenish-stone, marked all over with irregular-shapert spot of dark purplish-black and smaller underlying ones of lavender ; axis 44.5 to $45 \mathrm{~mm}$, diameter 30.5 to 31.5 .

Breeding-season.-April, May, August to October.

Distribution and forms.-.-Throughout Australia and the Molucea Islands and also Now Zealank. Four subspreeies have been distinguished, as: 11. l. leurocepludus Gould, from Eastern Australia; II. l. assimilis (Nathews) from North-western Australia and Northem Territory, a smaller form with smaller bill, wing and legs, wing $\hat{j} \hat{0}$ 2.23-232 against typical jô 239-245; culmen 59-61 against 64 ; tarsus 109-119 against 123-127 mm., males being always larger than females; $H . l$. timoriensis (Mathews) from East Timor and ? North Celebes agreeing in general size with the typical bircls but with notably shorter legs, as tarsus 117-119.5 against 123-127 mm.; and H. t, albus Ellman from New Zealand, the white collar being mottled with black and the tail being darker.

\section{Genus CLADORHYNCHUS.}

Cladorhynchus Gray, List Genera Birds, 1st ed., p. 69, April 1810. Type (by original designation): Himantopus palmatus = Recurirostra leucocephala Vieillot.

Recurvirostra Boie, Isis, 1826, heft 10., col. 979, Oct. 'Type (by monotypy): $R$. orientalis Cuvier $=R$. leucocephala Yieillot.

Not of Linné, Syst. Nat., 10th ed., p. 151, Jan. 1st, 1758.

Leptorhynchus Du Bus, Mag. de Zool., 1835, pl. 45 (dated Aug.). Type (by monotypy): $L$. pectoralis Du Bus $=R$. leucocephala Vieillot.

Not of Guerin, Voy. Coquille, Zool., Vol. II., p. 110, 1831.

Xiphidiorhynchus Reichenbach, Vögel Neuholl, pt. I., p. 28, 1845. Typo (by monotypy): R. leucucephala Vieillot.

Timeta Gistel, Naturg. Thierr. Schul., p. 9, (pref. Easter, 1847) 1848. New name for Leptorhynchus Du Bus.

The solitary member of the genus Clatorhynchus differs from those of Himantopus in its stouter legs and fully webbed toes. The euimen is much more than half the length of the metatarsus, the wings are about twice the length of the metatarsus, while the tail is short but nearly half the length of the wing. There is no hind-toe.

\section{r07. Cladorhynchus leucocephalus. BANDED STILT.}

Gould, Vol. VI., pl. 26 (pt. II.), March Ist, 18t1. Mathews, Vol. III., pt. 2, pl. 142, May 2nd, 1913.

Recurvirostra leucocephala Vieillot, Nouv. Dict. d'Hist. Nat., Vol. III., p. 103, Sept. 14th, 1816: " anx 'Terres australes" = Victorin.

Recurvirostra orienalis Cuvier, Règne Anim., Vol. I., p. 496, Dec. 7th, 1816. ? Same specimen. Leptorhynchus pectoralis Du Bus., Mag. de Zool., 1835, pl. 45 (dated Aug.) : Vietoria.

Himantopus palmatus Gould, Synops. Birds Austr., pt. II., pl. (33), April 1st, 1837 : Victoria. Cladorhynchus australis Lawson, Emu, Vol. IV., p. 131, July 1905. Nomen nudum.

Cladorhynchus lencocephalus rottnesti Nathews, Austral Av. Rec., Vol. I., pt. 2, p. 31, April 2nd, 1912: Rottnest Island, South-west Australia.

Distribution.-Australia generally and Tasmania.

Adult male.-Head and neck all round and entire back white, like the sides of the breast and ablomen, under tail-coverts, and inner under wing-coverts; marginal coverts brown, edged with white; upper wing-coverts and scapulars black; small corerts on outer edge of wing brown : batard-wing. primary-coverts and quills dark brown, the fire outer primaries paler brown on the inner webs, the remainder white on the inner webs; secondaries whitr exeegt two of the inner ones which have 
a brown spot on the outer web, the long innermost secondaries black like the scapulars; tail, middle feathex pale grey, outer feathers grey on outer webs, white on inner ones; breast chestnut, the feathers of which have white bases followed by blackish and very broally tipped with chestnut, so that the white of the fore-neck and the chestnut on the breast is divided by a narrow blackish line, the feathers on the midclle of the abdomen dark brown, some of which are suffused with chestnut; bill black; iris dark brown ; tarsi and feet yellow. Total length $405 \mathrm{~mm}$. ; culmen 69 , wing 193 , tail 80 , tarsus 88 .

Adult female.-Similar to the male.

Young male (bird of the year).-Differs from the adult in the entire absence of the chestnut, or dark pattern, on the breast and middle of the abolomen, these parts being white like the rest of the under-surface; upper wing-coverts very narrowly edged with white.

The first stage of advance towards the breeding-plumage is shown in specimens which have the chestnut pattern on the breast and the dark patch on the middle of the abdomen just faintly outlined on the white unler-surface, while others demonstrate more clearly the colour of these parts, which can be seen by the chestnut, more especially on the sicles of the breast, which is still much intermixed with white.

Other specimens also show the advance of the chestnut and the dark portion on the middle of the abdomen; the white, so prevalent in the first one mentioned. above, is fast disappearing and the next stage appears to be the fully adult.

Nestling.--Undescribed.

Nest.-A rough construction placed in a low salt bush.

Eggs.-Clutch, four; the ground-colour varies from an olive-brown to creamybrown, irregularly spotted and blotched with black, in shaje oval but slightly pointed; axis 44-48, diameter 29-33.

Distribution and forms.-Confined to Australia, and at present through lack of good series no subspecies admitted.

\section{Genus RECURVIROSTRA.}

Recurvirostra Linné, Syst. Nat., 10th ed., p. 151, Jan. 1st, 1758. Type (by monotypy): Recurvirosira avosetta Linné.

Avocetta Brisson, Ornith., Vol. I., p. 60, Vol. VI., p. 537, 1760. Type (by tautonymy): Avocetia $=$ Recurvirostra arosetta Linné.

In the genus Recurvirostra the bill is long and recurved, the feet are fully webbed, and a hind-toe is present; otherwise it resembles Himantopus. The bill is very long, somewhat flexible, flattened, then tapering with a strong upward turn and the tip again decurved; the nostrils a very narrow slit in a flat, short groove; the culmen is almost as long as the metatarsus and equal to the tail. The wings are long and pointed, and more than twice the length of the tail, which is syuare. The metatarsus is reticulated and the toes are fully webbed, and there is a hind-toe.

\section{Recurvirostra novæhollandiæ.-RED-NECKED AVOCET.}

Gould, Vol, VI., pl. 27 (pt. Ix.), Dec. 1st, 1842. Mathews, Vol. III., pt. 2, pl. 143, May 2nd, 1913.

Recurvirostra novechollandice Vieillot, Nouv. Dict. d'Hist. Nat., Vol. III., p. 103, Sept. 14th, 1816 : "Nouvelle Hollande" = Victoria.

Recurrirostra rubricollis Temminck, Manuel d'Orn., 2nd ed., Vol. II., p. 592, Oct. 21st, 1820 : Victoria.

Recurvirastra novcehollandice stalkeri Mathews, Nov. Zool, Vol, XVIII., p. 220, Jan. 31st, 1912: Alexandra, Northern Territory.

Distribution.-Australia generally and Tasmania. 
Adult male-Head, hind-neck, throat, and fore-neck chestnut; lower hind-neck, back, outer scapulars, tail, and tentire under-surface. pure white including the under tail-eorert axillaries, and under wince-coverts: the small marginal coverts round the bend of the wing white like the bastard-wing, greater corerts, secondaries, and imer primarien, sme of the latter tipued with dark brown: primary-eoverts and primary-yuills black, the basal portion white; median wing-coverts and long innermost secondaries very dark brown; some of the inner scapulars dark brown, others are brown on the inner web and white on the outer one; small feathers round the eve white wheh widen out and forms a jateh below the eye ; bill black; iris dark red; taris and feet slate-blue. Total length 457 mm.; culmen si, wing 22.5, tail 86 , tarsus 94 .

Adult female.-Similar to the adult male.

Immature and Nestling.-Apparently undescribed.

Nest.-Made on little heaps of stiff grass.

Eggs,-Clutch, four; ground-colour light stone to creamy-yellow, some of the former tint have a faint olive-green shade, some are heavily bloteherl towarls the thicker end, others sparingly covered with spots, dots anil freckles of dark amber-brown and black, with a few obsolete spots of slate-grey; axis 48-51 mm., diameter $32-36$.

Breeding-season.-September to December.

Distribution and forms.-Australia and straggling to New Zealand. Two subspecies have been distinguished, as: $R$. n. nouchollandice Vieillot, from Eastern Australia; and $R$. n. stalkeri Mathews from the Northern Territory as being smaller, especially in the bill measurement, and with a darker chestnut head. The northwestern birds are attached to the latter, but may be separable.

\section{SUPERFAMUY CHARADRIOIDEA.}

Wo have arranged in, this superfamily four families, Oystercatchers, Turnstones, Plovers (restricted) and Wattled Plovers. Here again the distribution is eriatice and interesting, the first two families cominting of generalised forms of different range, the third world-wide range of both percialised and generalised species, while the last named is a specialised group of definite range. Oystereatchers occur throughout the world save in the Arctic and Antarctic zones. Turnstones breed in the Aretic Jegions but migrate southwards even to the Antaretic, similarly to and in company with Waders. Some Plovern, as the true Plovers, have the same habits but breed in the North Temperate zomes; while the shure Plovers breed throughout the world, some migrating from the north nouthwark, others stationary in the south and showing much specialisation. Other forms, as the sand Plorers, agree in similar manner, but while the shore Plorers farour the shores of the countrices they breed in for nesting purposes, the sand Plover go inland to sanly plains in the north. The Wattled Plovers are probahly the most intere-ting group as having localised themselves in the moro or less tropical zone, one or two have extended their ranges outside. Generally specialised, they have continued their specialisation in detail developing huge facial wattles in some canes, large fighting sulus on the wings in others, and crests on the head in others; some hare retained a hind-toe, others hare lost it; yet withal maintaining a general coloration recogni:able at sight and peculiarly constant throughout the serien, though showiug duller or brighter plumage changes as well. There is variation in the pre. ence or abence of the hind-tee thoughout the superfamily, as woll as in the nature of the tarsal corering, but no species has the toes fully webeel, though wame have sight webs. The bill is generally sort, long only in the Oystercatchers.

The osteological aml anatomica! features: are generally as recorded for the suborder, no detailed account of the variou-s peeses and forms having yet been prepared. 


\section{FAMILY H EMLATOPODIDF.}

All Oystercatchers are referable to one genus, as lumpers consider the value of that group, but the lintinction of Prohumatomus. Mathews will later be fully aclanowledged. The group is undoubtedly ancient, as the distribution proves, the species ow urring on all shores sare in the Iretic and Antarctic ('rele:s and Polynesia. 'There is ! ittle variation in the eolour an l size of the pexie, a darls uncolour series apparently having independently evolved in different lexalities. Superfiejally with their leng bills: and short legs they present a difierent alpearance from other Charadriform birds, and are seen to belong here by examination of the structural features of the downy young.

\section{Genus HEMATOPUS.}

Homatopus Linné, Syst. Nat., 10th ed., p. 152, Jan. 1st, 1758. Typo (by monotypy): Hamatopus ostralegus Linné.

Ostralega Brisson, Omith., Vol, I., p. 46, Vol. V., p. 38, 1760. Type (by tautonymy): $H$. ostralegus Linné.

Ostrelaga Bonnaterre, Tabl. Ency. Méth. Ornith., Vol. I., pp. LxxxIr., 25, 1791. Type (by monotypy): $H$. ostralegus Linné.

Ostralegus Reichenbach, Nat. Syst. Vögel, p. xur., 1852 (? 1853). Type (by original designation): Hematopus longirostris Vieillot.

Melanibyx Reichenbach, $i b$. Type (by original designation) : H. niger Temminck.

The Oystercatchers constitute a distinct family of birds, whose exact relationships are somewhat obscure.

They are Wading birls characterised by very long straight, lateraliy compressed bills, long wings, short legs and stout feet.

The bill is long and straight, laterally compressed in front of the nostrils, much longer than the head and also longer than the tarsus; the nostrils lie near the base of the culnen as lomgiturlinal Hit.; in a groove which extends along half the length of the bill. The wings are long and pointed with the first primary longest andi more than twice the length of the tail which is square. Metatarsus short and thick and entirely covered with somewhat hexagonal scales; toes short and thick, with slight webs between the basal phalanges, and the skin of the soles laterally extended. Hind-toe entirely absent.

\section{I09. Hæmatopus ostralegus,-PIED OYSTERCATCHER.}

[Homatopus ostralegus Linné, Syst. Nat., 10th ed., p. 152, Jan. 1st, 1758: Sroden, Europe. Extra-limital.]

Gould, Vol. VI., pl. 7 (pt. xvנII.), March 1st, 1845. Mathews, Vol. III., pt. 1, pl. 126, Apri] 2nd, 1913.

Homatopus longirostris Vieillot, Nouv. Dict. d'Hist. Nat., Vol. XV., p. 410, Sept. 13th, 1817 : "Australasiæ " = Now South Wales.

Hamatopus picatus King, Survey Intertrop. Coasts Austr., Vol. II., p. 420, "1827" = April 26th, 1826. No locality $=$ Point Torment, North-west Australia.

Hrematopus australasianus Gould, Synops. Birds Austr., pt. IV., App., p. 6, April 1st, 1838 : New South Wales.

Hømatopus longirostris mattingleyi Mathews, Nov. Zool, Vol. XVIII., p. 213, Jan. 31st, 1912 : Cooktown, Queensland.

Distribution.-Australia generally and Tasmania.

Adult male.-Head and neck all round, back, wings, and tail black; lower back, rump, upper tail-coverts, and base of tail white, like the breast, ablomen, axillaries, and under tail-coverts; under wing-coverts black margined and tipped with white; some of the feathers on the upper-breast fringed with white at the tips; upper greater wing-coverts broadly tipped with white; secondary-quills white at the base with 
black tips. I few blakels feathers on the thighs; bill scarlet, cream colour at the tip; iris and eyelid red; feet pinkish-red. Total length $500 \mathrm{~mm}$.; culmen 82 , wing 282-7, tail 116, tarsus 61 .

filult female.- Timilar in colour of plumage to the adult male but larger and with a longer bill.

Immature.-Differs from the adult in having the parts that are black in the alult, brown. The wing-coverts and scapulars are tipjerl and colged with white. The flank feathers are tipned with brown. The brown extends on to the lower back. The upper tail-coverts are almot all brom, having rmly a sliegh exlging of white. Bill, culmen, and point dark brown; legs and feet dark in the skin.

Nestling in down.-Greyish-buff, with black spots on the back, and with a dark longitudinal stripe on each side above the wing.

Nest.-A depression in the sand.

Eggs.-Clutch, two; ground-colour pale stone, spotted all orer with marks of very dark reddish-brown and lavender; axis 61-65 mm., diameter 40-43.

Breeding-season.-August to January.

Distribution and forms.-Through Europe and Asia, the MIoluccas, Australia and New Zealand, wintering in North . Ifriea and India. The number of forms is not well known at pre-ent, probably many more than the five admitted by Minthews in 1913 being later aceepted ; these are: $i 1$. o. ostraleyas limé, from Sweden, through Europe, probably not in Turkestan, where a form with much longer bills may breerl, as all Indian birds in winter-plumage have much longer bills and more white on the throat; H. o. osculans Swinhoe from China and Japan, with less white on the primaries, longer bill and black tips to the upper tail-coverts; $H$. o. picatus King from Northern Territory and North-mest Lu-tralia, with a black celging to the immer wing, and small amount of white on imer web of fuimaties; H. o. longirostris Vieillot from East and South Australia, with no white on the inner webs of primaries, more black on inner portion of wing, the black of the upper back extending on to the lower back (the smaller form from North Queen-lant and South-east New Guinea which Mathew named $I I$. o. mullingleyi being probubly later reinstated); and II. o. finsehi Martens from New Zealand, with still longer bills and apparently a strong tendency to melanism as evidenced in the aberration named $H$. reischeli Rothschild.

\section{II0. Hæmatopus unicolor.-BLACK OYSTERCATCHER.}

[Hcomatopus unicolor Forster, Descr. Anim., ed. Licht., p. 112, (pref. Jan. 1st) 1814: Now Zealand. Extra-limital.]

Gould, Vol. VI., pl. 8 (pt. Xvirr.), March 1st, 1815. Mathews, Vol. III., pt. 1, pl. 127, April 2nd, 1913.

Homatopus niger Stephens, in Shaw's Gen. Zool., Vol. XIV., pt. I., p. 336, I82G : Australia. Not of Temminck, Man. d'Orn., 2nd ed., Vol. II., p. 533, Oct. 21st, 1820 : South Africa.

Hamatopus fuliginosus Gould, Birds Austr., pt. xvIr. (Vol. IV., pl. 8), March 1st, 1815: Tasmanir.

Hematopus niger australasianus Bonaparte, Comptes Rendus Acad. Sci. Paris, Vol. XLIII., p. 420 , Sept. 1st, 1856 : New name for $H$. fuliginosus Gould.

Hoematopus opthalmicus Castelnau and Rarnsay, Proc. Linn. Soc. N.S.W., Vol. I., p. 385, March 1877: Gulf of Carpentaria, Queensland.

Hamatopus unicolor bernieri Mathews, Nov. Zool., Vol. XVIII., p. 214, Jan. 31st, 1912: Bernier Island, West Australia.

Distributron.-Australia generally and Tasmania.

Alult male.-Entirely glossy black above and below ; bill orange-yellow; iris red ; eyelid orange-yellow ; fect dull brick-red. Total length 520 mm. ; culmen 82, wing 297 , tail 124 , tarsus 51 .

Adull female.-Similar to the adult male, but larger, browner, and with a longer bill. 
Immature.-Much browner and paler with dull greyish-pink feet and horn coloured bill, the feathers of the back with pale tips.

Nestling in down.-Sooty-brown with white tips on the upper-parts; head black as also two longitudinal lines on the back.

Nest.-A depression in the earth.

Eggs.-Clutch, two; very similar to the eggs of the preceding but the groundcolour seems darker; axis $65 \mathrm{~mm}$., diameter 44.

Breeding-season.-August to January.

Distribution and forms.-Confined to Australia and New Zealand. Four subspecies are easily recognisable: $H . u$. unicolor Forster from New Zealand; $H . u$. fuliginosus Gould from South-east Australia, with a shorter, more rounded bill anterior to the nostrils; $H . u$. bernieri Nathews, from South-west Australia, with a browner coloration, smaller wing but longer legs; as typical, wing 297, tarsus 51 , against wing, 282 tarsus 56 ; and $H$. u. opthalmicus Castelnau and Ramsay from Northern Australia, of smaller size but with a remarkable bare ngee round the ere.

\section{FAMILY ARENARIIDE.}

This family containing only two species both breeding in the northern hemisphere and one migrating almost to the Antarctic in winter. The superficial fratures are peenliar, a conical bill with no differentiated dertrum, and a well-dereloped hind-toe, with astrong Plover-like apprearance. The hill of the nestling when hatehed is Pluvialine but in a few days it takes on the adult appearance, thus indicating the Pluvialine descent. The tarsus is quite peculiar, being transversely scuted in front and behind. To detailed examination of the onteology or anatrmy appeans to have been made, the leg muscle formula being AXY + . By some writers the American genus Aphriza was included owing to the presence of the hind-toe, but the bill is typically Pluvialine and the tarsal covering different. Ridgway has recently allowed a family Aplorizide for this genus alone, but upon insufficient srounds, as he stresict. the presence of the hind-toe, though including the Tanelline forms in his Charadriida. We camnot see any reason for separating Aphriza from the Charadriida as here restricted.

\section{Genus ARENARIA.}

Arenaria Brisson, Ornith., Vol. I., p. 48, Vol. V., p. 132, 1760. Type (by tautonymy): Arenaria $=$ Tringa interpres Linné.

Morinella Meyer und Wolf, Taschenb. d. Vögel, pt. I., p. 383, note, (pref. March) 1810. Typo (by monotypy) : M. collaris Meyer und Wolf $=$ Tringa interpres Linné.

Strepsilas Illiger, Prodr. Mamm. et Av., p. 263, (pref, April) 1811. Type (by monotypy): T. interpres Linné.

Cinclus Gray, List Gen. Birds, 2nd ed., p. 85, Sept. 1811. Typo (by original designation) : $T$. interpres Linné.

Not of Borkhausen, Deutsch. Fauna, Vol. I, p. 300, 1797.

Small Wading birds with short straight bill, long wings, and short and stout legs and feet. The bill is ristinctive, being somewhat conical, almost straight or very slightly upturned, the culmen flattened. The nostrils are linear, situated near the base of the culmen, in a groove which extends nearly half the length of the bill. The wings are long and pointed, the first primary longest. The metatarsus, just exceeding the culmen in length, is transversely scutellated in front, reticulated behind. Hind-toe well developed, the toes not connected or webbed at all.

\section{Arenaria interpres.-TURNSTONE.}

[Tringa interpres Linné, Syst. Nat., 10th ed., p 148, Jan. let, 1758: Europe. Extra-limital.] Gould, Vol. VI., pl. 39 (pt. $\operatorname{xxxiv.),~Dec.~1st,~1848.~Mathews,~Vol.~III.,~pt.~1,~pl.~125,~April~}$ 2nd, 1913. 
Tringa oahuensis Bloxham, Voy. "Blonde," Sandwich Is,, p. 251, $1826=$ Feb. 20th, 1827 : Sandwich Islands.

Charadrius cinclus Pallas, Zoogx. Rosso-Asiat., Vol. II., p. 148, 1827 : Siberia.

[Strepsilas interpres] pacificus Nelson, Cruise of the Corwin in 1881, p. 83, 1883, pref, March 3rd : Behring Sea, Coast and East Asia.

Arenaria inlerpres nova Mathews, Austral Av. Rec., Vol. III., pt. 4, p. 69, July 21st, 1917: Rottnest Island, West Australia.

Distrubtion. - Winter visitor to Australia, breeding in the northern hemisphere.

Adult male in breeding-plumage.-Lores, fore-part of crown, sides of crown, asy wiles of neck white like the lower back and upper tall-corerts, as: also the throat, middle of breast, abdomen, under tail-coverts, axillaries, and under wing-coverts; fore-head black with white fringes to the feathers; a black line in front of the eye joined to a black patch on the sides of the face which extends in a line on to the sicies of the neek and is eontinued in a large space of black round the lower throat and sides of breast; crown of the head, the feathers fringed with white, giving a streaked appearance; hind-neek white, the feathers tipped with brown and buff; a black spot on each side of the nape; the feathers of the mantle white. tipped with chentnut and a small black elongated spot; some of the feathers of the back and scajular's are chestnut tipjed with black, while others are black tipped with chestrut; rump dark brown; tail mostly white with a broad subterminal black band, the outermost pair of feathers white with the exeeption of a brown spot on the inner web near the tip; lesser upper wing-coverts dark brown, some of the imermost white, those on the outer edge white with a subterminal bromn spot; bastard-wing and outer median coverts brown, the inner ones for the most part chestmut; greater coverts brown margined and tipued with white; primary-coverts and primary-culls brown, the latter paler brown on the inner webs, with white shafts and white on the outer webs towardi; the lase; secondaries for the most part brown margined and tipperl with white, the imnermost brown raried with ehestnut and white. some of the feathers pure white; bill black, eyes brown, feet red, joints brown. Total length $225 \mathrm{~mm}$; ; culmen 25, wing 155, tail 61, tarsus 24.

Adult female in breeding-plumage. - Similar to the male but with more black on tho mantle and less chestnut; the feathers on the crown of the head black margined with brown; the white on the sides of the head and fore-part of crown not so clearly defined.

Adult in winter-plumage.-Differs from the breeding-plumage in the entire absence of chestnut on the upper-surface where it is replaced by dark brown, or b'ack, with pale brown margins to the feathers; head and hind-neck du-ky-brown more or less intermixed or streaked with white like the ear-coverts and sicles of face, the feathers on the sides of the upper-breast very similar.

Immature.-Upper-parts dark brown with paler brown edges to the feathers of the scapulars and upjer wing-coverts; entire head, sides of face, hind-necli and sisles of neck dusky-brown becoming black on the fore-neck and sides of breast, where the feathers are more or less edged with white.

Immature just out of down.-Black breast-band mottled with white tips; upper-parts with pale rufous tips.

Viestling in doun.- Pale greyish-brown with a wash of yellow and mottled with black on upper-surface and top of head, showing no definite pattern; an indistinct frontal streak not reaching bill ; fore-head and above and around the eres yellowishbrown; loral black stripe with a black spot below in front of gaje; under-surface pale creamy-white, an inclistinct dark band across chest through dark bases to down ; winglet mottled black and brown with white tip. A few days older shows typical bill formation ; coloration greyer, mottling more confused on tor of head and lack; neck paler as in previou: stage while there is a distinct broad blackich breast-band, the chin and throat and rest of under-surface pure white.

Nest.-A slight depression, sometimes lined with grass. 
Eggs.-Clutch, four; ground-colour pale green, marked all over, but more on the larger end, with irregular markings of olive-brown and lavender; axis 40$43 \mathrm{~mm}$., diameter 30 .

Breeding-season.-June and July. (East Siberia.)

Distribution and forms.--Breeding right round the Pole in the Arctic Regions and wandering southwards almost to the Autaretic Circle in winter. Three subspecies are recognisable: the European A. $i$. interpres (Linné); the American A. $i$. morinella (Linné) a much paler race, the ehestnut on the back being lighter and more pronouncel; and $A$. $i$. oahuensis (Bloxham) the form visiting Australia, jerhaps breeding north of Alaska, somewhat intermediate in coloration, darker than American but paler than European, and also intermediate in sizc, the European being the largest form with probably the longest bill.

\section{FAMIY CHARADRIIDE.}

The Plover series includes three fairly distinct groups, the Pluvialis (= Charadrius olim), the Charadrius (= Egialitis olim) and the Cirrepidesmus ( = Ochthotromus olim) alliances. The superticial features of these have been fully detailed by Mathews and we may here atd that the downy young show that these distinctions are well founded. As regards internal features we may just note that skeletal items of some import oceur as confirmation of these civisions, but that detailed accounts have not yet been published. In Pluivalis the leg muscles are recorded as $\mathrm{AXY}+$, but in Charadrius the full formula $\mathrm{ABXY}+$ is reported. Lntrinsic muscles of the syrins are also stated to be present in the latter series but absent in the former.

The Pluvialis series breed in the Arctic and Subarctic regions migrating southwards in winter, two forms more or lens commonly occurring in Australia. It might be here noted that some birds remain in the southern hemisphere during the summer and even take on their breeding-plumages but they do not breed. The Charculrius series, with which is here included the Lencopolius group, breed more or less on the littoral throughout the world and the Australion breeding forms number three, one almost indistinguishable from a Palæarctic species, another superficially distinct but easily showing its alliance through its plumage changes with the Palrearetic type, while the thiril is so specialised as to obscure its descent, though as far as can be gauged of the Charadrius group. The Cirrepidesmus series breed in the southern Piliearetic desert ind migrate southwards to Australia in winter. Further the bill varies in form and coloration as detailed by Mathews, in one form being black, the dertrum more or less strongly developed, the base of the bill not much deeper than the dertrum ; in the other parti-coloured, the dertrum less developed and generally the bill at the base noticeably deeper; the former occurs in Pluvialis and the sliape was termed Pluvialine, the latter is typical of the next family, the Vanellicle, and the shape was termed Vanelline. It would now appear that these terms were well chosen, as osteological studies suggest distinct derivation. from the sources indicated.

\section{Genus SQUATAROLA.}

Squatarola Cuvier, Règne Anim., Vol. I., p. $467[1817=]$ Dec. 7 th, 1816. Type (by tautonymy): Tringa squalarola Linné.

Large Plovers with stout bills, long wings, short legs and strong feet.

The bill is straight and stout, the dertrum much swollen and rounded, as long as the head; the nostrils linear and placed in a groove. The wings are long, and the first primary is longest. Tail rounded. Metatarsus short and covered both in front and behind with hexagonal scales. Outcr and middle toes connected by a short web at the base. Minute hind-toe and claw present. 


\section{II2. Squatarola squatarola.-GREY PLOVER.}

[Tringa squatarola Linné, Syst. Nat., 10th ed., p. 149, Jan. 1st, 1759 : Sweden. Extralimital.]

Gould, Vol. VI., pl. 12 (pt. xxxv.), Dec. 1st, 1818. Mathews, Vol. III, pt 1, pl. 132, April 2 nd, 1913.

Charadrius hypomelus Pallas, Reise Russ. Reichs, Vol. III., p. 699, pref. Feb. 10th, O.S., 1776 : Siberia.

Charadrius hypomelanus Pallas, Zoogr. Rosso-Asiat., Vol. II., p. 138, 1827 : Siberia.

Charadrius pardela Pallas, ib., p. 142: Siboria.

Squatarola helvetica australis Reichenbach, Novit. Syn. Av., No. v., 175, cccxL., Nos. 2683. 2681, 1851 : Australia.

Distributrow.-Winter visitor to Australia, breeding in northern hemisphere

Adult male in summer-plumage.-Upper-surface rariegated with black, brown, and white; fore-head and a line over the eye which is continued on to the sides of the breast white like the under wing-coverts, thighs, and under tail-coverts; sicles of face, throat, middle of breast and abdomen black like the axillaries; primarycoverts black edged with white at the tipss ; the four outer primaries black with white shafts and white on the immer web at the base; the fifth has a white longitudinal line adjoining the shaft on the outer web towards the tip which is increased on the sixth, on the serenth it crosses the onter web, the onter web of the eighth primary is almost absorbed with white, and the ninth likewise; secondaries pale brown with white bases and fringed with white; bill black, base of lower mandible purplishblack: iris dark brown; feet greyish-black. Total length $290 \mathrm{~mm}$.; culmen 31, wing 195 , tail 76 , tarsus 50 .

Adult female.-Very similar to the adult male.

Adult in winter-plumage.-Differs from the aclult in breeding-plumage in being more uniform alove, the feathers dark hrown, with hlack shaft-lines and edged with white; sides of crown, siles of face, and e r-covert-streaked with brown and white; a dark spot in front of each eye; throat, abdomen, and under tail-coverts white, the latter with spots of brown on the outer webs; primary-quills black with white shafts, the sixth, seventh, and eighth showing an inclication of a white line on the outer web next to the shaft.

An adult male, immediately after breeding, has commenced to cast off the nuptial-plumage, which is only retained for a short period, and has become more brown on the upjer-surface, the white and black markings being everywhere wom off : the upper tail-corerts are almost white instead of being regularly barred ; sides of face, throat, brea-t, abdomen, and sides of boly cherpuered with white; sides of crown white, but the line leading to the sides of the breast scarcely defined.

Immature of the firt year. - Upmer-surface mottled with brown and white which is produee! by the feathers being broman-motehed on the sides and tipped with white, these markings more minute on the top of the head and hind-neck ; sides of crown, ear-coverts and sides of face strealied with pale brown and white, paler and more coarsely markel on the breast; axillarien hlack: primary-and seconclary-quills much the same as in the adult; a short white line immediately below the eye; breast and siles of body notted with pale brown and white horing oholete lars on the flanks; throat and middle of abdomen white like the under tail-coverts.

Young.-Dark brown above, the feathers spotted and notched with dull white or buff on the margins; upper tail-coverts white, some of them tingerl with buff and barred with brown; tail brown, barred with white, the brown beeoming merged at the ents with marginal spots of huti ; crom of head like the back but the pattern much smaller; fore-head, sides of face, fore-neck, and breast mimutely marked with longitudinal brom streals; throat, alxlomen, under tail-corerts, and under wing-coverts for the most part white. 
The young of this species can always be distinguished by its black or blackish axillaries from the Golden Plover (Pluvialis apricarius) which have white axillaries, and from the Asiatic Golden Plover (Pluvialis dominicus fulvus) -which havo the axillaries dusky-brown-by being smaller.

Nestling.-Upper-parts greenish-yellow, mixed mith black, or dark brown and buff, with a white nuchal collar; under-surface silky-white.

Nest.-A depression in the earth lined with dry leaves and lichen.

Eggs. Clutch, four; ground-colour yellowish-grey to brownish-yellow, covered with dark brown spots ; axis 48 to $56 \mathrm{~mm}$., diameter 36 .

Breeding-season,-Jume and July:.

Distribution and forms.-Breeding all round the Aretic Cirele and migrating southward in winter to Australia, ete. The birds breeding in eastern Siberia and visiting Australia constitute a recognisable race, S. s. hypomelus (Pallas) in their larger size throughout, the bill stouter, and also in winter-plumage paler.

\section{Genus PLUVIALIS.}

Pluviatis Brisson, Ornith., Vol. I., p. 46, Vol. V., p. 42, 1760. Type (by tautonymy): Pluvialis = Charadrizs apricarius Linné.

Structurally like Squatarola, but with the hind-toe and claw missing. The bill is not quite so stout, and one of the species is less strongly built, but still considerably larger than the Ring-and Sand-Plovers.

The close connection between this and the preceding genus is easily traced by their general coloration, notwithstanding the absence of the hind-toe. In Squatarola the summer-plumage is mottled black-and-white above with the undersurface black: in the present grenus the summer-plumage is mottled black-andgolden above with the under-surface black, but in the former genus the immature has the upper-surface showing a inottled black-and-golden appearance. No other Plovers, save the three included in the two genera Squatarolit and Pluvialis, have the upper-surface mottled, nor have they uniform black under-surfaces.

\section{I13. Pluvialis dominicus.-LESSER GOLDEN PLOVER,}

[Charadrius dominicus P. L. S. Müller, Vollst. Natursyst. Suppl., p. 116, pref. Jan. 4th, 1776 : St. Domingo, America, Extra-limital.]

Gould, Vol. VI., pl. 13 (pt. xxxi.), June 1st, 1848. Mathews, Vol. III., pt. 1, pl. 133, April 2nd, 1913.

Charadrius fulvus Gmelin, Syst. Nat., Vol. I., pt. II., p. 687, April 20th, 1789: Tahiti.

Charadrius griseus Latham, Index Ornith., Suppl,, p. LxvII., 1801, after May: Now South Wales, based on Watling drawing No. 245.

Charadrius taitensis Lesson, Dict. Sci. Nat. (Levrault), Vol. XLII., p. 35, Sept. 23rd, 1826: Tahiti.

Charadrius xanthocheilus WVagler, Syst. Av. Charadr., sp. 36, p. (68), Oct. 1827 : Australia. Charadrius glaucopus Wagler, Isis, 1829, heft 6, col. 619, June (ex Forster MS.): Tahiti.

Charadrius pluvialis orientalis Temminck und Schlegel, Fauna Japonica (Siebold), p. 104, $18 \pm 9$ : Japan.

Charadrius auratus longipes Schlegel, Vogel von Nederl., p. 411, 1854 : East Asia.

Distrimutiox.-Winter visitor to Australia, breeding in the northern hemisphere.

Adult male in breeding-plumage.-Crown of head, entire back, and scapulars black, thickly spangled with golden-butf, beeoming paler and inclining to brow and white on the upper wing-coverts; greater coverts brown, edged with white; bastard-wing brown, small coverts on the margin of the wing dark brown tipped with white like the primary-coverts; primary-quills dark brown, paler on the inner Tebs, and white on a portion of the shafts towards the tip; secondaries brown, white 
at the base, the immer ones elged with white, and the innemost long feathers darls brown notehed with golden-buif on each web, and fringed at the sicle with the same colour; central tail-feathers barred with dark and pale brown, outer feathers pale brown and whito; fore-head and a line over the eye white, which is continued down the sides of the neck and united to a small white patch on the sides of the upperbreast; lores, a spot in front of each eye, cheeks, throat, middle of breast, and niicldle of abdomen black; sides of boly variegated with black, white and golden-buft; axillaries and under wing-coverts pale ash-brown; under tail-coverts white, the short ones tipped with black, and the long ones barred with black towarls the tip ; bill black; iris dark brown; feet leaden-grey. Total length $243 \mathrm{nmm}$; culmen 22 , wing 166 , tail 60 , tarsus 44.

Adult female in breeding-plumage.-Similar to the aciult male but slightly larger. The tarsi of seventeen Eastern birds varies from 40 to $45 \mathrm{~mm}$.

Adult in winter-plumage. - Similar, on the upper-parts, to the adult in breedingplumage, but differs in the absence of the white on the fore-head, line over the eye, and the sicles of the neek, as also the white pateh on the sides of the upjer-breast. It is further distinguished on the under parts by the absence of black on the throat, sides of face, middle of the breast and abdomen, these parts being streakect with brown and buff on the sides of the face and throat, and dusky-brown with twin buff spots on the breast and sides of the body; the feathers on the lower flanks dull white barred with dusky-brown; under tail-coverts white inclining to buff on the lateral ones. The moult from the summer- to the winter-plumage in this species is similar to that of Squatarola squatarola.

Immature.--General colour above, dark brown, inclucling the head, back, wing:, and tail, the feathers margined or spotted with bright golden-yellow; upper wingcoverts paler brown with lemon-yellow spots and margins; bastarl-wing, primarycorerts, and quills dark bromn with white elgings to the tips of the feathers, white shafts to the quills and greyish-brown on the inmer webs; outer tail-feathers paler brown than the middle ones and the light pattern inclining to whitish: have of fore-head, a small pateh behind the ere and the hind-neck covered with whitish down which have dark base's on the latter; lores and fore-cheeks golden yellow, the feathers centrel with brown; hinder cheeks and throat similar but praler; chin and upper throat covered with white down; fore-nock and breast greyish-brown, the feathers markerl with lemon-yellow; sides of body lemon-yellow elged with dark brown, which gives a barred appearance; middle of abdomen and under tailcoverts creamy-white, the lateral under-tail coverts marked with brown; axillaric: and under wing-coverts dusky-brown.

Nestling in down.-Dusky-black on the upper-surface, with golden-yellow tipk to the down, more or less mixed with white, the predominating colour being golien-yellow. Under-surface dull white with blackish bases to the thighs and under-surface of the wings.

Nest.-A mere hollow in the ground upon a piece of turfy land, overgrown with moss and lichen, and lined with broken stalks of reindeer moss.

Eggs. Clutch, four; ground-colour pale buff, spotted and blotehed with rich purplish-brown, with a few underlying ones of inky-grey ; axis 47-49 mum, diameter $32-34$.

Breeding-scason.-June, July.

Distribution and forms.-The arctic regions of Eastern Siberia and North America migrating southward through the Pacific Islands to Australia and to south America, straggling to Europe. Two subseceses are well known: $P$. d. dominicus (Müller) from the West Indies, the American raee with brownish axillaries (the Golden Plover, $P$. apricarius (Linn') of Europe having white axillaries); and $P$.d. fulvus (Gmelin) from Eastern Siberia, the form visiting Australia, with shorter wings and tail but longer legs and toes, and more boldly marked with yellow. 


\section{Genus CIRREPIDESMUS.}

Cirrepidesmus Bonaparte, Comptes Rendus Acad. Sci. Paris, Vol. XLIII., p. 417, Sept. 1st, 1856. Type (by tautonymy): Charadrius pyrrhothorax Gould $=C$. atrifrons Wagler.

Small Plovers with stout bills, long wings, short legs, and medium-sized feet. The culmen is straight, with a swollen clertrum which is almost half the length of the eulmen. The wings are long and pointed with the first primary longest. The tail is short and square. The metatarsus is short and reticulated throughout. The toes are comnected by very small webs at the base. No hind-toe. The culmen is shorter than the middle toe without claw.

\section{4. Cirrepidesmus mongolus.-MONGOLIAN SAND-DOTTEREL.}

Gould, Vol. VI., pl. 19 (pt. sxIv.), Sept. 1st, 1846 (small fig.). Mathews, Vol. III., pt. 1, pl. 135, April 2nd, 1913.

Charadrius mongolus Pallas, Reiso Russ. Reichs, Vol. III., p. 700, (pref. Feb. 10th, O.S.) 1776 : Mlongolia.

Charadrius sanguineus Lesson, Dict. Sci. Nat. (Levrault), Vol. XLII., p. 35, Sept. 23rd, 1826: Java.

Charadrius cirrhepidesmos Wagler, Syst. Av. Charadr., sp. 18, p. (61), Oct, 1827: Hab. unknown, Mus., Paris = Java.

Charadrius gularis Wagler, ib., sp. 40, p. (69). New name for $C$. mangolus Pallas.

Hiaticula inornata Gould, Birds Austr., pt. XxIv. (Vol. VI., pl. 19), Sept. 1st, 1816 (small fig.): Torres Straits.

Charadrius sonneratii Gray, Handl. Gen. Sp. Birds B.M., pt. IIr., p. 15 (pref. July 8th) 1871. In synonymy of $C$. mongolus Pallas.

Agialitis mastersi Ramsay, Proc. Linn. Soc. N.S.W., Vol. I., p. 135, July 1876 : Capo York, North Queensland.

DistributugN. - Winter visitor to Australia, breeding in the northern hemisphere.

Adult male in summer-plumage.-Lores, feathers surrounding the eye, earcoverts, and a band across the fore-part of the crown black ; fore-part of head and sides of crown cinnamon-rufous, becoming darker rufous on the hind-neck and continued on to the chest and sides of breast, where it becomes bright chestnut; fore-head, throat, abfomen, under tail-coverts, and axillaries white; a rery narrow line of black dividing the white of the throat from the rufous ehest-band; lesser under wing-coverts white, more or less spotted with brown; greater under wingcoverts grey with white at the tips ; middle of crown, back, scapulars, wings, and middle tail-feathers pale brown; upper tail-coverts inclining to grey fringed with white; bastard-wing, primary-coverts and quills darker than the back, and inclining to black; greater wing-coverts and secondaries fringed with white at the tips; outer tail-feathers paler than the middle ones, and tipperl with white, the outermost pair white on the outer web; bill and iris black; feet lead-grey. Total length $204 \mathrm{~mm}$, ; culmen 17 , wing 135 , tail 52 , tarsus 31 .

Adult female in summer-plumage.-- Similar to the adult male but the characters on the head less pronounced.

Adult in winter-plumage.--Distinguished from the nuptial-diress by the absence of cinnamon-rufous on the head and hind-neck, and the rufous and black hands on the fore-neck, these parts being represented by greyish-brown more sparsely on the fore-neck; fore-hearl and eyebrow white without any black band on the former; lores, cheeks, and ear-coverts brown.

Nestling with down adhering. - Top of head brown ; fore-head white down, sides of head black and white down, the markings almost linear and meeting at back; nape of neck white down; back brown feathers with minute pale rufous tips ; lower back still with black and white mottled down; tail black down; wing-coverts pale brown with pale rufous edges tipped with down; primaries just sprouting brown; throat white down; chest fawnish feathering with brown at sides; abdomen fawnish-white. 
Nestling in down.-Sides of head (including a broad supraloral and superciliary stripe), hind-neck, and under parts white, slightly tinged with pale greyi:h-buffy, especially on breast and sides, the whole of under parts immaculate; a loral line (from bill to eye), a postocular streak, a small spot near mieldle of malar region, a larger spot beneath suborbital region, an obliquely transterse bar on sicles of nape, and a longitudinal stripe down middle of naje (the last widening posteriorly) black; median jortion of crom and occiput (broadly) irregularly mottled with black and cinnamon or sayal-brown; back, rump, etc., irregularly but boldly marbled with black, cinnamon and whitish, the markings more longitudinal on back, more transverse on lower rump. (Ridgway.)

Nest.-A slight hollow in the ground lined with leaves.

Eggs.-Clutch, three; ground-colour between cream-buff and clay colour; spotted, less numerously at the small end, with markings of irregular size, chiefly of elove-brown, bistre, and even as light as wood-brown. The lighter markings are for the most part rather obscure, as if imbedded in the shell, or as if laid on before the ground-colour. The markings are irregularly confluent on the greater hemisphere of the egg; axis 36-37 mm.; diameter 26.5-27.5.

Breeding-season.-June.

Distribution and forms.-Breeding in eastem Siberia and the Commander Islands, westward to the Kirghiz Steppes, wintering in Australia and Africa and India. Two subspecies are with diffieulty separable: C. mongolus mongolus (Pallas), and $C$. $m$. atrifrons Wagler, the latter the westem form with a black fore-head in summer and lacking the black pectoral line, while it is slightly larger in the bill and tarsus.

\section{Genus NESOCERYX.}

Nesoceryx Mathers, Bull. Brit. Orn. Club, Vol. XLI., p. 35, Nov, 30th, 1920. Typo (by original designation): Charadrius bicinctus Jardine and Selby.

Mathew's has separated the species $C$. bicinctus Jardine and Selby as a distinet gerus as we find the immature stages to difer entirely from thene of the preceding genus with which it was associated recently. The bill is quite difierent and the legs. are longer when immature specimens just losing down are compared.

In the adult the bill is a little longer with the dertrum much less pronounced, and though the wing is shorter, the tail is a little longer, while the tarsus is also a little longer. Thus, gauging the adult structural features, the two were consiclered congeneric, whereas from a stuly of the immature stages there is really little close relationship, and the case is better considered as apparently homeomorphic.

\section{II5. Nesoceryx bicinctus,-DOUBLE BANDED DOTTEREL.}

Gould, Vol. VI., pl. 16 (pt. XIx.), June 1st, 18t5. Mathews, VoI. III., pt. 1, pl. 134, April 2nd, 1913.

Charadrius bicinctus Jardine and Selby, Illust. Ornith., Vol. I., pl. 28, (June) 1827: New Holland $=$ New South Wales.

Charadrius bicinclus incertus Mathers, Nov. Zool., Vol. XVIII., p. 217, Jan. 31st, 1912 :

Point Malcolm, South-west Australia.

Distrizution,-South Queensland, New South Wales, Victoria, Tasmania, South Australia and South-west Australia.

Adult male.-General colour above olive-brown, including the hinder cromn, hind-neck, sides of neck, entire back, seapulars, long innermost secondaries and upper wing-coverts; greater eoverts margined with white at the tipss ; bastard-wing and primary-coverts tipled with white; primary-quills dark brown with white shafts, somewhat paler on the inner wehs towards the base, basal portion of inner primaries white on the outer web; secondaries brown with pale imner webs and fringed with 
white at the tips on the outer web; middle tail-feathers rather darker brown than the back, becoming paler on the outer feathers which have white edges at the tip, the outermost pair almost pure white; fore-part of crom, lores, and cheeks black like the broad band which crosses the lower throat: a wide chestnut band on the lower-breast; fore-head and a narrow line over to behind the eve white like the throat, the space dividing the chestnut-and-black bands on the breast, abdomen, under tail-coverts, axillaries, and under wing-coverts; bill black slightly tinged with olive; iris blackish-brown, eyelids scarlet; feet pale yellowish-white, the joints of the toes and knees browner. Total length $190 \mathrm{~mm}$; culmen 19, wing 127 , tail 56, tarsus 33 .

Adult female.-Similar to the adult male but the colours not so distinct.

Female nearly adult.-Upper-parts similar to the adult male but the feathers everywhere margined with rufous, the black on the fore-head and eheeks searcely pronounced, the dark band on the lower throat brown instead of black, and the chestnut band on the breast much paler and narrower.

Adult in vinter-plumage. -Distinguished from the adult in breeding-plumage by the absence of the black on the lores, cheeks, and fore-part of head, also the chestnut and black bands on the lower throat and breast.

Young.-Differs from the adult in the feathers of the upper-surface being margined with rufous, by the absence of any black on the fore-hearl, lores, and checks, these parts being washed with sandy-buff, which colour is also shown on the lower throat, where the black band of the adult is indicated by an irregular band of brown feathers; but there is no sign of a chestnut band.

Other immature birds in Mathews's collection differ from the adult in having the bands on the chest and throat narrower, less defined, and mixed with white, and the black on the fore-head, lores, and cheeks less pronounced.

Nestling with down adhering.--Top of head brown with well-marked brown tips; no loral stripe; back of neck spotted black and white down which also can be seen on rump and tail; all back, secondaries, scapulars, etc., are brown with broad rufous edges; primaries very short brown; under-surface chestnut from chin to abdomen which is white; bill long.

Nestling in down.-Covered with soft down of a bright sandy-yellow on the upper-surface, changing to yellowish-white on the under parts; the crown of the head and the back prettily mottled with dark brown, of which there is also a broad streak on the wings and thighs.

Fladgeling.-Feathers of the upper-parts brown largely margined with fulvous, uncler parts white with fulvous markings on the breast; the sides of the head and lower part of back and rump covered with down of a dull sandy-yellow, spotted with black, and with fluffy down still adhering to other parts of the bocly. Bill dark brown, legs brownish-grey.

Nest.-A depression in the earth.

Eggs. - Clutch, three; greenish-brown, much sprinkled with dark brown markings ; axis $35 \mathrm{~mm}$., diameter 26.

Breeding season.-August to December. (New Zealand.)

Distribution and forms.-Australia and New Zealand, but not yet found breeding in Australia, though occurring in West Australia, from which locality Mathews proposed the subspecies $N$. b. incertus, but no further knowledge has since been added.

\section{Genus PAGOA.}

Pagoa Mathews, Birds Austr., Vol. III., pt. 1, p. 82, April 2nd, 1913. Type (by original designation): Charadrius geoffroyi Wagler $=C$. leschenaultii Lesson.

Plovers of medium size with very stout bills, long wings, short legs, and medium feet. 
The characters are as in Cirrepidesmus, but the long powerful bill, which is longer than the midulle toe and claw, at once characterises this genus. The culmen is almost half the length of the tail and two-thirls the length of the tarsus, which is more than one-fourth the length of the wing. These proportions are exactly opposite to those of C'irrenidesmus. The wing is long and pointed with first primary longest and the tail is short and square. The tarsus is covered throughout with hexagonal scales, smaller behind.

\section{I16. Pagoa leschenaultii.-LARGE SAND-DOTTEREL.}

Gould, Vol. VI., pl. 19 (pt. Xxiv.), Sept. 1st, 1846 (large fig.). MIathews, Vol. III., pt. 1, pl. 136, April 2nd, 1913.

Charadrius leschenaultii Lesson, Dict. Sci. Nat. (Levrault), Vol. XLII., p. 36, Sept. 23rd, 1826 : Pondicherry, India.

Charadrius geoffroyi Wagler, Syst, Av. Charadr., sp. 19, p. (61), Oct. 1827 : "In Pondichery," India.

Charadrius columbinus Wagler, Isis, 1829, heft 6, col. 650, June (ex Hempr, und Ehrenb. MS.): Arabia.

Charadrius rufinus Blyth, Ann. Mag. Nat. Hist., Vol. XII., pp. 169, 231, (Sept. 1st) 1843 : India.

AEgialitis gigas Brehm, Vollständige Vogelfang, p. 283, (pref. Nov. 8th, 1854) 1855: Suez to East Europo.

Charadrius columboides " Reich." Gray. Handl. Gen. Sp. Birds B.M., pt. Im., p. 14, (pref. July 8th) 1871. In synonymy of $C$. geoffroy $i$ Wagler.

Eudromias crassirostris Severtzoff, Bull. Soc. Moscow, Vol. VIII., livr. 2 [Turkest Jevotnie.], p. 146, 1873 : Fort Peroffsky, Turkestan.

Eudromias magnirostris Severtzoff, Journ. für Ornith., 1875, pt. 2, p. 183 (April). ? Error for preceding.

Pagoa zanda Mathews, Emu, Vol. XVI., p. 35, July 1st, 1916 : Point Torment, North-west Australia.

Distribution.-Winter visitor to Australia, breeding in the northern hemisphere.

Adult mule in breding-plumage.-Genetal colour above pale brown, the feathers everywhere showing black shaft-streaks, with a wash of cinnamon-rufous on the upper back and scapulars; greater coverts brown margined and tipped with white; median eoverts grey ; lesser coverts dark brown fringerl with white at the tips: like the primary-eoverts; primary-quills dark brown, inner welos fringed with white towards the base, shaft of the first primary white, the four following white only towards the tips, the remaining primaries white on tlie onter web and fringed with white at the tips; secondaries brown on the outer webs, fringed with white at the tip, some of the inner ones white on the outer web and pale grey on the inner one, the long immermont cecondaries like the back; upper tail-coverts grey, tipped with white; micldle tail-feathers dark brown fringed with white at the tips becoming paler on the outer feathers, the outermost pair being almost pure white with an obsolete spot of grey near the tip; crown of head, hind-neck, and a narrow collar round the fore-neck cimmamon-rufous, which extends more or less on to the sides of the upper-breast; lores and a line across the fore-head black fringed with white; a black spot below the eye; ear-coverts dark brown streaked with white; middle of crown darker than the hind-neck and inchining to grey; fore-head, throat, and the remainler of the under-surface white including the under wing-coterts, axillaries, and under tail-coverts; bill black; iris brown; tarsi light brown; feet darker brown. Total length $230 \mathrm{~mm}$.; culmen 25 , wing 140 , tail 55, tarsus 37.

Adult female in breeding-plumage.--Similar to the male in nuptial-dress, but the characters evervwhere less pronounced: the black on the lores, fore-head, and under the eye being ab.ent, the ear-coverts rufous-brown, and the middle of the crown more grey.

Adult in winter-plumage.-Differs from the breeding-plumage in the entire absence of cinnmon-rutous on the hearl, hind-neck, and collar on the fore-neck; 
also by the absence of black on the fore-head, lores, and a spot below the cre ; the ear-corerts grey, the fore-head and a line over the eye white like the cheelis, throat, and under-surface of body.

One example, just assuming winter-plumage, still retains an incication of the cinnamon-rufous collar on the hind-neck, the band on the fore-neck is more strong] pronounced and is composed of rufous and grey feathers, the superciliary line bufi"; there is no black line across the fore-head, and the patch under the eye and on the ear-coverts is rufous-brown.

Nestling.-Unknown.

Nest.-A depression in the sand and fine shingle, on the borders of a lake.

Eggs.-Clutch, four? In shape the egg is oval, very slightly pointed at one end. Ground-colour pale stone, heavily marked at the larger end, and sparingly on the smaller, with dark purplish-black and lavender spots ; and about the middle of the shell there are some spots of pale greenish-yellow ; axis $40 \mathrm{~mm}$., diameter 29 .

Breeding-season.-. June.

Distribution and forms.-Eastern Siberia, breeding in Tibet, migrating southward to Australia in winter and accidental westward to Europe. No subspecies yet determined.

\section{Genus LEUCOPOLIUS.}

Lercopnlius Bonaparte, Comptes Rendus Acad. Sci. Paris, Vol. XLIII., p. 417, Sept. 1st, 1856. Type (by tautonymy): Charadrius nivifrons Cuvier $=C$. marginatus Vieillot.

Egialophilus Gould, Handb. Birds Austr., Vol. II., p. 234, (Dec.) 1865. Type (by original designation): Charadrius cantianus Latham $=C$, alexandrinus Linné.

Smallest Plovers, with long slender Pluvialine bills, long wings, short tails and legs, and weak feet. The bill is Pluvialine, and all black, about half the length of the tarsus and equalling the middle toe in length. The wing has the first primary longest. The tail is short and square. The legs are slender, and between the outer and middle toe, near the base, is a distinct web. There is no hind-toe.

\section{II7. Leucopolius ruficapillus.-RED-CAPPED DOTTEREL.}

Gould, Vol. VI., pl. 17 (pt. xxirr.), June 1st, 1816. Mathews, Vol. III., pt. 2, pl. 138, May 2nd, 1913.

Charadrius ruficapillus Temminck et Laugier, Planch. Color, d'Ois., Se livr. (Vol. I., pl. 47, f. 2) (Vol. V., pl. 68), March 1821: "Oceanie" = New South Wales.

Charadrius marginalus Lesson, Dict. Eci. Nat. (Levrault), Vol. XLII., p. 25, Sept. 23rd, 1820 : south coasts of New Holland = Victoria.

Not of Vieillot, Nouv. Dict. d'Hist. Nat, Vol. XVIII., p. 138, Dec. 26th, 1818.

Egialitis? canus Gould, Synops. Birds Austr., pt. rv., App., p. 6, April 1S3S : New South Wales.

Charadrius ruficapillus tormenti Mathows, Nov, Zool., Vol. XVIII., p. 217, Jan. 31st, 1912: Point Torment, North-west Australia.

Drstributron.-Australia generally and Tasmania.

Adult male in summer-plumage.-General colour above pale reddish-brown, including the back, wings, scapulars, and long innemost seconciaries: bastard-nizg, primary-coverts and quills dark brown, the latter paler brown on the inner webs and the shafts white; secondaries grey with the basal and apical portions white, this colour increasing in extent on the inner ones; upper tail-coverts and tail darker than the back; hinder crown, hind-neck, and sides of neck bright chestnut; a black band across the upper fore-head, which is continued backward over the eye ; earcoverts black, as also a patch on the sides of the neck; fore-head, cheeks, throat, and entire under-surface white, including the under wing-coverts, axillaries, and under tail-coverts; bill black, iris deep brown, tarsi and feet dull black. Total length $16 \pm$ mm.; culmen 14, wing 108, tail 43, tarsus 29. 
Adull female.- Nimilar to the adult male, but everywhere duller, the black band on the upper fore-head very slightly indicated, the chestnut of the head and hindneck only faintly pronounced, ear-coverts brown instead of black, as also the patch on the sides of the neck; wing 105 .

Adults in winter-plumage have no black on the fore-head. A patch in front of the eve and on the side of the breast brown.

Immature.-Similar to the adult in winter-plumage, but the white of the forehead not so pronounced and the feathers of the upper-surface edged with buff.

Young. Slightly darker on the upper-surface than the adult with ninute dark shaft-lines and very narrow rufous edgings to the feathers; upper tail-coverts inclining to dark brown; head like the back; no black line across the upper forehead; a dusky streak on the lores; ear-coverts like the head; fore-head, throat, and under parts generally white.

Nestling in down. - Upper-parts pale rellowish-buff, fincly spotted with black; fore-head buff; spot in front and behind the ere black as also spot below in front of gape; white collar at back of neek but no black nape band; tail black; winglet black with pale centre and white edges; all under-surface pure white; a spot on ear-coverts black.

Nest.-A depression by the shore.

Eggs.-Clutch, two; ground-eolour pale greenish, marked all orer with dark brown to purplish-black markings and fewer ones of lavender, some of the markings being dots and lines; axis 28.5 to $32 \mathrm{~mm}$., diameter 23 to 24.

Breeding-senson.-August to January.

Distribution and forms.-Australia only, straggling to New Zealand (once). Two subspecies bave been seprarated: L.r. ruficajillus (Temminck and Laugier) from Eastern Australia, and $L$. r. tormenti (Mathews) from West Australia, pa]er and slightly larger.

\section{Genus CHARADRIUS.}

Charadrius Linné, Syst. Nat,, 10th ed., p. 150, Jan. 1st, 1758. Type (by tautonymy): Charadrius hiaticula Linné.

Egialitis Boie, Isis, 1822, heit 5, col. 558, May. Type (by subsequent designation Gray, Cat. Gen. Subgen. Birds, p. 111, 1855) : C. hiaticula Linné.

Hiaticula Gray, List Gen. Birds, 1st ed., p. 65, April 1840. Typo (by tautonymy): $C$. hiaticula Linné.

Small Plovers with short Vanelline bills, long wings, short tails and legs, and strong feet. The bill is Tanelline, as previously defined, and is much shorter than the tarsis and also than the middle toe; it is parti-coloured in the adult, the tip being black, the base jale flesh. The wing is long with the first primary longest. The tail is short and square and less than half the length of the wing. The tarsus is short and thick and covered with hexagonal scales. The tons are long, the outer being connected with the middle one by a web near the base. No hind-toe.

\section{II8. Charadrius cucullatus.-HOODED DOTTEREL.}

Gould, Vol. VI., pl. 18 (pt. xxxrv.), Dec. Ist, 1848. Mathews, Vol. III., pt. 2, pl. 139, May 2nd, 1913.

Charadrius cucullatus Vieillot, Nouv. Dict. d'Hist. Nat., Vol. XXVII., p. 136, Dec. 26th, 1818 : Nerv South Wales.

Charadrius monachus Wagler, Syst. Av. Charadr., sp. 15, p. (60), Oct. 1827, ex Geoffroy MS. New namo for preceding.

Charadrius cucullatus tregellasi Mathews, Nov. Zool, Vol. XVIII., p. 218, Jan. 31st, 1912 : Ellensbrook, South-Twest Australia.

Charadrius cucullatus torbayi Mathers, Austral Av. Rec., Vol. I., pt. 2, p. 30, April 2nd, 1912: Torbay, South-west Australia.

Distributron.-New South Wales, Victoria, Tasmania, South and South-west Australia. 
Adult male.-Back, wing-coverts, scapulars, and long innermost secondaries ashy-grey ; outer edge of wing white; bastard-wing brown; small coverts near the edge of the wing and primary-coverts brown tipped with white, the four outer primary-quills dark brown, the remainder white tipped with brown; secondaries similar in colour, some of the inner ones entirely white; head and throat black as also a collar on the upleer mantle which joins the black of the throat on the sides of the neck; a black patch on the sides of the breast, the feathers of which have white tips; a collar on the hind-neck and the entire under-surface pure white, including the axillaries; bill yellowish-red, tip black; iris hazel, eyelids scarlet; tarsi and feet flesh-pink. Total length $215 \mathrm{~mm}$.; culmen 17, wing 145, tail 66, tarsus 27.

Adult female.-Similar to the adult male but smaller.

Melanistic form $(C, c$, torbayi).-Head and throat black; a white collar on the nape; entire back and upper tail-coverts black like some of the wing-coverts; primaries black, with a large white patch on the inner web; rest of under-surface white, including the under wing- and tail-coverts.

Littler, Handb. Birds Tasm., p. 133, wrote: "Female--Resembles the male save that the head is mottled with white," folloming Gould, but we find the male and female to be alike in coloration.

Immature.-Differs from the adult in the entire absence of black on the head and throat, the former being greyish-brown while the latter, as also the fore-head, is white; the black of the upper-surface, in the adult, is here indicated by dark brown feathers; the dark pateh on the sides of the breast, much the same as in the adult; secondaries white with broad subterminal band of brown; throat pure white; brown patch on the side of the breast; bill dark brown, yellowish at the base; legs and feet paler yellow than in the adult.

Nestling.-Upper-surface pale buff, vermiculated with dark brown; tail black; fore-head more sparsely marked than the back; a black nuehal band ; cheeks, chin, throat, and entire under-surface white, including the under tail-coverts and the under wing-coverts; a spot of black on each side of the lower throat.

Nest.-A depression in the ground.

Eggs.-Clutch, two or three; ground-colour pale stone, marked all over, but more at the larger end, with purplish-black and lavender spots ; axis 39 to $39.5 \mathrm{~mm}$., diameter 26.5 to 27.

Breeding-season.--September to January.

Distribution and forms.-Confined to Southem Australia, outside the tropics, and two subspecies admitted : the eastern C. c. cucullatus (Vieillot) and the western C. c. tregellasi (Alathews) a larger and darker form, with apparently a tendency to melanism as eridenced strongly in the aberration above named $C$. $c$. torbayi Iathews.

\section{Genus EUPODELLA.}

Eupodella Mathews, Birds Austr., Vol. III., pt. 1, p. 83, April 2nd, 1913. New name for Eupoda Brandt 1815; not Eupodes Koch 1835. Type (by monotypy): Charadrius asiaticus Pallas.

Eupoda Brandt, in Tchihatcheff's Voy. Sci, Atlai Orient., pt. II., p. 444, May 3rd, 1845. Type (by monotypy) : C. asiaticus Pallas.

Not Eupodes Koch, Deutschl. Crust., Vol. I., tab. 8, 1835.

Medium-sized Plovers with long slender bills, long wings, long legs, and small feet.

The culmen is long and slender, the dertrum littleswollen, much longer than the micldle toe. Wing long and pointed, first primary longest. Tail hort and slightly roumled. The metatarsus is very long, more than twice as long as the middle toe and about twice as long as the culmen. 


\section{Eupodella vereda.-ORIENTAL DOTTEREL.}

Gould, Vol. VI., pl. 14 (pt. xxxIr.), Dec. 1st, 1818. Mathervs, Vol. III., pt. 1, pl. 137, April 2nd, 1913.

Charadrius veredus Gould, Proc. Zool. Soc. (Lond.), 1848, p. 38, Nov. 14th: North-west Australia.

Distribution.-Winter visitor to Australia, breeding in the northern hemisphere.

Adull male.--Entire back, wings, and tail olive-brown, all the feathers narrowly fringed with rufous; bastard-wing, primary-corerts and quills dark brown, the latter with pale inner webs, the outer primary has a white shaft ; secondaries somewhat paler than the primaries and fringed with white, the long innermost secondaries like the back; all the tail-feathers tipped with white, outer feathers much paler, the outermost pair entirely white on the outer webs; collar on the nape and eyestreak pale brown; fore-part of crown white intermixed with olive-brown ; earcoverts more or less stained with pale rufous or buff; fore-head and lores pale buff; throat buffy-white; patch below the eye, middle of the abdomen, flanks, and under tail-coverts white; fore-neck chestnut, extending on to the sides of the breast followed by a black patch on the middle of the breast, which also extends down the sides of the upper-abdomen, where the feathers are tipped with white; under wingcoverts and axillaries olive-brown, the former tipped with grey; bill black, lower base hom colour; iris hazel; feet light flesh colour; joints almost black. Total length $245 \mathrm{~mm}$. ; culmen 25, wing 170 , tail 62 , tarsus 49.

Adult female.-Similar to the male.

Adult male in winter-plumage.-Differs chiefiy from the male in summer-dress by the almost entire absence of chestnut and black on the fore-neck, ehest, and sides of breast. The sexes are alike.

Young female.-Olive-brown above, the feathers everywhere margined with rufous which are paler and almost pure white on the median and greater wingcoverts; fore-head and eyebrow white; throat whitish, more or less tinged with rufous, which is more pronounced on the fore-neck and chest; abdomen and uncler tail-coverts white.

Immature female.--Distinguished from the adult chiefly by the absence of the chestnut on the fore-neck and the broad rufous margins to the feathers of the uppersurface; the chestnut collar on the fore-neck of the alult is here represented by a grey band with a few rufous feathers intermixed, which shows that the bird is attaining the breeding-plumage.

Nestling, Nest and Eggs.-Unknown. Breeds in South-east Mongolia.

Distribution and forms.-Breeding in Mongolia and migrating southward in winter to Australia, mainly in the north. No subspecies have been proposed.

\section{Genus ELSEYORNIS.}

Elseyornis Mathews, Austr. Av. Rec., Vol. II., pt. 5, p. 87, Sept. 24th, 1914. New name for Elseya Mathews 1913 not Grandidier 1867. Type (by original designation): Charadrius melanops Vieillot.

Elseya Mathers, Birds Austr., Vol. III., pt. 2, p. 125, May 2nd, 1913. Type (by original designation): Charadrius melanops Vieillot.

Not Elseya Grandidier, Rev. de Zool., p. 232, 1867.

Smallest Plovers with long Vanelline bills, long wings, and long tail ; slender legs and feet.

The bill is very long for the Tanelline-billed group of Ping-Plorers, being only exeeeded by that of the genus Thinomis; it is almost as long as the tarsus and exceds the middle toe. The wing is long with the first primary longest. The tail is long and rounded, about half the length of the wing. The tarsus is short and slender; 

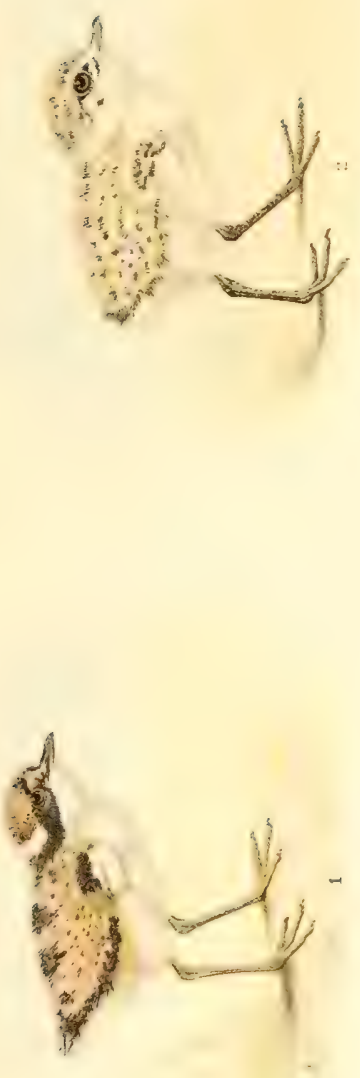

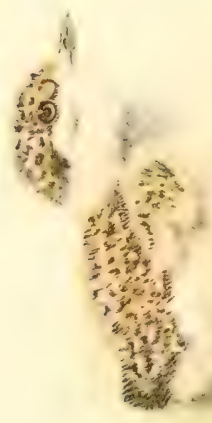

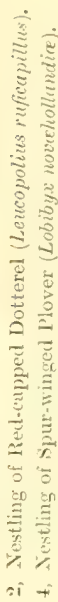

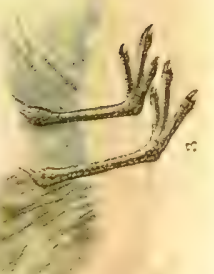

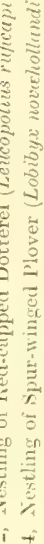

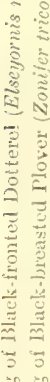

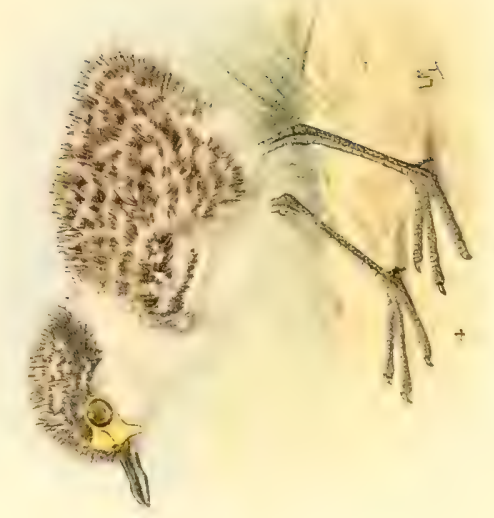

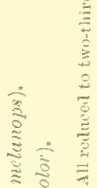

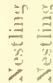



the sealing is indistinct and shows a strong tendency to fusion ; it does not show the regular hexagonal sealing of Charadrius. The toes are long and slender and the outer one is connected with the middle one by a web near the base. No hind-toe.

\section{Elseyornis melanops.-BLACK-FRONTED DOTTEREL.}

Gould, Vol. VI., pl. 20 (pt. xIx.), June 1st, 1815. Mathews, Vol. III., pt. 2, pl. 140, May 2nd, 1913.

Charadrius melanops Vieillot, Nouv. Dict. d'Hist. Nat., Vol. XXVII., p. 139, Dec. 26th, 1818 : " aux Terres Australes Baudin Exp." = Now South Wales.

Charadrius nigrifrons Temminck et Laugier, Planch. Color. d'Ois., se livr. (Vol. I., pl. 47, fig. 1), (Vol. V., pl. 68), March 1821, ex Cuvier MS.: Nouvelle Hollande $=$ New South Wales.

Charadrius russatus Jerdon, Madras Journ. Lit. Sci., Vol. XII., p. 213, Oct. 1810: Madras, India.

Charadrius melanops marngli Mathews, Nov. Zool., Vol. XVIII,, p. 218, Jan. 31 st, 1912 : Marngle Creek, North-west Australia.

Distribution.-Australia generally and Tasmania.

Adult male.-Fore-head, middle of cromn, lores, a line below the eye, ear-coverts, hind-neck, sides of neck and a broad band across the fore-neck deep black; a line orer the eye along the sides of the crown and nape white like the throat, sides of the breast, abdomen, and axillaries; crown of head, back, long scapulars, and long innermost secondaries greyish-brown; short scapulars maroon-chestnut; lesser wing-eoverts brown; median coverts greyish-brown with dark shaft-lines, greater coverts also greyish-brown broadly tipped with white forming a wing-bar ; a portion of the outer edge of the wing white; bastard-wing and primary-coverts black; primary-quills very dark brown; secondaries white at base, apical portion dark brown, some of the inner ones almost entirely white; upper tail-coverts rufous with dark shaft-lines; middle tail-feathers dark brown, outer pair white, next pair with a brown spot on the inner web near the tip, the remainder brown tiplod with white ; under tail-coverts white, the lateral ones with a black spot on the outer web; under wing-coverts white, the small marginal coverts brown edged with white; quills below dark brown; bill red, black at tip ; iris brown, eyelids scarlet; feet red. Total length $165 \mathrm{~mm}$; culmen 15 , wing 110 , tail 53 , tarsus 25.

Adult female.-Similar to the adult male but slightly smaller.

Immature.-Differs from fully adult by being darker on the upper-surface, in being rufous on the scapular instead of maroon-chestnut: paler rufous on the upper tail-coverts, the buff tips to the central tail-feathers, the incomplete black forehead and the very much narrower band on the chest, which is also intermixed with buff. (May.)

Immature (younger).-Head, back and scapulars earth-brown, with slightly paler edges to the feathers, the scapulars somewhat tinged with rufous. Among the latter may be noticed two or three deep chestnut feathers which suggent the first appearance of the adult plumage; the long scapulars, innermost secondaries, and middle tail-feathers bronze-brown, the latter tipped with buff, the outer tailfeathers white marked with pale brown; the lesser upper wing-coverts show the remains of youth, and are similar to the stage next described, but not quite so bright, the secondaries differing also in having more white; fore-head and lores dusky; a line over the eye and continued round the nape buffy-white becoming whiter on the nape; a dark line from behind the eye joining the black collar on the hindneck, which extends in an incomplete band across the chest; under-surface white. (April.)

Immature just losing down.-Crown of head, back, scapulars, innermost secondaries, and upper tail-coverts pale earth-brown strongly tinted with rufous, 
with semicircular dark bars to the feathers which gives a scalloped appearance to the back, the feathers on the head havo dark central spots ; lesser, upper and some of the inner median wing-coverts blackish, edged with rufous and spotted with black, others are white on the inner web ; greater series for the most part white with a small amount of earth-brown near the base; bastard-wing, primary-coverts and quills black, secondaries edged with whito at the tips, some of the inner ones almost entirely white; lower hack and upper tail-coverts have the downy texture of the restling, which is fawn colour dotted with black; tail-feathers bronzy-brown tipped with rufous; a broad band from behind the eye encircling the hind-neck, black, a crescentic patch of white on the nape; entire under-surface white, except a few dark feathers on the chest, which is the first indication of the black band; the small coverts on the outer elge of the under-wing black, margined with whito. Bill, tip black, base orange; eye black, eyelids orange ; feet pink. (February.)

Nestling in down. - Crown of head and entire back fawn colour, dotted with black; a semicircular black line across the fore-part of the head from eye to eye, a short line of black on the hinder crown, followed by a semicircular band of white, a lino of black commencing in front of the eye, enclosing the latter, continued and widened out round the hind-neek where it forms a collar; another black band starting on the inner portion of the wing, continued along the sides of the back, dividing the fawn colour and enclosing the tail ; outer portions of the wings and entire undersurface white. (January.)

Nest.-A depression in the earth.

Eggs.-Clutch, three; ground-colour stone, coverecl with strange markings of lavender and brown, patches of the ground-colour frequently appearing; axis 29-30 mm., diameter 21-21.5.

Breeding-season.-April, May, September to December.

Distribution and forms. - Confined to Australia, but one bird said to have been. killed at Madras, India. Two subspecies aro recognisable, as: Elseyornis melanops melanop.s (Vieillot) from Eastern Australia generally, and Elscyornis melanops russatus (Jerdon) from Western Australia, a smaller and paler race with less black on the second outer tail-feather.

\section{FAMII VANELLIDA.}

This family is better circumseribed than any other Charadrine group, ret has never been acepted through lack of examination. Mathews gave details and these are confirmed by more complete criticism of all the series. Though the confusion of the members of this family with those of the preceding no detailed account of their osteological and anatomieal peculiarities is on record. Fet that such exist is gleaned from the item "I anellus cristatus has been recorcled with two separate bicepi slips." The leg muscle formula is AXY + and the intrinsic muscles of the syrinx are very large.

Of the three genera occurring in Australia, two havo hind-toes, the other not; two have facial wattles, one with a rery large wing spur, the third neither wattles nor spur.

\section{Genus LOBIBYX.}

Lobibyx Heine und Reichenow, Nomencl. Mus. Hein., p. 334, (pref. Sept.) 1890. Type (by original designation): Tringa lobata Latham $=$ Vanellus novcekollandice Stephens.

Lobivanellus Reichenbach, Nat. Syst. Vögel, p. xvrr., 1852 (? 1853). Typo (by original

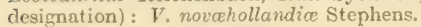

Not of Strickland, Proc. Zool. Soc. (Lond.), p. 32, 1841, Oct.

Large Lapwings with facial pendant wattles, long spurs at the bend of the wing, long bills, long wings and long legs with small feet. 
The bill is typically Vanelline; in front, above and behind the eyes a fleshy wattle which develops into a long pendant lappet in front. The wing is long with the first three primaries about equal ; on the bend of the wing a long sharp spur oceurs which is smaller in the female. The legs are long and the feet small, the metatarsus being more than twice the length of the middle toe : the metatarsus is transversely scaled in front, and in mature specimens apparently similarly covered behind.

\section{I2r. Lobibyx miles.-LESSER MASKED PLOVER.}

[Tringa miles Boddaert, Tabl. Planch. Enlum., p. 51, (pref. Dec. 1st) 1783: Timor Laut. Extra-limital.']

Gould, Vol. VI., pl. 10 (pt. virr.), Sept. 1st, 1812. Matherrs, Vol. III., pt. 1, pl. 130, April 2nd, 1913.

Lobivanellus personatus Gould, Birds Austr., pt. virr. (Vol, VI,, pl. 10), Sept. 1st, 1842 : Coburg Peninsula, Northern Territory.

Lobibyx miles harterti Mathews, Nov. Zool., Vol. XVIII., p. 215, Jan. 31st, 1912 : Inkerman, Queensland.

Distribution.-North Queensland, Northem Territory, North-west Australia.

Adult male.-Crown of head black; hind-neck, sides of face, ear-coverts, throat, and entire under-surface pure white including the under wing-coverts, axillaries, and under tail-coverts; wings ash-grey; middle of back, scapulars, and the innermost secondaries olive-grey; upper outer edge of wing white; primary-coverts and primary-quills black, the latter paler on the inner webs and white at the base, some of the outer primaries brown at the ends; secondaries black with grey at the base on the outer web and white on the inner one, the white and grey increasing on the inner secondaries where the black is confined to the tip; tail white with a broad subterminal band of black which is preceded by pale grey and tipped with the same colour-this same colour occupies the outer web of the innermost featheris; facial wattles larger than in $L$. lobatus and extending over and behind the eye; bill yellow, tip brown; iris yellow; lapels and spurs yellow; tarsi and feet purple-red; lower ens of tibia pink. Total length $377 \mathrm{~mm}$; culnen 35 , wing 2.28 , tail 95 , tarsus 74 .

Adult female.-Similar to the adult male.

Immature and Nestling.-Appear to be undescribed.

Nest.-A depression in the ground.

Eggs.-Clutch, two to four; of a yellowish-stone ground-colour, slightly tinged with olive, with freckles, spots, and larger irregular-shapal markings of olive-brown and blackish-brown distributed over the entire surface of the shell, together with a few superimposed spots of dull bluish-black; axis 41-42 mm., diameter 33.

Breeding-season.-August to October, January to April.

Distribution and forms.-North and North-western Australia and the Ioluecas. Three subspecies can be admitted : L. m. milcs (Bodldaert) from Timor Laut and the Moluccas; $L . m$. personatus (Gould) from Northern Territory and North-western Australia, a darker race; and L. m. harterti Nathew's from Northem Queensland, still darker and also larger.

\section{Lobibyx novæhollandiæ.-SPUR-WINGED PLOVER.}

Gould, Vol. VI., pl. 9 (pt. virr.), Sept. 1st, 1S12. Mathews, Vol. III., pt. 1, pl. 129, Apri1 2nd, 1913.

Tringa lobata Latham, Index Omith., Suppl., p. Lxv., 1801, after May: New South Walos, based on Watling drawing No. 242.

Not of Linné, Syst. Nat., 10th ed., p. 148, Jan. 1st, 1758.

Vanellus novcehollandice Stephens, in Shaw's Gen. Zool, Vol. XI., pt. II., p. 516, 1819, Aug. New name for $T$. lobata Latham. 
Charadrius gallinaceus Wagler, Syst. $\Delta v$., Charadr., sp. 50, p. (75), Oct. 1827, ex Temminck MS. : "Timor" errore = New South Wales.

Lobibyx novchollandiae gracemeri Mathews, Austral Av. Rec., Vol. II., pt. 7, p. 126, Jan. 2sth, 1915: Gracemere, Queensland.

Distributrox,-East Australia, Tasmania, South Australia.

Arult mals.-Back, seapulars, and wings olive-brown, becoming paler and inclining to ash colour on the outer wing-coverts; the wing with the first three primaries subequal, the first probably the longest; outer, median, and primarycoverts black as also the primary-quills; the latter brown at the tips and paler on the inner web at the base of inner primaries; secondaries for the most part black with grer at the base and white on the inner wel, the grey and white increasing in extent on the inmer ones, two of which are elged with white at the tip; the innermost secondaries like the back; tail white with a subterminal broad black band, and white or greyish-brown tips; head, hind-neck and a collar skirting the upper mantle black like the patch on the sides of the breast; throat, cheeks and sides of neck white like the entire under-surface, including the under wing-corerts, axillaries, and under tail-coverts; bill, wattles, and iris canary-yellow; feet and legs very dark crimsm; sjurs canary-yellow with black tips. Total length $360 \mathrm{~mm}$; ; eulmen 34 , wing 245 , tail 107 , tarsus 81 .

Adult female.-Similar to the ardult male, second and third primaries equal and longest, the first equal to the fourth.

Immature.- IVith pale tips to feathers of upper-surface.

Yowlling in doun.-General colour of the upper-surface buff, mottled with black; wings broadly lined with buffy-white; fore-head ochreous-buff; a black line over the eve, which widens into a band on the upper hind-neck, this being followed by a white collar which extends in a narrow line on to the cheeks; throat and under-surface dull-white, becoming tinged with buff on the under tail and thichs; hinder portion of the thighs lined with black; a yellow wattle above and in front of the eye. Iris dull blue; bill and feet slaty-blue, the lower mandible pale flesh colour.

Nest.-A depression in the ground.

Eggs.-Clutch, three to four; ground-colour green, heavily blotched with spots of dark purple-brown and lavender; axis $50-54 \mathrm{~mm}$., diameter 36 to 36.5 ,

Breeding-season.-July to January.

i)stribution and forms.-Confined to East and South Australia and Tasmania, ranging northwards to mid-Queensland only. Nathews has named a northem race $L$. $n$. gracemeri as being smaller and paler and this may be accejted, as the representative species $L$. miles (Boddaert) of the extreme north and north-went is a smaller bird.

\section{Genus ZONIFER.}

Zonifer Sharpo, Cat. Birds Brit. MIus, Vol. XXIV., pp. 145, 154, (pref. July 10th) 1S96. Typo (by original designatiou) : Charadrius tricolor Vieillot.

Sarciophorus Reichenbach, Nat. Syst. Vogel, p. xvirr., 1852 (? 1853). Type (by original designation) : C. rectoralis Wagler $=C$. tricolor Vieillot.

Not of Strichland, Proc. Zool. Soc. (Lond.), p 32, 1841, Oct.

Large Lapwings with short bills, long wings, no spurs, small facial wattle, short legs and small feet with no hind-toe.

The bill is short (eomparatively) and stouter than in the preceding genus; in frust of the ere is a mall oral fleih lapnet but no pendant rattle. Wings long, with the first three primaries sulequal : only a blunt knob on the bend of the wing. Tail square, with broad feathers, less than half the length of the wing. 
Metatarsus short and apparently irregularly scutellated on the back, though regularly scaled in front. Toes short, less than half the length of the tarsus, and no hind-toe.

\section{Zonifer tricolor.-BLACK-BREASTED PLOVER.}

Gould, Vol. VI., pl. 11 (pt. Ix.), Dec. 1st, 1842. Mathows, Vol. III., pt. 1, pl. 131, April 2nd, 1913.

Charadrius tricolor Vieillot, Nouv. Dict. d'Hist. Nat, Vol. XXVII, p. 147, Dec. 26th, 1818 : "aux Terres Australes, Baudin Exp." = New South Wales.

Charadrius pectoralis Wagler, Syst. Av., Charadr., sp. 8, p. (58), Oct. 1827. Now namo for preceding ex Cuvier MS.

Not of Vieillot, loc. cit., p. 145, 1818.

Charadrius vanelloides Peale, United States Expl. Exp., Vol. VIII., p. 240, 1848 (cf. 2nd ed., p. 328, 1858): New South Wales.

Zonifer tricolor gwendolence Mathews, Nov. Zool., Vol. XVIII, p. 216, Jan, 31 st, 1912 : Broome Hill, South-west Australia.

Distributrox.-Australia generally and Tasmania.

Adult male--General colour above purplish-bronze somewhat paler on the hind-neck; darker and inclining to blackish on the lower back ; lesser wing-corerts rather darker than the back; the small coverts on the outer edge of the wing dark brown edged with white; median coverts tipped with white; the greater series almost entirely white; tail white, with a broad black band at the tip, the outer feathers fringed with white at the ends; crown of head, cheeks, sides of neck, and breast black, the latter with a purplish gloss; in front of the eye an oval-shaped red wattle; a line behind the eye, throat, and fore-neck white, like the abdomen, under tail-coverts, axillaries, and under wing-coverts; bill, iris, and eyelid canary-yellow ; knees and tibia dark crimson; tarsi and feet black; soles of feet dark greyishHesh colour; wattle bright red. Total length $284 \mathrm{~mm}$; culmen 22, wing 194, tail 83 , tarsus 49 .

Adult female.-Similar to the adult male.

Immature-Has the marginal wing-coverts above edged with rufous.

Nestling in down.--Upper-parts reddish-yellow ground with small dark brown blotches, white collar round hind-neck, with a black circular nape band above; under-surface pure white with indistinct black band across chest; tips of feathers white, bases dark; winglet with a whitish edge ; edges of thighs with darkish bases to down ; fore-head reddish, a minute oral lappet in front of eye hidden by down.

Young in nesiling plumage (partial down).-Rufous-brown on the upper-parts with indistinct barrings of sandy-buff ; fore-head, sides of crown, and nape covered with black-and-buff down; a narrow white line under the eye, continued over earcoverts and around the hind-neck; ear-corerts pale brown ; throat, abdomen, and sides of body white; broarl black band across chest, feathers tipped with rufous; tail, composed of down, blackish, tipped with white.

Nest.-A depression in the ground, lined with dead sticks, etc.

Eggs.-Clutch, four; ground-colour stone, covered all over with spots of reddish-purple and lavender; axis 42-44, diameter 30-31.

Incubation-period.--Said to be twenty-eight days.

Breeding-season.-May to January.

Distribution and forms.-Confined to Australia. Two subspecies are admis. sible: an eastern, Z. $t$. tricolor (Vieillot); and a western race, Z. $t$. givendolence Mathews with a narrower black breast-band, a larger wattle abore the eye and generally of darker coloration.

\section{Genus ERYTHROGONYS.}

Erythrogonys Gould, Synops. Birds Austr., pt IV., pl, 73, April 1st, 1838. Typo (by monotypy): Erythrogonys cinctus Gould. 
Small Lapwings without spurs or wattles, proportionately long bills, long wings, short tail, long legs and feet. The bill is straight, as long as the head, with a distinet swollen dertrum; nostrils short and linear, situated near the base of the bill in a groove which extends over two-thirds the length of the bill. Wings long with the first primary longest. There is a bony knob at the bend of the wing in place of a spur. Metatarsus long and slender, apparently scutellated before and behind with a narrow row of hexagonal scales on each side; middle toe more than half the length of the metatarsus; distinct hind-toe and claw. Toes only slightly connected at the base. This genus is monotypic and confined to Australia.

\section{Erythrogonys cinctus,-RED-KNEED DOTTEREL.}

Gould, Vol, VI., pl. 21 (pt. IIr.), June 1st, 1841. Mathews, Vol. III., pt, 1, pl, 128, April 2nd, 1913.

Erythrogonys cinctus Gould, Synops. Birds Austr., pt. Iv., pl. 73, April 1st, 1838: New South Wales.

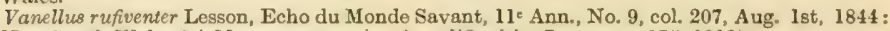
New South Wales (cf. Menegaux, reprint Art. d'Ornith., Lesson, p. 175, 1913).

Erythrogonys cinctus mixtus Mathews, Nov. Zool., Vol. XVIII., p. 215, Jan. 31st, 1912 Parry's Creek, North-west Australia.

Distribution.-Australia generally. Not Tasmania.

Adult male-Head, sides of face, hind-neck, upper mantle, and a broad band across the breast black; back and wings olive-brown like the middle of the rump, upper tail-coverts, and middle tail-feathers ; a portion of the outer edge of the wing, white; primary-coverts and primary-quills brown, the latter paler on the inner webs and becoming white at the base, the inner primaries white at the tips and fringed with white on the inner webs; secondaries dark brown at base with broad white tips, the long innermost secondaries like the back; outer tail-feathers white, the outermost pair edged with olive-brown on the outer web near the tip ; throat and fore-neck white like the lower sides of neck, abdomen, and axillaries; the long feathers on the sides of the body chestnut, edged and tipped with white; some of the feathers adjoining the pectoral band black, edged with white on the outer web; flanks, sides of rump, and under tail-coverts white, with dark centres to the feathers at the tip, more or less mixed with chestnut; inner under wing-coverts white, the long ones with a brown spot at the tip, the marginal corerts blackish; bill, culmen, and distal third black, remainder red; iris brown; feet and tarsi blue; knees and tibia red. Total length $174 \mathrm{~mm}$; culmen 22, wing 108 , tail 46 , tarsus 41 .

Adult female.-Similar to the adult male but has the crown of the head brown.

Young.-General colour of the upper-parts earth-brown, including the head, back, wings, and middle tail-feathers, with pale edges to the upper wing-coverts, the dark and light patterns on the wing similar to the adult; throat and general under-surface white, including the middle of the breast, with a slight indication of the black pectoral band on the sides of the latter, and the chestnut flank feathers appearing.

Another immature example, rather more advanced in age, has the upper wing-coverts uniform without any pale edges, the cheeks, ear-coverts, and a band on the hind-neck inclining to black, the pectoral band more pronounced on the sides of the breast and faintly indicated across the middle of the latter, the chestnut on the sides of the body well marked, under wing-coverts for the most part white.

A further speeimen shows a still greater advance, in having the pectoral band complete in form but brown in colour, with a few white feathers intermixed, the dusky-brown on the top of the head still retained, the black on the under wingcoverts increased as also the black on the sides of the breast. 
Another specimen, which appears to be a year old, has nearly gained the adult plumage and has the head, sides of face, and hind-neck black with a few brown feathers remaining; the pectoral band shows similar colours.

Nestling, three weeks old.-The crown and back are brown, each feather being tipped with a lighter shade, which give it a mottled appearance. All the undersurface is white, including the throat, and also a band just behind the crown extending to the back of the eye, and adjoining this white band, but behind it, is a black one extending to the lower part of the eye. The primaries are black slightly tipped with white. The secondaries are also black and tipped boldly with white, and also white at the base, the amount varying in each feather. The lesser and median wing-coverts are mostly white, with a few brown feathers just coming, and a small patch of white on the spurious wing. Humeral feathers dark brown, tipped with a lighter shade. The tail-feathers are black, tipped with lighter brown; under tail-coverts white, with a few brownish-black spots. Beak yellowish for about half its length, the end being black. The nasal groove is more than half the length of the beak. Feet yellowish and toes black.

Nestling in down.-Appears to be undescribed.

Nest.-None is made; the eggs are placed in a slight depression in the ground, on the edge of a large inland lagoon.

Eggs.-Clutch, four; ground-colour varies from light to dark stone, thickly covered all over with irregular angular and curved hair-lines, and irregular-shaped markings of black, which erows and recross each other in various directions, the lines vary in thickness from that of a fine haj $\mathbf{r}$ to that of coarse thread, on the thicker end here and there they loop and form tangles; axis 29-31 mm., diameter 23.

Breeding-season.-October, November and December.

Distribution and forms.-Confined to Australia. Two subspecies are easily acceptable: E. c. cinctus Gould, from East Australia; and E. c. mixtus Mathews, from West Australia in its darker upper coloration, less marked chestnut flank feathers and narrower black breast-band.

\section{SUPERFAMLY JACANOIDEA.}

A delightful little group of birds apparently developed from a pre-Charadrine source, and recalling in many ways the Wattled Plovers, the coloration, head wattling and bill formation all suggesting their deriration from that basic source, the wing also sometimes being spurred. Their distribution is more or less coincident, being rather more restricted to the Tropical zones of the world. Agreeing in the extreme elongation of the toes and claws and in the possession of the hind-toe and claw similarly elongated they show as much diversity otherwise in evolution as the Wattled Plovers do. That the development of the peculiar feet is adaptive seems proven by the formation of the flexor tendons of the feet, there being no special slip for the extraordinary hallux.

Osteological items of note are few; the skull has well-developed basipterygoid processes, but no occipital foramina nor supraorbital grooves. The sternum is singly notched on each side at its posterior margin. The tracheo-bronchial syrinx has a pair of intrinsic muscles, while the caca are reduced to mere passeriform nipples. Other internal features as recorded seem to agree with the ordinal characters given.

\section{FAMILY JACANIDE.}

\section{Genus IREDIPARRA.}

Irediparra Mathews, Nov. Zool,, Vol. XVIII., p. 7, June 17th, 1911. Type (by original designation): Parra gallinacea Temminck et Laugier. 
Jacanine birds with short bills, peculiar facial ornament, long wings, short tails, and long toes with very long claws.

The culmen is short with a notable rhamphotheca, the nostrils pervious and placed before the middle of the mandible in a shallow groore; no groore present in the lower mandible. At the base of the mandible arises a large leaf-like lappet of bare skin with a thin erect upright comb running up the centre of the head. The wing is long and the primaries are normal in shape; the first primary is longest; the tail is short and rounded, of ten feathers only; the metatarsus long and regularly scutellate in front and behind, the scutes sometimes fusing; the tibia long and naked and regularly scutellate in front and behind; the toes are rery long, not webbed either internally or externally ; and the claws are longer, quite straight, and tapering to a fine point. The claw of the hind-toe is extraordinarily lengthened, being longer than the hind-toe and the metatarsus.

\section{Irediparra gallinacea.-LOTUS BIRD.}

[Parra gallinacea Temminck et Laugier, Planch. Color. d'Ois., 78 livr. (Vol. IV., pl. 464), July, 1828: Celebns. Extra-limital.]

Gould, Vol. VI., pl. 75 (pt. x.), March 1st, 1843. Mathews, Vol. III., pt. 4, pl. 169, Dec. 31 st, 1913.

Hydralector novchollandice Salvadori, Ornit. Pap. e Mol., Vol. III., p. 309, (pref. Dec.) 1882: New South Wales.

Irediparra gallinacea rothschildi Mathews, Nov. Zool., Vol. XVIII., p. 224, Jan. 31st, 1912 : Parry's Creek, North-west Australia.

Irediparra gallinacea melvillensis Mathews, Austral Av. Rec., Vol. I., pt. 3, p. 73, June 28th, 1912: Melville Island, Northern Territory.

Distribution,-New South Wales, Queensland, Northern Territory, North-west Australia.

Adult male.-Hinder crown, hind-neck, and mantle black like the lower back and rump, the feathers tinged with metallic-purple; back, seapulars, and wings light bronze-brown; lesser upper wing-coverts round the bend of the wing, bastard-wing, primary-coverts and quills deep black with a metallic-purple tinge; tail white at the extreme base, the remainder bronze-black; a short narrow line of black on the lores, a white spot in front of the eye; sidles of face, ear-corerts, sides of neck and fore-neck golden-buff ; chin and entire throat white ; the feathers of the breast deep black with white bases; sides of body, axillaries, and under wing-coverts uniform black; abdomen, thighs, under tail-coverts, and sides of rump buffy-white; bill -distal half black, extreme tip brown, basal half and frontal plate pale red; iris pale yellow, eyelids blue; feet and legs olive-brown. Total length $205 \mathrm{~mm}$.; culmen and comb 37, wing 122 , tail 35 , tarsus 56.

Adult female. - Similar to the adult male but larger. Total length $225 \mathrm{~mm}$. ; culmen and comb, 44, wing 142, tail 37, tarsus 64 .

Young (bird of the first year).-Differs chicfly from the adult in having the loral streak, entire head and nape rufous, the feathers of the back, scapulars, and wings with rufous margins, the upper tail-coverts and tail dult black tipped with rufous, and the entire under-surface of the body white with a tinge of buff on the fore-neck and breast.

Immature (bird of the second year). - Shows an advance towards the adult plumage by the appearance of black intermixed with rufous on the head, the black loral streak, the encroachment of black on the sides of the breast, and the outline of golden-buff on the sides of the neek and the fore-neek, but still leaves an open space on the breast which is completely corered with black in the next stage.

Nestling (just out of dou'n).--Has a reddish head; very dark bromn hind-neck and mantle; upper back brown with rufous edges to the feathers; lower back black with rufous edges, giving a barred appearance; wings buft; under-surface white, the frontal plate just showing. 
Plate 7.
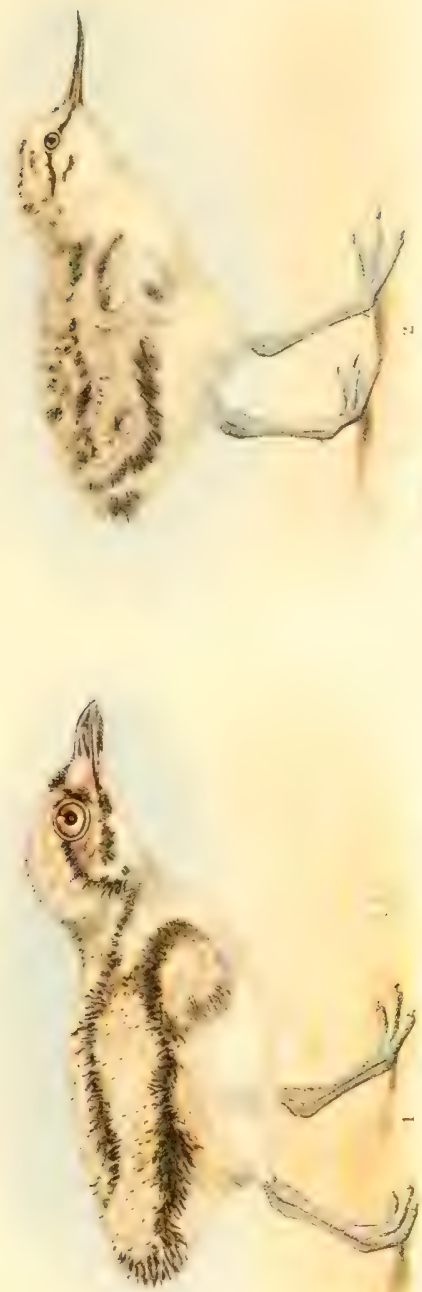

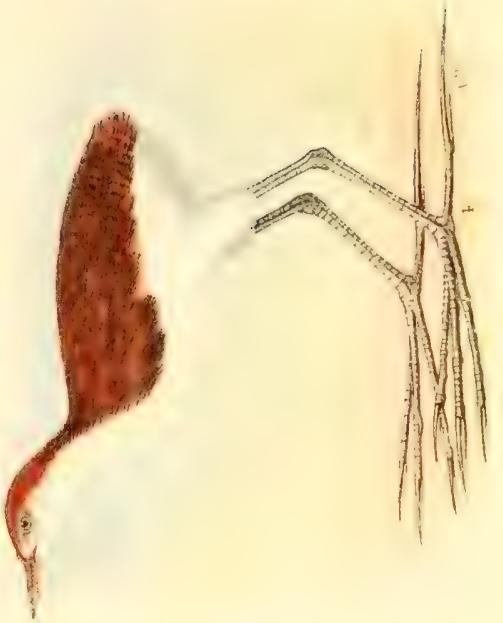

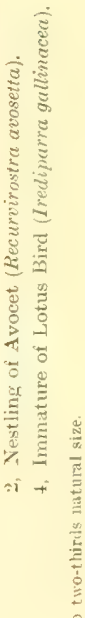

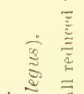

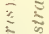

\%

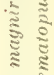

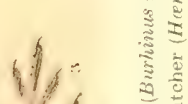

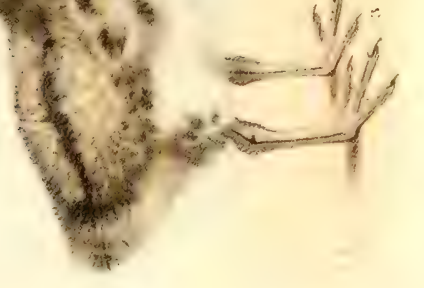

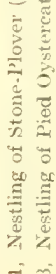



Nestling in down. - Appears to be undescribed; in egg, lappet scarcely discernible, and feet almost normal, no long claws yet developed.

Nest.-Composed of sedge, grass and aquatic plants, placed close to the water's edge, or upon any bunches of weeds or grass growing in the water which may be sufficiently strong to bear its weight.

Eggs.-Clutch, four ; ground-colour brownish-buff, marked all over with lines of blackish-brown and highly polished; those from Melville Island have no polish and are much lighter; axis 28-31 mm., diameter 21-23.

Breeding-season.-September to January.

Distribution and forms.-Australia, only in the north but ranging as far south as northem New South Wales, and New Guinea, the Moluccas and Celebes. Five subspecies are separable, thus: I. g. gallinacea (Temminck and Laugier) from Celebes ; 1. g. novaguinere (Ramsay) from New Guinea, separable by its much blacker coloration, more oil-green sheen, not bronze-brown as in the succeeding forms; $1 . g$. novochollandic (Salradori) a paler, bronze-brown form with less black on the back and the tail bronze-black; $I . g$. rothschildi Mathews from North-west Australia, a much darker race than the preceding, but not as dark as $I . g$. novorguinece; and I. g. melvillensis Mathews from Melville Island, with a heavier bill than the preceding and the coloration of the under-surface more subdued.

\section{SUPERFAMILY GLAREOLOIDEA.}

We unite the Pratincoles and Coursers in this superfamily as, though the extremes seem very different, a regular gradation of species is still existent. The bill is more conical and the linear nostrils are placed parallel to the edges of the culmen; the dertrum is less pronounced and the legs are scutellated in front and behind. The neck may be long or short, the wings may be very long and pointed or short, while the tail may be short and rounded or very long and deeply forked, and the legs may be very long or very short, a hind-toe absent or present. As above noted the connecting links are all available. The superficial features of the Pratincoles are so peculiar that great difference of opinion was formerly held as to their location, but now it is generally admitted that they are aberrant Plorer forms. As usual, some anatomists have been just as puzzled as to the origin of the variations seen in internal features also.

The schizognathous skull has the nasals of schizorhinal origin, but showing pseudo-holorbiny, while basipterygoid processes and occipital fontanelles are absent, and supraorbital grooves present. The tracheo-bronchial syrinx has a pair of intrinsic muscles and the leg muscle formula is ABXY + . The coracoids do not overlap.

\section{FAMILY GLAREOLIDA.}

The three genera represented in Australia are easily distingujshable by means of superficial characters, and it may be noted that the two breeding forms aro peculiarly modified, one so much as to obscure its relationship without careful study. The other, while still a true Pratincole, has the legs lengthened after the style of the Coursers.

\section{Genus GLAREOLA.}

Glareola Brisson, Ornith., Vol. I., p. 48, Vol. V., p. 141, 1760. Type (by tautonymy): Glareola = Hirundo pratincola Linné.

Trachelia Scopoli, Annus I., Hist. Nat., p. 110, 1769. Type (by monotypy): Hirundo pratincola Linné.

Pratincola Forster, Fauna Indica, p. 11, (pref. June 20th) 1795. Type (by monotypy): Glareola (Pritincola) maldivarum Forster. 
Pratincola Schrank, Fauna Boica, Vol, I., p. 209, (pref. July 20th 1797), 1798. Type (by tautonymy): Pratincola glareola $=$ Hirundo pratincola Linné.

Dromochelidon Landbeck, Jahresh. Ver. Nat. Württemb., 1847, p. 228, after March. Typo (by monotypy) : Dromochelidon natrophila Landbeck = Hirundo pratincola Linné.

Glareoline birds with very short bills, long wings, long tail and short legs with rather long toes. The bill is very short; the feathering of the fore-head extends on the culmen, so that the depression in which the nostrils lie is covered save the portion showing the nostrils; it is broad at its base and the tip decurved; comparatively like a miniature of that of Stiltia with the greater portion covered with feathers; the lower mandible is practically without a marked gonys.

The wings are very long and pointed with the first primary longest, but not attenuate and lengthened as in Stittia. Tail long and very deeply forked; the outer tail-feathers measuring almost half the length of the wing. The legs are short ; the metatarsus is regularly scutellate in front and behind; the toes aro long and the outer one connected with the middle one by a web, the inner disconnected; middle claw extraordinarily long and pectinated; hind-toe present.

\section{Glareola maldivarum.-ORIENTAL PRATINCOLE.}

[Glareola (Pratincola) maldivarum Forster, Fauna Indica, p. 11, (pref. June 20th) 1795: open sea near the Maldivo Islands. Extra-limital.]

Gould, Vol. VI., pl. 23 (pt. xxxv.), Dec. Ist, 1848. Mathews, Vol. III., pt. 4, pl. 171, Dec. 3 lst, 1913.

Glareola orientalis Leach, Trans. Linn. Soc. (Lond.), Vol, XIII., pt. I., p. 132, 1821 : Java (breeding ?).

Glareola pratincola parryi Mathews, Austral Av. Rec., Vol. III., pt. 4, p. 70, July 21st, 1917 : Parry's Creek, North-west Australia.

Distrinution.-Winter visitor to Australia, breeding in the northern hemisphere.

Adult male.-General colour of the upper-parts olive-brown, somewhat darker on the head, and a slight shade of rufous on the hind-neck; bastard-wing, primarycoverts, primary - and secondary-quills dark brown; upper tail-coverts pure white ; tail also white with dark brown tips to the feathers; loral space black, which colour is continued in a narrow line below the eye on to the sides of the throat and joining on the fore-neck, encircling the buff colour on the throat : these black feathers have white bases; the patch on the side of the breast olive-brown like the back; middle of fore-neck and breast rufous becoming paler on the flanks; abdomen and under tail-coverts pure white; axillaries and inner under wing-coverts chestnut, marginal and greater under wing-coverts black, more or less tipped with white; bill black, basal half of tomium and corner of mouth red; iris dark brown; tarsi and feet blackish-brown. Total length $227 \mathrm{~mm}$, ; culmen 16, wing 191, tail 82, tarsus 34 .

Adult female. - Similar to the adult male but differs by the absence of the black lores, which are more or less rufous.

Immature male (of the year).-Differs from the adult only in being paler on the throat (which is streaked) and breast, and by the absence of the white bases to the feathers which encircle the buff throat patch.

Immature female.-Differs from the immature male in being almost white on the throat, and the entire absence of rufous on the fore-neck.

Young.-Differs from the adult chicfly in having white margins to the feathers on the upper-surface ; the upper-breast is brown, with lighter margins to the feathers, and the throat has white feathers with narrow brown centres. As the bird gets older, the margins to the feathers of the upper-surface become narrower, the feathers approaching those of the fully adult in colour, and the black rim surrounding the throat becomes pronounced.

Nestling.-Appears to be undescribed.

Nest.-A depression in the soil. 
Eggs.-Clutch, two; ground-colour pale stone, marked all orer with bold markings of dark purplish-black, and underlying ones of smoky-grey; axis $31 \mathrm{~mm}$., diameter 24.

Breeding-season-April, May.

Distribution and forms.-Breeding in eastern Siberia, migrating southward to Australia in winter. The subspecies are imperfectly known, so that Mathews's G. $p$. parryi may even later be recognised as separable from the form occurring in Java, the migration routes being as yet undetermined.

\section{Genus STILTIA.}

Stiltia Gray, Cat. Gen. Subgen. Birds, p. 111, Oct. 1855, ex Bonaparte MS. Type (by original designation): Glareola isabella Vieillot.

Rhimphalea Heine und Reichenow, Nomencl. Mus. Hein., p. 338, (pref. Sept.) 1890. New name for Stiltia Gray.

Glareoline birds with short bills, very long wings, short tail, and long legs and small feet.

The bill is short, very broad at the base, tip decurved and sharp; the lower mandible straight, gonydial angle a little marked, but tip slightly decurver. The wings are very long and pointed, the first primary somewhat attenuated and exceeding the second by nearly an inch. The tail is short and slightly emarginate, only about a third, or less, the length of the wing. The legs are long, the metatarsus is regularly scutellate, both before and behind; the toes comparatively long and slender, the claws very long, the middle claw not at all pectinated; hind-toe present. The combination of short Glareoline bill, very long attenuate wings, short tail and long Cursorine legs, make this genus distinctive and unmistakable.

\section{Stiltia isabella.-PRATINCOLE.}

Gould, Vol. VI., pl. 22 (pt. xxrrr.), June 1st, 1846. Mathews, Vol. III., pt. 4, pl. 170, Dec. 31 st, 1913.

Glareola isabella Vieillot, Analyse nouv. Ornith., p. 69, April 14th, 1816 : Australia.

Glareola grallaria Temminck, Manuel d'Orn., 2 e ed., Vol. II., p. 503, Oct. 21st, 1820 : South Asiø.

Glareola australis Leach, Trans. Linn. Soc. (Lond.), Vol. XIII., pt. I., p. 132, 1821 : Australia. Distribution.-Australia generally. Not Tasmania.

Adult male.-Pale olive-brown on the head, back, scapulars, and wings; all the fenthers margined with rufous except on the rump; hind-neck, fore-neek, and breast rufous; bastard-wing, primary-coverts and quills blackish, the short innermost primaries pale brown and edged with white on the inner webs, the shaft of the outer primary conspicuously white, secondaries uniform olive-brown; upper tailcoverts white; base of tail and outer pair of tail-feathers also white with a broad subterminal black band, which becomes much narrower on the outer feathers, tipped with brown on the outer webs and white on the inner ones; lores blackish; throat inclining to white; flanks and abdomen maroon-chestnut; rent and under tail-coverts white; axillaries and under wing-coverts black; bill, base scarlet, tip black; iris and feet brown. Total length $210 \mathrm{~mm}$.; culmev 15, wing 198, tail 60 , tarsus 50 .

Adult female.-Similar to the adult male.

Immature.-Have very broad reddish-buff edges to the feathers of the uppersurface, giving it a uniform appearance.

Nestling in down.--Does not appear to have been described.

Nest.-A depression in the soil.

Eggs.-Clutch, two; ground-colour pale stone, marked all over (sometimes 
very heavily) with irregular-shaped markings of dark brown and underlying ones of grey ; axis 32-33 mm., diameter 23.5 to 24.5 .

Breeding-season.--September to February.

Distribution and forms.-Through the Molucca Islands and Australia. No subspecies have been separated.

\section{Genus PELTOHYAS.}

Peltohyas Sharpe, Cat. Birds Brit. Mus, Vol, XXIV., p. 307, (July 10th) 1896. Type (by monotypy): Eudromius australis Gould.

Glareoline birds with rather long bills, short wings, short tail, and long legs with small feet. The bill is long, with the tip very little decurved; the depression in which the nostrils lie extends more than half the length of the bill; the nostrils are linear and placed at the anterior end of this depression; lower mandible is straight, with the gonydial angle little marked, but more so than in most genera of this family. The wings are short, with the first primary longest. The tail is short and rounded, less than half the length of the wing. The legs are long; the tarsus is regularly seutellate in front and behind; the toes are short, and the middle claw is not pectinate; while there is no hind-toe.

The status of this genus requires confirmation from criticism of immature and nestling specimens and also osteological examination, as if the present location should prove to be inaccurate it is quite aberrant wherever it may be placed.

\section{Peltohyas australis.-DOTTEREL.}

Gould, Vol. VI., pl. 15 (pt. IIII.), Dec. 1st, 1843. Mathews, Vol, III., pt. 4, pl. 172, Dec. 31 st, 1913.

Eudromius australis Gould, Proc. Zool. Soc. (Lond.), 1840, p. 174, July 1841: interior Australia (South Australia).

Charadrius australis whitlocki Mathews, Nov. Zool., Vol. XVIIJ., p. 219, Jan. 31st, 1912 : Daydawn, mid-West Australia.

Distribetron.-South Australia, Victoria, New South Wales, West Australia.

Adult male.-General colour of the upper-surface rufous and dark brown, the feathers being dark brown broadly margined with rufous, the dark pattern becoming paler on the lower back, rump, and upper tail-coverts; outer edge of wing rufous ; bastard-wing and primary-coverts dark brown tipped with rufous; primary-quills black on the outer webs and at the tips, shaft of first or outer primary white, remainder reddish-brown, inner webs rufous, some of the inner primaries rufous on the outer webs; secondaries brown with rufous margins ; tail dark brown, the feathers edged with sandy-rufous and white; hinder crown and nape like the back; a broad black band across the top of the head which is continued in a narrow line backward orer the eye on to the sides of the neck, where it joins a narrow collar on the hind-neck which is extended on the fore-neck and ends in a point on the middle of the breast; a black patch from below the eye to the sides of the throat; car-coverts buff streaked with black; a spot behind the eye, chin, and throat fawn colour, somewhat darker on the lower throat; sides of breast and sides of body rich famn colour; the feathers adjoining the black mark on the fore-neck much paler as also a spot below the earcoverts; middle of abdomen and flanks deep chestnut; rent, thighs, and under tail-coverts white tinged with buff ; under wing-coverts and axillaries fawn colour, rather paler than the sides of the body ; bill black, paler at base ; iris dark brown; tarsi and feet drab colour. Total length $221 \mathrm{~mm}$.; culmen 17, wing 142, tail 65, tarsus 34.

Adult female.-Similar to the adult male. 
Immature--Differs from the adult in having all the characters much more faintly indicated, except on the crown of the head where the black band of the adult is entirely absent.

Nestling.-Appears to be undescribed.

Nest.-A depression in the soil.

Eggs. - Clutch, three to five; ground-colour is of a rich cream or buff, sparingly sprinkled all over with irregular spots and some elongated crooked markings of chocolate-black with a few minute dots and dashes of a lighter tint; the markings look black in certain lights, but of a chocolate tint in others; axis $37 \mathrm{~mm}$., diameter 27.

Breeding-months.-April, May, August, September and October.

Distribution and forms.-Confined to Central Australia. Two subspecies have been determined, but more may later be recognised; these are: $P$. a. australis (Gould) from eastern interior (South Australia), and P. a. whitlocki (Mathews) from interior Western Australia, a darker and larger race.

\section{SUBORDER OTIDIFORMES.}

The Bustards we have allowed as a suborder of the order Lari or Limicolæ, though we acknowledge this is a debatable point. The examination of the bill proclaims it to be Plover-like, while the legs are quite unmistakably of the same affinity and certainly not at all Gruine. The nestling plumage is also referable to the Limicoline series and not to the Gruine form. They are all large stoutly-built birds with longish necks, short heads, flattened broad bills, long round wings, short tail and long stout legs and small feet with no hind-toe. The distribution of the suborder is tropical and subtropical.

Osteologically, the skull shows a schizognathous palate while the nasals are commonly cited as holorhinal, but this is a pseudo-holorhiny and is of schizorhinal origin. There are no basipterygoid processes, and the descending process of the lachrymal does not anchylose with the ethmoid. The coracoids do not touch at their articulation with the stemum, the cervical vertebræ sixteen to eighteen in number, and the sternum is doubly notched. The members of the suborder are remarkable for the variation in the number of the carotids, some genera having both, others only the left, and for A ustrotis australis the right has only been recorded, a state unique. The digestive system is pericolous, and the creca are remarkable and variable in form. The syrinx is tracheo-bronchial, without intrinsic muscles. The leg muscle formula is BXY +, and there is no biceps slip, but an expansor secundariorum is present. There is no oil gland, but an aftershaft is present; the wing is aquincubital and the pterylosis is variable and the variation yet undetermined.

\section{FAMILy OTIDIDA.}

In this family from internal items Austrotis is almost the best marked genus, possessing the least modified form of syrinx, the most peculiar ceca, extraordinary carotid development, and a "showing-off" apparatus quite distinet from that of the well-known type.

\section{Genus AUSTROTIS.}

A ustrotis Mathews, Austral Av. Rec., Vol. II. pt, 1, p. 12, Aug. 2nd, 1913. Type (by original designation): Otis australis Gray.

Otidine birds with medium-sized bill, long wings, long legs, and long tail.

The bill is rather long, flattened, wide at the base, with the nostrils placed near 
the base of the culmen. The culmen is less than one-third the length of the tail. The crown of the head bears a crest, but this is not extended on to the hind-neck. The feathers of the throat and fore-neck are also elongated. The wing is long and rounded, the fifth primary longest; the wing length is more than twice that of the tail.

The tail, composed of twenty feathers, is long and rounded and is more than. three times the length of the culmen and less than half that of the wing.

The legs are strong and long; the metatarsal covering is composed throughout of hexagonal scales; tho metatarsus is less than one-third the length of the wing. The toes are strong and comparatively long ; no hind-toe.

\section{Austrotis australis.-BUSTARD.}

Gould, Vol. VI., pl. 4 (pt. vir.), Sept. 1st, 1842, Mathews, Vol. III., pt. 4, pl. 175, Dec. 31 st, 1913.

Otis australis "Gray," Griffith and Pidgeon, Anim. Kingd., Cuvier, Vol. VIII., p. 305, "1829" ? 1830 : Now South Wales.

Otis australasianus Gould, Proc. Zool. Soc. (Lond.), 1840, p. 176, July 1841 : interior of New South Wales.

Otis novahollandice Leichhardt, Journ. Overl. Exped. Austr., p. 260, 1847. Error for preceding. Nomen nudum.

Choriotis australis derbyi Mathews, Nov. Zool., Vol. XVIII., p. 226, Jan. 31st, 1912: Derby, North-west Australia.

A ustrotis a ustralis melvillensis Mathews, Austral Av. Rec., Vol. III., pt. 2, p. 51, Nov. 19th. 1915: Melville Island, Northern Territory.

Distribution,-Australia generally, Not Tasmania.

Adult male.-Entire back, wings, and tail dark brown, everywhere finely rermiculated with sandy-buff; median and greater wing-coverts white with pale brown vermiculations on their basal portions, subterminally black, and tipped with white; bastard-wing and primary-coverts lead-grey edged with white at the tips; primaryquills pale brown, more or less vermiculated with white towards the base ; secondaryquills greyish-brown, finely rermiculated with sandy-buff and tipped with white, the long innermost secondaries like the back; middle tail-feathers also like the back, the outer feathers subterminally black, tipped with white, and some dark bars more or less indicated; crown of head and an elongated nuchal crest black; lores. eyebrows, and ear-corerts buffy-white; throat, sides of face, neck all round, and breast white, finely barred with dark brown and tinged with buff; an irregular black band across the breast, the feathers of which are black, white, and buff; abdomen, sides of body, and axillaries buffy-white; lesser under wing-coverts white; the small marginal coverts black, edged with white, the larger series grey, rermiculated with white; a patch of black feathers on the lower flanks rermiculated with white and buff; the short under tail-coverts black tipped with white, the long ones buffy-white irregularly marked with brown, the thighs also buffy-white more or less vermiculated with brown. Total length 1,155 mm.; culmen (exp.) 72, wing 610 , tail 245, tarsus 180 .

Adult female.-Similar to the adult male but smaller and differs in haring the tail regularly barred with dark brown, the outer marginal upper wingcoverts coarser, and the sides of the face and neck all round darker. Total length $830 \mathrm{~mm}$.; culmen (exp.) 5l, wing 563, tail 210 , tarsus 149.

Nestling (losing down but retaining egg-tooth).-Fore-head and top of head downy, down continuing on back of neck and throat, but patch of feathers showing at back of head; another pateh of down still retained on rump, flanks and thighs. Down on fore-head pale fawn; top of head mottled black and fawn, surrounded by a fawn line, above the eyes, but a narrow loral streak runs just over the eyes to the back of the neck, where it becomes indistinct; the back of the neck is fawn as below 
the eyes and most of the throat; a linear dark line runs from the gape probably meeting the loral line; the interramal space is dark coloured as is the centre of the throat, indistinct linear edges to the throat patch darker; the down on the rump is fawn profusely mottled with black, the flank and thigh down fawn with brownish markings on the thighs. The feathers on the back of the head are black with fawn markings and narrow fawn tips; those of the back are reddish-fawn with black vermiculations, the scapulars showing brown tips of fawn with a black edging posteriorly, of a triangular shape; the lesser wing-coverts are similarly reddishfawn but the black vermiculations scantier and no broad fawn tipping; the secondaries, however, approach the scapulars in style of marking, but not in so pronounced a manner ; the apparent primary-coverts are pale fawn with irregular black markings in bar formation and broad fawn bars to tips; primaries just sprouting with black tips; tail scarcely showing as such; the tail-coverts as the back feathers; undersurface pale sandy.

Nestling (in similar plumage procured at same time but larger, probably male).The down has been lost from fore-head, which shows feathering as back of head in preceding but darker; the dark patch on throat more pronounced and showing distinctly a central light patch followed by a darker line, and a darker line surrounding the whole, and also less distinctly darker lines on the lower throat ; also the feathering on the breast is seen to consist of vermiculated feathers similar to those of the back, while the feathers of the under-surface are paler than in the above. The feathers of the back are longer and show much darker vermiculation and much smaller buff tips, less triangular in shape, the black edging straighter; the edges of the wings are as above described, but the lesser wing-coverts generally agree with the description of the primary-coverts above and the broad tips are much more pronounced, making a pale fawnish bar and proving them to be the secondary coverts; the primarycoverts are just seen in connection with the primaries as much darker vermiculated feathers with black bars and narrow tips of darker fawn and the primaries are longer with minute fawnish tips to their black colour; tail not yet discernible.

Nest.-None made.

Eggs.-Clutch, one to two; ground-colour reddish-brown with blotches of darker brown all over; axis $75 \mathrm{~mm}$. by 55 ; eggs from West Australia are smaller, darker, and more heavily blotched than those from the eastern side of the continent.

Breeding-season.-Niay to November.

Distribution and forms.-Confined to Australia. Three subspecies may be admitted: A. a. australis (Gray) from the East coast; A. a. derbyi (Nathews) from the North-west coast, a much browner and smaller form; and A. a. melvillensis (Nathews) from Melville Island, a blue-grey form also larger than the preceding. There are probably more subspecies, but long series of these rariable birds have never been collected owing to their edible qualities.

\section{Order PSOPHII Or GRUES.}

This order includes large birds of raried superficial appearance and doubtful close relationship. Three suborders, Cariamiformes, Psophiformes and Eurypygiformes, are recognised, the last named a heterogeneous assemblage of peculiar forms, Eurypygidæ, Rhinochetidæ and Mesitidæ. As one authority" has written : "If we don't put these here, where have we to put them?" This was written from the study of the anatomy and osteology of the forms, and is good evidence of the futility of attempting to classify birds by the "deeper-seated " features without complete study of the external items. All the items yet depended upon are variable, the palate is generally schizognathous, the nasals schizorhinal, but sometimes holorhinal ; basipterygoid processes are absent and supraorbital grooves and occipital fontanelles absent or present. The sternum has the posterior margin entire or 
singly notehed on each side; the furcula variable. The cervical rertebræ vary from fifteen to twenty in number and both carotids are present. The syrinx is tracheo-bronchial but variable in detail. The digestive system is pericœlous, but again variation is to be noted. The leg muscle formula varies from $\mathrm{XY}+$ to $\mathrm{ABXY}+$, the biceps slip may be present or absent, but the expansor secundariorum is always present. The oil gland is present but it may be feathered or nude; the aftershaft is supposed in one group to be absent, otherwise always present; while the wing may be aquincubital or quincubital. The pterylosis is, as far as has been studied, variable. Such a series of variable items indicates the indeterminate nature of the association, which seems purely artificial.

As regards the birds themselves, they probably represent the results of isolation and convergence, as the whole collection is few in number. The distribution is also peculiar, the typical Cranes being generally distributed through the tropics and subtropical regions, the Hesitidxe one Madagascar genus, the Rhinochetidx one New Caledonian genus, the Eurypygidx, Psophiidæ, and Cariamidæ, the two former with one genus, the latter with two genera restricted to South America.

Many fossils have been referred to this neighbourhood, generally on very insufficient evidence, such as a single piece of bone. The similarity in osteological characters of these birds to the Rails has also confused matters. Thus the Neozelanic Aptornis was first regarded as allied to Dinornis, was then considered to be a Ralline form, and more recently relegated here. Its Ralline affinity seems the most probable. Then, the "Stereornithes" of the lower Tertiary of Patagonia are generally placed alongside this order, but much more material and study are necessary before a definite opinion can be maintained.

\section{SUBORDER PSOPHIIFORMES.}

\section{FAMIL BALEARICIDA.}

This family includes the true Cranes, to which the Native Companion or Brolga must be referred. There is some dirergence in connection with internal features, though externally there is great similarity. The palate is schizognathous and the nasals schizorhinal, basipterygoid processes absent but supraorbital grooves and occipital fontanelles present. The sternum is not notched posteriorly and the cervical rertebre nineteen or twenty, the furcula sometimes anchylosed with the sternum, but not always. The syrinx raries, that of Balearica more modified than in the true Cranes, while the trachea is convoluted in the latter, but not in the former. The digestive system shows Jittle rariation in this family. The leg muscles, howerer, rary from $\mathrm{ABXY}+$ to $\mathrm{XY}+$ only in apparently closely allied species at present referred to the same genus; the biceps slip is generally present, the expansor secundariorum always. The oil gland is always tufted, the aftershaft present and the wing is aquincubital. There are no powder downs, which are present in the aberrant superfamilies.

\section{Genus MATHEWSENA.}

Mathewsena Iredale, Austral Av. Rec., Vol. II., pt. 5, p. 82, Sept. 24th, 1914. New name for Mathewsia Iredale. Type (by original designation) : Ardea rubicunda Perry.

Mathewsia Iredale, Bull. Brit. Ornith. Club, Vol. XXVII., p. 47, Jan. 23rd, 1911. Typo (by original designation): Ardea rubicunda Perry.

Not Matthewsia Sauley, Catal. Coleop., Vol. II., p. 745, 1868.

Psophiine birds with long bills, long neck, long wings, long legs and feet.

The culmen is long, compressed, straight, and sharp pointed ; the upper mandible bas on each side a depression extending rather more than half its length; the nostrils 
covered with a membrane; an obsolete groove can be traced in the lower mandible. The culmen is longer than the head, little shorter than the tail, and more than half the length of the metatarsus. The head is denuded of feathers save on the earcoverts. The wing is long, with the inner secondaries longer and resolving themselves into drooping plumes. The tail, composed of twelve feathers, is more than one-third the length of the wing. The legs are very long, as also the exposed tibia, while the very long metatarsus is scutellate, and is equal to half the length of the wing. The toes are long with no webbing between; hind-toe present and raised above the level of the others; the middle toe is about half the length of the culmen.

\section{Mathewsena rubicunda.-BROLGA.}

Gould, Vol, VI., pl, 48 (pt. xxx.), March 1st, 1848. Mathews, Vol. III., pt. 4, pl. 176, Dec. 31 st, 1913.

Ardea rubicunda Perry, Arcana, pt. vi. [pl. 22], June 1810: Botany Bay, New South Wales. Grus antarctica Illiger, Abhandl. Ak. Wissen Munch., 1811-12, p. 230, 1816: New South Wales.

Grus australasianus Gould, Birds Austr., pt. $\mathrm{xxx}$. (Vol. VI., pl, 48), March 1st, 1848 : New South Wales.

Mathewsia rubicunda argentea Mathews, Nov. Zool., Vol. XVIII., p. 227, Jan. 31st, 1912 : Derby, North-west Australia.

Distribution.-Australia generally. Not Tasmania.

Adult male.-General colour above and below silvery-grey, with pale edgings to the feathers of the upper-parts; bastard-wing, primary-coverts and quills dark brown; lower throat covered with hair-like feathers ; bill and crown of head olivegreen; papillæ on the sides of the face and the back of the neck red; iris yellow; tarsi and feet brown. Total length $1,220 \mathrm{~mm}$.; culmen 163 , wing 580 , tail 210 , tarsus 290.

Adult female.-Similar to the adult male ; culmen 150, wing 555.

Young.- Still retaining a portion of the clowny plumage. Differs from the adult by having the head covered with pale rufous feathers, becoming paler and inclining to buff on the upper hind-neck, the grey ear-coverts only slightly indicated.

Immature.-Differs from the adult in being darker and the feathers of the mantlo edged with brown.

Nest.- None made.

Eggs.-Clutch, two; surface minutely pitted; ground-colour creamy-white, sparingly covered with spots of brown and lavender; axis $84-91 \mathrm{~mm}$., diameter 60 to 62 .

Breeding-season.-September to March.

Distribution and forms.-Australia only, a straggler once recorded from Central Asia! Two well-marked subspecies are recognised : $M . r$. rubicunda (Perry) from the East, and M. r. argentea (Mathews) from the North-west, a smaller and much paler silvery-grey race.

\section{ORDER RALLI.}

This order, as recognised by us, comprises three suborders, Rails proper, Finfeet and Grebes. All are small to medium wading or swimming birds, though some are mainly land birds, all three forms being seen among the Rails. The bill is of varied shapes, the body generally slender, rarely stout, the wings short and the legs stout, sometimes peculiarly developed for swimming purposes. They all seem to hare a strong tendency to flightlessness, which is seen in many cases acting now through isolation. A few semi-flightless forms still exist, some flightless ones are only recently extinct, and quite a few fossil flightless forms are known. Rails and Grebes are of world-wide distribution, while the Finfeet occur only in tropical America and Africa. 
The skull shows a schizognathous palate with holorhinal nasals and without basipterygoid processes; the lachrymals do not join the ectethmoids, which have a process jointing the frontal, producing a foramen. The cervical vertebra vary from fifteen to twenty-one, the Rails fifteen, the Finfeet seventeen, Grebes twenty-one. The sternum is singly notched on each side of its posterior margin ; the furcula is somewhat variable in position. The carotids vary, the syrinx is typically tracheobronchial, and the digestive system pericœlous, crea long. The leg muscle formula varies, the Rails showing $\mathrm{ABXY}+$, the Finfeet $\mathrm{ABX}+$, and the Grebes $\mathrm{BX}-$, the expansor secundariorum as also the biceps is variable. The oil gland is generally tufted, the aftershaft present and the wing aquincubital or quincubital (in the Finfeet.) The pterylosis is somewhat rariable and the nestlings hatched corered with down. Fossil Rails are comparatively frequent, but they are generally of flightless form, and show convergence in the most marked manner, as the famous instance of Aphanaptery $x$ from the Mauritius and Diaphoroapteryx from the Chatham Islands recalls, the bones being regarded as congeneric on account of their similarity. Again Tribonyx was used for a Iadagascar Rail, the author admitting its usage was due to non-differentiation of the osteological items, though probably no near relation of the living birds was a fact.

\section{SUBORDER RALLIFORMES.}

We allow three families in this suborder, Rails (including Crakes), Moorhens and Coots. These are easily separable by almost intangible superficial features, the bill in the first named developing no frontal plate, while a more or less strongly formed frontal plate is seen in the latter two, which differ in the peculiar lobe formation surrounding the toes in the Coots. The general distribution of the whole three is world wide, but Coots do not occur in New Zealand. Rails and Crakes are more or less land forms, generally living about swamps but not swimming; Moorhens frequent water more commonly and swim a lot, while Coots invariably swim.

Osteologically the skull is schizognathous and holorhinal, but in order to estimate the value of the last term Nesolimnas has been cited as having schizorhinal nasals. The schizorhiny in this case is pseudo-holorhiny, and not schizorhinal as used in the Limicoline series; there are no basipterygoid processes and the lachrymals do not fuse with the ectethmoids, while there are no supraorbital grooves. The cervical vertebræ number fifteen, the sternum is singly notched with very long lateral processes and the furcula does not reach the keel of the sternum. There are two carotids, the syrinx is typically tracheo-bronchial with little variation and the digestivesystem typically pericolous with the creca long. The leg muscle formula is ABXY+, and the expansor secundariorum is present, as also the biceps. The oil gland is tufted, but exceptions have been recorded, while an aftershaft is present and the wing aquincubital. The pterylosis is variable and has been little studied. The downy nestling is generally able to swim from birth.

\section{Family RALLIDE.}

Includes the Rails and Crakes, non-swimming Ralline forms of raried superficial features but very similar internal characters.

\section{Genus RALLUS.}

Rallus Linné, Syst. Nat., 10th ed., p. 153, Jan. 1st, 1758. Typo (by subsequent designation Fleming, Mem. Werner. Soc., Vol. III, p. 176, 1821): Rallus aquaticus Linne.

Lewinia Gray, Cat. Gen. Subgen. Birds, p. 120, (Oct.) 1855 (ex Reichb. and Pr. B (onaparte), MS.). Typo (by original designation) $: R$. lewinii Swainson $=$ Rallus pectoralis Temminck et Laugier.

Donacias Heine und Reichenow, Nomencl. Mus. Hein., p. 321, (pref. Sept.) 1890. New name for Lewinia Gray. 
Small Rails with long slender bills, short rounded wings, short tail and short legs and long toes.

The bill is long and laterally compressed, generally decurved and slender; the culmen ridge is a little flattened and does not develop any frontal plate; a very long deep groove extends more than half the length of the upper mandible and the nostrils are linear pervious apertures, placed near the base of the culmen, parallel and adjacent to the lower edge of the mandible; the under mandible is a little curved and slender, the rami enclosing a very narrow space and merging near the tip forming no gonys; there is only a minute shallow groove on sides of lower mandible near the base; the culmen is longer than the tarsus. The wing is short and rounded, the first primary short, less than the fifth, the second usually the longest ; the inner secondaries long, very little shorter than the longest primaries. The legs are short, the tarsus regularly scutellated in front and behind, the scutes separated on the sides by rows of small hexagonal scutellæ; the middle toe longest, and the inner shorter than the outer, claws long, thin and little curved, the hind-toe long. The tail is composed of twelve soft feathers, rounded in shape, and less than half the length of the wing.

Coloration scalloped dark brown and black above, brownish-grey below; flanks barred, black and white.

\section{I3I. Rallus pectoralis.-SLATE-BREASTED RAIL.}

Gould, Vol. VI., pl. 77 (pt. xxxirr.), Dec. 1st, 1848. Mathews, Vol. I., pt. 4, pl. 46, Aug. 9tb, 1911.

Rallus pectoralis Temminck et Laugier, Planch. Color. d'Ois., 88e livr. (Vol. V., opp. pl. 523), May 14th, 1831: New South Wales.

Rallus brachipus Swainson, Anim. in Menag., Dec. 31st, 1837, p. 336 : Tasmania.

Rallus lewinii, Swainson, ib.

Rallus pectoralis clelandi Mathews, Birds Austr., Vol. I., pt. 4, p. 189, Aug. 9th, 1911 : West Australia.

Distribution.-South Queensland, New South Wales, Victoria, Tasmania, South Australia and South-rrest Australia.

Adult male.-General colour above black, all the feathers broadly margined with olive-brown, including the mantle, back, upper tail-coverts, and tail ; scapulars black, barred with white; lesser wing-coverts olive-brown; median and greater coverts blackish, narrowly barred with white-these white bars are not always continuous across the feathers, but only represented by a short bar on each web; bastard-wing, primary-coverts, quills, uniform dark brown, the long inner secondaries barred with white on the outer webs ; tail-feathers black, margined with olive-brown ; feathers of the head and hind-neck black margined with chestnut; fore-head, eyebrow, and sides of neck bright chestnut; cheeks, throat, and breast grey with a brownish tinge, becoming whitish on the chin; remainder of the under-surface, including the sides of the body black, barred with white, not so sharply defined on the thighs; vent and under tail-coverts tinged with sandy-buff; axillaries and under wing-coverts blackish, slightly tipped with white; bill brownish-red; feet flesh colour, becoming darker about the toes; iris hazel. Total length $210 \mathrm{~mm}$.; culmen 33, wing 103 , tail 45 , tarsus 29.

Adult female.-Similar to the adult male but differs in being smaller and in having the breast almost pure grey. Total length $203 \mathrm{~mm}$.; culmen 33, wing 93, tail 41, tarsus 26.

Immature female.-Differs from the adult female in having a darker appearance ; the absence of chestnut on the head, hind-neck, and sides of neck; fore-neck and sides of neck blackish, like the under-surface of body, showing only traces of white cross-bars on the lower flanks; throat pale grey like the adult; also paler on the middle of the abdomen. 
Nestling.-Covered with black, silky down.

Nest.-Composed of fine grass and rushes, and situated in a swamp amongst thick rushes, which are usually drawn together above, so as to form a covering. There is a staging or landing leading to the nest, which is variously placed from six inches to three feet above the water.

Eggs.-Clutch, four to six; ground-colour pale stone, sparingly spotted with pinkish-brown spots, and more thickly with larender-grey ones; axis 36-37 mm., diameter 28-29.

Breeding-season.-October to December.

Distribution and forms.-Australia, Now Guinea and South Flores. Four subspecies have been distinguished: $R$. pectoralis pectoralis Temminck and Laugier from Eastem and Southern Australia; R. p. clelandi Mathews from South-west Australia, a much larger and darker form, culmen 42, wing 114, tarsus $36 \mathrm{~mm}$. against typical culmen 33 , wing $93-103$, tarsus $26-29 \mathrm{~mm}$.; $R$. p. exsul (Hartert) from South Flores, with a more uniform chestnut head, more olivaceous back, and greyer breast, culmen 27, wing 101, tarsus $28 \mathrm{~mm}$; R. p. alberti (Rothschild and Hartert) from British New Guinea (Angabunga River) in its smaller size, more uniform chestnut head, the chestnut extending on to the shoulders, darker back and whiter throat; culmen 26-30.5, wing 93.5-95, tarsus $30-31.5 \mathrm{~mm}$.

\section{Genus TOMIRDUS.}

Tomirdus Mathews, Nov. Zool., Vol. XVIII., p. 193, Jan, 31st, 1912. Type (by original designation): Eulabeornis tricolor robinsoni Mathews.

Medium Rails with short stout bills, short wings, short tail and medium Iegs and feet. The bill is short, stout, laterally compressed and at the base the depth is more than ore-third its length ; the culmen ridge is pronounced but flattened, the tip a little decurved and notehed; the nasal groove is large, extending more than half the length of the culmen, but shallow; the nostrils are pervious slits placed near the anterior end of the groove parallel to the edges of the mandible. The culmen ridge shows no flattening nor extension at the fore-head where the frontal feathers approach on to the edge of the nasal groove. The rami of the under mandible are deep, the gonys nearly half the length and with a distinct upward tendency but scarcely angulated; the intermandibular space is scarcely feathered, and a minute process is seen anteriorly.

The wings are short and rounded, the first primary shorter than the serenth, the intervening ones nearly all the same length, the second and sixth shorter, third and fourth the longest; secondaries long. The tail is short and rounded, composed of soft, broad feathers, and less than half the wing, and about twice the length of the culmen. The legs are of medium length, a small portion of the tibia exposed. The tarsus is scutellated in front and behind, a single narrow row on the sides between the two series of scutes; the toes are long but the middle toe is shorter than the tarsus, the outer subequal with the inner and with their claws equalling the middle toe alone; the hind-toe is long, while the lateral membranes on the edges of the toes are very small.

Coloration brown with red head, neck, and breast, the abdomen brown with yellowish bars.

\section{Tomirdus tricolor.-RED-NECKED RAIL.}

[Rallina tricolor Gray, Proc. Zool. Soc. (Lond.), 1858, p. 188, July 13th : Aru Island. Extralimital.]

Gould, Suppl., pl. 78 (pt. v.), Aug. 1st, 1869. Mathews, Vol. I., pt. 4, pl. 49, Aug. 9th, 1911.

Eulabeornis tricolor robinsoni Mathews, Birds Austr., Vol. I., pt. 4, p. 203, Aug. 9 th, 1911 : Cairns, North Queensland.

DistributroN,-North Queensland. 


Adult male.-Head, hind-neck, mantle, and entire breast bright chestnut, somewhat paler on the sides of the face, and whitish on the chin ; back and scapulars olive-brown; wings, rump, upper tail-coverts and tail dark brown; bastard-wing brown, with whitish spots on the inner webs, and sometimes on the outer webs also; primary-coverts uniform brown; primary-and secondary-quills brown, with white bars on the inner webs and faint traces of bars on the outer webs; abdomen, lower flanks, vent, and under tail-corerts sonty-black with rufous cross-bars, paler and inclining to white on the middle of the abdomen; under wing-coverts and axillaries black, barred with white; bill green; iris red; feet slaty-green. Total length $276 \mathrm{~mm}$. ; culmen 34 , wing 148 , tail 70 , tarsus 47 .

Adult female.-Similar to the adult male.

Nestling.--The young, on leaving the egg, are corered with a sooty-black down, having a dark, plumbeous tinge on the under-surface.

Immaticre. - The young at about five months old have the upper-surface of a dull, dark brown tinged with olive, and washed with light rufous-brown on the back of the neck; the under-surface is of a duller and more plumbeous-brown, with a faint wash of rufous-brown on the chest and uncler tail-coverts, which latter have two pale rufous bars on each feather; the under-surface of the wings blackish, dull brown, a band of white spots near the base, and a similar band about the middle of the quill-feathers; bill olive-brown; legs greenish-olive; iris reddish-brown. Total length $176 \mathrm{~mm}$; ; culmen 23 , wing 92 , tail 38 , tarsus 51 .

Nest.-Composed of a few leaves and grass and hidden among debris at the root of a tree, in a dense part of the scrub.

Eggs.-Clutch, four; glossy white; axis 40-38.5 mm., diameter 30-28.5.

Breeding-season,-January.

Distribution and forms.- North Australia, New Guinea and Aru Islands. Three subspecies have been named: $T$. $t$. tricolor (Gray) from the Aru Islands; T. $t$.grayi Mathews from New Guinea, with more numerous and whiter bars on the abdomen and flanks; and T. $t$. robinsoni Mathews from Queensland, with a shorter, more slender bill, shorter tarsus, less barring on the abdomen and browner back, less grey, and darker chest.

\section{Genus HYPOT 포IDIA.}

Hypotanidia Reichenbach, Nat. Syst. Vögel, p. xxmr, 1852 (? 1853). Type (by original designation): Rallus pectoralis Gould (not Temminck) $=$ Hypotcenidia australis Pelzeln.

Small Rails with rather short stoutish bills, short rounded wings, very short tail and stout legs and feet. The bill is longer than the head, fairly stout, the tip a little decurved ; the nasal groove is long, more than half the length of the culmen, the ridge a little flattened, but not expanded basally into a frontal plate; the nostrils are narrow pervious slits placed about the midclle of the nasal groove; the under mandible has a distinct gonys about one-third of its length, an indistinct groove being seen along the other two-thirds of the mandibular rami. The culmen is less than the length of the tarsus. The wing is short and rounded, the first primary being shorter than the serenth, the seeond usually longest, the succeeding ones slowly decreasing; the secondaries are almost as long as the primaries. The tail is short, about two-fifths the length of the wing, the twelve feathers rather soft and somewhat pointed, the shape being rounded, the upper tail-coverts about half the length of the tail, the under reaching to the tips. The legs are rather stout, scutellated in front and behind, a row of smaller scales between the scutes on the sicles; the toes rather short, the middle toe longest, the outer and inner notably shorter, and practically subequal. The hind-toe rather short, the claw short, the claws of the anterior toes longer and little curved.

Coloration browuish-black above with white spots, superciliary whitish line, throat grey, under-surface barred black and white, a red chest-band usually present, 


\section{Hypotænidia philippensis.-BUFF-BANDED RAIL.}

[Rallus philippensis Linné, Syst. Nat., 12th ed., Vol. I., p. 263, (prof, May 24th) 1766 : Philippine Islands. Extra-limital.]

Gould, Vol. VI., pl. 76 (pt. xxrv.), Sept. 1st, 1846. Mathews, Vol. I., pt. 4, pl. 47, Aug. 9th, 1911.

Hypotanidia australis Pelzeln, Ibis, Jan. 1873, p. 42 : New South Wales.

Eulabeornis philippensis mellori Mathows, Nov. Zool., Vol. XVIII., p. 192, Jan. 31st, 1912 : Sandy Hook Island, South-west Australia.

Eulabeornis philippensis yorki Mathews, Austral Av. Rec., Vol. II., pt. 1, p. 6, Aug. 2nd, 1913 : Cape York, North Queensland.

Distribution,-Australia generally and Tasmania.

Adult male.-Head reddish-brown, streaked with black; superciliary streak white, merging into grey behind the eyo; lores and a broad line through the eye chestnut, like the hind-neck, to which it is joined; sides of neek, lower hind-neck, and mantle blackish, barred and spotted with white; back, rump, upper tail-coverts, and tail black, broadly edged with ochreous-brown, and a few marginal white spots on the upper tail-coverts; scapulars dark brown, margined with ochreous-brown, and spotted with white; lesser wing-coverts ochreous-brown, with black and white spots on the margins of the feathers; bastard-wing dark brown, barred with rufous and white; primary-coverts and quills dark brown, barred with rufous, some of the bars on the two outer primaries white, the innermost secondaries black, with rufous and white bars and fringed with ochreous-brown; throat and fore-neck pale grey, darker on the latter; upper-breast and abdomen banded with narrow black and white bars, more broadly on the sides of the body and abclomen, as also the axillaries and under wing-coverts; a band of ochreous-buff across the breast; thighs buffy-white; under tail-coverts black, barred with white, and tipped with sandy-buff; quills below barred with rufous and brown of almost equal widths, the two outer primaries more broadly banded with blackish, and more narrowly with whito; bill warm brown; feet flesh-red; iris indian-red. Total length, $335 \mathrm{~mm}$; culmen 33 , wing 153 , tail 66 , tarsus 39 . Tho wing measurements of seventeen birds from the same locality give-the males 143 to 153 , the females 133 to 145 .

Adult female.-Similar to the adult male but slightly smaller.

Young about cleven days old.-General appearance sooty-black, with down of a hair-like texturo. Breast and flanks black, barred with white. Sides of the throat and cheeks black, flecked with white. Iris, grey-hazel.

Nestling.-Covered with glossy black down.

Nest.-Situated near swampy ground and placed in the vegetation. Composed of grass and leaves. Egg cavity, 4 inches.

Eggs.-Clutch, about six. Eggs from the Dawson River, North Queensland, are smooth and glossy; ground-colour creamy or buff, with spots and blotches of chestnut-brown over the surface, but more thickly at the larger end; underlying spots and blotches of lilac-grey; axis, 33 to $36 \mathrm{~mm}$, diameter 24 to 26 .

Breeding-season.-September to February.

Distribution and forms.-From the Philippine Archipelago southward to the Macquarie Islands, eastward to Samoa and Tonga, throughout Australia and westward to the Cocos Keeling Islands. In 1911 Mathews distinguished twelve subspecies, and has since added two more, so that fourteen are here diagnosed : H. p. philippensis (Linné) from tho Philippine Islands; H. $p$. australis Pelzeln from East Australia, with a decided red hind-neek, smaller bill, shorter tarsus, reddishbrown fringes (not ochraceous as in preceling) to feathers on top of head, darker upper-surface with more spotting on back, secondaries shorter and wide pale buff pectoral band; arerage measurements, culmen 30 , wing 144, tarsus $39 \mathrm{~mm}$. as 
against typical culmen 31, wing 144, tarsus $43 \mathrm{~mm}$. ; H. p. mellori (Mathews) from South-west Australia, darker than the preceding above but similar below; H. p. yorki (Mathews) from North Queensland, which may include some New Guinea birds, is smaller and with a darker buff pectoral band; H. p. sethsmithi (Mathews) from the Fiji Islands, a little larger with the pectoral band obsolete and lower throat grey, average culmen 34 , wing 148 , tarsus $46 \mathrm{~mm}$.; H. p. forsteri Hartlaub from Tonga, darker than the preceding with more spotting on the wing-coverts, shorter bills and wings, but longer tarsi, culmen 28-30, wing 132-14l, tarsus $40-43 \mathrm{~mm}$.; $H$. $p$. goodsoni (Mathews) from Samoa, a larger form with a faint pectoral band, darker below and tail much barred with white; culmen 32-36, wing 136-155, tarsus 46-48 mm.; H. p. swindellsi (Mathews) from New Caledonia, a very dark race, scantily spotted above and very closely barred with black below; faint red hind-neck, faint pectoral wash only; culmen $31-33$, wing 143 , tarsus $41-43 \mathrm{~mm}$.; H. p. lesouëfi (Mathews) from New Hanover, nearly as dark as preceding, but with lower hind-neck barred with white and a distinct pectoral band; culmen 32-33, wing 136-141, tarsus $40-43 \mathrm{~mm}$. ; H. p. assimilis (Gray) a very well-marked form with almost uniform dull brown upper-surface, no red hind-neek, and large bill, abnormally developed wing-coverts and long secondaries, well-marked pectoral band; culmen average $37 \mathrm{~mm}$., wing 146 , tarsus $42 \mathrm{~mm}$. ; H. p. macquariensis Hutton, from the Macquarie Islands, with a shorter bill and wing and darker above and below, culmen 29-33, wing 122-131, tarsus 39-41 mm. ; H. p. chandleri (Mathews) from Celebes, nearest to the typical race but with a distinct red hind-neck, more spotted above, generally darker and no pectoral band, more pronounced barring underneath, dusky lores and shorter secondaries, culmen $31-32$, wing 147 , tarsus $43 ; H$. p. wilkinsoni (Mathews) from South Flores, larger than preceding, culmen 32-33, wing 155-157, tarsus 45-46; and H. p. andrewsi (Nathews) from Cocos Keeling Group, a distinct race, with much white spotting above, the rump even spotted, well-marked hindneck of dull red, and distinct brick-coloured pectoral band, culmen 33, wing 148, and tarsus $42 \mathrm{~mm}$.

There may be more subspecies to be named.

\section{Genus EULABEORNIS.}

Eulabeornis Gould, Proc. Zool. Soc. (Lond.), 1844, p. 56, Sept. Type (by monotypy): E. castaneoventris Gould.

Large Rails with long stout bills, medium wing, long tail and stout legs and feet. The bill is straight with the tip decurved, much laterally compressed, culmen ridge flattened; nasal groove large and deep, extending more than half the length of the bill, nostrils as linear pervious slits about the middle of the groove; the lower mandible stout, with a shallow groove half way along, reaching almost to the gonydial angle; the gonys being nearly half the length of the mandible; interramal space narrow and feathered; depth of the bill about one-third of its length. The wing rounded with the third, fourth, and fifth primaries longest, the second equal to the sixth and the first about equal to the ninth; the inner secondaries long, almost equal to the second primary. The tail, composed of twelve feathers, somewhat decomposed, and of rounded shape, the outer ones being notably shorter, is more than half the length of the wing. The legs are long and stout, the scaling in front of the tarsus being regular transverse scutes, those of the back being broken into hexagonal scales and becoming confused with the hexagonal scaling of the sides; the tarsus is longer than the culmen and about half the length of the tail. The toes are long and strong; the middle toe longest, the inner just a little shorter than the outer, the hind-toe short and stout and somewhat opposed ; all the claws stout and sharp.

Coloration olive above, head and throat ashy, chestnut below. 


\section{Eulabeornis castaneoventris.-CHESTNUT-BELLIED RAIL.}

Gould, Vol, VI., pl. 78 (pt. xvI.), Doc. 1st, 1844. Mathews, Vol, I., pt. 4, pl. 48, Aug. 9th, 1911.

Eulabeornis castaneoventris Gould, Proc. Zool. Soc. (Lond.), 1844, p. 56, Sept. : Flinders River, Gulf of Carpentaria, Queensland.

Eulabeornis castaneoventris rogersi Mathews, Nov. Zool., Vol. XVIII., p. 193, Jan. 31st, 1912 : Obagama, North-west Australia.

Eulabeornis castaneoventris melvilli Mathews, Austral Av. Rec., Vol. I.; pt. 2, p. 29, April 2nd, 1912: Melville Island, Northern Territory.

Distribution.-North Queensland, Northern Territory, North-west Australia (Mangroves only).

Adult male.-General colour abore olive, including the hind-neck, back, wings, and tail, with a tinge of rufous-brown on the rump; inner web of bastard-wing, primary-and secondary-quills chestnut-brown, as also the tail-feathers; crown of the head, sides of the face, and throat ash-grey; under-surface of body rich chestnut, deeper in colour on the under wing-coverts and under tail-coverts; washed with grey on the fore-neek and chest; thighs ash-grey; base of bill green, tip hom colour ; iris red; feet and legs olive-yellow. Total length $537 \mathrm{~mm}$.; culmen 61 , wing 212 , tail 136 , tarsus 70 .

Adult female.--Differs from the adult male in haring the upper hind-neck ash-grey like the head, instead of olive like the back. Total length $512 \mathrm{~mm}$.; culmen 56, wing 206 , tail 130 , tarsus 66 .

Immature but breeding male.-Has iris yellow, slightly mottled with brown.

Nestling.-Appears to be undescribed.

Nest.-Placed on a low slanting mangrove, and built of sticks, with no lining. Placed from 3 to 7 feet from the ground.

Eggs. - Clutch, four; rather lengthened in form, of a pale pinky'-white, spotted all over with reddish-chestnut and lavender, the spots being thinly dispersed; axis $51.5-54 \mathrm{~mm}$., diameter $36.5 \mathrm{~mm}$.

Breeding-season.-September to November.

Distribution and forms.-Northem Australia and Aru Islands only. Four races have been distinguished: E. c. castancoventris Gould from North Queensland; E. c. rogersi Mathews from North-west Australia, a darker race; $E$. c. melvilli Mathews from Melville Island, Northern Territory, still darker both above and below; and E.c. sharpei Rothschild from the Aru Islands, not darker above but a deeper red below.

\section{Genus CREX.}

Crex Bechstein, Ornith. Taschenb., Vol. II., p. 336, 1803. Type (by monotypy): Crex pratensis Bechstein $=$ Rallus crex Linné.

Octogometra (recte Ortygometra, p. 59), Forster, Synopt. Cat. Brit. Birds, p. 27, Dec. 1817.

Type (by monotypy): Rallus crex Linné.

Sole species similar to nembers of the genus Poraana, but larger and of stouter buikl, with a short stout bill and shert toes; the bill at the base is more than half its length, and the culmen tapers to a point as it enters the fore-head. The culmen is shorter than the middle toe, which is shorter than the tarsus, while the base of the gonys forms a decided angle. Other characters as in Porzana.

\section{Crex crex.-LAND RAIL.}

[Rallus crex Linné, Syst. Nat., 10th ed., p. 153, Jan, 1st, 1758: Sweden, Europo. Extrnlimital.]

Mathews, Vol. I., pt. 4, pl. 50, Aug. 9th, 1911.

Fallus fcatherstonii Buller, Essay Ornith. New Zeal., p. 18, (pref. dated Feb. 1st) 1865: New Zealand.

Distrnbution.-Australia (visitor). One specimen preserved in Australian Museum, Sydney. 
Adult male (in autumn).-General colour above olive-grey with blackish centres to the feathers, including the head, hind-neck, back, seapulars, long innermost secondaries, upper tail-coverts and tail; lesser median and greater wing-coverts pale chestnut, like the bastard-wing; primary-coverts dark brown edged with rufous; quills dark brown; the first primary white along the outer edge, the remainder rufous on the outer webs, with a blackish spot at the tips, the secondaries for the most part pale rufous ; lores and a line over the eye rufescent ; throat and middle of abdomen whitish; breast sandy-rufous, clarker on the sides of the body, where it is barred with white; under tail-coverts similar, and tipped with white; axillaries and under wing-coverts pale chestnut; edge of wing white. In summer, the sides of the neck and a stripe over the eye are blue-grey; bill, feet and claws a pale brown; iris hazel. Total length $240 \mathrm{~mm}$.; culmen 22, wing 130 , tail 75 , tarsus 35.

Adult female.-Similar to the male.

Nestling.-Covered with sooty-black down, which is darker on the head and throat, with lines of rufous feathers and black tips on the back, sides of the body, and the flanks. Another example, rather more advanced in age, shows that the dorsal tracts of feathers hare merged, the feathers having dark brown centres with rufous-brown margins; the tracts on the side of the body are divided by a wide ventral space of black down; the feather tracts on the flanks are more rufous. Another example, slightly older and still more fledged, shows the last remains of the black down on the head, throat, wings, tail, thighs, and a narrow ventral line; the growth of the feathers having closed in the spaces mentioned above; the secondary-quills are just making their appearance, but the primary-quills are scarcely perceptible.

An almost adult approaching brecling-plumage has the flank feathers very definitely barred with rufous-brom and white; the white on the throat, the grey on the face, and the buff streak through the eye, very clearly defined.

Nest.-A depression in the ground, lined with a pad of dried grasses; usually in meadows, but where cover is scanty in clumps of flags, coarse regetation, ete. (Europe.)

Eggs.-Clutch, 8 to 13 ; ground-colour drab-grey, blotched and spotted with chestnut, and underlying spots of lavender-grey, chiefly at the larger encl ; surface smooth and glossy; axis 35 to $38.5 \mathrm{~mm}$., diameter 26 to 27 .

Breeding-season.-Mid-May, June (eggs also in July).

Distribution and forms.-Breeding through Europe into Western Siberia, and wintering in Africa, Arabia and India and has oceurred once in Australia and once, questionably, in New Zealand. The races are, at present, undetermined, but it is certain such occur, and consequently we are using the name Buller gave to a Neozelanic (?) specimen, but if the record is proved bad, the name may not be ralid. All the eastem specimens available appear to be more boldly marked abore and with the flanks more boldly barred with darker colour; the plumages are not well understoorl, as some birds have pure grey edgings to the feathers of the upper-surface and the breast grey; such birds hare been secured both in the winter and in the breeding-season.

\section{Genus PORZANA.}

Porzana Vieillot, Analyse nouv. Ornith., p. 61, April 14th, 1816. Typo (by monotypy): "Marouette Buffon" = Rallus porzana Linné.

Mustelirallus Bonaparte Comptes Rendus Acnd. Sci. Paris, Vol, XIIII., p. 599, Sept. 1856. Type (by monotypy) : Rallus albicollis Vieillot.

Galeotimnas Heine und Reichenow, Nomencl. Mus, Hein., p. 320, (pref. Sept.) 1890. New name for Mustelirallus Bonaparte.

Smallest Rails with stout bills, short wings, short wedge tail and short legs and long toes. The bill is short, deep at the base, laterally strongly compresied, even 
more than preceding; the culmen ridge narrow, a little swollen but not expanded at fore-head where it meets with a semicircular base; other characters of bill as in Tomirdus, but interramal space much narrower and gonys slightly less, an indistinct groove along the sides of the lower mandible reaching to the gonys. The wing is short, but strong for this group, the first primary comparatively long, but still shorter than seventh, the second, however, almost the longest, equalling or exceeding the third, the others successively little shorter; inner secondaries long and pointed. The tail is composed of twelve rather narrow pointed feathers forming a wedge and less than half the length of the wing and not twice the length of the bill; the tarsus is short and strong, though laterally compressed and scutellated in front and behind ; the toes are long, the inner with the claw equal to the middle toe but shorter than the outer; the hind-toe long.

Coloration brownish above with white spotting, leaden-grey below, flanks and abdomen barred with white,

\section{Porzana fluminea.-SPOTTED CRAKE.}

Gould, Vol. VI., pl. 79 (pt. x.), March 1st, 1843. Mathews, Vol. I., pt. 4, pl. 51, Aug. 9th, 1911.

Porzana fuminea Gould, Proc. Zool. Soc. (Lond.), 1842, p. 139, Feb. 1843 : New South Wales. Rallus novchollandice Pucheran, Revue Mag. Zool., p. 278, for June 1851 (July) : ex Cuvier MS., New South Wales (Peron and Lesueur Coll.).

Porzana fluminea whitei Mathews, Austral Av. Rec., Vol. I., pt. 3, p. 73, June 28th, 1912 : Eyre's Peninsula, South Australia.

Distribution.--Queensland, New South Wales, Victoria, Tasmania, South Australia, South-west Australia.

Adult male.-General colour above olive-brown, the feathers centred with black mostly concealed, and thickly spotted with white on the mantle and strealied with white on the lower back and rump; all the white markings edged with a narrow line of black; upper tail-coverts also olive-brown, with concealed black centres to the feathers, which have small white spots on either web; wing-coverts for the most part uniform olive-brown, the median and greater coverts with white spots, each of which is margined with black; quills brown, the first primary with a few linear spots of white on the outer web, which is less indicated on the others; inner secondaries spotted with white, the innermost blackish down the centre and more profusely spotted with white, like the adjoining greater coverts; tail-feathers olive-brown, centred with black and spotted or edged with white; crown of head like the back, the white spots being very small and nearly obsolete on the mantle; base of fore-head, sides of crown, sides of face and ear-coverts leaden-grey, the latter washed with olive-brown, and speckled with tiny white spots; lores black; feathers in front of the eye, as well as the fore-part of the cheeks, grey; throat, fore-neck and entire breast leaden-grey; centre of abdomen whitish, barred with grey; under tail-corerts black, lateral ones white; sides of body and flanks distinctly barred with white and black, the black bars being somewhat the broader; axillaries blackish, barred with white, and resembling the flanks; under wing-coverts dusky-brown barred with whitish; quills dull ashy-brown below; bill olive-green, orange-red at the base; feet dark olive-green. Total length $172 \mathrm{~mm}$.; culmen 20, wing 93 , tail 37, tarsus 27.

Adult female.-Similar to the adult male.

Immature.--Upper-surface similar to that of the adult, but the back browner with buff edges to the feathers; lores, sides of face and all under-surface paler with white tips to the feathers; sides of chest washed with brownish; abdomen and flanks feathers with less distinct brownish bars and tips; iris dark yellow; feet pale green; bill pale green.

Nestling.-Appears to be undescribed. 
Nest.-Composed of grass, dry and green intermixed, placed above waterlevel, in a bush growing in the water of a lake or swamp.

Eggs.-Five; the ground-colour is of a light olive-brown, with dark reddishbrown spots, more plentiful at the larger end, but not forming a distinct ring, some of the marking appear as if beneath the surface. At the larger end there are, in each egg, a few round, almost black spots. Measurements 31 by $23 \mathrm{~mm}$.

Breeding-season.-August to December.

Distribution and forms. - Southern Australia only. Two subspecies have been separated: P.f. fluminea Gould from New South Wales, Victoria and Tasmania ; and P.f. whitei Mathews from Eyre's Peninsula, South Australia and South-west Australia, a paler race noticeably on the under-surface.

\section{Genus ZAPORNIA.}

Zapornia Stephens, in Shaw's Gen. Zool., Vol. XII., pt. I., p. 230, 1824. Type (by monotypy): Z. pusilla $=$ Rallus parvus Scopoli.

Zaporina Forster, Synopt. Cat. Brit. Birds, pp. 27, 59, Dec. 1817: Nom. nudum.

Phalaridion Kaup, Skizz. Entwick.-Gesch. Nat. Syst., p. 173, (pref. April) 1829. Type (by subsequent designation Gray, Gen. Birds, Vol. III., p. 593, Nov. 1816) : 0. minuta = Rallus parvus Scopoli.

Rallites Pucheran, Rev. Zool., 1845, p. 277 (for Aug., publ, in Sept.). Type (by subsequent designation): $R$. parvus Scopoli.

Small Rails with slender bills, short wings, short tail and weak legs and long toes. The bill is shorter and much more slender than that of Porzanr, the under mandible weaker, the gonys less marked; the upper not much swollen at base of culmen ridge but more laterally compressed. The wing is short and more rounded, the first primary short, the second equal to the fifth, the third and fourth longest, the inner secondaries long. The tail similarly formed is longer, being more than half the length of the wing. The legs are slender and the toes thinner and longer, the hind-toe very long; claws very long.

Coloration like the preceding generally but paler.

\section{I37. Zapornia pusilla.-LITTLE CRAKE.}

[Rallus pusillus Pallas, Reise Russ. Reichs, Vol. III., p. 700, (pref, 10th Feb., O.S.) 1776. Dauria, Siberia. Extra-limital.]

Gould, Vol, VI., pl. 80 (pt. x.), March 1st, 1843. Mathews, Vol. I., pt. 4, pl. 52, Aug. 9th 1911 .

Porzana palustris Gould, Proc. Zool. Soc. (Lond.), 1842, p. 139, Feb. 1843 : Tasmania.

Porzana pusilla fitroyi Mathews, Austral Av. Rec., Vol. I., pt. 3, p. 73, June 28th, 1912 : Derby, North-west Australia.

Distributron.-Australia generally (?) and Tasmania.

Adult male.-General colour above tawny-brown, duller on the head, which is mottled or spotted, with black centres to the feathers, more sparsely on the nape and hind-neck ; mantle and back black, as well as the scapulars, the feathers mostly edged with tawny-brown or white, and having subterminal spots or streaks of white, producing a freckled appearance; upper tail-coverts and tail-feathers tawny-brown, with black centres and white spots or bars; wing-coverts tawny-brown, the greater series with white, black-edged spots or bars near the ends; bastard-wing brown, with white on the outer margin; primary-coverts and quills dark brown, the first primary edged with white; the long inner secondaries black, with tawny-brown borders and broken bars of white ; eyebrow, sides of face and sides of neck, slate-grey, becoming paler on the chin, throat and middle of breast and abdomen; sides of body and flanks, and under tail-coverts regularly barred with black and white; thighs uniform slaty-grey, paler internally; under wing-coverts dusky-brown, with 
brow white margins; axillaries dusky-brown with a few white bars; bill and feet olive-brown. Total length $158 \mathrm{~mm}$.; culmen 15 to 17 , wing 86 (varies from 77 to 88 ), tail 45 , tarsus 25 .

Adult female.-Similar to adult male.

Immature.-Differs from the adult in having the bars on the sides of the body not so sharply defined, and more or less mixed with the tamy colour of the uppersurface, which also pervades the sides of the breast, which is white like the undersurface.

Nestling.-Covered with greenish-black down.

Nest.-Slightly concave on top; composed of portions of small round or flat (according to the species) rushes or other aquatic plants, and concealed in rushes etc., in shallow water or on the mud of swamps. Dimensions over all, about $4 \mathrm{in}$. by 6 in. in height; egg cavity, about 1 in. deep. There are usually two small (back and front) entrances to the nest, through the clump of herbage containing the nest.

Eggs.-Clutch, four to eight; oval in shape; texture of shell fine; surface glossy; colour brownish-olive, fairly but faintly mottled over the whole surface with a darker shade of the same colour. Dimensions 25-28 mm. by 19-20.

Breeding-season,-Cctober to January.

Distribution and forms.-Central and southern Europe and northem Africa, wintering in Africa but local races also occurring there, across Asia to Japan wintering southwards, and through Australia to New Zealand where it is stationary. The northern forms have not been accurately determined, the western being accepted as Z. p. intermedia (Hermann) by its darker coloration and the lack of the brown loral streak; the southern Australinn race Z. p. palustris (Gould) is a darker form throughout, also with no loral stripe; Z. p. fitzroyi (Mathews) is a little larger with a stouter bill and a little paler coloration; and Z. p. affinis (Gray) from New Zealand, is larger and darker, and without the white on the primaries.

\section{Genus PORZANOIDEA.}

Porzanoidea Mathews, Austral Av. Rec., Vol. I., pt. 5, p. 117, Dec. 28th, 1912. Type (by original designation): Gallinula immaculata Swainson.

Gallinula Swainson, Classif. Birds, Vol. II., p. 358, July 1st, 1837. Type (by subsequent designation, Mathews, Check List, p. 15, 1920): G. immaculata Swainson.

Not of Brisson, Ornith., Vol. VI., p. 2, 1760.

Small Roils with medium bills, short wings, shrort tail and short legs and long toes. The bill is like that of Zapomia, but the base of the cuimen has no distinet line of demareation from the fore-head and the hend seems flatter; the gonys is well marked but not angulated. The wing is short and rounded, the first primary shorter than the second which is a little shorter than the third which is longest, the fourth little Jess, but the fifth less than the second; the inner seendaries long, hut comparatively, for this series, short. The tail is short, but js rounded, composed of twelve broad soft feathers, and is Innger than half the wing. The legs are medium, the tarsus longer than the culmen and alsolonger than the micldle toe: it is scutellated back and front; the middle toe is longest, the outer longer than the inner, with the hind-toe very long.

Coloration dark brown above, head and under-surface dark leaden-grey.

\section{Porzanoidea plumbea.-SPOTLESS CRAKE.}

[Crex plumbea "Gray" Griffith and Pidgeon, Anim. Kingd., Cuvier, Vol. VIII., p. 410, " $1829 "=1830$. No loc. = New Zealand. Extre-limital.]

Gould, Vol. VI., pl. 82 (pt. Xxrv.), Sept. 1st, 1846. Mathews, Vol. I., pt. 4, pl. 53, Aug. 9th, 1911. 
Gallinula immaculata Swainson, Anim. in Menag., p. 337, Dec. 31st, 1837 : Tasmania.

Porzana plumbea roberti Mathews, Nov. Zool., Vol. XVIII., p. 446, Jan. 31 st, 1912 : South west Australia.

Porzanoidea plumbea campbelli Mathews, Austral Av. Rec., Vol. II., pt, 5, p. 85, Sept. 24th, 1914: Botany Swarnps, New South Wales.

Distribution.-New South Walos, Victoria, Tasmania, South and South-west Australia.

Adult male.-Colour above chocolate-brown; wing-corerts like the back, the greater series dull sepia-brown, externally chocolate-brown; bastard-wing sepiabrown, with white margins to the outer feathers; the primary-coverts and quills sepia-brown, the first primary edged with white, the imner secondaries blackish, margined with chocolate-brown; upper tail-coverts and tail blackikh. slightly washed with chocolate-brown; top of the head and hind-neck slaty-black; lores, sides of face, sides of neck and entire under-surface of body dark leaden-grey, a little paler on the throat; under tail-coverts black, with a few twin spots or bars of white; axillaries ashy-brown with narrow whitish ends; under wing-coverts dusky-grey, more or less intermixed with white; quills dusky-brown below; bill black ; eye and evelash red ; feet dull briek-red. Total length $181 \mathrm{~mm}$. ; culmen 20 , wing 82 (varies from 80 to 91 ), tail 50 , tarsus 26.

Adult female.-Similar to the adult male.

Nestling.-Corered with greenish-black down.

Immature.-An apparently immature bird from Tasmania is not so chocolatebrown above; slightly darlier underneath, with the throat uniform with the brea-t. Bill and iris black; legs and feet light brown.

Nest.-Composed of dry grass, placed on the ground under the shelter of a clump of rushes or band-grass, in the proximity of water.

Eggs.-Clutch, three or four; ground-colour stone, covered all orer with brown and lavender markings; $30 \mathrm{~mm}$. by 22 .

Breeding-season.-August to January.

Distribution and forms.-Through Australia, New Zealand, the Kermadees and Niew Caledonia; replaced in the Pacific by other species. Six subspecies are named, as follows: P.p.plumbea (Griffith and Pidgeon) from New Zealand ; P. p. immaculita (Swainson) from Tasmania, with shorter bill and tarsus and brighter upper coloration with secondaries short; $P$. p. roberti (Nathews) from South-went Australia with a maler chestnut back and clarker head: $P . p$. camplelli Hathews from New South Wales, smaller and paler above and below; $P$. p. oliceri Mathews and Iredale from the Kermadee Islands, with darker back and short wing-corerts; and $P . p$. calcdonica (Brasil) from New Caledonia, with a short wing $(75 \mathrm{~mm}$.) and short tarsus $25 \mathrm{~mm}$.).

\section{Genus POLIOLIMNAS.}

Poliolimnas Sharpe, Bull. Brit. Ornith. Club, Vol. I., p. ¿xvirr, Jan, 26th, 1893. Type (by original designation): Porphyrio cinereus Vieillot.

Small Rails with long stout bills, short wings, short tails, and long legs and feet. Tho bill is laterally compressed as in the preceding, but is stouter and not so pointed ; the culmen ridge is a little broader and more arched, thus while the depth at base is less than half the length of the bill, the depth at the gonys is not nuch less; the culmen base broadens out and the feathers of the fore-head form a projecting semicircle, quite unlike the bases of the culmen in the preceding genera ; the lower manclible is deep, the rami strong, the gonys marked, the interramal race anteriorly unfeathered where a small process can be seen; the nasal apertures are linear and pervious as usitual, but only little more than half the length and more open. The wing is short and rounded, the first primary short, the second, third, fourth, and fifth subequal, the inner secondaries very little less. The legk are long, the tibia being exposed for 
more than one-third the length of the tarsus and regularly scutellated in front and behind like the tarsus; the toes are long; the middle toe longest equal to the tarsus, and the hind-toe is very long.

Coloration brown above with a grey head, white eyebrow, and white below.

\section{I39. Poliolimnas cinereus.-WHITE-BROWED CRAKE.}

¡Porphyrio cinereus Vieillot, Nouv. Dict. d'Hist. Nat., Vol. XXVIII., p. 29, early 1819 : Loc. unknown = Java. Extra-limital.]

Gould, Vol. VI., pl. 81 (pt. xxvur.), Sept, 1st, 1847. Mathews, Vol. I., pt. 4, pl. 54, Aug. 9 th, 1911.

Porzana leucophrys Gould, Proc. Zool. Soc. (Lond.), 1847, p. 33, April 27th : Port Essington, Northern 'Territory.

Porzana cinerea parryi Mathews, Austral Av. Rec., Vol. I., pt. 3, p. 73, June 28th, 1912 : Parry's Creek, North-west Australia.

Drstributron.-North-west Australia, Northern Territory, North Queensland.

Adult male.-General colour above clark brown mottled with black, the centres: of the feathers being blackish with light olive-brown margins, the blackish centres being indistinct on the mantle, but very distinct on the back and scapulars, less pronounced on the lower back, rump and upper tail-coverts, which become browner; wing-coverts olive-brown; bastard-wing, primary-coterts and quills dark sepiabrown, the first primary margined with hoary-white; the immermost secondarie: resembling the scapulars, being blackish, edged with light rufous-brown; tailfeathers dark brown; cromn of head almost blackish in appearance, and slightly washed with olive-lrown on the nape; lores and feathers around the eye black, with a small supraloral spot of white extending over the fore-part of the eye ; throat white, extending in a line below the eye and above the ear-coverts, which are grey, like the sides of the neck and upper-breast; abdomen white; the lower flanks and under tail-coverts sandy-buff ; thighs intemally whitish, externally brown; axillaries smoky-brown; under wing-coverts grey, with paler tips, lower primary-coverts and under-surface of quills dusky-browis; bill red at base, distal half olive-yellow; feet olire-yellow, the tarsus olive-green ; iris red; eyelid red. Total length $184 \mathrm{~mm}$.; culmen 22 , wing 95 , tail 48 , tarsus 33 .

Adult female.-Similar to the adult male.

Young.-The young differ from the adult in having only an indication of the marks on the face, in having the crown of the head brown instead of bromnish-black, and the sides of the neck and flanks deep buff instead of grey.

Nestling.-Appears to be undescribed.

Nest.-Made of rushes or coarse herbage, lined with grass, and situated among swampy vegetation.

Eggs.-Vary from four to six in number; are oval or rounded in form, the shell being elose-grained, smooth and slightly lustrous. The ground-colour varies from a dull greenish-white to a light yellowish-clay shade, which is almost obscured by innumerable fleecr markings, varying from jellowish-brown to dull chestnutbrown. As a rule the markings are fairly even in size and clistributed over the entire surface; in others they are intermingled with a few large confluent patches; while in some they are larger and predominate chiefly on the thicker end. Measurements 27-28 mm. by 21-22.

Breeding-season.-January to May.

Distribution and form.s.-From the Philippine Islands to North Australia and the Pacifie Islands; Collingwood Ingram in 1911 admitted fire races, Brasil has since added a sixth, and Mathews a seventh. These are as follows: $P$. c cincreus (Vieillot) from Jara; $P$. c. leucophrys (Gould) from Port Essington, Northern Territory, with an almost black head and dark brown upper coloration, darker below 
and short secondaries; P. c. parryi (Mathews) from North-west Australia, still darker as to head, back, thighs and under tail-coverts; P. c. brevipes (Ingram) from the Bonin Group, with lower flanks and under tail-coverts more rufous, lower back more ruddy, a deeper bill and smaller feet, tarsus $32 \mathrm{~mm}$., middle toe $33 \mathrm{~mm}$. against typical tarsus $36 \mathrm{~mm}$., middle toe $39 \mathrm{~mm}$.; P. c. ocularis (Ingram) from the Philippines, especially on the head, purer olive-black and grey neck and greyer breast; P.c.tannensis (Forster) for birds from Fiji and Samoa, with more rudky back and with little grey wash on head and none on neck; and $P$. c. ingrami Brasil from New Caledonia, with a small delicate bill, culmen $19 \mathrm{~mm}$. long by $7 \mathrm{~mm}$. high, against the preceding 22.5 by $8.5 \mathrm{~mm}$.

\section{Fanily GALLINULIDE.}

Nearly allied to Rallide, but comprising forms developing frontal shields and more or less swimming habits. Probably comprising most extinct semi-flightless "Rails." A semi-flightlesis form, Tribony. $x$, native of Tasmania, is obviously only a degenerate island form of the mainland Hicrotribonyx, which is just as surely the unchanged representative of the well distributed Gallinula, the immature of the last named showing the bill coloration of Tribonyx. That genus has left the water and is more a land bird and the toes are comparatively short, while in the swimming Gallinula the toes are long. The mainland Ificrotribomy is also a land bird and the sequence seems exactly parallel to that of many other Australian birds. In the times when Australia and Tasmania were joined, the ancestral form of Gallinula arrived and populated the country; then Tasmania was severed and Tribonyx evolved through isolation and indolence; on the continent Hicrotribonyx developed but competition allowed it no rest to induce flightlessness; at a later period the stronger, more powerfully constructed Gallinula arrived to oust the stationary Nicrotribony. $x$ which it has not yet done, and thus we have a tableau of the struggle for existence in present view. In New Zealand we see a further stage in the present almost extinction of Mantellornis, a parallel case with the Australian Porphyrio. Many extinet forms have followed the same course.

\section{Genus AMAURORNIS.}

Amaurornis Reichenbach, Nat. Syst. Vögel, p. xxI., 1852 (? 1853). Type (by original designation): Gallinula oliracea Meyen.

Small Moorhens with long stout bill with small frontal plate, short wings, short tails and long legs with short (for this group) toes.

The bill agrees in detail with that of Tomirdus, save that it is a little larger and stronger and has developed a frontal plate at the base of the cuimen. In this genus this is scarcely seen until the bird is adult. The wing is short and rounded, the feathers strong, the first primary short, the second and fifth subequal and little less than the third and fourth which are longest; the inner secondaries are long. The tail is short and rounded, much less than half the length of the wing, the feathers broad and soft. The legs are long, the tibia unfeathered for about one-third the length of the tarsus, and like that, scutellated in front and behind; the toes are long but less than the tarsus in length; hind-toe very long and lateral membranes to toes little developed.

Coloration brown above, slaty-grey below, under tail-coverts rufous.

\section{40. Amaurornis moluccanus.-RUFOUS-TAILED MOORHEN.}

[Porzana moluccana Wallace, Proc. Zool. Soc. (Lond.), 1865, p. 480, Oct. 1st: Amboyna. Extra-limital.]

Gould, Suppl., pl, 79 (pt. v.), Aug. 1st, 1869. Mathews, Vol. I., pt. 4, pl. 58, Aug. 9th, 1911. 
Gallinula ruficrissa Gould, Birds Austr. Suppl., pt. v. (pl. 79), Aug. 1st, and Ann. Mag. Nat. Hist., Ser. IV., Vol. IV., p. 110, Aug. 1st, 1869 : Cape River, Queensland.

Gallinula moluccana yorki Mathews, Austral Av. Roc., Vol. I., pt. 8, p. I94, March 20th, 1913 : Cape York, Queensland.

Distribution.-North Queensland, Northern Territory.

Adult -Hearl, hind-neck and mantle olive-brown, becoming chocolate-brown on the scapulars, back, upper tail-coverts and tail; wing-coverts like the back, somewhat more chestnut-brown on the greater coverts, which resemble the inner secondaries; bastard-wing, primary-coverts and quills dark brown, somewhat paler on the outer webs; lores and sides of head and ear-coverts dull slaty-grey, lighter on the cheeks and inclining to greyish-white on the chin and upper throat; lower throat, breast and abdomen darker slaty-grey, slightly washed with olive on the fore-neck; sides of body entirely olive-brown; lower-abdomen vinous-isabelline ; a patch of feathers on each side of the vent, thighs and under tail-coverts vinouschestnut; under wing-corerts and axillaries dark sepia-brown ; quills dusky-brown below; bill green, frontal shield orange ; iris reddish-brown ; feet yellow. Total length $213 \mathrm{~mm}$.; culmen, including frontal shicld, 30, wing 143, tail 56, tarsus 56 .

Immalure.-A little paler than the adult above and below, the throat whitish, the under tail-coverts paler, the frontal plate not developed; bill green, iris dark brown, feet yellowish-brown.

Neslling.-Appears to be unknown.

Nest.-Composed of coarse grass and other herbage; $3 \frac{1}{3}$ inches in breadth.

Eggs.-Clutch, four to six; colour creamy-white, with rust-brown spots and blotches, and underlying spots of lilac-grey over the entire surface, more thickly at the larger end ; axis $41 \mathrm{~mm}$., diameter 29.

Breeding-season,-January.

Distribution and form. - Through the Moluecas, New Guinea to New Britain and Northern Australia. Subspecies not aceurately determined but Australian form well marked by means of smaller bill and legs and warmer coloration of the upper-surface. Schlegel deseribed a uniform bird from umbnown locality received via N.E. New Guinea as Gallinula frankii, which may he ajplicable to this species. Mlathews named the Cape York form $G, m$. yorki as being altogether paler than Gould's Cape River bird. Recently the species has been recorderl from the Northein Territory, but we have seen no specimens.

\section{Genus GAILINULA.}

Gallinula Brisson, Ornith., Vol. I., p. 54, Vol, VI, p. 2, 1760. Type (by tautonymy): Gallinula $=$ Fulica chloropus Linné.

Hydrogallina Lacepède, Tabl. Ois., p. 19, Dec. 1799. Species added by Daudin in Hist. Nat. (Buffon) ed. Didot, Quadr., Vol. XIV., p. 336 [1799] = (Oct.) 1802. Type (by subsequent designation, Mathews, List, p. 27, 1913): F. chloropus Linné.

Stagnicola Brehm, Vögel Deutschl., p. 702, 1831 (pref. July). Type (by subsequent designa. tion, Mathews, List, p. 27, 1913): $F$. chloropus.

Large MLorhens with long stout bill with well-cleveloped frontal shield, long wings, short tail, long legs and very long toes.

The bill similar to that of the preceding but a little more slender with a horny plate extending backwards and covering the fore-heal; the nostrils longer and gonys less marked; the nasal apertures linear and long, and pervious as usual. The wing long, the feathers strong, the first primary long and equal to the sixth, the second and third longest, the former generally exeeeding the latter; inner secondaries very short. The tail is short and little rounded, composed of twelve broad feathers and only about one-third the length of the wing. The legs are long and stout, a short exposed tibia seutellated behind but reticulated like the joint in front; the tarsus is covered with broad scutes in front and rarious size scales on 
the sides and back. The toes are very long with lateral membranes, the middle twe longest and exceeding the tarsus in length; the outer and inner subequal; toes very long and thin; hind-toe long.

Coloration : olive-brown back ; dark leaden-grey head and under-surface ; lateral under tail-coverts white.

\section{4 I. Gallinula tenebrosa.-BLACK MOORHEN.}

Gould, Vol. VI., pl. 73 (pt. xxmI.), March 1st, 1846. Mathew8, Vol. I., pt. 4, pl. 57, Aug. 9th, 1911.

Gallinula tenebrosa Gould, Birds Austr., pt. xxm., March 1st, 1846 : South Australia. Gallimula tenebrosa magnirosiris Mathews, Nov. Zool., Vol. XVIII., p. 195, Jan. 31st, 1912 : Guilford, West Australia.

Gallinula tenebrosa subfrontata Mathers, $i b$.: Richmond River, New South Wales.

Distributron.-Queensland, Now South Wales, Victoria, South and West Australia. Not Tasmania.

Adult male.-General colour dark slate-grey, including the head, hind-neck and under-surface, becoming paler on the lower-abdomen ; entire back and scapulars tinged with brown; wing-coverts dark slate-grey; bastard-wing, primary-coverts and quills black; tail-feathers black, more or less fringed with brown on the outer webs; central under tail-corerts black, the lateral ones white; bill, frontal plate orange, base blood-red, tip greenish-yellow, above the knee a garter of yellow and scarlet; joints of legs and feet olive; sides of tarsi and frontal plates of toes yellow; iris olive. Total length $360 \mathrm{~mm}$.; culmen, including frontal shield, 47, wing 220 , tail 80 , tarsus 65 .

Adult female. - Similar to the adult male.

Immature male.-Similar to the adult female but having the under-surface paler with white margins to the feathers, most conspicuously on the chin and lowerabdomen; a line round the bend of the wing white, as also the outer edge of the first primary; bill mottled green and horn in male; mottled green and black (lower base green), frontal plate black in female; legs, ô olive-green, + grass-green.

Nesiling in down.-Greenish-black above, sooty-black below, with white hair-like tips to the down on the chin and throat, the skin of the top of the head shining bluish through the scant down; bright red frontal plate.

Nest.-Slightly concave on the top, composed of dead flags or rushes, sometimes with twigs added; lined with the paper-like bark of tea-tree (Melaleuca), and placed in water among rushes, etc., or at the base of tea-trees. Dimensions over all, about 12 inches; height (from the water) about 12 inches.

Eggs.-Clutch, seven to ten; smooth and glossy; ground-colour buff; blotched and spotted with purplish-brown over the entire surface; axis 53 to $54 \mathrm{~mm}$., diameter 36.

Breeding-season.-November to January.

Distribution and forms.-Australia only. Three subspecies have been distinguished as follows: G. $t$. tenebrosa Gould, from South Australia, Victoria and southern New South Wales; G. t. magnirostris Nathews, from South-western Australia with a notably larger bill; and $G$. $t$. subfrontuta Hathew, from northem New South Trales and southern Queensland, a smaller form in every dimension.

\section{Genus MICROTRIBONYX.}

Microtribonyx Sharpe, Bull. Brit, Ornith. Club, Vol. I., p. xxIx, Jan. 26th, 1893. Type (by original designation): Gallinula ventralis Gould.

Large Moorhens with short, very stout, bills, long wings, short square tail and long legs and short toes. 
The bill is short, and rery deep, at base of culmen the depth is more than half the length; the bill is laterally compressed but the culmen ridge widens out at base into an indistinct frontal plate, not covering the fore-head; the nostrils are as in the preceding, linear pervious apertures placed at the anterior portion of the nasal groove and lying along the edge of the mandible; the tip is not decurved while the lower mandible is very strong and deep, the gonys ill defined and not at all angular, the interramal space being shallow and almost completely feathered. The wings are long, the first primary long, almost equal to the fourth, longer than the fifth, the second and third subequal and longest; inner secondaries short. The tail is square and less than half the length of the wing, composed of sixteen broad strong feathers, the outer two on each side a little shorter than the others. The legs are long, the tibia exposed for nearly half the length of the tarsus, reticulate in front, scutellate behind; large plates horizontally placed cover the front of the tarsus, the back having similar smaller plates, the sicles with a narrow row of seutes between. The toes are shorter than the tarsus, the middle toe longest, the outer longer than the inner, the hind-toe long, but comparatively short.

Coloration olive-green above, leaden-grey below; tail black.

\section{Microtribonyx ventralis.-BLACK-TAILED WATER HEN.}

Gould, Vol. VI., pl. 72 (pt. xx.), Sept. 1st, 1845. Mathews, Vol. I., pt. 4, pl. 56, Aug. 9th, 1911.

Gallinula ventralis Gould, Proc. Zool. Soc. (Lond.), 1836, p. 85, Jan. 16th, 1837 : Swan River, West Australia.

Tribonyx ventralis whitei Mathews, Nov. Zool, Vol. XVIII., p. 194, Jan. 31st, 1912 : Nevertire, New South Wales.

Tribonyx ventralis territorii Mathews ib., p. 195: Alexandra, Northern Territory.

Distribution.-Australia generally. Not Tasmania.

Adult male,--Olive-grey above, including the head, hind-neck, sides of neck, back and upper tail-coverts; wing-coverts olive-brown; bastard-wing, primarycoverts and quills blackish, olive-brown on the outer webs; outer web of first primary edged with white; tail-feathers black, fringed with olive-brown on the outer webs; chin, lores and cheeks black; lower throat, fore-neck and breast dark slate-gref, which extends on to the sides of the body; middle of abdomen and under tailcoverts black, axillaries and lower flanks brown; long flank plumes black with white pear-shaped spots at the tips; under wing-coverts dusky with subterminal black bars and white tips; bill apple-green, base of lower mandible orange ; iris deep yellow; tarii and feet coral pink. Total length 340 ; culmen, including frontal shield, 32 , wing 221 , tail 85 , tarsus 56 .

Adult female.-Very similar to the adult male but smaller, and differs in having the flank plumes grey instead of black, and the wing-coverts paler. Total length $309 \mathrm{~mm}$; ; culmen, including frontal shield, 28, wing 194, tail 73, tarsus 59.

Immature.-Similar to adult.

Nestling in down.-Wholly greenish-black; bill coloured as in adult.

Nest.-Open, eonstructed of grass, and placed on the ground among bushes, such as polygonums, etc., in a swamp situation.

Eggs.-Clutch, five to seven; smooth and glossy in texture; ground-colour pale green, minutely spotted over the entire surface with brown dots, with a few large, bold blotehes of chestnut-brown, as well as paler underlying spots of a lavender-grey; axis 43 to $46 \mathrm{~mm}$., diameter 29 to 32 .

Breeding-season. - October to January or February; July and August.

Distribution and forms.- Confined to Australia. Three forms have been named, but on account of sporadic movements due to drought subspecies probably 
indefinable; these are: $M . v$. ventralis (Gould) from West Australia; $M . v$, whitei (1Lathews) from Eastern Australia, smaller and browner with a more slender bill; and $M, v$. territorii (Mathews) from Northern Territory, a still browner form.

\section{Genus TRIBONYX.}

Tribonyx Du Bus, Bull. Acad. Roy. Sci. Brux, Vol. VII, No. 4, April, p. 212, May 1840. Type (by monotypy): Tribonyx mortierii Du Bus.

Brachyptrallus La Fresnaye, Revue Zool, Aug. 1840, p. 231, Sept. Type (by monotypy) : $B$. ralloides La Fres. = T. mortierii Du Bus.

A degenerate form of the preceding, the whole bird of much heavier build, the bill larger, stouter, the nostrils more open, the frontal plate better indicated. The wing is absolutely shorter, and much more rounded, the first primary still long but scarcely longer than the tenth, while the second to the seventh are almost all the same length; the inner secondaries longer and the coverts disintegrated and encroaching over the secondaries. The tail longer, over half the length of the wing and is composed of sixteen very broad square-tipped feathers, a little softer than in the preceding, and the two outer feathers on each side shorter than the others, but otherwise the tail is quite square. The legs are long and very stout; the tibia only exposed for a very little bit: the front of the tarsus covered with horizontal scutes, the hind edge with a similar indefinite row while the sides are reticulated with three or four rows of small hexagonal scales; the toes are very stout, the middle toe little shorter than the tarsus and longer than the outer and inner, the former exceeding the latter; the hind-toe is short and stout.

Coloration the same as the preceding.

These are obviously degenerate Moorhens, the island form being related to the mainland one exactly as Mantcllornis is to Porphyrio; the same processes appear to have been followed in exactly the same way; the isolated form growing larger and stouter, the wings rounder and flightless, the tail-feathers broader and softer, the legs shorter and stouter, and the toes stouter, the hind-toe also shortening and thickening; all these changes taking place in the structural features and being accompanied by similar alterations internally while the coloration has remained unchanged.

\section{Tribonyx mortierii.-NATIVE HEN.}

Gould, Vol. VI., pl. 71 (pt. xxxi.), June 1st, 1848. Mathews, Vol. I., pt. 4, pl. 55, Aug. 9th, 1911.

Tribonyx mortierii Du Bus, Bull. Acad. Roy. Sci. Brux., Vol. VII., No. 4, April, p. 214 and pl., Hay 1840: Nouvelle Hollande = Tasmania.

Brachyptrallus ralloides La Fresnaye, Revue Zool., Aug. 1840, p. 231, Sept.: Tasmania.

Tribonyx gouldi Sclater, Ann. Mag. Nat. Hist., Ser. III., Vol. XX., p. 123, Aug. Ist, 1867 : Tasmania.

Distribution.-Tasmania.

Adult male-General colour above warm brown, includng the head, hind-neek, back, upper tail-coverts, scapulars and innermost secondaries; lesser wing-coverts slate-grey; bastard-wing black, with pale outer webs and white tips; quills black with pale edges, the two outer primaries fringed with white at the tips; tail-feathers black, with brown on the outer webs; lores and feathers behind the eye and forepart of cheeks brown, like the head, but slightly paler; throat, fore-neck and breast slate colour; a tuft of black feathers, with broad white tips, on the sides of the body, giving the appearance of a lateral white patch; lower flanks and thighs grey; minutely tipped with white; middle of abdomen black, with minute white tips to the feathers; under tail-coverts intense black; under wing-coverts blachish, tipped 
with white; bill yellowish-green; iris ruby; tarsi and feet yellowish. Total length $5103 \mathrm{~mm}$, ; culmen, including frontal shicld, 41, wing 187, tail 95, tarsus 78 .

Adult female.-Similar to the adult male but very slightly smaller. Total length $502 \mathrm{~mm}$; culmen 39, wing 185 , tail 95 , tarsus 77 .

Immatre male. - Is distinguished from the adult in being paler brown on the liead, grey on the himl-neck and mantle, and having the lower back washed with grey. The chief distinction is the white marks on the wing-coverts, which are pear shaped, and as the bird advances in acre, become narrow streaks, and finally disappear when the adult plumage is attaine: ; the white margins to the feathers of the lower flanks are also much more strongly pronounced.

Nestling (ten days old).-Covered with black down, with a white spot on each side of the flank; ear-coverts silver-grey.

Young (three weeks old).-Olive-brown above; tail black; head streaked with black; chin white, throat streaked with blackish and grey ; sides of the neek grey; a stripe of blackish-brown down the middle of the under-surface, on both sides of which is grey; the tuft of feathers on the side buff.

Nest.-Usually placed on the bank of a stream or lagoon. Made of tussocks pulled up by the roots and tramped down by the birds' feet, lined with soft reeds.

Eggs.-Clutch, six to nine; smooth and slightly glossy ; stone colour, minutely spotterl with chestnut over the entire surface, with bolder blotching of the same colour ami paler underlying markings, sparsely distributed ; axis $59 \mathrm{~mm}$., diameter 39 to 41 .

Breeding-season-September, October, and November.

Distribution and forms.-Confined to Tasmania and therefore no subspecies.

\section{Genus PORPHYRIO.}

Porphyrio Brisson, Ornith., Vol. I., p. 54, Vol. V., p. 522, 1760. Type (by tautonymy): Porphyrio = Fulica porphyrio Linné.

Casarornis Reichenbach, Nat. Syst. Vögel, p. xxr., 1852 (? 1853). Typo (by original designation): Gallinula poliocephala Latham.

Birls generally larger than the species of Gallinula, with a short, high, and strongly curved, compresed bill, and the frontal shield very large. Nostrils oval or rounded, pervious; no nasal groove, but a shallow depression only. Wings short and roundes: toes rery loug, the midile toe with claw exceeding the tarsus in length; no lateral membranes or lobes to the toes. The tarsus is corered with horizontal scutes in front and behind with searcely a row between on the sides; the hind-toe is long as in Gallinula; the claws are long and little curved; the tibia is exposed for nearly one-third the length of the tarsus and is scutellate in front and behind with reticulation between.

The tail is rather long, composed of twelve rather broad feathers and square, less than half the length of the rounded wings which have the second primary longest.

\section{Porphyrio melanotus.-BALD COOT.}

Gould, Vol. VI., pl. 69 (pt. $\mathrm{xxx}$ ), March 1st, 1818. Mathews, Vol. I., pt. 5, pl. 60, Oct. 31st, 1911.

Porphyrio melanotus Temminck, Manuel d'Orn, 2e ed., Vol. II., p. 701, Oct. 21st, 1820 : "Australia" = Now South Wales.

Porphyrio melanotus fletcherce Mathews, Birds Austr., Vol. I., pt. 5, p, 243, Oct. 31 st, 1911 : Tasmania.

Porphyrio melanotus neomelanotus Mathews, ib., p. 246, pl. 60: Parry's Creek, North-west Australia.

Drstributron.-Australia (except South-west) and Tasmania. 
Plate 9.
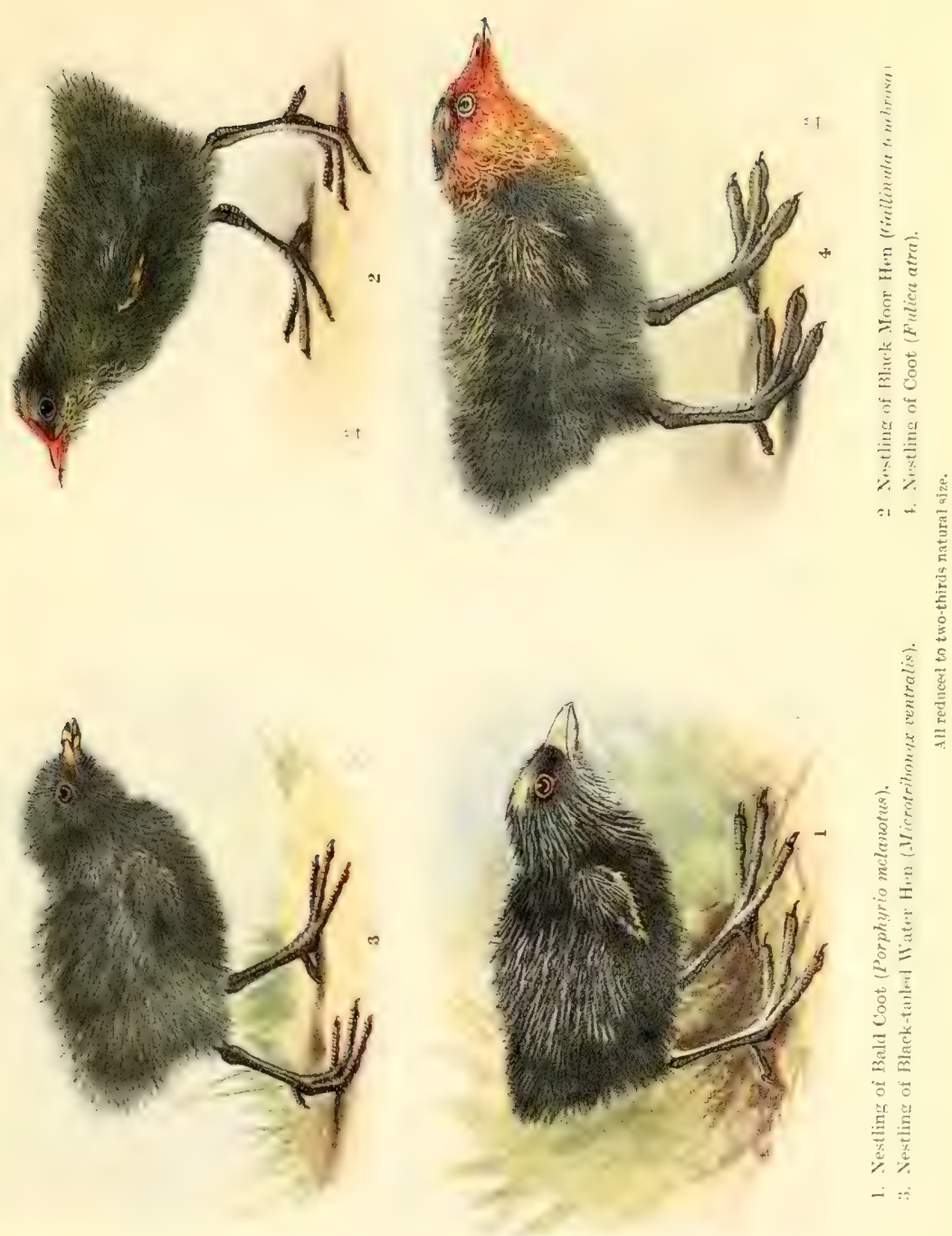

Arlult male.-Entire back, scapulars, tail, and the greater portion of the wings grcenish-black, with a slight glossy tinge; lesser wing-coverts ultramarine-blue, like the outer webs of the bastard-wing; marginal coverts, inner webs of the bastardwing. primary-coverts, and quills black; lores, fore-part of the cheeks, occiput, and himb-neek also black; hinder neek, throat, entire breast, sides of the body, under wing-coverts, and flanks purplish-blue; middle of abdomen black; under tailcoverts pure white; axillaries black, some tipped with blue; quills below glossy black; lill and frontal plate red ; iris red ; tarsi and feet dusky-red. Total length $500 \mathrm{~mm}$.; culmen and frontal plate 69 , wing 266 , tail 110 , tarsus 95 .

filull female. - Similar in colour but the plumage duller and the size smaller.

Immature--Upper-surface blackish-brown, the wing-coverts first showing the bluish colvuring, the under-surface paler brown, the chin palest, the breast dull bluish-brown, and the abdomen fulvous-brown; the under tail-coverts dirty yellowish-white; iris brown; bill brownish, reddish towards the base and the small frontal plate; legs dark reddish-brown.

Immature (younger, half-fleilged). -Upper-surface blackish-brown, the feathers edged with pale brown, the senpulars and wing-coverts showing a tinge of blue ; all under-surface pale dusky-brown, the breast feathers with pale bluish tips, the vent feathers fulvous.

Nestling in down.-Covered with dense black down, the head, neck, wings and back tipped with white lines, which are in reality sheaths of the down, and which soon fall off; bill greyish-white, black at the tip; legs dull slate-grey ; in a few days the chick is wholly black; bill, helmet and feet light red.

Nest. Bulky, carelessly built of dry and green reeds, which had been apparently crusher and softened between the bird's bill. Situated on the top of tussocks of grass, in shallow water; sometimes ten feet from the bank. Outside measurements, 14 inches from top to bottom, and sixteen inches wide; egg cavity nine by four inches.

Eggs. -Cluteh, three to five; smooth and slightly glossy ; ground-colour sandybuff, blotehed and spotted with chestnut over the entire surface, with underlying spots of lead-grey; axis $48-49 \mathrm{~mm}$., diameter 35-36. Tasmanian eggs are larger, and more boldly marked; axis 50-53.5, diameter $35-37 \mathrm{~mm}$.

Breeding-season.-August to November. (Tasmania, Victoria, etc.) January and February. (Queensland.)

Distribution and forms.-From the Moluccas through New Guinea, Australia, save the south-west, Tasmania. New Zealand, and the Chatham Islands, and apparently the western islands of the Pacific Ocean. The extra-limital forms are as usual imperfectly known, and no advance seems to have been made since Mathews's sturties in 1911, when he suggesterl investigation as below ; the Australian subspecies are three in number, but probably more will be later reeognised-these are: $P . \mathrm{m}$. melanotus Temminck from Eastern Australia; $P . m$. fletcherce Mathews, from Tanmania, a larger form with the wing measuring $310 \mathrm{~mm}$. against 275 of the typical race but showing the same coloration; and $P . m$. neomclanotus Nathews, from the North-west of Australia, about the same size as the typica! form, but with the under coloration ultramarine or cobalt rather than purple, the colour on the upper-breast and throat brighter than on the flanks and lower-breast. The Neozelanic bircl is a brighter purple below, tending to verditer on the upper-breast, and may be called $P$. $m$. slauleni lowley (the name given to an albino specimen apparently received from Now Zatand, which is famed for its albinistic specimens), and sharpe called the ('hatham Islankl form, on account of the verditer tinge all through the breast, $P$. chathamensis, but this scems to be a feature of mainland birds also at certain Erowth stage: : the Samoan form has been called $P$. samoensis, the Fijian $P$. vitiensis, the one from the I'elew Islands $P^{\prime}$. pelewensis, the form inhabiting the New Hebricles $P$. arcitunensis, and the New Guinea bird P. melanopterus, all of these appearing 
to be only subpecios of $P$. melcendus, but no long series is available, all these names having been given to ocil birds. Hartert also rangel the species westward to .Java, ete., and inclurkel all these as forms of $P$. calcus, but this cloes not seem justificit, though admittedly the matter is a difficult one.

\section{Porphyrio bellus.-BLUE BALD COOT.}

Gould, Vol. VI., pl. 70 (pt. v.), Dec. 1st, 1841. Mathews, Vol. I., pt. 5, pl. 59, Oct. 31 st, 1911. Porphyrio bellus Gould, Proe. Zool. soc. (Lond.), 1840, p. 176, July 1841 : Western Australia. Porphyrio melanotus woodwardi Mathews, Austral Av. Rec., Vol. I., pt, 2, p. 29, April 2nd, 1912 : Monger's Lake, South-west Australia.

Distribution,-South-west Australia.

Adult male.-Back, wings, and tail glossy blackish-brown; lesser wing-coverts ultramarine-blue, forming a shoukler pateh; median and greater coverts like the back; bastarl-wing, primary-coverts, and quills blackish, with biue on the outer web: ; imesmost secondaries like the back; chin, lores, fore-part of checks, crown of head, hind-neek, and sides of neek blackish; mantle purplish-blue like the lowerbreast, sides of body, and outer portion of thighs; middle of abdomen and inner portion of thighs sooty-black; throat and upper-breast verliter-blue; axillaris hlaskish, tinged with verditer-blue; lewser under wing-coverts verditer-blue, greater coverts glowsy black, like the quills below; under tail-coverts pure white; frontal plate and bill scarlet; iris red-hazel, tarsi and feet olive-green to reddish. Totial length $480 \mathrm{~mm}$; eulmen, including frontal shield, 70, wing 293 , tail 110 , tarsus, 97.

Adull female.-Similar to the adult male, slightly less, but not so brilliarify coloured.

Immature.-Does not appear to have been described.

Neslling.-Black; bill bluish, the base pink; eyes deep brown, eyelid pirk; feet brown.

Nest.-Similar to that of the Bald Coot ( $P$. melanotus).

Eggs.-Clutch, five (about); stout oval in shape; texture of shell somewhat coarse; surface glossy; colour deep stone, fairly blotched and spotted with brown and purplish-brown of different shades. Dimensions $56-58 \mathrm{~mm}$. by $40-42$.

Breeding-season.-August to November.

Distribution and forms.- Restrieted to south-west Australia and therefore no subspecies.

\section{FAMILY FULICIDAE.}

Moorhens, which have developed peculiar swimming lobes to the toes of their feet, are here segregated as of family rank, especially as their distribution is workl wide and they are of ancient origin. Thus fossil "Fulica" have been described from Mauritius and from New Zealand, and as these had also become degraded and semi-flightless, the fixity of the Coot-form is of long date.

\section{Genus FULICA.}

Fulica Linnó, Syst. Nat. 10th ed., p. 152, Jan. 1st, 1758. Type (by tautonomy) : Fulica atra Linno.

Birds like the speeies of Gallinula but differing in haring the toes lobed. Bill stout and somewhat laterally* comprewerl, shorter than the head, and with a larke frontal shield. Nostrils pervious, elongated slit in the fore-part of the na-al grons; wings short and rounded ; tarsus short, laterally compressed, provided posteriorly with a membranous fringe; tail short, only about one-fourth the length of the wing, consisting of fourteen, sometimes sixteen, reetrices; toes long, the midclle toe withunt 
lav exceeling the tarsus in length, each joint having a membranous lobe on each side, the claws, very peculiar, being long, very narrow, and rather sharply curved; the front edge of the tarsus is covered with a row of horizontal scutes, the lateral cumpression of the tarsus making the side reticulations elongate and tending to obsolete scutes as on the back.

Coloration blackish-grey above and below.

\section{I46. Fulica atra.-COOT.}

[F'ulica atra Linné, Syst. Nat., 10th ed., p. 152, Jan. 1st, 1758: Sweden, Europe. Extralimital.]

Gould, Vol, VI., pl. 74 (pt. xxIV.), Sept. 1st, 1846. Mathews, Vol. I., pt. 5, pl. 61, Oct. 31st, 1911.

Fulica a ustralis Gould, Proc. Zool. Soc. (Lond.), 1845, p. 2, April : West Australia.

Fulica tasmanica Grant, Tasm. Journ. Sci., Vol. II., p. 310, (April ?) 1815 : Tasmania.

Fulica atra ingrami Mathews, Nov. Zool., Vol. XVIII., p. 196, Jan. 31st, 1912: Alexandra, Northern Territory.

Distributron,--Australia generally and Tasmania.

Adult male,-General colour plumbeous-grey, paler and duller on the undersurface ; heal and neck all round black; bastard-wing, primary-coverti, and quills lark brown; edge of wing white at base of outer primary-quill; under tail-covert:; black, greater under wing-eovert and quill-lining slaty-grey; bill pale bluishgrey ; iris brick-red, feet steel-grey. Total length $390 \mathrm{~mm}$.; culmen and frontal shield 42, wing 187, tail 45, tarsus 55 .

Adult female.--Similar to the adult male but paler in colour, more especially on the under-surface. Total length $324 \mathrm{~mm}$, ; culmen 40, wing 191 , tail 47 , tarsus 5.5.

Immature.-The upper-surface paler grey and of a dull shade, the throat is whitish and the under-surface is much paler greyish.

Young in down are black, having yellow hair-like tips, the clown thickest about the face and neck; bill cream colour.

Nest.-Large, loose structure, composed of reeds and rushes; placed near the water. Dimensions 15 inches by 8 inches deep; egg cavity 8 by 3 deep.

Eggs.-Clutch, about six or seven ; smooth and glossy; stone colour, minutely dotted with black, evenly over the entire surface; axis $44 \mathrm{~mm}$., diameter 33.

Breeding-season.-August to February.

Distribution and forms.- Through Europe, Asia, Australia and Tasmania, the extra-limital forms not well distinguished at present. The Australian form is separable only by size from the European, the coloration being practically the rame in every detail. It is however probable that a very small difference is worthy of consideration in a genus so widely distributed as this, but sufficient material has not been collected nor studied to determine exactly the status even of the Australian-named forms. These are three in number: Fulica australis Gould from West Australia ; Fulica tasmanica Grant from Tasmania; and Fulica atra ingrami Mathews from the Northern Territory:

\section{SUBORDER PODICIPIFORMIES.}

There is only one family and not many species in this suborder which has a world-wide distribution, little variation being seen in one form ranging over the ()ld World, through Australia into New Zealand. The species are easily reeognisable hy their peeuliarly lobed feet, recalling those of the Coots, but yet different in dictail ; the borly is long anil rather slender, the feet being placed very far backward ; they have short rounled wings and no appreciable tail, a longish neck, small head and pointed bill, in one form stout and short, in another long and slencler. Many species have feather ornaments on their heads and necks cluring the breeding-season. 
Generally the Grebes have been placed distant from the Rails, but there can be little doubt that this is their correct place. The palate of the skull is schizognathous and the nasals holorhinal, and there are no basipterygoid processes. It has been written by an osteolngist that it would be diffieult to find differences in the skulls of the Grebes and Rails. The cervical vertebre are twenty-one in number, the sternum is one notched and there is no anterior spine, and the procoracoid is absent. There is only one carotid and the digestive system does not appear to huve been particularly studied, but may be similar to the Ralline style. The leg musele formula is B. , which is instructive. The oil gland is tufted, the aftersaft present and the wing aquincubital. The pterylosis has not been eomparatively ileterminel, and the swimming clowny nestling is of a peculiar striped coloration. While fosils are on record as suggestert relations of this group, as this has continually been confuner with the phylogenetically listinct group of Divers (= Colymbiformes, a suburcler of the Lari or Limicolas), it is difficult to conjoler such at present. Thus the Heperornithe from the Cretaceous of North America have been regarced as showing ancestral features of both Grebes and Divers, but such conclusions rlo not seem to have been based on sound premises, and most of the resemblances noted are simply due to similar environmental stresses.

\section{FAMUY PODICIPIDE.}

The limits are those of the order, and some workers are diffident in accepting many genera, as the ordinal form is omipresent. Howerer, both osteolngists and anatomists have recorled, aceording to their views, important items for separation, $\because o$ that distinet genera must be accepted. Thus the syrinx in Podiceps and Polioorphalus is of difierent form, while the skull shows numerous differences also. It mus be noted that the swimming habits of the Grebes have developed a stuong tibial crest; this is the most marked feature for the association of this group with the Diress, but it is so purely an alintive feature that it is difficult to understand why much stress was laid upon it with regard to phylogenetic relationship.

\section{Genus PODICEPS.}

Podiceps Latham, Gen. Synops. Suppl., Vol. I., p. 294, (pref. May 1st) 1787. Typo (by subsequent designation, Gray, p. 76, 1840): Colymbus cristatus Linné.

Colymbus Illiger, Prodr. Mamm. et Av., p. 281, (pref. April) 1811. Type (by subsequent designation, Ogilvie-Grant, Cat. Birds Brit. Mus., Vol. XXVI., p. 502, 1898): Colymbus cristalus Linné.

Not Linné, Syst. Nat., 10th ed., p. 135, Jan. 1st, 1758.

Lophaithyia Kaup, Skizz. Entwick.-Gesch. Nat. Syst., p. 72, (pref. April) 1829. Typo (by monotypy): C. cristatus Linnó.

Largest Grebes, with long straight bills, short rounded wings, rudimentary tiril and peeuliar, dlattened tar:i, and largely loberl toes with broal, flattened elaws. bill lomg, straight, and pointed, sometimes slightly curverl at the tip: nostrils pervious, and placed at the base of the upper mandible. Wings very short and roundel, the fouthers narrow and pointed, the first longent, the secondaries usually as long as the primaries. Titil rudimentary, consisting of a tuft of domy feathers, no rectrices being distingui-halble. Tarsus shorter than the middle toe and claw, compre sed so a to form a ridge anteriorly and posteriorly, where it is serrated. The: twes are flattened and surrumblet by large lobes of skin, only connected at the base, not contracted at the joints. The claws are also flattened, forming part of the lobe: the fourth toe js the longest, the hallux is small and also provided, like the others, with a lateral lobe. The anterior ridge is regularly scutellate, and the 
sides of the tarsus are similarly regularly seutcllate in double rows, the posterior edge being scutellated, the scutes projecting so as to form a serrated ridge. The feet are placed very far back in the body.

There is a full double crest in the breeding-season; general coloration above brown, below white.

\section{I47. Podiceps cristatus.-TIPPET GREBE.}

[Colymbus cristatus Linné, Syst. Nat., 10th ed., p. 135, Jan. 1st, 1758 : Sweden, Europe. Extra-limital.]

Gould, Vol. VII., pl, 80 (pt. xvıI.), Dec. 1st, 1844. Mathews, Vol. I., pt. 5, pl. 64, Oct. 31st, 1911.

Podiceps cristatus christiani Mathews, Birds Austr., Vol. I., pt. 5, p. 267, pl. 64, Oct. 31st, 1911: Victoria.

Distribution.-Australia generally and Tasmania,

Adult male in breeding-plumage--Upper-surface brown, including the head (which has a double crest), hind-neck, mantle, scapulars, and upper back; lower back somewhat darker and inclining to dusky-brown; marginal wing-coverts white, median and greater coverts brown like the bastard-wing and primary-coserts; primary-quills similar in colour, paler on the inner webs and white at the base; secondaries white, the imner ones brown on the outer webs and tips, the innermost like the back; humerals white, outer ones slightly margined with brown; lores whitish; the ruff on the upper neck and throat chestnut, tipjed with black; middle of throat, sides of the face, fore-neck, breast, abdomen, axillaries, and under wingcoverts pearly-white; sides of body brown; bill dark hom colour; iris red; upper-surface of the tarsi and toes dark olive-green, under-surface jale yellow. Total length $520 \mathrm{~mm}$.; culmen 53, wing 180 , tarsus 59.

l'emale (adult).--Similar to the bird described above.

The winter-plumage seems to be the same.

Immature.-Similar to the adult but lacking the crest and paler; the head pale greyish-black, the feathers of the fore-head and superciliary stripe with white tips; the feathers of the neck with a chestnut wash, the throat is white, the chestnut coloration of the adult missing and the flanks scarcely brown tinged.

Nestling in down. - Head and all upper-surface pale buff, longitudinally striped with black, the stripes down the middle of the back broadest; the under-surface rellowish-white; the fore-head is whitish with the top of the head white, a black bar across the centre; three stripes can be counted on each side of the neck and there is a blotch at the gape, the winglet is black striped; the bill is yellowish, white at the tips and crossed by two black bars; legs and feet olive.

Immature, just losing down.-Is pale grey above striped with black similarly to the nestling. As it grows it loses the striping, retaining it longest on the head and neck.

Nest.-Constructed of rushes, weeds, etc. Placed low in the water, and always damp. Dimensions outside 18 to $20 \mathrm{in}$. by 12 to 18 deep; egg cavity 6 in. by 3 deep.

Eggs.-Clutch, five; ground-colour pale green, coated over with a thin layer of lime, which soon becomes nest-stained (brown); axis 50 to $52 \mathrm{~mm}$., diameter 34-36.

Breeding-season.-November to December.

Distribution and forms.-Europe, Asia, Africa, Australia and New Zealand. In 1911 Mathews suggested the recognition of five forms, as follows: P.c.cristatus (Linné) for European birds ; P. c. infuscatus Salvadori for African birds, which are probably separable into two races, a North African and a South African one; the difference in the superciliary stripe had been before indicated and has sinco been 
confirmed by every worker on African birds; Asiatie birch, which were larger, were left unnamed and do not secm to have been studied since; Australian bircis, which were found to be lighter and smaller, were renamed $P$. c. christiani Nathew : s: Gould named Pudiceps australis as being larger and clarker, which are the characteristics of the New Zealand race, which should be ealled $P$. c. australis Gould. There may be two races in New Zealand, and it is probable that series in Australia would show differences.

\section{Genus POLIOCEPHALUS.}

Poliocephalus Selby, Cat. Gen. Subgen. Types Aves, p. 47, 1840. Type (by original designation): Podiceps poliocephalus Jardine and Selby.

Dasyptilus Swainson, Classif. Birds, Vol. II., p. 369, July 1st, 1837. Type (by original designation): $P$. poliocephalus Jardine and Selby.

Not Wagler, Abhandl. Ak. Wiss. Münch., Vol. II., p. 502, 1832.

Tachybaptus Reichenbach, Nat. Syst, Vögel, p. III., 1852 (? 1853). Type (by monotypy): Colymbus minor Gmelin $=$ C. ruficollis Vroeg.

Colymbetes Heine und Reichenow, Nomencl. Mus. Hein., p. 364, (pref. Sept.) 1890: New name for Poliocephalus Selby.

Not of Schellenberg, Helvet. Entom., Vol. II., p. 188, 1800.

Smallest Grebes with short stout bills, short wings, no tail and large legs and feet. The bill is stout, about the length of the head, the culmen almost straight, the ridge a little arehed, the tip sharp, not decursed; a well-marked nasal groore extends about half the length of the culmen, the nostrils pervious linear small slits, about midway between the ridge and the edge of the mandible, in the anterior portion of the groove; the depth of the bill at the base is about one-third the length and the under mandible is about as strong as the upper; the strong rami are not grooved and coalesce to form a strongly angulated gonys, which shows the separate rami ; the interramal space is narrow and unfeathered. The wings are very short, the first and second a little sealloped on the imner webs and practically subequal, the second probably the longest, the secondaries as long as the primaries. Tail showing no differentiated tail-feathers. Feet and legs as in preeding, the serrations on the posterior ridge of the tarsus much more prominent and stronger, sometimes a double row being present. The lobes of the toes are commected a little different at their bases, the claws more pectinate, sometimes all the claws showing strong pectinations.

Coloration dark brown above, head and neck dark with colour markings e! white tips, abdomen white.

\section{I48. Poliocephalus ruficollis.-PLACK-THROATED GREBE.}

[Colymbus ruficollis Vroeg, ex Pallas MS., Cat. Rais. d'Ois., Adumb., p. 6, (before Sept. 22nd) 1764; Holland, Europe. Extra-limital ]

Gould, Vol. VII., pl. 81 (pt. XI.), Sept. 1st, 1843. Mathows, Vol. I., pt. 5, pl. 62, Oct. 31st, 1911.

Podiceps novchollandio Stephens, in Shaw's Gen. Zool., Vol. XIII, pt. I., p. 18, Feb. 18th, 1826: New South Wales, based on Latham's description of Watling drawing No, 263.

Podiceps gularis Gould, Synops. Birds Austr., pt. I., pl. 19, Jan. 1st, 1837: New South Wales.

Podiceps fluviatilis carterce Mathers, Nov. Zool., Vol. XVIII., p. 197, Jan. 31 st, 1912 : Broome Hill, South-west Australia.

Podiceps fluviatilis parryi Mathews, ib. : Parry's Creek, North-west Australia.

Distributron,- Iustralia generally and Tasmania.

Adult male, breeding.-Upper-surface dark brown, with a tinge of grey on the wings ; wing-coverts like the back; bastard-wing and primary-coverts clarli brown: primary-quills dark brown, white at base which inereases in extent towardis the 
inner ones; secondaries white, with a shade of brown on the outer webs; the long innermost secondaries brown with white bases; head black, glossed with green; $\approx$ line of chestnut from behind the eye which widens out on the sides of the neck ; throat patch glossy black; fore-neck rusty-brown; feathers of the breast tipped with dark brown, more intensely on the sides, giving a speckled appearance; remainder of the under-surface pearly-white, bccoming dusky on the sides of the body and sides of vent; axillaries and under wing-coverts pure white; bill black, tip) pearly-white; iris orange, orbits yellow; feet bluish-grey. Total length $250 \mathrm{~mm}$.; culmen 23, wing 110 , tarsus 34 .

Adult female, breeding.- Similar to the above.

Adult male in winter.-Differs from the adult in breeding-plumage in having the top of the head, hind-neck, back, and wings dark ashy-grey; the throat pure white, a tinge of buff on the sides of the neck, upper-breast and sides of boriy, lower flanks rufous-buff, the feathers tipped with grey; tips of primaries grey.

Adult female in winter. - Similar to the above.

Immature female. - Similar to the adult in winter, but differs in having longitudinal lines of brown and white on the sides of the head and neck; fore-head and a streak over the eye brown; a white line above the eye which crosses the middle of the crown, where it is sandy-buff, and extends in a narrow streak on to the sides of the neck; a white spot on each side of the nape; a very narrow line of white from the hinder part of the eye, which joins the one on the side of the crown; a brown streak from behind the eye to the sicles of the neck; a white line from the hinder part of the eye, which unites with another on the cheeks and extends to the siles of the neck enclo-ing a patch of brown at the grope, which extencis in a narrow line along the sides of the face; a less rlistinct line of brom slisting the sicles of the throat and extending backwards to the sides of the neck.

Nestling in down.-Upper-surface black, with numerous narrow lines of buffishwhite which run horizontally from the hind-neck to the end of the body; undersurface white; crown of head and hind-neck black, as also two streaks on the sides of the neck and another on the fore-neck; a small chestnut patch on the middle of the crown; a rufous and white $\mathrm{V}$-shaped line from the fore-part of the crown to the sides of the nape; throat white, with three irregular lines of black running longitudinally on to the fore-neck.

Nest.-Constructed of rushes, weeds, etc., low down in the water, and always damp, and warmed by fermentation. Dimensions 12 in. by 6 to 12 deep; egg cavity 6 in. by $2 \frac{1}{2}$ deep.

Eggs.-Clutch, five to eight; usually nest-stained, which on being scraped off reveals a pale green ground-colour; axis 31-38, diameter 24-26.

Breeding-season.- September to February.

Distribution and forms.-Through Europe, Asia, Africa and Australia, and many subspecies may be recognised. The extra-limital forms have not been suliciently studied to limit the subpecic: but in Australia three fairly recronisable races are easily seen : Poliocephalus ruficollis nocwhollandice (Stephens) from Eastem Australia; Poliocephalus mificollis cartere (Mathews) from South-went Australia, of darker coloration above and with a shorter thicker bill; and Poliocephalus ruficollis perryi Nathew from North-west Australia, of lighter coloration than the typical race and with a more slender bill.

\section{49. Poliocephalus poliocephalus.-HOARY-HEADED GREBE.}

Gould, Vol. VII., pl. 82 (pt. xrI.), Sept. 1st, 1843, Mathews, Vol. I., pt. 5, pl. 63, Oct. 31st, 1911.

Podiceps poliocephalus Jardine and Selby, Illustr. Ornith., Vol. I., pt. I., pl. 13, Feb. 1827: New South Wales. 
Podiceps nestor Gould, Synops. Birds Austr, pt. r, pl. 19, Jan. 1st, 1837 : Van Diemens Land and Now South Wales=Tasmania. (IV. Stone.)

Podiceps poliocephalus cloatesi Mathews, Nov, Zool., Vol. XVIII,, p. 197, Jan. 31st, 1912 : Point Cloates, mid-IVest Australia.

Distribution.-Australia generally and Tasmania.

Alult male in brealing-plumage. General colour of the upper-surface dark slate-grey, the feathers of the mantle, back, seapulars, and wing-coverts fringed with white; bastard-wing, primary-eoverts, and quills dark brown, the latter blackinh at the tips and white on the inner webs, the white inereasing in extent on the inner primaries, where they become white shaded with brown at the tips, the dark pattern increasing on tho inner secondaries, where it sprearls over the greater portion of the feathers, the white pattern being reduced to the base only ; sicles of the lower back and rump white streakerl with brown; head and neck all round black, dusky on the fore-head and lores, the feathers on the top of the hearl and sides of the face continued into white, hair-like tijs, which impart a streaked appearance ; lower hind-neck dusky-brown, becoming buff on the fore-neek; breast also bufi, darker on the sides, which is continued along the sides of the body on to the lower flanks, where they are greyish-brown; under-surface pearly-white; under wingcoverts and axillaries white, the latter with dark brown on the outer webs; bill black, tip flesh colour; iris straw-yellow; tarsi and feet olive. Total length $271 \mathrm{~mm}$. ; culmen 25, wing 111, tarsus 35.

Adult female in breding-plumage.- Similar to the adult male but differs in boing paler, the throat dark brown, and the fore-neek pale fam. It is also somewhat smaller. Total length $230 \mathrm{~mm}$; ; culmen 25 , wing 111 , tarsus 32 .

Adult in winter.-Everywhere paler on the upper-parts; top of head grey, blackish on the hind-neck; the hair-like plumes short on the fore-head, longer on the hinder face and sides of upper neck; throat pale grey.

Immature and Nestling.- Similar to those of preceding.

Nest.-Very much like that of the preceding species.

Eggs. Cluteh, four to six; ground-colour when fresh pale green, corered with white chalky nodules; axis 39 , diameter 26-27.

Breeding-season.-October to January.

Distribution and forms.-Throughout Australia and Tasmania. It is possible that more subspecies will be admitted later, but with the material at hand only two are reengnised, an eastern and a western form, the latter being darker above and the buff on the sides of the breast being more extensive. The New Zealand bird, P. rufopectus Gray is closely related but is specifically distinct.

\section{ORDER GALLI.}

This order comprises five suborders, the Hoatzin as sole member of one, Curansows, Megapodes, ete., Hemipodes, and Seed Suipe. The Hoatzin, constituting the Opisthocomiformes, has a womderful literature on account of its mangrove breeding-habits and its use of otherwise disused members. Nevertheless, it is only a little modified relative of the Curassows and Guans and must be included in the same: order. Moreover, it inhabits the same eountries, both being restricted to South and Central Ameriea. The Craciformes, including the Curassows and Guans, are peculiar low forms of Galline birls, agreeing in some internal features with the Megapodes with which they have no near relationship. The former are large birks which live in the forests in trees: they are stoutly built with rested heads and bare spaces round the eyes, varying in the different species, and mostly of dark coloration. The Megapotes are famed for their peeuliar lack of incubating their exgs and will be more fully dealt with below as they belong to the Papuanian and Australian Iiegions. They are only regarded as constituting a superfanily 
of the suborder Galliformes, the other superfamily being the Phasianoidea, which includes all the well-known domesticated fowls and most of the desirable game-birds, with a world-wide range but only thee small forms in Australia. The Hemipodes constitute the fourth suborder, Turniciformes, and is st rongly represented in Australia, but the forms aresmall birds. The last suborder, Attagidiformes, for the Seed Snipe of South America, cousist s of a few s mall birds, which are purely modified forms, but which on account of the idiosynerasies of anatomists have been variously classed, commonly with the Plovers, to which they are not nearly related. The internal character's cited in favour of the Charadriform allianee were obviously misunderstood. There are no absolute anatomical or osteological features for diagnosis, so we will cite the general characters quoted. The skull shows the palate to be sehizognathous with the nasals holorhinal, and basipterygoid proceses are present; the palatines without internal lamina as a general rule; the lachrymals are variable, sometimes large with a large deseending proee: s as in the Craciformes, sometimes small with a weak or missing descending process as in the Galliformes. The sternum is strongly keeled generally with very deep notching and peculiar lateral processes; the furcula is always present and curved and there are sixteen cervical vertebrx. The carotids are either one or two, the syrinx is variable and the digestive system is somewhat variable, of apmarently low origin and showing relationship to the Tinami, the lowest forms being seen in the Opisthocomiformes and Craciformes. There is a large crop) present and the exea are large. The leg-museles are generally complete, ABXY+, the expansor secundariorum present but somewhat peculiar, the biceps slip variable. The oil gland is sometimes tufted, sometimes nucle, an afterhaft always present, and the wing quincubital or aquineubital. The pterylosis has only been studied in a few forms without much variation determined, and the nestling is hatched covered with down. Though regarded as an ancient group, the factor, quincubitalism of the wing, suggesting this, fow fossil forms are known.

\section{SUborder GALLIFORMES.}

We separate this suborder into two superfamilies, Megapodioidea for the Megapodes and other mound-building forms as Leipou, and Phasianoidea for the Turkeys, Guineafowl, Grouse, Pheasants, Partridgen and American Quail. While superficially the Megapodes are rather different from the remainder, the anatomists have pointed out many small peeuliarities in their internal strueture. Thus Huxley divided the Galliformes into two, the Peristeropodes and the Alectoropodes, the former covering the Craciformes and the Megapodioidea, the latter the remaining Galliformes. The former differed in the less notehing of the sternum and the short obtuse costal processes, with the hallux on the level with other toes; the latter have the sternum very decply notched and long costal processes and the hallux attached above the level of other toes. We have separated the Craciformes as of subordinal rank distinct from the Galliformes in which we include the Megajodes, and this arrangement agrees with the results of anatomical investigation.

\section{Superfamily MEGAPODIOIDEA.}

This superfamily includes the mound-building Galliformes, but the three forms represented in Australia are of diverse apperance and posibly of different origin. We have admitted only one family but posibly three will later be reeognined, the three Australian npecies being each ieferred to a separate family. It is almost certain that Leipoa has no close relation with the others, and we anticipate careful osteological and myologica! compari-on will reveal more differences than likenesses. The range of the mounl-builders is Papuasia and Australia, but the Papuasian group only ranges into the extreme north of Australia, while Leipoa is isolated in the extreme suuth, both eant and west, but not Tammania. The superficial details 
of the: e are eriven under the genera, and the general internal characters have been

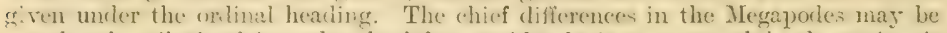
nuterl: the oil grant is nude, the left carotid only is present, whlle the srrinx is peruliar and of a primitive nature: the basjoterygoid processes are more noticeable and the skull shows detalls of difference, and the wing is aquincubital. We have triteed no cletails of Lripoa, and Shufeldt in his recent papers on this subject in the Emu mentions nothing.

\section{Famity MEgAPODIDZE. \\ Genus MEGAPODIUS.}

Megapadius Gaimard, Bull. Gen. Univ. Annon. Nouv. Sci, Ferussac, Vol. II., p. 450, (read June 6th) 1823 (July, Aug.). Type (by subsequent designation, Mathews, List Birds Austr., p. 5,1913$)$ : Megapodius freycinet Gaimard.

Alecthelia Lesson, Bull. Sci. Nat. Ferussac, Vol. VIII., p. 115, pt. I., (Jan ?) 1826. Type (by monotypy): Alecthelia urvillii Lesson and Garnot $=$ M. freycinet Gaimard.

Amelous Gloger, Hand-u. Hilfsb., pt. $\nabla .$, p. 375, 1811 (end). New name for Alecthelia Lesson. Megathelia Mathews, Austral Av. Rec., Vol, II., pt. 5, p. 112, Sept. 24th, 1914. Typo (by original designation): Megapodius tumulus Gould.

Simall Galline birds, with short head and bill, oeeipital erest, long rounderl wings, short tail and very stout legs and short toes. The bill is shorter than the leat, rather delicate for this group, a little flattened and laterally compresed, the tip (lecurvel, the no:trils linear ovals, almont hidden by a membranous operenlum ; under mandible flattenert. The lores and round the eres scantily feathered. The wing is very rounded, the feathers stiff, the first primary long but only equal to the ninth, the second equal to the eighth, all the intermediate ones subequal ; the secondaries comparatively short. The tail is rounded and very short, eomposed of twolve broad rounded feathers and is only about two-fifths the length of the wing. The legs are very stout, the tarsus having strong scaling, the broad frontal scutes being broken into hexagonal feales towards the toes, the sides having large scutes of similar shape; the toes are rather short, the outer and inner subequal and little shorter than the middle toe, while the hind-toe is two-thirds its length; the claws are very long and little curved.

Coloration rlark chestnat-brown above, lead-grey below. Nestling barred with brown and black.

\section{I50. Megapodius reinwardt.-SCRUB FOWL.}

[Megapodius reinuardt Dumont, Dict. Sci. Nat. (Levrault), Vol. XXIX., p. 416, Dec. 27th, 1823: Amboina errore = Aru Islands, Extra-limital.

Gould, Vol. V., pl. 79 (pt. vi.), March 1st, 1812. Mathews, Vol. I., pt. 1, pl. 6, Oct. 31 st, 1910.

Megapodius tumulus Gould, Birds Austr., pt. vi., March 1st, 1842: Cobourg Peninsula, Northern 'Territory.

Mega podius assimilis Masters, Proc. Linn. Soc. N.S.W., Vol, I., p. 59, Feb. 1876: Dungenese Island, Torres Strait, North Queensland.

Megapodius duperrevi melvillensis, Mathers, Austral Av. Rec., Vol. I., pt. 2, p. 26, April 2nd, 1912 : Melville Island, Northern 'Territory.

Drstrizution.-North Queensland, Northern Territory.

Adult male (from the Northern Territory).-General colour above, including the wings and tail, dark chestnut-brown, becoming darker on the lower back, rump, upper tail-coverts and tail; primary-coverts and quills blackish, paler on the outer webs; head crested, darker than the back, the feathers being lanceolate in form imparts a more or less streaked appearance; hind-neck and upper mantle darli lead-grey like the entire unker-surface, except the under tailcoverts, which are dark chestnut like the flanks; under wing-coverts dark leadgroy; fore-heal, space round the eyes and sides of face very sparsely feathered 
with dark haix-like phumes; chin and upper throat with very short blackith feather: bill reddish-brown with yellow edges; iris dark brown; tarsi and feet bright Oinger, the seales on the front of the tarsi from the funth downards and the reales on the toes dark reddish-brown. Total length $450 \mathrm{~mm}$.; culmen, from hinder point of nostril, 21, wing 275 , tail 105 , tarsus 65 .

Adult female (from the same locality).- Similar in every respect to the plumage to the male. Iris brown; feet red. Total length $431 \mathrm{~mm}$; ; culmen, from hinder point of nostril, 20, wing 257 , tail 106 , tarsus 70 .

An adult female from Port Keats, Northern 'Territory, is in much abraded plumage and evidently moulting after the breeding-seincn. Nany of the feather of the wings and back are much worn and have paler margins which gives a more or less barred appearance on the upper-surface.

An adult male from Cape York is very similar to the adult male described abore in the distribution of colour, but everywhere much paler, the midile of the abdomer? is inclining to olive-brown; the lower flanks, thighs and under tail-coverts deep chestnut and inclining to maroon. Total length $455 \mathrm{~mm}$.; culmen 20, wing 266, tail 105 , tarsus 67.

Immature female (from Bartle Frere, Queensland).--Rich chestnut-brown on the head, entire back, ujper tai-coverts and wing, the latter showing the remains of indistinct barrings and rufour marrins on the elges and tips of the greater coverts as shown in the nestling plumage. It is also distinguished from the adult by the chestnut colour of the lower flanks, thighs and under tail-coverts; quills and tailfeathers blackish as in the adult; bill and iris brown; feet yellow. Total length $370 \mathrm{~mm}$; wing 234.

Chick (from Port Keats, two weeks old).-Dark reddish-brown on the head, wings, lower back and tail; the scapulars and wings show more or less distinct brown and rufous bars; hind-neck and upper mantle olive-brown; sides of face and lower throat lead-grey, becoming more or less whitish on the chin; sides of body and under wing-covert lead-grey ; remainder of under-surface russet-brown; under aspect of tail conspicuously darker.

Another chick, from Cedar Bay, Queensland, is similar to the above, but everywhere paler; the hind-neck and upper mantle slate-grey, as also the lower throat, the sides of the face paler and the chin whiter; the under-surface pale rust-lorown or more less mixed with grey; unier aspect of tail not conspicuou-ly darker than under-surface.

Nest or egg mound, usually of immense size, rotund in shape, occasionally conical; composed of loose, black vegetable mould or soil, $1 \mathrm{ixed}$ with sticks, leaves. etc., if close to the beach the mound is chiefly sand and shells; usually situated within a few hundred yards of the sea-shore, and protected by thickly-foliaged scrub or trees. Dimensions, about 20 feet in diameter at base, or a circumference of about 60 feet; height about 5 feet.

Eggs.-Clutch, or complement to a mound, variously stated, but probably eight to ten; long ellipse in shape, both ends being nearly alike; texture of shell coarse; surface without gloss; colour, pinkish or yellowish-buff, the outer or beautiful pinkish-buff coating, when renoved, show the ycllowish-buff. If both colours are seratched off a whitish shell is revealed. Dimensions 84 to $92 \mathrm{~mm}$. by $50-53$.

Breeding-season.- October to February.

Incubation-period.-About six weeks.

Distribution and forms.-Owing to the individual variation (perhaps seasonal) the forms of this species, which occurs in the Aru Islands, New Guinea and Northem Australia are not well understood. At the present time four sub-pecies are inclicated with the possibility of more; these are: Megapodius reinwardt reinwardt Dumont from the Aru Islands; $M$. $r$. tumulus Gould, from the Northem Territory, more 
olivaceous on the upper-surface and larger ( $M .$, r. molvillensis . Tathews from Melville Island, namel on accomnt of its lighter upper coloration may later be reinstated) ; 1I. $r$. assimilis Masters from North Quemsland, with darker and more rufou. upper-surfice and also smaller size ; $M . r$. dupervyii Lesson and Garnot from Dorey, New Guinea, may be used for the Arfali Peninsula and Dutch New Guinea birch, unless the latter be separated on account of their more olive coloration, but Pothschild and Hartert, twenty years ago, also included the Molucean and Bismarck Archipelago, etc., birds as conspecific, recognining five additional subspecies, hut two species appear to have been confused, and more study is required to determine accurately the extra-limital forms.

\section{Genus LEIPOA.}

Leipoa Gould, Birds Austr., pt. I., Dec. 1st, 1840. Typo (by monotypy): Leipoa ocellata Gould.

Large Galline birds with very small heads and bills, short full crest, long rounder wings, long rounded tail, strong legs and feet. The bill is short, shorter even than head, the culmen ridge basally flattened, the tip forming a dertrum somewhat deflected and comparatively delieate; the nasal groove large, the nasal apertures strongly operculate, rather linear and pervious; the under mandible is flattened, a little spoon shaped, the mandibular rami very short and more or less feathered towards their bases, the interramal space feathered; there is a naked space round the eyes. The wing is rery rounded, the feathers rery stout and stiff, the first primary long but shorter than the sixth, which is less than the second, third, fourth and fifth little longer, the fifth generally the longent; the secondaries are very long, almost as long as the longest primaries. The tail is very long, more than half tho length of the wing, consisting of sixtecn broad feathers, rounded in shape, the tailcoverts very long, both upper and under almost reaching to the end of the tail. The legs are very strong, the tarsus a little more than one-fifth the length of the wing, the tarsal covering in front being a clouble row of large hexagonal scutes, the remainder coarsely reticulated; the toes rather short, the middle toe about half the length of the tariss, the outer and inner shorter and subequal, the bind-toe long and straight, about half the length of the middle toe; claws very long and little curved.

Coloration banderl and ocellated above, head grey, breast with black stripes, under-surface otherwise white to pale buff. Nestling mottled rufous-bromi.

\section{I5I. Leipoa ocellata.-MALLEE FOWL.}

Gould, Vol. V., pl. 78 (pt. I.), Dec. 1st, 1840. Mathers, Vol. I., pt. 1, pl. 7, Oct. 31st, 1910.

Leipoa ocellata Gould, Birds Austr., pt. I, Dec. 1st, 1840: Swan River, Western Australia. Leipoa ocellata rosince Mathews, Nov. Zool., Vol. XVIII., p. 177, Jan. 3lst, 1912 : South Australia.

Distributron.-New South Wales, Victoria, South Australia, South and mid-Wost Australia.

Adult male.- General colour above grey and rufous-brown, barred on the wings: and tail with black and white, which gives the bird a banded appearance; head grey, with dark lancecolate feathers tipped with whitis on the middle of the crown, which imparts a more or less strcalied appearance; feathers of the hind-neck leadgrey, some of them margined with rufous-brown : the back eovered with silky or down-like feathers also grey with galer tips: mantle grey barred with black, white, and rufous-brown, as also the scapulars, median and greater wing-corerts ; sices of neck and lesser wing-coterts ashy-grey, the latter fringed with paler edgings al a some of the outer ones showing dark shaft-streals; frimary-corerts pale bionn 
tipped with whitish ; primaries blackish, paler on the outer webs, marbled towards the ends and margined with white at the tips; secondaries blackish on the inmer web.s, irregularly barred with tawny, scimitar-shaped white and black marks on the outer webs; the long inner secondaries rermiculated and barred with these colour on both web; ; the upper tail-coverts and widdle tail-feathers are similar in colour to the secondaries; remainder of tail blackish tipped with white; cheeks, chin and upper throat ferruginous; on the lower throat a pateh of black feathers which are streaked with white down the middle, some fringed with white at the ends and the lateral ones with white outer webs; sides of breast grey, barred with black, becoming paler on the sides of the body, and the dark bars broader and more pronounced; middle of abdomen and vent silvery-white; lower flanks, thighs and uncler tail-coverts buff, more deeply tinted on the latter, and with black shaft-streaks to the long under tail-coverts towards the base; wing-coverts grey on the outer margins, some of the inner ones barred with ferruginous and black lilie the axillaries; bill slate black; bare skin below the eye bluish-white; remainder of bare skin round eye dusky-black ; iris light hazel ; feet blue-grey. Total length $569 \mathrm{~mm}$.; culmen, from hinder point of nostril, 25 , wing 345 , tail 197, tarsus 75 .

Adult female.- Similar to the male but distinguished by the marblings or vermiculations on the outer webs of the primaries, on their lower aspect. Total length about $565 \mathrm{~mm}$; ; wing 346 , tarsus 71 .

Immature male (three-quarters grown).--Similar in every respect to the adult, but has the under wing-coverts and axillaries more xufous and the remains of mottlings on the onter webs of the primaries below.

Immature female (of the same age).- Similar to the above.

Immature (about half grown). - Under wing-coverts more numerously but faintly barred and less rufous; the mottlings on the under-surface are more pronounced.

Chick.-The general colour of the dorsal surface of the downy plumage of the Foung bird shortly after leaving the mound is a mottled rufous-brown, whilst the ventral surface is an ashy cream-buff. The legs and feet are well developed and strong and the toes are provided with long and powerful elaws capable of scratching vigorously for food. The primaries and secondaries are fully developed and are of a brown colour, barred with white. The wing-coverts, which are of a downy nature, are brown, mottled with white. The downy feathers situate on the flanks and abdominal surface and throat are a creamy-buff. The lores, auriculars and fore-head feathers which are also downy are a brownish cream-buff. Crown, nape, back and rump feathers are a light-mottled brown washed with buff. The tail, which is downy, is a light brown barred with white on the dorsal surface, and is an inch long, whilst the ventral surface is somewhat lighter in colour. The breast, which has a mottled appearance and downy, is an ashy-buff, whilst the sides are somewhat similar in colour only possessing a barred appearance. Total length $200 \mathrm{~mm}$.; culmen 10, wing 100 , tarsus 25.

Nest.-A large conical-shaped heap or mound of sand, etc., covering a bed of leaves and other vegetable debris about 8 inches in thickness, usually situated in a water track in the dense scrub of sandy tracts, or in reddish ironstone gravel country, such as the Mallee, etc. Dimensions 10 to 12 feet in diameter at base, or a circumference 30 to 40 feet, and height 2 to 4 feet.

Eggs.-Clutch, twelve to eighteen - other authors seven to eight; long oval in shape or elliptically inclined; texture coarse, but whell excexlinely thin ; surface without gloss ; colour, when first laid, light pink or pinkish-buff, which on being scratched or removed shows a yellowish-buff ground ; this, in turn, as incubation proceeds, chips off in patehes and reveals a whitish khe?. Dimenisins $85-94 \mathrm{~mm}$. by $57-60$.

Breeding-season.-September to February. 
Incubation-period. -42 to 45 days.

Distribution and forms,-Confined to southern extra-tropical Australia. Two forms have been indieatenl, an eastern and wentern form, the latter being darki and smaller than the former.

\section{Genus ALECTURA.}

Alectura Latham, Gen. Hist. Birds, Vol, X., p. 455, 1824. Typo (by monotypy): Now Holland Vulture $=$ A. lathami Gray.

Catheturus Swainson Classif. Birds, Vol. II., p. 206, July 1st, 1837. Now name for Alecture Latham.

Large heavily built falline birls with longis neclis, small hearl and bill, long roumlel wings, very long romied tail, strong strout legs and feret. The hearl and neck are bare with a seanty eovering of bristly feathers, ani a lare tle-hy wattle at the base of the sides of the neek. The bill is comparatively small, stout, laterally compressed, eulmen strongly areherl, no dertrum differentiated, the depth half an long as the length and more than the width, the lower elges of the upper mandible: straight, tip not deeurved : the nasal groove inclefinite, less than half the length of the culum, and in the anterior portion the nostrils are situated half-way between culmen ridge and elge of mandible; the apertures are rounded ovals, large and open, but there appears a small intemal process: the under mandible spoon shaped, the gony's about half the length and almost straight, the mandibular rami ill clefined posteriorly, the interramal space sparsely bristly as the head and neck. The wing is composed of stiff feathers, rounded, the first primary a little more than half the fifth, which is longest, the seeond is about two-thirds, the third and fourth longer, and the sixth to the tenth almost the same length as the fifth, and the secondaries are almost as long. The tail is peculiar in that it consists of eighteen very broad feathers with rounderl tips, the out ide feather shortest and the fifth from the outsicie longest, the middle one shorter so that it is doubly rounded; it is very long, about two-thirds the length of the wing, and the tail-coverts are short, the upper shorter than the under ones. The feet are very stout, the tarsus rery broad with the front envered with a row of broad scutes, often divided into two, the sides with small hrxagonal seutes, but the back with large scutes, smaller on the inside; the tow: are long, the claws long and little curred; the mickle toe shorter than the tarku. the inner and outer shorter and subequal, the hind-toe about half the length of the middle toe.

Coloration above and below blackish. Nestling bromnish.

\section{Alectura lathami.-BRUSH-TURKEY.}

Gould, Vol. V., pl. 77 (pt. I.), Dec. 1st, 1840. Mathews, Vol. I., pt. 1, pl. 8, Oct. 31 st, 1910. Alectura lathami Gray, Zool. Miscell., pt. I., p. 4, 1831, Nov. 5th: [near Sydney], New South Wales.

Meliagris lindesayii Jameson, L'Institut., Vol. III., No. 115, p. 238, July 22nd, 1835. Nom. nut.

Catheturus australis Swainson, Classif. Birds, Vol. II., p. 206, July 1st, 1837. New namo for A. lathami Gray.

Catheturus novahollandioe Bonaparte, Comptes Rendus Acad. Sci. (Paris), Vol. XLII., p. 876, May 1856. Nom. nud.

Talegallus purpurcicollis Lo Souëf, Ibis, Jan. 1898, p. 51 : Cape York, Queensland.

Alectura lathami robinsoni Mathews, Nov, Zool., Vol. XVIII., p. 177, Jan. 31st, 1912 : Cairns, North Queensland.

Distributron.-Queonsland, Now South Wales.

Adult male.-- vieles of neek, upper back, wings ahove and below and tail bleck ; midelle of back covered with domz-lilic feathers which are sooty-grey at hase and backinh at the tips; under-surface blackish, the feathers of the upper-breant 
narrowly, and those of the lower-breast and ablomen broally edger with white as also the thighs; under tail-coverts composed of black down-like feathers. Skin on head and upper part of neck red, remainder of neck yellow; bill black; iris brownish-white; feet yellow. Total length $586 \mathrm{~mm}$.; culmen, from hinder point of nostril, 29, wing 296, tail 200, tarsus 93.

Adult female. - Similar to the male, distinguished only by the absence of the wattle at the base of the neck. ; bill black, iris brownish-white; feet yellow. Total length $577 \mathrm{~mm}$.; culmen 24, wing 291, tail 210 , tarsus 77 .

Young.-Covered with down of a dark fulvous-brown colour, with some black feathers appearing on the back; wings and tail black, and the feathers on the under-surface of the same colour, with whitish margins, as in the adult bird.

Chick.-Has the down much lighter colour, wing feathers pale brown with paler margins; under-surface of body more inclining to whitish.

Nest.-A large rotund mound of earth, chiefly black vegetable mould, with an arlmixture of decaying matter, some of the mounds being surromeled with stick? Usually situated in dense scrub or forest. Dimensions about 12 feet in diameter at the base, or a circumference of about 34 to 36 feet, and height about 21 feet.

Eggs.-Complement to a mound, if used by a pair of birds, twelve to fifteen ; if used by sevoral birds, i.e., three pairs, thirty-five to thirty-six; elliptical in shape, while some are more or less compressed at one end ; texture of shell coarse; surface without gloss, and rough ; colour pure white, more or less stained with the earth of the mound. Dimensions $89-95 \mathrm{~mm}$. by $53-62$.

Breeding-season.--September to January.

Incubation-period.-About forty-two days.

Distribution and forms. - Confined to Eastern Australia, ranging from Cape York to New South WVales; threo forms have been recorded: thesouthern $A$. $l$. luthami Gray from New South Wales, the largest with the skin of the ncek red, the wattles yellow; A. l. robinsoni Mathews from North Queensland, with similar coloured but paler skin and wattles, and smaller size; and A. l. purpureicollis (Le Suuëf), from Cape York, North Quecnsland, also smaller with the skin of the lower portion of the neck and the wattles purplish-white.

\section{SUPEREAMLY PHASLANOIDEA.}

This superfamily, containing all the well-known and familiar game-birds, is separable into six families: Meleagrididas, Numidida, Tetranida, Phasianidx, Perdicide and O.lontophonidw. The tirst and lint named families are American, the serond African, the third name.l Holaret:e, the Phasianicle practically confined to the Indo-Chinese Region, and the Perdicide with headquarters in Indlia range into Palæarctic Region, into Africa and into Australia. Superficially there is a great resemblance among the members, the Turkeys and Guineafowl being handsome and peeuliar grouls, while the Pheasants are very remarkable for their extravig.mee in colour and de ign. The Perdicidre, with the greatest range, inclules the most modest and smallest members of the order, and is the only family penetrating into Australia of this superfamily, only three small necies referable to three genera, one of which, as $u \div u 2 l$, is endemic, agreeing with the theory of continued immigrations from the north.

\section{FAMILY PERDICIDE.}

\section{Genus COTURNIX.}

Coturnix Bonnaterre, Tabl. Ency. Méth. Ornith., Vol. I., pp. LxxxrIr., 216, 1791. Typo (by tautonymy) : C. communis Bonn, = Tetrao coturnix Linné.

Ortygion Keyserling und Blasius, Wirbelth. Europa's, pp. LXVI, 112, 202, (before April) 1810.

Type (by monotypy): T'etrao coturnix Linné. 
Perdortyx Montessus, Mém. Soc. Saone, Vol, VI., p. 36, 1885. Typo (by monotypy): Synoicus lodoisce" Vorreaux et Des Murs " Montessus = Tetrao coturnix Linné.

Maroturnia Mathews, Austral Av. Rec., Vol. II., pt. 5, p. 112, Sept. 24th, 1914. Type (by original designation): Coturnix pectoralis Linné.

Small Galline birls with short curved bills, short wings, short tail and short legs and feet. The bill is short, browlly triangular, tip somewhat spoon shaped, sides sloping, culmen not keeled but pronounced, decp at base; the lower murlible shallow and entirely overlapped by upper mandible which projects into a prominent tip ; the no:trils are situated in a semicireular depresion, appearing as linear slits, situated midway between ridge and elere of manlible near the ba:e, the feathers of the lores projecting on to the namal groove below the mal ap - turm, which are almost hidden by the strong membranous operculum characteristic of this family. The wings are short and rather pointed, the flight feathers stout and capable of long flight; the first and second primaries are almost or quite equal, the third a little shorter, and these constitute the tip of the wing; the secondaries rather short, reaching to the ninth primary only. The tail is composed of ten short soft feathers, less than one-third the length of the wing, rounded in shape and the upper tailcoverts long, reaching to the end of the tail, the under tail-corerts aloout as long. The legs are short and stout, the tarsus transversely scutellate in front, covered with hexagonal scales on sides and behind, the toes scutellate ; the tarsus is nearly twice. as long as the culmen. The toes are short and stout, the middle toe longest, the inner and outer subequal, the hind-toe long about one-third the length of the inner; claws fairly long and sharp.

Coloration streaked black and white above and below.

\section{Coturnix pectoralis.-STUBBLE-QUAIL.}

Gould, Vol. V., pl. 88 (pt. Xxv.), Dec. 1st, 1846. Mathews, Vol. I., pt. 1, pl. 9, Oct. 31st, 1910.

Coturnix pectoralis Gould, Synops. Birds Austr., pt. II., pl. (29), April 1st, 1837: New South Wales.

Coturnix pectoralis protermissa Mathews, Nov. Zool., Vol. XVIII., p. 178, Jan. 31st, 1912 : Broome Hill, South-west Australia.

Distributron.-Australia generally. Tasmania.

Adult male.--Head, neck, entire back and scapulars rufous-brown and black streaked with white; a white streak from the middle of the erom to the himl-neck. another one which commenees at the base of the bill and goes over the eye and along the sides of the neek forming a white eyebrow ; mantle and upper back rufous-brown more broadly streaked with white, some of the feathers broadly barred with black, and narrowly with rufous bars; some of the feathers of the back black with very narrow zigzag markings; scapulars like the back with grey margins to the tips of the feathers; lower back and rump show more black, with a hy tips to the feathers. the rufous-brown broken up into very narrow cross-bars; tail-feathers dark grey. with a white shaft-streak and white bars on both webs towards the margins; leser wing-coverts, melian and primary-coverts ashy-grey with paler shaft-lines; primaryand secondary-quills ashy-grey with dark shaft-lines somewhat fraler on the inner webs; lores, sides of face, chin and throat rufous, with a few black dots from the gritpe, which indieate a line along the sides of the neek and meet on the middle of the lower throat; the feathers on the chest and breast almost entirely black and some with white outer wols, the feathers of the lower-breast white with a broal st real of black down the micklle, those on the sicles of the breast and sides of the butr are white narrowly linerl on eneh side with black and maregined with rufous : the feathers on the lower ilanks more loroally eentrexl with white, the dark brown on the outer webs divided by a narrow longrituainal line of buft : middle of abdomen, thighs and under tail-coverts white, the latter more or less lined with black; under wing- 


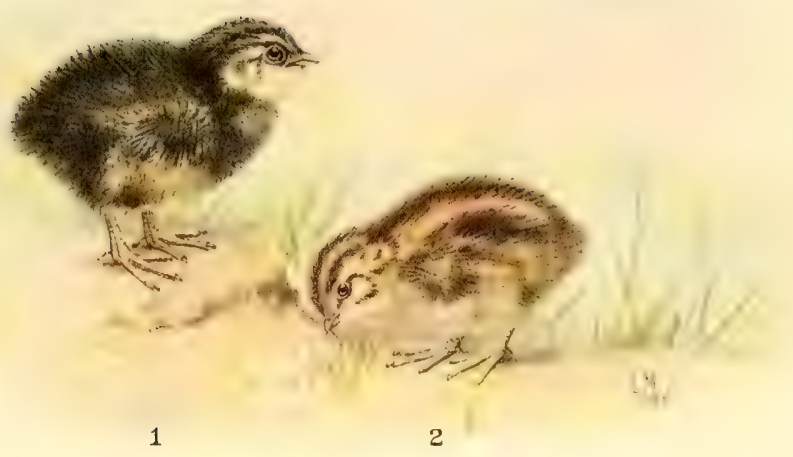

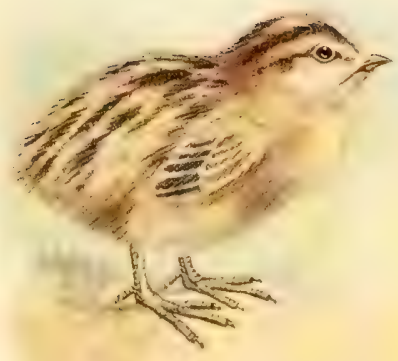

3

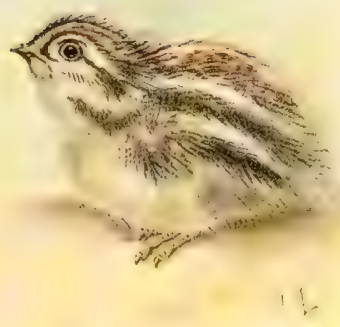

4

1. Nestling of King Quail (Exccalfactoria chinensis) Australian form.

2, Nestling of King Quail (Excalfactoria chinenais) Extra-limital form.

3. Nestling of Stubble-Quail (Coturmix pectoralis).

4. Nestling of Painted Quail (Marianornis varius). 

coverts and axillaries white; bill bluish-horn; iris red-hazel: feet yellowi-h. Total length $191 \mathrm{~mm}$; ; wing 110 , culmen, from base of fore-head, 15, tail 32, tarsus 26.

Atult femule.- Differs from the male in having less black above, the rufous much paler and the grey moie in erillence ; the throat white instead of rufous, the feathers of the chest are les: black, some of them margined with buff. Tutal length $180 \mathrm{~mm}$. ; wing 107 , culmen 17 , tarsus 26.

Another female from Wentern Australia has the head amost entirely black with the exception of the white eyclorow; the back more rufous-brown with no aplearance of grey; sides of face isabelline, becoming paler on the throat, but not white; feathers of the breast and ablomm fulvous with submarginal lines of black; the long feather: on the sides of the bodre and flanks with broad white shaft-rtreaks lined ons. each side with black and mottled with fulvous on the margins.

Young male.-Has the white streak of the adult just appearing on the middle of the crown; sides of the crown, chin and throat are covered with buff hair-like feathers; the feathers of the back and scapulars pale brown crosed by ferruginous and black bars broully lined with white; the long inner secondaries and uprer tailcoverts with longitudinal lines of black next to the pale shaft-streak; under-surface buffy-white with twin black spots on each feather, the long flank feathers with broad white shaft-streaks and three dark spots on each web.

Nestling.-Tawny and black above, these colours arranged in four lines, more or less longitudinally, from head to tail ; under-surface fulvous.

Nest.-Upon the ground in crop or herbage, the nesting hollow, $4 \frac{1}{2}$ inches across, being lined with straw or grass as the case may be.

Eggs.-Clutch, about eight; three eggs collected in Victoria are oval in shape, with a slight gloss on the surface, and have the ground-colour buff, frecliled and blotcherd with reddish-brown over the entire surface; axis 30 to $32 \mathrm{~mm}$., cliameter 21 to 22 .

Breeding-season.-Usually September to January, but eggs have been taken much later.

Incubation-period.-(In captivity) eighteen days.

Distribution and forms.-Restrieted to extra-tropical Australia and Tasmania. An eastern and a western form, the latter much darker above and below, especially on the head and breast. The extinct Neozelanic bird, Coturnix novazealandice, Quoy and Gaimard, is very closely related, but may be considered specifically distinct.

\section{Genus YPSILOPHORUS.}

$Y$ psilophorus Mathews, Austral Av. Rec., Vol. I., pt. 5, p. 127, Dec. 24th, 1912. New name for Synoicus Gould 1843, not Synoicum Phipps 1774. Typo (by monotypy): Perdix australis Latham.

Synoicus Gould, Birds Austr., pt. xII. (Vol. V., pl. 89, text), Sept, 1st, 1843. Type (by monotypy): $P$. australis Lath.

Not Synoicum Phipps, Voy. North Pole, App., p. 199, 1774.

Small Galline birds with small bills, short rounded wings, very short tail and stout legs and feet.

The bill is similarly formed to that of the preceding genus but a little longer, while the legs are also very similar to those of the last named but are a shade shorter, so that they are correspondingly less when compared with the culmen length. The wing is very different, being much rounded, the first four primaries being subequal and longest and the fifth little shorter, while the secondaries are correspondingly much longer, reaching to the tip of the serenth prinary. The tail is short and softer, being less than half the length of the wing and also having twelve feathers.

The coloration is different from that of the preceding, having streaks above but with wavy bars below. 


\section{Ypsilophorus ypsilophorus,-BROWN QUAIL.}

Gould, Vol. V., pl. 89 (pt. XI.), Sept. 1st, 1843; pl, 90 (pt. XxpI.), March 1st, 1847 ; pl. 91 (pt. xxix.), Doc. 1st, 1817. Mathews, Vol. I, pt. 1, pls, 10 and 11, Oct. 31 st, 1910.

Coturnix ypsilophorus Bose, Journ. d'Hist. Nat. (Paris), Vol. II., No. 20, p. 297, pl. 39, 1792: No loc. = I have designated Tasmania (Frederick Henry Bay).

Perdix australis Latham, Indox Ornith. Suppl, p. LxII., 1801, after May 30th: Sydnoy, Now South Wales.

Synoicus diemenensis Gould, Birds Austr, pt. xxvi., March 1st, 1817; Tasmania.

Synoicus sordidus Gould, Proc. Zool. Soc. (Lond.), 1817, p. 33, April 27th : South Australia. Synoicus cervinus Gould, Handb. Birds Austr., Vol. II., p. 195, (Dec.) 1865 : Port Essington, Northern Territory.

Coturnix australis rogersi Mathows, Nov. Zool, Vol. XVIII., p. 179, Jan, 31st, 1912 : Parry's Creok, North-west Australia (coast).

Ooturnix australis mungi Mathews, ib. : Mungi, North-west Australia (interior).

Coturnix australis melvillensis Mathews, Austral Av. Rec., Vol. I., pt. 2, p. 26, April 2nd, 1912 : Nelville Island, Northern Territory.

Coturnix australis queenslandicus Mathews, ib. : Cape York, Queensland.

Distribution.-Australia generally. Tasmania.

Adult male.-Brown, more or less rufous or vinous, washed with bluish-ash colour, and with narrow and evanescent shaft-lines of white to the feathers of the back. Head brown, mottled with broad black markings, not rery distinct, but more so on the sides of the crown, the centre of the latter being rather more vinous and showing narrow white shaft-lines which are continued to the nape, and appear in a lesser degree on the hind-neck and mantle, which have a more vinous tint, with ill-defined wavy blackish bars, most of the feathers bluish-ash colour at the ends, imparting an ashy shale to the upper-parts; scapulars, remainder of back and upper tail-coverts similarly shaded and marked, the white shaft-lines scarcely perceptible, but the black eross-bars more distinct; wing-coverts rufous-brown, with indistinct blackish bars, but no conspicuous ashy shade, and the white shaftlines obsolete; quills brown, the primaries externally mottled with dull rufous, crossed with blackish bars, tho secondaries more conspicuously freckled and barred with rufous extemally, the pattern being rufous with irregular dusky bars and spots, the inner secontaries being entirely rufous, vermiculated with blackish-brown, and having a black subterminal bar before a pale rufescent tip; tail-feathers duskybrown, with zigzag bars of rufous, the centre feathers with black and fulvous bars; eyebrow, lores, and sides of face dull ashy-brown, the ear-coverts with narrow shaftlines of white; the throat uniform pale vinous, whiter on the chin; lower throat and remainder of under-surface vinous-buff, varied with wary bars of black, with white shaft-lines or centres to the feathers, the white often dividing the wary black bur in the middle; the black bars more distinet and broader on the abdomen, sides of boly and flanks; under tail-coverts like the abdomen and broally barred with black; under wing-eoverts pale ashy, as also the axillaries and quill-lining. Total length about $189 \mathrm{~mm}$; culmen 18, wing 96, tail 41, tarsus 25.

Adult female.-Difiers from the male in having the back blotehed with broar black spots or bars, the latter mostly reaching one side of the white shaft-streak, thus causing the latter to stand out in bolder relief; the sides of the crown blackish, forming a broad band on each side, slightly mottled with rufous; along the centre of tho crown a distinct line of white, corresponding to the whitish supereiliary streak over each eye, the feathers being white, edgerl with black; throat ashy-whitish; remainder of under-surface pale ochraceons-buff, regularly barred with wary lines of black, with white shaft-lines, generally dividing the latter, the waved bars much broaler on the sides of the body and especially on the flanks; under tail-corerts al<o broadly barred with black; under wing-coverts and axillaries, as well as quilllining, ashy-grey ; Bill bluish ; eyes dark red ; feet orange. Total length $197 \mathrm{~mm}$.; enlmen 16 , wing 100 , tail 45 , tarsus 18 . The absence of vinous colour and grey on 
the upper-surface, as well as the coarser black markings, distingui: h the female from the male.

Younger male birds closely resemble the females, but are everywhere more coarsely birred below, and mottled above with bars of black on the back and wing .

Sometimes in very old birds the cross-bars of the chest and breast are reduced to a very small wavy line, and a vinous colour pervades the under-surface.

The adult females are much more coarsely blotched with black spots, more thickly barred below and with more distinet white shaft-streaks.

Nestling. - Chestnut-red above, with black bars on the back and wings; two chestnut patches on the head divided by a white line from the middle of the crown to the hind-neck, each of these patches is margined on the inner side with black; a black line from the base of the bill to the middle of the crown; a white line on each side of this black streak from the base of the bill orer and behind the ere ; a black line immediately above the eye and a second immediately below it; undersurface of the body whitish.

Nest.-A hollow in the ground, under the shelter of a tuft of grass or rushes, lined with a few dead grass stems and leaves.

Eggs,-Seven to eleven; roundish in form, sharply compressed at one end; texture, somewhat coarse and strong; surface glossy; colour sometimes of a uniform dull white, occasionally showing a pereeptible bluish tone, but more frequently more or less finely freckled with olive or light brown. The markings when fresh may be removed by moisture; axis 29-32 mm., diameter 22-23 $\mathrm{mm}$.

Breeding-season.-October to February.

Incubation-period.-(In captivity) twenty days.

Distribution and forms. - Throughout Australia and Tasmania, and on some of the Moluccas. A very variable species, seven subspecies being named, as follows: Ypisilophorus ypsilophorus ypsilophorus (Bonc) from Tasmania; $Y$. $p$. australis (Latham) from New South Wales, Victoria and South Queensland, smaller and lighter; Y. p. queenslandicus (Mathews) from Cape York, Queensland, a more reddish form, especially below; $Y . p$. cerinus (Gould) from Northern Territory, a smaller form of more delicate sandy and buff shade; Y.p. melvillensis (Mathews) from Mel ville Island, still smaller but darker than preceding; $Y$. p. rogersi (Mathewn) from the coastal districts of the North-west, much darker than the last named; and Y. p. mungi (Mathews) from the interior of the North-west, a pallid derert form; while the South-west and South Australian race may bear Crould's name $Y$. $a$. sordidus, given to an aberration.

\section{Genus EXCALFACTORIA.}

Excaljactoria Bonaparte, Comptes Rendus Acad. Sci. Paris, Vol. XLII., p. 881, May 1856. Type (by tautonymy): Tetrao chinensis Linné.

Compsortyx Heine und Reichenow, Nomencl, Mus. Hein., p. 292, (pref. Sept.) 1890. New name for Excalfactoria Bonaparte.

Smallest Galline birds with short bills, short rounded wings, very short tail and short legs and feet.

The bill is similarly formed but is much less conical, narrower and longer in proportion to depth. The wing is short and rounded, like that of Ypsilophorus, the first five primaries subequal and longent and the secondaries long, reaching to the eighth primary and not much shorter than the longest ones. The tail is very fhort, about one-third the length of the wing, the feathers eight only and rery :oft, entirely hidden by the tail-coverts, which are longer, both the upper and under. The legs and feet are of the same nature in every detail as in the preceding genus.

Coloration: the sexes very different; the female as in the other Quail forms, streaked abowe, more or less barred below, but the male has develojed a beautiful more or less uniform coloration, black above, breast slate, abdomen chestnut. 


\section{I55. Excalfactoria chinensis.-KING QUAIL.}

[Tetrao chinensis Linné, Syst. Nat., 12th ed., Vol. I., p. 277, (pref. May 24th) 1766: China. Extra-limital.]

Gould, Vol. V., pl. 92 (pt. xir.), Sept. 1st, 1843. Mathows, Vol. I., pt. 1, pl. 12, Oct. 3 lst. 1910

Excalfactoria anstratis Gould, Handb. Birds Austr., Vol. II., p. 197, (Dec.) 1865 : "Australia " $=$ Queensland.

Excal/actoria clinensis victoria Mathows, Nov. Zool., Vol. XVIII., p. 179, Jan. 31st, 1912 : Koo Wee Reep, Victoria.

Excalfactoria chinensis colleti Mathews, Austral Av. Rec., Vol. I., pt. 3, p. 73, Juno 28th, 1912 : Glencoe, Northern Territory.

Excalfactoria chinensis cairnsce Ilathews, ib.: pt. 4, p. 83, Sept. 18th, 1912 : Cairns, Queensland.

Distrinutron.-Northern Territory, Queensland, Now South Wales, Victoria, South Australia.

Adult male.-General colour above black with pale shaft-lines which are bracker and more pronounced on the lower back and rump; crown of head black with a longitudinal line of white from the middle of the crown to the hind-neck; feathers of the mantle rufous-brown crossed with black, strealied with narrow white shaftlines and margined with lead-grey; scapulars lead-grey with broken up marking: of black which are submarginal on some of the longer feathers; upper tail-covert. black with lead-grey margins; wing-coverts greyi-h-brown with more or less tracings: of black bars: primary-coverts and quills pale brown; tail-feathers lead-grey at the bave and with a marginal notch at tips; remainder deep chestunt live the minder tail-coverts and middle of the alxlomen; siles of crown, breant and sides of body decp slate-colour, some of the feathers bordering the chestnut of the under-surface: a small white line from the base of the bill to the eye, followed by a black line betcw the ere which is continued along the sides of the face and joined to the black of the throat; a longitudinal white pateh enclosed between the black line below the eye and the black of the throat; a semicircular white collar which commences at the bask of the ear-eorerts and meets on the midclle of the throat where it is broader ; this white collar is followed by a narrow line of black which seprarates it from the slate colour of the chest and upper-breast; sides of brenst more or less barred with black; bill black; iris red; feet yellow. Total length $130 \mathrm{~mm}$; culnen 12 , wing 74 , tail 26 , tarsus 20 . Two apparently adult birds still retain a trace of chestrut on the outer margin of the greater wing-coverts.

Adult female.-General colour above reddish-brown streaked with white shaftlines and black blotehes or eross markings: ; crown of head black with a white line. down the middle; sides of crown, sides of face, and lower throat tawny; wingcoverts pale reddish-brown finely barred with black and longitudinal white shaftlines; primary-coverts and quills pale brown; outer primary white along the outer elge; under-surface fulvous crossed by narrow black bars broad on the sides of the body and flanks, less on the thighs and under tail-eoverts. Total length $130 \mathrm{~mm}$.; culmen 12 , wing 70 , tail 25 , tarsus 18 .

Immature.-Closely resembling the adult female.

Nestling.-Sooty-black everywhere except the throat which is buft, and threo inclistinct streaks of the same colour on the top of the head.

The chicks are able to fly when ten days old, and are practically in adult plumage at six weeks.

Neat.-A hollow in the ground, lined, more or less, with grass, ete., and sheltered by herbage.

Eggs.-Clutch, four; oval in form, with a glossy surface; and drab groundcolour, minutely freckled with reddish-hrown over the entire surface, but moro thickly at the larger end ; axis 14-15 mm., diameter 17-18. 
Brecling-sedson.-August to January. March and April in Central Quecnsland. Incubation-period.- (In captivity) eighteen to twenty days.

Distribution and forms.-Eastern Asia from China to India and though the Philipunes, ete, to Eastem Australia. The extra-limital forms have been imperfectly studied and the subspecies are not well known ; four names have been given to Australian birds and three sub pecies may he easily recognised but the names need rearrangement. Gould named the Australian bird as a speres and in 1912 Mathers selected Queensland as the restricted type locality, but when Witmer Stone studied the Gouldian eollection in Philadelphia he selected a speeimen from South Australia as " the tyoe," and Mathews renamed the Qucensland form from C'airns. However, the type could not be in the Philadelphia collection, as the species was not named until 1865, and therefore Mathew's locality selection must be maintained, especially as the Queensland birds agree better in size with Gould 's measurements; therefore we have E. chinensis australis Gould from mid-Quecnsland, probably to Glencoe, Northem Territory (the type locality of Mathews 's $E_{\text {. }}$. c. colletti, but which may be separable by paler coloration); E. c. cairnse Wathews, from North Queensland, a darker form above and below; and E. c. victorice Nathews from Victoria, New South Wales, and South Australia, a larger form, also lighter than preceding and with a narrower white band on the throat. A somewhat variable speeies which will repay still further study.

\section{SUBORDER TURNICIFORMES.}

The little Button Quails, superficially like Quails, but without a hind-toe, have peculiar internal features, and as these have been misunclerstood by anatomists they have been removed from the near vicinity of the Galli, to which they undoubtedly belong. The Plain Wandecer resmbles these but has retained the hindtoe and is regarded as representing a distinet family, enpecially as intemal modifications are recorded. It is confined to the south central portion of Australia, whereas the Button Quails range from south Europe and North Ifrien through Tndia to Australia, where they are most strongly represented. The skull is rery peculiar, having the palate of a pattern namel iegithognathous, which is otherwise unknown in this commection, but here again there can be little doubt that this is a false regithognathism, and that it has been produced from a state of schizognathism, such as is always seen in the Galli. The nasals are recorded as sehizorhinal, but it is almited that this is a pseudo-achizorhiny and is of holorhinal orjgin. There are well-marlied ba-ipteryoid processes and the lachrymals fuse with the eetethmoids. There are fifteen cervical vertebre and the stemum shows a pair of long postero-lateral processes as in the Galliformes. The carotids are variable, and the tracheo-bronchial syrinx is somewhat degenerate; the digestive str.tem is somerhat peculiar, the cæca long. The muscle formula is variable, as is also the presence of the expan or secundariorum. The oil gland is tufted and the aftershaft present and the wing aquincubital or quincubital. The pterylosis is abnormal and the downy nestling is typically Galline.

\section{FAMILX TURNICIDE.}

Until recently all the Button Quails were referred to a single genus, but superficially they show variation, so that many genera are here admitted; no investigation has yet been made as to the differences in the internal features of the species, but in the few species yet examined variation has been noted. Thus, the syrinx shows variation in detail, while skeletal items have been recorded and even the leg muscles are not constant, the accessory femoro-caudal being present in some cases, though generally absent. Other features require comparison. 


\section{Genus TURNIX.}

Turnix Bonnaterre, Tabl. Ency. Méth. Ornith., Vol. I., pp. Lxxxur., 5, 1791. Type (by subsequent designation, Gray, p. 63, 1810): T. gibraltarica Bonn. = Tetrao sylvatica Des. fontaines.

Ortygis Illiger, Prodr. Mamm. et Av., p. 212, (pref. dated April) 1811. Newname for Turnix Linn. = Bonnaterre.

Hemipodius Temminck, Pigeons et Gall, Vol. III., p. 607, 1815 ex Reinwardt MS. New name for Turnix Bonnaterre.

Ortyx Oken, Lehrb. der Naturg., Vol. III., Zool., pt. II., p. 611, vIII., 1816. New name for "Turnix."

Oriyx Billberg, Synops. Fauna Seand., Vol. I., pt. I., tab. A, 1828. New name for Ortygis Illiger (cf. Austral Av. Rec., Vol. II., pts. 2 and 3, p. 37, Oct. 23rd, 1913).

ITelium Turnices with long thin bills (for this Order), short round wings, short. tail and stont legs and feet. The bill is comparatively long and thin, laterally compresserl, tip sharp; the nasal groove long, about half the length of the bili, the nostrils linear pervious slits orerhung by strong membranous operculum, placed near base of bill; the under mandible with clistinct perpendieular rami enclosing feathered interramal space, not so spoon-like as in the Quails.

The wing is rounded, the first three primaries subequal and longest, the fourth very little less and the secondaries fairly long, reaching to the seventh primary. The tail is composed of soft feathers and is short and rounded, less than one-thiri the length of the wing, and the upper and under tail-coverts are longer than the tail-feathers. The legs are stout, the tarsus regularly scutellate in front and behind, the toes long, the middle toe longest, the outer longer than the inner and there is no hind-toe; the claws are sharp.

Coloration: the females are larger and more brightly coloured than the males; the upper-surface greyish-brown barred with black and chestnut, the under-surface showing throat and abdomen unbarred, the barring appearing on the chest.

\section{I56. Turnix maculosa.-BLACK-BACKED QUAIL.}

Gould, Vol. V., pl. 84 (pt. Xxr.), Dec. 1st, 1845. Mathews, Vol. I., pt. 1, pl. 13, Oct. 31st, 1910.

Hemipodius maculosus Temminck, Pigeons et Gall, Vol. III., p. 631, 1815: Nouvello Hollande = Sydney.

Hemipodius melanotus Gould, Synops, Birds Austr., pt. II., pl. (30), April 1st, 1837: "Van Diemen's Land " = Moreton Bay, Queensland.

Turnix maculosa pseutes Mathews, Nov. Zool., Vol. XVIII., p. 180, Jan. 31st, 1912 : Parry's Creek, North-west Australia.

Turnix maculosa yorki Mfathews, Austral Av. Rec., Vol. III., pt. 3, p. 53, April 7th, 1916 : Cape York, North Queensland.

Distribution,-North Victoria, New South Wales, Queensland, Northern Territory, Northwest Australia.

Adult female.-Head greyish-bromu, barred with black; feathers of the fore-head marginerl with rufous ; hind-neck and sides of neck bright rufous; back slate-grey, barred with black and chestnut; seopulars similar in colour, margined with white or ochreous-buff on the outer webs; lower back, rump and upper tail-coverts black, the feathers very narrowly barrel or margined with chestnut or white; tail-feathers brown, with indications of black hars; lesser wing-coverts dusky; median and greater wing-coverts barred with ochreous and black; bastard-wing dark brown margined on the outer web with buffy-white; primary-coverts blackish; quills dark brown, the outer one edged with white; the immermost secondaries like the back, with oclurenus, black and white markings; fores and a line over the eye, earcoverts, sides of face and throat pale rufous, as al-o the flanks and under tail-coverts : fore-neck and sicles of loreast brighter rufous, the feathers on the latter barred or spotterl with black; middle of ablomen whitish; axillaries and aspect of wings 
below pale grey; bill, distal portion brown, basal part yellow; iris greyich-lorown ; tarsi and toes dull yellow. Total length $160 \mathrm{~mm}$.; culmen 14, wing 80 , tail 25, tarsus 21 .

Adull male.-Smaller than the fenale but similar in plumage, with less chestnut on the upper-surface, and less vinous-chestnut on the neck; the inner secondaries without any chestnut, but mottled with black and ochreous-buff rermiculations. Bill yellow, the distal half and the tip of the lower mandible brown; iris white; feet yellow. Total length $135 \mathrm{~mm}$.; culmen 12, wing 78, tail 20, tarsus 17.

Immature--Very similar to the adult.

Nestling.-Very like those of the next species.

Nest.-A scantily grass-lined hollow in the ground, sheltered by a convenient tuft of grass or low bush.

Eggs. Clutch, four ; ground-colour very pale slaty-grey, almost entirely hidden by brown spots, intermixed with largor blotches of dark slaty-grey; surface smooth and very glossy; axis $25 \mathrm{~mm}$, diameter 19.

These eggs can easily be distinguished from those of $T$. velox by being much darker and the surface of the shell bright and glossy.

Breeding-season.-October to January.

Distribution and forms.-From India through the Moluccas and New Guinea to Northern Australia, the only member of the family in Australia which has an extra-limital clistribution. The extra-limital forms bave becn insufticiently studied to diagnose correctly their subspecifie differences, but three fairly well-marked subspecies occur in Australia, as : T. m. maculosa (Temminck) from New South Wales and South Queensland (of which $H$. melanotus Gould is a synonym); T. m. pseutes Tathews from North-west Australia, with a well-marked fulvous superciliary stripe and the fulvous under coloration more extensive and uniform; and $T$. $m$. yorki Mathews from North Queensland, a much paler form than the preceding.

\section{Genus MARIANORNIS.}

Marianornis Mathews, Austral Av. Rec., Vol. III., pt. 5, p. 128, Doc. 28th, 1917. Type (by original designation): Perdix varia Latham.

Larger Turnices with longer and stouter bills, short wings, tail, and legs and feet. The bill is formed as in the last named but is much longer and stouter, and the wings, legs and feet are also similar; the tail is longer, more than one-third the length of the wing, the feathers a little stronger than in the preceding. The legs are also a little shorter proportionately, being less than one-fourth the length of tho wing, whereas in the preceding they are more.

Coloration, general coloration above chestnut, streaked with black, white and grey ; under-surface, chin and abdomen whitich, breast with bold black marking; sexes similarly coloured, males duller and smaller.

\section{I57. Marianornis varius,-PAINTED QUAIL.}

Gould, Vol. V., pls. 82-3 (pt. XxI.), Dec. 1st, 1845. Mathews, Vol, I., pt. 1, pl. 15, Oct. 31st, 1910.

Perdix varia Latham, Index Ornith. Suppl., p. Lxin., 1801, after May 30th : (Sydney), Now South Wales, based on Watling drawing No. 227.

Hemipodius scintillans Gould, Proc. Zool. Soc. (Lond.), 1845, p. 62, Sept. : Houtman's Abrolhos, West Australia,

Turnix varia stirlingi Mathews, Nov. Zool., Vol. XVIII., p. 181, Jan. 31st, 1912; Stirling Range, South-west Australia.

Turnix varia subminuta Mathews, ib.: Cooktown, North Queensland.

Distribution.-Australia generally. Tasmania.

Adult female.-General colour above chestnut, varied with black and grey, and linearly streaked with white. Mantle and back chestnut, with a few bars or spots of 
black, the feathers of the back more plainly barres with way crose lines of black, and having a broul black subterminal band; on each sicle of the featlecs a margin of white, producing a striped appearance; scapulars like the back, grey, with chestnut and black markings towards the end of the feathers, which have somewhat broader white linear margins; lower back and rumplike the rest of the back, but more mottled with chestnut, and black bars, and with the white marginal streal:s less strongly derelopel; upper tail-eoverts like the rump), but with broader white edges to some of the feathers; wing-coverts dull ashy, the lesicr scrics with a fow black bars, the median and imer greater coverts chestnut towards their ends, which have a white tip preceled by a black subterminal bar; primary-covert and (quills blackishbrown, the primaries with narrow margins of paler brown, the three outermont edged with ashy-white : the innermost secondaries mueh varied, being chestnut, with black cross-bars, of which the subterminal one is rery broad ; the distal aspect of some of them notched with buffr-white and edged with this colour, before which is a sul)terminal line of black, precedel by some blackivh rermiculations; tail-feathers ashy-grey, with slight blackish vermiculations; crown of head black, the hincler crown and nape barred with chentnut; the base of the fore-head, lores, and a line of feathers along the sides of the crown white, with black edges, producing a spotted appearance; ear-coverts, dark ashy-grey, with white shaft-lines below the eye; cheeks white, with black margins, resembling the sides of the neek, which are similarly spotted, the hind-neck mostly a-hy-grey, with a twin bar of white and black and a chestnut tip, this followed by an area of nearly uniform chestmut, which overspreads the upper mantle, and ha: only a few black bars; chin and upper throat white; the lower throat, chest. upper-breast and sides of the body dull plumbeousgrey, each feather centred with an orate spot of buff. with more or less of a blacki-h margin, the buff taking the form of bars on the sides of the breast, where there are a few black bars; on the sides of the fore-neck and chest an area of chestnut continuous with the chestnut of the upper mantle, and extencling down to the sides of the upper-breast, where there are a few white pots mul blark bars: midllle of the breast and abdomen white, with a slight tinge of buff; under tril-corerts sandybuff, with some lateral black suots: uneter wing-eoverts, axillaries, and inner lining of quills dull ashy-grey. Total length $190 \mathrm{~mm}$; culmen 18, wing 108, tail 43, tarsus 23.

Alult mals--Differs from the female in being : ma!ler ; the distribution of colour above is similar, but everywhere duller, particularly on the mantle, where the extended colour of the back takes the place of the bright chestnut patch, which is conspicuon in the fomale; the feathers of the lower threat and chest are buffy-white, with twin black spots, which gives an irregular barred appearance; bill bluishhorn colour; iris deep orange ; tarsi and feet deep yellow.

Immature.-Very similar to that of the adult male.

Nestling. - Covered with black, white and grey down, with an admixture of chestnut on the middle of the back and wings; a white line on each side of the crown, from the lores to behind the eye : a black line from the late of the fore-head, which widens out on the crown and cncloses a narrow white line on the hinder crown; there is also a more or less pronounced donble white line on! the mide!le of the lack; under-surface entirely dusky-grey.

Two other young individuals, a little more adranced in age, have the head similarly coloured to that of the ne-tling : the feathers of the hack are black, with white on rufous margins : primary-and : ceondery-quills brown, with hufir-white elges; throat covered with grey dewn; the feathers of the breat and sisles of neck sandy-rufous, with hlack shaft-lines in one speeimen: in the other the black talies the form of bars; ablomen and flanks buffe-white, becoming tamy on the under tail-coverts.

Nest.-A slight depression in the ground, sometimes lined with a little grass 
or fine leaves, and sheltered by a tussock, stone, etc.; usually in an exposed dry locality.

Eggs.-Clutch, four ; smooth and glossy, with a whitish ground-colour, minutely freckled with blue and brown spots over the entire surface, as well as redclish-brown spots more sparsely distributed; axis 26-27 mm., diameter 2l-22.

Breeding-season.-September to February.

Incubation-period.--Probably thirteen days.

Distribution and forms.- Throughout Australia and Tasmania. The subspecies have not yet been aceurately determined, though four races have been named, and more are indicated. Gould named the specimens from the Houtman's Abrolhos as a distinct species on account of their small size and paler coloration and brighter markings, also noting that the West Australian birds were smaller than the typical birds and the Tasmanian birds larger; the birds from the Stirling Ranges wero distinguished by Nathews on account of their darker upper coloration but paler under coloration, and the North Qucensland form was also named for its smaller size. Thus we have $M$. v. varius (Latham) from South Queensland, New South Wales, South Australia and Tasmania (?) ; M. v. subminutus (Mathews) from North Queensland; $M . v$. stirlingi (Mathews) from the Stirling Ranges, West Australia; and $1 I . v$. scintillans (Gould) from Houtman's Abrolhos, and probably the mainland adjacent of West Australia.

\section{Genus AUSTROTURNIX.}

Austroturnix Mathews, Austral Av. Rec., Vol. I., pt. 8, p. 195, March 20th, 1913. Type (by original designation): Hemipodius castanotus Gould.

Large Turnices with stout "parrot-like" bills, short wings, longer tails and short legs and feet. The bill is peculiarly stout, strongly laterally compresiced, the culmen ridge notably arehed, the nasal groove short, the lower mandible with strong deep perpendicular rami.

The wing has the first four primaries subequal and longest and the secondaries long, reaching to the tip of the primaries. The tail is less than half the length of the primaries as in the preceling, but is about twice the length of the tarsus. The legs are very similar to those of the preceding but are comparatively shorter.

Coloration similar to the foregoing in general style but paler and less boldly marked and the markings on the breast becoming obsolete, only a darker breast-band remaining.

\section{Austroturnix olivii.--ALIIED QUAIL.}

Mathews, Vol. I., pt. 1, pl. 17, Oct. 31st, 1910.

Turnix olivii Robinson, Bull, Brit. Ornith. Club, Vol. X., p. xLm., Feb. 28th, 1900 : Cooktown, Queensland.

Distribution.-Queensland (Cooktown). One specimen preserved in Tring Museum.

Adult female (type of the species).-General colour above, pale vinous-chestnut with lavender-grey edges to the feathers of the upper-surface; on the mantle anr back a certain number of feathers are crossed with black bars towards their ends and hro:ully edged with ashy-white, forming streaks, which have a coterminal line of black accomparying the white treaks on their inner side; these banderl and whitestreaked feathers being present among the seapulars but absent on the rump, upper tail-coverts and tail which are pale cinnamon; wing-coverts vinous-chestnut, like the back and with the same ashy-grey edges to the feathers, which are differently marked, being spotted with white on the inner median and greater coserts, thesio white spots haring a more or less distinet subterminal line of black; leser wingcoverts more dusky, having bliuk centres to the feathers; primary-coverts blackish, 
forming a wing pateh; quills sepla-brown, with ashy or clull rufous margins anci slightly palex ends, the first primary externally whitish, the next ones elged with hoary-grey, inner secondaries spotted with white, like the coverts; heal prale slatygrey with a line of chestnut feathers on each sicle of the crown which are barred with black ; sicles of face and ear-corerts ashy-grey spotted with minute specks of white ; chin white followed by buff on the throat which spreads over the breast, where it is wawhed more or less with ashy-grey ; on the sides of the body the feathers are vinouschestnut edged with pale grey; abdomen whitish, more or less suffured with buff; flanks and under tail-coverts sandy-buff; under wing-coverts, axillaries and the muler aspect of quills pearly-grey with a eertain amount of pale vinous on the under wing-coverts; the margin of the wing below is dotted with black; bill brown; iris yellow ; fect yellow. Total length $191 \mathrm{~mm}$; culmen, from base of skull, 21, wing 106, tail 42 , tarsus 25.

The only lnown speeimen of this birl is the type which is in the Tring Museum. Immature, Nest, Eggs and Distribution.-Unknown.

\section{I59. Austroturnix castanota.-CHESTNUT-BACKED QUAIL.}

Gould, Vol. V., pl. 85 (pt. xIrr.), Dec. 1st, 1843. Mathews, Vol. I., pt. 1, pl. 16, Oct. 31st, 1910.

Hemipodius castanolus Gould, Proc. Zool. Soc. (Lond.), 1839, p. 145, March 1840: Port Essington, Northern Territory.

Turnix castanota magnifica Mathews, Nov. Zool., Vol. XVIII, p. 181, Jan. 31st, 1912 : East Kimberley, North-west Australia.

Turnix castanota melvillensis Mathews, Austral Av. Rec., Vol. I., pt. 2, p. 27, April 2nd, 1912 : Melville Island, Northern Territory.

Turnix castanota alligator Mathews, ib. : South Alligator River, Northern Territory.

Distribution.-Northern Terxitory. North-west Australia.

Adult female-General colour above vinous-chestnut, the feathers edged on either web with white, producing a streaked appearance; these white marginal lines accompanied by an inner line of black; towards the end of the feathers : me more or less broken bars of black; lower back, rump and upper tail-coverts, dull vinots-chestrut shated with ashy-grey, and having nearly ob-olete blackish bars; seapulars like the back, but with somewhat broaler white margins externally; wing-coverts vinous-chestnut, the marginal coverts exlged with black, the median and greater series slightly ashy-grey on the elges, and having ovate spots of white, bordered with black on their upper margins; primary-coverts and quilis sepia-brown, almost black, with narrow rufescent edges, the first primary whitish along the outer web; tail-feathers vinous-chestnut with faintly indicated dusky cross-bars; crown vinous-chestnut, with a line of ashy-grey down the middle of the erown to the nape, the sides of the crown with searcely any spots or bars of black, forming a broad band of vinous-chestnut con each sicle of the mesial grey hand; fore-head, lores, and a broad eyebrow mottled with small white spots, each of which has a black margin, this spotted appearance being enntinued on to the siclea of the nape ; ear-coverts streaked with white, the feathers narrowly elged with black; sides of neck, hinder neck and upper mantlo vinous-chestnut, with orate spots of white, cach spot narrowly margined with black; this vinous colnur extending down the sicles of the breant, where the spots aresomewhat larger: throat clull white, tinged with pale ochre on the lower part; fore-neck, chest, and upper-breast ashy with a slight ochreous tinge and plentifully marlied with ovate spot of pale ochre, increasing in size, on the sides of the breasts, which are also somewhat ashy ; centre of breast and abdomen white, the sides of the body and flankis pale ocheous-buff, the flanks more dusky and having ashy hawes to the feathers; under tail-coverts sandy-luff ; ikxillaries ant under wine-coverts learlen-grey, the former slimtly washed with rufous; quills leaden-grey below, tinged with rufous along the inner web; iris 
yellow; feet yellow; bill brown. Total length $162 \mathrm{~mm}$.; culmen 16, wing 85, tail 37 , tarsus 19.

Adult male.-Differs from the female chiefly in being smaller; and the grey of the breast being mixed with buff. Total length $158 \mathrm{~mm}$.; culmen 15, wing 79, tail 41, tarsus 21 .

Immature.-Apparently similar to the adult.

Nestling.-Appears to be undescribed.

Nest.-A depression beneath a tussock of grass or where the grass grows long, especially in the neighbourhood of water.

Eggs.--Clutch, four; rounded, glossy and finely pitted ; they are greenishwhite, and some are buldly speckled with very dark brown, or almont black markings, especially on the larger cnd, while others have nuch smaller faint spots of purplinhbrown. The marking beneath the surface appear gIey. The egg rary somewhat in size and measurement. Dimensions 23-26 mm. by 19-21.

Breeding-season.-January.

Distribution and forms.-Pestricted to North-west Australia and Northem Territory. The forms are not yet understood. Gould described the species from Port Essington, Northem Territory, and his de-cription and measurements apply to the smaller race, and probahly i. c. alligutor (Mathews) frem the South Alligator River will prove srmonvmons as the Helville I.land race, A. c. melillensis (Mathews) is larger and resembles 1. c. mengifice (ALathew) from North-west Australia but is darker though of the same size. There seems to be individual as well as sexual variation and the plumage changes do not appear to be understood.

\section{Genus ALPHATURNIA.}

Alphaturnia Mathews, Austral Av. Rec., Vol. II., pt. 5, p. 112, Sept. 24th, 1914. Type (by original designation): Hemipodius velox Gould.

Smallest Turnices with stout "parrot-like" bills, short wings, shorter tails and short legs and feet. The bill is formerl like that of the preceding genus but is even more arched and deeper, the lower mandible even stronger. The wing is like that of the preceding genus, the inner secondaries long, reaching to the tips of the primaries. The tail is similar, but only abont one-third the length of the wing, and less than twice the length of the tarsus. The tarsus is short and is less than one and a half times the length of the culmen.

Coloration similar to that of the preceding generally, the male smaller and duller than the female.

\section{I60. Alphaturnia velox.-LITTLE QUAIL.}

Gould, Vol. V., pl. 87 (pt. II.), March 1st, 1841. Mathews, Vol, I., pt. 1, pl. 19, Oct. 31st, 1910.

Hemipodius velox Gould, Birds Austr., pt. II., March 1st, 1841: Yarrundi, Upper Hunter River, New South Wales.

Turnix leucogaster North, Ibis, July 1st, 1895, p. 342: Davenport Creek, Central Australia. Turnix velox vinotincta Mathews, Nov, Zool., Vol. XVIII., p. 182, Jan. 31st, 1912: Mungi, North-west Australia (interior).

Turnix velox picturata Mathews, ib. : Derby, North-west Australia (coast).

Distriburion.-Queensland, New South Wales, Victoria, South Australia, North-west Australia.

Adult female.-General colour above pale vinous, becoming darker on the back and scapulars, where the feathers incline to chestnut, barred with black, a submarginal line of black and ergerd with white, which gives a streaked alluearance; lescer and median wing-coverts jale vinous with a few dark spots here and there; 
bastard-wing and primary"-coverts blackish; primary-quills darli brown, the three outer ones margined with buffy-white on the outer webs, the remainder mottled with randy-bulf on the outer edges; innermost secondaries and tail-feathers similar to the back; head with a dotterl line of black on each side of the crown; sides of the face, neek, and boly pale vinous; chin, throat, midllle of the aboxmen, flanks, and under tail-eoverts white, more or less tinged with sandy-rufous; axillaries grey; under wing-coverts buffy-white; under aspect of quills pearl-grey ; bill, eulmen and tip) leaden-brown, remainder lealen-blue; iris yellowish-white; tar:us and feet fleshy-white. Total length $145 \mathrm{~mm}$.; culmen 13, wing 80, tail 28, tarsus 16 .

Adult malc. - D stinguished from the female by it s maller size and more strealied appearance above, the median line of white on the middle of the head, the white bars on the sides of the neck, and the submarginal black lines on the side of the breant; also by the more pure white of the abdomen. Soft parts similar to those given in the female. Total length $140 \mathrm{~mm}$; culmen 12, wing 75, tail 26, tarsus 15 .

Immature and Nestling of this common bird appear to be undeseribed.

Nest.-Formed of grass placed in a hollow of the ground behind some convenient tuft of grass.

Eggs, -Clutch, four; ground-colour buffish-white thickly spotted with slategrey, chestnut, and odel spots of purplish-brown ; surface with faint trace of gloss; axis 20 to $21 \mathrm{~mm}$., diameter 16.5 to 17 .

Breeding-scason.-The usual breeding-season is from September to December, but individuals may be found breeding practically all through the year.

Distribution and forms.- Through Australia, save the South-west and Tasmania. Four subspecies are named : f. $v \cdot \operatorname{ctc} x$ (Gould) from New South Wales, Victoria and South Australia ; A. $v$. leneogeter (North) a pallicl form from Central Anstralia with the lower-parts nearly all white: $A . \imath^{\prime}$. picherata (Jathews) from North-west Australia (coastal) much more rufous than the typrical form both above and helow; and A. 2 . vinotincta Mathews from the interior of the North-west, a much more pallid phase with the flanks and abdomen pale rue tinged, not so white below as .1. $v$. lencograster, but paler above.

\section{I6I. Alphaturnia pyrrhothorax,-RED-CHESTED QUAIL.}

Gould, Vol. V., pl. 86 (pt. II.), March 1st, 1841. Mathews, Vol. I., pt. 1, pl, 18, Oct, 31st, 1910.

Hemipodins pyrrhothorax Gould, Birds Austr., pt. II, March 1st, 1841 : Aberdeen, Upper Hunter River, New South Wales.

Turnix pyrrothorax berneyi Matherrs, Nov. Zool, Vol. XVIII., p. 182, Jan. 31st, 1912 : Parry's Creok, North-west Australia.

Austroturnix pyrrothorax intermedia Mathews, Austral Av. Rec., Vol. III., pt. 3, p. 53, April 7th, 1916: Wyangarie, Queensland.

Distribumos.-New South Wales, Queensland, Northern Territory, North-wost Australia, South Australia.

Adult female. - General colour above, dark asly-grey, varied with black in the form of narrow vermieulated bars, with cross lines of dull rufous on many of the feathers, several of which are elged with dull white, producing a slightly streaked appearance; these streakis more apparent on the margins of the seapulars, which have black markings, and reddish and black vermiculations towards their ends; wing-eoverts dull a hy-grey, with faint fulveseent edges: the inner melian and greater eoverts rufe-eent-buff with a few black cross-bars: bastard-wing and primarycoserts blackish-brown, formines a wing patch; quills dukliy-brown, with very marrow fulvescent margin. lighter on the four outer primaries, the first of which is ensunicun-ly margine 1 with buliy-white, like the edge of the wing; the secondaries 
fringed with ashy-white at the ends, the inner ones barred with buffy-white, and vermiculated and barred with black; rump and upper tail-coverts rather darker than the back, and regularly barred across with black and dull rufous, resembling the seapulars; tail-feathers ashy-brown, with indistinct blackish bars; crown of head dusky-brown, with cross-bars of black and a narrow line of white down the midclle of the hearl; the hine-neck like the mantle, swotted with moll white streaki, edged with blackish; on the ides of the neek, a sightly scaly aplyearance, the feather: being white, barred with black; lores, eyebrows, cheeks, and ear-coverts white, minutely barrerl with black, the ear-coverts ajpearing as if streaked with white; entire throat and breast orange-chestnut, like the flanks and under tail-coverts; on the silles of the breast a pateh of mottled grey; the feathers being grey, barred with fulvous and black; the abdomen whiter ; under wing-coverts very pale ashygrey, with a slight fulvous wash; quills dull ashy below; bill blue-grey; the culmen brown; iris white; feet fleshy-white. Total length $141 \mathrm{~mm}$; culmen 15 , wing 81 , tail 27 , tarsus 17 .

Adult male. - Snaller than the female, with the chin, upper throat and the whole of the abdomen white; the eyebrow and sicles of face, as also the line of feathers down the crown reddish-buff, and more miform than the white, black-edged plumage of these parti in the frmale; the sides of the neek buffy-white, with dusky-brown edges to the feathers, producing an escalloped appearance, which is continued dom the sides of the breast; the lower throat and breast orange-chestnut, like the tail and under tail-coverts; the upper-surface of the body less distinctly strealied, the white marigns of the scapular, and imer secondaries being more isabelline or rufescent. Total length $147 \mathrm{~mm}$.; culmen 13, wing 75, tail 31, tarsus 16.

Nest.-A slight depression in the ground, scantily lined with grasses, usually protected by a grass tuft or sheltered in a grain crop.

Eggs.-Clutch, four; ground-colour buffish-white, spotted, but not so thickly as Turnix velox, with slate-grey, chestunt, and dark brown; surface dull ; axin 22 mm., diameter 17.5 .

Breeding-season.-September to December.

Distribution and forms.-Through tropical Australia, rarely occurring outside save in northerm New South Wales. Three subspecies have been named: Alpha-

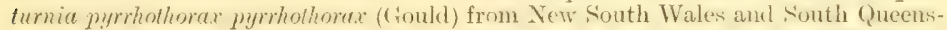
land and northem South Australia; Alphoturnie pyrrhothorax berneyi (Hathews) of much darker coloration above, especially on the mantle, which is dark ashygres instead of famish, and much more rufous below from North-west Australia and Northern Territory; and Alphatumia pyrrhothorax intermedia (Mathews) from North Queensland, intermediate, lighter generally than the preeding, but darker than the typical race.

\section{Genus COLCLOUGHIA.}

Colcloughia Mathews, Austral Av. Rec,, Vol. II., pt. 5, p. 112, Sept. 24th, 1914. Type (by original designation): Hemipodius melanogaster Gould.

Largest Tumices with long stout bills, short wings, medium tails and short legs and feet. The bill is long and stout, but shaped more like that of Turnix than that of Austroturnix, and stouter than that of ILarianornis. The wing is like that of Austroturnix, and the tail is similarly shaped and is about one-third the length of the wing, sometimes a little more; the legs are short and stout, the tarsus more than half the length of the tail.

Coloration: the female has developed a very distinct coloration quite unlike any of the others, the black head and blackish abdomen being distinctive; the nestling shows the stout bill and legs and darkish abdomen. 


\section{I62. Colcloughia melanogaster.-BLACK-BREASTED QUAIL.}

Gould, Vol. V., pl. 81 (pt. Exrr.), March 1st, 1816. Mathews, Vol. I., pt. 1, pl. 14, Oct. 31st, 1910.

Hemipodius melanogaster Gould, Synops. Birds Austr., pt. I., pl. 31, April 1st, 1837: New South $\mathrm{Wales}=$ Moreton Bay, Queensland.

Colcloughia melanogaster goweri Mathews, Austral Av. Rec., Vol. III., pt. 3, p. 53, April 7 th, 1916 : Gowrie Creek, Rockingham Bay, Queensland.

Distribotion.-Queensland, New South Wales.

Adult female.-General colour above brown, with a good deal of chestnut on the mantle, upper buck and seapulars, which are all cromecl with narrow bars of black, the seapulars with a broad black subterminal bar, and having a longitudinal white streak on the elge of either web; these streaks of white, borderel by a line of black, are also apparent on the mantle and upjoer back; but less marked on the lower back, which is almost entirely brown, sare for a few inclistinct bars of rufou. and black; rump) and upper tail-coverts with a slight shade of chestunt, but otherwise brown, sparsely barred across with black, and having a few white, black-edged, streaks or spots of white on the margins of the feathers, some of the upper tail-coverts with whitish spots or bars, followed by a terminal bar of black; wings much more thickly spangled with white, the wing-eoverts in the main ashy-brown, but mixed with ehestnut, most of them being of the latter colour, narrowly barred with black towards the ends, and having a broad white streak along the outer margin, before which is a conspicuous black streak; the lesser coverts nearly uniform dark bromn, slightly tinged with chestnut, but devoid of white streaks; the greater covert: dusky-brown, with sandy-brown margins; primary-coverts and quills uniform dusky-brown, the two outer primaries sandy-brown along the outer web; secondaries also dusky-brown, more or less sandy-buff towards the end of the outer web, the inner secondaries externally tinged with chestnut, and with a few dusky cross-bars; tail-feathers dusky-brown, freckled with a few cross lines of black; crown of head black, with a slight tinge of chestnut towards the nape, and a few white spotted feathers above the ere, continued above the ear-coverts to the sides of the neck, the feathers of which are black, with a broad subterminal spot of white, these white spotted feathers extending across the hind-neck; lores, ear-corerts and cheeks black, with a streak of white on the fore-part of the cheeks below the eye ; throat and entire breast black, with white spots or subterminal bars on the feathers, the white bar: being very distinct on the sides of the breast, where a few feathers are chestnut; abdomen and flanks dull ashy-grey, with a blackish bar on the ends of some of the feathers, the flanks also showing an occasional subterminal white spot between two burs of black; the long feathers of the lower flanks and the under tail-coverts vermiculated with blackish, and having a subterminal spot of dull white or buff; under wing-eoverts and axillaries dull ashy; the marginal corerts darker; quills dull ashy below. Total length $190 \mathrm{~mm}$. ; culmen 19, wing 114 , tail 38 , tarsus 23. Adult male. -Distinguished from the female by the absence of the black on the head, and throat, paler abdomen and smaller size. Total length $164 \mathrm{~mm}$, ; culmen 16, wing 104, tail 40, tarsus 23.

Immature.-Above like that of Marianornis, a shade moro buff, the breast feathers quite similar but the abdomen with buff feathers barrel inclintinetly with black; the bill and legs stout.

Nestling.-Undescribed.

Nest.-Merely a slight depression in the ground, in grassed or open scrub country.

Eggs.-Clutch, three to four; smooth and glossy; with the ground-colour greyish-white, minutely freckled over the entire surface with blue-grey, and bolder blotehes of blackish-brown ; with underlying blotehes of blue-grey; axis $26-27 \mathrm{~mm}$, diameter 21 . 
Breeding-season.- September to February.

Distribution and forms.-Restricted to Queensland and New South Wales. No subspecies recognised at present, though more material may necessitate the reinstatement of Mathews's $C . m$. goweri for the Northem form.

\section{FAMLY PEDIONOMIDA.}

This monotypic family, endemic to Australia, resembles in superficies the preceling, the most notable feature being the presence of a long hind-toe missing in the former. The bill is somewhat similar but the feathering is softer. Skeletal details are lacking for comparison and the pterylosis needs :tudy. In this family the wing is aquincubital, while it is quincubital in the Tumicicle, as far as is known. The leg muvele formula is ABXY + and both carotids are present, whereas in Turnix and its allies the left carotid only occurs. Gadow concluded from an anatomical examination that ornithologists who studied superficial features had been clever in guessing approximately its systematic position, which otherwise he would have been unable to determine.

\section{Genus PEDIONOMUS.}

Pedionomus Gould, Birds Austr., pt. I., Dec. 1st, 1840. Type (by monotypy) : P. torquatus Gould.

Turnicigralla Des Murs, Rev. Zool., Aug. 1845, p. 276, Sept. New namo for Pedionomus Gould.

Long-legged Turnices with a hind-toe.

The bill is long and thin, somewhat recalling that of Turnix (maculosa) but with the tip shorter and the nasal groove longer; the feathers of the fore-head advancing on the culmen ridge; the nasal apertures long and narrow slits, membranous opereulum present and generally as in Turnix. The wing is rounded with the primaries rather soft, the first five primaries subequal and longest; the inner secondaries very soft and extensive, reaching to the tips of the primaries. The legs are long, the tibia exponed for about one-third the length of the tarsus; the tarsus is half as long again as the culmen and is transversely sealed in front and behind; the toes are long, the middle toe longest but shorter than the tarsus, the inner and outer shorter and subequal, the hind-toe short but prominent; the claws sharp. Plumage soft.

Coloration generally freckling sandy-rufous with black, with a black and white collar and a rufous chest-band. Female larger than males and brighter coloured.

\section{Pedionomus torquatus.-PLAIN WANDERER.}

Gould, Vol. V., pl. 80 (pt. I.), Dec. Ist, 1840. Mathews, Vol. I., pt. 2, pl. 20, Jan. 31 st, 1911.

Pedionomus torquatus Gould, Birds Austr., pt. I., Dec. 1st, 1840: plains near Adelaide, South Australia.

Pedionomus microurus Gould, Proc. Zool. Soc. (Lond.), 1842, p. 20, Nov.: South Australia (interior).

Turnicigralla gouldiana Des Murs, Rev. Zool., Aug. 1845, p. 276, Sept. New name for $P$. torquatus Gould.

Turnicigralla macroura Des Murs, ib. : Error for P. microurus Gould.

Pedionomus torquatus goulburni Mathews, Austral Av. Rec., Vol. III., pt. 3, p. 53, April 7th, 1916: Goulburn, New South Wales.

Distribution.-Adjoining parts of Now South Wales, Victoria and South Australia; and north-west of New South Wales.

Adult female.-General colour above sandy-rufous, everywhere barred and rermiculated with narrow lines of black, including the head, back, scapulars, upyer 
tail-coverti, tail anel wings; primary-corerts blackish with buff tips; primaryyuills samly-buff at the base, becoming brown or vermiculated with brown towards the ends, the secombaries similar but more broakly tiplecel with bufi; a pateh on the fore-neck and nuchal collar bright chestnut; an entire collar of black and white feathers; sides of the face and upper throat white, minutely dotted with black, formur more or lesis washed with sandy-rufous ; chin and miclde of abdomen white, breast and ides of boly buff, barred or spotted with black like the under tail-coverts; $111 \mathrm{ler}$ wing-curerts white, washerl with buft and more or less dotted with black; under-surface of quills brown, chated with sandy-rufous; bill yellow, rhading into black at the point; iris striw-yellow; feet greenish-yellow. Total length $170 \mathrm{~mm}$, ; culmen 16 , wing 100 , tail 30 , tarsus 24.

Adult male. -Distinguished from the female by the chestnut jatch on the breast as well as the nuchal band being very much paler. The collar is only jndicated by buif and white, instead of black and white. Total length $152 \mathrm{~mm}$.; culmen 13 , wing 83 , tail 30 , tarsus 24 .

Immature mule. - Difiers from the adult in the absence of the chestnut patch on the breast.

Nestling.-Appears to be undescribed.

Nest.-Constructed of dried grasses, and is placed in a slight depression in the gromel underneath the shelter of some convenient shrub or tuft of grass.

Eggs.-Four in number for a sitting; in shape pyriform; of a stone-white ground-colour, thickly freckled and blotehed, and a few smudges here and there of clifferent shades of umber-biown and slaty-grey, a few nearly obsolete blotehes of the latter colour arpearing as if beneath the surface of the shell. Dimensions $35 \mathrm{~mm}$. by 25 .

Breeding-season.-September to February.

Distribulion and form.s.- South-eastern Central Australia only, and consequently no subspecies are at present admitted.

\section{ORDER COLUMBE.}

This order includes the Pigeons and the extinct Dodo and allied forms, the latter being separated with subordinal rank only as merely degenerate flightless formin, but this mav be wrong as no recent investigator has sturlied the facts from recent linowledge. The general features of Pigeons are not easily diagnosed, though the birds themselves can neter be confused: the bill with its generally pronounced dertrum suggests that of a Plover, while the operculate nostrils, the opereulum swollen, just as strongly reeall those of the Galline birds. In some cases the legs are absolutely Galline even to detail, while in others the legs are Parrot-like in appearanee. The species are numerous and world wide in distribution, and are remarkable as laying two white eggs, which generally hatch out a male and female, hence the expression "pigeon pair." Internal features are very variable, and when Garrod attempted to classify them by these means he made an extraordinary muddle. By means of superficial features, however, a fairly satisfactory scheme can be prepared. Many families will be admitted, and then it will be seen that the species have direrged in different directions from several kources. Thus the Australian Ground-Dores, here uniterl with the Turtle-Doves, may represent one family, the peculiar genus Ocyphaps another, and Lopholnimus a third. At present we are not so dividing the species, but wo anticipate fuller knowledge will necessitate such action.

():teologically, the skull shows a schizognathous palate with schizorhinal nostrils, and with ba-ipteryegold procesees in the Columbiformes, which are absent in the R.zphiformes. Some of the Columbiformes, howerer, show the nasals pacucto-holorhinal ; the lachrymal fuses with the ectethmoid and forms a large bone, in which sometimes a foramen is fomed. There is generally a supraoccipital formen and 
as in the Galliformes the postfrontal process fuses with the zygoma. The cervical vertebræ are fifteen to seventeen in number, the sternum having its posterior margin two motchel on each -iıle, or a single notch and a foramen on each side, this resulting in different groups.

The carotids are variable, but the tracheo-bronchial syrinx shows little variation, the intrinsie muscles always present, the extrinsic asymmetrical, while the digestive syintem is pericelous, showing gradation from the typically pericolous to the typically mesogyrous, cæeca small and nipple-like or absent. The leg muscles are variable, the complete formula ABXY + being common, sometimes the ambiens is missing, and in the genus Lopholaimus the accessory femoro-caudal absent. The biceps slip is present of peculiar formation, and the expansor secundariorum sometimes absent though generally present. The oil gland is sometimes present, sometimes absent, but when present never feathered; this variation is seen in closely allied species. The aftershaft is always said to be absent but the wing, though generally aquincubital has been recorded in one instance as quincubital. The pterylosis, as to detail, has not yet been reported upon. In the Raphiformes the scapula and coracoid are anchylosed, but in the Columbiformes the coracoids are free and though they meet they do not overlap; in both the furcula has no hypocleidium. It is probable that the association of the extinct flightless forms, Pezophaps and Raphus (= Didus olim) is incorrect, palæontologist having been misled by items of convergence, not of phylogenetic import.

In this place may be mentioned the Sand Grouse, which we have allowed as of ordinal rank between the Galli and the Columbe. Extemally they agree better to our eyes with the former, and we cannot understand those who have considered them as Pigeon-like. Internally they show many characters of Galline aspect and a few approaching those of the Pigeons, and hence have been regarded as a living representative of the Galline ancestral form from which the Pigeons developed. Vie cannot see, however, that any other than orlinal rank must be accorded the three groups.

\section{SUBORder COLUMBIFORMES.}

The superficial homogeneity of this group has marle the acceptance of families and even genera a difficult takk, and not the least assistance, but rather the reverse, has resulted from the criticism of the so-called deeper-seated characters. As a matter of fact, we find comparative? gool superlicial features but comparatively valueless deeper-seated ones in comection with the groups.

The internal features have been synopsised above, but we may here add that Garrol's differentiation was based on the presenee or absence of the ambiens, exca, oil gland and gall hladeder, and by u-age of this set of items he classed C'arpophayg with Phaps and then Phlogonas with Ptilopus in different families. It may be that Carpophaga and Ptilopus have descended from different sources, and that Phaps and Phlogonas (of which Gallicolumba seems to be the correct name) are also homeomorphic, but it would require more evidence than the above set of items to prove it. As a matter of fact, the most aberrant form, judged from the superficies, proves to be the most peculiar when internal features are examined. We have illower six families, Columbidas, Turturidae, Treronida, Microgouridae, Gourida, ans Didunculidax. The first namerl includes the Palearetie forms, and one or two of the seend family also range into the Palaaretic but the headquarters are tropical : the remaining four families are Oriental and Papuasian-Australian in range, the last three being reprenented by single species, but not Australian. Three families are therefore regardes as being representerl in Australia the Columbide, Turturide mil Tremidis and we are of the opninion that this arrangement is imperfect, thut we cannot at this time prove it. In America the first two families occur, and 
throughout Africa both are present as also in the Palwaretie Region. Fruit Pigeons range from India to Australia and the Pacific Islands, where they are generally associated with a series of Ground Pigeons which are here included in the Turturiclae, probably incorrectly.

\section{Family COLUMibide.}

We have allowed in this family two genera, Loxcomelana and Macropygir, owing to the prejudice of Garrod's observations on the internal features, but the former may be an aberrant Fruit Pigeon and the latter an aberrant Turtle-Dore. As these groups need careful investigation in a scientific manner we have preferrel to leave this matter as it stands without prejudice for the present.

\section{Genus LEUCOMELCENA.}

Leucomelona Bonaparte, Comptes Rendus Acad. Sci. Paris, Vol, XXXIX., p. 1104, Dec. 1854. Type (by monotypy): Columba norfolciensis Latham.

Large Pigeons with short bills, long wings, long square tail, short legs halffeathered in front and strong feet. The bill is less than the length of the head, a swollen dertrum with tip slightly deeurved about half the length; the eulmen ridge being flat behind, nostrils linear slits practically hidden by a swollen membranous operculum, more than half the length of the nasal groove ; the nostrils are parallel to the edge of the upper mandible which is parallel to the culmen as far as the nasal groove extends, from which point it descends to the tip, which is narrowert but not greatly from the base. The under mandible has a short gonys, the mandibular rami pronounced and grooved, the interramal space notable and completely feathered. The eulmen is less than the tarsus and less than one-tenth of the wing. There is no bare space round the eye. The wing is long, composed of strong broad feathers, the second and third only slightly scalloped on the outer webs and not at all on the inner webs; the first primary is long, equal to the fourth, the second and third subequal and longest. The tail is long and square, more than half the length of the wing, the feathers rery broad, the tips truncate, the upper and under tail-coverts short but composed of strong feathers. The legs are short, the tarsus being half-feathered in front but not behind where the sealing consists of small hexagonal scales, the front having a single row of strong horizontal seutes; the tarsus is longer than the culmen but shorter than the middle toe; all the twes are covered with strong seutes and the middle toe is verylong with a verylong claw, the outer and imner subequal; the hind-toe long with a strong membranous eige on each side, on the inside attached to similar membrane dereloped at the base of the inner toe.

Coloration greenish back above with head white as under-surface to abdomen which is slate.

\section{Leucomelœna norfolciensis.-WHITE-HEADED FRUIT PIGEON.}

Gould, Vol. V. pl. 59 (pt. xII.), Sept. 1st, 1843. Mathers, Vol. I., pt. 2, pl. 29, Jan. 31st, 1911.

Columba norjolciensis Latham, Index Ornith., Suppl., p. Lx., after May 30th, 1801: Norfolk Island (errore) $=$ New South Wales.

Columba leucomela Temminck, Trans. Linn. Soc. (Lond.), Vol. XIII., pt. I., p. 126, 1821 : Queensland.

Leucomelena norfolciensis quecnslandica Mathers, Austral Av. Rec., Vol. III., pt. 3, p. 54, April 7th, 1916: Queensland.

Distribution,-Queensland, New South Wales. 
Adult male.-Head and neck all round, as well as the greater portion of the under parts, cream colour with a pinkish metallic gloss; throat and cheeks pure white; lower flanks dark slate colour; entire back and wings black with copperyureen margins which have purple reflections; bastard-wing, primary-coverts, and ytuills black like the tail ; under wing-coverts blackish, as also the under tail-corerts, the latter with coppery reflections; bill and feet red; iris yellowish; bare space round the eye red. Total length $406 \mathrm{~mm}$.; culmen 22, wing 240, tail 140, tarsus 26.

Adult female.-Similar to the male.

Immature female.-Differs from the adult in being darker, with fine dusky rermiculations on the head, neck and under-surface, but with the same coppery reflections on the upper-surface.

Nest.-The usual flat and frail structure of twigs, three or four inches across.

Eggs.-Clutch, one to two, but mostly one ; elliptical in shape, sharply nipped off at one end ; texture comparatively fine; surface glossy; white. Dimensions $35 \mathrm{~mm}$. by 24 .

Breeding-season.-October to February.

Distribution and forms.-Restricted to Queensland and New South Wales. Two forms have been named: $L$. n. norfolciensis (Latham) from New South Wales (if which $C$. leucomela Temminck is a synonym from South Queensland); and $L . n$. queenslandica Mathews from North Queensland, as a paler race.

\section{Genus MACROPYGIA.}

Macropygia Swainson, Classif. Birds, Vol. II., p. 318, July 1st, 1837. Type (by subsequent designation Gray, p. 58, 1840) : C. phasianella Temminck, Planch. Color. 1821 not Trans. Linn. Soc. Lond, $1821=M I$. tenuirostris Bonaparte.

Coccyzura Hodgson, Journ. As. Soc. Bengal, Vol. XII., p. 937, 1843 (? 1844). Type (by original designation): Coccyzura tusalia Hodgson.

Tusalia Hodgson, ib., same type.

Large Pigeons with short bills, long wings, long wedge tails and small legs and long toes.

The bill is short, a little dilated at the base, the dertrum fairly strong, the gonys well angulated, the sides of the under mandible faintly grooved, the interramal fyace fully feathered; otherwise details as in preceding. The wing is long, the first primary faintly scalloped on the inner web, the second and third faintly on the outer webs; the first primary is lons, about equal to the fifth, the second and fifth suberual and searcely exceeded hy the third which is a trifle the longest. The tail is very long and wedge shaped, composed of twelve feathers, the outside ones unly about half the length of the inmost pair; the feathers are rery strong and broad but have the ends rounded, not truncated; the tail is almost as long as the wing. The tarsus is very short, less even than the culmen, and feathered half its length, the lowermost portion showing in front a few broad horizontal seutes, the tarsus behind showing a wrinkled skin only, save at base, where a few obscure minute reticulations remain. The toes are as in the preceding but much weaker.

Coloration rufous-brown above, paler brownish below.

\section{I55. Macropygia phasianella.-PHEASANT PIGEON.}

Gould, Vol, V., pl. 75 (pt. xvIr.), Dec, Ist, 1844. Mathews, Vol. I., pt. 2, pl. 30, Jan. 31st, 1911.

Columba phasianella Temminck, Trans. Linn. Soc. (Lond), Vol. XIII., pt. I., p. 129, 1S21 : near Port Jackson, New South Wales.

Macropygia phasianella robinsoni Mathews, Nov. Zool., Tol. XVIII., p. 185, Jan. 31st, 1912 : Alexandra, Northern Territory.

Distributrox,-Northern Territory, Queensland, New South Wales. 
Adull male-General colour above and below rufous-chestnut, paler on the under-surface, with purjle and green reflections on the hinder neck and mantle; bastard-wing, primary-coverts and quills blackish-brown, the latter with rufous edgings; tail chestnut with indications of a blackish bar towards the tip on the three outer feathers, middle feathers with obsolete dark bars, searcely visible; fore-head paler rufous than the crown; chin buff; throat, sides of face, and chest dark cimnamon, becoming paler on the breast and rufous-chestnut on the flanks and under tail-coverts; under wing-coverts much darker chestnut; under-surface of tail pale rufous, some of the outer feathers marlied with slateerey; iris deep yellow or blue with an outer circle of searlet, orbital skin biuishlilac, feet pink-red. Total length $382 \mathrm{~mm}$; culmen 24, wing 197, tail 187, tarsus 22.

Adult female.-Differs from the adult male in its smaller size and paler coloration, the head chestnut, the lower hind-neck, and upper back brown, minutely barred or dusted with rufous, the feathers of the wings and scapulars dark brown, everywhere margined with bright chestnut, the bastard-wing, primary-coverts and quills dark brown, edged with rufous; rump and upper tail-coverts bright chestnut; the tail similar but dluller; chin and middle of upper throat buff; sides of face and sides of neck pale chestnut with narrow black bars, becoming deeper chestnut colour on the fore-neck and chest, and with the dark bars wider ajart, the abdomen paler chestnut and the dark bars less defined; bill black; iris white ; feet red. Total length $393 \mathrm{~mm}$. ; culmen 23, wing 173, tail 180, tarsus 22 .

Immature male.-Differs from the actult male in having the cromn of the head bright chestuut; the feathers of the wings margined with bright rufous-chestnut; hind-neck, mantle, fore-neck and chest narrowly barred with rufous and black, more broadly on the breast; a buff streak below the eye; bill very dark slate colour; iris chestnut; tarsus and feet dark magenta. Wing $184 \mathrm{~mm}$.

Immature female. - Similar to the immature male described abore. Bill black: iris white; feet red.

Nest.-A very primitive structure being simply a few sticks placed crosswise, without any cavity, and barely sufficient to retain the egg in position.

Egg.-Clutch, one; a true ollipse in form; pure white; the texture of the shell boing fine and slightly glossy. Dimensions $34 \mathrm{~mm}$. by 24 .

Breeding-season.-October to February.

Distribution and forms.-Queensland, Eastern Northern Territory and New Siouth Wales, and probably extra-limital. The two dustralian forms are easily separable by size, the northern form 11,1 robinsoni IIathews, being notably smaller. Puthschild and Hartert, twenty years ago, indicated four additional subspecies ranging west to sumatra and north to the Philippines, but this distribution wants reconsideration with more material available than at present.

\section{FAMLX TLPTLTIDE.}

There appears to be at least two distinct groups associated in this family; the Turtle-Doves and the Ground-Doves. The former are more delicate groundfeeding but flying birds, while the latter are stouter ground-feeding and groundliving birds. The feet of the latter are rery stout and of Galline form, while those of the former are more slemter and of a semi-perching character. The bills differ in much the same way, and of course the wings show corresponding difierences. Garrot's peruliar grouping cast a blight upon Pigeon systematics, and novel work must be undertalien in a seicntifie manner to rearrange the birds accurately. If the restricted families here asmitted are polyphyletic, as farrod's conclusions suggent, the rearrangement will provide many surprises. 


\section{Genus CHRYSAUCHCENA.}

Chrysauchoena Bonaparte, Comptes Rendus Acad. Sci. Paris, Vol. XL., p. 210, Feb. 1855. Type (by original designation): Columba humeralis Temminck.

Erythauchona Bonaparte, Comptes Rendus Acad. Sci. Paris, Vol. XL., p. 221, Feb. 1855. Type (by monotypy) : Columba humeralis Temminck.

Medium Doves with slender bills, long wings, long wedge tail and short legs and long toes. The bill is comparatively long and slender, the dertrum short and decurved with a forward direction, tip not hooked, nor the dertrum swollen; the culmen ridge is flattened for more than half its length, the linear no.trils overhung by a swollen membranous delicate operculum not expanded at the base; the lower mandible has a short semi-angulated gonys, the rami long and obsoletely grooved, the narrow interramal space feathered. The wing is long with the first primary shorter than the sixth, the : econd equal to the fifth and the third longest; the secondaries are comparatively. long and the first primary has the tip abruptly attenuated for about ono-third the length, the outer edge a little scalloped; the fourth and fifth primaries show a little scalloping on the outer edges but none, except the first, show any on the inner edges. The tail is long and strongly wedge shaped, almost as long as the wing; the feathers are fourteen in number, with rounded tips, fairly broad, the outer ones about two-thirds the length of the central pair. The legs are short and unfeathered, the tarsus being little longer than the culmen and about the same length as the middle toe; the front of the tarsus is corered with regular broad horizontal scutes, the sides and hind portion haring an unbroken skin; the toes are regularly sealed, the middle toe longest, but not abnormally so, the inner and outer subequal, the claws long but the mid-claw not extraordinarily elongated ; the hind-toe very long and straight and without much lateral skin expansion.

Coloration brownish above with black tips to feathers, fore-head and breast bluish-grey, abdomen whitish, tail brombish with white tips to outer feathers.

\section{I66. Chrysauchœna humeralis.-BARRED-SHOUIDERED DOVE.}

Gould, Vol. V., pl. 72 (pt. xr.), June 1st, 1844. Mathews, Vol. I., pt. 2, pl. 31, Jan. 31 st, 1911. Columba humeralis Temminck, Trans. Linn. Soc. (Lond.), Vol. XIII., pt. I., p. 128, 1821 : Broad Sound, Queensland.

Columba erythrauchen Wagler, Syst. Av., Columba, sp. 98, p. (266), (before Oct.) 1827. New name for C. humeralis Temminck.

Geopelia humeralis inexpectata Mathews, Nov. Zool., Vol. XVIII., p. 186, Jan. 31st, 1912 : Parry's Creek, North-irest Australia.

Geopelia humeralis apsleyi Mathews, Austral Av. Rec., Vol. I., pt. 2, p. 27, April 2nd, 1912 : Melville Island, Northern Territory.

Geopelia humeralis headlandi Mathers, Austral Av. Rec., Vol. I., pt. 8, p. 187, March 20th. 1913: Port Headland, mid-IVest Australia.

Distribution.-New South Wales, Queensland, Northern Territory, North and mid-West Australia.

Adult male-General colour abovo earth-brown, the feathers everywhero margined with black; occiput and hind-neck barred with grey and black; feathers of the lower hind-neck and mantle very pale cinmamon, edged with black; entire buck and wings carth-brown, margined with black, being somewhat paler on the outer wing-coverts; bastard-wing almost entirely earth-grey, with scarcely any black margins; primary-coverts blackish, with chestuut on the inner webs; quills blackish on the outer wobs and at the tips, inner webs chestnut; innermost secondaries like the back, with chestnut on the inner webs at the base; middle twil-feathers grey, next pair reddish-brown, the outer ones chestnut-hrown, tipped with white; fore-head, line behind the eye, and throat pale blue-grey, becoming clarker on the lower throat, sides of neck and upper-breast; lower-breast, ablomen 
and under tail-coverts white, more or less tinged with pink, eppecially on the brea-t : under wing-coverts cimmamon-rufous, including the quill-lining, the latter tiplied with brown. Bill dull blue, iris pale rellow, hare skin round the eyes dull purple: tarsus pinkish-red, feet clarker. Total length $300 \mathrm{~mm}$; culmen 22, wing 1:2, tail 132 , tarsus 23

Adult female.-Similar to the adult male with respect to the plumage, but smaller. Total length $295 \mathrm{~mm}$; culmen 18, wing 131, tail 122, tarsus 21 .

Immature female. -Differs from the alult female in being much more barred on the upper-surface; cromn of head almost entirely covered with narrow barring ; the melian and greater eoverts tipped with white, forming a more or less cionh? wing-bar; inmermost secondaries narrowly tipped with white; the blue-grey feathers of the chest moro or less tinged with pink.

Nest.-A loose, light structure or platform, three to four inches in diameter, composed of twigs, portions of elimbing plants, and sometimes grass. L'ually. situated in a low tree or thick bush in scrub.

Eggs.-Clutch, two; pure white, smooth and glossy; axis 26-28 mm., diameter 21 .

Breeding-season.-August to March.

Distribution and forms.-Restricted to Australia and only in the northern portion, but closely allied species in the islands north of Australia. Four subspecies are distinguishable: $C . h$. humeralis (Temminck) from Queensland and New south Wales; $C . h$. incxpectata (Mathews) from North-west Australia, smaller and paler; C. h. apsleyi (Mathews) from Melville Island, differing in its darker upyer-surface, praler fore-head and shorter bill; and $C$. h. headlandi (Mathews) from mid-We:t Australia, paler even than $C$. $h$. incrpectata and smaller, being thus the palest and smallest form.

\section{Genus GEOPELIA.}

Geopelia Swainson, Classif. Birds, Vol. II., p. 348, July 1st, 1837. Typo (by monotypy): Columba lineata Sparrman.

Tomopeleia Reichenbach, Nat. Syst. Vögel, p. xxv., 1852 (? 1853). Type (by monotypy): Columba maugeus Temminck.

Small Dores with weak bills, long wings, long werige tail and small legs and feet. The bill is formed as in the preceding genus but is shorter and weaker and is shorter than the head, is a little more expanded at the base, the dertrum lexs deflexed, the gonys less marked and searcely ascending, the interramal space a little wider and searcely any signs of a groove on the sides of the rami, while the interramal space is not fully feathered. The wing is rounder than in the preceling case, the first primary being equal to the fifth, and little shorter than the second, third and fourth which are subequal, while the secondaries are comparatively shorter, the scallopir.g and attenuation of the primaries being the same as in the last-named genus. The tail is composed of fourteen feathers, a little rounded but broad at the tijs, and strongly werlge shape but the micklle eight feathers almost all the same length. the outside pair more than half the length of the central pair. The tarsus is short and comparatively stout, the front having a row of large horizontal scutes and naked unsealed skin at sides and back; the toes are slender, the middle toe longest, the inner longer than the outer, all the elaws short; the hind-toe very long and straight with a long claw equalling the inner toe and claw, and with scarcely any lateral skin expansion.

Coloration brownish, the back feathers, wing-coverts, and scapulars with bold black tips, the hind-neck and breast whitish with black bars closely formed ; top' of heal and throat bluish-slate, ablomen pinkish-white, tail brownish, the outer feathers with long white tips. 


\section{I67. Geopelia placida.-GROUND-DOVE.}

Gould, Vol. V., pl. 73 (pt. xr.), June 1st, 1845. Mathews, Vol. I., pt. 2, pl. 32, Jan. 31st, 1911.

Geopelia placida Gould, Proc. Zool. Soc. (Lond.), 1844, p. 55, Sept. : Port Essington, Northern Territory.

Geopelia tranquilla Gould, ib., p. 56 : Liverpool Plains, New South Wales.

Geopelia placida clelandi Mathews, Nov. Zool., Vol. XVIII., p. 186, Jan. 31st, 1912 : Coongan River, mid-West Australia.

Geopelia placida melvillensis Mathews, Austral Av. Rec., Vol. I., pt. 2, p. 28, April 2nd, 1912 : Melville Island, Northern Territory.

Geopelia placida hedleyi Mathews, ib., pt. 4, p. 84, Sept. 18th, 1912 : Cape York, Queensland.

Distribution.-Australia generally. Not Tasmania.

Adult male--Upper-surface barred everywhere with black, white and grey; fore-head and throat pale blue-grey ; hinder crown and nape earth-brown, narrowly barred with blackish; neck all round narrowly barred with black and white, each feather having two black bars and three white ones; the hind-neck darker and more like the back; entire back and wings earth-brown, barred with black, paler on the outer coverts; bastard-wing and primary-coverts blackish; quills brown, paler on the outer edges and on the inner webs towards the base; innermost secondaries like the back; middle tail-feathers grey, the next two pairs blackishbrown; the outer feather: for the mont part black, tiplped with white: the outermost black, margined on the outer web, and broally tipeed with white: breast and sides of body with a pinkish tinge; abdomen and under tail-coverts white; axillaries and under wing-coverts deep chestnut; a patch of white at the base of the secondaryquills below; quills below, brown, inner webs inclining to rufous. Bill black, base bluish-black; iris white; bare space round the eves bluish-green; tarsi and feet flesh colour. Total length $210 \mathrm{~mm}$.; culmen 15, wing 104, tail 88, tarsus 17.

Adult female.-Similar in every respect to the adult male both in the colour of its plumage and in measurements.

Immature.-As adult but paler and with white edges to feathers.

Nest.-A small, slight platform, about two or three inches in diameter, composed of twigs and rootlets, or just sufficient materials to ensure the safety of the contents. Isually placed on a horizontal himb of a tree, where branches or suckers shoot, often overhanging a stream.

Eggs.-Clutch, two; pure white; smooth and glossy; axis 21-22 mm., diameter 15.

Breeding-season,-August to January, but practically all the year round.

Distribution and forms.-Australia only. Five subspecies have been named, as follows: G.p. placida Gould from the Northem Territory and North-west Australia; G. $p$. tranquilla Gould from New South Wales, South Queensland, Victoria and South Australia, much darker and also larger in every item : G.p. clelandi Mathews from mid-West Australia, a much paler form in every particular; G. p. melvillensis Mathews from Melville Island, Northern Territory, larger than $G$. p. placida, and a.-o lighter: and $(i, p$. hedleyi MIathew, from Northem Queensland, a darker form, even than G. p. tranquilla, and also smaller.

The bird described by Ogilvie-Grant as Geopelia shortridgei (Bull. B.O.C., Vol. XXIII., p. 73, 1909), from Carnarvon, West Australia, is a hybrid between this species and the next.

\section{Genus STICTOPELEIA.}

Stictopeteia Reichenbach, Nat. Syst. Vögel, p. xxv., 1852 (? 1853). Type (by original designation): Columka cuncata Latham.

Smallest Doves with slender bills, long wings, very long wedge-shaped tail, and small legs and feet. The bill is slender and a little shorter than the liead, the 
dertrum a little more developerl but even les deflexest, the membranous nasal opereulum nore swollen, the under mandible with the genys longer but scarcely ansulated, the intermmal space half-featheres, the anterior portion tending to fusion shewing depresion only, the rami grooved as far as the gronys. The wing long with the attenuated first primary a little shorter than the fifth, and both much shorter than the second, third and fourth, which are longent and subergal ; seallopeing as in the two preceding forms and secondaries short. The tail is very long, lenger eren than the wing, strongly grauluated, the feathers long and rather thin, the outsiche feathers much less than half the central ones, the four midclle ones alout equal, fourtern feathers in all forming the tail. 'The tarsus is short, about equal to the eulmen and midlle toe, and stout, the front of the tarsus with strong horizontal feutes, the siles and hind portion with skin only showing no seale formation, the middlc toe long and thin, the mid-claw clengated, the inner and outer toessubernal, the hind-toe long and straight, the elaw nomal; very little skin secn on sides of hind-too which is shorter than inner toe.

Coloration : blue-grey head and breast, ablomen pinkish, tail with outer feathers half-way white, upper-surface pale brown without any bars but white spots on wingcoverts, inner secondaries and scapulars; immature barred above and below.

\section{Stictopeleia cuneata.-SPOTTED-SHOULDERED DOVE.}

Gould, Vol. V., pl. 74 (pt. Xvrr.), March 1st, 1845. Mathews, Vol. I., pt. 2, pl. 33, Jan. 3lst, 1911.

Columba cuneata Latham, Index Ornith. Suppl., p. Lxr., 1801, after Mlay: Sydney, Now South Wales.

Columba macquarie Quoy et Gaimard, Voy. do l'Uranio et Physic., Zool., p. 122, pl. 31, Aug. 28th, 1824: New South Wales.

Columba spiloptera Vigors, Zool. Journ,, Vol. V., p. 275. June 1830: New South Wales.

Geopelia cuneata mungi Mathews, Nov. Zool., Vol. XVIlI., p. 187, Jan. 31st, 1912 : Mungi, North-west Australia.

Distribution - Australia generally. Not Tasmania.

Adult male-General colour above including the entire back and wings, pale brown, with small rounded spots of whito on the wing-coverts and scapulars; batan?-wing brown ; primary-coverts, and quills brown on the outer webs and tips, inner webs chestnut; ;econlaries grey, without any chestnut : middle tail-feathers grey, beoming blackish towards the tips and showing obolete dark cross-hars for the entire length, the next pair blackish; the four outer pairs black at base, with long white tips; fore-head and crown pale blue-grey like the chin and throat, becoming darker on the breast and under wing-coverts; axillaries and sides of boly of the same colour, but paler ; abclomen and under tail-eoverts white; quilllining pale chestnut. Bill black; iris red ; feet reddish-eream colour. Total length $200 \mathrm{~mm}$.; culmen 15, wing 95, tail 101, tarsus 15.

Adult female.-Differs from the malo in having the sides of neck, fore-neck and chest pale brown, somewhat like the hime-neck; bill brown; iris light red ; bare skin round tho cyo also red; tarsi flesh-white, feet white,

Immature.-Fore-head whitish, top of head fawn with brown tips to feathers, back of heal and neck a little greyer with inlintinct browner tips, back brown with pule rufous tips, tail-fenthers short, exntral ones brown, outer ones white; primaries brown with inner webs chestnut, outer one attenuated but more broadly than in adult; coverts brown with broad whitish tips; inner secondaries with fawnish tip): ; chin pale bluish-white, chest bluish with brewn and fawn barring, alxlonten and flanks dirty.

Immature (a little older).-Head more boldly marked, scapulars and wingcoverts with broader fawn tips, the former also barred with fawn, the rump and upler tail-eoverts with brown tips, the inmer secondaries fawn tipled, the central 
tail-feathers broad, darker towards ends, the onter similar to those of adult; chin and throat whitish, breast brownish, feathers barred with fawnish-white, lowerbreast more obsoletely barred, abdomen and flanks dirty; inner wing-lining brownish, the feathers on the edge with fawn tips.

Nest.-A small, frail structure, usually composed of dry grass, including the flowering portions, and placed in the fork of a low or bushy tree.

Eggs.-Clutch, two; roundish in shape; texture of shell fine ; surface glossy; pure white. Dimensions $19 \mathrm{~mm}$. by 15 . Narch.

Breeding-season.- Practically all the year. May to September. January to

Incubation-period.-(In captivity) twelve days.

Distribution and forms.-Australia only. The form from the interior of the North-west of Australia has been named S. c. mungi by Mathews, on account of its paler coloration, both above and below, and it is probable that this form occurs throughout Central Australia, the typical form being named from Sydney, New South WVales.

\section{Genus CHALCOPHAPS.}

Chalcophaps Gould, Birds Austr., pt. XIII., Dec. 1st, 1843 (Vol. V., pl. 62). Typo (by monotypy): Columba chrysochlora Waglor.

Monornis Hodgson, in Gray's Zool. Miscell., p. 85, June 29th, 1814. Typo: Monornis perpulchra? Nomen nudum.

MTedium Ground-Doves with slender bills, long wings, short rounded tail and hort legi and feet. The bill is compratively long and slender, the culmen ridge flattened, the dertrum descending and rather strongly decurved but not much swollen; the nostrils linear and the membranous operculum a little swollen; the rami long and ren-ibly grooved, the gonys very short, a little angulated and aseending, the interramal space narrow and half-feathered, anteriorly showing a naked skin space. The wing is rounded, the secondaries long, the primaries very little scallowed, the outer one slightly on the inner web; the outer primary is long, equal to the fourth, the second and third a little longer, subequal and longest. The tail is composed of twelve broad feathers with rounded ends, and only a little rounded in shape and about three-fifths the length of the wing. The tarsus is short and stout, a little longer than the culmen, and unfeathered, shows a little reticulation only faintly on the back and only a few broad scutes on the lower portion in the front. The toes are comparatively short and stout, the middle toe longest, the inner and outer a little less and subequal and the hind-toe notably shorter, though : till long and straight, the claws short and little curved.

Coloration: head, neck and chest vinous-brown paler below, abdomen paler vinous, wing-coverts and back bronze-green, primaries and tail reddish-brown.

\section{I69. Chalcophaps chrysochlora.-LITTLE GREEN PIGEON.}

Gould, Vol. V., pl. 62 (pt. xir.), Dec. 1st, 1843. Mathews, Vol. I., pt. 3, pl. 34, April 29th, 1911.

Columba chrysochlora Wagler, Syst. Av., Columba, sp. 79, p. (256), (before Oct.) 1827:

"Ceylon, Java, etc.," error = New South Wales (Gosford).

Chalcophaps longirostris Gould, Birds Austr., Introd., 8vo ed., p. 79, Aug. 1st, 1848 : Port Essington, Northern Territory.

Chalcophaps occidentalis North, Viet. Naturalist, Vol, XXIV., No. 8, p. 135, Dec. 1907 : Port Keats, Northern Territory.

Chalcophaps chrysochlora rogersi Mathews, Nov. Zool., Vol. XVIII., p. 187, Jan. 31 st, 1912 : Cairns, Queensland.

Chalcophaps chrysochlora kempi Mathews, ib.: Cape York, North Queensland.

Chalcophaps chrysochlora melvillensis Zietz, South Austr. Ornith., Vol. I,, pt. I., p. 12, Jan.

1914: Melville Island, Northern Territory.

Distribution.-Northern Territory, Queensland, New South Wales, Victoria. 
Adull male--IIead, hind-neek, sides of the neck, and mantlo dark vinous.

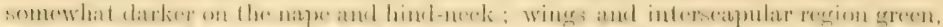

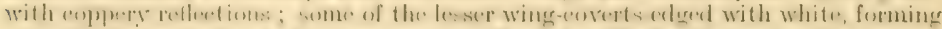

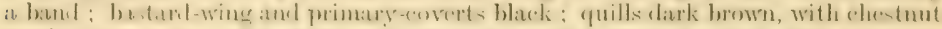

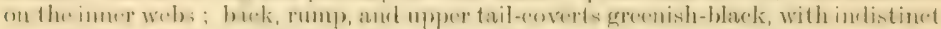

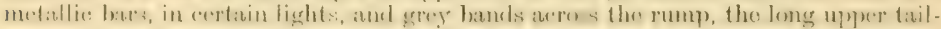
eovorts palor towards tho baso; outor tril-feathors groy, with a subapical black band, romainder of tho tail bronzy-brown; sides of tho face, chin, throat, and fore-

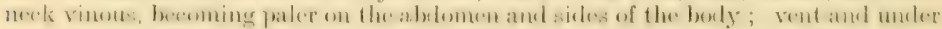
tail-covorts slate-grey, longer onos blackish; under wing-coverts and tho greater part of tho quill-lining ehestnut; bill red, base groyish-bluo; iris brown, orbits groy; foot dull rod. 'Total longth $240 \mathrm{~mm}$.; culmon 22, wing 153, tail 89, tarsus 27.

Adull female.-Differs from the adult male in having the head and hind-neck paler vinous; wing-bar grey, instead of whito; upper tail-coverts brown, with dark odgros to tho feathors; chin, throat and under-surface rust-brown; under tail-covorts redklish-brown, with dark edges. 'T'otal length $233 \mathrm{~mm}$.; culmen 22, wing 147 , tail 79 , tarsus 25.

Alult male.-Head, hind-neck, sides of tho neek and mantle lilac, somewhat darker on the hinder part of the head; wings and interseapular region green, with

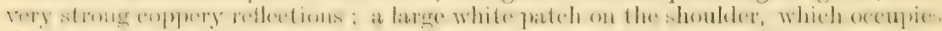
tho greater portion of the lesser wing-coverts; bastard-wing and primary-coverts hlack; quills dark brown on the margins of the outor webs, chestnut on the inner ones, the latter colour encroahing on both webs at the base of the inner primaries and secondary-quills; lower back blackish, with minute bronze bars on some of the feathers and crossed by a grey band; tail for the most part black, tho two outer pairs of feathers on cach sido grey, with a wide subterminal black band; chin and throat vinous, becoming paler on tho breast and abdomen; vent and short under tail-coverts slato colour, the longer ones black; lower aspect of the tail-feathers black, with palo tips; under wing-eoverts and quill-lining palo chestnut; bill red; iris brown; tarsi and feet pink. Total length $260 \mathrm{~mm}$, ; culmen 26, wing 158 , tail 86, tarsus 27. (I'ypo of C. occidentalis North.)

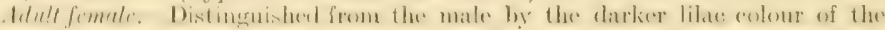

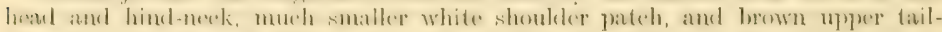
eoverts. 'Total length $260 \mathrm{~mm}$; culmen 25, wing 156, tail 84. (Typo of $C$. occidentalis North.)

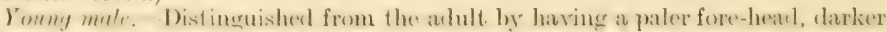

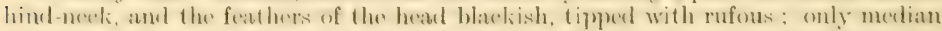
wing-eovorts greon, primary-eoverts chestuut, most of the quills tipped with the same colome, featlers on the siles of the neck and breats blackish, matrines with

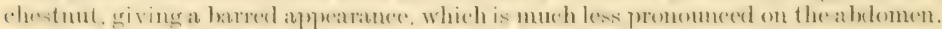

Nest.-A frail, llat structuro of twigs ; placod in $n$ low treo.

Eqq. - Clutch, two; smooth and slightly glossy; of a pale cream-colour; axis $2.5-26 \mathrm{~mm}$., diametor: 20 .

Brecting-season,-October to January.

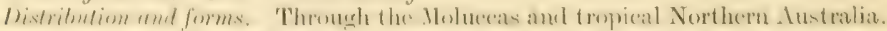

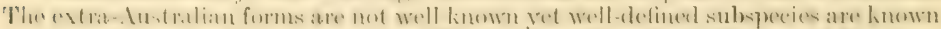

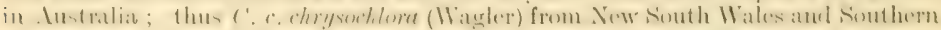
Queensland; C. c. longirostris Gould from Northern 'Territory (so distinet that it has been renamed twico- by North as $C$. occidentalis, and by Zietz as C. c. melvillensis, tho latter perhapes later reeognisablo) with a notably longer bill, with brighter

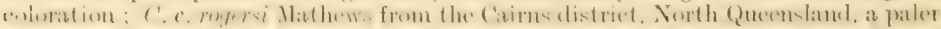
form, with the under-surface paler and the nape coloration duller; and $C$. c. kempi from Cape York, North Queensland, a much smaller form. 


\section{Genus PHAPS.}

Plaps Selby, Naturalists' Library, Pigeons, p. 194, (beforo Aug.) 1835. 'Iypo (by original dosignation): Columba chalcoptera Latham.

Very largo Ground-Doves, with slender bills, long wings, medium tail and small legs and feet. The bill is larger, but formed very similarly to that of the

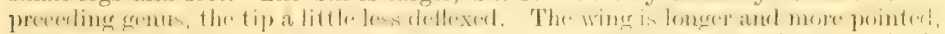
the feathers showing very little scalloping, though rather narrow, tho first a little incised on the inner web; the first is long, almost as long as the second and third, which are subequal and longest, and longer than the fourth; secondaries short. The tail is long and round, of sixteen broad feathers, rounded at the tips, and is a

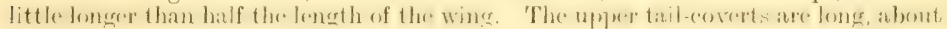
three-quarters tho length of the tail. 'The feet are short and stout, the tarsus covered

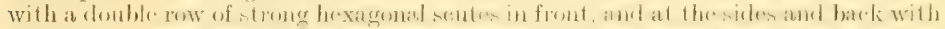
very small hexagonal scutella, scarcely recognisable separately. The toes are covered with definite scutes, the middle too longest, the outer shorter than the inner, both much less than the middle one, the hind-foe still shorter, though still long and straight and practically unmargined, claws rather long.

Coloration: fore-head whitish, throat white, under coloration palo vinous, upper

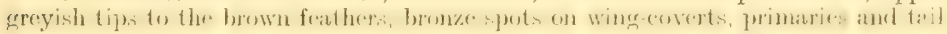
brown.

\section{I70. Phaps chalcoptera.-BRONZE-WINGED PIGEON.}

Gould, Vol. V., pl. 64 (pt. xur.), Dec. 1st, 1843. Mathows, Vol. I., pt. 3, pl. 35, April 29th, 1911.

Columba chalcoptera Latham, Index Ornith., Vol, II., p. 604, (bcforo Dec. 9th) 1790: Sydnoy, Now South Wales.

Phaps chalcoptera consobrina Mathows, Nov. Zool., Vol. XVIII., p. 188, Jan. 31st, 1912: P'arry's Crook, North-west Australia.

Phaps chalcoptera murchisoni Mathews, ib. : East Murchison, mid.West Australia.

Phaps chalcoptera riordani Mathews, Austral Av. Rec., Vol. I., pt. 2, p. 28, April 2nd, 1912: Melville Island, Northorn Territory.

Distribution.-Australia generally. ? Tasmania.

Adult male.-Fore-head to the middle of the crown white, tinged with fulvous; sides of the crown, and a band areros the hearl arljoining the white matrente-he-tnut ; hinder part of head washod with grey, like the hind-neck; car-coverts and sides of the neck lead-grey; back and scapulars, as also the rump and upper tail-coverts dark brown, with paler brown margins to the feathers, some of the seapulars and feathers of the lower back blackish-brown; wing-coverts pale grey, with whitish edgings, the outer webs of the lesser and median coverts have metallic coppery reflections, those of the greater coverts are for the most part green, and those on the inner secondaries purple and dark green; bastard-wing, primary-coverts and quills greyth-brown, the latter erdecel with white on the outer wets and pale rufous on the inner ones; tail-feathers grey, with a blackish subterminal band; eyebrow

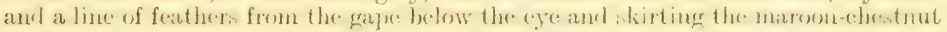
on the side of the crown, white; chin and throat white; fore-neck and upper-breast palo vinous; abdomen pale grey, becoming darker on the thighs and under tailcoverts; sides of the body, axillaries, and under wing-coverts cinnamon, like the quill-lining; bill brownish-black; iris dark brown; tarsi and feet pinky-red. 'Total length $360 \mathrm{~mm}$; ; culmen 28, wing 194, tail 106, tarsus 27.

In what appears to bo a very old male bird, the hinder part of tho head is entirely marosn-ebestnut, the metallie esolom on the wings very bright, inelining to fiery red, instead of green, on the greater coverts, and the purple-green of tho seeondaries is extended over a great number of feathers. 
Adult female.-Differs from the male in smaller size and in having the fore-part of the head grey, the hinder crown earth-brown, like the hind-neck and upper back, the absence of grey on the ear-cuverts and sides of neck, the much paler vinous on the breast, and the paler grey on the abdomen. Total length $330 \mathrm{~mm}$.; culmen 26 , wing 182 , tail 103 , tarsus 28 .

Young male. Distinguished from the adult male by the almost entire absence of metallic spote on the wing-coverts, which are dark grey, eclged with white; bincler part of head earth-brown, with a few maroon-chestnut fenthers aplearing, and the fore-part of the head white.

Nest. - A slight structure or platform of twigs, slightly concave and about five inches in diameter. Usually placed in the fork of a horizontal limb of a low tree, sometimes on a bushy branch or even on a stump in the forest, rarely on the ground.

Eggs.-Clutch, two; smooth and glossy and pure white; axis $32-36 \mathrm{~mm}$., diameter 23-24.

Breeding-scason.--Usually from October to November; but eggs hare been taken from April to September. Two broods are reared in the year.

Distribution and forms.-Restricted to Australia, where four races baro been diagnosed as: P. c. chalcoptera (Latham) from New South Wales, Victoria and South Queensland; $P$. c. consobrina Mathews from North-west Australia, Northem Territory and Northem Queensland, a paler race of smaller size, as wing o about $190 \mathrm{~mm}$., typical $200 \mathrm{~mm}$.; wing o about 180, typical about $193 \mathrm{~mm}$. arerage; P. c. murchisoni Iathews from mid-ITest Australia, of more sandy coloration above, and more suffused with pink below; and $P$. c. riordani Nathews from Melville Island, Northem Territory, with a lighter fore-head, a darker back and still more pinkish under-surface.

\section{Genus COSMOPELIA.}

Cosmopelia Sundevall, Méth. Nat. Av. Disp. Tent, pt. IT., p. 100, (before June 12th) 1873. Type (by original designation): Columba elegans Temminck and Knip.

Large Ground-Dores with slender bills, leng wings, short rounded tail and stout short legs and feet. The bill is as long as in the preceling genus, though the bird is less and is formed exactly on the same plan, the clertrum scarcely differentiated, the tip projecting and deflexed in a forward direction, the gonys a little longer, but little ascending, the interramal space showing anteriorly a nalied space. The wing js more rounded, the first primary about equal to the fifth, the second, third and fourth a little longer, subequal and longest, the secondaries rery broad, rounded and short, the first primary is faintly incised on the inner web, the second to the fifth rather noticeably scalloped on the outer web. The tail is a little rounded, about half the length of the wing, composed of fourteen feathers, very broad and rather square at their extremities. The legs are short, the tarsus stont and on the front showing a double row of large hexagonal scutes and on the sides and back very small reticulate scaling can only be seen: the tarsus is about the same length as the culmen and longer than the midclle, the outer a little, horter than the inuer; the hind-toe short, all the claws rather short and becoming flattened. below.

Coloration rufous-brown above with bronze markings on corerts and rinous

\section{Cosmopelia elegans. -BRUSH BRONZE-WINGED PIGEON.}

Gould, Vol, V., pl. 65 (pt. ImI.), Dec. 1st, 1813. Mathews, Vol. I., pt. 3, pl. 36, April 29th, 1911 .

Columba elegans Temminck and Knip, Les Pigeons, Vol. II., p. 56, pl. 22, 1810: Tasmania. 
Columba lawsonii " Sieber, Isis, No. 67," [=Isis, 1825, heit 1, Beylage No. 1, Nomen nudum, in a price list of "Nowholland" birds], Wagler, Syst. Av., Columba, sp. 58, p. (249), 1827 (before Oct.). In synonymy of $C$, elegans.

Phaps elegans neglecta Mathews, Nov. Zool., Vol. XVIII., p. 188, Jan. 31st, 1912: Long Bay, Now South Wales.

Phaps elegans affinis Mathews, ib. : Emu Woll, South Australia (interior).

Distrnbuton.-New South Wales, Victoria, Tasmania, South Australia, South-west Australia.

Adult male-General colour above olive- or rufous-brown, including the back, wings, and tail; throat, a line from behind the eye, hind-neck, and sides of the neck rich chestnut; wings more rufous than the back; wing-speculum metallicbronze, copper, green and purple: some of the median and greater wing-coverts tipped with grey; bastard-wing, primary-coverts, and quills brown, edged, more or less, with rufous, increasing in extent on the fuills, which are rufous on both webs. for the greater part of their length ; the outer primaries have white margins towards the tips; middle tail-feathers like the back, the outer ones slate-grey, with a blackish subterminal band and tipped with rufous-brown; fore-part of the head and chin white, slightly tinged with chestnut; hinder crown slate-grey; sicles of face and entire under-surface pale slate-grey; axillaries and under wing-coverts chestnut, like the quill-lining. Iris hazel-brown. Total length $335 \mathrm{~mm}$; culmen 26, wing 167 , tail 88, tarsus 27.

Alult femule.-Differs from the adult male chiefly in having much less rufous or chestnut on the plumage of the upper-parts, and the under-surface darker grey. There is no white on the fore-head, as in the male, and the chestnut colour is indicated only by a small patch on the sides of the nape and a wash on the sides of the neck; the hind-neck and mantle are like the back; bill black; iris reddish; tarsi and feet deep coral-pink. Total length $298 \mathrm{~mm}$.; culmen 25, wing 165, tail 84, tarsus 27.

Immature,-Distinguished from the adult, more particularly by the rufous fore-head, very slight indication of the chestnut throat pateh, and the entire absence of chestuut on the hind-neck.

A male example, from the Dandenong Ranges, Victoria, has the general colour much clarker and more intensified, the most conspicuous feature being the chestnut colour on the fore-part of the head.

Nest.-A flat structure or platform of twigs; usually placed in a thick bush, on a fallen tree, or even on the ground, in secluded scrubby localities.

Eggs.-Clutch, two; elliptical in shape; texture of shell fine, except the smaller end, which is slightly granular; surface glossy; pure nhite. Dimensions $31 \mathrm{~mm}$. by 24 .

Breeding-season.--October to January or March.

Incubation-period.-Fifteen to eighteen days.

Distribution and forms. - Southern Australia and Tasmania only. Three races have been distinguished: $C$. e. elegans (Temminck and Knip) from Tasmania; C. e. neglect (Mathews) from New South Wales, Victoria, South and South-west Australia, in its large size and generally paler coloration; and ( . c. affinis (Mathews) from the interior of South Australia, a much paler form, both above and below, but especially on the mantle.

\section{Genus HISTRIOPHAPS.}

Histriophaps Salvadori, Cat. Birds Brit. Mus., Vol. XXI,, p. 529, June 30th, 1893. Type (by original designation): Columba histrionica Gould.

Large Ground-Doves with medium bills, very long wings, short tails and stout legs and feet. 
The bill is very similar to those of the preceling genera, but stouter, the dertrum a little more swollen, and less deflexed, the gonys searcely angulated and little ascending, the interramal space anteriorly unfeathered.

The wing is very long, with the first primary longent, the secondaries short and none of the primaries showing any sealloping either on the outer or inner webs. The tail is rery short, composerl of fourteen reetrices, not very broad, with rounded tifs and forming a rounded wedge, less than half the length of the wing. The upper t a.l-eoverts are very long, reaching almost to the end of the tail while the under tailcowerts are as long as the tail itself. The legs are short and very stout, the front of the tarsus covered with two rows of strong hexagonal scales, the sides and back with very fine reticulations, the tarsus a little longer than the culnen. The toes rather slender, the middle toe longest, the inner longer than the outer, the hind-toe with a scant lateral margin and comparatively shorter but with a very long claw similar to the long claws of the anterior toes, narrow and little curved but not flattened.

Coloration upper sandy-reddish to brown, wing-feathers pale grey, undersurface blue; eye, fore-head and spot on chest white; top of head, checks and throat black; metallic spot on inner secondaries; female not so boldly marked.

\section{I72. Histriophaps histrionica.-FLOCK-PIGEON.}

Gould, Vol. V., pl. 66 (pt. II.), March 1st, 1841. Mathews, Vol. I., pt. 3, pl. 37, April 29th, 1911.

Columba (Peristera) histrionica Gould, Birds Austr., pt. II., March 1st, 1841 ; Liverpool Plains, New South Wales (interior).

Phaps histrionica alisteri Mathows, Nov. Zool., Vol. XVIII., p. 189, Jan. 31st, 1912 : Parry's Creek, North-west Australia.

Distribution,-New South Wales, Queensland, Northern Territory, North-west Australia.

Adult mole.-General colour above, including the entire back, wings, and tail sandy-brown; marginal coverts round the bend of the wing, bastard-iwing, and primary-coverts blue-grey, more or less margined with white on the outer webs; primary-quills pale grey with sandy edges and white tips to all but the outer two, inner webs rufous with the exception of the first quill, outer secondary-quills grey, darker towards the tips, inner ones sandy on the outer webs with a metallic-purple and green crloss followed by grey and an ovate spot of white; middle tail-feathers like the back, the outer feathers grey, with a dark, subterminal band and tipped with white, sometimes in the form of a spot, some of the lateral ones sandy on the outer wels; sides of face, ear-coverts and crown of head black; fore-head, lores, a line b.hind the eve, almost enclosing the ear-coverts, and a patch on the lower throat pure white; fore-neck, breast, and abdomen blue-grey, like the axillaries and under wing-coverts; lower flanks sandy-brown, becoming paler on the shorter under tail-coverts, the long ones grev, with sandy-white tips; quills pale brown, with a patch of chestmut towards the base; bill brown; iris dark brown; tarsi and feet in front lealen-blue, back of tarsi flesh-red. Total length about $317 \mathrm{~mm}$.; culmen 24, wing 193, tail 83, tarsus 26.

Alult female. -Differs from the adult male in having the entire upper-parts, including the head, darker sandy-brown, as also a wide greyish-bromn band on the fore-neck and breast, the black on the chin and throat only faintly indicated, and the fore-head inclining to whitish; wing-speculum very faintly indieated and the white tipe to the primaries absent. Total length about $3013 \mathrm{~mm}$; culmen 24 , wing 190 , tail 83 , tarsus 26.

Immature male.-Similar to the adult female but with the fore-part of the head white, as in the male, and with the white spots and white tips to the primaries. Immature female.-Differs from the adult in having the wing-coverts and tips 
of quills margined with whitish, as also the feathers of the fore-neck; the black throat patch scarcely indicaten; a certain amount of chestnut on the under wingcoverts like that of the quill-lining.

Nest.-The bare ground, under any convenient low corert-tussock or bush -on the plains.

Eggs.-Clutch, two ; elliptical in form ; texture of shell fine but strong; surface glossy; white, with a slight creamy tone. Dimensions 32-34 mm. by 24.

Breeding-season.-Practically all the year round.

Distribution and forms.-Interior of Australia only. The western form, living in interior clistricts of the North-west of Auntralia is much paler above and below, being named $H . h$. alisteri (Mathews), than the typical eastern $H$. $h$. histrionica (Gould) from the interior of New South Wales and Queensland.

\section{Genus PETROPHASSA.}

Petrophassa Gould, Proc. Zool. Soc. (Lond.), 1840, p. 173, July 1841. Type (by monotypy): Petrophassa albipennis Gould.

Large Ground-Doves with slender bills, very rounded wings, long rounded tail and very small legs and feet. The bill is formed as in the preceding genus, the dertrum a little more swollen, the bill itself a little more slender, the interramal s pace less feathered, the gonys a little longer and more ascending but not angulated. There is a small space round the eye and part of the lores naked of feathers as in the preceding genus but more marked. The wing is very rounded, the primaries very narrow, none showing any scalloping on the inner webs but the third to the eighth itrongly incised on the outer webs; the first is not much shorter than the second and is about equal to the ninth, the intervening eight being almost the same length, the eighth being a little less than the others. The secondaries are very long and broad, the longest inner secondary being equal to the outermost primary. The tail is composed of fourteen rery broad feathers, their extremities being almost square and is nearly as long as the wing; in shape it is a broad werlge, the outer feathers being more than half the length of the middle eight which are practically equal in length. The upper tail-coverts are very dense and only* reach about half-way down the tail, the under ones being about the same length. The legs are very small; the tarsus is short and thick, about the length of the culmen, and longer than the middle toe; the tarsus is covered on the front with two rows of hexagonal plates, the back and sides being covered with minute reticulation. The toes are very hort, the midclle toe longest, the outer and inner about equal and not a great deais longer than the straight hind-toe; all the claws are short and blunt.

Coloration uniform brown or grey with darker elges to all the feathers, forming a scalloped appearance; primaries showing red or white bases, rery noticcable.

\section{I73. Petrophassa albipennis.-WHITE-QUILLED ROCK PIGEON.}

Gould, Vol. V., pl. 71 (pt. x.), March 1st, 1843. Mathews, Vol. I., pt. 3, pl. 38, April 29th, 1911.

Petrophassa albipennis Gould, Proc. Zool. Soc. (Lond.), 1840, p. 173, July 1841 : "Western Australia" = Wyndham, North-west Australia (East).

Petrophassa albipennis alisteri Mathews, Austral Av. Rec., Vol. 1., pt. 2, p. 28, April 2nd, 1912 : Napier Broome Bay, North-west Australia (West).

Distribution.-North-west Australia, Northern Territory.

Adult female.-General colour of the upper-surface rufous-brown, with pale whges to the feathers; crown of the hearl blackish-brown, with whitish margins to the feathers; neck all round, breast and sides of the face grer, with rufous-bromin (iges to the feathers; lores and a narrow line at the base of the fore-head relvety- 
black; the feathers of the chin and throat black, with white pear-shaped tips; batstarl-wing and primary-coverts blackish, the latter dusted with white towards the tips; primary-quills white at the base, becoming darker towards the tips, the inner ones dusted with brown and shaded with rufous; secondary-quills entirely brown, somewhat darker on the inner webs; the innermost secondaries like the back; some dark metallic-purple spots are indicated on one or two of the inner major coverts and long scapular feathers; tail rufous-brown, the outer feathers inclining to blackish; abdomen, sides of the body, under tail-eoverts, axillaries and under wing-coverts blackish, with palo margins to the feathers; tail and quills below blackish, the latter with white bases; bill black; iris dark bromn; tarsi and feet blackish-brown. Total length about $310 \mathrm{~mm}$; culmen 20, wing 135, tail 120 , tarsus 20. The sexes are alike.

Immature.-Apparently similar to the adult plumage.

Nest.-A slight hollow about two inches in depth scooped in the ground near a small tuft of spinifex, or stone, and lined with soft dead grass.

Eggs.-Clutch, two; oval in form, the shell being close-grained, smooth, and lustrous, cream colour or creamy-white. Dimensions 27-29 mm. by 21 .

Breeding-season.-July to October.

Distribution and forms. North-west Australia only. Two subspecies have been named : P. a. albipennis Gould from "Western Australia," described as having "all the "pp)er-surface rufous-broun," and, therefore, Wyndham selected as ty.pe locality and Northern Territory birds agree; the specimens from Napier Brome Bay, North-west Australia, named $P$. a. alisteri Nathews, lack the rufous coloration, bcing dark uniform brown above, and differ appreciably.

\section{I74. Petrophassa rufipennis.-CHESTNUT-QUILLED ROCK PIGEON.}

Mathews, Vol. I., pt. 3, pl. 39. April, 29th, 1911.

Petrophassa rufipennis Collett, Proc. Zool. Soc. (Lond.), 1898, p. 354, Oct. 1st : South Alligator River, Northern Territory.

Distribution.-Northern Territory.

Adull male-The feathers of the upper-surface, as well as those of the breast, grey, margined with brown; throat and a narrow line above and below the cye white; sides of face also inclining to white; bastard-wing blackish; primarycoverts chestnut, blackish at the tips; primary-quills chestnut, margins of the outer webs towards the ends, and the tips blackish; secondaries dark bromn ; tail blackish, as also the axillaries and lesser under wing-coverts; quills below, greater, and a few of the lesser, wing-corerts chestnut; bill black; iris brown ; feet black. Total length $345 \mathrm{~mm}$.; culmen 21, wing 151, tail 145, tarsus 22.

Adult female.-Differs from the adult male only in haring metallie spots on a fe' of the seapular feathers. Total length $310 \mathrm{~mm}$.; culmen 22, wing 152, tail 131 , tarsus 22 .

Nest and Eggs.-Undescribed.

Distribution and forms.- Restricted to Northern Territory and no subspecies.

\section{Genus GEOPHAPS.}

Geophaps Gray, Appendix List Gen. Birds, p. 12, March 1st, 1842. Type (by original designa. tion): Columba scripla Temminck.

Terraphaps Mathews, Austral Av. Rec., Vol. I., pt. 8, p. 195, March 20th, 1913. Typo (by original designation): Columba smithii Jardine and Selby.

Medium Ground-Dores with stout bills, long wings, long tail and stout legs and feet. The bill is short and stout, the dertrum swollen, the tip deflexed, the 
dertrum half the length of the culmen; the nasal groove sharply defined, the culmen ridge posteriorly flattened, the nasal covering much swollen; the lower mandible stout, the gonys not angulated but ascending, the mandibular rami ungrooved and the interramal space feathered. The bill is stouter in the male than in the female, and in the form called Terraphaps by Mathews the bill in the male is abnormally stout, the depth being almost half the length of the culmen, the dertrum, much swollen and more than half the length of the culmen, the nasal groove occupied by the nasial covering, the mandibular rami very short and ungrooved, the gonys longer an' more rapidly ascenting without any angulation; in the female, however, the bill agrees with that of Geophaps. There is a notable bare space alout the eyes. The wing is long, the first primary, a little incised on the inner web, the third to the sixth rather strongly incised on the onter webs; the first primary is long, a littlo shorter than the seventh, the second and sixth a little longer and subecual, the third to fifth a little longer still, subequal and longest; the secondaries long, reaching almost to the seventh primary. The tail is long, composed of fourteen broad, rounded feathers, and nearly straight, only a little rounded; the upper tail-corerts very long reaching almont to the end of the tail-feathers and the under tail-coverts nearly as long. The legs are short and rery stout, the tarsus very thick, the front being covered with a double row of stout hexagonal scutes, the sides and back with less well-marked hexagonal seales. The toes are very short, the middle toe longest, the inner longer than the outer, which seareely exceeds the hind-toe. All the claws are rather long but little eurved; lateral skin at sides of hind-toe obsolete.

Coloration earth-brom above, a small bronze spot on inner secondaries, white throat with black markings bordering it, more or less pronouncel ; chest brominish, belly slaty, flanks and abdomen white.

\section{Geophaps scripta.-PARTRIDGE PIGEON.}

Gould, Vol. V., pl. 67 (pt. vII.), June 1st, 1842. Mathews, Vol. I., pt. 3, pl. 40, April 29th, 1911.

Columba scripta Temminck, Trans. Linn. Soc. (Lond.), Vol. XIII., pt. I., p. 127, 1821 : Shoalwater Bay, Queensland.

Columba inscripta Wagler, Syst. Av,, Columba, sp. 59, p. (249), (before Oct.) 1827. New name for C. scripta Temm.

Geophaps scripta bourkei Mathews, Austral Av. Rec., Vol. II., pt. 7, p. 124, Jan. 28th, 1915 : Bourke, New South Wales.

Drstribution.-Queensland, New South Wales.

Adult.-General colour of the upper-surface earth-brown, including the head, entire back, and middle tail-feathers; wings darker than the back, with broad pale margins to the feathers; wing-speculum wavy green, with coppery reflections; bastard-wing, primary-coterts, and quills pale bromn, with whitish edges to the outer webs of the latter; margins of the secondary-quills rufous ; outer tail-feathers rufous-grey, with black tips; a white line on the lores, which surmounts the narrow black band round the eye; chin and throat white, as also a line along the cheeks, which includes the ear-corerts; a line of black feathers which encircles the white throat and extends on to the sides of the neck behind the ear-coverts; fore-neck and sides of the neek like the back; breast ant micldle of the abdomen blue-grey; sides of the body and under wing-coverts white; small marginal coverts on the under edge of the wing similar in colour to the upper-surface; axillaries white at bave, and dusted with grey towards the ends; lower-abdomen, thighs, and under tail-coverts sandy-buff, the long under tail-covert: blackish, paler on the outer webs; bill black; iris black; naked skin surrounding the eyes bluish-lead colour, the comer immediately before and behind the eye mealy vinous-red ; feet and frontal 
scales dark purplish vinous-red. Total length $325 \mathrm{~mm}$; culmen 22, wing 148, tail 110, tarsus 25 .

Immature.-Undescribed.

Nest.- - little hollow, scooped in the ground, about an inch deep, and lined more or less with dead, soft grass, sometimes sheltered by herbago.

Eggs.-Clutch, two. A cluteh from the Daw:on River, North Queensland, are creamy-white, smooth and glossy; axis 30-31 mm., diameter 21-22. the year.

Brecting-season. - September to January, but breeds at almost any period of

Incubation-period.-(In captivity) seventeen days.

Distribution and forms.- Restrieted to Eastern Australia in the interior of Qucensland and New South Wales. Two forms hare been indicated: G. s. scripta (Temminck) from Shoalwater Bay, Queensland ; and G. s. bourlici Mathews, from Bourke, New South Wales, as being larger and darker.

\section{I76. Geophaps smithii,-NAKED-EYED PARTRIDGE PIGEON.}

Gould, Vol. V., pl. 68 (pt. vIr.), June 1st, 1842. Mathers, Vol. I., pt. 3, pl. 41, April 29th, 1911.

Columba smithii Jardine and Selby, Illustr. Ornith., Vol. II., pl. 104, (? Dec.) 1830: No locality $=$ Northern Territory.

Geophaps smithi blaauwi Mathews, Austral Av. Rec., Vol. I., pt. 2, p. 28, April 2nd, 1912 : Napier Broome Bay, North-west Australia.

Geophaps smithi cecilce Mathews, ib. : Melville Island, Northern Territory.

Distribution,-Northern Territory, North-west Australia.

Adult.-General colour above earth-brown, including the head, back, wings and nifadle tail-feathers; wing-speculum, which is formed by the metallic spots on the outer webs of some of the greater coverts and innemost secondaries, wary purple and green; outer tail-feathers brown, with broad black tips; a narrow white and black line on the lores, encircling the eyc; the white of the throat extending on to the sides of the neck to behind the ear-coverts ; cheeks grey, like the narrow line which fringes the white patch on the throat; fore-neck and breast vinous-grey on the middle of the latter, a few grey feathers narrowly barred with black; sides of body, axillaries and under wing-coverts white; lower flanks like the breast; abdomen and vent whitish-buff; thighs buff; under tail-coverts brown, margined with white ; bill blackish; iris white, feet clull pink. Total length $290 \mathrm{~mm}$.; culmen 20, wing 136, tail 101, tarsus 23.

Female.-Similar in coloration but with noticeably weaker bill.

Immature. - Similar above but all the feathers of upper-surface minutely freckled, the freekling more noticeable on rump and upper tail-coverts, the upper wing-coverts similarly freckled, tips whitish ; imer secondaries with all outer webs freckled, tailfeathers also frecliled as feathers of breast which are brownish and show also white tipping; indistinct central breast patch ; face markings less defined.

Nest.--Eggs are laid on the ground in a slight nest male of grass, or sometimes on a tussock of grass.

Eggs.-Clutch, two ; somewhat oval, slightly glossy ; colour, very pale cream. Dimensions 27-28 $\mathrm{mm}$. by 20 .

Breeding-season.-All the year round.

Distribution and forms.-- Northem Territory and North-west Australia only. Three subspecies as $G$. s. smithii (Jardine and Selhy) from Northern Territory ; (i. s. blaami Mathews from North-west Australia, a paler form, with the naked cre-s]ace yellow, not scarlet as in typical form; and $G$. s. cccile Nathews from ilelville Island, a still paler form with the upper-breast suffused with pink, and the stripe below the eye lighter. 


\section{Genus LOPHOPHAPS.}

Lophophaps Reichenbach, Nat. Syst. Vögel, p. xxv., 1852 (? 1853). Type (by original designation): Geophaps plumifera Gould.

Small stoutly-built Ground-Doves, with short stout bill, long occipital crest, short rounded wings, short tail and small stout legs and feet. There is a bare space round, in front and behind the eyes. The bill is shorter than the head, nearly half as deep as long, dertrum swollen more than half the length of the culmen, inder mandible stout, gonys very long, more than half the length of the mandible. It agrees very closely with that of the preceling genus in most details. The occipital crest is composed of a few very long and thin feathers. The wing is rounded, the primaries narrow, the first showing no attenuation but the second to sixth notably incised on outer webs, seventh slightly ; the first is only a little less than the accond and equal to the sixth, the second, third, fourth and fifth subequal and longest, the secondaries long and only a little shorter. The tail is nearly square, only slightly rounded, the feathers broad, rounded at the tips and fourteen in number; it is a little more than half the length of the wing, the tail-coverts are very long, both upuer and under nearly reaching to end of tail. The legs are very small and stout, the tarsus about equal to the culmen, covered with hexagonal scutes, a double row of large scutes in front, fewer but strong ones on sides and back. The toes very short and straight, the middle toe a little longer than the outer and inner, which are subequal, the hind-toe shorter, the claws short and little curved, the hind-toe showing no lateral skin expansion.

Coloration sandy-buff above and below; barred with blackish above and a dark line aeross the breast, the abdomen varying to pure white; the fore-head slatyblue, chin white, black line above and below eyes and a black patch on throat; occipital crest varying to straw colour; bronze patch on inner secondaries.

\section{I77. Lophophaps plumifera.-PLUMED PIGEON.}

Gould, Vol. V.. pl. 69 (pt. VII.), June 1st, 1812 ; Suppl., pl. 69 (pt. IV.), Dec. 1st, 1867. Mathews, Vol. I., pt. 3, pl. 43, April 29th, 1911.

Geophaps plumifera Gould, Birds Austr,, pt. vir., June 1st, 1842 : near Cape Hotham, Northern Territory.

Lophophaps leucogaster Gould, Birds Austr., Suppl., pl. 69, pt. Iv., Dec. 1st, 1867 : Machrihanish Station, South Australia (interior).

Lophophaps plumifera pallida Mathews, Nov. Zool., Vol. XVIII., p. 190, Jan. 31st, 1912 : Parry's Creek, North-west Australia.

Distribution.-North Queensland, Northern Territory, North-west Australia. Interior South Australia.

Adult male-General colour above sandy-buff, barred with black and grey, more coarsely on the wings and sides of neck; primary-coverts and quill chestnut, the latter tipied with blackish-brom; the outermost primary blackinh on the onter web; the greater number of the primaries have black shafts; some of the inmer secondaries brown, with whitish margins; the innermont secondarien like the hack, with metallic-purple spots on the outer webs; middle tail-feathers like the back, outer pair almost entirely black, the remainder reddish-brown, broadly timped with black; fore-part of the head and ear-coverts blue-grey; hinder part of the crown and crest bright fawn colour, the elongated plumes straw colour; a narrow line of black on the fore-head, which extends over and below the eye; chin and lower throat black; checks and upper throat white; fore-neck, sides of tho body and under wing-coverts fawn colour; abdomen and a band across the breast white; an irregular band across the breast, composed of grey and black bars : under tail-coverts slate-grey, margined with white; bill blackish; iris yellow, bare skin round the 
eves crimson; tarsi and feet very dark purple. Total length $230 \mathrm{~mm}$; culmen 19 , wing 108 , tail 62 , tarsus 20.

Adull female. - Similar to the adult male but slightly smaller. Total length $223 \mathrm{~mm}$.; culmen 19, wing 105.

Immature female.- Differs from the adult female in the absence of the metallic wing-speculum.

Nest-- A sight deprension in the ground, sheltered by herbage-spinifex, etc.

Eggs.-Clutch, two; elliptical in shape; texture of shell fine ; surface glossy; colour light creamy-white. Dimensions $25 \mathrm{~mm}$. by 20.

Breeding-season.-July to October.

Distribution and forms.- Confined to the interior of northern tropical Australia. The forms are not easily definable. Gould distinguished $L$. leucogaster on account of the more extensive white markings on the abdomen, but this seems a very variablo feature. The North-western form, named L. p. pallida Nathews on account of it paler coloration, is also based on a variable feature and there is not sufficient material to determine the subspecies exactly.

\section{I78. Lophophaps ferruginea.-RED-PLUMED PIGEON.}

Gould, Suppl., pl. 68 (pt. IV.), Dec. 1st, 1867. Mathews, Vol. I., pt. 3, pl. 42, April 29th, 1911.

Lophophaps ferruginea Gould, Handb. Birds Austr., Vol. II., p. 137, (Dec.) 1865: Shark Bay, West Australia.

Lophophaps ferruginea mungi Mathews, Nov. Zool,, Vol. XVIII., p. 190, Jan. 31st, 1912 : Mungi, North-west Australia.

Distributron.-North and mid-IVest Australia.

Adult male.-General appearance of the upper-parts rich fawn colour, with indistinct dark bars on the back; sides of neck and wings more distinctly barreel with grey and black; primary-coverts and quills bright chestnut, the latter margined on the outer webs, and tipped with brown; the secondaries brown, with pale margins, the innermost ones with purple metallie spots on the outer webs, which forms the wing-speculum ; micklle tail-feathers like the back, the outer ones black; fore-part of the head and ear-coverts blue-grey; a narrow line of black at the base of the fore-hearl encireling the eye and meeting its fellow on the chin, followed by a white band, which cromses the throat from the ear-coverts; this is joined by a black collar on the lower throat; remainder of the under-surface fawn colour, including the under wing-coverts; a narrow pectoral band crosses the breast, the feathers of which are grey, banded with black and tipped with fawn colour; fore-head bluegrey" ; hinder crown and crest fawn colour, the elongated feathers luff ; long under tail-coverts grey, fringed with white; lower aspect of the tail black; bill black; iris inclian-red, orbits remulion; tasi and feet grey-black. Total length $205 \mathrm{~mm}$.; culmen 20, wing 104, tail 61 , tarsus 22.

Adult female. - Similar to the adult male both in colour of plumage and measurements.

Immuture-Appaxently similar to adult, but may lack metallie wing-speculum.

Nest. - A slight grass-lined depression beneath the shelter of a spinifex tussock.

Eggs.-Clutch, two; a swollen ellipse, and are more globular in shape than the generality of pigeons eggs, the grain of the shell being very fine, and its surfaco sightly glesy. They are of a uniform prale cream colour. Dimensions $23 \mathrm{~mm}$. by 19.

Breeding-season.-Narch to October. Two broods are reared.

Distribution and forms.-Restricted to mid-and North-west Australia. The interior and northern form L.f. mungi Mathews is much paler than the rarer typical southern race L.f. ferruginea Gould, and is easily recognisable. 


\section{Genus OCYPHAPS.}

Ocyphaps Gray, Appendix List Gen. Birds., p. 12, March 1st, 1842 (ex Gould MS.). Type (by original designation): Columba lophotes Temminek et Laugier.

Lophaon Streubel, in Ersch und Gruber's Encycl,, Sect. III., Vol. XVII., p. 94, 1842. Type (by monotypy): C. lophotes Temm. et Laugier.

Large Ground-Doves with short stout bills, long occipital crest, long wings, long wedge tail and small legs and feet. There is a small bare space around the eye.

The bill is not so stout as in the preceding genus, the dertrum less swollen and more deflexed, the gonys of the under mandible shorter and less ascending, the mandibular rami weaker and obsoletely grooved; altogether it recalls that of Geopelia but is stouter. The bill is much shorter than the head; the oceipital crest is formed of long, narrow attentuate feathers. The wing is very long and rather pointed, the secondaries short; the first primary is not scalloped, the second a little incised on the outer web, the third strongly attenuated for about half its length, being deeply incised on the outer web and scalloped on the inner web; the others only faintly scalloped on the outer webs; the first primary is about equal to the sixth, the second to fourth subequal and longest; the secondaries short. The tail is strongly wedge shaped, composed of fourteen feathers, broad and with rounded tips, the upper and under tail-coverts short; the tail is about three-fourths the length of the wing. The tarsus is short and stout, not much longer than the culmen and the front is covered with a single row of large horizontal scutes, the sides and back with minute reticulation. The toes are slender and long, the middle toe nearly as long as the tarsus, the outer longer than the inner, the hind-toe long but much shorter than the inner toe and notably margined with soft skin.

Coloration brownish-grey above, barred on wing-coverts, and with a purple and green patch; under-surface dove-grey. Apparently more closely related to Geopelia than to the "Phaps" series.

\section{I79. Ocyphaps lophotes.-CRESTED PIGEON.}

Gould, Vol. V., pl. 70 (pt. xmr.), Dec. 1st, 1843. Mathews, Vol. I., pt. 3, pl. 44, April 29th, 1911.

Columba lophotes Temminek et Laugier, Planch. Color. d'Ois., $24^{\mathrm{e}}$ livr. (Vol. II., pl. 142), (Vol. IV., pl. 117), July 26th, 1822: Blue Mountains, Nerw South Wales.

Columba palustris Bennett, Cat. Spec. Nat. Hist. Austr. Mus., p. 42, 1837, after July 26th. New name for "Columba lophotes Temm."

Ocyphaps lophotes whitlocki Mathews, Nov. Zool., Vol, XVIII,, p. 191, Jan. 31st, 1912:

East Murchison, mid-West Australia.

Ocyphaps lophotes stalkeri Mathews, ib.: Alexandra, Northern Territory.

Distribution,-Australia generally. Not Tasmania.

Adult male.-General colour of the upper-parts grey, with a strong blush of pink, more particularly on the hind-neck, sides of neck, and sides of breast, becoming more olive-grey on the rump and upper tail-coverts, with metallic coppery reflections on the rump; lesser wing-coverts pale grey, remainder of the coverts and scapulars barred with black, the median and greater series tipped with white, giving the appearance of two parallel bars of white, and enclosing a bronzy-green speculum ; the secondary-quills also tipped with white, which indicates a third wing-bar; a second wing-speculum of metallic-pumple; butard-rring and primary-coverts grey, edgel and tipped with white; quills pale brown, whitish on the inner webs towards the base; tail-feathers blackish, showing bronzy-green reflections and tipped with white, more broally on the outer feathers; head pale lead-grey, with an elongate crest of black feathers; throat and under-surface pale grey, darker and more dusky on the flanks and under tail-coverts; under wing-coverts and axillaries white; b ll black; iris orange, orbits pinkish-red. Total length $310 \mathrm{~mm}$; culmen 22, wing 163 , tail 123 , tarsus 25 . 
Adult female.-Similar to the ardult malo but somewhat paler on the wings and scapulars, and darker on the under tail-coverts; bill dark grey, iris ochreous-red, orbits carmine; tarsi and feet pink. Wing 156.

Immature.-As adult.

Nestling showing cgg-tooth.--Coloration as in adult; head crested, and attenuated third primary sprouting.

Viest. - A slight, flat structure of twigs, usually placer in a bush-polygonum, hakea, salt, etc.- or low tree, sometimes on a stump.

Eggs. Clutch, two; elliptical in shape, sharply nipped off at one end ; texturc of shell fine; surface glossy; pure white. Dimensions $33 \mathrm{~mm}$. by 23 .

Breeding-season.-All the year round.

Incubation-period.--(In captivity) fourteen days (Sclater); nineteen days (Butler).

Distribution and forms.--Confined to Australia. Three subspecies have been clifferentiated as: $O$. l. lopholes (Temm. and Laugier) from Eastern Australia ; O. $l$. whitlocki Mathews, from Western Australia, on account of its smaller size, wing 1.57 against typical wing $175 \mathrm{~mm}$; and $O$. l. stalkeri Mathews from Central and Northern Australia, much paler form, both above and below.

\section{Genus LEUCOSARCIA.}

Leucosarcia Gould, Birds Austr., pt. xıII., Dec. 1st, 1843. Type (by monotypy): C. picata Latham $=C$. melanoleuca Latham.

Largest Ground-Doves with short bills, long wings, long tail and stout short leg; and small feet. The bill is short, the dertrum little swollen, the tip deflexed, the culmen ridge flattened posteriorly and the frontal feathers approaching on it almost to nasal opening; the nasal eovering swollen, the nasal groove long and narrow; the under mandible slender, the rami narrow and deeply grooved, the gonys very short and a little angulated, the interramal space almost completely feathered. The wing is long and roundly pointed, the first primary showing little scalloping, the succeeding five incised on the outer wehs; the primaries are rather narrow, the first long but only longer than the sixth, the second and fifth subequal and little shorter than the intermediate three which are subequal and longest; the secondaries are short, and there is no wing-speculum. The tail is long, about three-fourth: the length of the wing and is composed of fourteen broad feathers, the tips rounded and the whole shaje a little rounded, the upper tail-eoverts long, extending more than half-way down the tail while the under tail-coverts are even longer. The legs are short and stout, the front of the tarsus, which is longer than the culmen, having a double row of large hexagonal scutes, the outer side and back being covered with minute reticulation and on the inner side a bare strip of undivided stin is seen. The toes are rather short, the micklle toe longest, the outer shorter than the inner, the hind-toe about half the length of the middle toe and straight. The claws are short and blunt, all the toes showing lateral expansion of the skin of the soles.

Coloration: top of head white, all upper-surface slate-grey as breast; chin whitish and white crescent on breast; abdomen white with black scalloping; the feathers having black bases and broad white edging; tail uniform slate, wing brown.

\section{I80. Leucosarcia melanoleuca.-WONGA-WONGA.}

Gould, Vol, V., pl. 63 (pt. xmr.), Dec. 1st, 1843. Matherws, Vol. I., pt. 3, pl. 45, April 29th, 1911.

Columba melanoleuca Latham, Index Ornith. Suppl., p. LIx., 1801, after May 30th: Sydney, New South Wales, based on Watling drawing No. 225.

Columba picata Latham, ib. : same locality. 
Columba armillaris Temminck et Knip, Les Pigeons, Vol. II., p. 13, pl. 6, IS09: New South Wrales.

Columba goadgang Temminck, Les Pigeons et Gall, Vol, I, p. 369, June 11th, 1813 : New South Wales.

"Columba" jamieson Quoy et Gaimard, Voy, de l'Uranie et Physic., Zool., p. 123 note, Aug. 28th, 1824: New South Wales.

Leucosareia melanoleuca minor Mathows, Austral Av. Rec., Vol. III., pt. 3, p. 54, April 7th, 1916: North Queensland.

Distributron.-Queensland, New South Wales, Victoria.

Adult male-General colour above slate-grey, incluling the entire back, wings, and middle tail-feathers; bastard-wing, primary-coverts, and quills blackish, the latter with narrow white margins on a portion of the inner webs; the four outer tail-feathers tipped with white; crown of the head and a horseshoe band on breast and abdomen white; checks and throat grey ; fore-neck and a band on cach side of breast dark slate-grey, like the upyer-surface; some of the feathers on the abdomen, sides of borly, and flanks have elongated black marks or round spots of black on the middle of the feathers; under tail-coverts brown, with whitish margins; bill black, base pink ; iris brown, orbits red ; tarsi and feet pink. Total length $430 \mathrm{~mm}$. ; culmen 31 , wing 214 , tail 157 , tarsus 40 .

Adult fernale.--Similar to the adult male in the colour of the plumage but with smaller measurements.

Immature male.-Differs from the adult male in having the outer webs of the secondary-quills shaded with brown.

Nest.-Very frail in structure, composed of sticks or twigs placed on a horizontal branch of a tree at a height of from ten to twenty feet above the ground, in scrub or forest.

Eggs.-Clutch, two ; glossy, smooth and pure white; axis $38 \mathrm{~mm}$., diameter 26.

Breeding-season.-October to January. Two broods are reared in a season.

Distribution and forms.-Restricted to Eastern Australia from North Queensland to Victoria. A northern and southern race can be admitted, the former $L . m$. minor Mathews being smaller than the typical $L$. m. melanolenea (Latham) from New South Wales, Victoria and South Queensland, and occurning only in North Queensland.

\section{FAMILY TRERONIDA.}

This includes the Fruit Pigeons, which superficially seem a well-clefined group, but which Garrod by means of his " characters" split up somewhat peculiarly. If there be any reason in his facts it is certainly not seen at the first glance, and Garrod himself seemed doubtful of his associations. As noted above, the group needs careful study as to its osteology and anatomy by someone who is not obsesined by the value of insignificant items, and who can deal with facts in a broad sense, allowing for variation, convergence, degeneracy, etc. The present groupings must be regarded as purely of a temporary nature.

\section{Genus PTILINOPUS.}

Ptilinopus Swainson, Zool. Journ., Vol. I, p. 473, Jan. 1825. Typo (by monotypy) : Ptilinopus regina Swainson.

Lamprotreron Bonaparte, Comptes Rendus Acad. Sci. Paris, Vol. XXXIX., p. 876, Nov.

1854. Type (by original designation): Columba superba Temminck et Knip.

Reginopus Mathews, Austral Av. Rec., Vol. II., pt. 4, p. 73, Dec. 29th, 1913. Type (by monotypy): Ptitinopus ewingii Gould.

Smallest Fruit Pigeons with small bills, long wings, long tail and small feathered legs and long toes. The bill is short and slender, the culmen ridge scarcely differentiated from the dertrum which is not swollen but rather strongly cleflected, the nasal 
groove more than half the length of the culmen, the na:al apertures linear and rather Iong, the nasal covering little swollen, more delicate and in the dried skin shrunken; the under mandible slender, the gonys short and ascending, the rami not grooved, interramal space featherel. The feathering is soft and close, the feathers of the breast bifureate and harsh. The wing is pointed, the first primary strongly and abruptly attenuated for the apical third, the other feathers not incised and broad; the first primary is about equal to the sixth, the second to fourth subequal and longest; seeondaries short. The tail is about half the length of the wing, practically square in shape, the feathers fourteen in number, being broad with square tips; the tailcoverts exceed the half of the tail abore and are a little longer below. The legs are small, the tarsus shorter than the culmen and thickly covered with small feathers; the toes have all expanded membranes, the elaws short and curved; the middle toe is longest, exceeding the tarsus in length, the onter is a little shorter and is longer than the inner which is practically equal to the hind-toe and is jointed to it by the membranous extensions.

Coloration green above, crown purple or magenta, breast slaty, belly and abdomen various bright colours; tail with pale terminal bar.

\section{I81. Ptilinopus regina.-RED-CROWNED FRUIT PIGEON.}

Gould, Vol. V., pls. 55, 56 (pt. vir.), Juno 1st, 1842. Mathews, Vol. I., pt. 2, pls. 22 and 23, Jan. 31st, 1911.

Ptilinopus purpuratus var, regina Swainson, Zool. Journ., Vol. I., p. 474, Jan. 1825: New South Wales.

Ptilinopus swainsonii Gould, Birds Austr, pt. vIr, June 1st, 1812: Clarence River, New South Wales.

Ptilinopus ewingii Gould, ib. : Port Essington, Northorn Territory.

Ptilinopus regina melvillensis Mathews, Austral Av. Rec., Vol. I., pt, 2, p. 27, April 2nd, 1912 : Melville Island, Northern Territory.

Distribution.-Queensland, New South Wales, Northern Territory, North-west Australia.

Adult male.-General colour above green, the scapulars dark blue subterminally and margined with golden-rellow; lesser wing-coverts like the back; median and greater covert a darker green, elged with yellow ; bastard-wing and primary-coverts dark green with brown on the inner webs; primary-yuills dark brown on the inner wely, outer wels and tips green, narrowly edged with whitish on the outer cuills, becoming yellow on the imner ones; sceondary-quills more green and more broadly margined with yellow; middle tail-feathers green, tipped with yellow, the outer feathers dark brown on the inner webs; fore-head and crown magenta, borlered by a white line in front of the ere, followed by a yellow one, which skirts the magenta in a circular line on the hinder crown; occiput and hind-neck green, with a hoary wash; chin white; sides of face, sides of neck and throat pale grey; the feathers of the ehest bifureaterl, green at the base and tipped with grevish, imparting a streaked appearanee; a small patch of magenta on the mictule of the abdomen, which separates the orange-red of the lower-ablomen from the green of the chest; feathers of the vent yellow: sides of body, fanks anrl thighs green, the feathers of the lower flanks tipped with yellow, forming a rellow tuft on each of the thighs; under aspect of tail gres, tipiped with rellow; under wing-eoverts and axillaries grey ; bill greenish-hlack, tip horn colour; iris reklish-orange, evelid rellowishgreen; feet olive-brown. Total length $225 \mathrm{~mm}$.; culmen 19, wing 135, tail 67, tarsus 18.

Adult female. - Very similar to the male but not so brightly coloured and with the under tail-corerts yellow instead of orange. Total length $215 \mathrm{~mm}$.; culmen 17 , wing 122 , tail 63 , tarsus 18.

Immature. Green on the top of the head, back of neck, back, rump and uppler tail-coverts, the feathers of the latter with minute pale yellowish tips; the feathers 
of the wing-eoverts, scapulars and secondaries with broader yellow tips; the primaries with white edgings and pale yellow tips; the tail-feathers also green with pale grey broad tips and also largely edged with yellow; throat greyish, softening to green with faint yellowish tips; the breast darker and duller green with faint yellow tips; the abdomen lemon-yellow mixed with orange-red feathers; the sides, flanks and thighs green with pale yellow tips; under tail-coverts pale yellow; inner wing-lining green with yellow tips; lower aspect of primaries lead-grey ; a narrow lemon-yellow line from gape to eye; and fore-head just showing begimning of magenta cap. Iris yellow; bill and feet green. First primary not so much attenuated as in adult.

Nest.-Placed about 50 feet from the ground. A very slight platform, 5 or 6 inches across and about 2 inches in thickness, composed of dry twigs placed in a slender horizontal fork. The contents may be easily seen through the nest from beneath.

Eggs.-Clutch, one; white; an ellipse in form ; texture of shell fine; surface glossy. Dimensions $29 \mathrm{~mm}$. by 20 .

Breeding-season.-October to February.

Distribution and forms.-Tropical Northern Australia and probably some of the Moluceas. Two forms have been accepted : P.r. regina (Swainson) from Eastern Australia, and $P . r$. ewingii Gould, from Northern Territory and North-west Australia, with a paler crown and paler abdomen pateh and an orange band on the breast.

\section{Ptilinopus superbus.-PURPLE-CROWNED FRUIT PIGEON.}

Gould, Vol. V., pl 57 (pt. xтv.), March Ist, 1844. Mathews, Vol. I., pt. 2, pl. 24, Jan. 31st, 1911

Columba superba Temminck et Knip, Les Pigeons, p. 75, pl. 33, 1810 : [Otaheiti] = Halmahera.

Columba cyanovirens Desmarest, Dict. Sci. Nat, Vol. XL., p. 343, June 24th, 1826 ; Lesson, Voy. "Coquille," Zool., pl, 42, f. 1, July 25th, 1827 : New Guinea.

Ptilonopus leucogaster Swainson, Classif. Birds, Vol. II., p. 347, July 1st, 1837. New name for C. cyanovirens.

Lamprotreron porphyrostictus Gould, Ann. Mag. Nat, Hist., Ser IV., Vol, X゙III., p. 137, Feb. 1st, 1874: Cape York, Queensland.

Ptilopus minutus Campbell, Emu, Vol. V., pt. Ir., p. 155, Jan. 1st, 1906 : Cairns, Queensland. Distribution.-Queensland, New South Wales, Victoria, and Tasmania (accidental).

Adult male-Crown of head dark purple; lores, sides of face and band round the occiput green, as alsn the entire back and wings; the scapulars and some of the inner median corerts showing subterminal black spots ; les.er wing-coverts purplishblue, forming a shoulder patch ; remainder of the lesser and outer median coverts green, edged with yellow; greater coverts green on the outer webs and margined with yellow, inner webs black; bastard-wing, primary-coverts and quills black, some of the inmer primary-quills edged with yellow, more broadly on the secondaries; innermost secondaries with a certain amount of green on the outer webs; the two middle tail-feathers green, with pale tips; remainder of the tail-feathers black on the inner webs, green on the outer ones, and tipped with white; a large patch of orange-red on the hind-neck and mantle; throat whiti-h-grey ; fore-neek and ehest lavender-grey, the feathers on the fore-neck, and sides of neck barred with magenta; a blue-black band across the breast, followed by three irregular white bands with two, more or less, complete green ones, the feathers of which are fringed with white; under tail-coverts white, with green on the inner webs; under-surface of tail leadgrey, with white tips; under wing-coverts and axillaries grey, tipned with whitesome of the outer ones being more or less green; bill green; iris yellow; feet red. Total length $213 \mathrm{~mm}$, ; culmen 18, wing 130, tail 67, tarsus 19.

Adult female.--Differs from the male in the alsence of the lavender-grey and the 
purple band on the breast, which is green like the throat; the orange-red patch on the hind-neck and mantle, which is like tlee back ; the magrenta of the head is replaced by a purplish-black spot on the oceiput; and the blue shoulder patch of the male is ab-ent; bill clark indigo-blue; iris light yellow ; feet searlet. Total length $212 \mathrm{~mm}$.; culmen, 17 , wing 128 , tail 59, tarsus 17.

Young frmale of the year. - I ilko the aulult female, but the occipital spot is represented only by a patch of darker green.

Young female. - Is green above, including the head, with a certain amount of coppery reflections, and with pale narrow margins to the feathers on the lower back, rump and upper tail-coverts, as also the scapulars and lesser wing-coverts ; median and greater coverts moro broadly margined with yellow, like the innermost secondaries; bastard-wing, primary-coverts and quills blackish, the latter narrowly elged with white on the outer wels ; midille tail-feathers golden-brown, the outer ferathers being darker with whitish tips ; throat grey ; fore-neck and chent, as also tho sides of neck and sides of body, green, with pale edges to the feathers; abdomen and under tail-coverts white, more or lews, washed with yellow; under wing-coverts dark green, with palo yellowish margins; under aspect of quills lead-grey.

The young resemble those of $P$. suainsoni, particularly in having narrow yellow margins to the primaries and secondaries, and to the tips of the feathers on the chest and breast; they do not show the forked or split feathers on those parts before the end of the second year, although the green bands on the flanlis are conspicuous in the nestling.

Nest.-A platform, about three inches in diameter, composed of a few twigs. Usually situated in serub or in a small tree at a height of two to ten feet from the ground.

Eggs.-Clutch, one usually (sometimes two); elliptical in form; texture of shell somewhat fine, excepting the smaller end, which is slightly granular ; surface glossy ; colour white; slightly toned, or of a faint creamy tint ; axis 29-31 mm., diameter $22 \mathrm{~mm}$.

Breeding-season.-October to February.

Distribution and form.s. Through the Moluecas and New Guinea and ranging down the Wast Cont of Australia, but as yet no definite subsuecies have been determined.

\section{Genus MEGALOPREPIA.}

Megaloprepia Reichenbach, Nat. Syst. Vögel, p. xuvr., 1852 (? 1853). Type (by original designation): Columba magnifica Temminck.

Largo Fruit Pigeons with medium hills, long wings, very long tail and small legs and feet. The bill is broader basally than any of the preceding, the tip strongly deflecteri, no marked dertrum noticeable; the eulmen ridge flattened posteriorly, anteriorly developed and decurved; the nasal groove is long more than half the length, the nasal apertures linear and placed forwards in the groore, the nasal covering delicate and umswollen. though the bill is broad at base; the frontal feathers extend a little on the bill, the skull apparently very flattened; the rami of the under mandible are a little bowed, the interramail space fully feathered, the gonys very short and sharply angulated. The wing is long and pointed, the first primary not at all sealloped, the suceedling four a little incised on outer webs, the feathers hroal : the first primary is equal to the sixth, the fourth the longest, the third and fifth suberual and rery little shorter, the second -eareely less than the fifth; the secondaries short. The tail is rounded, composed of fourteen broad feathers with roumlerl tips, am is three-quarters the length of the wing; the upper and under tail-eorerts are short, only ahout one-thirl the length of the tail, The tarsus is stout but rery hort, only ahout the length of the culmen : the lower portion 
has a few broad seutes visible, the upper being feathered ; the toes are long, the middle toe longest, the outer longer than the inner which is a little longer than the hind-toe, the lateral membranes bring more strongly dereloped between these two than between the others, most noticeable on each side of the hind-toe; the claws long and strongly curved.

Coloration green above, head grey, yellow band across wing-coverts; under parts purple, chin grey, sides of breast green, lower-abdomen orange.

\section{Megaloprepia magnifica.-PURPLE-BREASTED FRUIT PIGEON.}

Gould, Vol. V., pl. 58 (pt. xxv.), Dee. Ist, 1846; Suppl., pl. 67 (pt. II.), Sept. 1st, 1855. Mathews, Vol. I., pt. 2, pls. 25, 26, Jan. 31 st, 1911.

Columba magnifica Temminck, Trans. Linn. Soc. (Lond.), Vol, XIII., pt. I., p. 125, 1821 : Red Point, south of Woollongong, New South Wales.

Carpophaga assimilis Gould, in Jardine's Contr. Omith., 1850, p. $(160=) 106$ : Cape York, North Queensland.

Megaloprepia magnifica keri Mathews, Nov. Zool., Vol. XVIII., p. 184, Jan. 31st, 1912 : Bellenden Ker Range, Queensland.

Distribution.-Now South Wales, Queensland.

Adult male-General colour above golden-green, including the sides of breast and sides of body; an irregular band of yellow or yellowish-white across the wing, which is composed of yellow or white spots on the outer webs of the median coverts and inner greater coverts; primary-quills blackish, green on the outer webs, and cinnamon-brown on the inner ones towards the base : tail-feathers green, with black shafts; head and neck all round, including the throat, lavencler-grey ; feathers of the breast dusky-black at base, with a bar of green, and tipped with rich purple, this latter colour extends in a narrow line up the middle of the neck to the chin; abolomen chll orange-yellow, like the axillaries; under wing-eoverts bright orangeyellow; lower aspect of tail grey, quills below somewhat darker, with a patch of cinnamon at the base; bill red, yellow at tip; iris red, bare skin round eye green; feet green. Total length $485 \mathrm{~mm}$. ; culmen 33, wing 237, tail 188, tarsus 35 .

Adult female.- Similar to the male but slightly smaller. Total length $460 \mathrm{~mm}$.; culmen 32 , wing 230 , tail 172 , tarsus 30 .

Immature.-Not described but apparently similar to the adult.

Nest. Substantial for a pigeon, slightly concave, and almost entirely composed of wire-like tendrils of elimbing plants, placed upon a founclation of a few coarse twigs. Dimensions about 6 inches across by $2 \frac{1}{3}$ inches in depth.

Eggs.-Cluteh, one; elongated in form, considerably pointed torards the smaller end; texture of shell somewhat granular; surface slightly glossy and irregular. Dimensions $45 \mathrm{~mm}$. by 26 .

Breeding-season.-October to February.

Distribution and forms. - New South Wales and Quecusland only, the differenco in size between the forms at the extreme limits of this range being very great. Threo subsprecies are recognisable: $. M . m$. megnifica (Temminck) from Now fouth Wales, very large; 11. m. kevi Mathews, from the Bellenden Ker Range, North Queensland, is nuch smaller, wing 206 against typical $237 \mathrm{~mm}$.; while $M$. m. assimitis (Could) from Cape York is smaller still. Roth child and Hartert, twenty years ago, included the New Guinea forms as only subspecifically separable.

\section{GenuS LEUCOTRERON.}

Leucotreron Bonaparte, Comptes Rendus Acad. Sci. Paris, Vol. XXXIX., p, 876, Nov. 1854. Type (by original designation) : Columlia cincta Temminck. Treralcma Bonaparte, Comptes Rendus Acad. Sei. Paris, Vol. XLI., p. 247, July 1855. Typo (by monotypy) : T. leclancheri Bonap. = Columba gularis Quoy et Gaimard.

Laryngogramma Reichenbach, Tauben, p. 102, 1862. Type (by monotypy): O.gularis Quoy and Gaimard. 
Large Fruit Pigeons with rery small bills, long wings, long tails, short legs and feet. The bill is very small, rather triangular in shape, being broad at the base, the culmen ridge flattened, the dertrum descending, not swollen, and little projecting ; the nasal groore short about half the length of the culmen, the nasal covering delieate and in the dried skin much shrunken, the nostrils linear ; the lower mandible shallow, the rami divergent, the interramal space fully feathered, the gonys rery short, angulated and abruptly ascending; the slaull is not so flattened as in preceding genus. The wing is long and pointed, the first primary abruptly attenuated for the apical fifth and narrowed for the remainler, the second to fifth primaries show no scalloping on outer webs, the sixth to the ninth with peculiar tips, the outer webs strongly pointed, the imer abruptly truncate; the first primary is shorter than the seventh, the second is much longer, the third longer, the fourth longest, the fifth broader and longer than the eceond, the tip apparently tending to attenuation; the secondaries short. The tail is slightly rounded, formed of twelve broad feathers with semi-truncate tips, about three-fourths the length of the wing. The tarsus is stout and short, less than the length of the culnen and densely corered with feathers; the toes are long and slender, the claws long and strongly curred, the middle toe longest, the outer longer than the inmer, the hind-toe a little shorter than the latter, the lateral membranes on sides of hind-toe broad as also on inner side of inner toe.

Coloration: head and neck all round white, back and wings blackish, lower back grey, tail basal black, tip' greyish-white; black breast-band, abdomen slate to green.

\section{I84. Leucotreron alligator.-BLACK-BANDED FRUIT PIGEON.}

Mathews, Vol. I., pt. 2, pl. 21, Jan. 31st, 1911.

Ptilopus (Leucotreron) alligator Collett, Proc. Zool. Soc. (Lond.), 1898, p. 354, Oct. 1st : Arnhem Land, Northern Territory.

Distribution.-Northern Territory.

Adult female.-Head and neck all round, including the upper-breast, white, with a wash of buff on the latter, as al so on the hind-rieck, a narrow white line dividing these parts from the greenish-black band on the breast and the black of the upper back; lesser wing-corerts like the upver back; mexlian and greater coverts slategrey, with black margins; primary-coverts and primary-quills greeni-h-black, as also the secontaries; lower back dark a-hy-grey, becoming paler on the upper tail-coverts; the long upper tail-coverts showing clark shaft-streaks; tail black, broadly tipped with white; abdomen, sides of body, uncler wing-coverts, axillaries, and under tail-coverts bluish-grey, becoming almost white on the long under taileoverts; bill (in skin) light coloured, tip vellowish; feet reddish. Total length $345 \mathrm{~mm}$.; culmen 23 , wing 184, tail 140, tarsus 21.

Adult male.-Similar to female.

Nest and Eggs.-Undescribed.

Distribution and forms.-Rentricted to Northern Territory and no subspecies.

\section{Genus MYRISTICIVORA.}

Myristicivora Reichenbach, Nat. Syst. Vögel, p. xxvI., 1852 (? 1853). Typo (by original designation): Columba littoralis Temm. $=C$. bicolor Scopoli.

Large Fruit Pigeons with morlerate bill, long wings, long tail and short stout legs and feet. The chief feature of this beautiful genus are its lack of peculiarities. The bill is formed as in Leucotreron, but larger, the clertrum proportionately less but strongly decurved. The wing is ecomposed of normal feathers, long and pointed, the lirst primary almost longest, equal to third and only exceeded slightly by second, 
which is the longest, the remainder grailually decreasing; the secondaries very short. The tail is ermaginate, the feathers fourteen in number, truncate at tip, and is only about half the length of the wing; upper tail-eoverts short, under a little longer, a little more than half the length of the tail. The legs are very stout, the tarsus about as long as culmen, only feathered on upper half of the front, the lower half showing a few large scutes, the hind portion bring coverel with minute reticulation. The toes are long and stout, formed as in Globicera, but much longer.

Coloration pure white, primaries, secondaries and apical portion of tail slatyblack, sometimes a few blackish spots on under tail-coverts, flanks, etc.

\section{I85. Myristicivora bicolor.-NUTMEG PIGEON.}

[Columba bicolor Scopoli, Del. Flor. et Faun. Insub., Vol. II., p. 94, 1786: New Guinea. Extra-limital.]

Gould, Vol. V., pl. 60 (pt. xா.), Sept. 1st, 1843. Mathews, Vol. I., pt. 2, pl, 27, Jan. 31st. 1911.

Carpophaga spilorrhoa Gray, Proc. Zool. Soc. (Lond.), 1858, p. 186, July 13th: Aru Islands. Myristicivora bicolor melvillensis Mathews, Austral Av. Rec., Vol. I., pt. 2, p. 27, April 2nd, 1912 : Melville Island, Northern Territory.

Distribution.-Northern Nerv South Wales, Queensland, Northern Territory, North-ivest Australia.

Adult male.-General colour white; bastard-wing and primary-coverts black; primary- and secondary-quills blaek, everywhere clusted with grey; tail white, broadly tipped with black, more narrowly on the outer feathers, the outermost margined with black down to the base; the feathers of the lower-ablomen, flanks and under tail-coverts with submarginal black spots; quills below lead-grey; bill yellow, black at the base ; iris brown, feet slate colour. Total Jength $345 \mathrm{~mm}$.; culmen 26 , wing 225 , tail 120 , tarsus 27.

Adult female.-Similar to the male.

Nest.-Flat, straight, being merely a few sticks or twigs placed crosswisesome are more substantial, being built of green branchlets; usually situated on a horizontal branch of any tree, not unfrequently in mangroves overhanging water, and occasionally near the ground or on rocks. Sometimes three or four nests are situated in one tree.

Eggs.-Clutch, one ; smooth and glossy"; pure white. Measurements of two eggs, axis $44-46 \mathrm{~mm}$., diameter $30 \mathrm{~mm}$.

Breeding-season.-November to January.

Distribution and forms.-Throughout the Moluccas, New Guinea and outlying islands, migrating into tropical northern Australia and on the east coast reaching into New South Wales. Subspecies are not easily clifierentiated on account of almost pure white coloration, the Australian form $. I . b$. spilorthoa (Gray) being recognised by means of the black spotting on the under tail-coverts, this feature being more or less absent in the typical race.

\section{Genus GLOBICERA.}

Globicera Bonaparte, Comptes Rendus Acad. Sci. Paris, Vol. XXXIX., p. 1072, (about Dec. 11th) 1854. Type (by tautonymy): Columba globicera Wagl. = Columba pacifica Gmelin.

Large Fruit Pigeons with stout bills bearing a basal globular excrescence, long pointed wings, long tails, small stout legs and feet. The bill is rather long for this group, the dertrum stout, about half the length of the bill, the culnem basally bearing a large exereseence (said to be glohular in the living bird) truncate by the frontal feathers and showing the nasal apertures as somewhat rounded holes in the anterior portion; the lower mandible rather strong, the rami a little curved, the interramal 
space feathered, the gonys very short and angulated. The wing is long, the feathers neither appreciably scalloper nor narrowed on either web, the first primary long, longer than the fifth ancl only a little less than the second, which eyuals the fourth and the third is barely longer; the secondaries are short. The tail is long, more than half the length of the wing, rather enarginate, being composed of fourteen broad feathers with truncate tips, tail-eovert: short. The legs are stout and longer than the culmen, the lower half showing coarse hexagonal scutes in front, minutely reticulate behind, the uprex portion densely feathered. The toes are coarse, the mid,le toe longest, the onter longer than the inner, which slightly exceeds the hindtoe, all the claw long and curved; the -ides of the hinel-toe show strong lateral slsin expansion as does the inside of the inner toe, but otherwise not much is seen.

Coloration: head and neek grey, back, tail, and wings metallic-green, undersurface vinous, under tail-coverts chestnut.

\section{Globicera pacifica.-GREY-HEADED PIGEON.}

[Columba pacifica Gmelin, Syst. Nat., Vol. I., pt. ח., p. 777, April 20th, 1789: Friendly Islands. Extra-limital.]

Mathews, Vol. VII., pt. 5, pl. 366, July 10th, 1919.

Globicera pacifica quecnslandica Mathews, Austral Av. Rec., Vol. II., pt. 5, p. 85, Sept. 24th, 1914: Mackay, North Queensland.

Distributrow,-Queensland (visitor). One specimen preserved in Matherws's collection.

Adult.-Crown of head, sides of face, hind-neck, and mantle ash-grey ; entire back, upper tail-coverts, seapulars, wings, and tail bronze-green with pale coppery reflections on the back and wings; inner webs of flight-quills blackish-brown; tail darker than the baek and inclining to steel-blue on the middle of the feathers, inner webs of the outer feathers blackish; lase of fore-head, fore-part of cheeks, chin, and throat greyish-white, becoming darker on the last; a very narrow dark line on each side of the throat; sides of the breast, sides of body, and thighs ash-grey, becoming darker on the last; middle of breast, abdomen, and vent pale vinous somewhat deeper in colour on the last; under tail-coverts chestnut; axillaries and inner under wing-coverts ash-grey, the outer ones darker and more slate-grey; under-surface of tlight-quills vinous-brown; lower aspect of tail black. Total length $375 \mathrm{~mm}$; culmen 21 (?), wing 239 , tail 136, tarsus 33.

\section{Globicera rubricera.-RED-CERED PIGEON.}

[Globicera mubricera Bonaparte, Comptes Rendus Acad. Sci. Paris, Vol. XXXIX., p. 1073, (about Dec. 11th) 1851: New Iroland. Extra-limital.]

Emu, Vol. XVIII., pt. 4, pl. Xxxヌ., p. 239, April 1st, 1919.

? Carpophaga lepida Cassin, Proc. Acad. Nat. Sci. Philad., Vol. VII., 1854, p. 230, 1855, March 23rd: Northern Australia.

Distribution.-Northern Australia (visitor). One specimen preserved in Philadelphia.

"Bill with a large frontal protuberance which includes the apertures of the nostrils; wing moderate, second quill longest; tail rather short, composed of twelve feather, under tail-coverts nearly as long as the tail. Legs short; tarsus feathered for half its length, thick; toes rather long, padded and llattened on their undersurfaces; claws strong, curred.

Frontal protuberances (at the base of the upper mandible) jellow. Entire head, neck, breast and ab lomen light purplish-cinereous (or light vinaceous) clsanging to light einereous on the back of the neck, where it joins the colour of the back, and becoming darker and clearer vinaceots on the breast and abdomen. 1Back, upper wing-coverts, secondary-(puills, rump) and upper tail-corerts brilliant metallic-gre('n, with golden and copper-coloured reflections. Primary-quills and tail-feathers 
brilliant metallic-blue, the outer edges of the former and both edges of the latter changing to green. Ventral region, under tail-corerts and tibia reddish-chestnut colour; short feathers of the tarsi cinereous. Inferior coverts of the wing light cinereous. Bill dark; feet light?

Dimensions.-Total length (of skin) about 151 inches, wing 81 , tail 5 inches.

Hab.-Northern Australia?" (Cassin's account of C. lepida.)

Note.-The preceling is all that is kuorn conceming the ocenrence of members of the genus Globicera in Australia, but as the former has not been identified with any known form of ( $t$. pacifica it seems best to keep) these on record, especially in view of the occurrences of the two Parrots of the genera Lorius (=Eclectus olim) and Geoffroyns, altogether unexpeeted, and had either of these been represented by single specimens only they would have been likewise discredited.

\section{Genus LOPHOLAIMUS.}

Lopholaimus Gould, Birds Austr., pt. v., Dec. 1st, 1841. Type (by monotypy): Columba antarctica Shaw.

Lophorynchus Swainson, Classif. Birds, Vol. II., p. 348, July 1st, 1837. Type (by monotypy): Columba ditopha Temm. = Columba antarctica Shaw.

Not Vieillot, Analyse, p. 59, April 14th, 1816.

Large Fruit Pigeons with a double crest, trifurcate feathers on hind-neck and breast, long wings, long tail, short legs and feet. The bill is short, the dertrum swollen but strongly decurved, the culmen bearing feathers basally forming an unstanding crest ; the nasal eovering is large, strong and smollen, the nasal apertures linear below; the lower mandible broader, the rami diverging and embracing the edge: of the upper mandible, the rumi deep and long, the interramal space fully feathered and the monys rery short, strongly angulated and alnuptly a-ceneling. The occipital crest is full, the feathers soft, the tips truncate; the feathers of the hind-neck and breast trifurcate. The wing is long and pointed, all tho feathers normal, none showing narrowing or sealloping ; the lirst primary is long and erual to the fifth, the second and fourth subequal, the third a little longer and longent; the secondaries short. The tail is very long, about two-thirds the length of the wing, the feathers, fourteen in number, being very broad with rounded tips and forming an ahsolutely square tail. The legs are short and stout, the tarsus corered thickly with feathers, a few scales seren at joint of toes which are long, the micklle too longest, the outer longer than the imner, which is a little longer than the hindtoe, the lateral expansions of the two latter being noticeable; all the claws are rery long and hooked.

Coloration: upper and under coloration grey, primaries and tail black, latter with a grey band across middle and grey base; occipital crest chestnut.

\section{I88. Lopholaimus antarcticus.-TOP-KNOT PIGEON.}

Gould, Vol. V., pl. 61 (pt. v.), Dec. 1st, 1841. Mathews, Vol, I., pt. 2, pl. 28, Jan. 31 st, 1911.

Columba antarctica Shaw, Zool. New Holland, p. 15, pl. V., 1793: New South Wales.

Columba dilopha Temminck, Trans. Linn. Soc. (Lond.), Vol. XIII., pt. I., p. 124, 1821: Red Point, south of Woollongong, New South Wales.

Lopholaimus antarcticus minor Mathews, Birds Austr., Vol. I., pt. 2, p. 122, Jan, 31 st, 1911 : North Queensland.

Distributron.--Queensland, New South Wales, Victoria.

Adult male.-General colour both above and below grey, being much paler on the latter; all the feathers with silky-white down-like bases; wings and back pale slate-grey, somewhat lighter on the lower back, rump and upjer tail-coverts; bustard-rving, primary-corerts and quills black, the immermost secondaries like the 
back, somewhat clarker on the inner webs ; tail black, grey at the base and crossed by a buff band near the tip); frontal crest grey, occipital portion chestrut, some of the lateral feathers black; feathers of the breast, hind-neck and upper mantle trifureated, showing black on the micldle portion, more particularly on the upper mantle, where it imparts a more or less streaked appearance ; remainder of undersurface, including the under wing-coverts and axillaries pale ashy-grey; bill rosered, inclining to lilac at the tip, fleshy part covering the mostrils and hase of lower mandible grecnish-lead colour; iris fiery orange, bare space round the eyes red; feet purplish-red, back of tarsus and soles of feet greyish-brown. Total length $460 \mathrm{~mm}$.; culmen (exp.) 14, wing 283, tail 172, tarsus 29.

Adult female.-Searcely different from the male. Bill rermilion, base slate colour; iris clear yellowish, with bromnish stains round the pupil surrounded by orange; feet pinkish-purple. Total length $407 \mathrm{~mm}$. ; culmen 14, wing 265 , tail 170 , tarsus 25.

Nest.-A platform of fairly stout twigs placed in a tall tree. Dimensions 8 to 10 inches across by about 3 inches in thickness.

Eggs.-Cluteh, one; elliptical in form, sometimes with the encls peculiarly pointed, especially the smaller; texture of shell somewhat granular; surface glossy; colour pearly-white. Dimension $42-45 \mathrm{~mm}$. by 31 .

Breeding-season.-October to December.

Distribution and forms.-Confuned to eastem Australia but may occur in New Guinea. Two subspecies have been distinguished: L. a. antarcticus (Shaw) from New South Wales, Victoria, and Southern Queensland, and L. a. minor Mathews from North Queensland, differing in smaller size and paler coloration. 


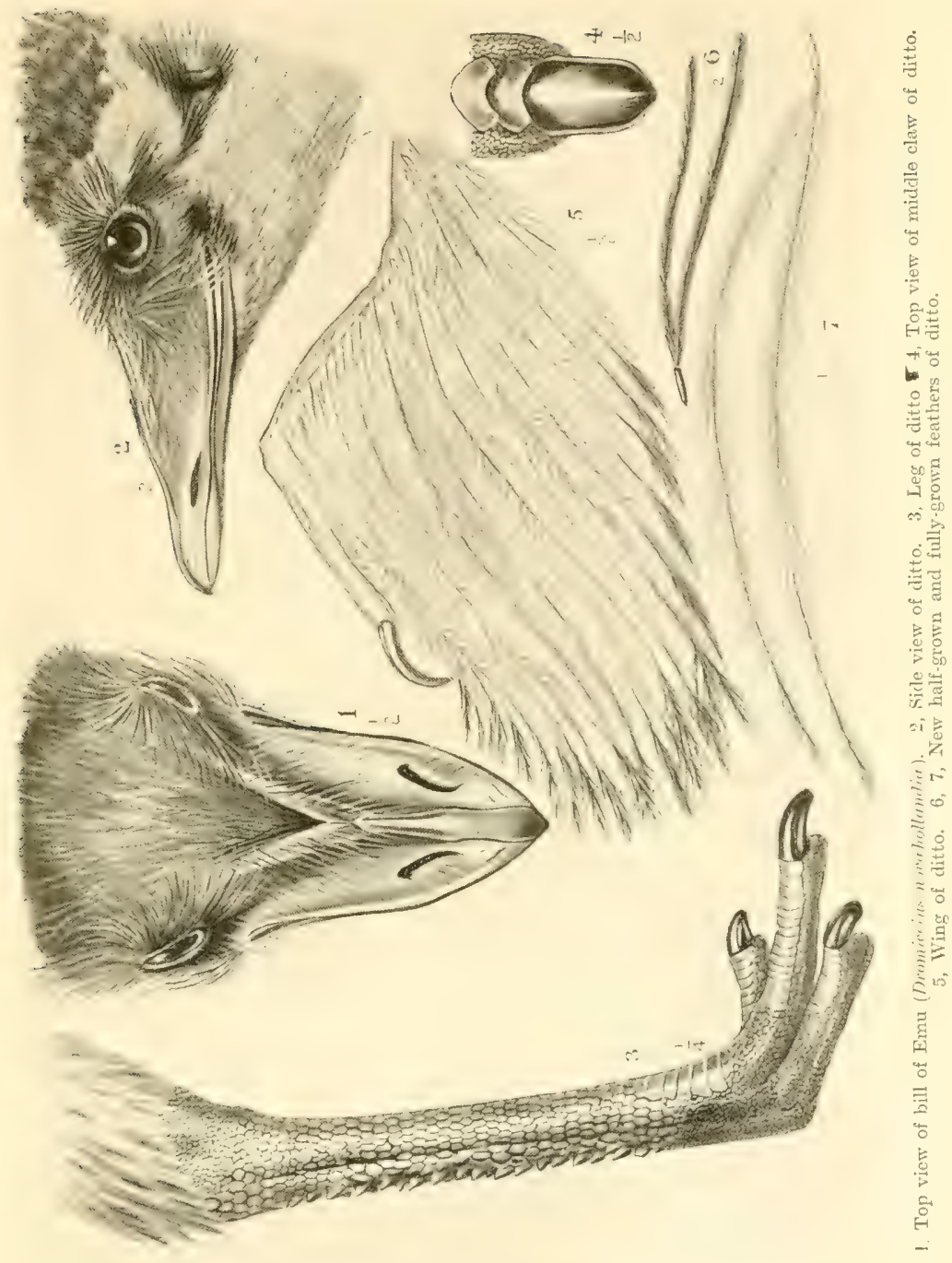




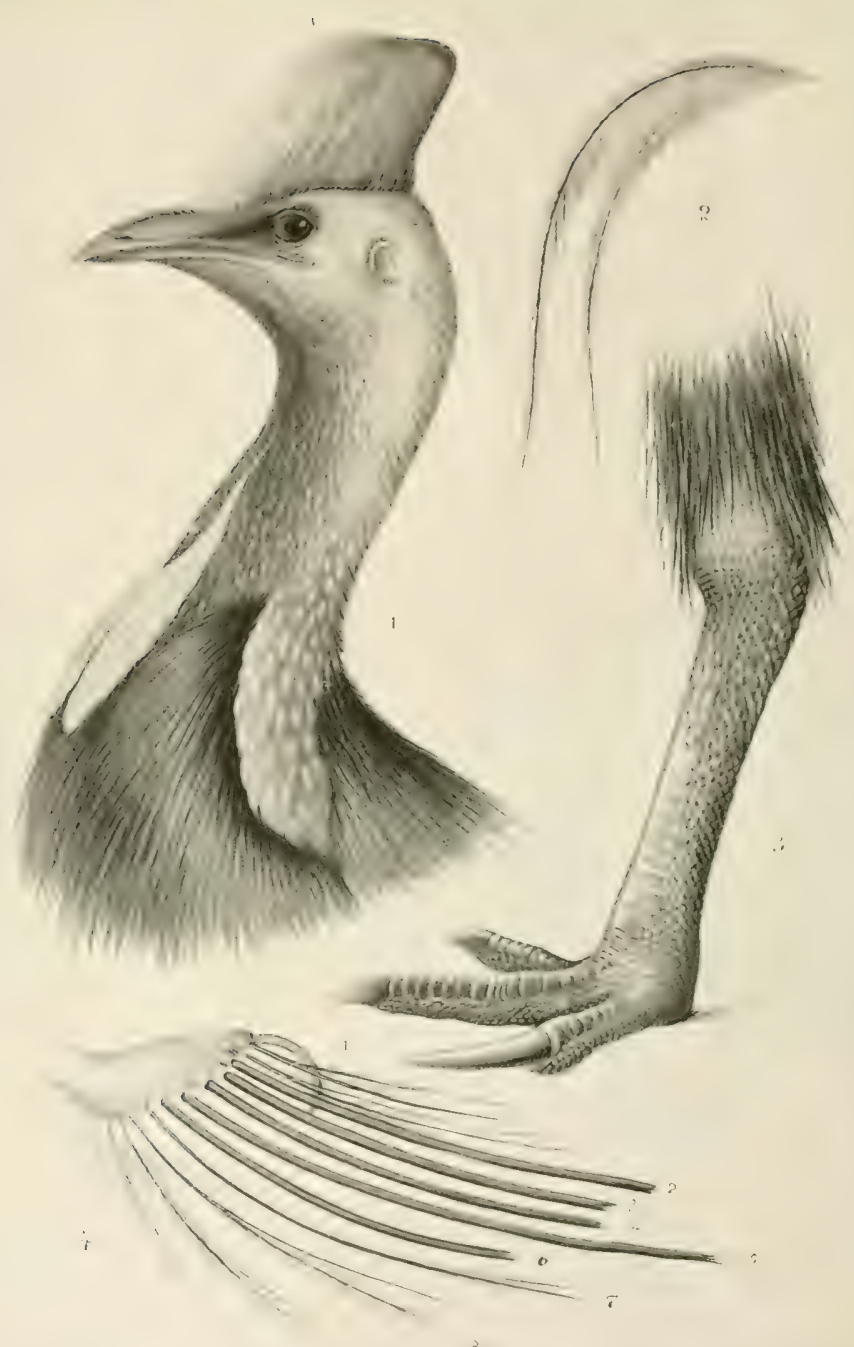

1. Hoad of Cassowary (Casuarius c. hamilton?). 2. Feather of ditto. 3, Leg of ditto. 4, Wing of ditto. Nll relued to one-fourth natural size. 

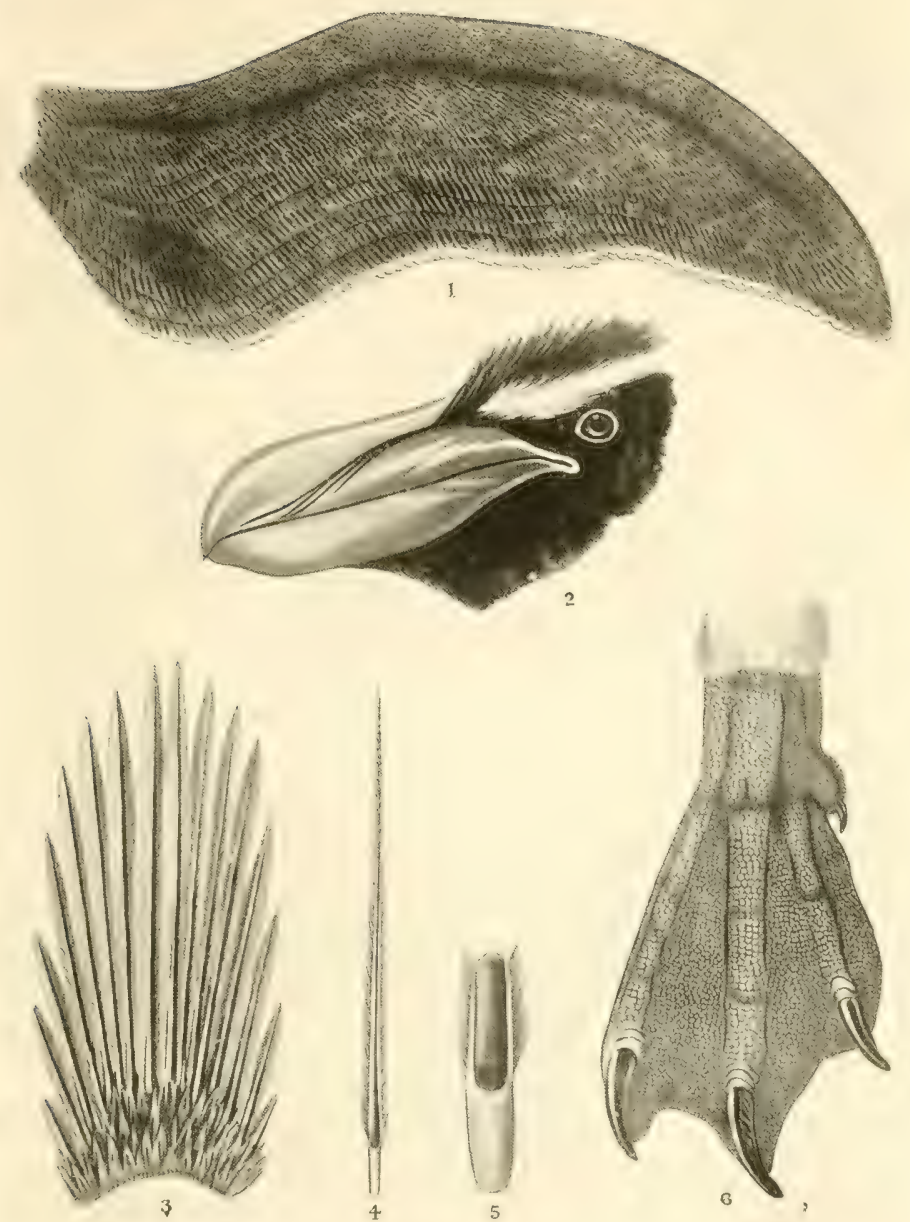

1, Flipper of Big-crested Penguin (Eudyptes pachyrhynchus). 2, IBill of ditto. 3 , Tail of ditto. 4, 5, Underside of tail-feathers, showing excavate shaft, 6, Foot of ditto. All reduced to two-thirds natural size, except No. 5, which is enlarged. 


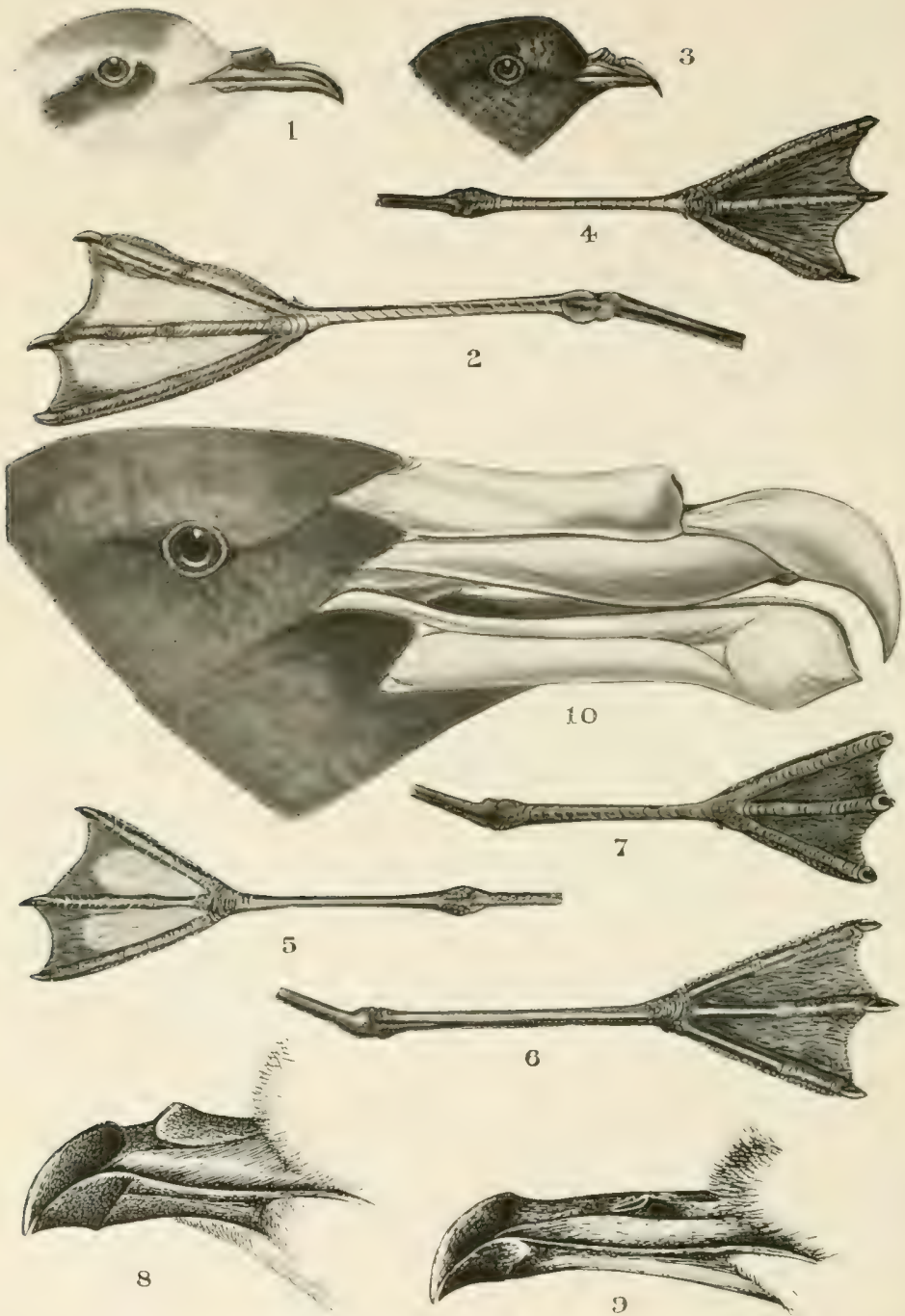

1. 2. Head and bey of White-faced Storm Petrel (Pelagodroma marina), 3, 4, Head and leg of Grej-bucked Stom Petrel (Cictrolia nereis). 5, Leg of Yellow-webted Storm Petrel (Oceanites oce 7nicus). 6, Ley of Black-bellien Storm Petrel (Fregcta tropica). 7, Leg of White-bellied Storm P'etrel (Eregettormis grallarius). 8, Bill of nestling P'feroulroma. 9, Bill of nestling Puffinus. 10. Head of Giant I'etrel (Macronectes gigantens). 


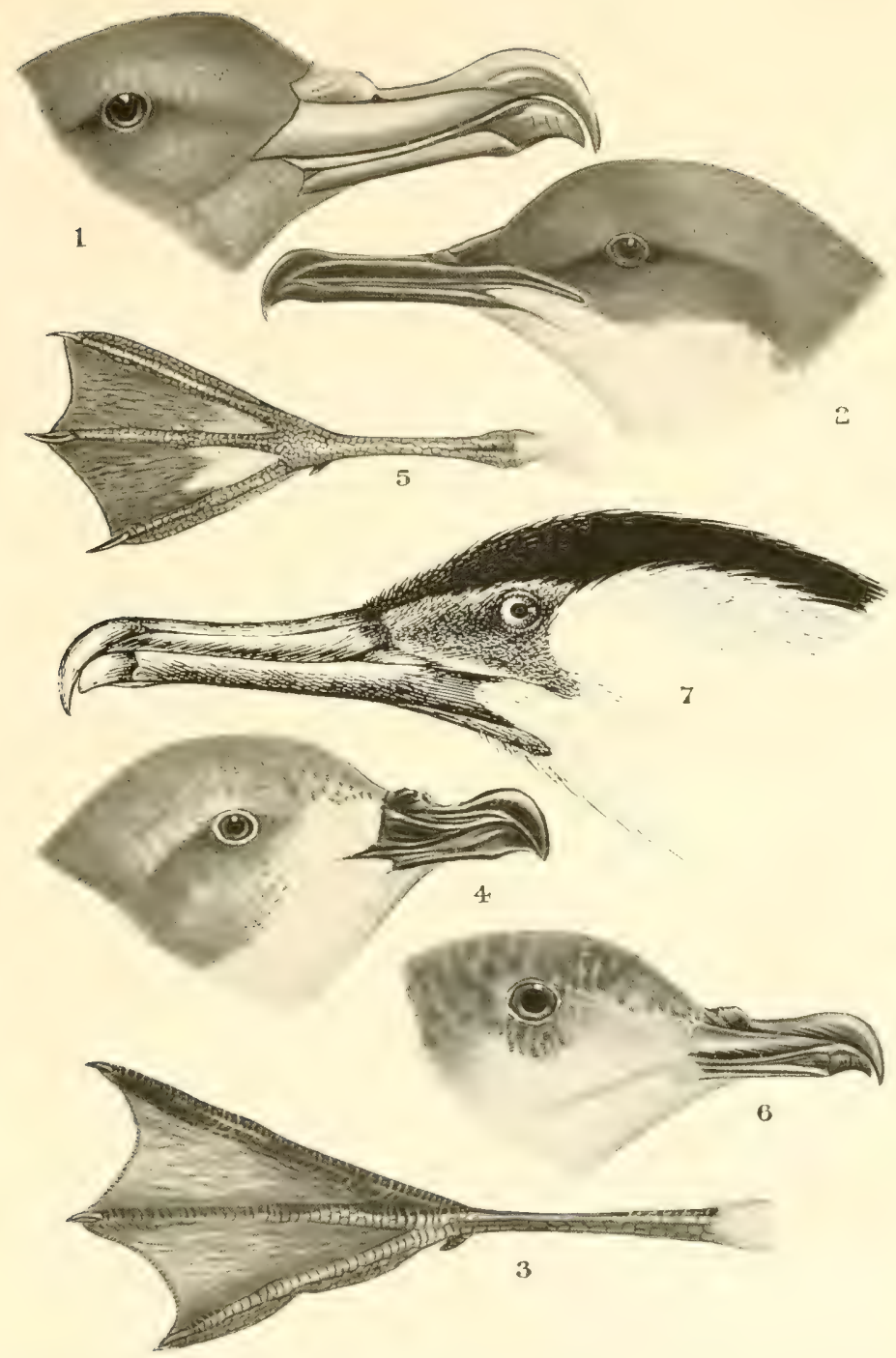

1, Heal of Fleshy-footed Shearwater (Hemipuffims cameipes). 2, 3, Head and leg of Allied Shearwater (Puffinus assimilis). 4,5, Head and Leg of White-winged Petrel (Cookilaria conkii). 6, Heal of Blue Petrel (Halohena cirulea). 7, Head of Whife-breasted Comorant (Hypoleacus

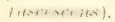




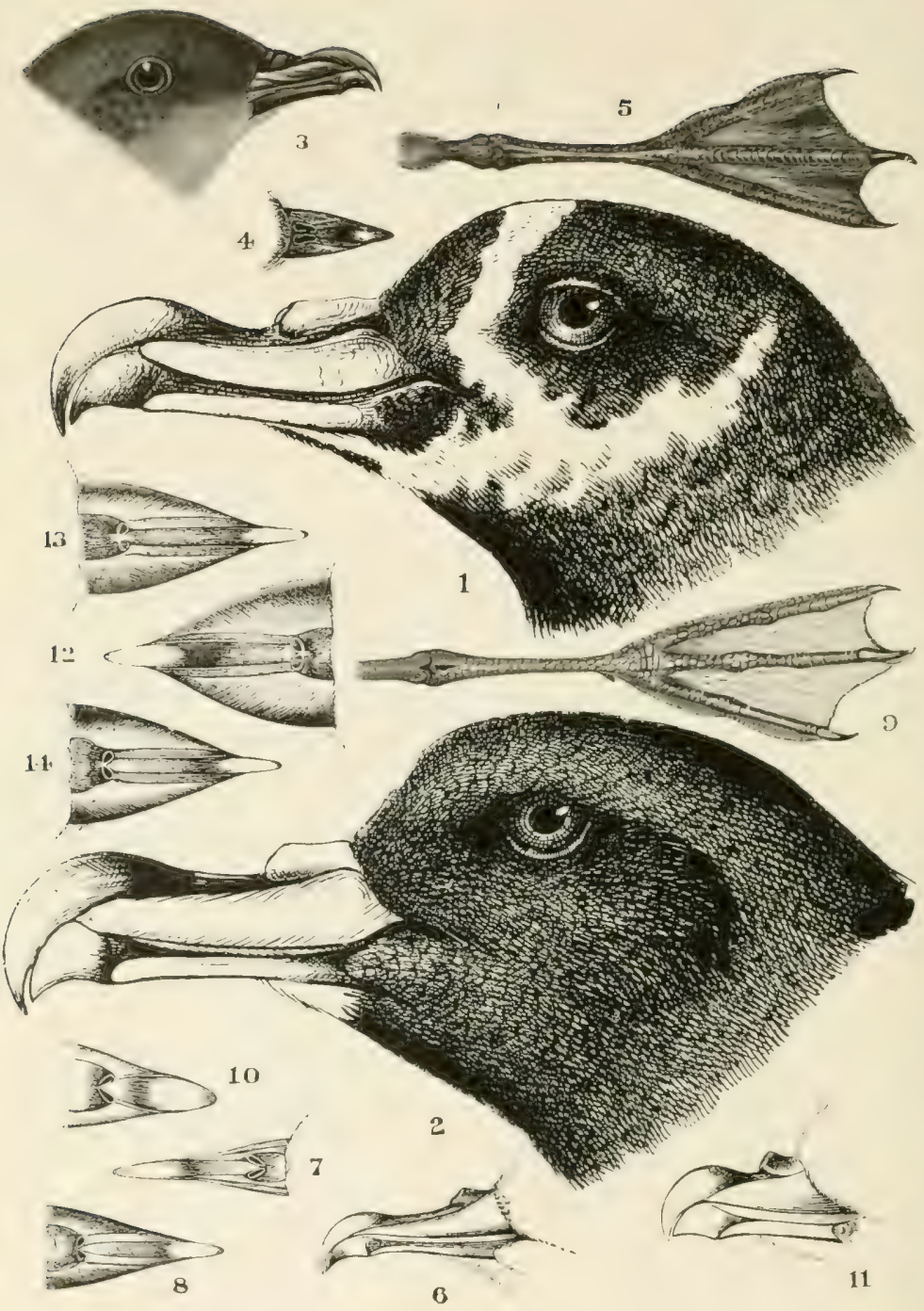

1. Head of Spectacled I'etrel (I'rocellaria conspicillata). 2, Head of White-chinned l'etrel Proccllaria aquinoctialis). 3, 4, 5, Head, top of bill and leg of Diving l'etrel (P'clecanoiles trinatrix). 6, 7 , side and top of bill of Thin-billed Prion (Heteroprion belcheri). 8, 9, Top view of bill and leg of Dove I'rion (H. desolatus mattingleyi). 10, 11, Top and side of hill of Fairy Prion (Pscudoprion turtur crassirostris). 12,13,14. Top views of bills of Broad-billed Prion (Pachyptila vittate vittata, $P$. $\%$. missus, $P$. \%. gouldi.) 


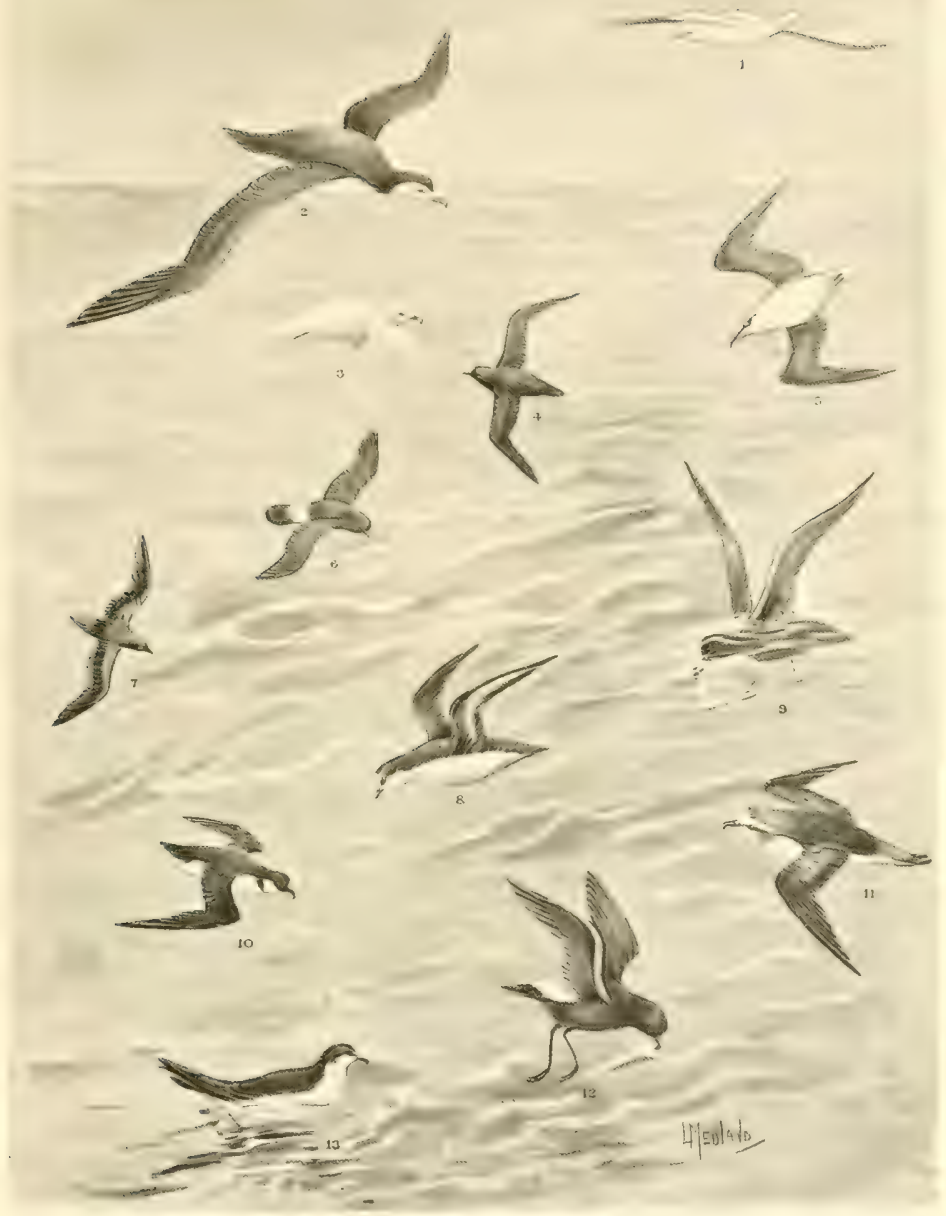

1, Diomedea chionoptere. 2, D. cxulans. 3, Payadrama mirea. 4, Ptcradrome macroptert. 5, Estrelata lessonii. 6, Fregettomis grallarins, 7, Pachyptila riftata. 8, Cookilaria cookii. 9, Procellaria equinoctialis. 10, Pelecanoides urinatrix. 11, Pelagalromamarina. 12, Oceanites oceanicus, 13, Puffinus assimilis. 
l'late IIII.

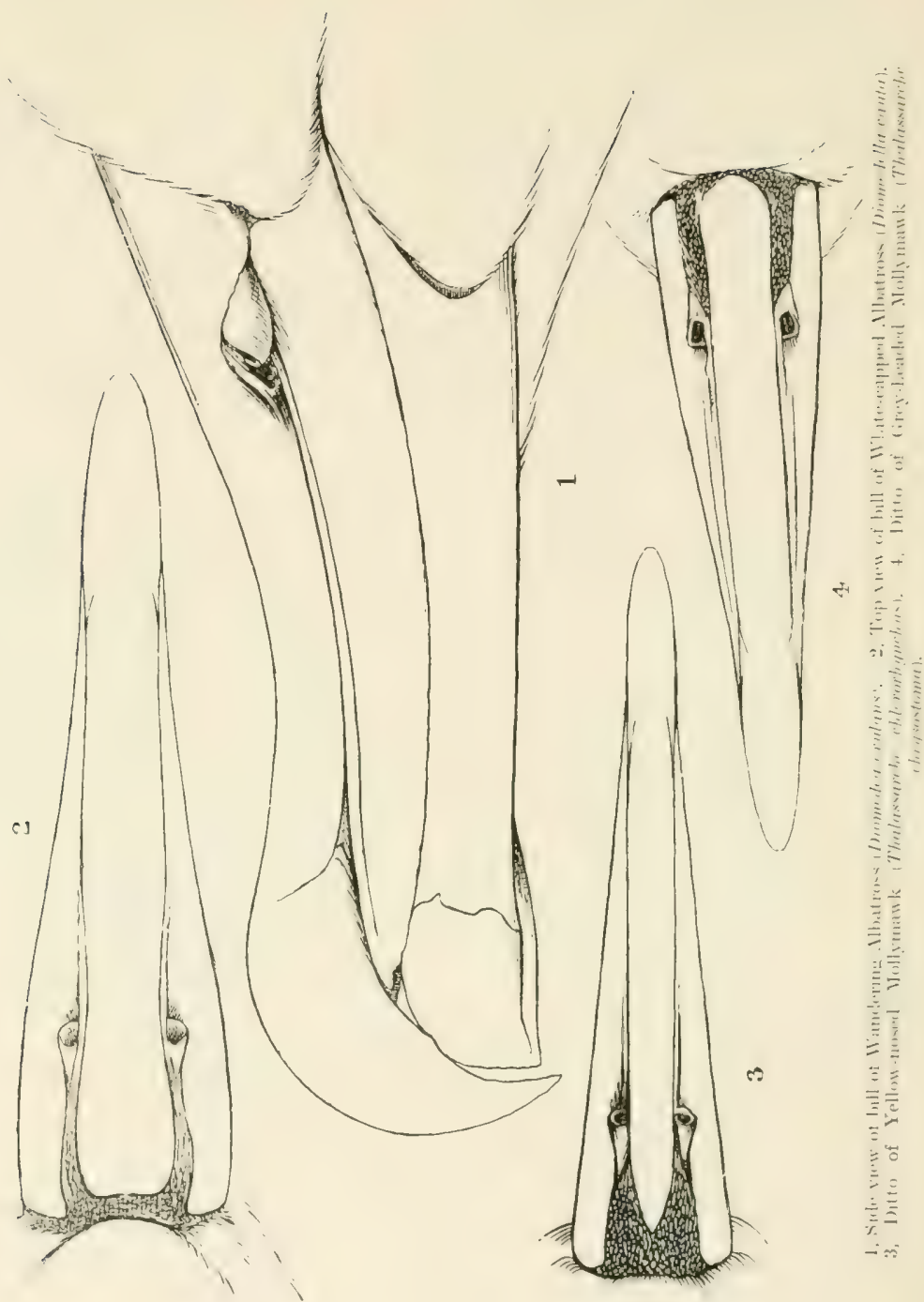




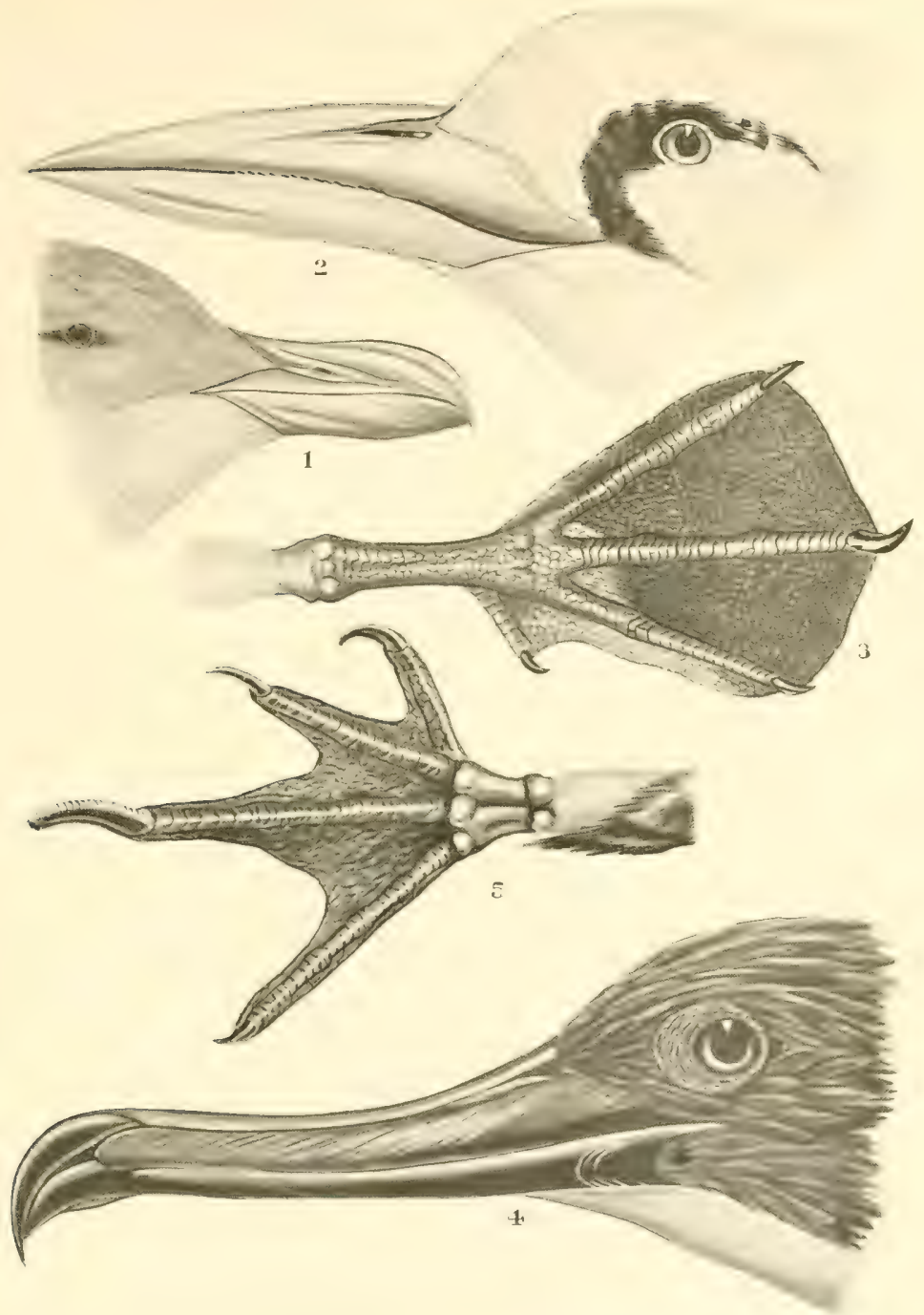

1. Bill of Fairy Penguin (kiudyptule minor). 2, 3. Head and lec of Red-tailed Tropic Bird (Sccophathon rubricauda). 4, 5, Head and leg of Lesser Frigate Bird (Fregala urict? 
L'T.ATF X'。
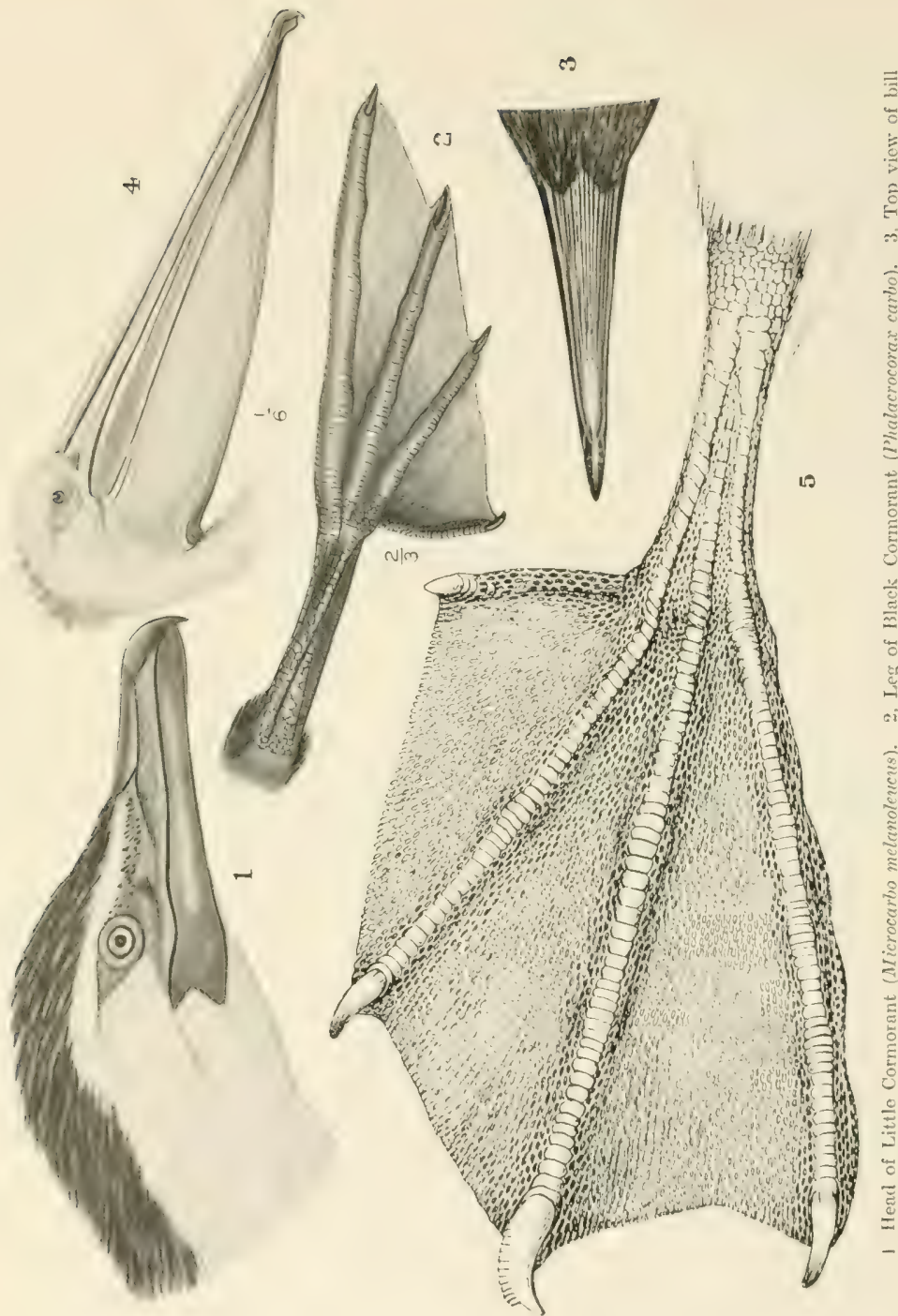

총

$\frac{5}{3}$

들

$11: 1$

(1) 1

bis 5 t

(4)

i. $y$

fis

if 1

is

(4) ! ! !

$2 y-1$ (x)

fid

3. $\mathrm{N} / \mathrm{m}$ fin
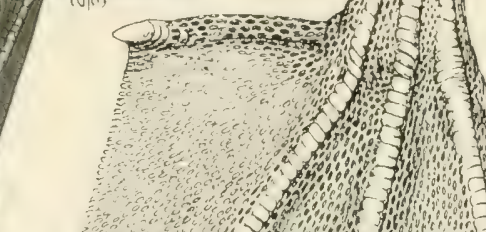


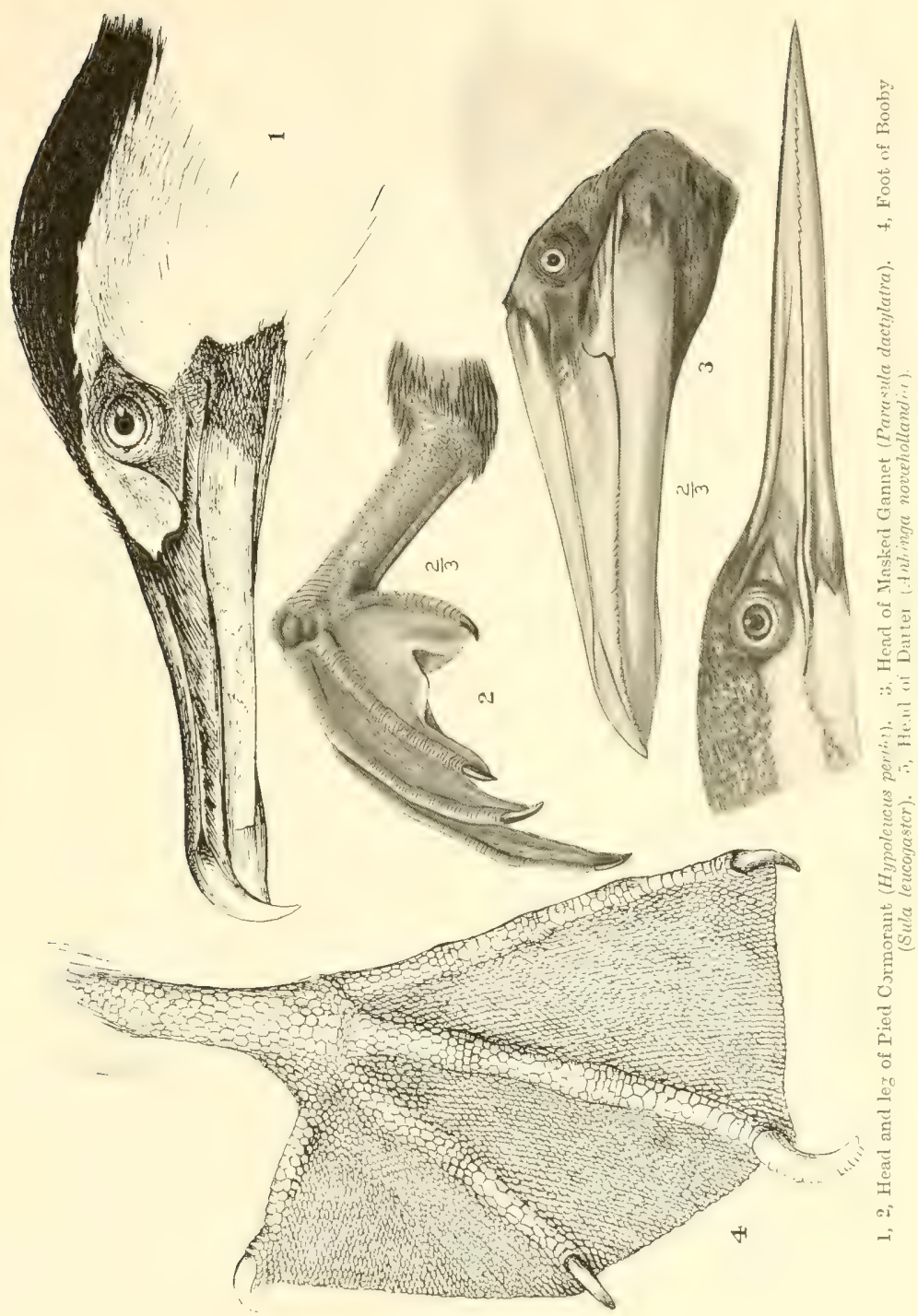




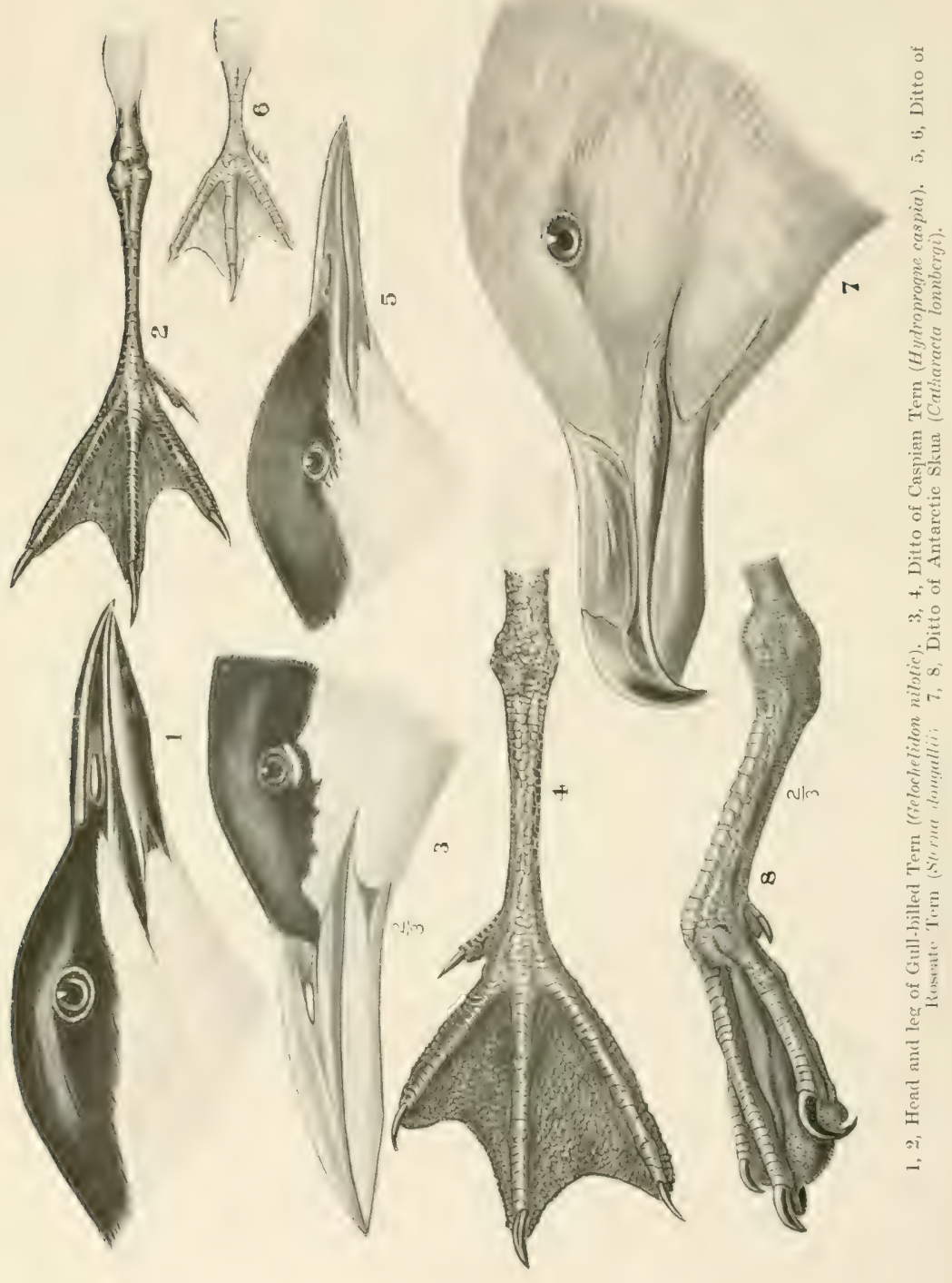



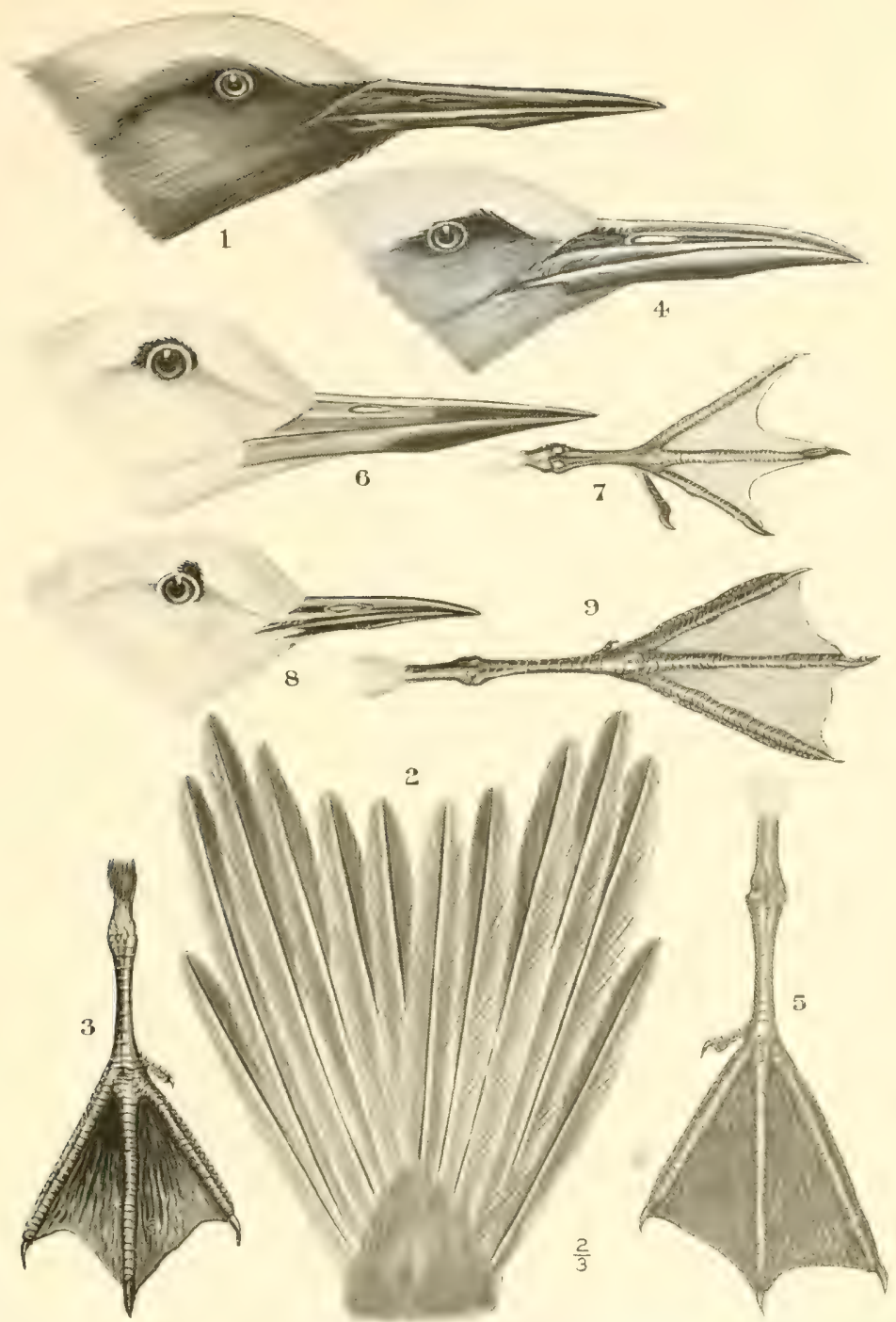

1, 2, 3, Head, tail and leg of White-apped Noddy (Megulopterus mimutus) 4, 5, Heat and lege

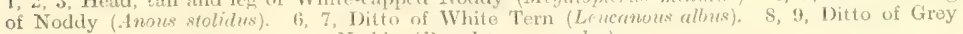
Nodily (l'rocelsterna cervilea). 
Prate XIY.

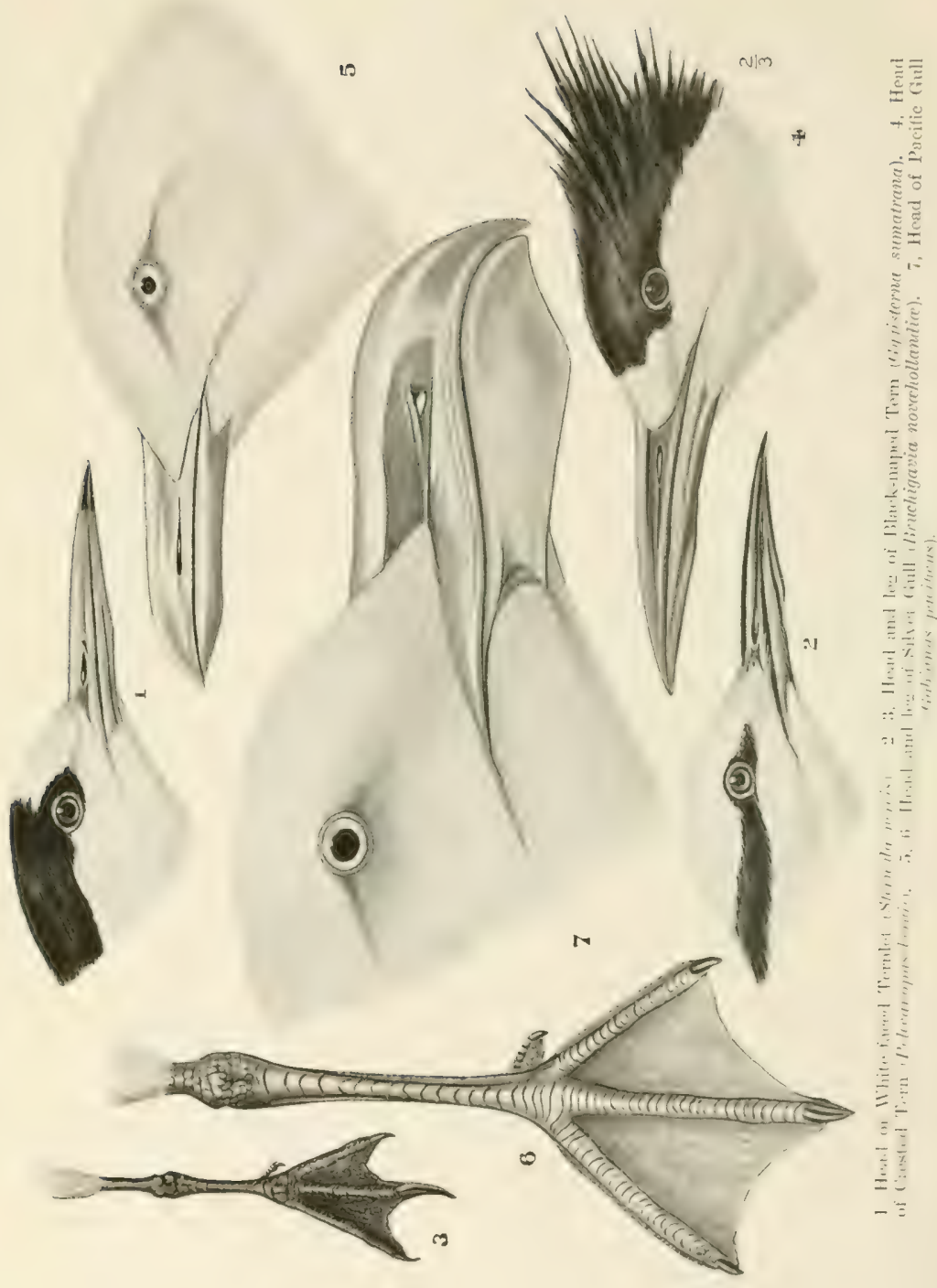




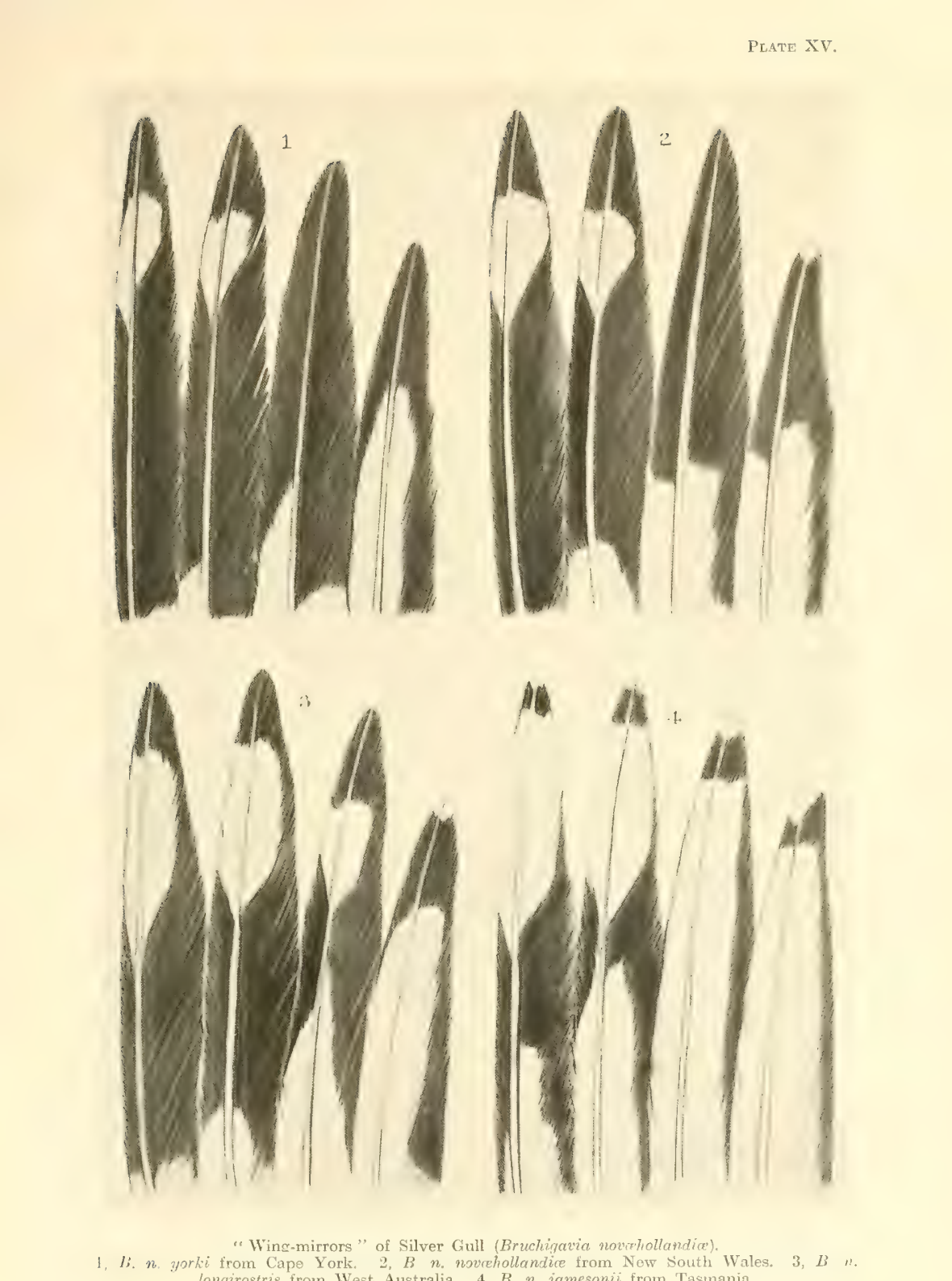



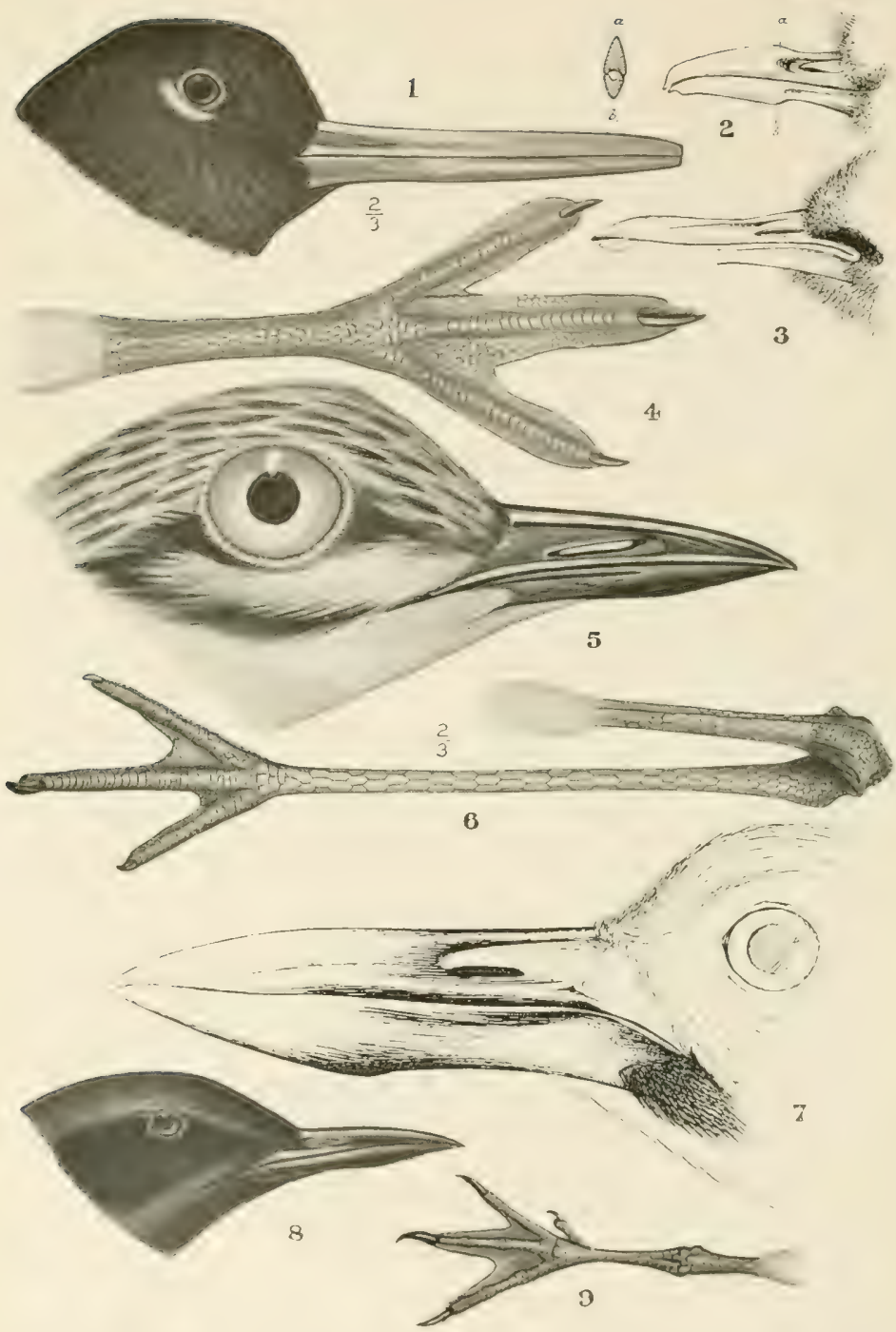

1. Bill of Pied Oystercatchor (IItemztopus ostralegus). 2, 3, J)itto of nestling and half-grown younc.

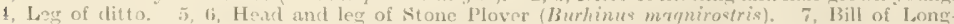
billed stone P'lover (Ortharhamphus magniroatris). 8, 9, Hend and leg of White-winged Ifash Tern (Chlidonias leweoptera). 

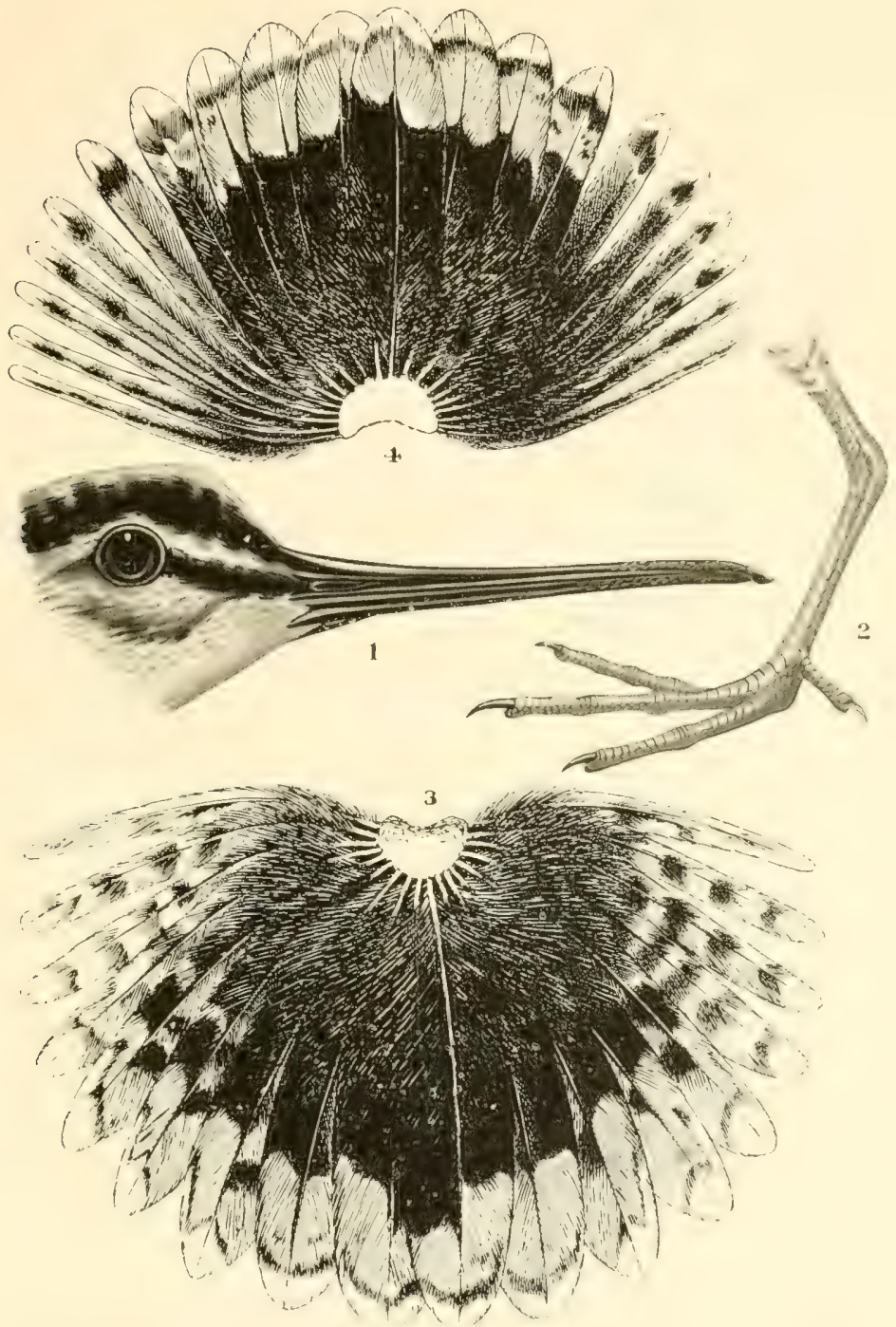

1, 2, 3, Head, leg and tail of Snipe (Ditelmatias harlwichii), 4, Tail of Pin-tailed Snipo (Subspilura megalla). 


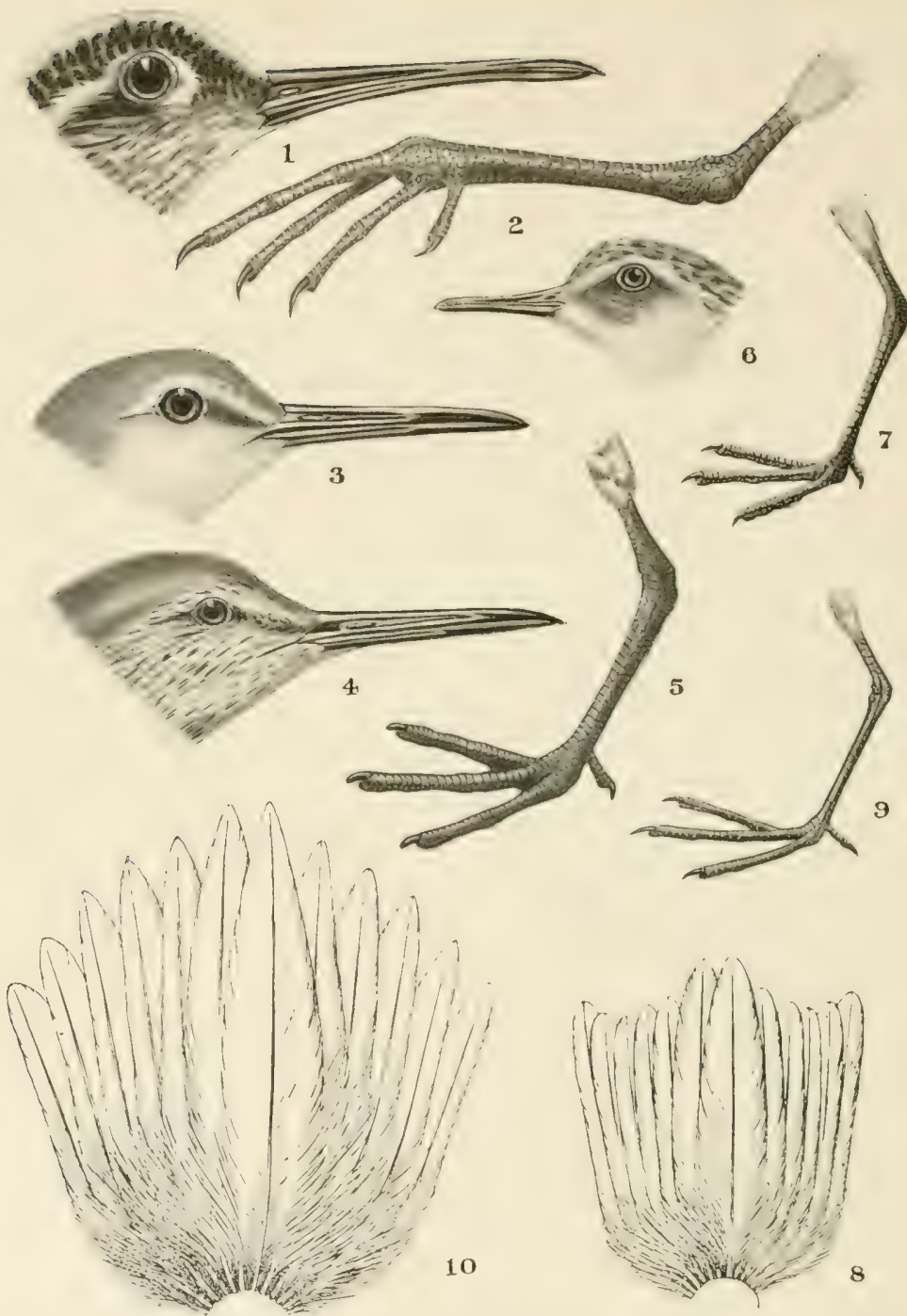

1. 2. Head and leg of Painted Snipo (Rostralula australis). 3, Head of Grey-rumped Tattler (Heteractitis brevipes). $t, \overline{5}$, Head and leg of Wandering Tattler (Heteractitis incarus). 6. 7, 8, Head, leg and tail of Red-necked Stint (Pisobia ruficollis). 9, Leg of Long-toed Stint (l'isobia subminuta). 10, Tail of Sharp-tailed Stint (Limnocinclus acuminatus). 


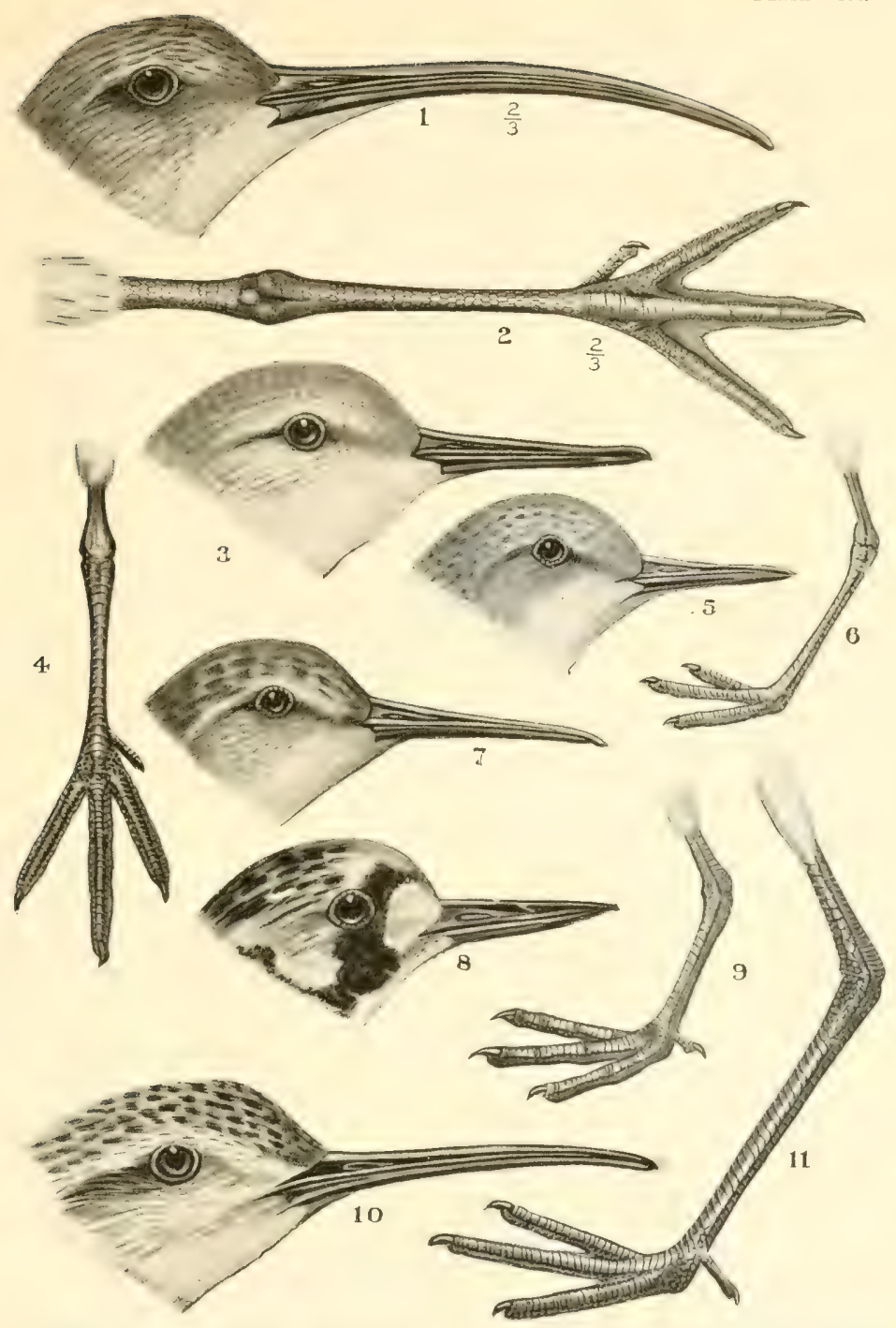

1, 2, Head and leg of Curlew (Numenius cyanapus). 3, 4, Head and leg of Knot (Calidris canutus). 5, 6, Head and leg of Sanderling (Cracethia alba). 7, Head of Curlew-Sandpiper (Erolia ferruginea). 8, 9, Head and leg of Turnstone (Arenaria interpres). 10, 11, Head and leg of Little Whimbrel (Mesoscolopax minutzs). 
P'LATE XX.
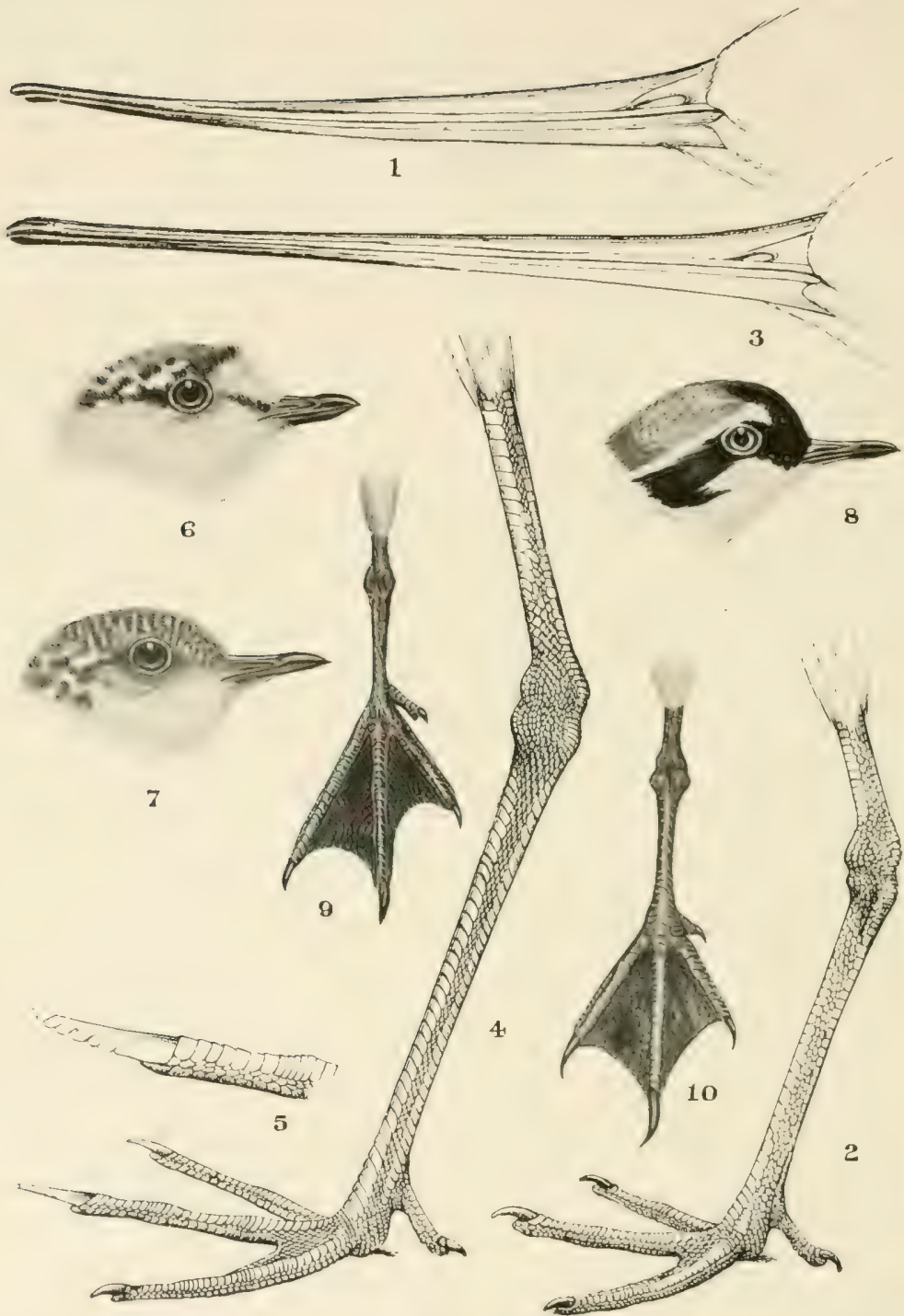

1. 2 Head and leg of Barrord-rumped Godwit (Vetola lapponica). 3, 4, 5. Ditto and middlle chaw of IBlack-tailed Godrrit (Limosa limosa), 6, Head of nestling Mongolian Sand Dotterel (Cirrepidesmus mongolus). 7, Head of nestling Double-handed Dotterel (Nesoceryx bicinctus). 8 . Head of Black-fronted Dotterel (Elseyormis melanops). 9, Foot of Bridled Tern (Melanosterna ancthetus). 10, Foot of Sooty Tern (Onychoprion fuscatus). 


\section{o.}

1

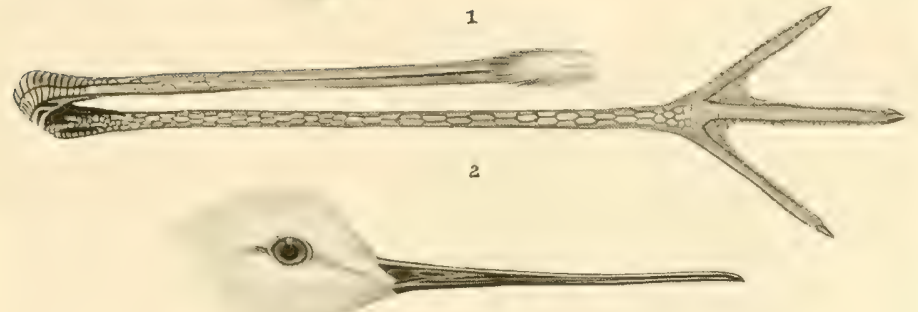

3
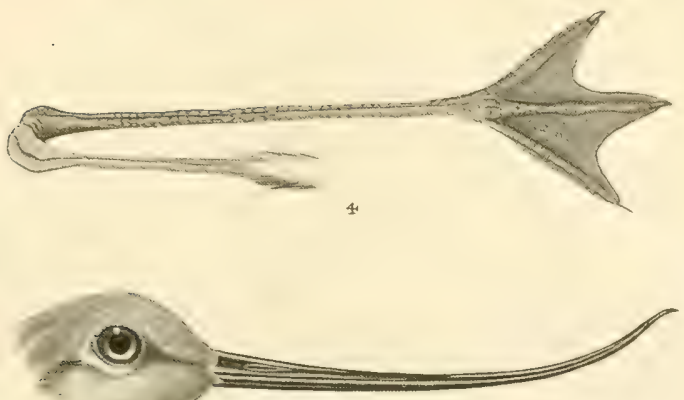

5

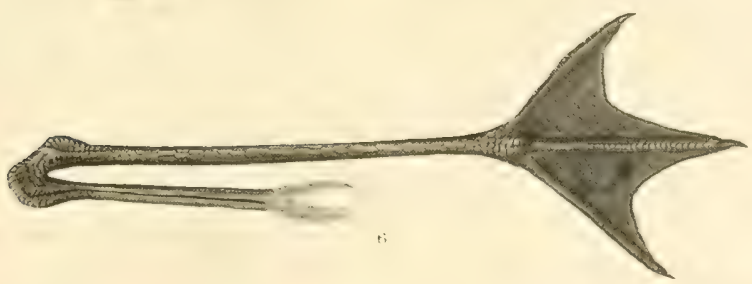

1. 2. Head and leg of White-headed Stilt (Himantopus leacocephaless), 3, 4, Ditto of Banded Stilt

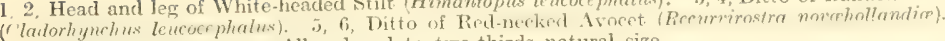
All reduced to two-thirds natural size. 

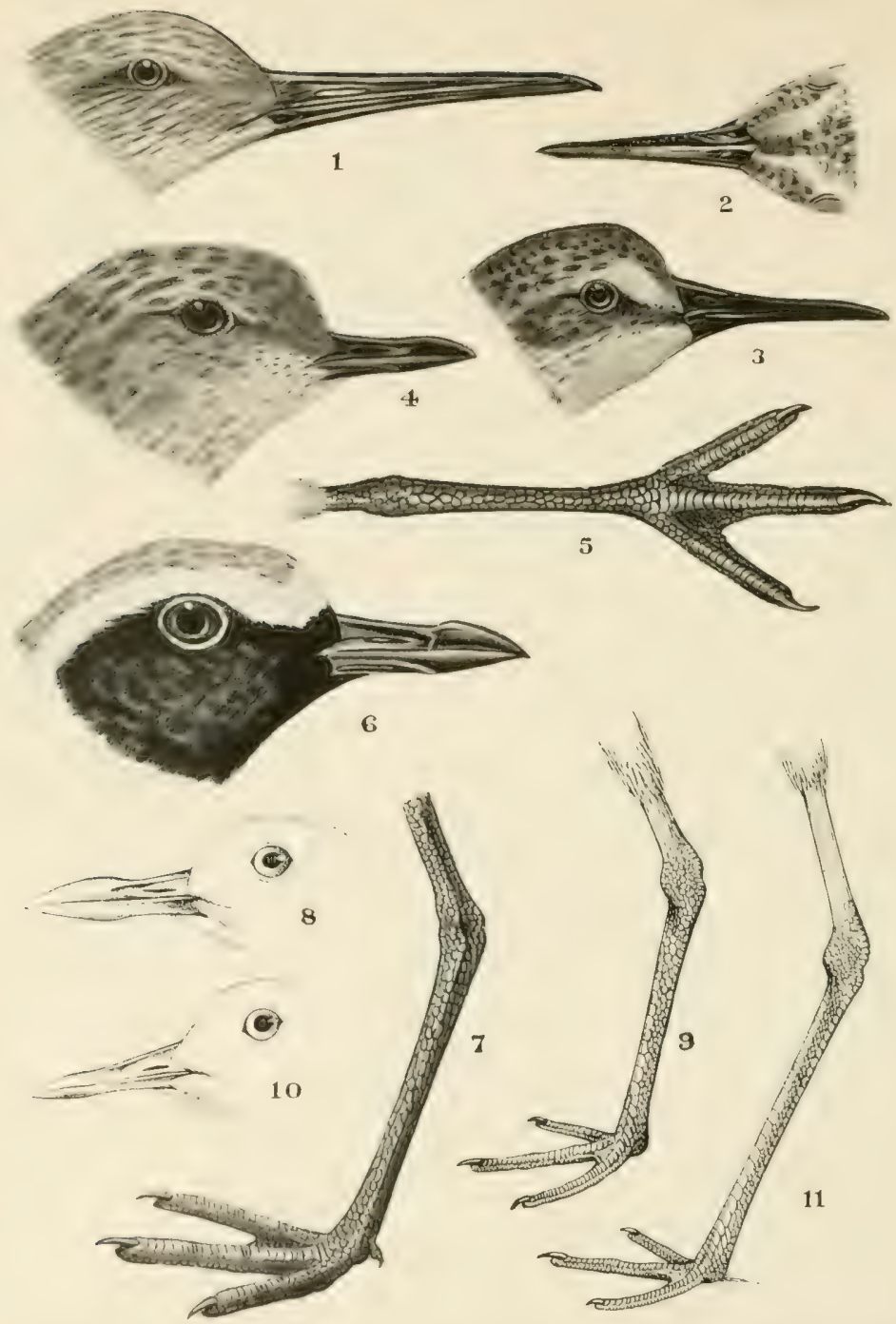

1. Head of Great Knot (Anteliotringa tenvirostris). 2, 3, Top and side view of bill of 13rond-billed Sandpiper (I'latyrhamphus falcinellus). 4, 5, Head and leg of Lesser Golden I'lover (Plurialis dominicus). 6, 7, Ditto of Grey Plover (Squatarola squatarola). 8, 9, Ditto of Large SandDotterel (Pagoa leschenaultii). 10, 11, Ditto of Oriental Dotterel (Eupodella vereda). 

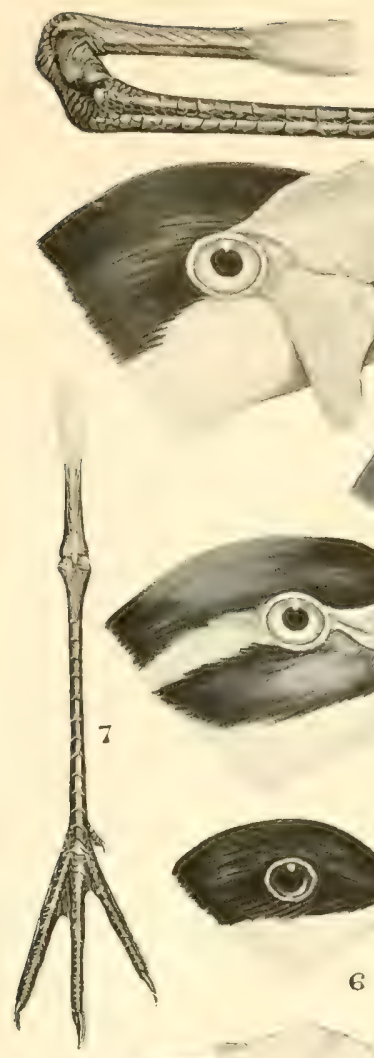

3
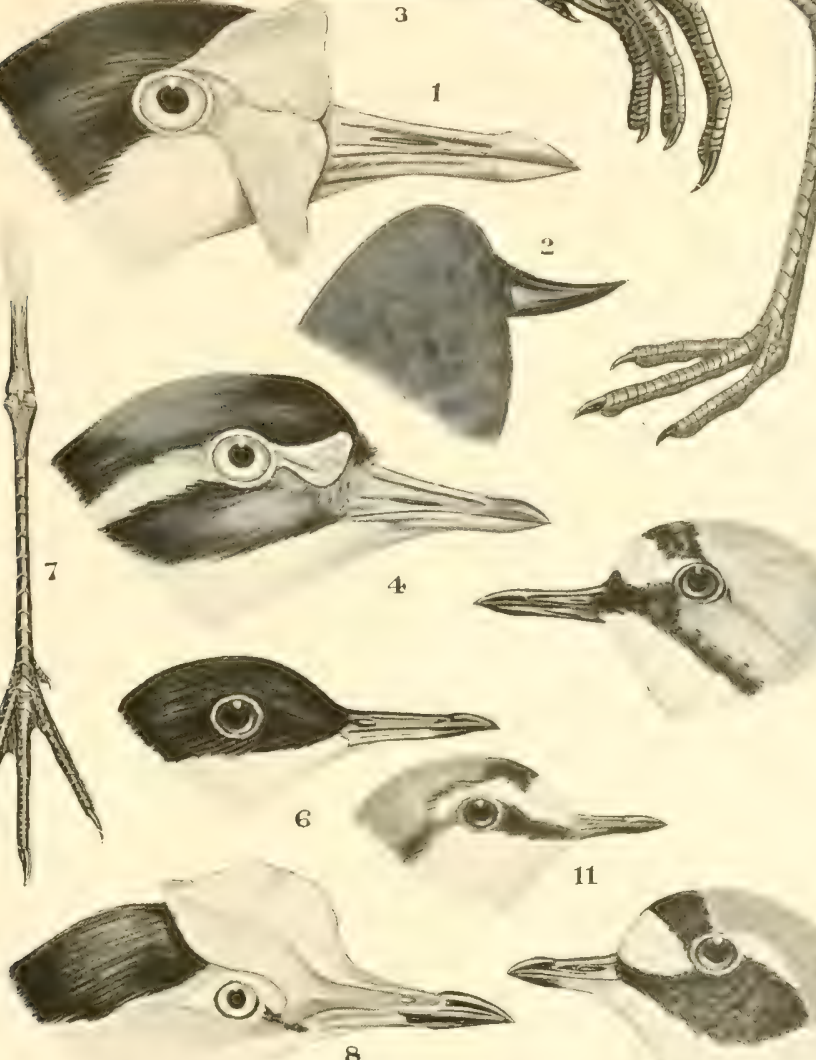

10

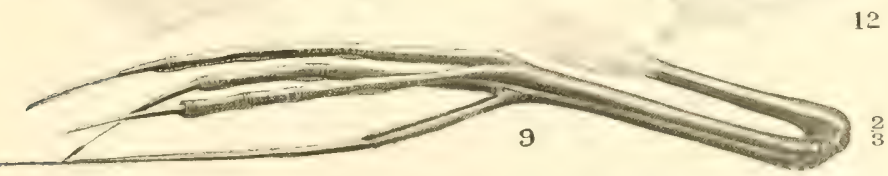

1, 2,3, Head, spur on wing and leg of Spur-winged Plover (Lobibyx nourehollandia). 4, 5, Head and leg of Black-breasted Plover (Zonifer iricolor). 6, 7, Ditto of Red-kneed Dotterel (Erythrogonys cinctus). 8, 9, Ditto of Lotus Bird (Irediparra gallinacea). 10, Head of Double-banded Dotterel (Nesoceryx bicinctus). 1], Head of Red-capped Dotterel (Leusopolins ruficapillus). 12, Head of Ringed Plover (Charadrius hiaticula). 


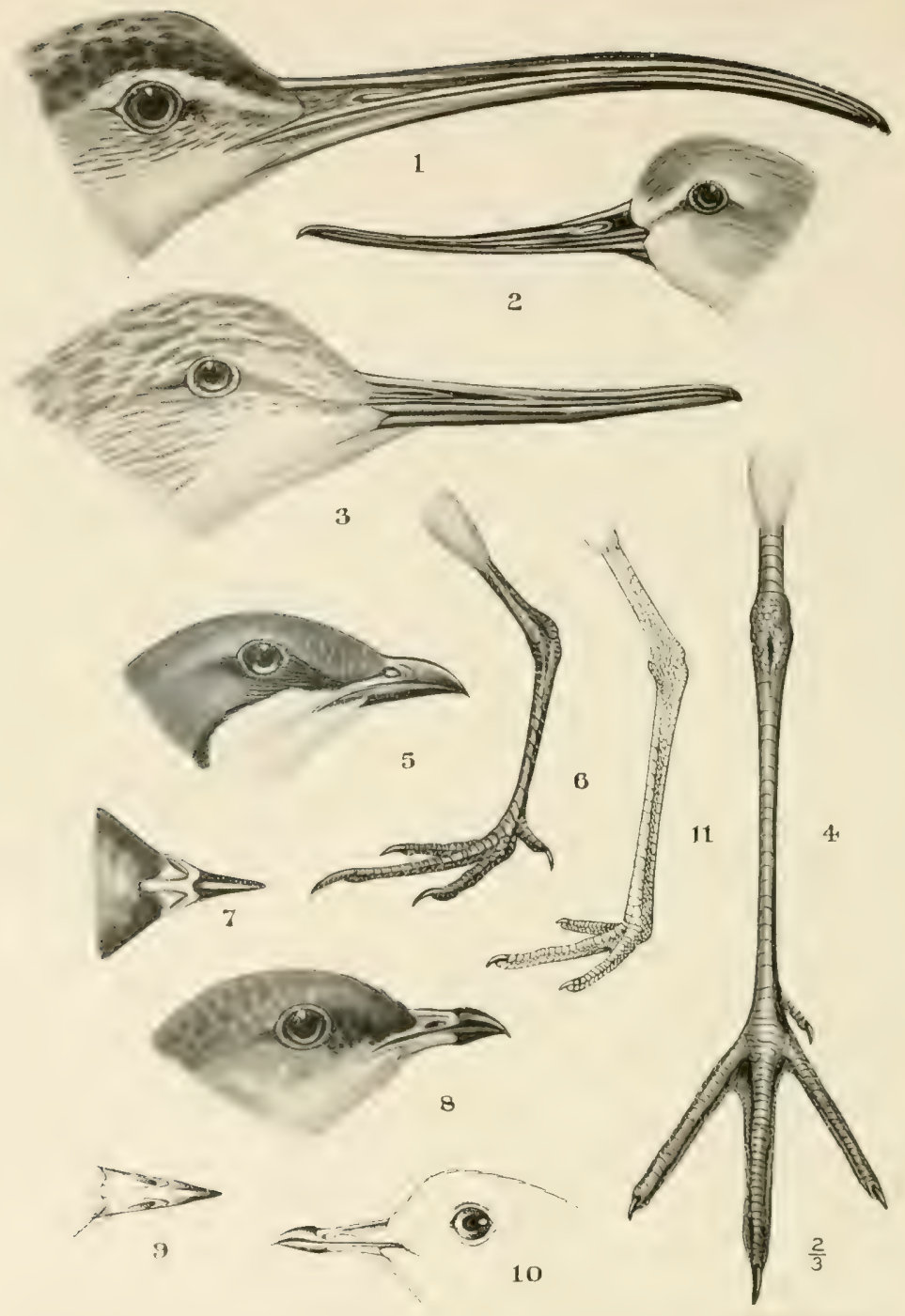

1, Heat of Whimhel (Iheropus phopus). 2, Head of Terek Sandpiper (Terekia cinerea). 3,4 Hearl and leg of (treenchank (Clottis nebularins). 5, 6, Head and leg of Oriental P'ratineole (filarcola maliturum). 7, 8, Top and side views of bill of I'ratincole (Stilia isabclla). 9, 10, 11, Top and side view of bill and leg of Dotterel (I'eltohyas australis). 

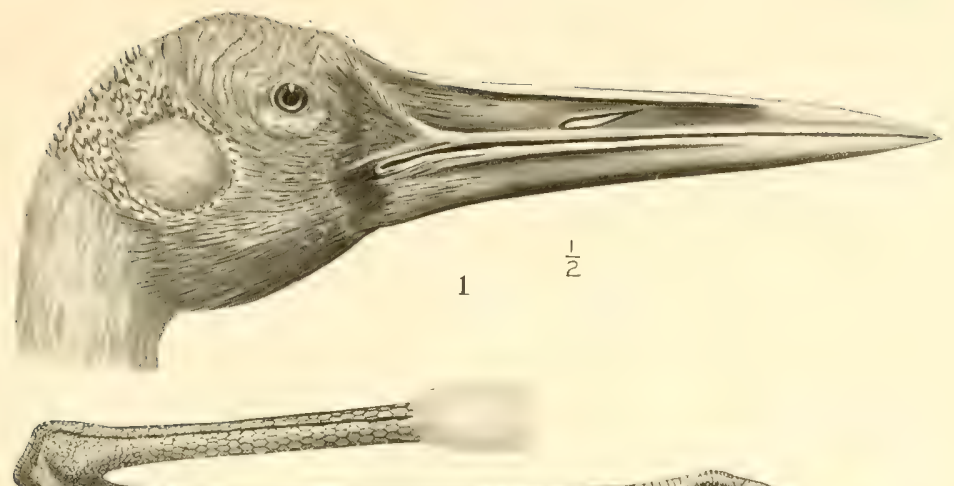

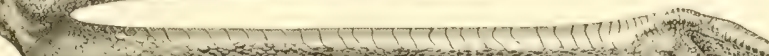

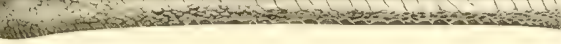

2
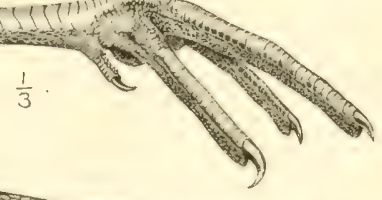

iा

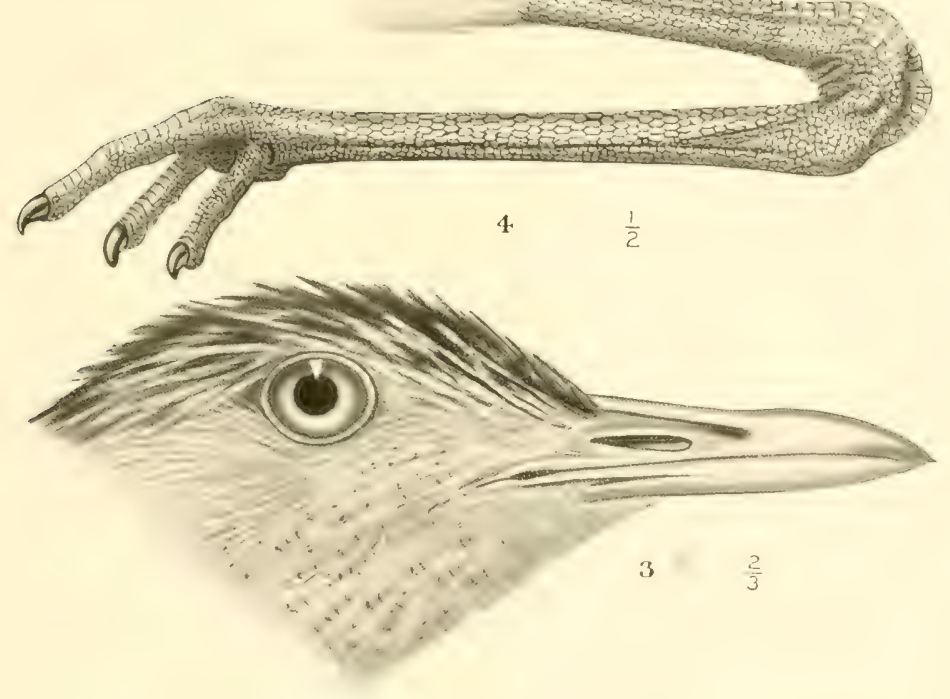

1, 2, Hearl and legr of Brolga (Mathewsena rubiomda). 3, 4, Ditto of Bustard (Austrotis australis). 
Plate Xxvi.

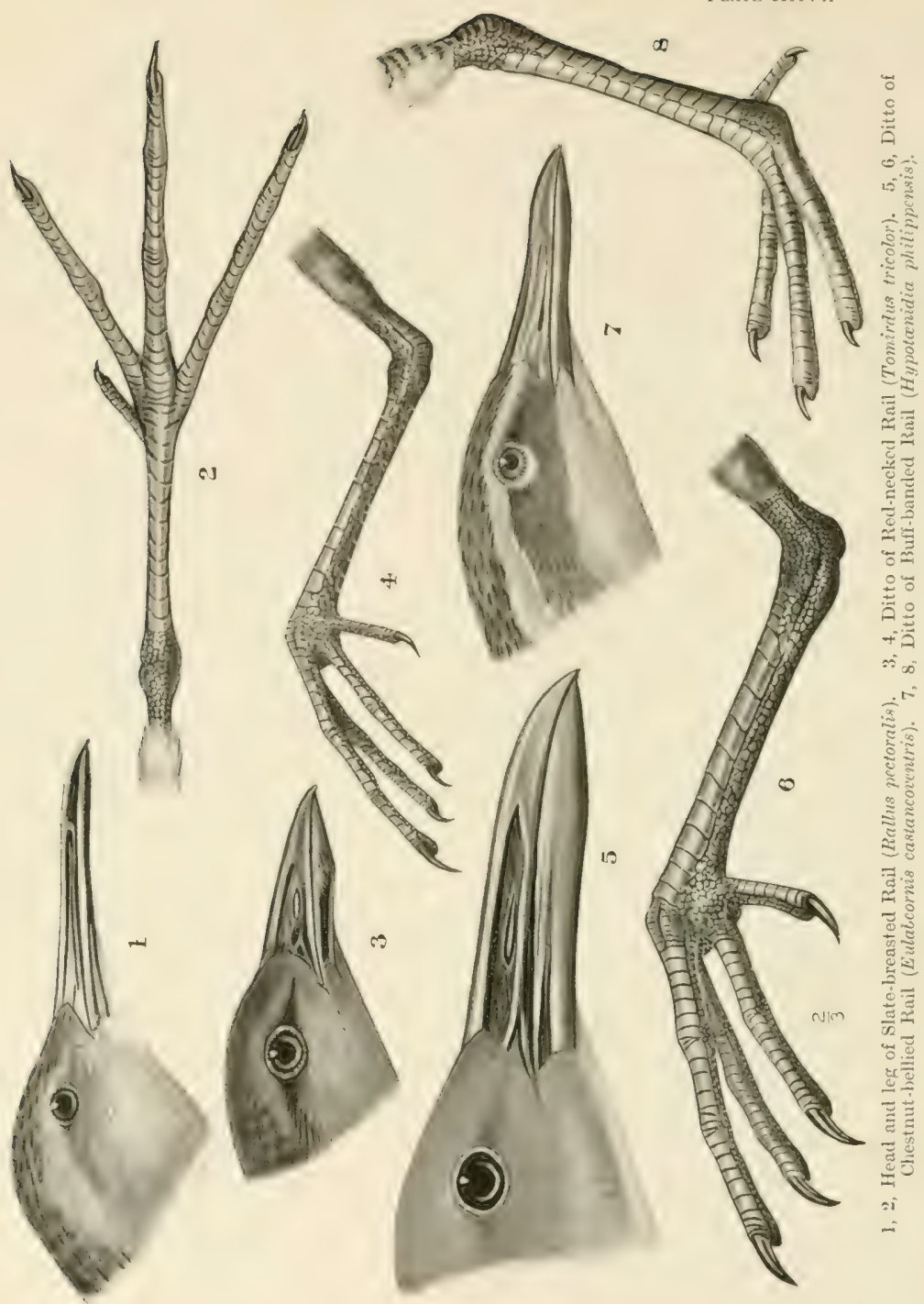




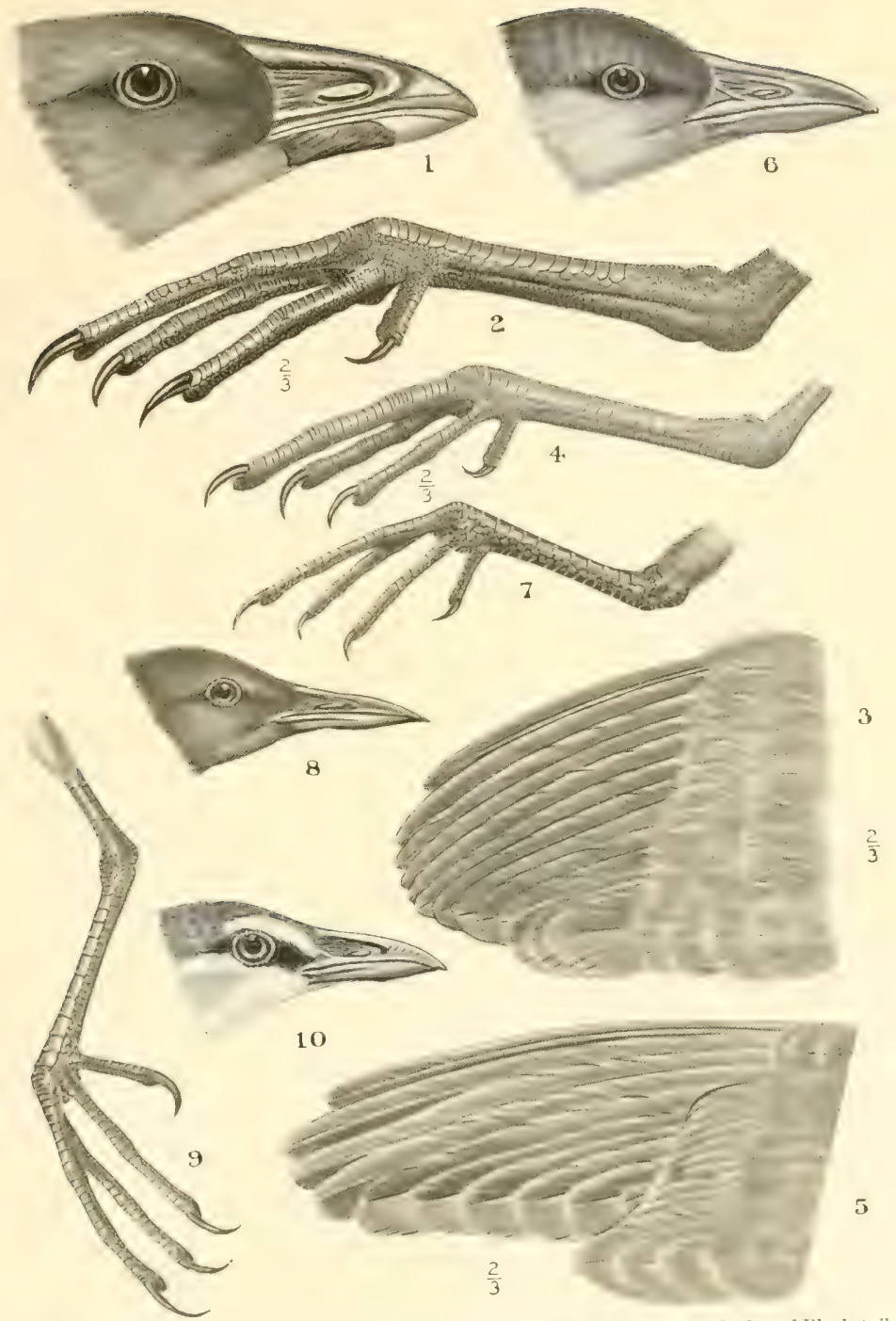

1, 2, 3. Head, lee and wing of Native Hen (Tribomyx morticrii). 4, 5, Leg and wing of Black-tailed Water Hen (Microtribonyx ventralis), 6, Head of Rufous-tailed Moorhen (Amanrormis moluccanus).

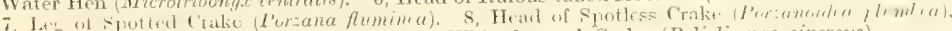
9, 10, Leg and head of White-browed Crake (Poliolimnas cincreus). 


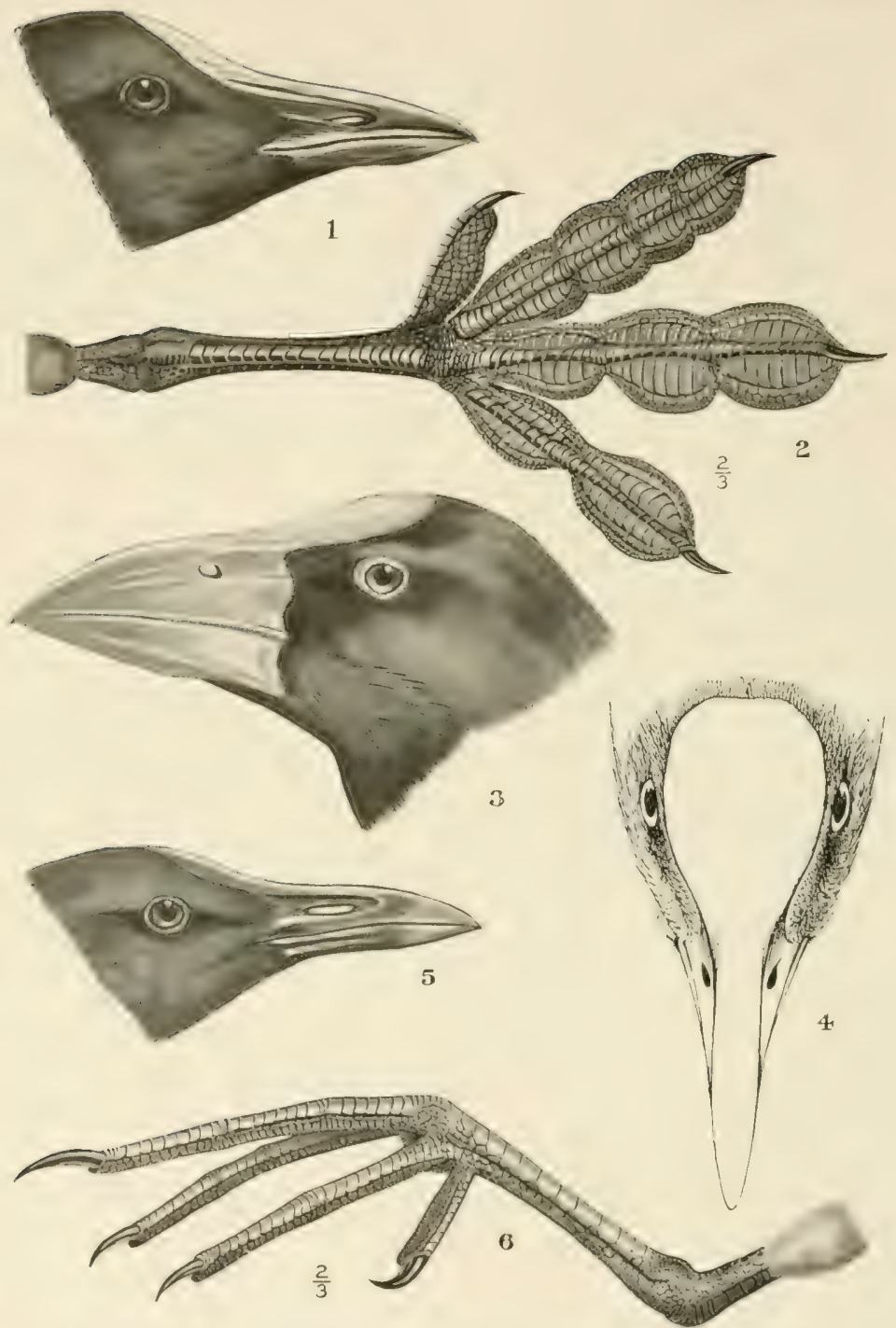

1. 2. Hend and leg of Coot (Fulica atra). 3, 4, Side and top riews of head of Bald Coot (Porpliyrio melanotus). 5, 6, Head and leg of Black Moorhen (Ciallimila tcncbrosa). 


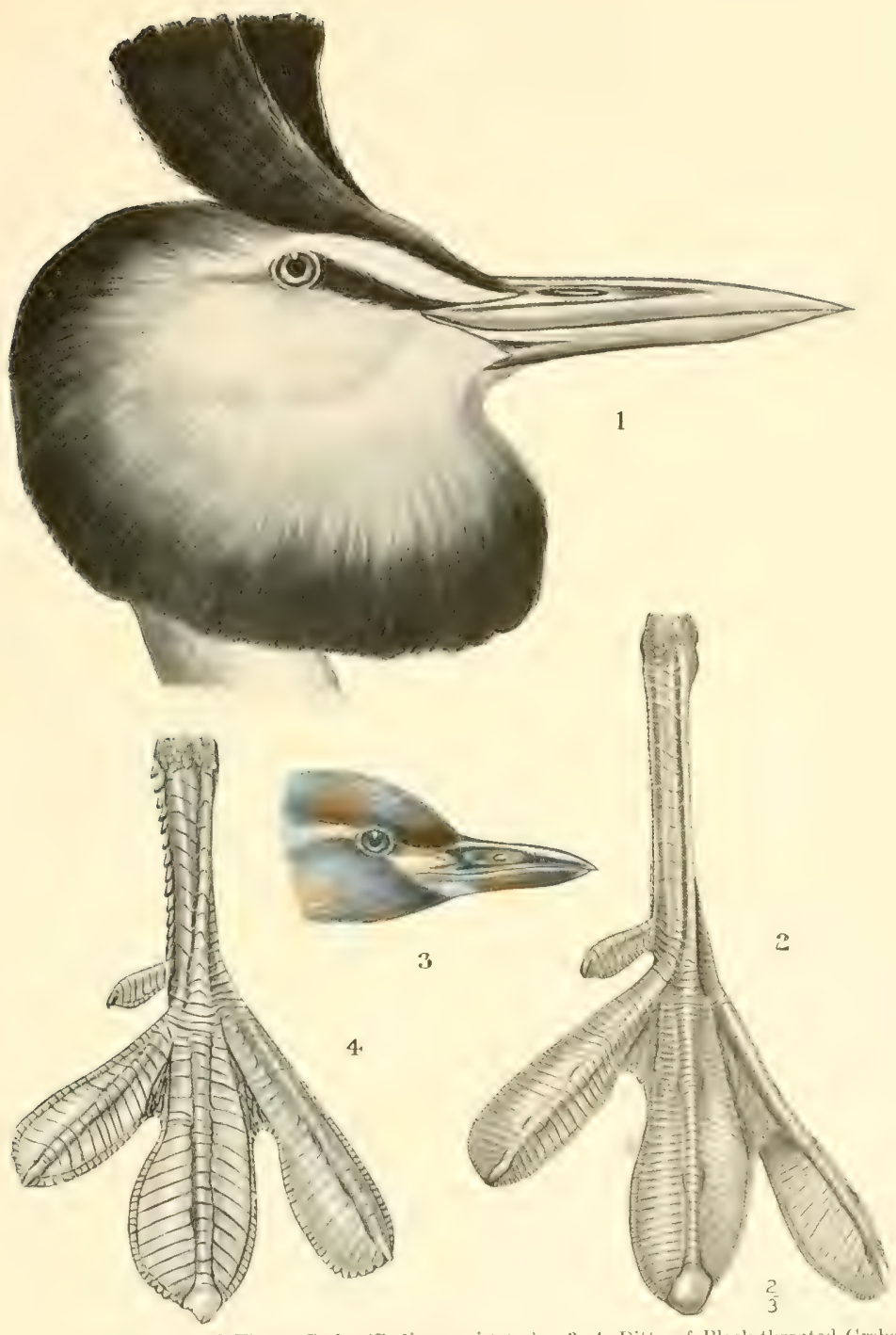

1. 2. Hearl and foot of Tippet Grebe (Podiceps cristatus). :, 4. Ditto of Black-throated (irebe (Poliocephalus ruficollis) 

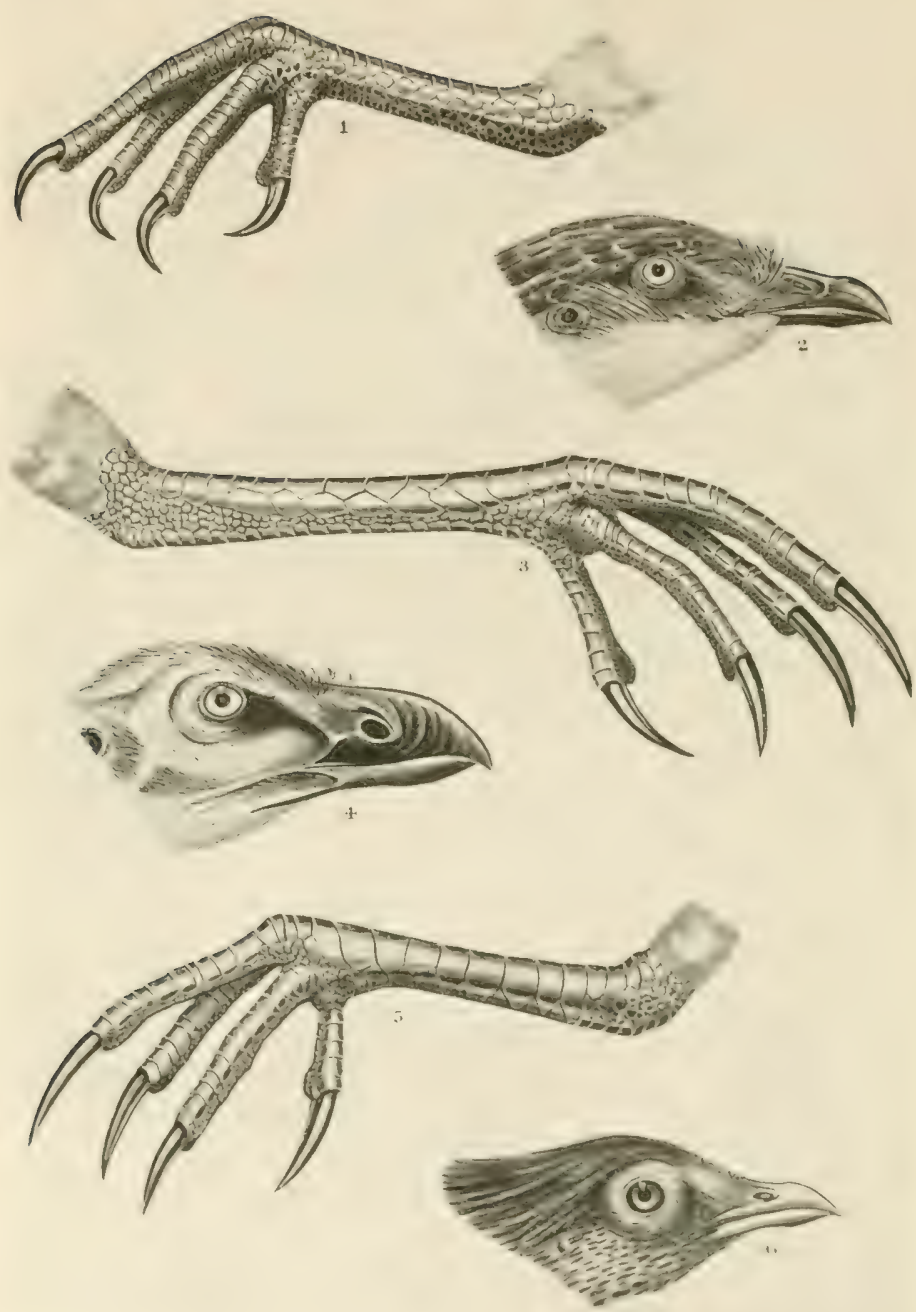

1, 2, Hearl and leg of Mallee Fowl (Leipoa ocellata). 3, 4, Ditto of Brush Turkey (Alcctura lallami). 5, 6, Ditto of Scrub Fowl (Mega podius reinwardl). All reduced to two-thirds natural size. 

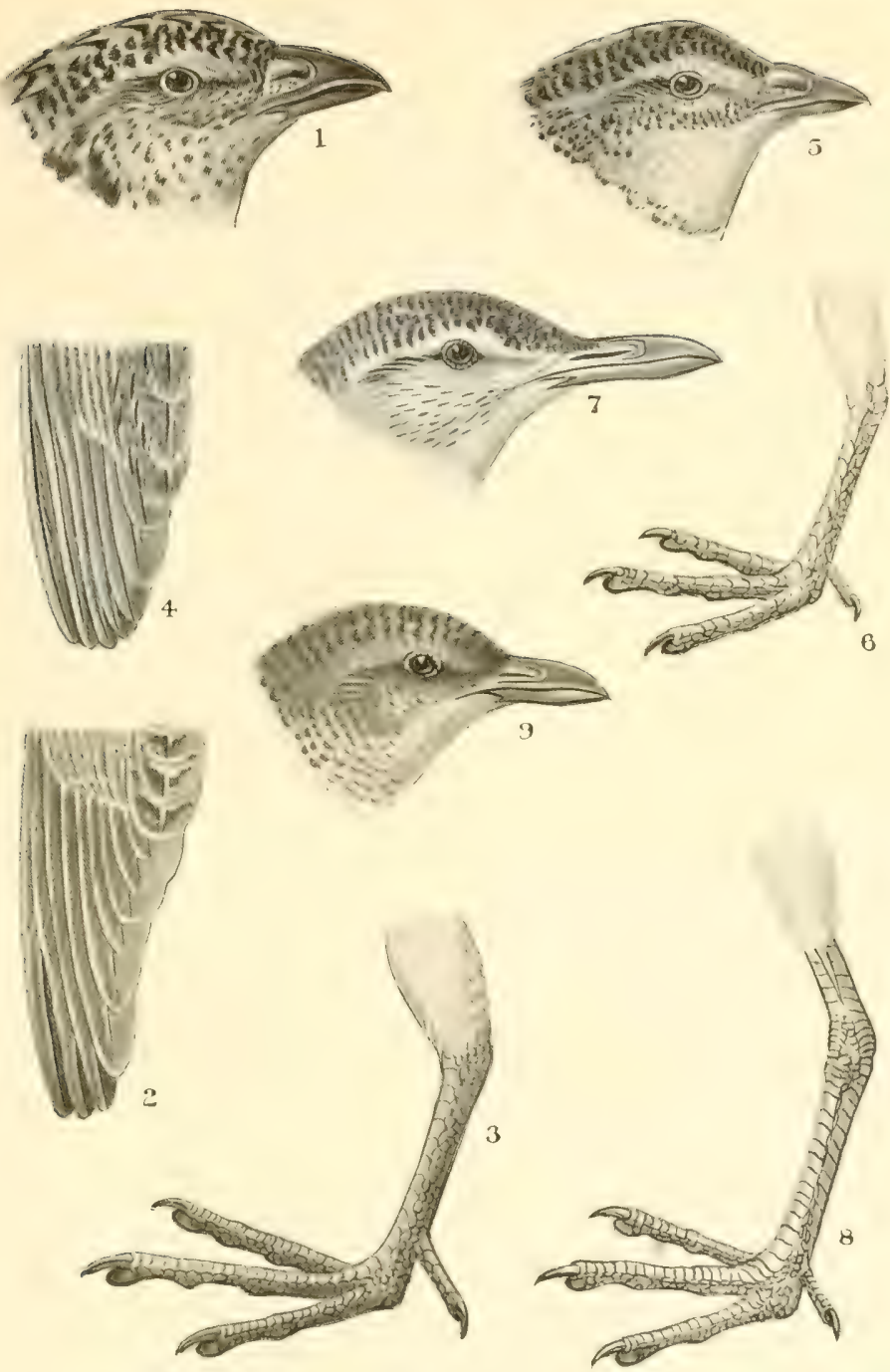

1, 2, 3, Head, wing and leg of Stubble Quail (Coturnix pectoralis). 1, Wing of Brown Quail

(Ypsilophorus ypsilophorus). 5, 6, Head and leg of King Quail (Excalfactoria chinensis). 7, 8, Ditto of Plain Wanderer (Pedionomus torquatus). 9, Head of Black-backed Quail (Turnix maculosa). 

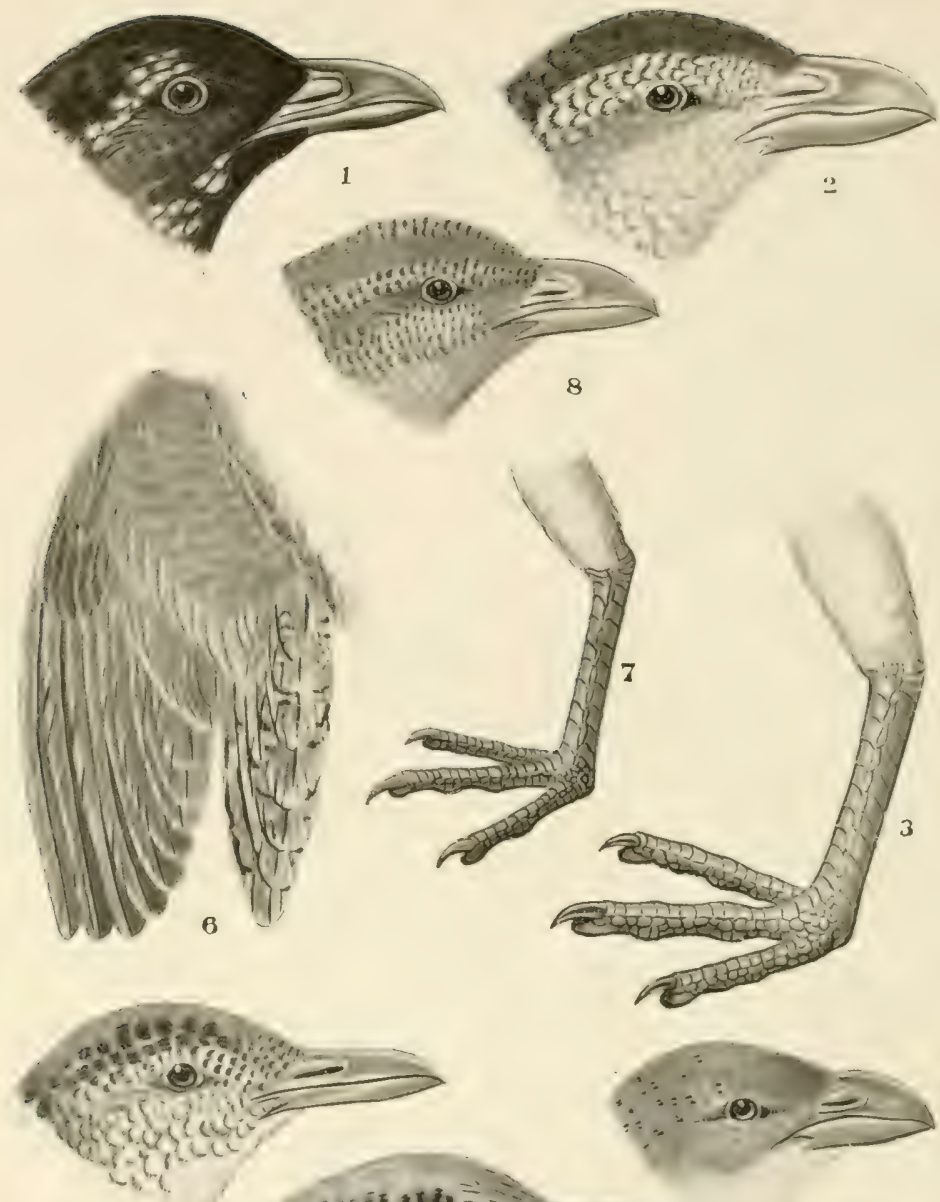

9
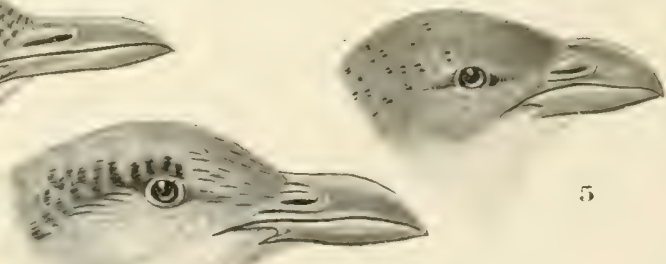

5

1.

1. Head of 13lack-brensted Quail (Colcloughia melamoaster), 2,3, Head and lere of Chestnutbncked Quail (Aurtroturnix castanota). A, Head of Allied Quail (Austroturnix olivii). $5,6,7$, Henil, wing and les of Little Quail (Alphaturnia relox). 8, Head of Red-ehested Quail (Alphatarmia pyrrhothorar). 9, Head of Painted Quail (Marianornis varius). 

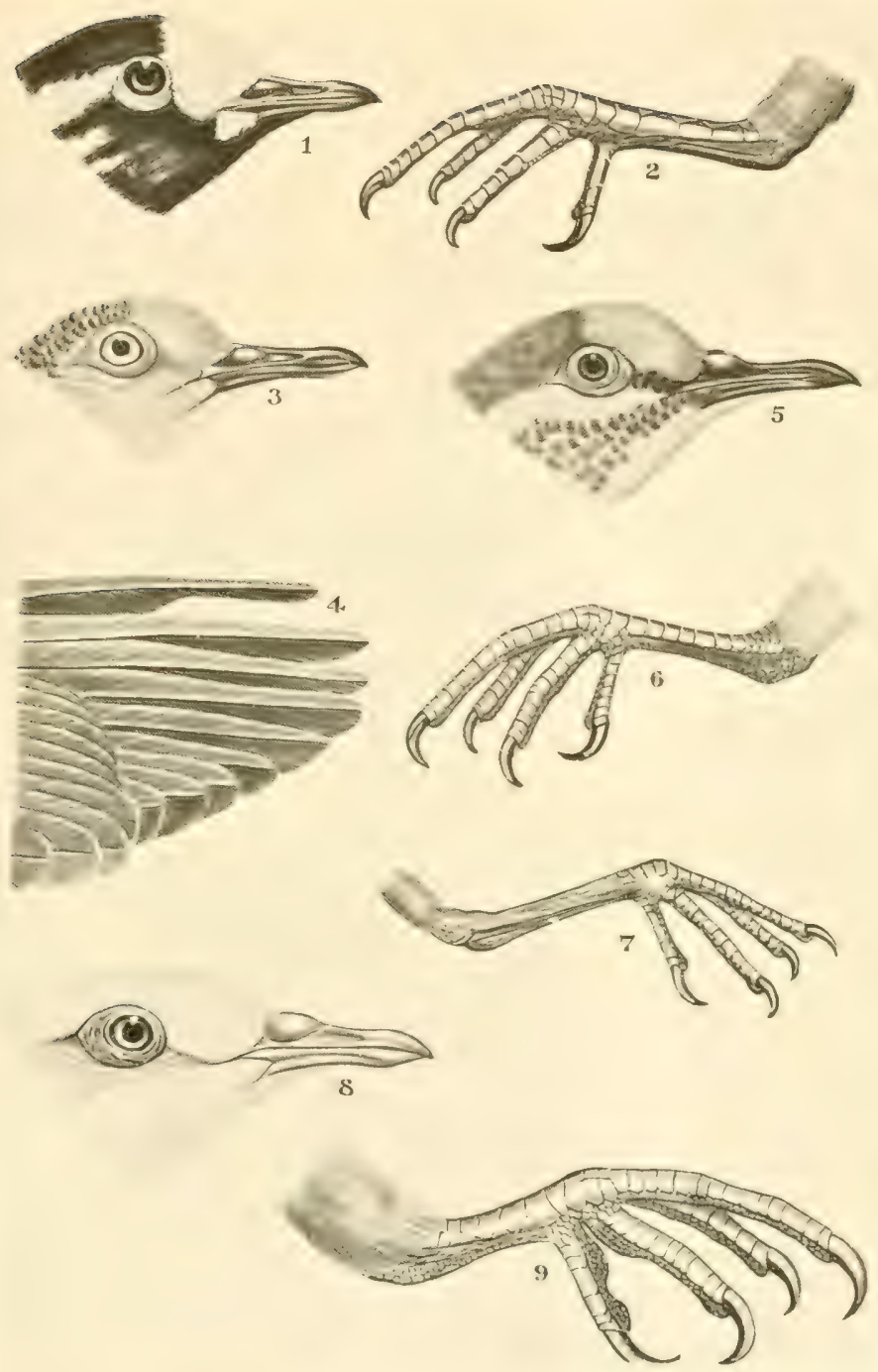

1, 2, Head and leg of Flock Pigeon (Histriophaps histrionice). 3, Head of Barred-shouldered

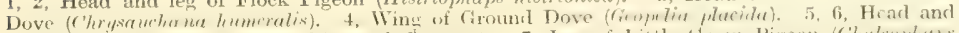

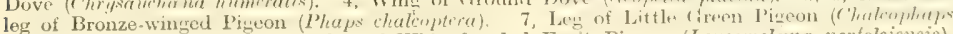
chrysochlora). 8, 9, Head and leg of White-headed Fruit Pigeon (Lencomclona norfoleiensis). 


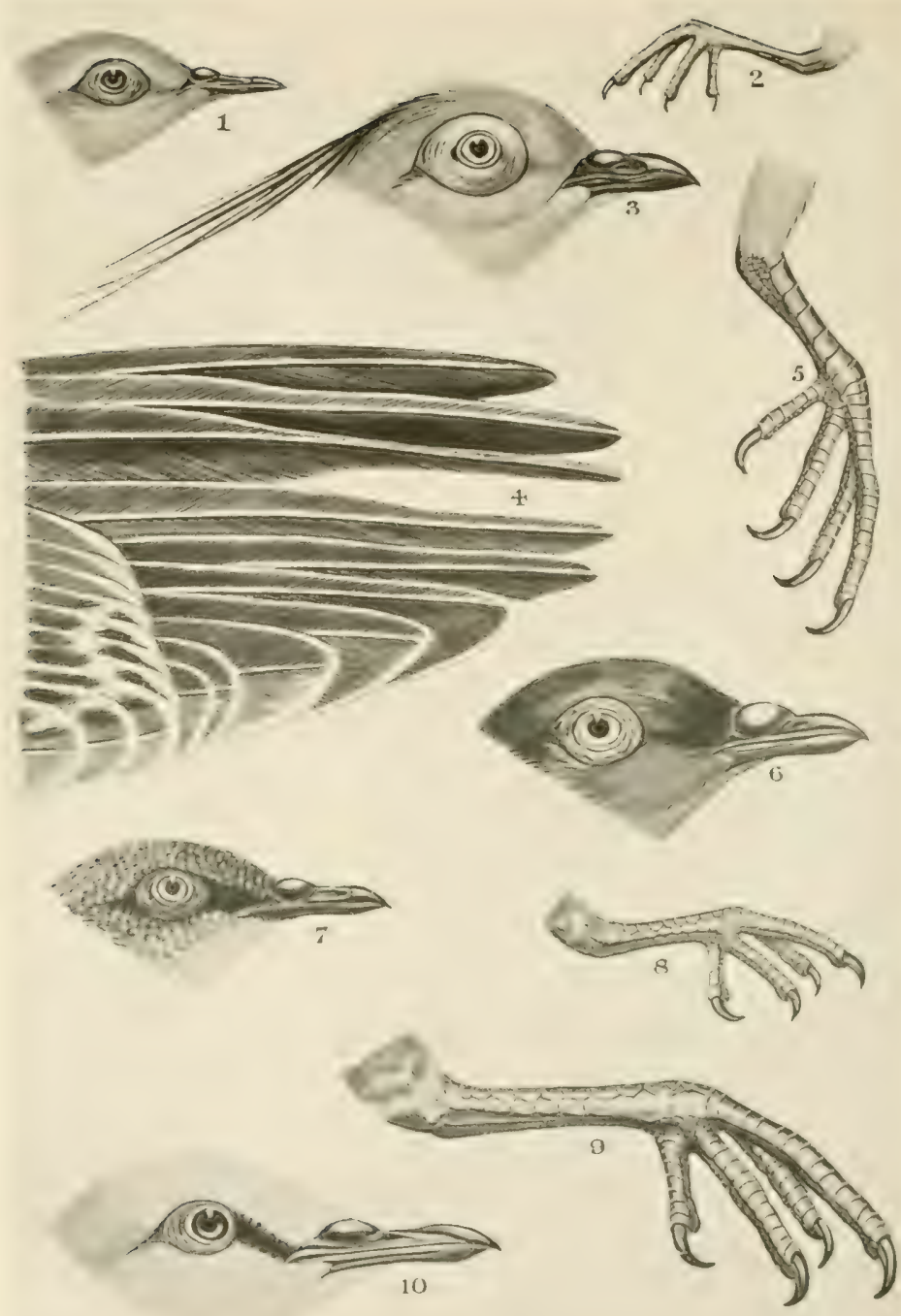

1, 2. Head and leg of Spotted-shouldered Dove (Stictopeleia cuneata). 3, 4, 5, Head, wing and leg of Crested Pigeon (Ocyphaps lophotcs). 6. Head of Pheasant Pigeon (Macropygia phasianella). 7, 8, Head and leg of White-quilled Rock-Pigeon (P'etrophassa albipennis). 9, 10, Head and leg of Wonga-Wonga (lencosarcia melanolenca). 

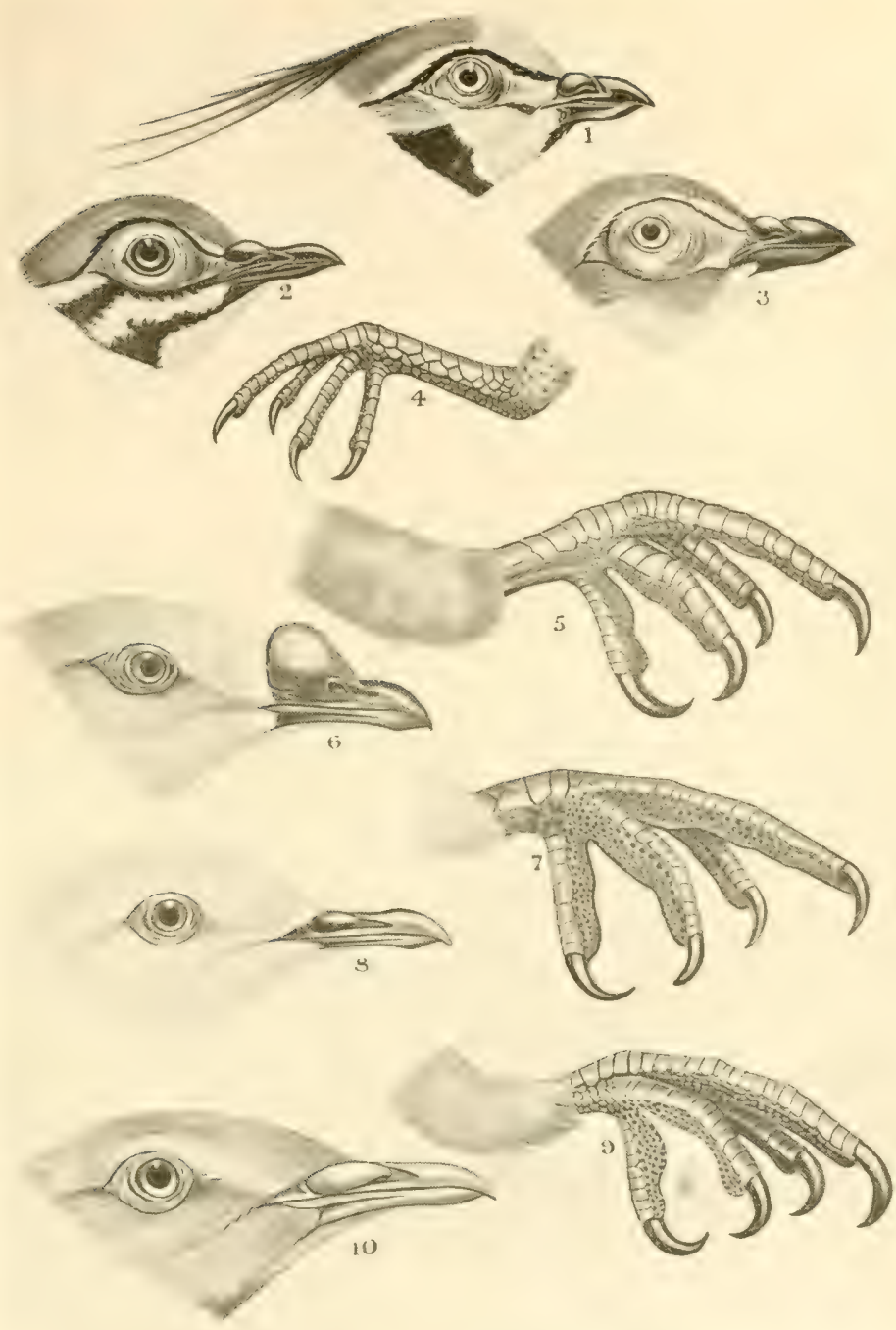

1. Head of Plumed Pigeon (Lophophaps plumifera). 2, Head of Partridge Pigeon (Geophaps scripta). 3, 4, Head and leg of Naked-eyed Partridge Pigeon (trophaps smithii). 5, 6, Ditto of Grey-headed Pigeon (rlobicera pacifica). 7, 8, Ditto of Nutmeg Pigeon (Myristicivora bicolor). 9, 10, Ditto of Purple-breasted Fruit Pigeon (Megaloprepia magnifica). 

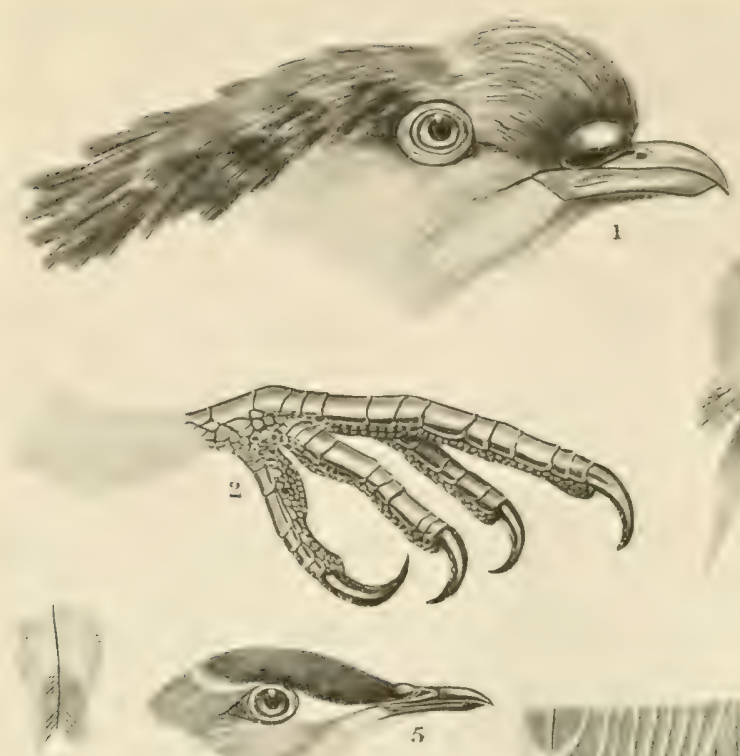

1.
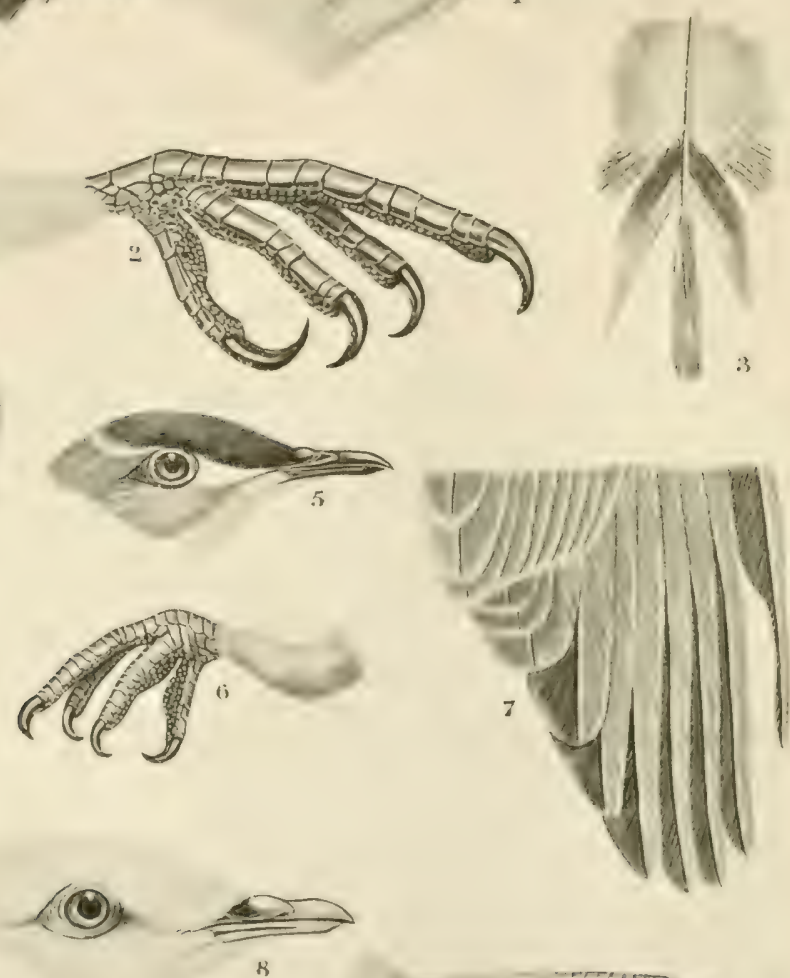

5

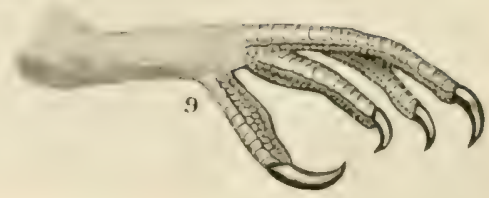

1. 2, :3, Head, leg and breast-fenther of Top-knot ligeon (Loplolaimus antarcticus).
4. 6,7, Breast-feather, head, leg and wing of Red-crowned Fruit Pigeon (Ptitinopus
regina). 8, 9. Head and leg of regina). 8, 9, Head and leg of Black-banded Fruit Pigeon (Leucotreron alligator). 


\section{INDEX.}

The Roman numerals refer to the plate numbers.

Actitis, 139.

hypoleucus, 139.

acuminatus, Limnocinclus, 129, XVIII.

Adamastor, 31 .

- cincereus, 31.

cequinoctialis, Procellaria, 29, VI., VII. Eistrelata, 36.

- lessonii, 36, VII.

$a l b a$, Crocethia, 133, XIX.

Albatross, Light-mantled Sooty, 49.

- Royal, 56.

-, Snowy, 55, VII.

- Sooty, 48 .

—_, Wandering, 54, VII, VIII.

-., White-capped, 53, VIII.

albitrons, Sternula, 89.

albipennis, Petrophassa, 255, XXXIV.

albus, Leucanous, 105, XIII.

Alectura, 222. - lathami, 222, XXX

alligator, Leucotreron, 268, XXXVI.

Alphaturnia, 235.

- pyrrhothorax, 236, XXXII.

- velox, 235, XXXII.

Amaurornis moluccanus, 203, XXVII.

anathetus, Melanosterna, 97, XX.

Anhinga, 68 .

- novahollandie, $68, \mathrm{XI}$.

ANHINGIDE, 68.

-4nous, 102.

- stolidus, 102, XIII.

untarcticus, Lopholaimus, 271, XXXVI.

- Priocella, 32.

Inteliotringa, 125.

- tenuirostris, 125, XXII.

Aptenodytes, 12.

patagonica, 13.

APTENODYTID 五, 12.

Arenaria, 159.

- interpres, 159, XIX

ARENARHDA, 159.

ariel, Fregata, 60, IX.

assimilis, Puffinus, 23, V., VII.

ater, Mesocarbo, 64, X.

atra, Fulica, 211, XXVIII.

australis, Austrotis, $186, \mathrm{XXV}$.

$\longrightarrow$, Peltohyas, 184, XXIV.

- Rostratula, 119, XVIII.

Austrotis, 185.

- australis, 186, XXV.

Austroturnix, 233.

- castanota, 234 , XXXII. olivii, 233, XXXII.

Avocet, Red.necked, 155, XXI

BALEARIOIDFE, 188.

Bartramia, 144.
Bartramia longicauda, 144.

belcheri, Heteroprion, 41, VI.

bellus, Porphyrio, 210.

bengalensis, Pelecanopus, 93.

bergii, Pelecanopus, 92, XIV.

bicinctus, Nesoceryx, 166, XX., XXIII.

bicolor, Myristicivora, 269, XXXV.

Booby, 72, XI.

brevipes, Heteractitis, 143, XVIII.

Brolga, 189, XXV.

Bruchigavia, 106.

novehollandia, 106, XIV., XV.

Brush-Turkey, 222, XXX.

BURFINIDE, 115.

BURHNOIDEA, 115.

Burhinus, 115.

- magnirostris, 116, XVI.

Bustard, 186, XXV.

crerulea, Halobana, 40, V.

Calidris, 123.

Canutus, 124, XIX.

Calonectris, 23. - leucomelas, 24.

canutus, Calidris, 124, XIX.

capensis, Daption, 39.

carbo, Phalacrocorax, 67, X.

carneipes, Hemipuffinus, 28, V.

caspia, Hydroprogne, 96, XII.

Cassowary, 6, II.

castareoventris, Eulabeornis, 196, XXVI.

castanota, Austroturnix, 234, XXXII.

Casuarit, 1.

Casuarito

Casuaringormes, 2 ,

Casuarius, 6

- casuarius, $6,1 \mathrm{I}$.

Catharacta, 110.

- lonnbergi, 110, XII.

Catoptropelicanus, 70.

Cons picillatus, $70, \mathbf{X}$.

cauta, Diomedella, 53, VIII.

cerulea, Procelsterna, 103, XIII.

Chalcophaps, 249.

chrysochlora, 249, XXXIII.

chalcoptera, Phaps, 251, XXXIII.

Charadriidie, 161.

Charadritformes, 114.

Charadriotdea, 156.

Charadrius, 170, XXIII.

- cucullatus, 170.

chinensis, Excalfactoria, 228, XXXI.

chionoptera, Diomedea, 55, VII.

Chlidonias, 82.

-_- leucopareia, 83.

- leucoptera, 84, XVI.

chlororhynchus, Thalassarche, 52, VIII. 
Chrysauchœina, 245.

humeralis, 245, XXXIII.

clirysochlora, Chalcophaps, 249, XXXIII.

chrysostoma, Thalassarche, 51, VIII.

cinctus, Erythrogonys, 178, XXIII.

cinerea, Poliolimnas, 202, XXVII.

- Terelia, 141, XXIV.

cinereus, Adamastor, 31.

Cirrepidesmus, 165.

- mongolus, 165, XX.

Cladorhynchus, 154 .

- levcocephalus, 154, XXI.

Colcloughia, 237.

- melanogaster, 238, XXXII.

COLUmbe, 240.

COLUMBIDE, 212.

Columbiformes, 241.

conspicillata, Procellaria, 30, VI.

conspicillatus, Catoptropelicanuss, 70, X.

cookii, Cookilaria, 37, V., VI.

Cookilaria, 37.

Cooliii, 37, V., Vl.

Coot, $211, \mathrm{XXVIII}$

- Bald, 208, XXVIII.

_., Blue Bald, 210.

Coprotheres, 111.

- pomarinus, 111.

Cormorant, Black, 67, 5 .

- Little, 65, X.

$\longrightarrow$, Black, 64, 1

Pied, 63, XI.

- W White-breasted, 63, V.

Cosmopelia, 252.

elegans, 252.

Coturnix, 223.

- pectoralis, 224, XXXI.

Crake, Little, 199.

—_. Spotless, 200, XXVII.

_ Spotted, 198, XXVII.

- White-browed, 202, XXVII.

Crex, 196

- crex, 196.

cristatus, Podiceps, 213, XXIX.

Crocethia, 132. alba, 133, XIX.

cucullatus, Charadrius, 170.

cuneata, Stictopeleia, 248, XXXIV.

Curlew, 151, XIX.

Curlew-Sandpiper, 128, XIX.

cyanopus, Numenius, 151, XIX.

lactylatra, Parasula, 75, XI.

Daption, 38. capensis, 39

Darter, 68, XI.

desolatus, Heteroprion, 41, VI.

Diomedea, 54.

- chionoptera, 55, VII.

_ epomophora, 56.

_. exulans, 54, VII., VIII.

Diomedella, 53.

- cauta, 53, VIII.

DIOMEDEOIDEA, 47.

Ditelmatias, 121.

-_ hardwickii, 121, XVII.

dominicus, Pluvialis, 163, XXII.

Dotterel, 184, XXIV.

-, Black-fronted, 173, XX.
Dotterel, Double-banded, I66, XX, XXIII

- Hooded, 170.

, Large Sand-, 168, XXII.

- Mongolian Sand-, 165, XX.

-_, Oriental, 172, XXII.

- Red-capped, 169, XXIII.

_., Red-kneed, 178, XXIII.

dougallii, Sterna, 87, XII.

Dove, Barred-shouldered, 245, XXXIII.

-, Ground-, 247, XXXIII.

-.., Spotted-shouldered, 248, XXXIV.

DROMEORNITHES, 1.

DROMICIID.E, 2.

Dromiceinis, 2.

- nozchollandice, 3, I.

clegans, Cosmopelia, 252.

Elseyornis, 172.

-, melanops, 173, XX.

Emu, 3, I.

-_, Dwarf, 5.

epomophora, Diomedea, 56 .

Erolia, 128.

- lerruginea, 128, XIX.

Erythrogonys, 177.

-Cinctus, 178, XXIII

Eirdyptes, 10.

- pachyrhynchus, 10, 111 .

__ schlegeli, 12.

serresianus, 11.

Eudyptula, 8.

minor, 9, IX.

Eulabeornis, 195.

- castaneotentris, 196, XXVI.

EUORNitres, 13.

Eupodella, 172.

- vcreda, 172, XXII.

Excalfactoria, 227. - chinengis, 228, XXXI.

cxulans, Diomedea, 54, VII., VIII.

falcinellus, Platyrhamphus, 126, XXII.

ferruginea, Eirolia, 128, XIX. , Lophophaps, 260.

Jilock-Pigeon, 254, XXXIII.

fluminea, Porzana, 198, XXVII.

Fowl, Mallee, 220, XXX.

- Scrub, 218, XXX.

Fregata, 58.

- ariel, 60 , IX minor, 58.

Fregati, 57.

Freatid 58.

Frengette, 19.

- tropica, 20, IV., VII.

- tubulata, 20.

Fregettornis, 21. arallarius, 21, IV.

lirigate Bird, 58.

L Lesser, 60, IX.

Fulica, 210.

- alra, 211, XXVIII.

FULICIDE, 210.

fusca, Phobetria, 48.

fuscalus, Onychoprion, 99, XX.

fuscescens, Hypolencus, 63, $\mathrm{V}$. 
Gabianus, 108.

- pacificus, 108, XIV.

GALII, 216.

Galdiformes, 217.

gallinacea, Irediparra, 180, XXIII

Ciallinula, 204.

- tencbros $\alpha, 205, \mathrm{XXVIII.}$

Gallinulid 203.

Gannet, 76, X.

$\longrightarrow$ Brown, 72, XI.

-, Masked, 75, XI.

-_ Red-legged, 74 .

Garrodia, 17.

, nereis, 17, IV.

Gelochelidon, 94.

-... milotica, 94, XII.

Geopelia, 246.

placida, 247, XXXIII.

(ieophaps, 256.

_- scripta, 257, XXXY.

- smithii, 258, XXXV.

giganteus, Macronectes, 45, IV.

(ilareola, 181.

- maldivarum, 182, XXIV

-.., Rhyacophilus, 138.

Glareolide, 181.

GLAREOLOIDEA, 181.

Glolicera, 269.

- pacifica, 270, XXXY

_. rubricera, 270.

(1lottis, 134.

nebularius, $135, \mathrm{XXIV}$.

Godwit, Barred-rumped, 145, XX.

..., Black-tailed, 147, XX.

grallarius, Fregettornis, 21, IV.

Grebe, Black-throated, 214, XXIX.

-.., Hoary-headed, 215.

.... Tippet, 213, XXIX.

Greenshank, 135, XXIY.

$\longrightarrow$ Little, 136.

qriseus, Neonectris, 27 .

Giruts, 187.

Gull, Pacific, 108, XIV.

-_- Silver, 106, XIV., XV.

(fygisterna, 88.

sumatrana, 88, XIV.

H.MMATOPODID $20,157$.

HIcematopus, 157.

___ostralegus, 157, XVI.

-nuicolor, 158.

Halobrena, 39. carulea, $40, \mathrm{~V}$.

hardwickii, Ditelmatias, 121, XVIT.

Hemipuffinus, 29.

- carneipes, 28, V.

Heteractitis, 142.

- brevipes, 143, XVIII.

- incanus, 142, XVIII.

Heteroprion, 41.

___ belcheri, 41, VI.

… desolatus, 41, VI.

Himantopus, 153.

_- leucocephalus, 153, XXI.

histrionica, Histriophaps, 251, XXXIII.

Histriophaps, 253.

histrionica, 254, XXXIII.

humeralis, Chrysauchona, 245, XXXIII.
Hydroprogne, 96.

- caspia, 96, XII

Hypoleucus, 62 .

Jusecsecizs, 63, V.

.... perthi, 63, XI.

hypolezters, Actitis, 139 .

Hypotrenilia, 193.

- philippressis, 194, XXVI.

Iliornis, 136.

- siagnatilis, 136 .

IMLENNISS, 7.

incanus, Heteractitis, 142, XVIII

inexpectata, Pterotroma, 34.

interpres, Arenaria, 159, XIX.

Irediparra, 179.

- gallinacea, 180, XXIII.

isabella, Stiltia, 183, XXIV.

JACANID E, 179.

JACANOIDEA, 179.

King-Quail, 228, XXXI.

Knot, 124, XIX.

-.., Great, 125, XXIJ.

Land-Rnil, 196.

lapponica, Vetola, 145, XX.

LARI, 77.

LARID $A$, 106.

LARIFORMES, 81.

lathami, Alectrra, 222, XXX.

Leipoa, 220 .

ocellata, 220, XXX.

Leptophaëthon, 79 .

- Lepturus, 79.

lepturus, Leptopliä̈thon, 79.

leschenaultii, Pagoa, 108, XXII

lessonii, Histrelata, 36, VII.

Leucanous, 104.

albus, 105, XIII.

leucocephalus, Cladorhymchus, 154, XXT.

- Himantopus, 153, XXI.

leucogaster, Sula, 72, XI.

Lencomelcena, 242 .

- vorfolciensis, 242, XXXIII.

leucomelas, Calonectris, 2 t.

lencopareia, Chlidonias, 83.

Leuco polius, 169.

- ruficapillus, 169, XXIII.

leucoptera, Chlidonias, 84, XVI,

Lcucosarcia, 262.

melanoleuca, 262, XXXIV.

Leucotreron, 267.

-.. alligator, 268, XXXVL.

therminieri, Puffinus, 25.

Limnocinclus, 129.

- acuminatus, 129, XVIII.

Limosa, 147.

-..-limosa, 147, XX.

Lobibyx, 174.

- miles, 175.

-_ novchollandice, 175, XXIII.

longicauda, Bartramia, 144.

lonmbergi, Catharacta, 110, XII.

Lopholaimus, 271.

- antarcticus, 271, XXXVI,

Lophophaps, 259. 
Lophophaps ferruginea, 260.

plumifera, 259, XXXV.

lophotes, Ocyphaps, 261, XXXIV.

Lotus Bird, 180 , XXIII.

Macronectes, 44 .

- giganteus, 45, IV.

macroptera, Plerodroma, 33, VII. Macropygia, 243.

phasianella, 243, XXXIV. maculosa, Turnix, 230, XXXI.

magnifica, Megaloprepia, 267, XXXV. magnirostris, Burhinus, 116, XVI.

...-Orthorhamphus, 117, XVI.

maldivarum, Glareola, 182, XXIV.

Iallee Fowl, 220, XXX.

Marianornis, 231.

varius, 231, XXXII.

Marsh-Tern, White-winged, 84, XVI.

Mathewsena, 189. rubicunda, 189, XXV.

megala, Subspilura, 123, XVII.

Megaloprepia, 266.

magnifica, 267, XXXV.

Megalopterus, 100. minutus, 100, XIII.

- temuirostris, 101.

Megafodide, 218.

MEGAPODIOIDEA, 217.

Megapodius, 218.

- reinwardt, $218, \mathrm{XXX}$

melanogaster, Colcloighia, 238, XXXII. melanoleuca, Leucosarcia, 262, XXXIV. melanoleucus, Microcarbo, $65, \mathrm{X}$.

melanophrys, Thalassarche, 50.

melanops, Elseyornis, 173, XX.

melanopus, Pterodroma, 34.

Melanosterna, 97.

- ancethetus, 97, XX.

melanotus, Porpluyrio, 208, XXVIII.

Mesocarbo, 64.

- ater, $64, \mathbf{X}$.

Mesoscolopax, 149. - minutus, $149, \mathrm{XIX}$.

Microcarbo, 65. melanolercus, $65, \mathrm{X}$.

Microtribonyx, 205.

ventralis, 206, XXVII.

miles, Lobibyx, 175.

minor, Eudyptula, 9, IX.

- Fregata, 58.

minutus, Megalopterus, 100, XIII.

-, Mesoscolopax, 149, XIX.

mollis, Pterodroma, 35.

Mollymawk, Black-browed, 50 .

-, Grey-headed, 51, VIII.

Y., Yellow-nosed, 52, VIII.

moluccanus, Amaurornis, 203, XXVII.

mongolus, Cirrepidesmus, 165, XX.

Moorhen, Black, 205, XXVIII.

- Rufous-tailed, 203, XXVII.

mortierii, Tribonyx, 207, XXVII.

Myristicivora, 268.

bicolor, 269, XXXV.

nebularius, Glottis, 135, XXIV.

Neonectris, 27. griseus, 27.
Neonectris tenuirostris, 27.

nereis, Garrodia, 17, IV.

-., Sternula, 91, XIV.

Nesoceryx, 166.

_- bicinctus, 166, XX., XXIII.

nilotica, Gelochelidon, 94, XII.

Noddy, 102, XIII.

-, Grey, 103, XIII.

- Lesser, 101.

White-capped, 100, XIII.

norfolciensis, Leucomelona, 242, XXXIII.

novchollandio, Anhinga, 68, XI.

-, Bruchigavia, 106, XIV., XV.

- Dromiceius, 3, I.

-, Lobibyx, 175, XXIII.

- Recurvirostra, 155, XXI.

Numenius, 151.

cyanopus, 151, XIX.

oceanicus, Oceanites, 16, IV., VII.

Oceanites, 16.

- oceanicus, 16, IV., VII.

ocellata, Leipoa, 220, XXX.

Ocyphaps, 261.

lophotes, 261, XXXIV.

olivii, Austroturnix, 233, XXXII

Onychoprion, 98.

- fuscatus, 99, XX.

Orthorhamphus, 117.

- magnirostris, 117, XVI.

ostralegus, Hamatopus, 157, XVI.

OTIDID $\approx, 185$.

OTIDIFORMES, 185.

Oystercatcher, Black, 158.

$\longrightarrow$, Pied, 157, XVI.

Pachyptila, 43.

- vittata, 43, VI., VII.

pachyrhynchus, Eudyptes, 10, III. pacifica, Globicera, 270, XXXV. - Thyellodroma, 26

pacificus, Gabianus, 108, XIV.

Pagoa, 167. - leschenaultii, 168, XXJI.

palpebrata, Phabetria, 49.

parasiticus, Stercorarius, 113.

Parasula dactylatra, 75, XI.

parkinioni, Procellaria, 30.

patagonica, Aptenodytes, 13

pectoralis, Coturnix, 224, XXXI.

- Rallus, 191, XXVI.

PEDIONOMIDE, 239.

Pedionomus, 239

- torquatus, 239, XXXI.

Pelagodroma, 18.

- marina, 18, IV., VII

Pelecani, 61.

Pelecanidie, 70.

Pelecanotdea, 69.

Pelecanoides, 46.

urinatrix, 46, VI., VII.

PeleoanoIdide, 45.

Pelecanopus, 91.

- bengalensis, 93.

- bergii, 92, XIV.

Pelican, 70, X.

Peltohyas, 184. 
Peltohyas anstratis, 184, XXIV. Penguin, Big-crested, 10, III.

-, Fairy, ?, IX.

, King, 13.

Macaroni, 1:2.

Yellow-crested, 11

PERDICIDA, 223.

peroni, Peronista, 5.

Peronista. 4.

peroni, 5.

perthi, Hypoleucus, 63, XI.

Petrel, Black, 30.

$\longrightarrow$, Blue, 40, V.
,- Brown, 31.

,-- and White, 25.

_., Brown-headed, 34

- Diving, 46, VI., VII.

, Giant, 45, IV.

Grey-faced, 33, VII.

Mottled, 34.

Silver-grey, 32.

Soft-plumaged, 35.

Spectacled, 30, VI.

Spotted, 39.

White-chinned, 29, VI., VII.

, White-headed, 36, VII.

- , White-winged, 37, V., VII.

Petrophassa, 255.

- albipennis, 255, XXXIV.

- rufipennis, 256.

Phropus, 150.

- phoeopus, 150, XXIV.

Phatrhontid $79,78$.

PHAETHONTIEORMES, 77.

Phalacrocoracide, 62.

Phalacrocoracoidea, 61.

Phalacrocorax, 66.

- carbo, 67, X.

Phaps, 251.

- chalcoptera, 251, XXXIII.

phasianella, Macropygia, 243, XXXIV.

Phasianoidea, 223.

philippensis, Hypotanidia, 194, XXVI.

Phoebetria, 48.

- tusca, 48.

palpebrata, 49.

Pigeon, Black-banded Fruit, 268, XXXVI

- Bronze-winged, 251, XXXIII.

, Brush Bronze-winged, 252.

, Chestnut-quilled Rock, 256.

Crested, 261, XXXIV.

Flock-, 254, XXX1I.

Grey-headed, 270, XXXV.

Little Green, 249, XXXIII.

Naked-eyed Partridge, 258, XXXV.

Nutmeg, 269, XXXV.

Partridge, 257, XXXV.

, Pheasant, 243, XXXIV.

, Plumed, 259, XXXV.

, Purple-breasted Fruit, 267, XXXV.

Purple-erowned Fruit, 265.

, Red-cered, 270.

, Red-crowned Fruit, 264, XXXVI.

Red-plumed, 260.

Top-knot, 271, XXXVI.

White-headed Fruit, 242, XXXIII.

White-quilled Rock, 255, XXXIV.

Piscatrix, 73
Piscatrix sula, 74.

Pisobia, 130.

- ruficollis, 131, XVIII.

-nsuminuta, 132, XVIII.

placida, Geopelia, 247, XXXIII.

Platyrhamphus, 126.

- lalcinellins, 126, XXII.

Plover, Black-breasted, 177, XXIII. Grey, 162, XXII.

_- Lesser Golden, 163, XXII.

- -... Masked, 175.

Long-billed Stone-, 117, XVI. Spur-twinged, 175, XXIII. Stone-, 116, XVI.

plumbea, Porzanoidea, 200, XXVII.

plumifera, Lophophaps, 259, XXXV.

Plurialis, 163.

- dominicus, 163, XXII.

Podiceps, 212.

- cristatus, 213, XXIX.

Podicipide, 212.

Podictpiformes, 211.

Poliocephalus, 214

- poliocephalus, 215.

- ruficollis, 214, XXIX

Poliolimnas, 201.

- cinerea, 202, XXVII.

pomarinus, Coprotheres, 111.

Porphyrio, 208.

bellus, 210.

- melanotus, 208, XXVIII.

Porzana, 197.

-..-Auminea, 198, XXVI.

Porzanoidea, 200.

- plumbea, 200, XXVII.

Pratincole, 183, XXIV.

- Oriental, 182, XXIV.

Priocella, 32

-. antarctica, 32.

Prion, Broad-billed, 43, VI., VII

-, Dove, 41, VI.

_ Fairy, 42, VI

Thin-billed, 41, VI.

Procellaria, 29.

- aruinoctialis, 29, VI.

- cons picillata, $30, \mathrm{VI}$. - parkinsoni, 30.

Procellarize, 14.

Procellaritd 21.

Proceliarifformes, 15.

Procellariolnea, 15 .

Procelsterna, 103.

- cerulea, 103, XIII.

Pseudoprion, 42.

- turtur, 42, VI.

PSOPHII, 187.

Psopmitorues, 188.

Pterodroma, 33.

- inexpectata, 34.

___ macraptera, 33, VII.

- melanopus, 34.

- mollis, 35.

Plilinopus, 263.

- regina, 264, XXXVI. superbus, 265.

Puffinus, 22.

_- assimilie, 23, IV., VII, lherminieri, 25. 
pusilla, Zapornia, 199.

pyrrhothorax, Alphaturnic, 236, XXXII.

Quail, Allied, 233, XXXII.

-., Black-backed, 230, XXXI.

-_, Black-breasted, 238, XXXII.

- Brown, 226, XXXI.

- Chestnut-backed, 234, XXXTI

- _, King-, 228, XXX1.

- Jittle, 235, XXXII

- Painted, 231, XXXII

-_, Red-chested, 236, XXXII.

-..., Stubble-, 224, XXXI.

Irail, Buff-banded, 194, XXVT.

- Chestnut-bellied, 196, XXVT.

_. Land, 196.

-.., Hed-necked, 192, XXVI.

- Slate-breasted, 191, XXYI.

RALLI, 189.

Rallide, 190.

RALLIFORMES, 190.

Rallus, 190. pectoralis, 191, XXVI.

Recurvirostra, 155.

- novahollandia, $155, \mathrm{XXT}$.

RECURVIROSTRID A., 152.

regina, Ptilinopus, 264, XXXVI.

reinholdi, Reinholdia, 24 .

Heinholdia, 24.

-..- reinholdi, 24.

reinwardt, Megapodius, 218, XXX.

Rhyacophilus, 137.

- glareola, 138.

Rostratula, 119.

- australis, 119, XVIII.

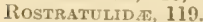

rubicunda, Mathewsena, 189, XXY. rubricauda, Screoplac̈thon, 80, IX.

rubricera, Globicera, 270.

ruficapillus, Leucopolius, 169, XXIII.

ruficollis, Pisobia, 131, XVIII.

- Poliocephalus, 214, XXIX.

rufipennis, Petrophassa, 256.

Sand-Dotterel, Large, 168, XXII.

- Mongolian, 165, XX.

Banderling, 133, XIX.

Sundpiper, Broad-billed, 126, XXII.

—_, Common, 139.

-, Curlew-, 128, XIX.

_.., Long-tailed, 141

- Terek, 141, XXIV.

-., Wood, 138.

Sccophaëthon, 80.

- rubricauda, 80, IX.

schlegeli, Eudyptes, 12.

SCOLOPACIDA, 120.

ŚCOLOPACOIDEA, 118.

scripla, Geophaps, 257, XXXT.

serub Fowl, 218, XXX.

serrator, Sulita, 76, X.

serresianus, Eudyptes, 11.

Shearwater, Allied, 23, V., VII.

Fleshy-footed, 28.

__, Kluttering, 24.

‥, Short-tailed, 27.

- Sombro, 27.
Shearwater, Wedge-tailed, 20.

-., White-fronted, 24.

Skua, Antarctic, 110, XIT

-_, Arctic, 113.

.. Pomarine, 111.

smithii, Geophaps, 258, XXXV.

Snipe, 121, XVII.

_., Painted, 119, XVIIJ.

- Pin-tailed, 123, XVII

SPHENISCI, 8.

SPHENISCID.E, 8.

SPHENISCIFOR:IES, 8.

Squatarola, 161.

- squatarola, 162, XXII.

slagnatilis, Iliornis, 130.

SiterCoRARIIDA, 108.

Stercorarizs, 112

- parasiticus, 113.

Sterna, 86.

- dougallii, 87, XII.

- striata, 86 .

STERNID.E, 82.

Sternula, 89.

-abifrons, 89.

- nereis, 91, XIV.

Stictopeleia, 247.

cuneata, 218, XXXIV.

Stilt, Banded, 154, XXI.

-, White-headed, 153, XXI.

Stiltia, 183. - isabella, 183, XXIV.

Stint, Long-toed, 132, XVIII.

-, Red-necked, 131, XVIII.

-, Sharp-tailed, 129, X VIIJ.

stolidus, Anous, 102, XIII.

Stone-Plover, 116, XVI.

-, Long-billed, 117, XVI.

Storm-Petrel, Allied, 20.

-.., Black-bellied, 20, IV.

_-, Grey-backed, 17, IV.

__ White-bellied, 21, IV., VII.

-, White-faced, 18, IV., VII.

_-, Yellow-webbed, 16, IV., VII.

siriata, Sterna, 86.

Stubble-Quail, 2:24.

subminuta, Pisobia, 132, XVIII.

Subspilura, 122.

- megala, 123, XVII.

Sula, 72 .

- levcogaster, 72, XI.

sula, Piscalrix, 74.

SULID.E, 71.

Sulita, 76 .

- serrator, 76, X.

SULOYDEA, $7 \mathrm{i}$.

sumatrana, Gygisterna, 88, XIV.

superbus, Ptilinopus, 265.

Tattler, Grey-rumped, 143, XVIII.

- Wandering, 142, XVIII.

tenebrosa, Gallinula, 205, XXVIII.

tenuirostris, Anteliolringa, 125, XXII.

$\longrightarrow$ Megalopterus, 10I, XIII.

- Neonectris, 27.

Terek Sandpiper, 141, XXIV.

Teretia, 140.

-_-cinerea, 141, XXIV.

Tern, Black-naped, 88, XIV. 
Tern, Bridled, 97, XX.

Caspian, 96, XII.

Crested, 92, XIV.

Gull-billed, 94, XII.

Lesser Crested, 93.

Roseate, 87, XII.

Sooty, 99, XX.

Whiskered, 83.

White, 105, XIII.

White-fronted, 86.

White-winged Marsh-, 81, XVI.

Ternlet, White-faced, 91, XIV.

White-shafted, 89.

Thalassarche, 50 .

- chlororhynchus, 52, VIII.

- chrysostoma, 51, V11I.

melanophrys, 50.

THALASSIDROMIDE, 15.

Thyellodroma, 25.

- pacifica, 26.

torquatus, Pedionomus, 239, XXXI.

Tomirdus, 192.

tricolor, 192, XXVI.

TRERONIDE, 263.

Tribonyx, 207.

mortierii, 207, XXVII.

iricolor, Tomirdus, 192, XXVI. Zonifer, 177, XXIII.

Tropic Bird, Red-tailed, 80, 1A.

- White-tailed, 79.

tropica, Eregetta, 20, IV.

TUBINARES, 14.

tubulata, Fregetta, 20.

Turkey, Brush-, 222, XXX.
TURnicides, 229.

TURNICIFORMES, 229.

Turnix, 230. - maculosa, 230, XXXI.

Turnstone, 159, XIX.

iurtur, Pseudoprion, 42, VI.

TURTURID电, 244.

unicolor, Hoematopus, 158, XVI.

wrinatrix, Pelecanoides, 46, VI.

VANELLIDE, 174.

variu, Marianornis, 231, XXXII.

velox, Alphaturnia, 235, XXXII.

ventralis, Microtribonyx, 206, XXVII.

vereda, Eupodella, 172, XXII.

Vetole, 145.

- lapponica, 145, XX.

vittata, Pachyptila, 43, VI., VII.

Wanderer, Plain, 239, XXXI.

Water Hen, Black-tailed, 206, XXVII.

Whimbrel, 150, XXIV

-., Little, 149, XIX.

Wonga-wonga, 262, XXXIV.

Wood-Sandpiper, 138.

Y prsilophorus, 225.

- ypsilophores, 226, XXXI.

Zapornia, 199.

- pusilla, 199.

Zonifer, 176.

- tricolor, 177, XXIJI. 



